\title{
O cinema do diretor de fotografia: traços estilísticos em Walter Carvalho
}

\author{
Versão Corrigida (versão original disponível na Biblioteca da ECA/USP)
}

Tese apresentada ao Programa de Pós-Graduação em Meios e Processos Audiovisuais da Escola de Comunicações e Artes da Universidade de São Paulo, para a obtenção do título de Doutor.

Área de Concentração: Poéticas e Técnicas

Orientadora: Profa. Dra. Maria Dora Genis Mourão

São Paulo 
Autorizo a reprodução e divulgação total ou parcial deste trabalho, por qualquer meio convencional ou eletrônico, para fins de estudo e pesquisa, desde que citada a fonte.

Catalogação na Publicação

Serviço de Biblioteca e Documentação

Escola de Comunicações e Artes da Universidade de São Paulo

Dados inseridos pelo(a) autor(a)

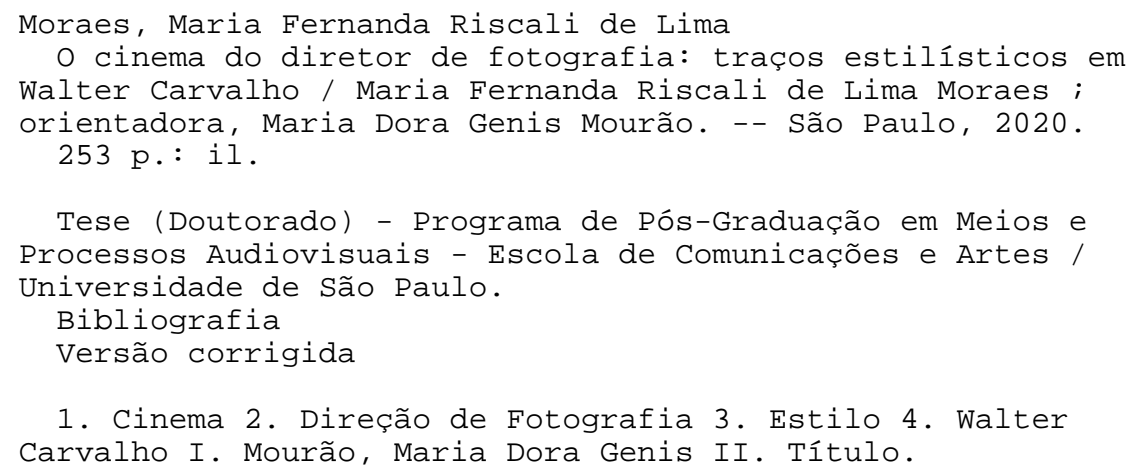


Nome: MORAES, Maria Fernanda Riscali de Lima

Título: O cinema do diretor de fotografia: traços estilísticos em Walter Carvalho

Tese apresentada ao Programa de Pós-Graduação em Meios e Processos Audiovisuais da Escola de Comunicações e Artes da Universidade de São Paulo, para a obtenção do título de Doutor.

Aprovado em:

\section{Banca Examinadora:}

Prof. Dr.:

Instituição:

Julgamento:

Prof. Dr.:

Instituição:

Julgamento:

Prof. Dr.:

Instituição:

Julgamento:

Prof. Dr.:

Instituição:

Julgamento:

Prof. Dr.:

Instituição:

Julgamento: 


\section{AGRADECIMENTOS}

À Profa. Dra. Maria Dora Genis Mourão, pela valiosa orientação durante esse longo e engrandecedor percurso do doutorado.

Ao Prof. Dr. Fernando Pasquale Rocco Scavone, pelo constante estímulo e apoio nos estudos sobre cinematografia.

Ao Prof. Dr. Atílio José Avancini, por ter me apontado, ainda no mestrado, a importância da fundamentação metodológica.

Ao Prof. Dr. Marco Garaude Giannotti, pela introdução e estímulo à pesquisa em artes visuais.

À minha família e amigos, que sempre apoiaram e incentivaram minha sede pelo conhecimento.

À minha mãe, Lena Maria Riscali de Lima Moraes, que me deixou de herança uma estante repleta de livros.

A meu pai, José Roberto de Lima Moraes, por tudo.

A Walter Carvalho, por suas imagens. 


\section{RESUMO}

MORAES, Maria Fernanda Riscali de Lima. O cinema do diretor de fotografia: traços estilísticos em Walter Carvalho. 2020. 253 páginas. Tese (Doutorado em Meios e Processos Audiovisuais) - Escola de Comunicações e Artes, Universidade de São Paulo. São Paulo, 2020.

O presente trabalho busca evidenciar a atuação de diretores de fotografia como parceiros dos diretores, e não apenas colaboradores, na autoria dos filmes. Objetivando investigar o papel criativo dos diretores de fotografia e a possibilidade de identificação estilística em sua atuação, parte-se da distinção entre filme e cinema, estabelecida por Jacques Aumont, buscando-se criar o conceito de cinema do diretor de fotografia: um modo de apreensão e de visão da realidade transposto na elaboração das imagens cinematográficas. Utilizando a metodologia estabelecida por David Bordwell, originalmente aplicada ao trabalho de diretores de cena, são analisados padrões internos dos filmes a partir da leitura formal dos elementos plásticos de composição e dos parâmetros técnicos de elaboração das imagens, com o objetivo de identificar traços recorrentes nas obras, que apontem para a autoria do fotógrafo. A metodologia é aplicada ao trabalho de Walter Carvalho (1947- ), diretor de fotografia com atuação relevante no cinema brasileiro, em sete filmes produzidos no período compreendido entre 1995 e 2017.

Palavras-chave: Cinema. Direção de fotografia. Autoria. Estilo. Jacques Aumont. David Bordwell. Walter Carvalho. 


\begin{abstract}
MORAES, Maria Fernanda Riscali de Lima. Cinematographer's cinema: the style of Walter Carvalho. 2020. 253 páginas. Tese (Doutorado em Meios e Processos Audiovisuais) - Escola de Comunicações e Artes, Universidade de São Paulo. São Paulo, 2020.

The present work focus on the performance of cinematographers as partners of directors, and not only as collaborators, in the autorship of movies. Aiming to investigate the creative role of cinematographers and the possibility of stylistic identification in their performance, and based on the distinction between film and cinema, established by Jacques Aumont, we create the concept of cinematographer's cinema: a way of apprehension of reality transposed to the creation of cinematographic images. Using David Bordwell's methodology, originally applied to the work of directors, internal patterns of the movies are studied, including formal aspects of composition's elements and technical parameters of the images, to identify cinematographer's authorship. The methodology is applied to the work of Walter Carvalho (1947- ), cinematographer with a relevant role in Brazilian cinema, with the analysis of seven movies produced between 1995 and 2017.
\end{abstract}

Keywords: Cinema. Cinematography. Author. Style. Jacques Aumont. David Bordwell. Walter Carvalho. 


\section{LISTA DE ILUSTRAÇÕES}

Figura 001 - Ancient sound, abstract on black (1925), Paul Klee...................................................... 27

Figura 002 - Composição 8 (1923), Wassily Kandinsky ..................................................................... 27

Figura 003 - O artista em seu estúdio (1626-28), Rembrandt van Rijn .............................................. 28

Figura 004 - Cabeça de um homem velho (1632), Rembrandt van Rijn ............................................ 29

Figura 005 - Humano - Uma viagem pela vida (2016), Yann Arthus-Bertrand.................................... 29

Figura 006 - A última ceia (1495-1497), Leonardo da Vinci ................................................................. 30

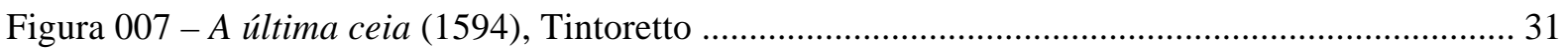

Figura 008- Moça com brinco de pérola (2003), Peter Webber........................................................... 33

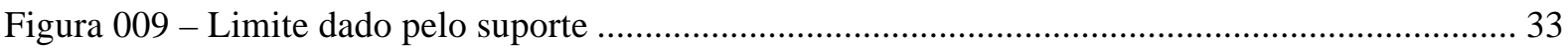

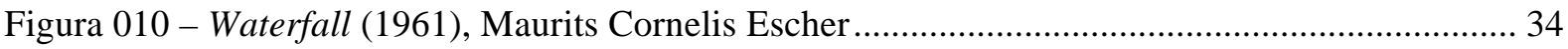

Figura 011 - Composição em vermelho, amarelo, azul e preto (1921), Piet Mondrian e Contracomposição em dissonância 16 (1925), Theo van Doesburg......................................... 36

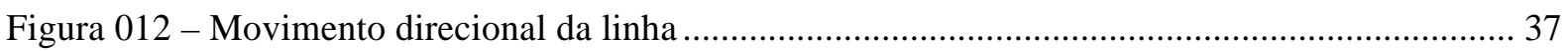

Figura 013 - Autumn rhythm n 30 (1950), Jackson Pollock …………………..................................... 37

Figura 014 - O Encouraçado Potemkin (1925), Sergei Eisenstein....................................................... 39

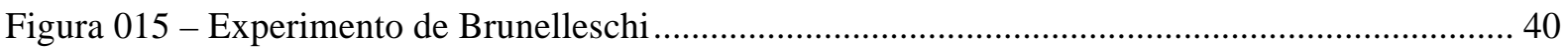

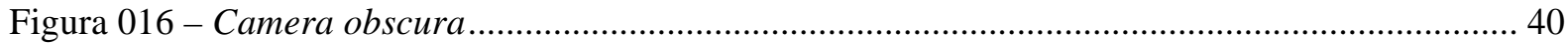

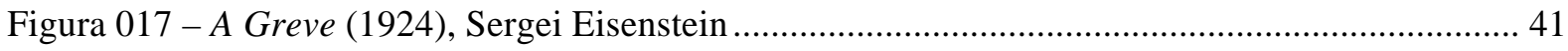

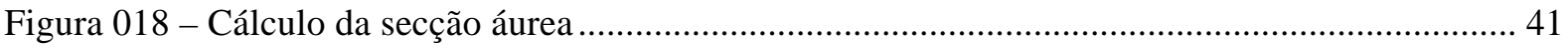

Figura 019 - Espiral áurea e detalhe da Mona Lisa (1503), Leonardo da Vinci.................................... 42

Figura 020 - Amor à Flor da Pele (2000), Wong Kar-wai................................................................. 43

Figura 021 - Ivan, o Terrível - Parte I (1945), Sergei Eisenstein......................................................... 43

Figura 022 - Viagem a Darjeeling (2007), A Vida Marinha com Steve Zissou (2004) e Moonrise Kingdom (2012), Wes Anderson ........................................................................................ 44

Figura 023 - O Fantástico Sr. Raposo (2009), Wes Anderson............................................................. 44

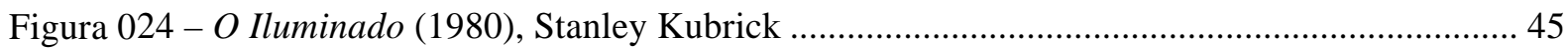

Figura 025 - Simetria em Stanley Kubrick e Wes Anderson ............................................................. 45

Figura 026 - Nascido para Matar (1987), Stanley Kubrick ................................................................... 46

Figura 027 - A Paixão de Joana d'Arc (1928), Carl Theodor Dreyer.................................................. 46

Figura 028 - Anphritie Point, Vancouver, Robert Berdan................................................................. 47

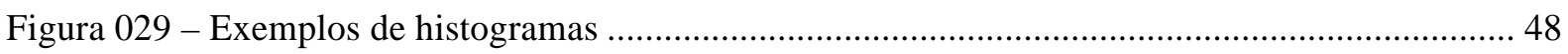

Figura 030 - Greta Garbo em A Rua Sem Sol (1925) e Inspiração (1931)........................................... 50

Figura 031 - Cristo curando os enfermos (1647-9), Rembrandt van Rijn .......................................... 50

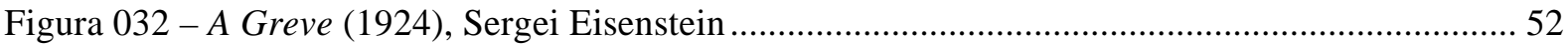


Figura 033 - Vidas Secas (1963), Nelson Pereira dos Santos............................................................... 52

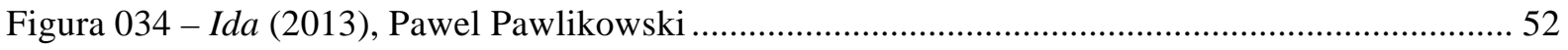

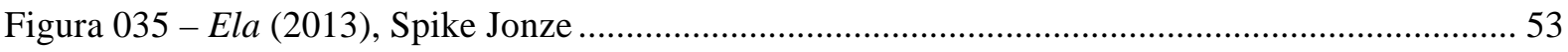

Figura 036 - Histograma de Ida (2013), Pawel Pawlikowski.............................................................. 53

Figura 037 - Histograma de Ela (2013), Spike Jonze......................................................................... 54

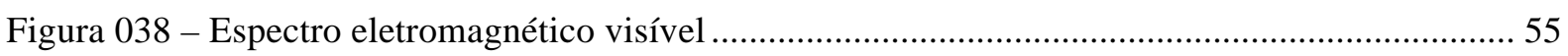

Figura 039 - Diagrama de Cromaticidade para o iluminante C.......................................................... 56

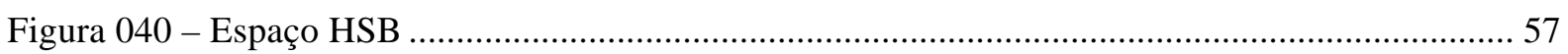

Figura 041 - Catedral St Michael (Toronto) e Vectorscope ................................................................... 57

Figura 042 - O Grande Hotel Budapeste (2013), Wes Anderson ........................................................ 58

Figura 043 - Análise de cores no modo HSL ……............................................................................. 59

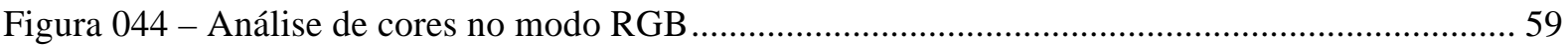

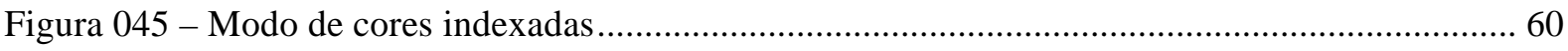

Figura 046 - O Encouraçado Potemkin (1925), Sergei Eisenstein...................................................... 62

Figura 047 - O Encouraçado Potemkin (1925), Sergei Eisenstein...................................................... 62

Figura 048 - A Chinesa (1967), Jean-Luc Godard e $O$ ateliê vermelho (1911), Henri Matisse ........... 63

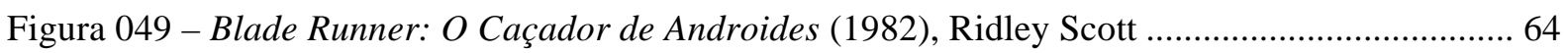

Figura 050 - Um Beijo Roubado (2007), Won Kar-wai ..................................................................... 64

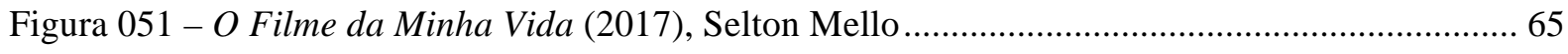

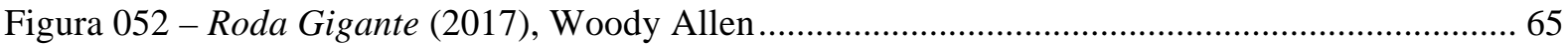

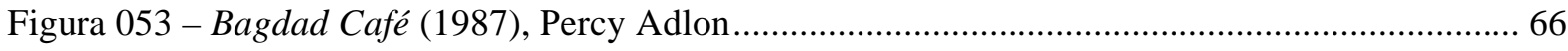

Figura 054 - O Céu de Suely (2006), Karim Aïnouz e Ela (2013), Spike Jonze .................................... 68

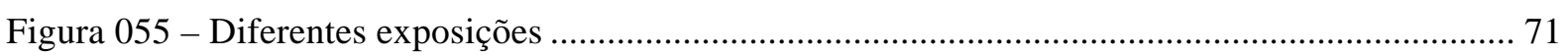

Figura 056 - Grãos em filmes de diferentes sensibilidades ........................................................... 72

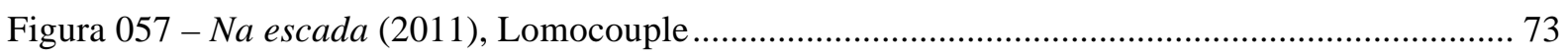

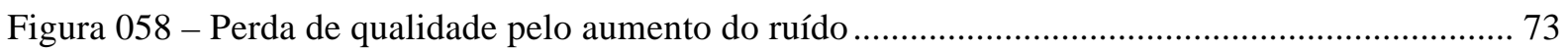

Figura 059 - Julien Donkey-Boy (1999), Harmony Korine …………................................................ 74

Figura 060 - Mecanismo básico de funcionamento da câmera fotográfica ........................................... 74

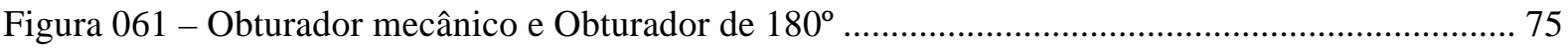

Figura 062 - Equivalência entre ângulo e velocidade do obturador ..................................................... 76

Figura 063 - Velocidade do obturador e nitidez do movimento .......................................................... 76

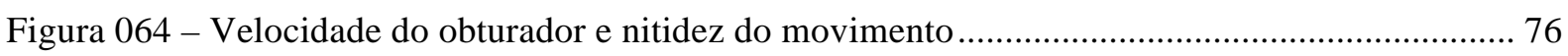

Figura 065 - O Resgate do Soldado Ryan (1998), Steven Spielberg .................................................. 77

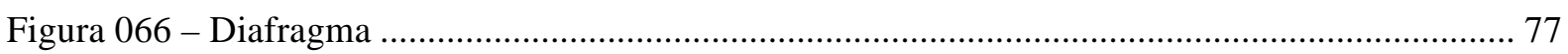

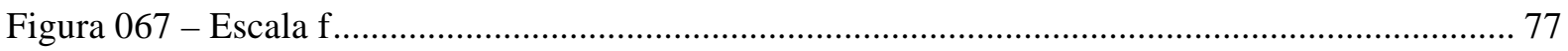

Figura 068 - Abertura de diafragma e profundidade de campo ........................................................... 78

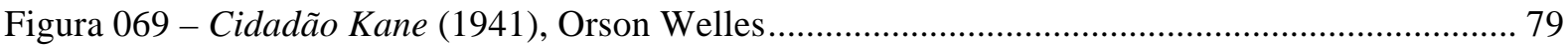




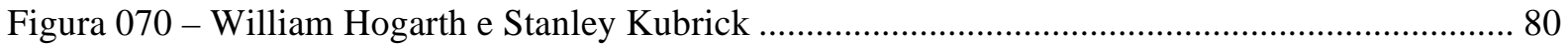

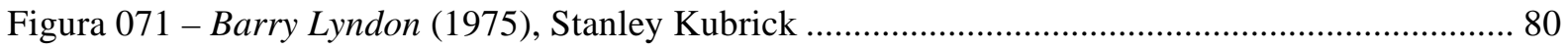

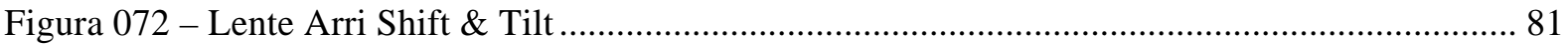

Figura 073 - O Escafandro e a Borboleta (2007), Julian Schnabel ................................................... 81

Figura 074 - Condições de luz - sensibilidade, obturador e diafragma ................................................. 82

Figura 075 - Unsafe journey (2011), Amy Helene Johansson .............................................................. 84

Figura 076 - Ivan, o Terrível - Parte II (1958), Sergei Eisenstein ...................................................... 84

Figura 077 - O Resgate do Soldado Ryan (1998), Steven Spielberg................................................... 85

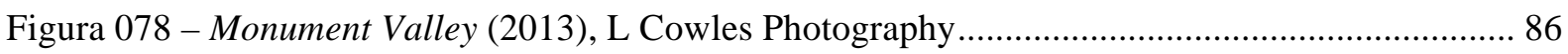

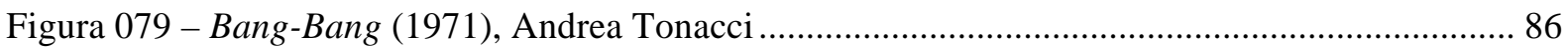

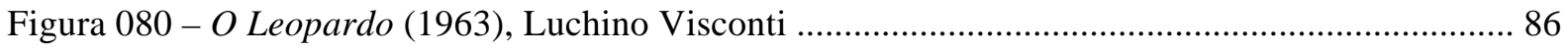

Figura 081 - No Tempo das Diligências (1939), John Ford ................................................................. 87

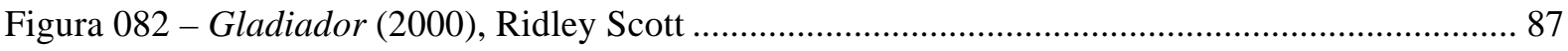

Figura 083 - O Fabuloso Destino de Amélie Poulain (2001), Jean-Pierre Jeunet................................. 88

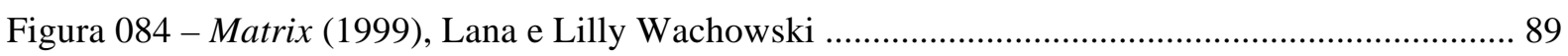

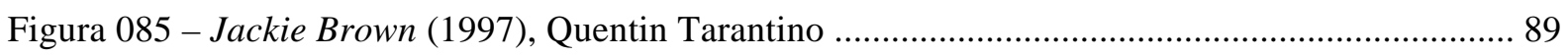

Figura 086 - Ângulo de visão X Distância focal das lentes................................................................. 89

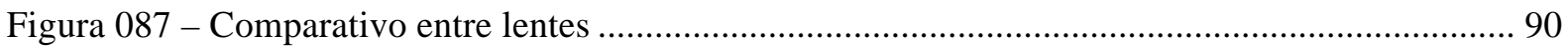

Figura 088 - Inverno de Sangue em Veneza (1973), Nicholas Roeg ................................................... 91

Figura 089 - Paul Thomas Anderson e David Fincher - Planos Gerais ................................................. 91

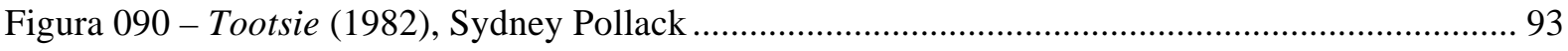

Figura 091 - Snow storm: steam-boat off a harbour's mouth (1842), William Turner ........................ 94

Figura 092 - O Nascimento de uma Nação (1915), D. W. Griffith e Napoleão (1927), Abel Gance .. 95

Figura 093 - Movimento interno nos filmes de Kurosawa ................................................................. 96

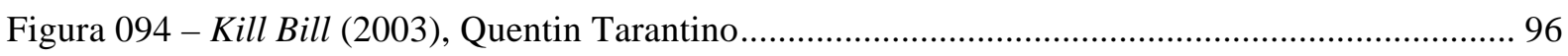

Figura 095 - Os Caçadores da Arca Perdida (1981), Steven Spielberg ............................................... 97

Figura 096 - Os Bons Companheiros (1990), Martin Scorsese …………........................................... 97

Figura 097 - Terra Estrangeira (1995), Walter Salles e Daniela Thomas ........................................... 103

Figura 098 - Terra Estrangeira (1995), Walter Salles e Daniela Thomas ........................................... 104

Figura 099 - O Encouraçado Potemkin (1925), Sergei Eisenstein........................................................ 105

Figura 100 - Terra Estrangeira (1995), Walter Salles e Daniela Thomas ........................................... 106

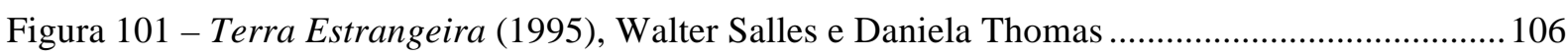

Figura 102 - Terra Estrangeira (1995), Walter Salles e Daniela Thomas ........................................... 107

Figura 103 - Terra Estrangeira (1995), Walter Salles e Daniela Thomas ........................................... 107

Figura 104 - Terra Estrangeira (1995), Walter Salles e Daniela Thomas ........................................... 108

Figura 105 - Terra Estrangeira (1995), Walter Salles e Daniela Thomas ........................................... 108

Figura 106 - Terra Estrangeira (1995), Walter Salles e Daniela Thomas ........................................... 109 
Figura 107 - Terra Estrangeira (1995), Walter Salles e Daniela Thomas ............................................ 109

Figura 108 - Terra Estrangeira (1995), Walter Salles e Daniela Thomas ........................................... 110

Figura 109 - Terra Estrangeira (1995), Walter Salles e Daniela Thomas .......................................... 110

Figura 110 - Terra Estrangeira (1995), Walter Salles e Daniela Thomas ........................................... 110

Figura 111 - Ivan, o Terrivel - Parte I (1944) e Terra Estrangeira (1995) .......................................... 111

Figura 112 - Terra Estrangeira (1995), Walter Salles e Daniela Thomas ........................................... 111

Figura 113 - O Encouraçado Potemkin (1925), Sergei Eisenstein...................................................... 112

Figura 114 - Terra Estrangeira (1995), Walter Salles e Daniela Thomas ............................................. 112

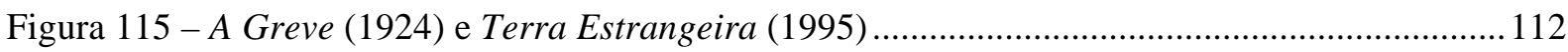

Figura 116 - O Encouraçado Potemkin (1925) e Terra Estrangeira (1995)........................................ 113

Figura 117 - Terra Estrangeira (1995), Walter Salles e Daniela Thomas ........................................... 113

Figura 118 - Terra Estrangeira (1995), Walter Salles e Daniela Thomas ........................................... 114

Figura 119 - Terra Estrangeira (1995), Walter Salles e Daniela Thomas ........................................... 114

Figura 120 - Terra Estrangeira (1995), Walter Salles e Daniela Thomas ........................................... 115

Figura 121 - Terra Estrangeira (1995), Walter Salles e Daniela Thomas ........................................... 115

Figura 122 - Terra Estrangeira (1995), Walter Salles e Daniela Thomas ..........................................116

Figura 123 - Terra Estrangeira (1995), Walter Salles e Daniela Thomas .......................................... 116

Figura 124 - Terra Estrangeira (1995), Walter Salles e Daniela Thomas ............................................ 116

Figura 125 - Terra Estrangeira (1995), Walter Salles e Daniela Thomas ........................................... 117

Figura 126 - Terra Estrangeira (1995), Walter Salles e Daniela Thomas ............................................ 117

Figura 127 - Terra Estrangeira (1995), Walter Salles e Daniela Thomas .......................................... 118

Figura 128 - Central do Brasil (1998), Walter Salles ......................................................................... 122

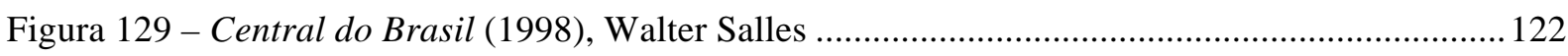

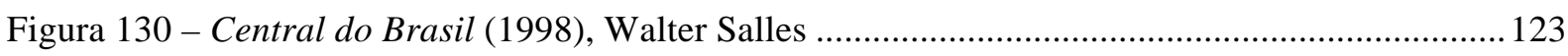

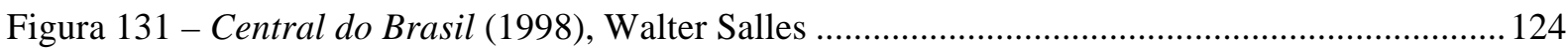

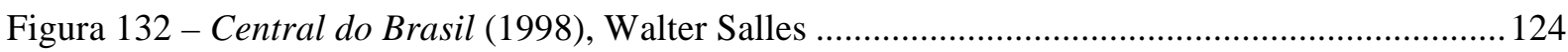

Figura 133 - Central do Brasil (1998), Walter Salles ...................................................................... 125

Figura 134 - Central do Brasil (1998), Walter Salles ....................................................................... 125

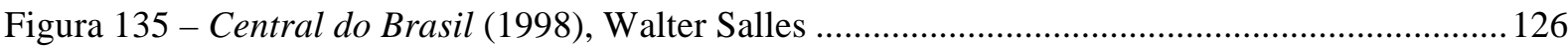

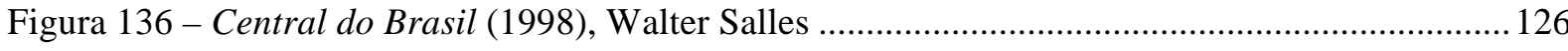

Figura 137 - Central do Brasil (1998), Walter Salles ....................................................................... 126

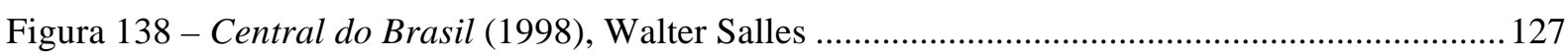

Figura 139 - Central do Brasil (1998), Walter Salles ......................................................................... 127

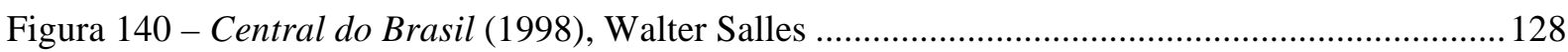

Figura 141 - Terra Estrangeira (1995) e Central do Brasil (1998) .................................................... 128

Figura 142 - Terra Estrangeira (1995) e Central do Brasil (1998) .................................................... 129

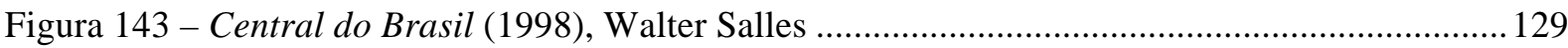


Figura 144 - Central do Brasil (1998), Walter Salles 129

Figura 145 - Central do Brasil (1998), Walter Salles 130

Figura 146 - Central do Brasil (1998), Walter Salles 130

Figura 147 - Central do Brasil (1998), Walter Salles 131

Figura 148 - Central do Brasil (1998), Walter Salles 131

Figura 149 - Central do Brasil (1998), Walter Salles 132

Figura 150 - Central do Brasil (1998), Walter Salles 132

Figura 151 - Central do Brasil (1998), Walter Salles 133

Figura 152 - Central do Brasil (1998), Walter Salles 134

Figura 153 - Central do Brasil (1998), Walter Salles 134

Figura 154 - Central do Brasil (1998), Walter Salles 135

Figura 155 - Central do Brasil (1998), Walter Salles 135

Figura 156 - Central do Brasil (1998), Walter Salles 136

Figura 157 - Central do Brasil (1998), Walter Salles 136

Figura 158 - Central do Brasil (1998), Walter Salles 137

Figura 159 - Central do Brasil (1998), Walter Salles 137

Figura 160 - Central do Brasil (1998), Walter Salles 137

Figura 161 - Central do Brasil (1998), Walter Salles 138

Figura 162 - Central do Brasil (1998), Walter Salles 138

Figura 163 - Central do Brasil (1998), Walter Salles 139

Figura 164 - Central do Brasil (1998), Walter Salles 139

Figura 165 - Central do Brasil (1998), Walter Salles 140

Figura 166 - Central do Brasil (1998), Walter Salles 140

Figura 167 - Central do Brasil (1998), Walter Salles 141

Figura 168 - Central do Brasil (1998) e O Dragão da Maldade Contra o Santo Guerreiro (1969) .. 142

Figura 169 - Central do Brasil (1998), Walter Salles 143

Figura 170 - Central do Brasil (1998), Walter Salles 144

Figura 171 - Central do Brasil (1998), Walter Salles 144

Figura 172 - Central do Brasil (1998), Walter Salles 145

Figura 173 - Central do Brasil (1998), Walter Salles 145

Figura 174 - Central do Brasil (1998), Walter Salles 145

Figura 175 - Lavoura Arcaica (2001), Luiz Fernando Carvalho 146

Figura 176 - Lavoura Arcaica (2001), Luiz Fernando Carvalho 147

Figura 177 - Lavoura Arcaica (2001), Luiz Fernando Carvalho 147

Figura 178 - Lavoura Arcaica (2001), Luiz Fernando Carvalho 148

Figura 179 - Lavoura Arcaica (2001), Luiz Fernando Carvalho 149

Figura 180 - Lavoura Arcaica (2001), Luiz Fernando Carvalho 149 
Figura 181 - Lavoura Arcaica (2001), Luiz Fernando Carvalho 149

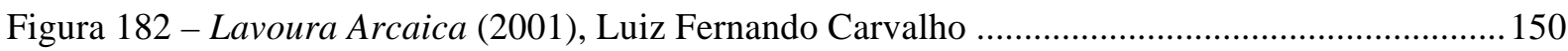

Figura 183 - Lavoura Arcaica (2001), Luiz Fernando Carvalho ...................................................... 150

Figura 184 - David com a cabeça de Golias (1610) e Lavoura Arcaica (2001) ................................. 151

Figura 185 - Lavoura Arcaica (2001), Luiz Fernando Carvalho ....................................................... 151

Figura 186 - Lavoura Arcaica (2001) e Auto retrato de El Greco (1600) ...........................................152

Figura 187 - Lavoura Arcaica (2001), Luiz Fernando Carvalho ...................................................... 152

Figura 188 - Lavoura Arcaica (2001) e O recém nascido (1648), Georges de La Tour.......................153

Figura 189 - Lavoura Arcaica (2001), Luiz Fernando Carvalho ........................................................ 153

Figura 190 - Lavoura Arcaica (2001), Luiz Fernando Carvalho ........................................................ 153

Figura 191 - Lavoura Arcaica (2001), Luiz Fernando Carvalho ........................................................154

Figura 192 - Lavoura Arcaica (2001), Luiz Fernando Carvalho ......................................................... 154

Figura 193 - Lavoura Arcaica (2001), Luiz Fernando Carvalho ....................................................... 155

Figura 194 - Lavoura Arcaica (2001), Luiz Fernando Carvalho ........................................................ 155

Figura 195 - Lavoura Arcaica (2001), Luiz Fernando Carvalho ....................................................... 155

Figura 196 - Lavoura Arcaica (2001), Luiz Fernando Carvalho ........................................................ 156

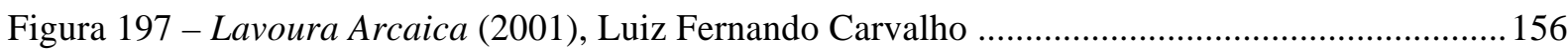

Figura 198 - Lavoura Arcaica (2001), Luiz Fernando Carvalho ......................................................... 156

Figura 199 - Lavoura Arcaica (2001), Luiz Fernando Carvalho ........................................................ 157

Figura 200 - Lavoura Arcaica (2001), Luiz Fernando Carvalho ........................................................ 157

Figura 201 - Lavoura Arcaica (2001), Luiz Fernando Carvalho ........................................................ 158

Figura 202 - Lavoura Arcaica (2001), Luiz Fernando Carvalho ........................................................ 158

Figura 203 - Lavoura Arcaica (2001), Luiz Fernando Carvalho ........................................................ 159

Figura 204 - Lavoura Arcaica (2001), Luiz Fernando Carvalho .......................................................160

Figura 205 - Terra Estrangeira (1995) e Lavoura Arcaica (2001) ..................................................... 160

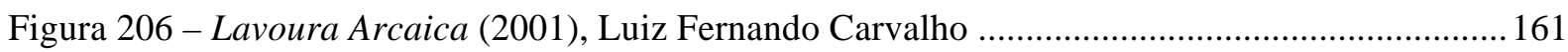

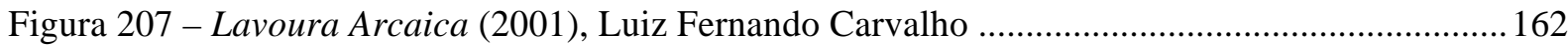

Figura 208 - Lavoura Arcaica (2001) e Central do Brasil (1998) ....................................................... 162

Figura 209 - Lavoura Arcaica (2001), Luiz Fernando Carvalho ......................................................... 162

Figura 210 - Lavoura Arcaica (2001), Luiz Fernando Carvalho .......................................................... 163

Figura 211 - Lavoura Arcaica (2001), Luiz Fernando Carvalho ........................................................ 164

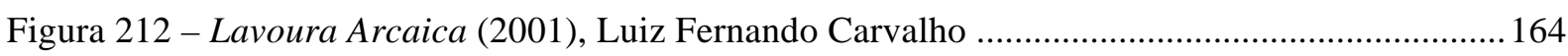

Figura 213 - Lavoura Arcaica (2001), Luiz Fernando Carvalho .......................................................... 165

Figura 214 - Lavoura Arcaica (2001), Luiz Fernando Carvalho ........................................................166

Figura 215 - Lavoura Arcaica (2001), Luiz Fernando Carvalho ........................................................ 166

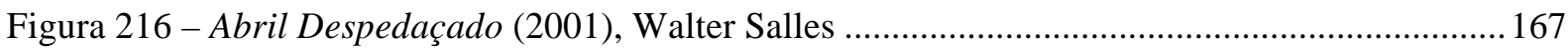

Figura 217 - O Velho e o Novo (1929) e Abril Despedaçado (2001) ...................................................168 


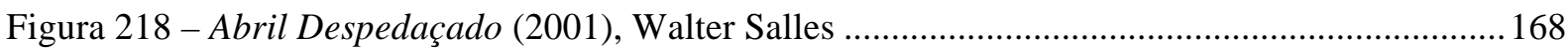

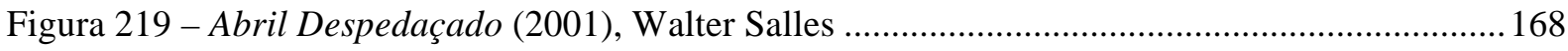

Figura 220 - O Velho e o Novo (1929) e Abril Despedaçado (2001) .................................................... 169

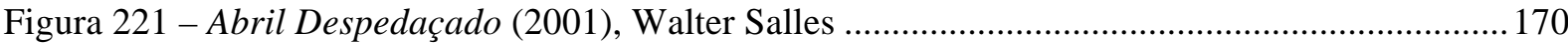

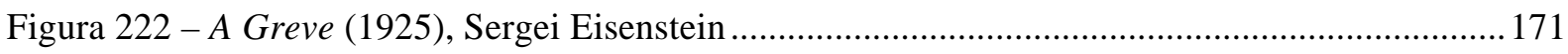

Figura 223 - Abril Despedaçado (2001), Walter Salles ..................................................................... 172

Figura 224 - Abril Despedaçado (2001), Walter Salles ..................................................................... 172

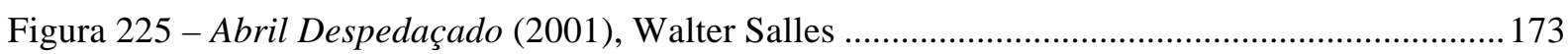

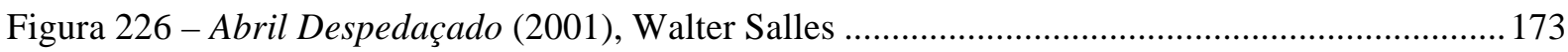

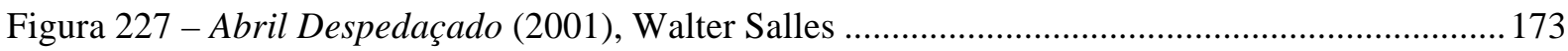

Figura 228 - Abril Despedaçado (2001), Walter Salles .......................................................................174

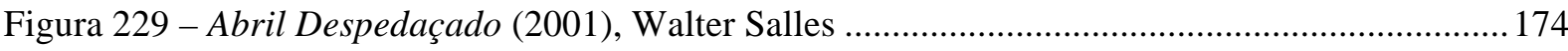

Figura 230 - Abril Despedaçado (2001), Walter Salles .................................................................... 174

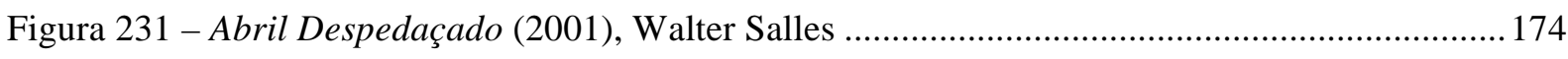

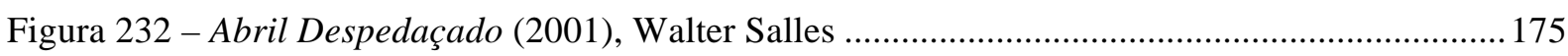

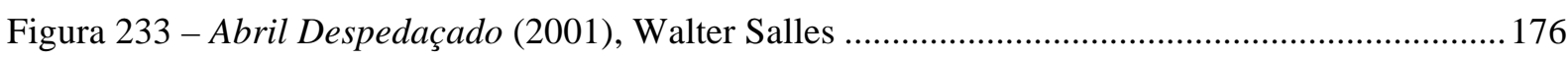

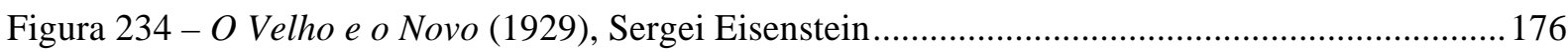

Figura 235 - Rastros de Ódio (1956) e Abril Despedaçado (2001) ....................................................177

Figura 236 - Rastros de Ódio (1956) e Abril Despedaçado (2001) .....................................................177

Figura 237 - Abril Despedaçado (2001), Walter Salles ........................................................................ 178

Figura 238 - Três Homens em Conflito (1966), Sergio Leone ..........................................................178

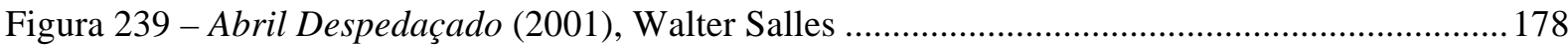

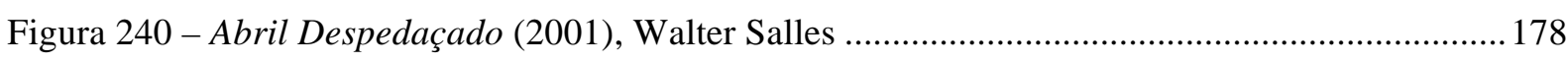

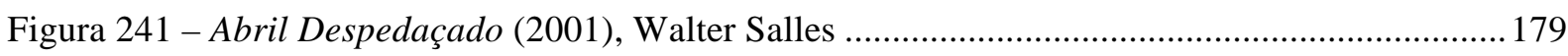

Figura 242 - Abril Despedaçado (2001), Walter Salles ....................................................................... 179

Figura 243 - Rastros de Ódio (1956) e Abril Despedaçado (2001) ...................................................... 180

Figura 244 - Abril Despedaçado (2001) e Lavoura Arcaica (2001) .................................................... 180

Figura 245 - Abril Despedaçado (2001), Walter Salles ....................................................................... 181

Figura 246 - Abril Despedaçado (2001), Walter Salles ....................................................................... 181

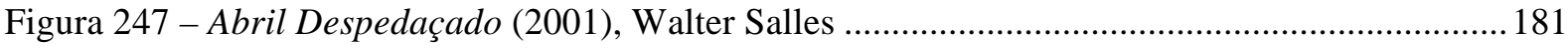

Figura 248 - Abril Despedaçado (2001) e Lavoura Arcaica (2001) ................................................... 182

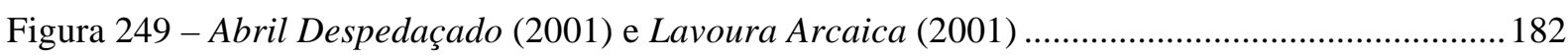

Figura 250 - Abril Despedaçado (2001), Walter Salles ..................................................................... 182

Figura 251 - Abril Despedaçado (2001), histograma e paleta do plano final....................................... 183

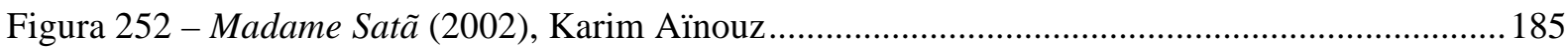

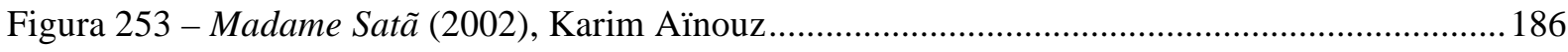

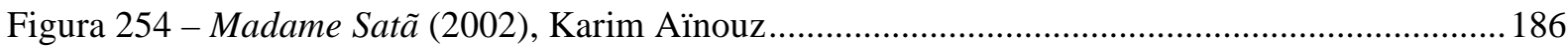


Figura 255 - Madame Satã (2002), Karim Aïnouz. 187

Figura 256 - Madame Satã (2002), Karim Aïnouz. 187

Figura 257 - Madame Satã (2002), Karim Aïnouz. 187

Figura 258 - Central do Brasil (1998), Abril Despedaçado (2001) e Madame Satã (2001)............... 188

Figura 259 - Madame Satã (2002), Karim Aïnouz........................................................................... 188

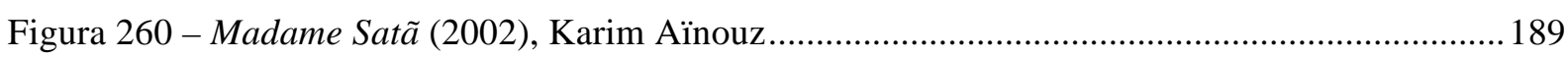

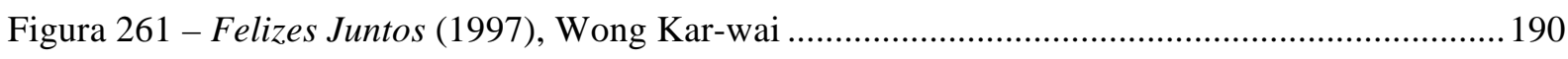

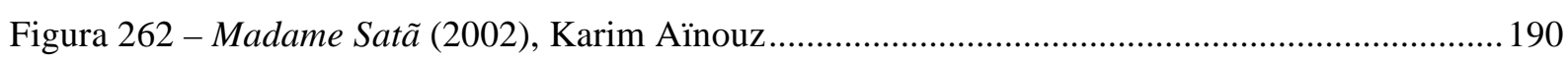

Figura 263 - Amor à Flor da Pele (2000) e Madame Satã (2002) ...................................................... 191

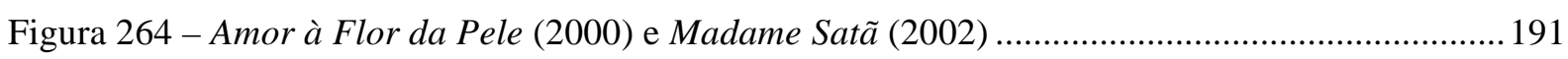

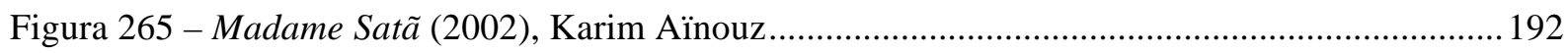

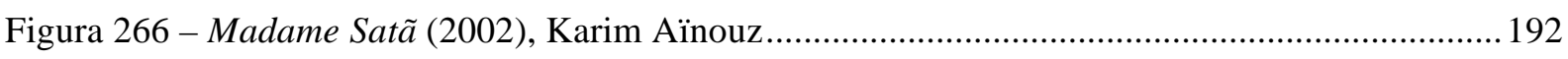

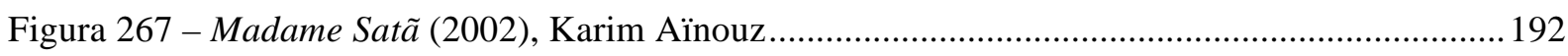

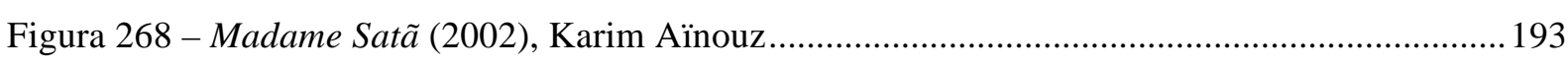

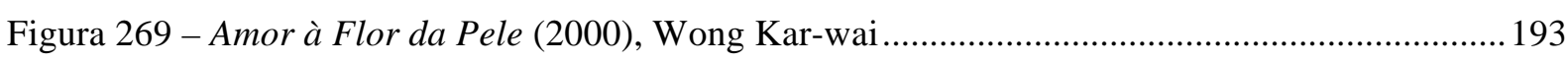

Figura 270 - Madame Satã (2002), fotograma original e sem a fonte de luz .................................... 193

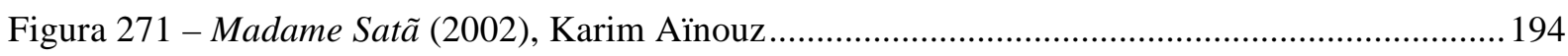

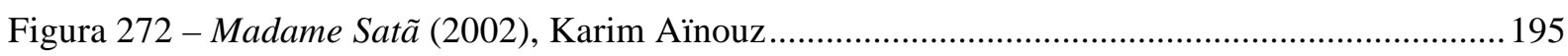

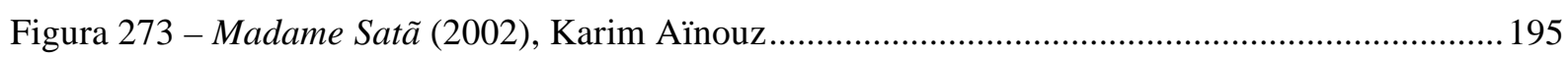

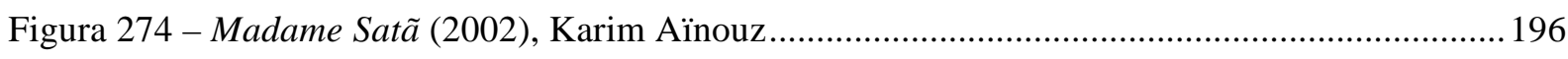

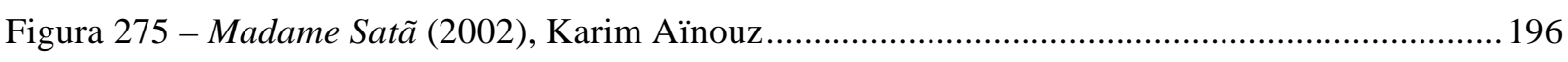

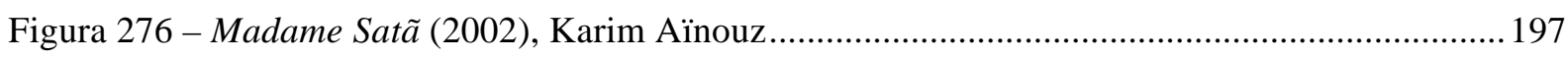

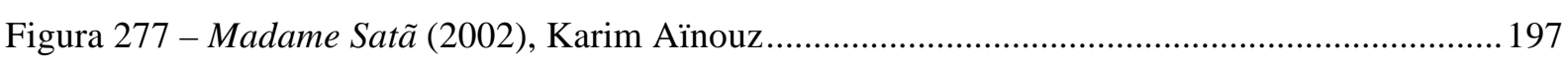

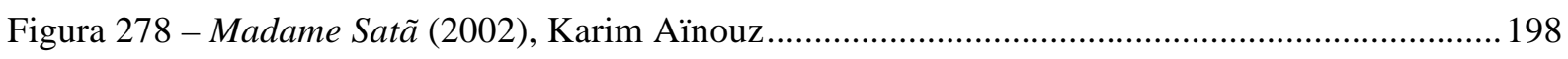

Figura 279 - Madame Satã (2002) e Madam Satan (1930) ................................................................... 198

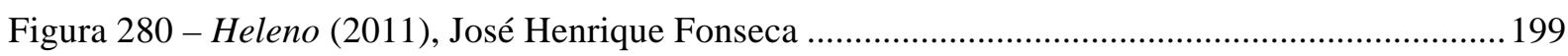

Figura 281 - Heleno (2011), José Henrique Fonseca ……………................................................... 200

Figura 282 - Heleno (2011), José Henrique Fonseca .................................................................. 200

Figura 283 - Heleno (2011), José Henrique Fonseca ...................................................................... 201

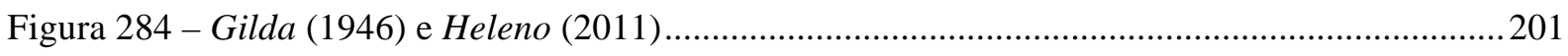

Figura 285 - Heleno (2011), José Henrique Fonseca ………......................................................... 202

Figura 286 - Heleno (2011), José Henrique Fonseca ..................................................................... 202

Figura 287 - Heleno (2011), José Henrique Fonseca ..................................................................... 202

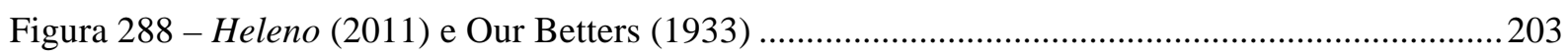

Figura 289 - Heleno (2011), José Henrique Fonseca ......................................................................... 204

Figura 290 - No Silêncio da Noite (1950) e Heleno (2011) .................................................................. 204

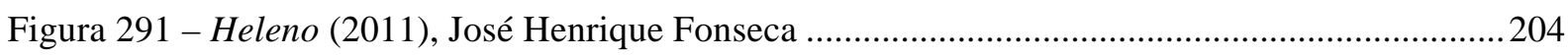




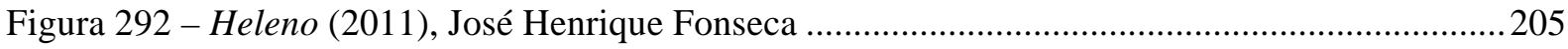

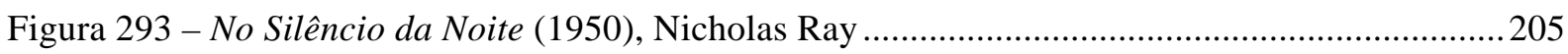

Figura 294 - Heleno (2011), José Henrique Fonseca ........................................................................205

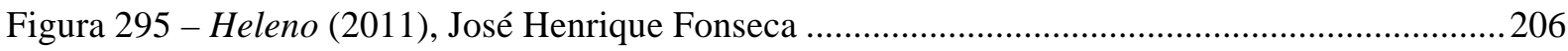

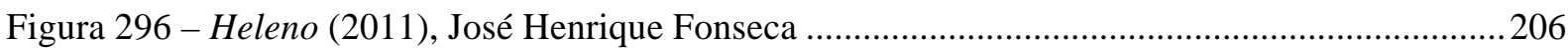

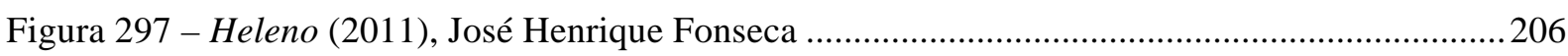

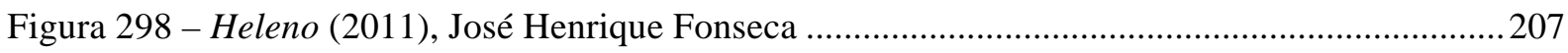

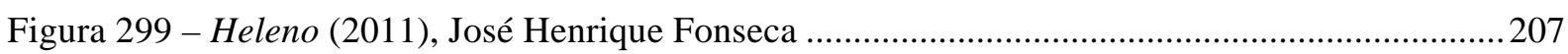

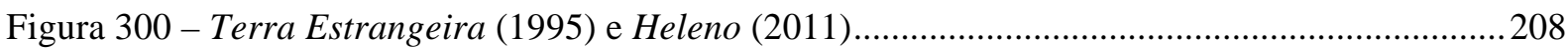

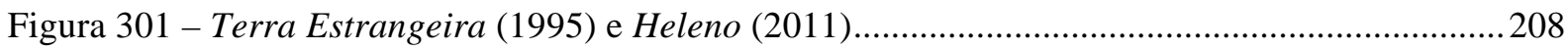

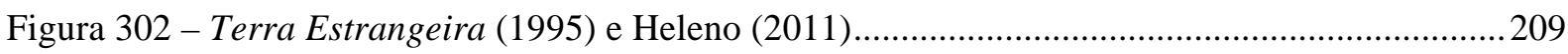

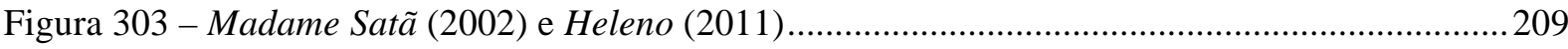

Figura 304 - Heleno (2011), José Henrique Fonseca .........................................................................210

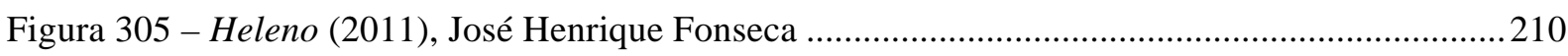

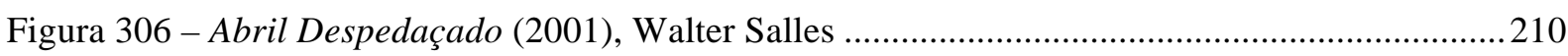

Figura 307 - Heleno (2011), José Henrique Fonseca ........................................................................ 211

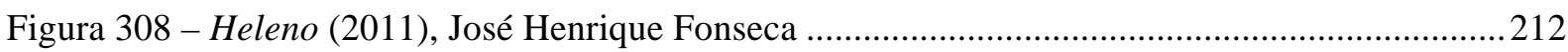

Figura 309 - Isto Não é Um Cachimbo (1929), René Magritte ……………………………..............213

Figura 310 - A Chegada de um Trem à Estação (1896), Irmãos Lumière …………...........................214

Figura 311 - O Filme da Minha Vida (2017), Selton Mello.................................................................215

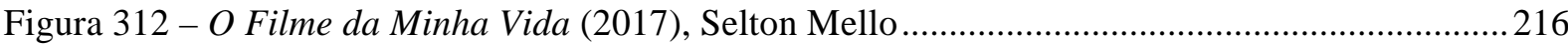

Figura 313 - Madame Satã (2002) e O Filme da Minha Vida (2017) ...............................................217

Figura 314 - Redemoinho (2016) e O Filme da Minha Vida (2017) ..................................................217

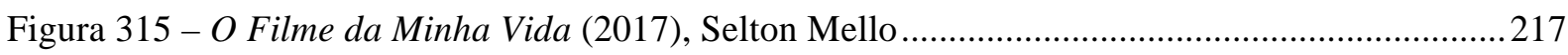

Figura 316 - O Filme da Minha Vida (2017), Selton Mello.................................................................218

Figura 317 - O Filme da Minha Vida (2017), Selton Mello...............................................................218

Figura 318 - O Filme da Minha Vida (2017), Selton Mello ...............................................................219

Figura 319 - O Filme da Minha Vida (2017), Selton Mello ..............................................................219

Figura 320 - Trajetória da luz na câmera e no projetor .....................................................................220

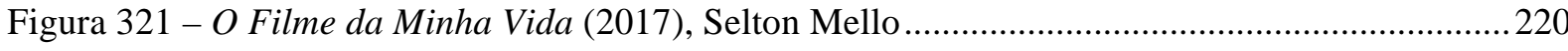

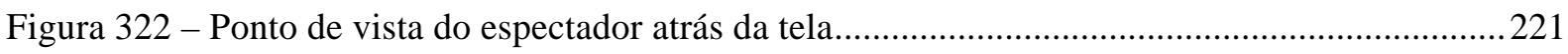

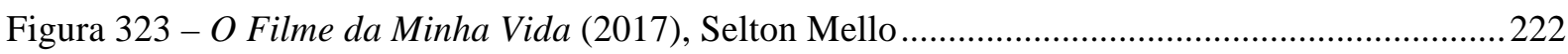

Figura 324 - O Filme da Minha Vida (2017), Selton Mello................................................................222

Figura 325 - Terra Estrangeira (1995) e O Filme da Minha Vida (2017) ..........................................223

Figura 326 - O Filme da Minha Vida (2017) e O Grande Hotel Budapeste (2014) ...........................223

Figura 327 - O Filme da Minha Vida (2017) e Os Bons Companheiros (1990) ...................................224

Figura 328 - Lavoura Arcaica (2001) e O Filme da Minha Vida (2017) ...........................................225 
Figura 329 - O Filme da Minha Vida (2017), Selton Mello ...............................................................225

Figura 330 - O Filme da Minha Vida (2017), Selton Mello .................................................................226

Figura 331 - O Filme da Minha Vida (2017), Selton Mello ................................................................226

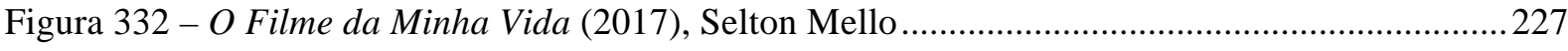

Figura 333 - O Filme da Minha Vida (2017), Selton Mello ................................................................227

Figura 334 - Lavoura Arcaica (2001) e O Filme da Minha Vida (2017) ..............................................228

Figura 335 - O Filme da Minha Vida (2017), Selton Mello ................................................................. 228

Figura 336 - Lavoura Arcaica (2001) e O Filme da Minha Vida (2017) .............................................228

Figura 337 - O Filme da Minha Vida (2017) e Lavoura Arcaica (2001) ............................................229

Figura 338 - Lavoura Arcaica (2001) e O Filme da Minha Vida (2017) ............................................229

Figura 339 - Lavoura Arcaica (2001) e O Filme da Minha Vida (2017) ............................................230

Figura 340 - Paisagem com gado e tropeiro (1780) e O Filme da Minha Vida (2017)......................230

Figura 341 - O Filme da Minha Vida (2017), Selton Mello ................................................................231

Figura 342 - O Filme da Minha Vida (2017), Selton Mello ...............................................................231

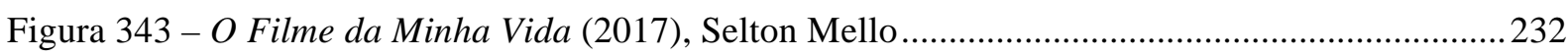

Figura 344 - O Filme da Minha Vida (2017), Selton Mello.................................................................2232

Figura 345 - O Filme da Minha Vida (2017), Selton Mello...............................................................233

Figura 346 - Lavoura Arcaica (2001) e Redemoinho (2016) .............................................................234

Figura 347 - Lavoura Arcaica (2001) e O Filme da Minha Vida (2017) ............................................235

Figura 348 - Lavoura Arcaica (2001), Amarelo Manga (2002) e Redemoinho (2016) .......................235

Figura 349 - Abril Despedaçado (2001) e Madame Satã (2002) .........................................................236

Figura 350 - O Filme da Minha Vida (2017) e Redemoinho (2016) ...................................................236

Figura 351 - Terra Estrangeira (1995), Lavoura Arcaica (2001) e Madame Satã (2002) ................. 236

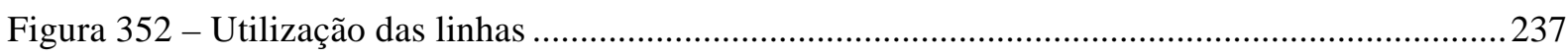

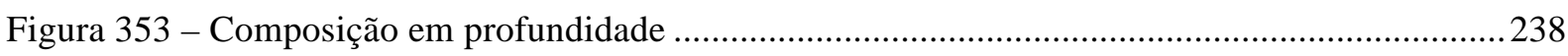

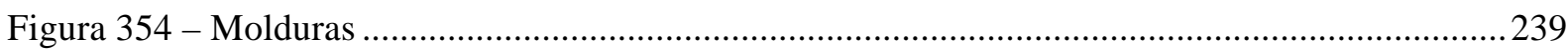

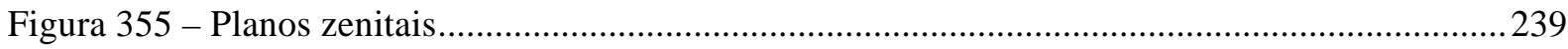

Figura 356 - Primeiros planos e planos de observação .......................................................................240

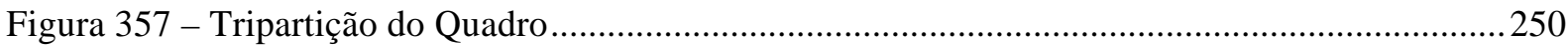




\section{SUMÁRIO}

\section{ELEMENTOS PLÁSTICOS}

1.1. Linha 36

1.2. Contraste Luminoso 47

1.3. Cor 55

2. IMAGEM TÉCNICA E O SISTEMA FOTOGRÁFICO 67

2.1. Variáveis do sistema fotográfico 71

2.1.1. Sensibilidade 72

2.1.2. Obturador 74

2.1.3. Diafragma 77

3. ESTRUTURA DA IMAGEM 83

3.1. De onde vejo 83

3.2. O que vejo 85

3.3. Como vejo $\quad 92$

3.3.1. Velocidade 92

3.3.2. Movimento 93

4. ANÁLISES 98

4.1. Terra Estrangeira (1995), Walter Salles e Daniela Thomas 102

4.2. Central do Brasil (1998), Walter Salles 120

4.3. Lavoura Arcaica (2001), Luiz Fernando Carvalho 146

4.4. Abril Despedaçado (2001), Walter Salles 167

4.5. Madame Satã (2002), Karim Aïnouz 184

4.6. Heleno (2011), José Henrique Fonseca 199

4.7. O Filme da Minha Vida (2017), Selton Mello 213 
REFERÊNCIAS 
"No mínimo, uma abordagem que enfatize o estilo e a forma pode ajudar os espectadores a apreciar melhor os filmes que veem, e ao mesmo tempo fazer com que os aspirantes a diretores sejam mais conscientes da série de escolhas possíveis."

David Bordwell 


\section{INTRODUÇÃO}

Os retratos feitos por um fotógrafo traduzem uma certa identidade. O fotógrafo busca a identidade de seu modelo e, ao mesmo tempo, uma expressão própria (CARTIER-BRESSON, 1994, p. 228).

Nos estudos de cinema, existe uma tendência em tratar os profissionais criativos envolvidos na realização de um filme como meros colaboradores, creditando todas as decisões ao diretor de cena, a quem, em geral, atribui-se a autoria de um filme. De fato, a tarefa de analisar filmes tendo como foco a visão de um único agente é mais simples, uma vez que esse tipo de estudo deixa de lado as complexas circunstâncias que envolvem a produção e as interações entre artistas e técnicos que nela trabalham.

Ao centrar o estudo na atuação do diretor de fotografia, algumas dificuldades impõemse ao pesquisador. A primeira delas refere-se à escassa bibliografia sobre o tema. Há muita informação sobre diretores de cena e poucos escritos sobre diretores de fotografia e história da cinematografia, tanto sob a perspectiva estética quanto a tecnológica. Muito desta escassez bibliográfica deve-se ao fato da importância da cinematografia não ser unanimidade entre os autores. Alguns acreditam que ela seja parte crucial na elaboração estética da obra, outros entendem que ela é apenas um meio para que o diretor de cena atinja seus objetivos. Alfred Hitchcock (1899-1980), por exemplo, afirmava que a cinematografia era apenas uma forma de registrar em celuloide as ideias do diretor, não creditando ao diretor de fotografia um papel importante no resultado de seus filmes.

Na dissertação de mestrado A fotografia do conflito, em que me propus a estudar o trabalho do fotógrafo Eduard Tissé (1897-1961) nos filmes do diretor Sergei Eisenstein (1898-1948), percebi o árduo caminho que teria que trilhar para reunir apenas algumas páginas de informações satisfatórias sobre a atuação desse importante diretor de fotografia. Para não incorrer em erros, acabei por creditar a visualidade dos filmes estudados à parceria entre Tissé e Eisenstein.

Outro desafio à pesquisa, refere-se à necessidade de um conhecimento mínimo sobre a técnica de captação da imagem cinematográfica. Profissionais com um conhecimento mais profundo sobre o assunto dedicam-se, em geral, à prática, e não interagem com os meios acadêmicos. Desse modo, estudiosos do cinema acabam tendo poucas oportunidades de compreender o assunto que estão a discutir e às vezes apresentam erros conceituais em seus textos. 
O presente trabalho é fruto de questionamentos surgidos nos mais de vinte anos de minha atuação como profissional da imagem. Em um primeiro momento, ainda como assistente de câmera, fui testemunha do processo criativo dos vários diretores de fotografia com quem trabalhei, um período importante para a formação da minha própria metodologia de trabalho. Ao longo desses anos, entendi como a atuação do fotógrafo é crucial para o resultado estético dos filmes, ainda que grande parte de sua criação seja posteriormente atribuída ao diretor de cena. Assim, coloco-me ao lado dos autores que consideram a cinematografia como um objeto de estudo fundamental.

Nesses anos de atuação, percebi também a existência de uma história da cinematografia que não é contada. Uma "história oculta", uma vez que tanto a crítica quanto os estudos acadêmicos, pelos motivos anteriormente elencados, ainda não acessaram com a devida profundidade.

Nesta mesma linha de raciocínio, o historiador Christopher Beach (1959- ), na introdução de seu livro A hidden history of film style, identifica uma tendência em tratar o diretor como criador do filme e aponta a necessidade de se romper com a noção do diretorautor, evidenciando o papel do diretor de fotografia na produção da imagem cinematográfica. Beach traz como premissa o argumento de que o cinema é resultado de uma colaboração interativa entre tecnologia e arte, em que as funções do diretor de fotografia e do diretor de cena não são rigidamente fixadas, tampouco mutuamente excludentes. Não cabe a um as decisões técnicas e a outro as decisões estéticas. Além de ser responsável por introduzir e aprimorar novas tecnologias visuais aos filmes, o diretor de fotografia também toma decisões esteticamente motivadas com relação à composição da imagem, ao emprego da luz e da cor.

Portanto, seria limitada a noção de que o trabalho do diretor de fotografia restringe-se a permitir que o diretor de cena conte histórias de forma mais eficaz. Esse tipo de visão ajuda a perpetuar a imagem do diretor-autor e a do diretor de fotografia apenas como um técnico a seu serviço. Há evidências de que desde o início do cinema esses dois profissionais trabalham juntos como parceiros criativos, sendo possível elencar muitos casos de utilização expressiva da fotografia no cinema e uma longa relação de cinematógrafos de destaque ao longo de sua história. O importante a evidenciar nesta trajetória é o fato do trabalho das equipes ter sido balizado por paradigmas estabelecidos por movimentos hegemônicos em um período de tempo ou localidade, de modo que a atuação criativa do diretor de fotografia teve momentos de maior ou menor liberdade.

Segundo Jacques Aumont (1942- ), quer o fotógrafo trabalhe com maior ou menor liberdade criativa, sua expressão nunca é absoluta, "mas sempre relacionada com um conjunto 
de convenções, com um sentido comum do que é admissível, normal, ou extraordinário - em resumo, com um estilo" (AUMONT, 1993, p. 285).

A noção de estilo remete a duas realidades: o estilo do grupo, caracterizado pelas convenções de um período ou escola, e o estilo individual, definido pela expressão pessoal de cada artista que trabalha dentro de um grupo, época e/ou local.

Uma investigação sobre estilo de diretores de fotografia levanta questões sobre o trabalho colaborativo entre esses profissionais e os diretores com quem trabalham, bem como sobre o desenvolvimento da visualidade no cinema.

Na cinematografia contemporânea, é possível observar a coexistência de vários estilos fotográficos, uma vez que existe a preocupação em se trabalhar um conceito para cada filme. A fotografia é criada a partir do roteiro e das referências e concepções do diretor de fotografia e do diretor de cena. Portanto, um diretor de fotografia pode trabalhar de forma muito distinta nas diversas obras que executa. Ainda assim, seria possível atribuir um estilo ao diretor de fotografia? Há traços comuns nas obras que evidenciam sua autoria?

Não seria possível responder essas perguntas de forma generalizada, pois em se tratando de estilo pessoal, cada caso exigiria uma análise minuciosa da obra do diretor de fotografia para que se tentasse evidenciar esses traços. É possível, contudo, estabelecer uma metodologia de trabalho aplicável à investigação dos casos particulares, que permita elucidar o papel de alguns diretores de fotografia na criação dos filmes.

Segundo o teórico David Bordwell (1947- ),

\begin{abstract}
Em vez de entender a história do estilo como um molde geral, dentro do qual todos os diretores devem ser enquadrados, tentei mostrar que as continuidades e descontinuidades que encontramos na história do cinema são mais bem compreendidas como o resultado de agentes humanos trabalhando nas instituições e explorando a capacidade da mídia de realizar certas funções, quase sempre por tentativa e erro (BORDWELL, 2008, pp.308 e 309).
\end{abstract}

Trabalhando por comparação e indução, Bordwell parte de casos concretos e posteriormente amplia para tendências maiores, apenas para explicitar as escolhas e influências dos diretores. Segundo o Dictionary of Film Studies, Bordwell pertence a uma geração de teóricos neoformalistas, que analisam a narrativa e estética dos filmes a partir de seus padrões internos, de sua forma. Desse modo, vai contra a corrente dos estudos cinematográficos que interpretam o fenômeno fílmico dentro de conceitos históricos e culturais. E justifica sua metodologia: 
Uma história social das mídias não é necessariamente uma rival da poética do cinema; cada uma estuda simplesmente aspectos diferentes de um fenômeno múltiplo (BORDWELL, 2008, p. 310).

O princípio básico que norteia as análises formalistas deriva do pensamento do filósofo Georg Wilhelm Friedrich Hegel (1770-1831), estabelecido em seu Curso de Estética. Segundo Hegel, a arte é uma produção humana, um processo que resulta do espírito na realização de sua liberdade. Ao considerar subjetividade e razão como construções históricas da existência humana, insere a criação artística no bojo da dinâmica social, uma vez que o repertório cultural do artista acaba por se materializar na expressão de seu espírito. Para Hegel, a autonomia pessoal absoluta não existe, posto que o ser humano está inserido em um contexto. O artista pode questionar ou superar as reflexões de sua cultura e seu tempo histórico, mas ainda assim, tais reflexões encontram-se presentes em sua criação. Se a arte é produto do pensamento humano, a forma torna-se a ideia visível, um veículo que se adequa a um conteúdo. Desse modo, por meio da forma seria possível compreender a obra, a sociedade que a produziu e o artista que a concebeu.

Bordwell analisa o estilo do filme a partir do ofício do diretor de cena. Utilizando sua metodologia, analisaremos aqui o trabalho do diretor de fotografia, agente histórico com poder decisório e permeado pela cultura. Partindo de casos concretos, ou seja, dos filmes, investigaremos a existência de traços visuais recorrentes, evidenciando um estilo pessoal.

Partimos do princípio de que o estilo se forma a partir de um certo número de escolhas, ou seja, pressupõe intencionalidade e decisões. Tais escolhas, independentemente de suas motivações e contexto, resultam da resolução de problemas específicos de suas tarefas e estão impressas nas imagens. É fundamental, portanto, analisar a imagem em si, considerando os elementos que a constituem, para a partir dela estudar seu autor.

A metodologia centra-se na avaliação dos elementos formais de composição da imagem cinematográfica e também em seus aspectos de imagem técnica, que resultam em uma visualidade específica.

O primeiro capítulo do trabalho foca os elementos plásticos do quadro cinematográfico e os aspectos compositivos da imagem. Uma pesquisa que investiga o trabalho de diretores de fotografia não pode restringir-se a métodos analíticos específicos do cinema, pois a imagem cinematográfica, apesar de suas especificidades como imagem técnica, pertence ao campo de estudo mais amplo das artes visuais. $\mathrm{O}$ cinema tem em comum com a pintura a planaridade do suporte, o emprego de elementos composição e as escolhas de 
ângulos de tomada. Desse modo, serão abordados três elementos de composição comumente estudados na pintura, fundamentais para a análise da imagem fílmica: linha, contraste luminoso e cor.

A linha tem movimentos, direções, e intensidades, a partir dos quais constrói formas e tramas. A forma engendra espaços e os espaços engendram profundidades. A luz na forma engendra volumes, espaços, profundidades e cor. Entende-se, portanto, que estes três elementos são estruturantes na composição da imagem.

Também serão apresentadas ferramentas do software Adobe Photoshop, por meio das quais é possível analisar com precisão alguns dos elementos plásticos abordados. Os instrumentos norteiam a avaliação aprofundada de cor e contraste, embasando quantitativamente as impressões resultantes de uma análise qualitativa.

O Capítulo 2 trata da cinematografia como imagem técnica, variáveis do sistema fotográfico que implicam em diferentes resultados de linguagem. A fotografia constitui um sistema em que a sensibilidade da película (ou do sensor), a escolha da lente, da velocidade do obturador e da abertura do diafragma estão intrinsecamente ligadas. A quantidade de informação de um sistema fotográfico está diretamente relacionada à quantidade de energia luminosa que entra nesse sistema. Maior quantidade de luz permite o uso de uma sensibilidade menor (grão mais fino), obturador mais rápido (menor blur) e diafragma mais fechado (maior profundidade de campo). Entretanto, nem sempre o objetivo é maximizar a informação dessas variáveis. O diretor de fotografia interfere no sistema fotográfico, de modo que suas escolhas técnicas têm um resultado imediato na linguagem do filme, agregam sentido e criam a poética da imagem.

O Capítulo 3 dedica-se ao estudo da estrutura da imagem, ou seja, a combinação dos elementos plásticos e técnicos, que constituem três patamares na construção de uma visualidade: de onde vejo, o que vejo e como vejo.

O Capítulo 4 é dedicado à analise de filmes fotografados por Walter Carvalho. A investigação de estilo só pode ser feita caso a caso. A escolha de Walter Carvalho como objeto de estudo deve-se a uma admiração pessoal por seu trabalho, mas sobretudo pela relevância deste diretor de fotografia na história recente do cinema brasileiro.

Walter Carvalho nasceu na Paraíba, em 1947, e iniciou suas atividades no cinema em 1973, fotografando os filmes de seu irmão, o cineasta Vladimir Carvalho (1935-). Hoje, com mais de sessenta filmes no currículo, é um dos principais diretores de fotografia em atividade no Brasil. 
Foram escolhidos sete filmes, que compreendem parte de sua produção entre 1995 e 2017: Terra Estrangeira (1995), Central do Brasil (1998), Lavoura Arcaica (2001), Abril Despedaçado (2001), Madame Satã (2002), Heleno (2011) e O Filme da Minha Vida (2017). Estudar toda a produção deste diretor de fotografia seria tarefa inviável para o período de tempo permitido a uma tese de doutorado. Entretanto, trabalhar com um número menor de obras comprometeria a avaliação da identidade presente em seu trabalho. Assim, a escolha do corpus fílmico teve por base uma amostra considerada significativa para identificar os traços de estilo.

A análise toca em elementos que não são atributos diretos do diretor de fotografia. A imagem cinematográfica está ligada à representação, portanto elementos de roteiro, construção de personagens, cenografia, som e montagem também são referenciados. Segundo Aumont, "os cineastas que pensam a imagem, pensam-na como uma representação afetada por um maior ou menor coeficiente formal (...) mas sempre como uma representação" (AUMONT, 2004, p. 53). Desse modo, a análise da imagem fílmica não pode deixar de lado a obra que representa, pois imagem e narrativa encontram-se atreladas.

Aumont faz uma importante distinção entre filme e cinema:

o cinema não é o filme: uma teoria de cinema, e sobretudo uma teoria de linguagem, visa a um objeto teórico, o cinema, que não deve ser confundido com o filme. $\mathrm{O}$ cinema é um modo de apreensão e de visão da realidade, comparável, por exemplo à imaginação (...) o cinema é virtual e indefinido, como a percepção, como estar no mundo, já o filme é uma obra finita, mostra as coisas fixando-as e interpretando-as (AUMONT, 2004, p. 31).

Ainda segundo Aumont e Michel Marie (1945-), não existe um método universal para análise de filmes, que é sempre interminável (AUMONT e MARIE, 2015, p. 29). O enfoque do presente trabalho é o de uma teoria estética da cinematografia. A estética constitui uma especialidade da filosofia que estuda o belo, que como objeto de investigação diferencia-se do sentido comumente empregado como conotação de beleza, e abarca reflexões sobre os fenômenos de significação considerados artísticos. A estética do cinema apresenta-se em dois aspectos: uma vertente geral, que estuda os elementos plásticos do cinema, e uma vertente específica, centrada na análise de obras.

Trabalharemos aqui a vertente específica. Partindo-se da análise de filmes, verificaremos se os elementos recorrentes nas imagens seriam capazes de configurar um estilo pessoal deste diretor de fotografia, ou seja um cinema de Walter Carvalho. 


\section{ELEMENTOS PLÁSTICOS}

Poderia alguém contar uma história visualmente sem guiar nossa atenção para conteúdos pertinentes sobre os protagonistas, suas ações e tudo mais? (BORDWELL, 2008, p. 339)

Os planos de um filme, organizados pela montagem, conduzem o espectador pela narrativa. Mas se considerarmos o interior de um plano, as estratégias pictóricas de composição podem ser utilizadas para este fim. Apesar das especificidades do cinema e da pintura, há pontos em comum entre as duas artes, principalmente no que tange a composição em uma superfície bidimensional. Para narrar visualmente é necessário dispor elementos no espaço da tela. Esta configuração espacial é fundamental para a produção de traços e trajetórias que são seguidos pelo espectador.

Ao olhar uma imagem, o espectador confronta o seu espaço real com o espaço da superfície da imagem, também denominado espaço plástico. Assim como é possível distinguir as palavras de uma frase, é possível apreender os conteúdos de uma imagem por meio dos elementos trabalhados pelo autor em sua configuração espacial.

Chamamos de busca visual ao processo de exploração em detalhe de uma cena. No livro A imagem, Jacques Aumont esclarece que a varredura da imagem não se dá de forma regular, o olho humano fixa-se em regiões com maior quantidade de informações e o percurso entre as regiões não obedece uma ordem explícita. Entretanto, é possível observar dois padrões que guiam a trajetória do olhar, o primeiro relaciona-se à introdução de uma ordem particular, o segundo refere-se à presença da figura humana na imagem (AUMONT, 1993, pp. 60 e 61).

A importância do primeiro padrão centra-se no maior ou menor dinamismo que a disposição dos elementos promove na leitura do espaço plástico. Neste sentido, Rudolph Arnheim (1904-2007), filósofo e psicólogo que estudou a percepção visual na arte, afirma que a percepção dos objetos não se dá de forma isolada, a visão os relaciona no espaço de forma dinâmica por meio de ordens espaciais de escala de tamanhos, luminosidade e distância, e que o observador é guiado por tensões entre os elementos da imagem (ARNHEIM, 2002, p. 21). Segundo Arnheim, no centro de qualquer composição as forças se equilibram e um objeto posicionado fora de centro adquire uma instabilidade que o faz tender ao movimento. Assim, o posicionamento dos objetos é fundamental para promover o caráter estático ou dinâmico da composição. 
Uma imagem pode ser ordenada por meio de contrastes ou semelhanças de seus elementos compositivos, alternativas que não são excludentes. Quando a composição é feita por semelhanças formais o resultado expressivo é a configuração de sequências rítmicas, uma vez que a visão humana percorre os elementos com relativa rapidez. Por outro lado, uma composição por contraste produz tensões espaciais, dado que há interrupções momentâneas da continuidade visual. Os dois modos de ordenação, portanto, impactam a leitura da obra e consequentemente seu conteúdo.

Como exemplo de ordenação por semelhança de linhas e superfícies podemos citar Ancient sound, abstract on black (1925) do pintor Paul Klee (1879-1940). Nesta obra, o artista cria ritmo por meio da repetição de uma mesma forma geométrica, e trabalha as tonalidades de alguns poucos matizes, gerando um espaço fluido por meio da luz e da cor.

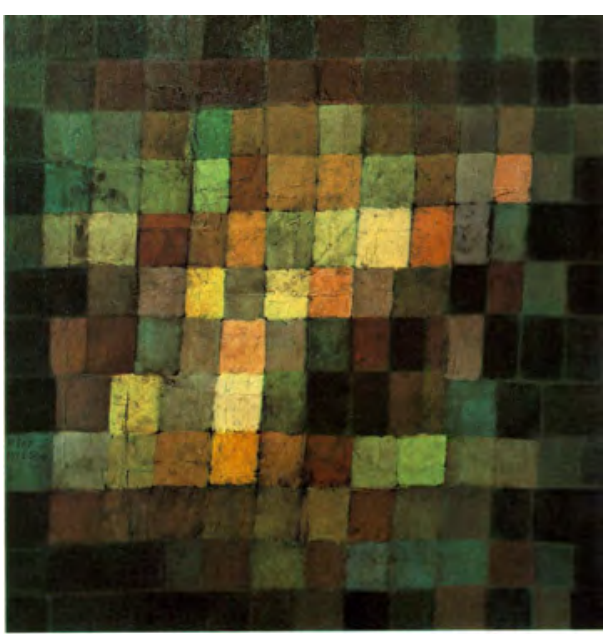

Fig. 01 - Ancient sound, abstract on black (1925), Paul Klee

Por outro lado, o quadro Composição 8 (1923) de Wassily Kandinsky (1866-1944) é um exemplo de composição por contraste. Kandinsky cria movimento visual contrastando linhas, formas geométricas e cores. Ao contrário da fluidez criada por Klee, a ordenação estabelecida por Kandinsky traz tensões visuais à obra.

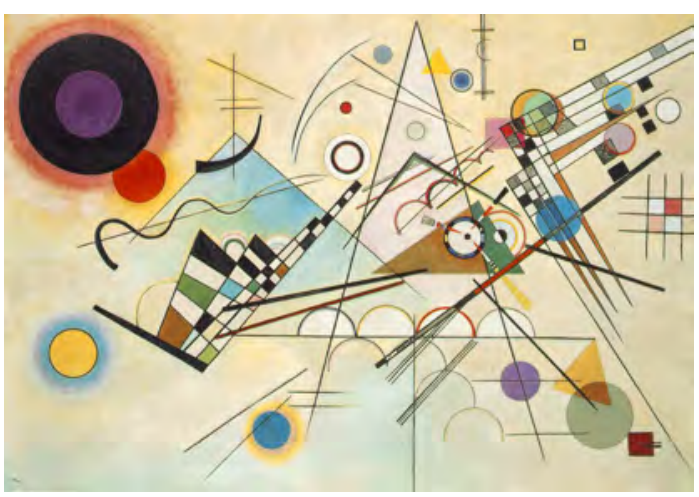

Fig. 02 - Composição 8 (1923), Wassily Kandinsky 
No caso de ausência de representação figurativa, como nos exemplos anteriores, o olhar guia-se por ordenações dos elementos, ocorrendo associações expressivas durante sua leitura. Com a presença da figura humana em quadro, o que geralmente ocorre no cinema narrativo, o segundo padrão de leitura apontado por Aumont é acionado, sem que o primeiro deixe de atuar. Ainda que ocupe uma pequena porção da imagem, existe uma tendência de que o olhar concentre-se na figura humana.

Podemos tomar como exemplo a obra $O$ artista em seu estúdio (1626-28), de Rembrandt van Rijn (1606-1669), um dos expoentes da Era de Ouro da pintura holandesa. O quadro observado pelo artista é o maior elemento da composição, e ocupa o primeiro plano. Entretanto, o olhar do espectador é atraído pela figura do pintor, ainda que ocupe menor proporção, esteja ao fundo e menos iluminado que o quadro no cavalete. Ao retirarmos a figura humana da composição, o centro de atenção deixa de ser o artista e passa a ser o cavalete em primeiro plano.
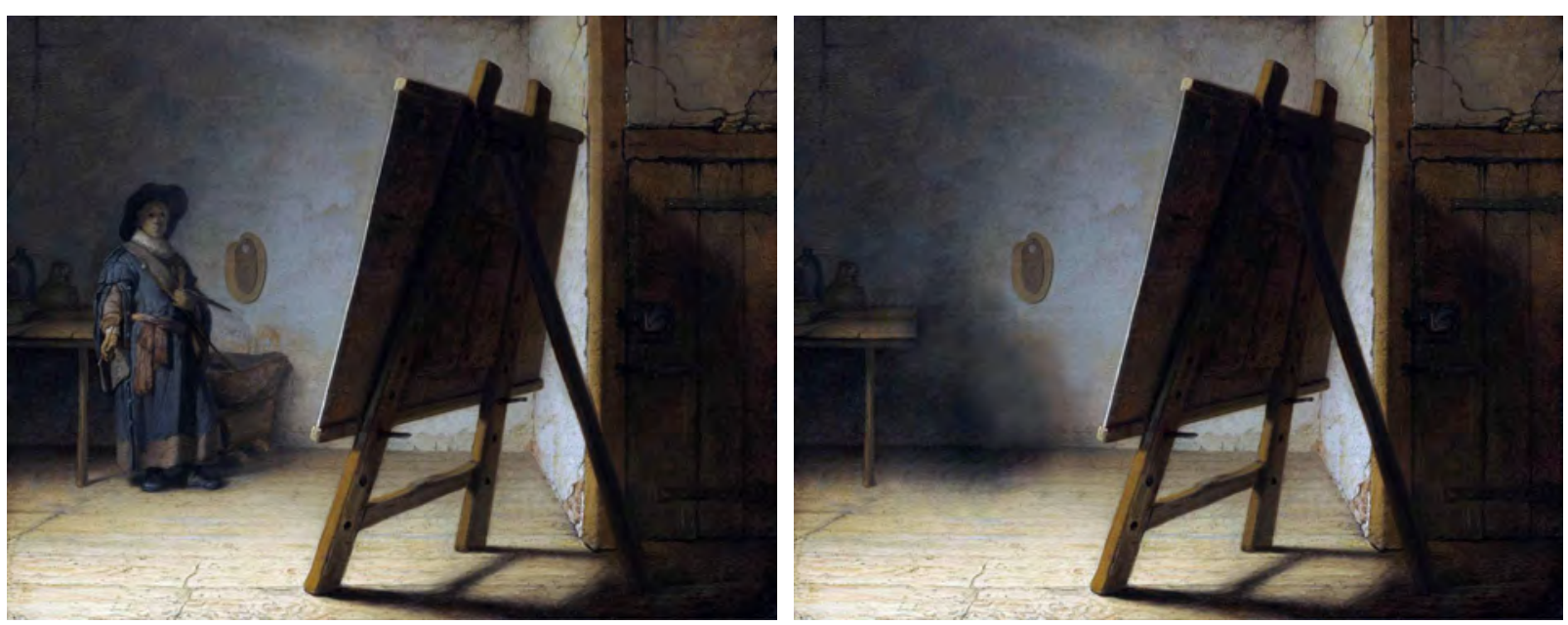

Fig. 03 - O artista em seu estúdio (1626-28), Rembrandt van Rijn

Já em Cabeça de um homem velho (Head of an old man, 1632), Rembrandt centra a composição na figura do homem, trabalhando as camadas de tinta para mostrar o movimento das massas em direção à luz. Assim, o quadro não traz um conjunto de detalhes separados, mas um movimento entre luz e sombra, que dá materialidade ao modelo. Um artista pinta o que para ele é significativo em sua observação do mundo. Através do seu olhar, ele mostra como "pensa" o mundo, qual é sua atitude, sua capacidade de ver e de sintetizar o que vê. 


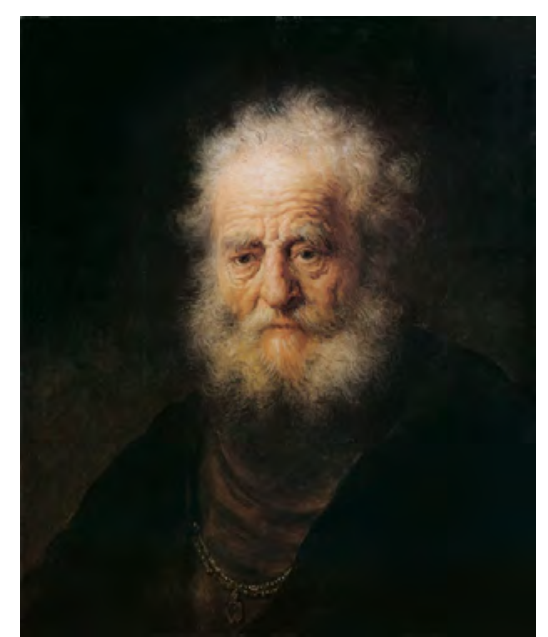

Fig. 04 - Cabeça de um homem velho (1632), Rembrandt

No documentário Humano - Uma viagem pela vida (Human, 2016), de Yann ArthusBertrand, a imagem centra-se nos personagens. Com uma composição semelhante à de Cabeça de um homem velho, as figuras parecem emergir do fundo escuro em direção à luz. Composto de entrevistas com personagens reais ao redor de todo o mundo, o filme dirige o olhar do espectador às expressões dos entrevistados, no intuito de centrar a atenção em seus discursos. Nada distrai o espectador: o fundo é neutro, o personagem é o único elemento em quadro, existe apenas uma fonte de luz suave direcionada ao rosto do depoente, que olha para a câmera, estabelecendo uma relação com o espectador. Trata-se de um exemplo da importância da composição para a apreensão de conteúdos, uma vez que a imagem do filme é decisiva para que se compreenda o sentido do que é ser "humano".

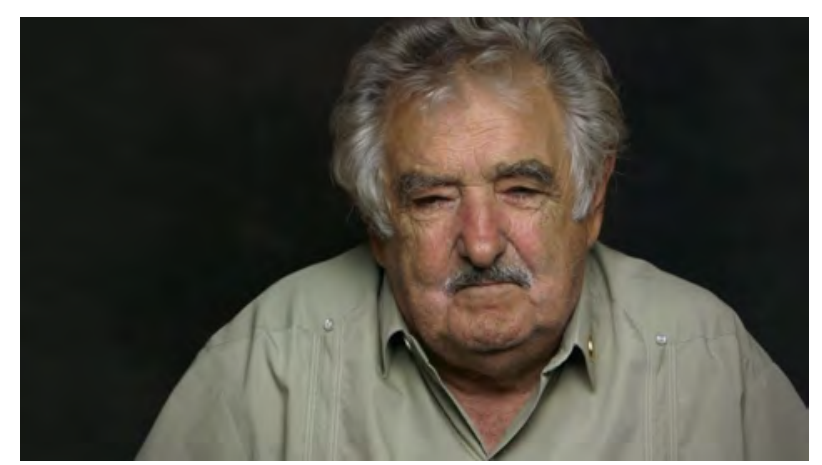

Fig. 05 - Human (2016), Yann Arthus-Bertrand

Ao criar uma imagem, o autor deve levar em conta determinados fatores da percepção humana para que forma e conteúdo estejam em conexão. Entretanto, é importante notar que apesar da intencionalidade do autor, a validade da afirmação artística não é puramente objetiva. Uma imagem não se impõe a todos os observadores da mesma forma, uma vez que as associações também são estimuladas cultural e individualmente. Ainda assim, Arheim 
afirma que as formas visuais não se separam do que elas dizem, que "a composição total faz uma afirmação que não podemos desprezar" (ARNHEIM, 2002, p. 16).

É possível investigar a validade do pressuposto de Arnheim por meio da análise de duas representações da última ceia: a de Leonardo da Vinci (1452-1519) e a de Jacopo Robusti (1518-1594), conhecido como Tintoretto. Ambas retratam a mesma narrativa bíblica, mas as escolhas estéticas e técnicas resultam em visualidades completamente distintas, que influenciam de forma determinante o sentido da imagem.

A obra de da Vinci foi pintada no monastério da Igreja de Santa Maria Delle Grazie (Milão), entre 1495 e 1497, utilizando a técnica do afresco. Foi projetada em perfeita simetria, enfatizada pela disposição de portas e janelas, com o rosto de Cristo ocupando o centro do mural e da mesa. Seu olho direito é o ponto de fuga da perspectiva, centro de convergência de todas as linhas. A composição é ordenada pela semelhança de volumes e luz.

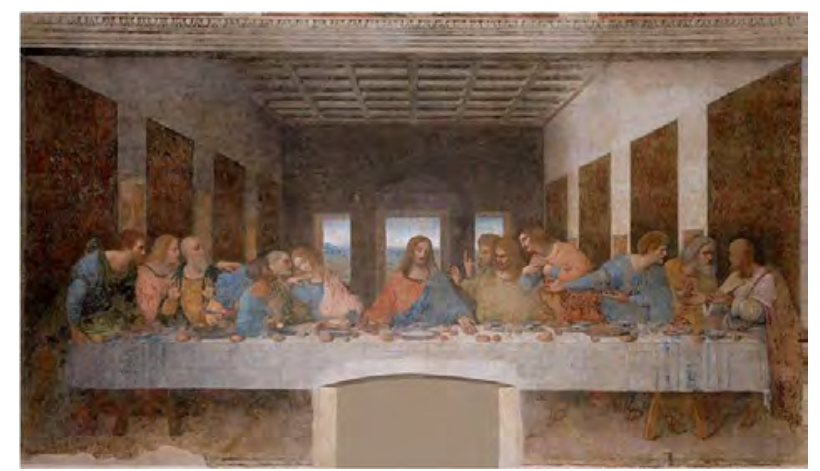

Fig. 06 - A última ceia (1495-1497), Leonardo da Vinci

Apesar da calma e serenidade no rosto do Cristo, a composição não é estática. $\mathrm{O}$ movimento da cena é observado nos gestos e expressões dos doze apóstolos, seis de cada lado da mesa, divididos em grupos de três.

Tintoretto, por sua vez, pintou o quadro em 1594, utilizando a técnica do óleo sobre tela (figura 07). A obra não é simétrica, a composição é caracterizada por um preenchimento desigual do espaço, com algumas regiões em que há concentração de figuras e outras onde predomina o espaço vazio.

A cena principal acontece em um plano mais ao fundo e as figuras do primeiro plano são secundárias dentro da narrativa. Jesus e os apóstolos não se destacam como protagonistas da ação, havendo uma desvalorização do indivíduo em favor do grupo. A ênfase no Cristo, evidente na obra de Leonardo, é transposta por Tintoretto para o conteúdo da comunhão, explicitado por meio da divisão do pão. 


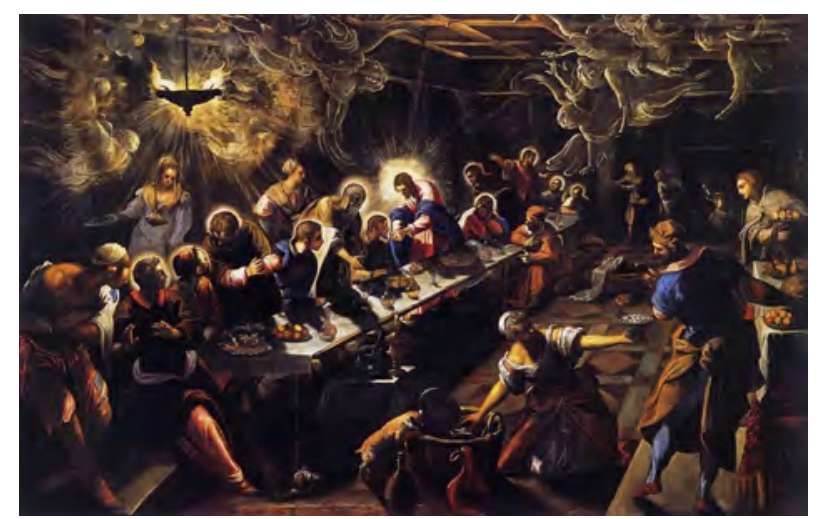

Fig. 07 - A última ceia (1594), Tintoretto

A figura do Cristo não se destaca nem pelo tamanho, nem pela convergência do ponto de fuga, entretanto, de sua cabeça emana a luz que ilumina a cena. Enquanto na obra de da Vinci a composição é ordenada pelas linhas de perspectiva, no quadro de Tintoretto é a luz contrastada que ordena a composição. $\mathrm{O}$ contraste luminoso cria uma atmosfera muito distinta da serenidade que emana do sfumato suave e plano da obra de Leonardo. Tintoretto optou por não dar ênfase aos detalhes e enfatizou o movimento da composição pelas linhas curvas do posicionamento dos personagens e pela diagonal da mesa.

A comparação entre as duas imagens nos permite compreender como as escolhas plásticas e técnicas influenciam a poética visual. A técnica deixa de ser neutra pois reflete as decisões do autor no sentido do que pretende comunicar, impactando diretamente o resultado da obra. Os elementos de composição utilizados pelo artista influenciam o conteúdo que pode ser apreendido na imagem. Desse modo, técnica e poética, forma e conteúdo, são indissociáveis.

O que vemos aqui são duas gerações com valores e expectativas diferentes, e duas personalidades que apresentam suas visões de mundo traduzidas na composição artística. Leonardo representa o momento em que o Cristo anuncia a existência de um traidor entre eles, portanto um momento de divisão do grupo. Tintoretto, por sua vez, representa outro momento da ceia, o da comunhão.

$\mathrm{Na}$ introdução do livro Arte e ilusão, o historiador da arte Ernst Gombrich (19092001) coloca um dado fundamental para o estudo do estilo: "A profissão do historiador da arte baseia-se na convicção certa vez formulada por Wölfflin de que 'nem tudo é possível em todos os períodos"'(GOMBRICH, 1986, p.4). Desse modo, a produção de um artista encontra-se estritamente vinculada ao momento em que foi produzida.

No Renascimento italiano, contexto artístico em que Leonardo produziu sua obra, o ser humano ocupava um lugar central. A pintura buscava representar os ideais de beleza 
inspirados na antiguidade greco-romana. Os modelos eram idealizados, as composições deveriam ser claras, limpas, buscando a simetria. A obra de Leonardo mostra a permanência de uma ordem, tão valorizada no período do Renascimento italiano, ainda que retrate um momento de conflito. Os paradigmas do período estão presentes na ceia de Leonardo, mas a pintura possui características que evidenciam um estilo pessoal, como a utilização do sfumato, técnica que atenua as linhas do desenho de forma a amenizar seus contornos.

No final do século XVI, os artistas passaram a mergulhar na multiplicidade das coisas, nos fluxos da vida, no movimento, e passaram a buscar composições mais dinâmicas. Neste contexto surgiu a Arte Barroca. Tintoretto, que viveu durante a transição entre o Renascimento e o Barroco, produziu em um momento em que a visão de mundo não compactuava com um ordenamento explícito das coisas. Seu quadro reflete esta visão de mundo menos ordenada, mais dramática, na qual mesmo um momento de comunhão apresenta conflitos e a insegurança da condição humana. $\mathrm{O}$ espaço é representado por meio da diagonalidade, e é desta forma que se movem os elementos humanos e sobre-humanos no quadro.

Da Vinci e Tintoretto trabalham suas visões de mundo por meio da materialidade da obra. O cinema, ainda que se caracterize por uma projeção de luz, tem sua materialidade assegurada pelo suporte da imagem e pela tela. Tanto a imagem pictórica quanto a imagem fílmica possuem limites com os quais os artistas necessitam lidar para compor suas obras: enquadramento e bidimensionalidade. No caso do cinema, o tempo certamente constitui um terceiro limite, uma vez que durante o movimento o quadro se altera. As questões relativas ao tempo e ao movimento serão alvo do segundo capítulo deste trabalho, uma vez que se relacionam à imagem técnica.

O termo enquadramento é proveniente do quadro pictórico. Refere-se ao limite físico da imagem, à separação entre o que pertence a ela e o que está fora dela. Este limite está ligado ao suporte da imagem, isto é, à tela no caso da pintura, e ao negativo ou sensor no caso da imagem fotográfica/cinematográfica. A lente da câmera promove a convergência dos raios luminosos projetando-os sobre um suporte, que determina o recorte da imagem.

No filme Moça com brinco de pérola (Girl with a pearl earring, 2003), dirigido por Peter Webber (1968- ) e fotografado por Eduardo Serra (1943- ), há uma cena em que o pintor Johannes Vermeer (1632-1675) mostra à sua criada Griet a imagem projetada no despolido de uma camera obscura. É possível ver que a imagem é vinhetada e possui um dégradée circular, consequência do desvio da luz na lente. 


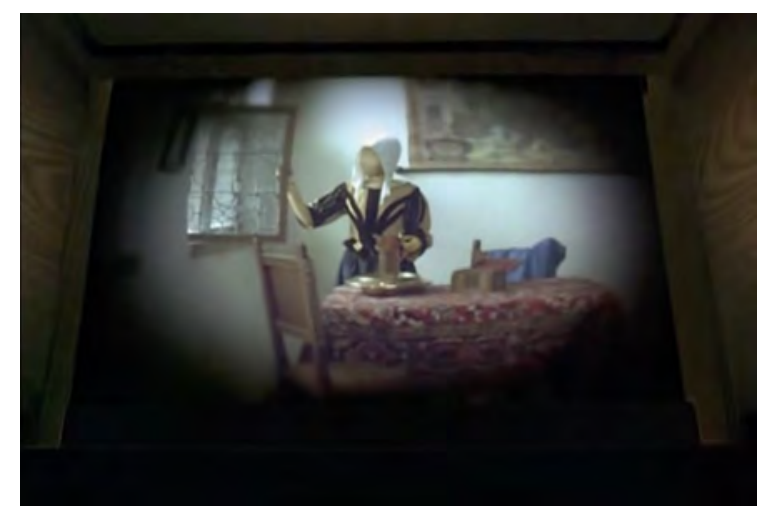

Fig. 08 - Moça com brinco de pérola (2003), Peter Webber

$\mathrm{O}$ aspecto retangular da imagem é dado pela janela da câmera analógica ou pelo sensor da câmera digital, como demonstra a figura 09.
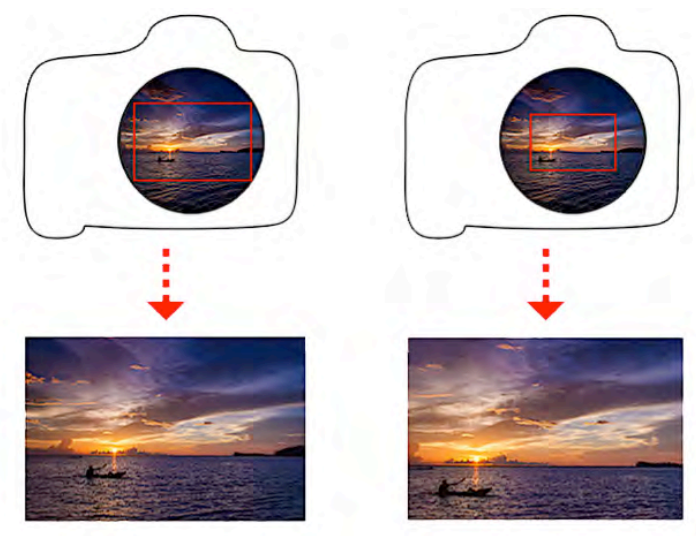

Fig. 09 - Limite dado pelo suporte

(Fonte: http://www.dicasdefotografia.com.br/o-que-e-fator-de-corte/)

O quadro desempenha um papel fundamental na composição do plano cinematográfico, uma vez que cria um espaço conceitual: o espaço fílmico. Constitui o primeiro direcionamento do olhar do espectador, pois determina o que será visto, tanto em relação ao limite da imagem quanto em relação ao ângulo de visão. Trata-se de um trabalho primordial de criação, uma vez que seleciona e organiza um fragmento do espaço real adequado à narrativa.

O segundo limite da imagem refere-se à sua planaridade. No livro Arte e percepção visual, Arnheim afirma que a representação de imagens em superfícies planas configura uma tradução, dada a impossibilidade de se reproduzir integralmente a concepção visual de volume em um único plano. Coloca-se, portanto um problema, que é o de como comunicar a tridimensionalidade de objetos no plano.

As regras para criar impressão tridimensional em imagens planas começam a ser elaboradas no início do século XV pelos pintores do Quattrocento, com a utilização da 
perspectiva linear. Trata-se de um método de representação geométrica que projeta o espaço sobre uma superfície plana, de modo que os volumes sejam reconstituídos mentalmente. Importante notar que essa busca da tridimensionalidade configura uma convenção. Tomemos como exemplo a obra Waterfall (1961), do artista Maurits Cornelis Escher (1898-1972). Para um observador acostumado a buscar na imagem a tridimensionalidade da perspectiva linear, a obra de Escher pode ser descrita como um cenário impossível, uma vez que os conjuntos de pilares estão simultaneamente no mesmo plano e em planos distintos. Entretanto, trata-se de um cenário impossível apenas sob a convenção de um tipo de perspectiva apreendida.

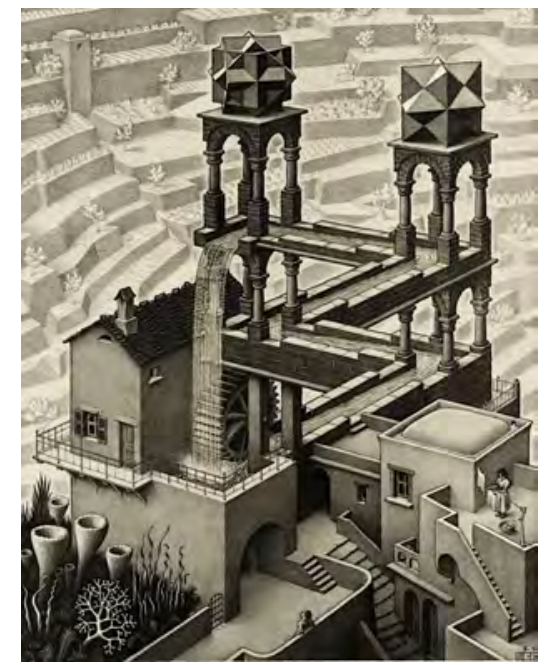

Fig. 10 - Waterfall (1961), Escher

A pintura moderna assumiu seu caráter bidimensional e ainda que utilize o conceito de profundidade, não se apoia na reprodução do mundo real. Entretanto, a questão da planaridade da tela não encontra ecos no cinema narrativo. Com algumas exceções, como no cinema experimental, em que a bidimensionalidade é muitas vezes evidenciada, os limites materiais da imagem cinematográfica são trabalhados de modo a provocar no espectador uma impressão de tridimensionalidade. Segundo Aumont, a analogia entre imagem fílmica e espaço real é tão poderosa que o espectador abstrai a bidimensionalidade e a eventual ausência de cores e sons (AUMONT, 1995, p. 24).

Ainda segundo Arnheim, um estímulo visual não é julgado em termos absolutos de percepção do mundo físico, mas em relação ao estilo de representação conhecido pelo espectador. Os filmes produzidos nos primórdios do cinema não causam no observador atual uma impressão de realidade, entretanto no século XIX impactaram profundamente as audiências não habituadas às imagens em movimento (ARNHEIM, 2002, p. 127). 
Portanto, a criação da visualidade no cinema ocorre a partir de seus limites materiais. O recorte do quadro e a bideminsionalidade impõem um tipo de pensamento para que o autor atinja seus objetivos na criação da imagem.

Partindo-se do pressuposto de que existe uma intencionalidade, ainda que intuitiva, nas escolhas do diretor/diretor de fotografia, podemos concluir que os elementos de composição são utilizados para maximizar a dimensão expressiva, produzindo traços e trajetórias para a leitura da imagem e permitindo o acesso a seus conteúdos.

São três os elementos estruturais de composição da imagem bidimensional: linha, contraste luminoso e cor. A estrutura da obra determina quais elementos estão presentes e com qual ênfase se apresentam. A análise dos elementos constitutivos de uma obra visual é importante para a compreensão de suas qualidades específicas, bem como de sua estrutura total. Vejamos de que forma esses elementos podem ser trabalhados na composição. 


\subsection{Linha}

Controlar o olhar do espectador é um processo incerto, não é possível obrigá-lo a seguir um roteiro de leitura, mas as linhas podem funcionar como guias, aumentando a impressão de tridimensionalidade da imagem ou enfatizando seu caráter bidimensional.

O termo linha refere-se aos limites das formas e suas inter-relações com o espaço. É um elemento visual que configura o espaço de uma dimensão, por meio do qual apreendemos o movimento direcional.

Em se tratando de expressividade do espaço, as linhas não são apenas elementos geométricos, mas direções vivenciadas. Assim, as horizontais remetem à ideia de repouso, calma, indicando imobilidade e estabilidade. A vertical, mesmo estando imóvel, remete à posição do homem em pé, por isso é associada ao movimento e à instabilidade. Divergindo das verticais e horizontais, e contrastando com suas qualidades estáticas, estão as diagonais, curvas e espirais, que trazem um caráter ainda mais dinâmico à imagem.

Na figura 11 podemos ver obras de dois expoentes do Neoplasticismo, movimento artístico do início do século XX que tinha como uma de suas premissas a depuração das formas para se chegar a seus componentes fundamentais: linhas, cores e superfícies. De início, os membros do movimento baseavam suas composições em uma geometria rigorosa, utilizando linhas horizontais e verticais. Na imagem da esquerda, Composição em vermelho, amarelo, azul e preto (1921), Piet Mondrian (1872-1944) busca o equilíbrio da composição utilizando linhas e massas coloridas retangulares de diversas proporções, sempre verticais, horizontais e formando ângulos retos. Posteriormente, a linha diagonal foi introduzida nas composições do neoplasticismo, como se verifica na imagem da direita, Contra-composição em dissonância 16 (1925), de Theo van Doesburg (1883-1931). Com a inclinação dos retângulos, van Doesburg tentou criar um equilíbrio mais complexo e dinâmico do que o inicialmente trabalhado no neoplasticismo.
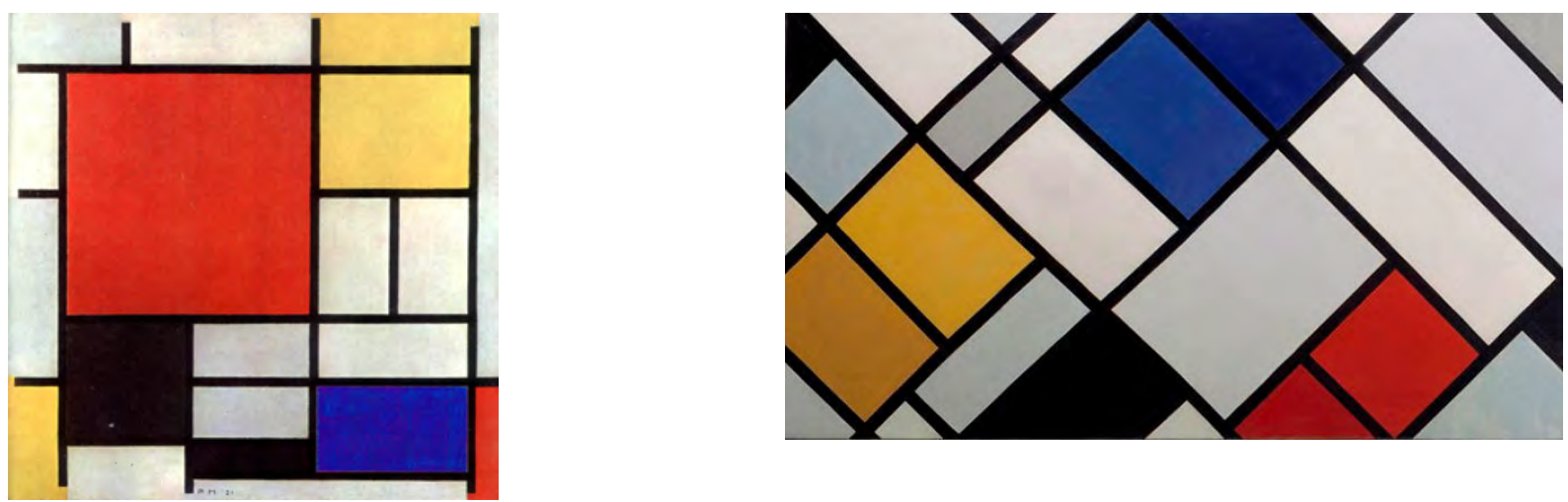

Fig. 11 - Mondrian (esq) e van Doesburg (dir) 
Além do caráter estático ou dinâmico promovido pela direção, o posicionamento no quadro confere diferentes valores de expressividade às linhas. Se forem colocadas no alto do plano, as qualidades formais que porventura existam (diagonal, horizontal, vertical, radial) são reforçadas no sentido de maior leveza e movimentação. Por outro lado, o que está na parte inferior apresenta um aspecto de maior peso, densidade e menor movimento.

A linha também possui movimento e velocidade de leitura, que podem ser modulados por meio da introdução de intervalos, funcionando como pausas. Quando há intervalos ou contrastes de direção, a velocidade do movimento é reduzida e há aumento em seu peso visual. É o que ilustra a figura 12, a linha superior tem uma leitura mais rápida do que a inferior, que possui mais intervalos e contrastes de direção.

\section{$\|1\|\|\|\|\|\|\|\|\| \|$ $x \times X X X X X X X X X$}

Fig. 12 - Movimento direcional da linha (Fonte: Universos da arte, Fayga Ostrower)

A importância da linha como elemento de composição reside no fato de que transporta o olhar e o pensamento do espectador para um determinado contexto de relações. No artigo Abstração como antítese, o historiador da arte Robert Kudielka (1945- ) interpreta o valor expressivo dos meios pictóricos no espaço do quadro como fatores deste nexo de relações. Ao analisar obras de Mondrian e Jackson Pollock (1912-1956), observa que a origem da ordem pictórica de Mondrian encontra-se na representação estética-matemática, exata, enquanto Pollock trabalha com uma fatura material que se furta à objetivação formal.

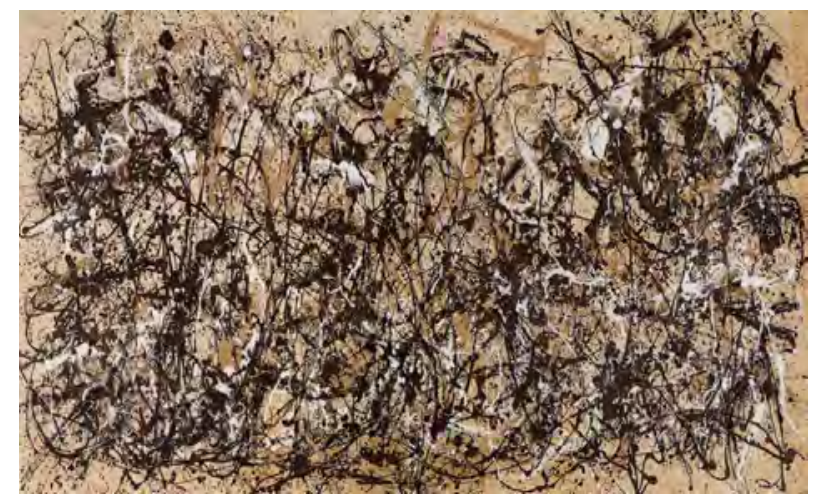

Fig. 13 - Autumn rhythm $n^{\circ} 30$ (1950), Jackson Pollock

O expressionismo abstrato, movimento artístico no qual Pollock estava inserido, surgiu nos Estados Unidos na década de 1940 e criou uma nova tendência de caráter 
simbólico e expressivo, sobretudo no que tange o sistema formal da pintura e no uso das linhas e cores.

Pollock trabalhava com uma técnica denominada action painting, que consistia em lançar a tinta sobre a tela. Não foi uma técnica inventada pelo artista, mas Pollock a utilizava como procedimento de pintura, com pragmatismo, e não apenas para o achado composicional inconsciente.

\begin{abstract}
No início dos anos 40, quando Hans Hoffmann tomou contato com a pintura de Pollock, de pronto só lhe veio esta frase professoral, que acertou na mosca: "Você não trabalha com a natureza". A resposta de Pollock foi: "Eu sou a natureza". A deixa pode ter sido dada pela doutrina surrealista do automatismo criativo. Contudo, essa réplica petulante, em toda a sua escrupulosidade, é a mais pessoal confissão de Pollock, que só desvenda todo o seu significado nos quadros clássicos do final dos anos 40. Pois a "natureza" reivindicada por Pollock não é a musa cega do inconsciente. "Eu sou a natureza" significa simplesmente: eu não sou o observador que se põe diante das coisas, e tampouco o olho que pensa em contornos - eu sou aquele que age, que busca orientar-se e articular-se em meio a seus ilimitados embaraços, indiferente à distinção teórica entre natureza e espírito, como deve proceder o artista, embora só o possa até certo grau, numa proporção humana. (KUDIELKA, 1998, p. 26).
\end{abstract}

Desse modo, enquanto a prática artística de Mondrian privilegia a forma positiva, convertendo posições formais em uma estrutura de relações no espaço do quadro, a composição de Pollock privilegia a ausência de figura e se resolve no ato de pintar. Ambos trabalham as linhas como uma estrutura rítmica original, por meio da alternância de elementos e pesos semelhantes e distintos, ordenados por Mondrian em proporções espaciais e articuladas por Pollock de forma temporal.

No espaço fílmico, a linha também aponta para um nexo de relações. Este fato pode ser evidenciado na sequência da escadaria de Odessa em $O$ Encouraçado Potemkin (1925), de Sergei Eisentein, fotografado por Eduard Tissé. A sequência não foi prevista no roteiro, nasceu do contato do diretor com a locação. "Foi a própria perspectiva da escadaria que sugeriu a ideia da cena. Foi seu lance que fez que a imaginação do diretor voasse. A fuga em pânico da multidão, voando de degrau em degrau, não fez mais que exteriorizar a minha primeira impressão da escadaria" (EISENSTEIN, 1969, p. 31).

A imagem eisensteiniana organiza-se a partir de elementos bidimensionais estruturantes, que podem ser figuras geométricas ou linhas horizontais, verticais e diagonais. $\mathrm{Na}$ escadaria, a figura plástica dominante é a diagonal, como evidenciam os fotogramas da figura 14. 

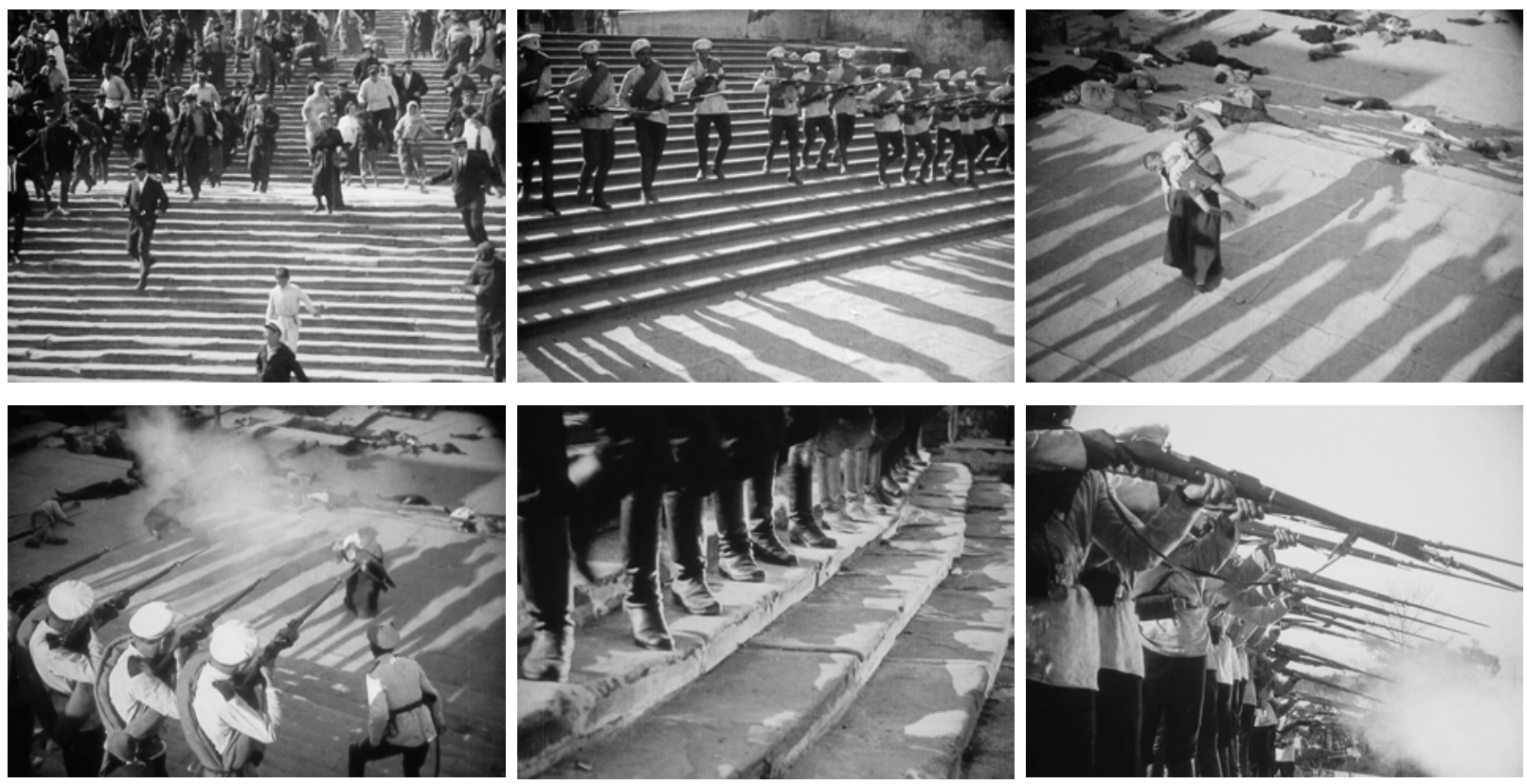

Fig. 14 - O Encouraçado Potemkin (1925), Sergei Eisenstein

As linhas criadas pelo posicionamento dos oficiais, por suas sombras, botas e armas, enfatizam as relações de conflito e de disparidade de forças presentes na sequência. Por meio das diagonais, elemento gráfico que sugere movimento em formas estáticas, o conflito entre a população e os oficiais é ampliado.

Apesar de partir de elementos bidimensionais, Eisenstein objetiva a composição em profundidade. Em seu relato, aponta a perspectiva da escadaria como motivador da cena. A perspectiva linear é um método de representação geométrica que projeta o espaço sobre uma superfície plana, de modo que os volumes sejam reconstituídos mentalmente. Assim, apesar de configurarem o espaço de uma dimensão, as linhas podem ser utilizadas para a representação tridimensional no plano.

No cinema, a perspectiva não é utilizada exatamente da mesma forma como na pintura, uma vez que a imagem é capturada fotograficamente e não pelo desenho. Entretanto, segundo Aumont, a perspectiva fílmica retoma a tradição representativa da perspectiva linear (AUMONT, 1995, p. 31) pois o aparato cinematográfico é uma herança dos dispositivos criados desde Filippo Brunelleschi (1377-1446) com o objetivo de representar a realidade por meio da perspectiva monocular.

Atribui-se ao arquiteto e escultor florentino Filippo Brunelleschi a primeira aplicação de princípios geométricos e matemáticos para o estabelecimento de regras da perspectiva linear. A figura 15 ilustra seu experimento. Primeiramente pintou sobre uma pequena prancha a visão do Batistério de Florença. Em seguida, por meio de um espelho e um orifício no 
centro do quadro, fez coincidir a pintura em perspectiva com a visão real, demonstrando a validade das leis que estabelecera.
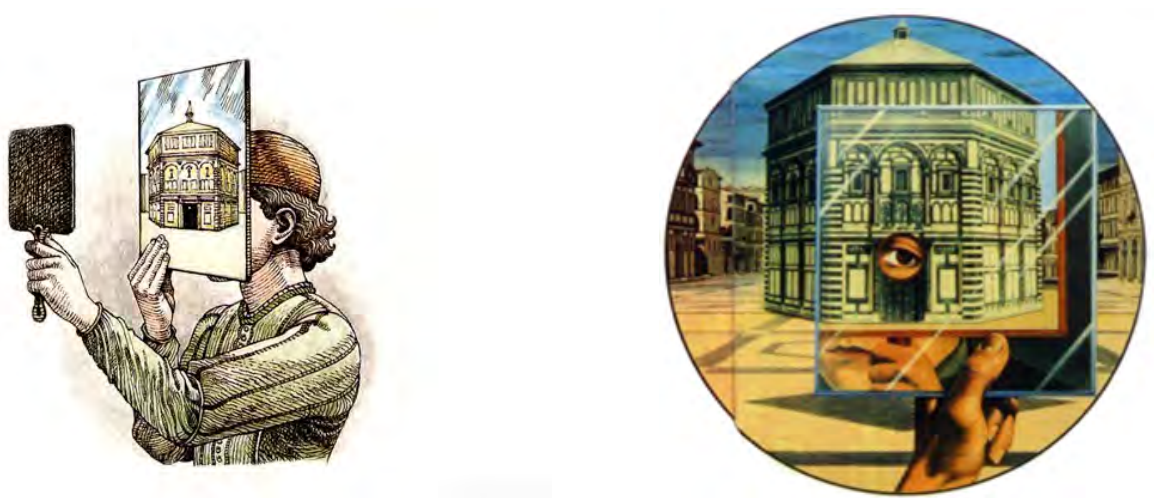

Fig.15 - Experimento de Brunelleschi

(Fonte: http://clubdedebate.blogspot.com/p/por-que-el-espacio-en-la-pintura-de-la.html)

A camera obscura é outro aparato do qual descende a câmera cinematográfica. Trata-se de um dispositivo capaz de produzir uma imagem que obedece às leis da perspectiva monocular, sem o auxílio de uma ótica. É munido de um pequeno orifício para a entrada de luz em um dos lados, que produz uma imagem projetada na superfície oposta. O princípio da camera obscura, associado ao uso de lentes e ao princípio da fixação da imagem, culminou na produção das câmeras fotográficas no século XIX.

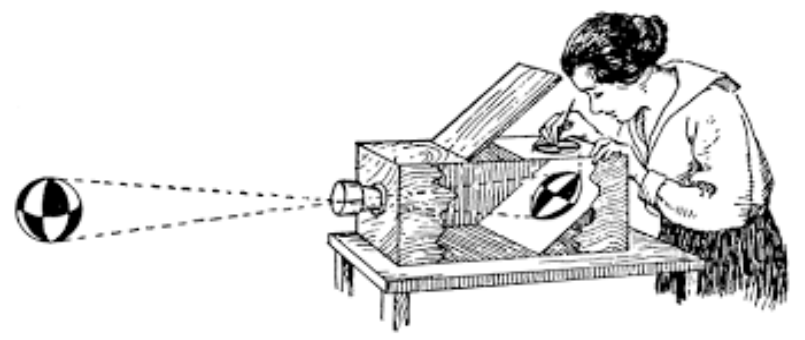

Fig. 16-Camera obscura

(Fonte: http://vidadeprofessor.pro.br/camara-escura-entenda-como-funciona-e-saiba-como-fazer-umacamara-escura-fotografia-atividade-de-arte/)

Além da importância na criação da perspectiva fílmica, a linha constitui um dos fatores de ordenação interior da imagem. A regra dos terços e a proporção áurea enquadramse nesta categoria.

A regra dos terços é uma norma clássica de composição que recomenda a divisão do enquadramento em três partes iguais, tanto no sentindo horizontal quanto no vertical, resultando na divisão do enquadramento em nove partes. Este método prega que os pontos de maior interesse se localizam nas intersecções das linhas divisórias. É o tipo de composição utilizada pelo cineasta Sergei Eisenstein em A Greve (Statchka, 1924), também fotografado por Eduard Tissé, na cena de confronto entre grevistas e polícia. 
No fotograma da figura 17, momento imediatamente anterior ao confronto, é possível verificar a disparidade de forças entre os dois lados. O quadro é dominado pelos cavalos, que indicam o poder de repressão da polícia do czar, entretanto a cabeça da criança, que ocupa apenas uma pequena parte do quadro, encontra-se em um dos pontos de intersecção da regra dos terços. Esse posicionamento do personagem atrai a atenção do espectador e intensifica o momento de tensão da cena.

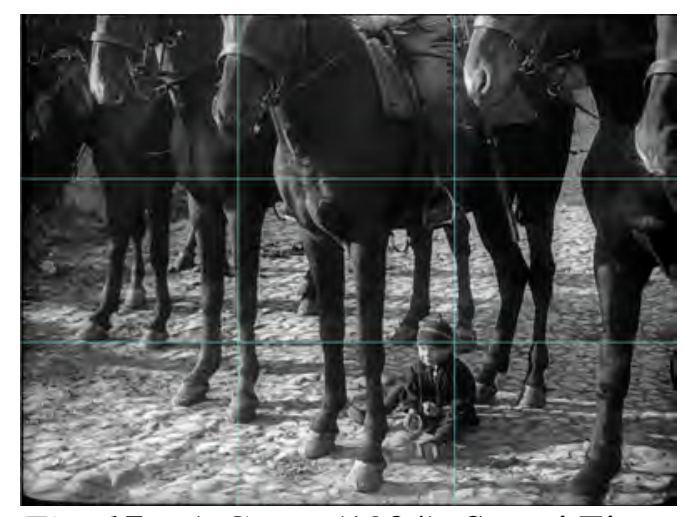

Fig. $17-$ A Greve (1924), Sergei Eisenstein

Com relação à secção áurea, podemos dizer que em termos matemáticos trata-se de uma constante algébrica obtida pela divisão de uma reta em dois segmentos, de forma que o segmento mais longo da reta dividida pelo segmento menor seja igual à reta completa dividida pelo segmento mais longo. O valor resultante dessa divisão é de aproximadamente 1,618, como mostra a figura 18.

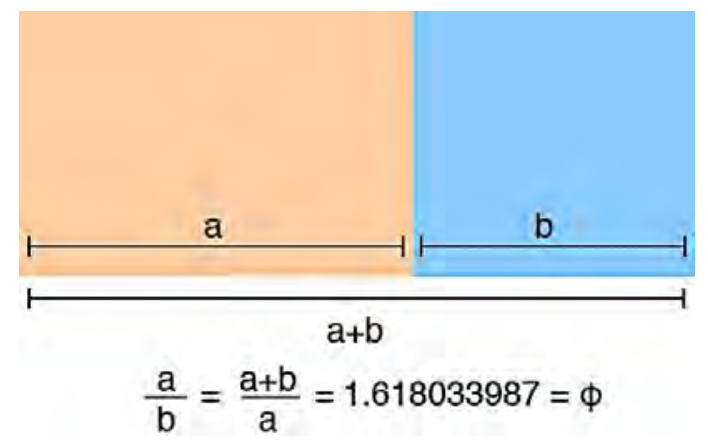

Fig. 18 - Cálculo da secção áurea

(Fonte: http://258science.blogspot.com/2018/11/dia-de-fibonacci.html)

A aplicação da secção áurea ao retângulo origina a forma geométrica conhecida como retângulo de ouro, que juntamente com a espiral áurea - espiral obtida seguindo-se o fluxo dos quadrados do retângulo de ouro - é utilizada nas artes e arquitetura por ser considerada uma das formas visuais mais agradáveis. A proporção áurea foi empregada por Leonardo da Vinci em obras como Homem vitruviano (ca 1490) e Mona Lisa (1503). Segundo Alfredo Bosi (1936- ), “as figuras pintadas pelo artista são, sem fácil paradoxo, reais e ideais. (...) 
Leonardo pesquisador da natureza, sim, mas também Leonardo fiel ao culto pitagórico das proporções ideais, do número áureo" (BOSI, 2017, pp. 20 e 21).
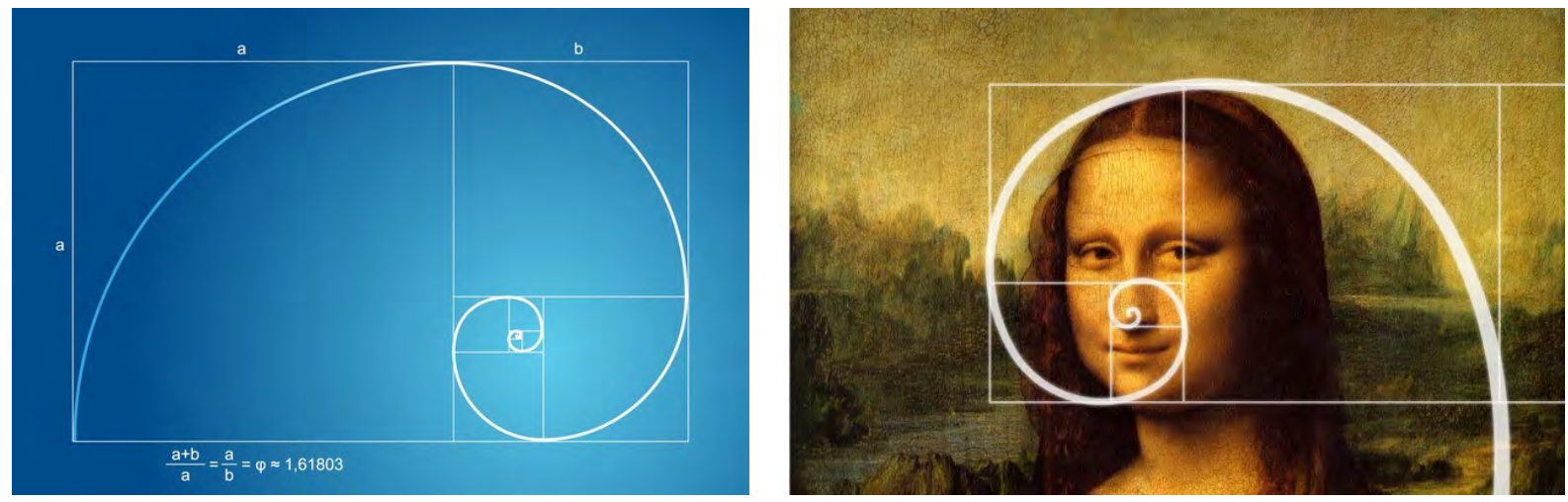

Fig. 19 - Retângulo de ouro e Espiral áurea (esq), detalhe da Mona Lisa (dir) (Fonte: https://imgur.com/gallery/3j4uG/comment/161730266)

Em seu livro Universos da arte, a artista e teórica Fayga Ostrower (1920-2001) explica porque atribui-se à proporção áurea o sentido clássico de equilíbrio.

\begin{abstract}
$\mathrm{Na}$ proporção áurea o espaço é visto articulado por direções contrastantes (inversões) cujo movimento, todavia, é comedido. Não se adensa nem se acelera demais. É como se amplos sopros de respiração animassem o espaço, alternadamente expandindo-o e contraindo-o. Daí resulta um equilíbrio que denominamos "clássico", pela perfeita síntese entre calma e movimentação (OSTROWER, 1983, p. 290).
\end{abstract}

Vale lembrar que assim como a perspectiva linear, as regras de composição são construções matemáticas, nem sempre aplicáveis à captação fotográfica. Por outro lado, há um tipo de composição bastante utilizada no cinema, fugindo das proporções ideais, que aproveita as linhas do cenário para criar profundidade, reforçando a impressão de tridimensionalidade por meio da sobreposição de planos.

Este efeito de profundidade é explicado por Arnheim: “A sobreposição estabelece uma hierarquia criando uma distinção entre unidades dominantes e unidades subservientes. Uma escala de importância leva, por meio de dois ou mais graus, do primeiro plano ao fundo" (ARNHEIM, 2002, p.115). Assim, a dimensão de profundidade total acaba por fundir-se em uma continuidade indivisível, conduzindo o olhar do espectador de frente para trás e de trás para frente na cena.

O diretor Wong Kar-wai (1958- ) utiliza esse recurso em muitos de seus filmes, mas especialmente em Amor à Flor da Pele (In the Mood for Love, 2000), fotografado por Christopher Doyle (1952- ), ao trabalhar em ambientes internos, sempre de pequenas dimensões, fazendo uso das linhas do cenário para dar profundidade à imagem, como mostra a figura 20. 


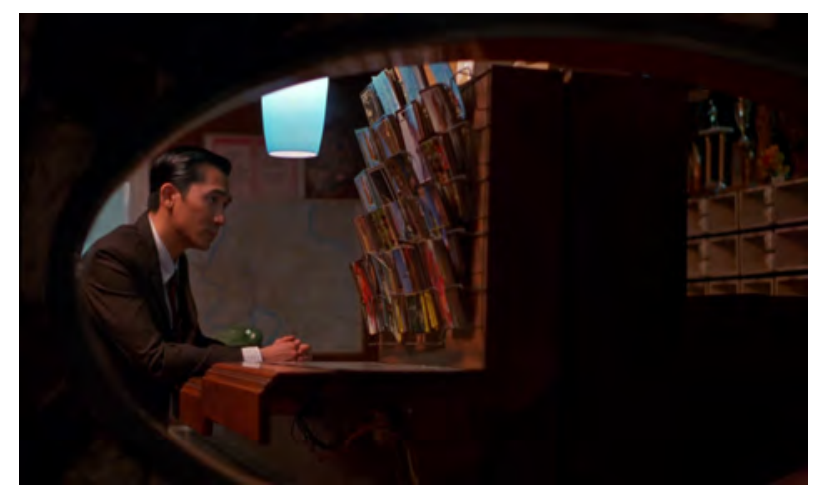

Fig. 20 - Amor à Flor da Pele (2000), Wong Kar-wai

Eisenstein elabora a composição em profundidade valendo-se da lente $28 \mathrm{~mm}$, que para o formato $35 \mathrm{~mm}$ permite enquadrar vários planos dentro da mesma cena. Na sequência final de Ivan, o Terrível - Parte I (Ivan Grozny, 1945), fotografado por Eduard Tissé, o diretor aproveita as linhas do plano intermediário, as linhas sinuosas do plano de fundo e os volumes do primeiro plano da cena para montar uma composição em que estabelece a relação entre Ivan e o povo.

Ivan está exilado e o povo vem clamar para que volte a Moscou. A perspectiva criada pelo ponto de vista da cena mostra o isolamento de Ivan e a proximidade do povo. O plano intermediário separa os personagens, mas ao mesmo tempo promove uma abertura que permite sua união.

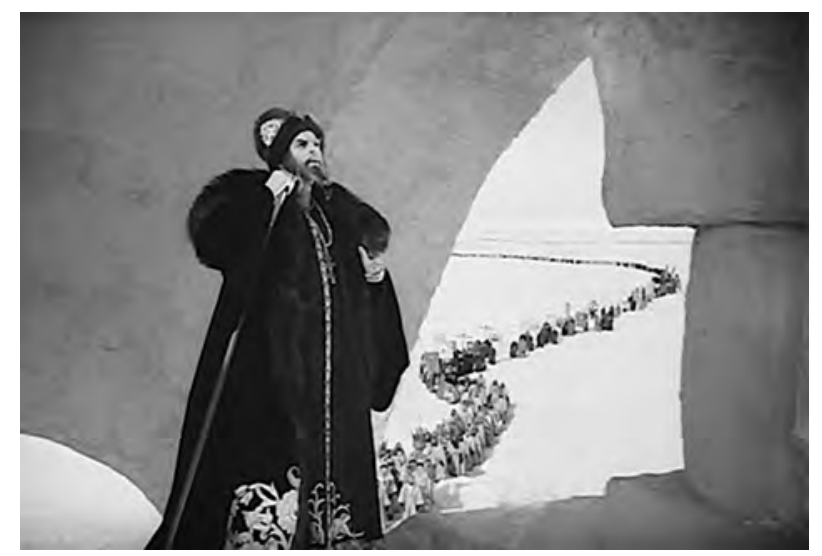

Fig. 21 - Ivan, o Terrível - Parte I (1945), Sergei Eisenstein

Em sentido contrário à busca de profundidade, podemos citar o trabalho do diretor norte americano Wes Anderson (1969- ). O registro de seus filmes distancia-se do realismo, o que fica evidenciado em procedimentos de composição que achatam a imagem, enfatizando sua planaridade. Utilizada com reserva por artistas e cineastas do século XX, a composição plana, centralizada e simétrica, transformou-se em forte elemento de estilo nas mãos do diretor. 
A figura 22 traz exemplos filmes de Anderson em que é possível verificar como centralização, simetria e cor conferem uma visualidade pouco realista, acentuando o tom de fábula e humor, característicos de suas obras. São eles Viagem a Darjeeling (The Darjeeling Limited, 2007), nos dois fotogramas superiores, e A Vida Marinha com Steve Zissou (The Life Aquatic with Steve Zissou, 2004) e Moonrise Kingdom (Moonrise Kingdom, 2012), nos fotogramas inferiores, fotografados por Robert Yeoman (1951- ).
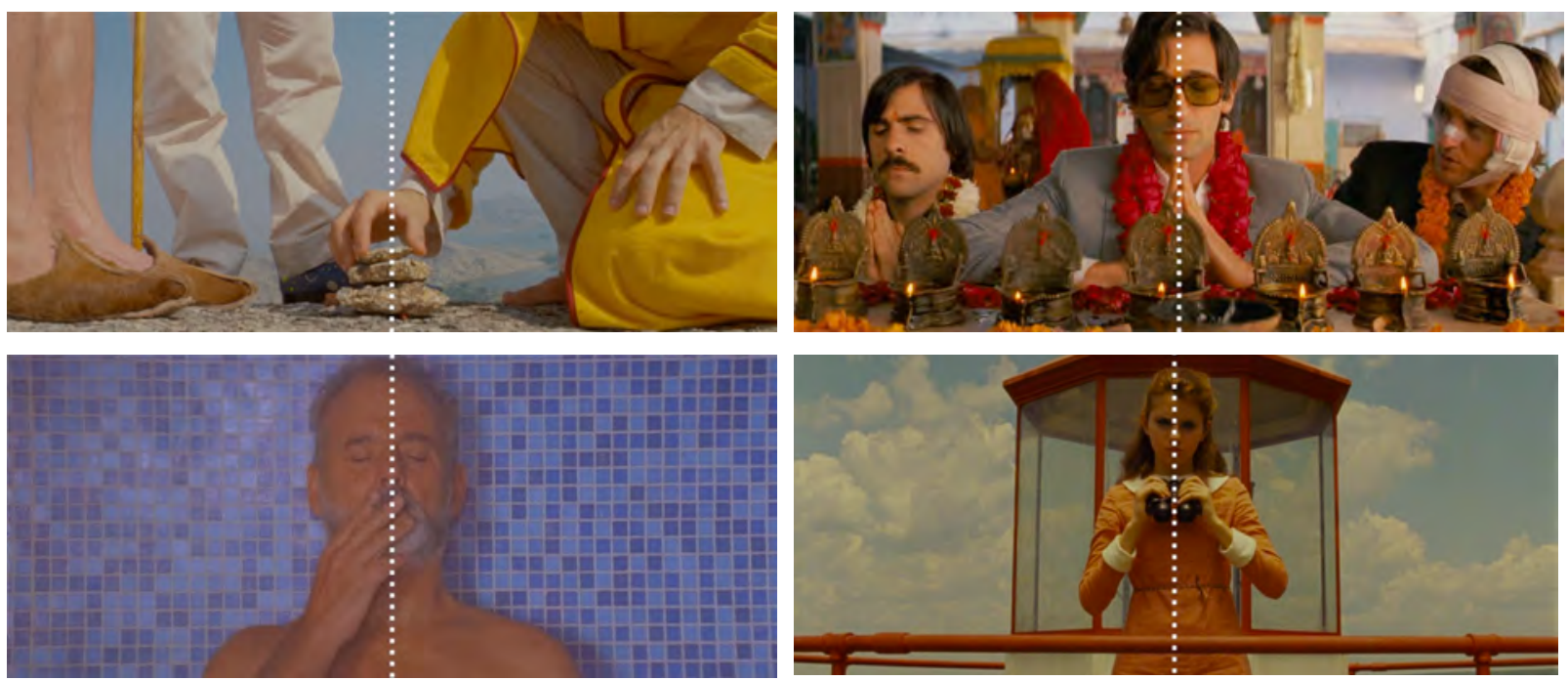

Fig. 22 - Viagem a Darjeeling (2007), A Vida Marinha com Steve Zissou (2004) e Moonrise Kingdom (2012)

Anderson combina a centralização com a regra dos terços, como pode ser visto no fotograma de O Fantástico Sr. Raposo (Fantastic Mr. Fox, 2009), fotografado por Tristan Oliver (1964- ). E a forma como organiza e cria imagens, imprime um estilo inconfundível à sua obra.

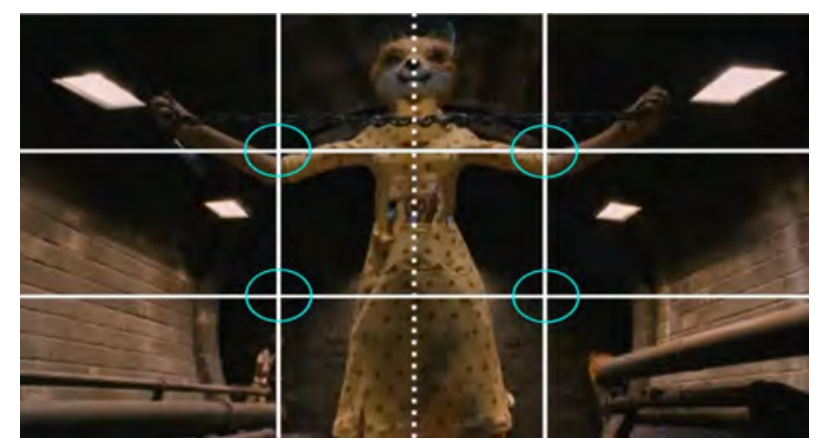

Fig. 23 - O Fantástico Sr. Raposo (2009), Wes Anderson

Wes Anderson é um grande admirador de Stanley Kubrick (1928-1999), diretor que também tem a centralização e a simetria como elementos de estilo. Entretanto, os dois diretores utilizam esse tipo de composição de maneiras distintas. Enquanto Anderson explora a planaridade da imagem, enfatizando a artificialidade de uma narrativa pouco realista, Kubrick utiliza a simetria em profundidade, provocando tensão no espectador, como nas 
sequências de longos corredores de O Iluminado (The Shining, 1980), fotografado por John Alcott (1931-1986).

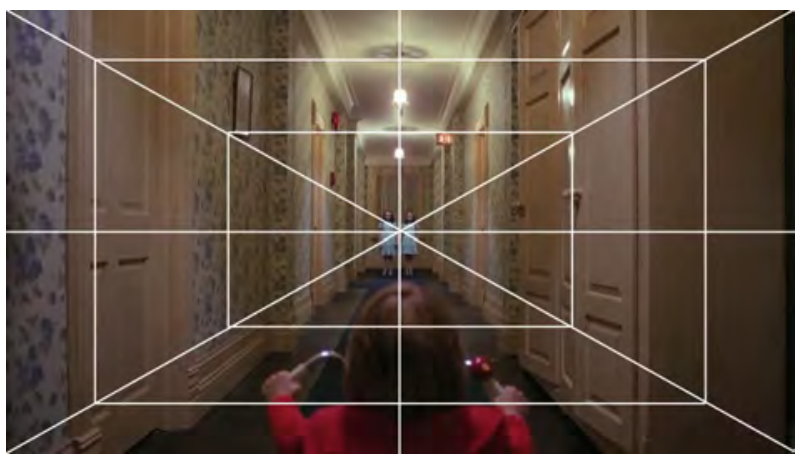

Fig. 24 - O Iluminado (1980), Stanley Kubrick

Comparando um fotograma de Nascido para Matar (Full Metal Jacket, 1987) a outro de Moonrise Kingdom (Moonrise Kingdom, 2012) torna-se evidente a referência de Kubrick na obra do diretor Wes Anderson (figura 25), bem como a maior profundidade na imagem de Kubrick. Em Nascido para Matar, fotografado por Douglas Milsome (1939- ), a profundidade é acentuada pelas verticais que se repetem até o fundo do quadro. Anderson encerra o movimento direcional das diagonais ao cruzá-las com a linha do horizonte.

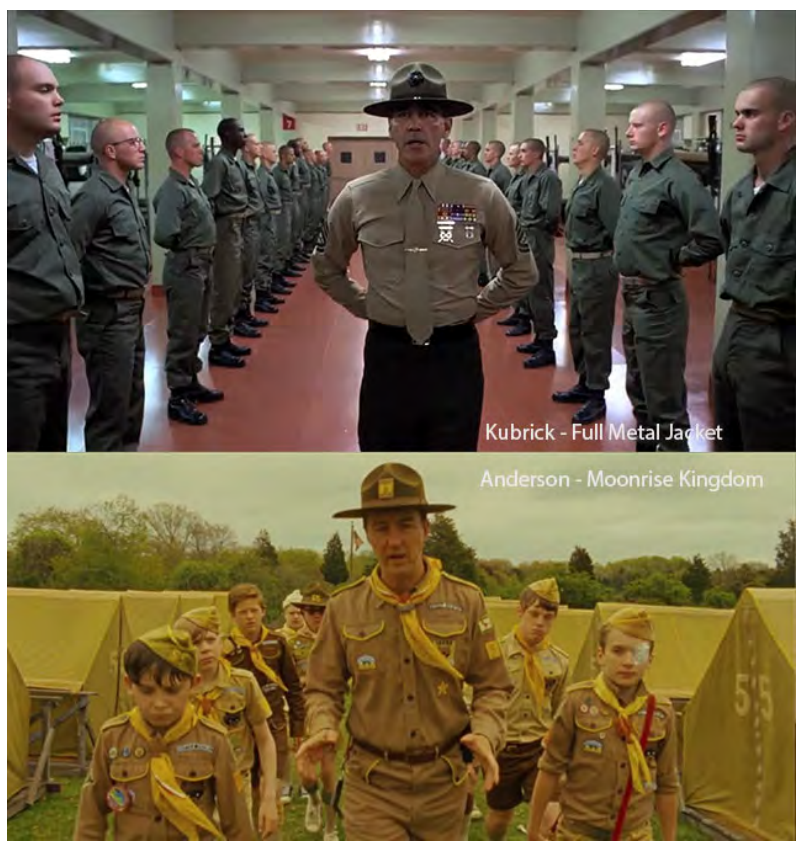

Fig. 25 - Simetria em Stanley Kubrick e Wes Anderson

Mas Kubrick vai além da simples composição centralizada, utiliza a "perspectiva de um ponto", um tipo de composição que atrai o olhar do espectador para um ponto central do quadro. O efeito tridimensional por ela criado coloca o espectador dentro da ação, ao invés de mantê-lo de longe, apenas como observador. É o que mostra o fotograma de Nascido para Matar. 


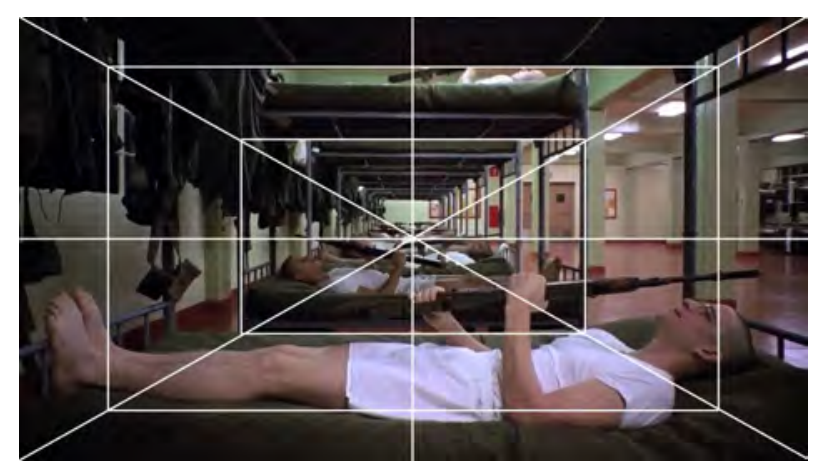

Fig. 26 - Nascido para Matar (1987), Stanley Kubrick

No século XX, a tradição representativa de um ponto de vista centralizador deu lugar a um procedimento denominado desenquadramento, termo cunhado pelo crítico e diretor Pascal Bonitzer (1946- ), que consiste em esvaziar o centro da imagem de objetos significativos.

O desenquadramento de Bonitzer refere-se a pontos de vistas que não chegam a ser perspectivas oblíquas, mas que tampouco constituem quadros clássicos, como os de Carl Theodor Dreyer (1889-1968), que filma o rosto da atriz Maria Falconetti (1892-1946) cortado pela borda da tela em A Paixão de Joana d'Arc (La Passion de Jeanne d'Arc, 1928), fotografado por Rudolph Maté (1898-1964).

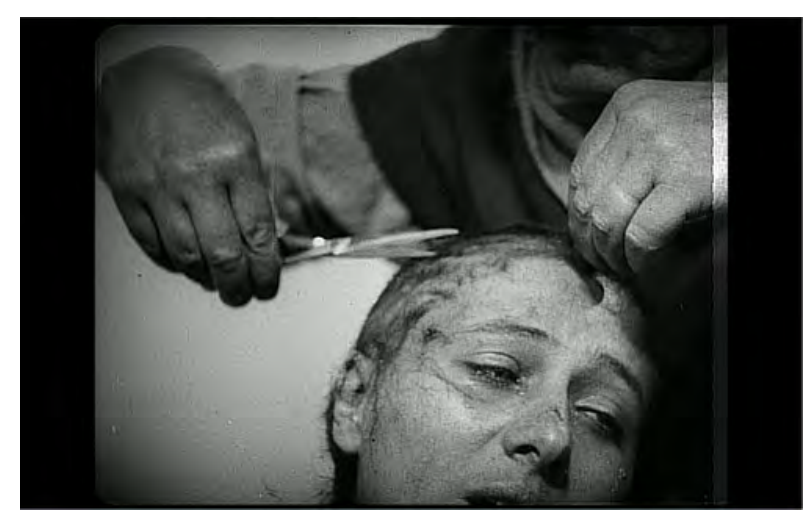

Fig. 27 - A Paixão de Joana d'Arc (1928), Carl Theodor Dreyer

Bonitzer faz uma distinção entre o que ocorre com imagens fixas e imagens móveis. No primeiro caso aponta uma resistência inicial do espectador em aceitar imagens descentradas, que com o tempo as assimila e lhes confere valor estético. No caso do cinema, o espectador pode esperar que o estranhamento causado por uma imagem desenquadrada seja resolvido por meio de transformações internas à imagem, como por exemplo, pelo movimento. "É uma das razões pelas quais, no cinema, o desenquadramento é ainda hoje percebido como mais anormal, mais escandaloso até, do que na pintura ou na foto" (AUMONT, 1993, p.159). Assim, para ser utilizado como elemento de estilo, o desenquadramento deve ser voluntariamente mantido nas imagens em movimento. 


\subsection{Contraste Luminoso}

Contraste designa fundamentalmente a distinção de elementos de mesma natureza. $\mathrm{O}$ contraste luminoso relaciona-se à reflexão da luz, fenômeno que ocorre quando o raio luminoso incide sobre uma superfície e retorna ao seu meio de origem. A luminância descreve a medição da quantidade de emissão de luz, que passa através ou é refletida a partir de uma superfície em particular, em um certo ângulo. Ela também indica o quanto de energia luminosa pode ser percebida pelo olho humano. Isto significa que a luminância refere-se ao brilho da luz emitida ou refletida por uma superfície. A intensidade de luz que incide em um ponto de uma superfície, conjugada ao seu índice de reflexão, gera um valor tonal. $\mathrm{O}$ contraste luminoso refere-se à amplitude tonal da imagem.

É possível traduzir as múltiplas gradações de tons de uma imagem em uma escala de cinzas, o que facilita a compreensão do contraste luminoso. No final dos anos 1930, os fotógrafos Ansel Adams (1902-1984) e Fred Archer (1889-1963) codificaram o Sistema de Zonas, uma metodologia que permite relacionar os valores de luminância dos objetos com o resultado fotográfico da imagem.

$\mathrm{O}$ sistema divide as áreas de luminância em onze zonas, de $0 \mathrm{a} X$, sendo zero o preto profundo e X o branco puro. A figura 28 identifica as zonas de luminância da imagem e traz seus correspondentes valores digitais na escala do software Adobe Photoshop, que variam entre 0 e 255 em imagens de 8 bits.

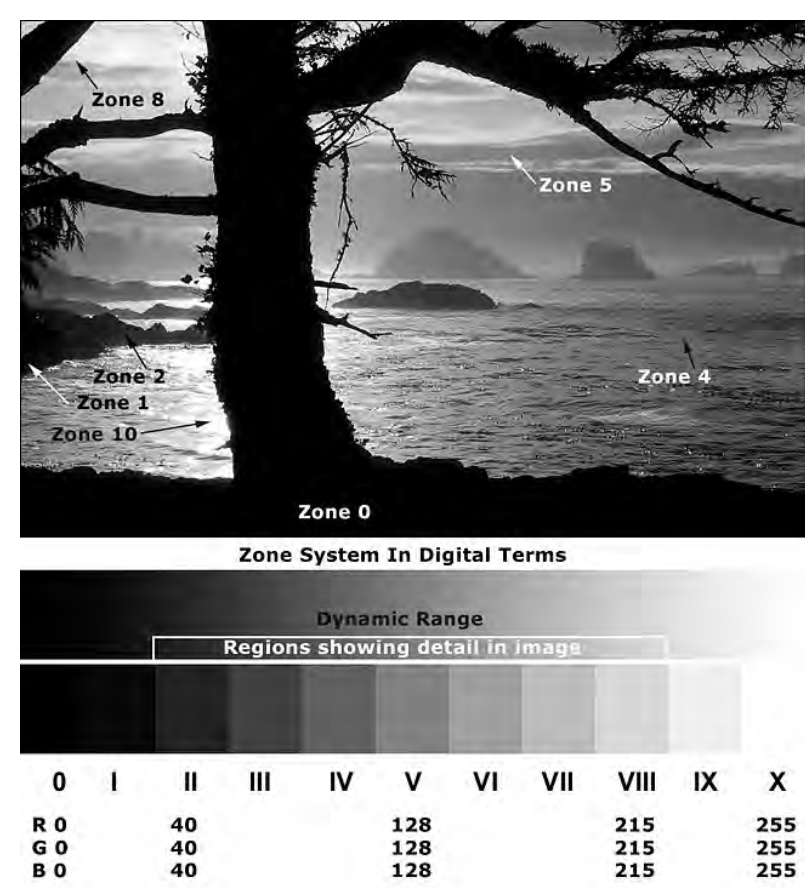

Fig. 28 - Anphritie Point, Vancouver, Robert Berdan

(Fonte: https://threecolumnblogger.com/black-and-white-photography-zone-system/) 
Apesar de ter sido codificado para uso na fotografia analógica em preto e branco, o sistema de zonas aplica-se à fotografia colorida e digital, configurando uma importante ferramenta na análise do contraste.

Como a visão humana adapta-se a diferentes intensidades luminosas, a avaliação do contraste é mais precisa quando feita por instrumentos de medição. O software Adobe Photoshop oferece uma ferramenta confiável, permitindo que a análise independa da apreciação visual particular de cada pessoa. Trata-se do histograma, um gráfico que ilustra como os pixels de uma imagem são distribuídos em cada valor tonal, possibilitando a visualização da faixa de tons da imagem como um todo.

O histograma é composto de 256 colunas, que representam os valores digitais atribuídos aos tons. Os valores distribuem-se da esquerda para a direita, de 0 (preto) até 255 (branco absoluto), passando por várias intensidades de cinza.
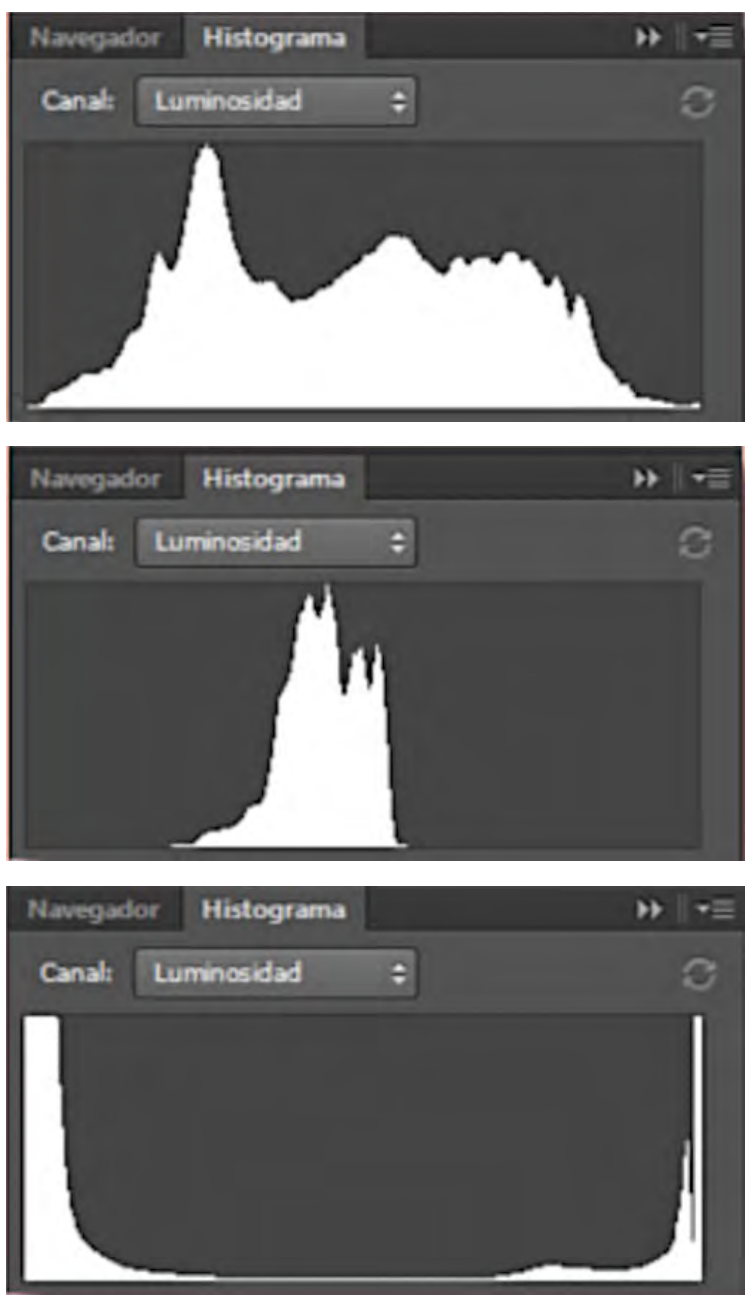

Fig. 29 - Exemplos de histogramas
Se as colunas se estendem da esquerda até a direita, a imagem apresenta um range dinâmico completo. Isso indica que todos os tons estão presentes na imagem.

Se a informação está concentrada em alguns poucos tons, a imagem apresenta baixo contraste.

Se a região central apresenta uma altura pequena e a informação concentra-se nos extremos, temos uma imagem de alto contraste. 
O Photoshop também apresenta o valor do desvio padrão do histograma. O desvio padrão, ou standard deviation, é uma medida de dispersão em torno da média da amostra, portanto indica o grau de uniformidade de um conjunto de dados. Se o valor do desvio é baixo, os dados estão próximos da média. No caso do histograma, o desvio representa como variam os valores tonais. Se a imagem apresenta desvio inferior a 40, tem baixo contraste, se for superior a 90, o contraste é alto.

A avaliação do contraste por meio de ferramentas diminui a imprecisão da análise qualitativa, uma vez que a apreensão da amplitude tonal comporta um grau importante de subjetividade. O olho humano não enxerga o claro e o escuro como pontos de uma escala contínua, que se estende do preto ao branco. Este fato, de fundamental importância ao pesquisador da imagem, não é relevante para a fruição da obra pelo espectador, que apreende o contraste como um contexto de relações.

Ao tratar da questão desenho x pintura na obra de Leonardo da Vinci, Alfredo Bosi aponta para o importante fato de que o homem não enxerga o relevo mas sim as diferenças entre claros e escuros (BOSI, 2017, p. 45). Desse modo, a gama tonal tem um papel fundamental na criação da imagem, pois o sistema visual humano é guiado por contrastes. Em seu livro O cinema, o crítico Henri Agel (1911-2008) fala da importância do contraste para a criação de uma "atmosfera do filme", que é sentida pelo espectador:

É através do contraste que o diretor de fotografia se exprime e dá à imagem uma cor e sonoridade própria. A atmosfera nascerá do jogo sutil das luzes e das sombras, cinzenta e triste, brilhante e luxuosa, dura e acre, conforme a história, o meio no qual ela se desenrola e a psicologia das personagens que a animam (AGEL, 1972, p. 168).

Por meio da escolha e posicionamento dos refletores é possível criar imagens suaves, contrastes baixos ou médios, bem como imagens duras, com alto contraste entre altas luzes e sombras profundas.

Podemos comparar a forma como a atriz Greta Garbo (1905-1990) é iluminada em $A$ Rua Sem Sol (Die Freudlose Gasse, 1925), de Georg Pabst (1885-1967), e Inspiração (Inspiration, 1931), de Clarence Brown (1890-1987). No primeiro caso, a variação tonal em seu rosto é pequena, o que o faz parecer plano e com pouca expressão. Já no segundo caso, os contrastes de luz e sombra dão vida e animam as feições bem marcadas da personagem. Ao definir e moldar os contornos dos objetos e os planos da imagem, a iluminação contribui para a impressão de volume, valor expressivo e dinamismo, ajudando a criar profundidade espacial em imagens bidimensionais. 

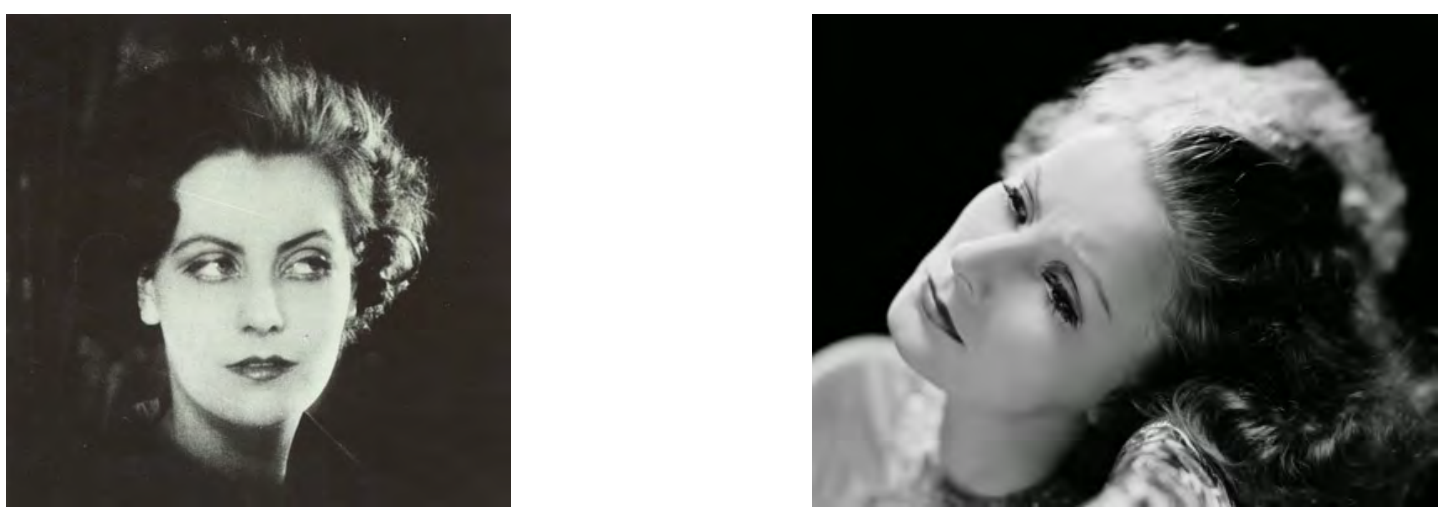

Fig. 30 - A Rua Sem Sol (esq) e Inspiração (dir)

A luz como elemento de linguagem não deve ser confundida com a luz como representação de um fenômeno natural. Em Universos da arte, Fayga Ostrower aponta para o fato de que muitas pinturas renascentistas que representam cenas à luz do dia têm na perspectiva linear seu elemento visual predominante. No movimento impressionista os quadros descrevem a luz atmosférica em distintos momentos do dia, entretanto têm na cor, e não na luz, seu elemento formal estruturante (OSTROWER, 1983, p. 96).

A composição por meio do elemento luz depende da existência dos contrastes efetivos entre claro e escuro. Entretanto, não basta a presença de uma área clara se destacando das áreas de baixa luz, é necessário que todo o movimento visual da imagem seja elaborado por meio do contraste. É o caso da gravura Cristo curando os enfermos (1647-9), de Rembrandt, em que o autor caracteriza a individualidade dos personagens por meio de alguns traços sumários, mas utiliza a figura luminosa do Cristo como elemento predominante da composição.

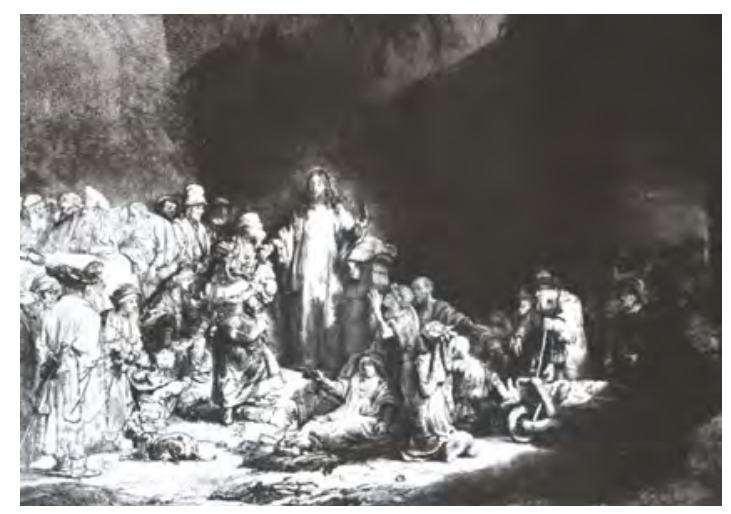

Fig. 31 - Cristo curando os enfermos (1647-9), Rembrandt van Rijn

$\mathrm{Na}$ gravura de Rembrandt, o movimento expressivo não linear é resultante das diferentes intensidades luminosas do fundo e dos personagens, sempre culminando na figura do Cristo. Esse resultado visual deve-se ao fato de que nas imagens contrastadas as áreas claras e escuras avançam e recuam no espaço, o que cria seu movimento expressivo. 
Desse modo, por meio do fenômeno do avanço-recuo simultâneo dos claros e escuros, a luz configura um caráter espacial em profundidade. De forma distinta do espaço criado pela linha, o contraste luminoso gera também uma percepção temporal, uma vez que a expansãocontração cria pulsações que podem ser formuladas como ritmo. Em termos temporais, quanto maior o contraste maior o ritmo presente na imagem, uma vez que as pulsações são aceleradas. Entretanto, contrastes muito acentuados também apresentam pausas, interrupções de leitura nas transições entre as altas e baixas luzes, que tornam as transições mais lentas.

Apesar dos elementos claros e escuros de uma imagem estarem reunidos de forma expressiva e apontarem para um contexto de relações, também conservam seu caráter individual. Assim, podem ser vistos como polaridades de um mesmo "modo de ser", mas também como oposições, forças distintas com significados antagônicos.

No contraste claro-escuro podem existir, portanto, dois tipos de qualificações que definem a gama expressiva do elemento luz. A primeira refere-se ao caráter individual dos elementos, uma oposição de valores que pode ser traduzida como conflito.

É a forma como Eisenstein trabalhou não apenas o contraste de seus filmes, mas todos os elementos visuais dos planos. Em seu livro A forma do filme, declara que a arte não se reduz ao registro ou imitação da natureza, mas é conflito, de acordo com sua missão social, natureza e metodologia. Assim, o conflito como contexto de relações é criado por meio de uma somatória de elementos individuais: "Primeiros planos e planos gerais. Fragmentos de direções graficamente variadas. Fragmentos resolvidos em volume com fragmentos resolvidos em área. Fragmentos de escuridão com fragmentos de claridade" (EISENSTEIN, 2002a, p. 43).

Na figura 32, um fotograma de A Greve (1924) explicita de que forma os elementos visuais do quadro enfatizam a relação que se desenvolve entre os operários e as forças policiais: oposições de direções gráficas (linhas), escalas, volumes, massas (volumes preenchidos com várias intensidades de luz) e profundidades. Praticamente toda a metade esquerda do quadro é tomado pela massa cinza do prédio. Do lado direito, ocupando mais ou menos um terço do quadro, existe outra construção, com valor tonal semelhante à da esquerda. E o quadro é cortado pela linha do muro, fortemente iluminado, que cria tensão espacial pela forma e pelo contraste. 


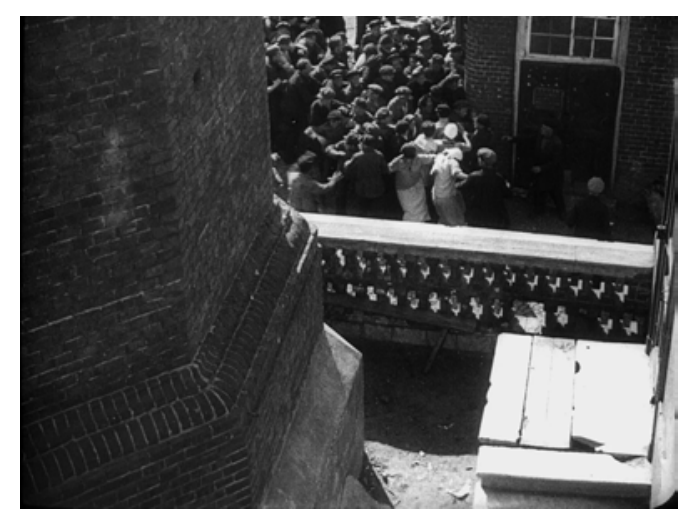

Fig. 32 - A Greve (1924), Sergei Eisenstein

Nesse mesmo sentido, a superexposição das janelas no filme Vidas Secas (1963), de Nelson Pereira dos Santos (1928- ), fotografado por Luiz Carlos Barreto (1928- ) e José Rosa (1934- ),acentua a oposição entre o confinamento do personagem e a liberdade do mundo externo.

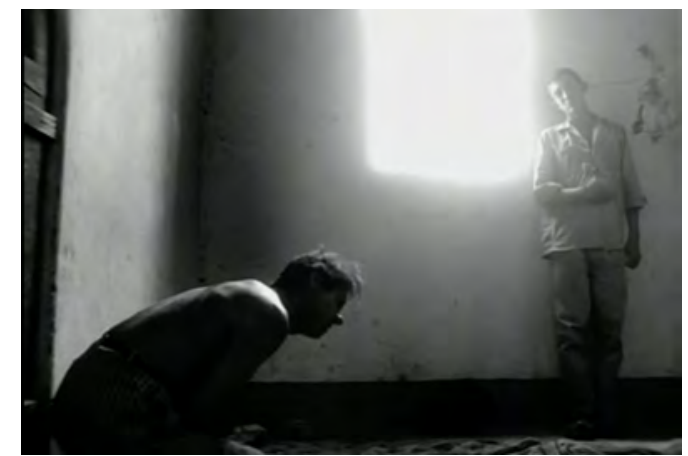

Fig. 33 - Vidas Secas (1963), Nelson Pereira dos Santos

Em Ida (Ida, 2013), de Pawel Pawlikowski (1957- ), fotografado por Ryszard Lenczewski (1948- ) e Lukasz Zal (1981- ), a constante oposição entre claros e escuros enfatiza o conflito da personagem principal, uma noviça que descobre ser judia. Os ambientes escuros trazem fontes luminosas em quadro ou fundos intensamente iluminados, os ambientes claros apresentam elementos com valores tonais entre o cinza escuro e o preto, de modo a acentuar o contraste.
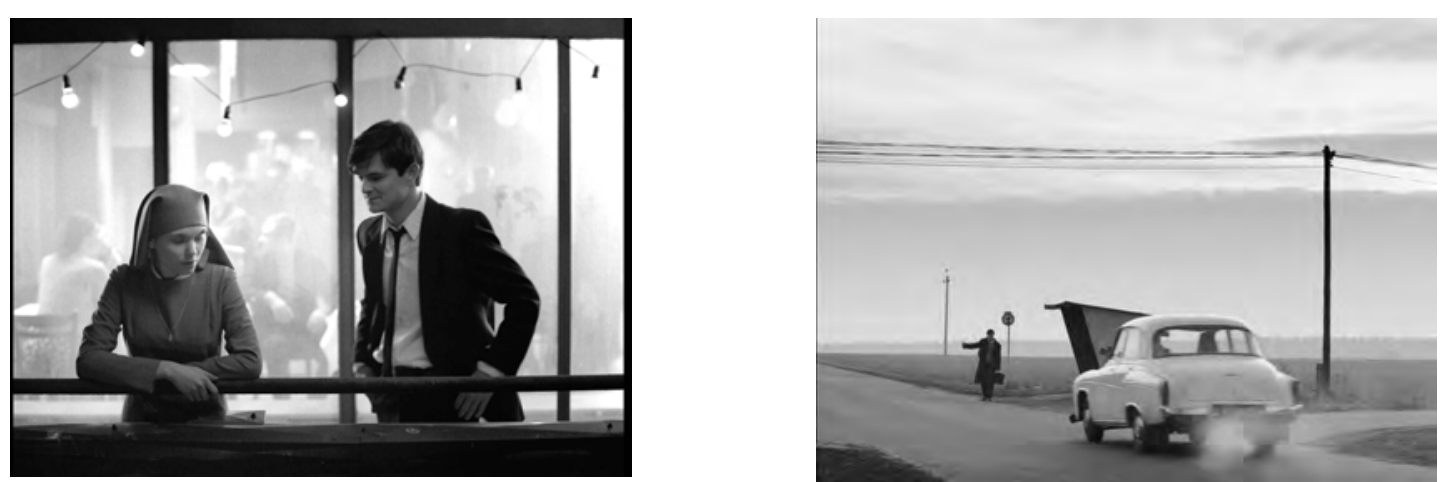

Fig. 34 - Ida (2013), Pawel Pawlikowski 
A segunda qualificação do contraste deve-se ao fato do claro e escuro estarem reunidos na imagem, portanto há uma integração das oposições e conflitos, o que gera uma síntese. É o caso do filme Ela (Her, 2013), em que o cineasta Spike Jonze (1969- ) e o diretor de fotografia Hoyte Van Hoytema (1971- ) utilizam imagens de baixo contraste para imprimir o universo monótono do personagem Theodore, um solitário escritor de cartões. No fotograma da figura 35, verificamos como nenhum elemento se destaca por seu valor tonal, fato que torna-se mais evidente quando eliminamos a crominância da imagem
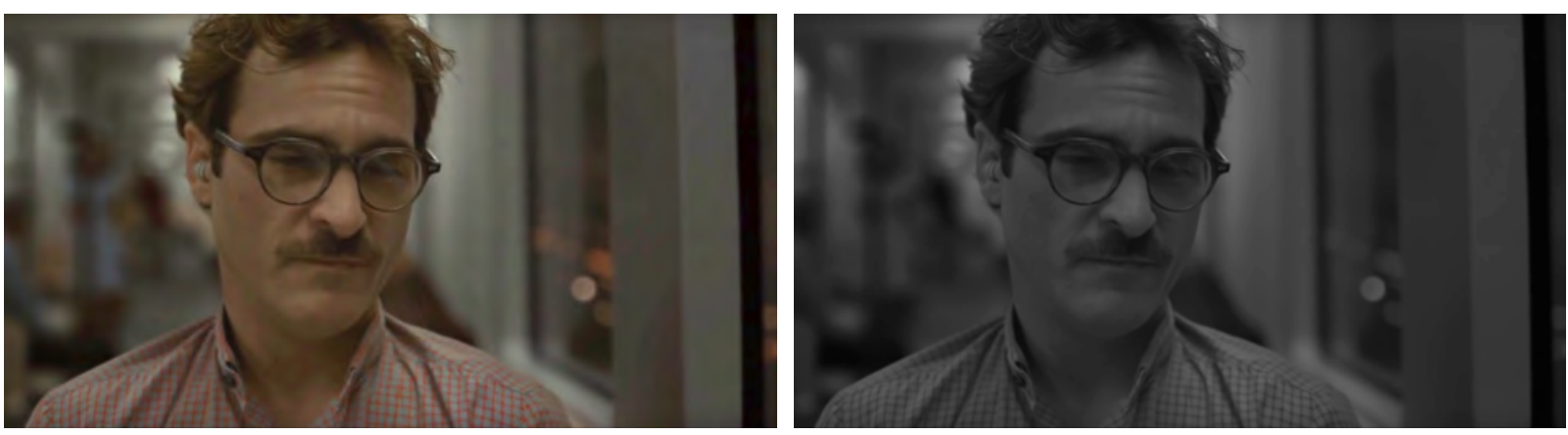

Fig. 35 - Ela (2013), Spike Jonze

Avaliando os histogramas e desvios padrão das imagens, a análise qualitativa dos contrastes se confirma. Nas figuras 36 e 37, trazemos fotogramas de Ida (Ida, 2013) e Ela (Her, 2013) acompanhados de seus respectivos histogramas de luminância. O histograma de Ida mostra uma grande concentração de pontos nos dois extremos do gráfico, o que indica o alto contraste.
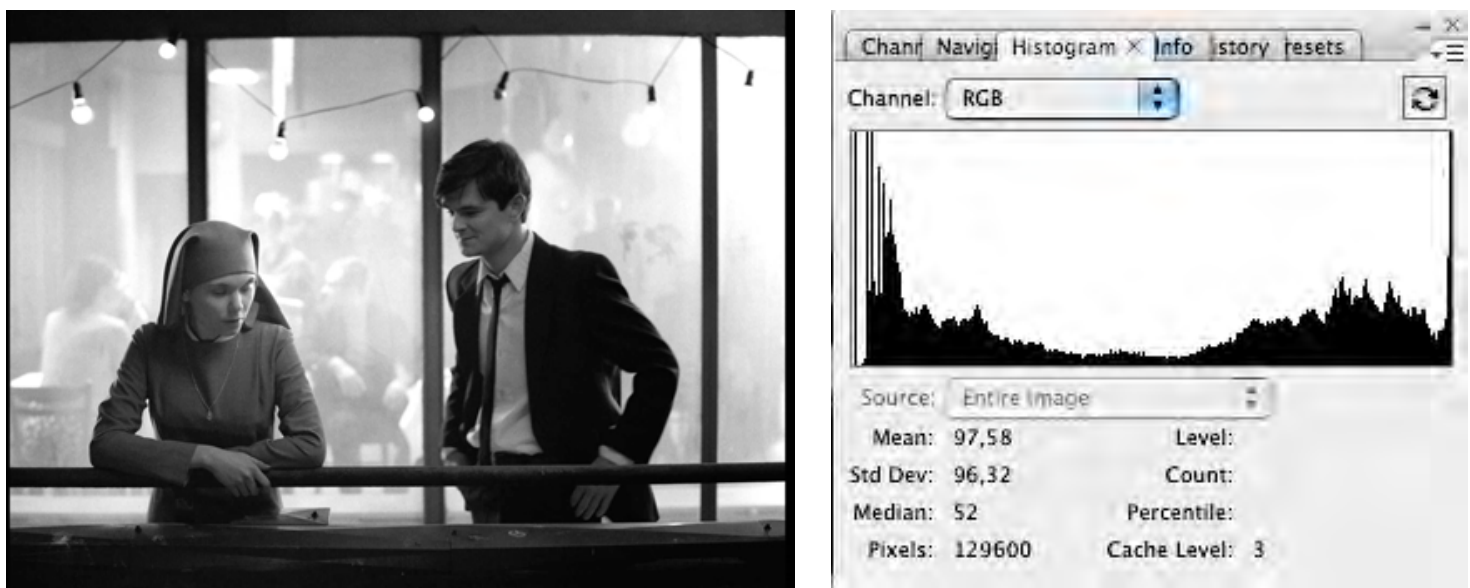

Fig. 36 - Histograma de Ida (2013), Pawel Pawlikowski 
Já em Ela, todos os pontos concentram-se à esquerda do cinza médio, ou seja, trata-se de uma imagem predominantemente escura e com reduzida amplitude tonal (baixo contraste).
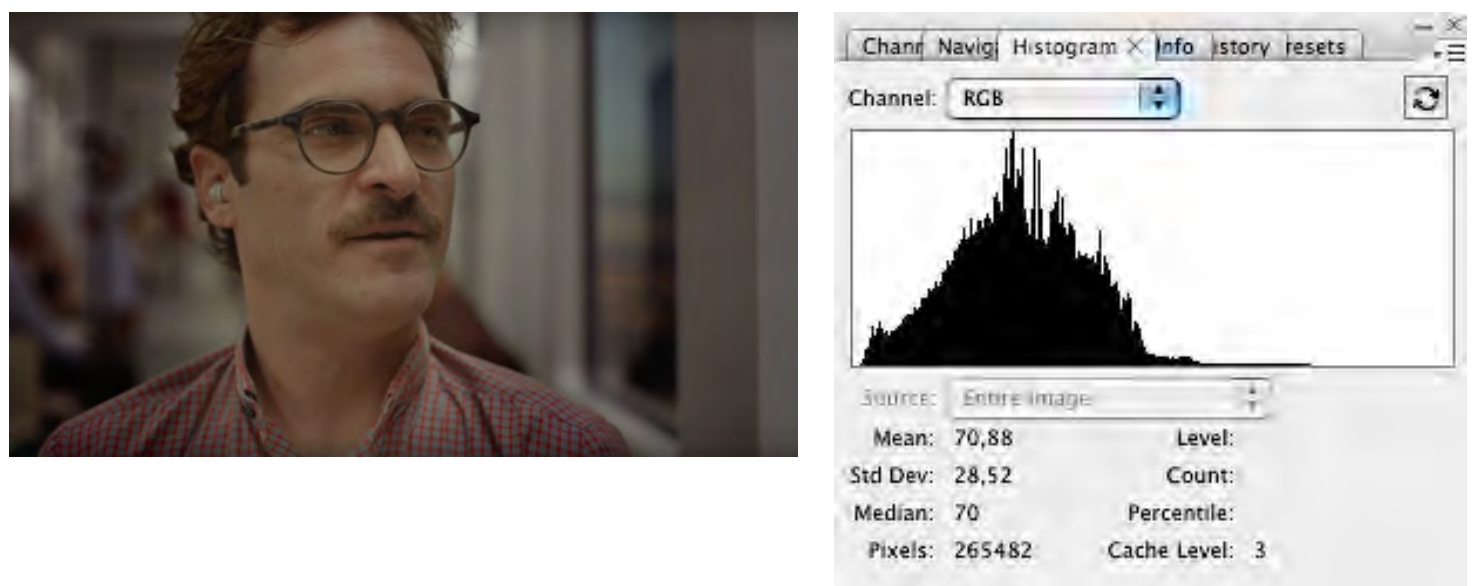

Fig. 37 - Histograma de Ela (2013), Spike Jonze

Os valores de desvio padrão confirmam isso, Ida tem um desvio de 96,32, enquanto Her tem desvio de 28,52. As imagens evidenciam como é possível representar a psicologia de personagens por meio do contraste. 


\subsection{Cor}

Cor é o resultado de um fenômeno físico-químico-fisiológico, em que diferentes comprimentos de onda dos raios luminosos sensibilizam os órgãos visuais e são interpretados pelo cérebro.

As cores que conhecemos representam uma pequena parcela do espectro eletromagnético, com comprimentos de onda que variam entre 400nm a 700nm. De acordo com a CIE (Comission Internationale de l'Eclairage) - organização internacional de estudos e normatização sobre assuntos relacionados à luz, iluminação, cor, visão, fotobiologia e tecnologia da imagem - os valores de 435,8nm, 546,1nm e 700nm representam espectralmente as cores primárias aditivas azul, verde e vermelho respectivamente.

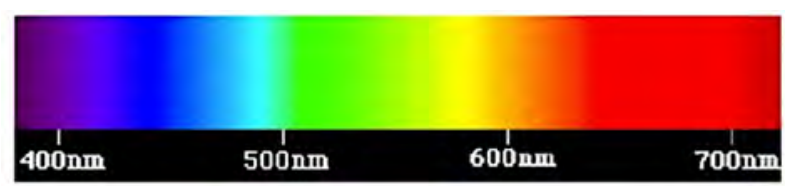

Fig. 38 - Espectro eletromagnético visível

(Fonte: https://cienciafisicoquimica8ano.blogspot.com/2013/06/espectro-da-luz-branca.html)

Por estar ligada ao sistema visual humano, a cor é subjetiva. Desse modo, pessoas diferentes atribuem características distintas às cores. Em Filosofia da caixa preta, Vilém Flusser (1920-1991) aponta a complexidade na relação entre a cor "real", a cor fotografada e a cor percebida.

Há, por certo, ligação indireta entre o verde do bosque fotografado e o verde do bosque lá fora: o conceito científico "verde" se apoia, de alguma forma, sobre o verde percebido. Mas entre os dois verdes se interpõe toda uma série de codificações complexas (FLUSSER, 1985, p. 23).

Para estabelecer uma padronização, a CIE criou um sistema que leva em conta tanto a padronização de iluminantes como de observadores. O órgão criou o observador padrão, os iluminantes A, B e C, e desenvolveu fórmulas para calcular os valores triestímulos (XYZ) e as coordenadas de cromaticidade $\mathrm{xy}$.

O observador padrão foi criado a partir de um experimento com um grupo de vinte indivíduos com sistema de visão normal. Nesse experimento, o observador visualizava duas cores separadas, uma produzida por uma fonte de luz de cor conhecida e outra criada pelo ajuste da potência de três fontes luminosas de cores primárias aditivas sobrepostas, o triestímulo. O ajuste era feito até que não houvesse diferença visual entre as duas cores. Desse modo, a CIE determinou os valores espectrais triestímulo do observador, quantificando 
numericamente a forma como o ser humano enxerga as cores. Assim, estabeleceu uma representação gráfica para cada iluminante padrão, chamado Diagrama de Cromaticidade.

A figura 39 traz o Diagrama de Cromaticidade para o iluminante padrão C (luz do dia), indicando como as cores são reproduzidas para este iluminante. Os triângulo localizados em seu interior são denominados gamut e representam os espaços cromáticos. Seus vértices estão sobre o vermelho, verde e azul e delimitam a região em que localizam-se todas as cores que as primárias aditivas são capazes de reproduzir. As cores espectralmente puras encontram-se no contorno do diagrama.

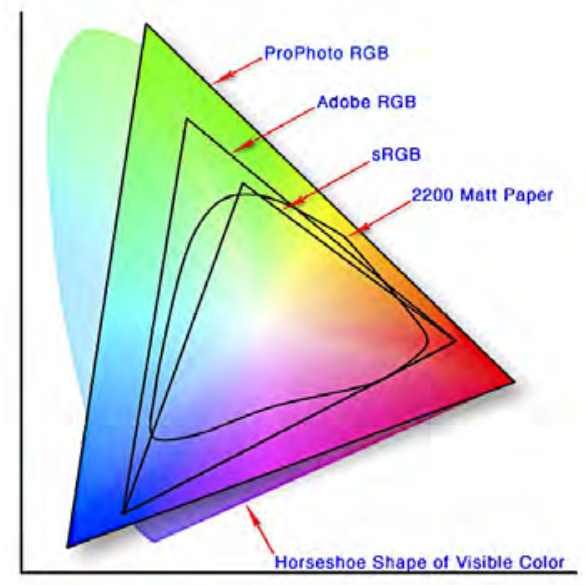

Fig. 39 - Diagrama de Cromaticidade para o iluminante C

(Fonte: https://www.adobe.com/digitalimag/pdfs/color_managed_raw_workflow.pdf)

A teoria triestímulo parte do princípio de que é possível reproduzir todas as cores visíveis a partir de combinações lineares monoespectrais de vermelho, verde e azul. Entretanto, no caso de uma mistura de quantidades arbitrárias das primárias do sistema RGB, não há dispositivo que consiga mostrar todas as cores do gamut.

Assim, a CIE definiu os valores triestímulos $\mathrm{X}, \mathrm{Y}$ e Z para substituir as primárias. $\mathrm{O}$ x, y e z são combinações de RGB e funções de representação de cores para as primárias. $\mathrm{O}$ Diagrama de Cromaticidade é uma projeção da equação $\mathrm{X}+\mathrm{Y}+\mathrm{Z}=1$, mostrando no plano todos os valores visíveis de cromaticidade. Entretanto, não representa os três atributos das cores: matiz, luminosidade e saturação.

O matiz refere-se à faixa do espectro cromático à qual pertence a cor, sendo definido pelo comprimento de onda, é o que define a cor de um objeto. A luminosidade vincula-se à luminância, ou seja, à relação entre intensidade luminosa e superfície. A saturação refere-se à intensidade cromática.

O Diagrama de Cromaticidade é aplicado a cores que possuem a mesma luminância. Cores com mesma cromaticidade mas diferentes luminâncias encontram-se no mesmo ponto. 
A representação que leva em conta diferentes luminâncias é um sistema tridimensional denominado espaço de atributos de cores. Existem várias representações de espaço cromático.

O sistema HSV ou HSB (Hue, Saturation and Brightness), criado em 1978 pelo engenheiro Alvy Ray Smith (1943 - ), caracteriza-se por uma transformação não linear do sistema de cores RGB. É representado por um cone no espaço, como mostra a figura 40.

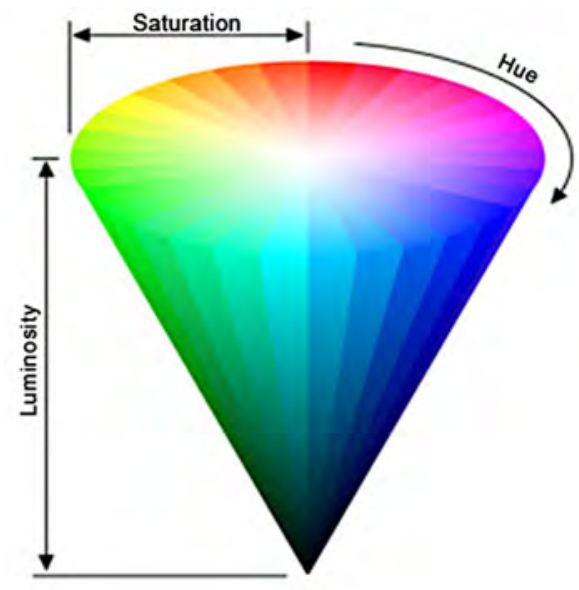

Fig. 40 - Espaço HSB

(Fonte: https://fotografiaprincipiantes.files.wordpress.com/2014/01/image28.png)

A altura do cone representa o eixo acromático do espaço, sendo o vértice o valor mínimo de intensidade luminosa e o topo o valor máximo. A intensidade é a medida da energia total envolvida em todos os comprimentos de onda, sendo a responsável pela sensação de brilho da energia incidente sobre o olho. Em qualquer seção transversal do cone a saturação é dada pela distância até o ponto central. O matiz é dado pelo ângulo formado com o vértice correspondente ao vermelho.

Esses conceitos são fundamentais para compreender alguns instrumentos dos softwares de correção de cor. O vectorscope, por exemplo, mostra uma seção transversal do espaço HSB, indicando matiz e saturação dos pixels da imagem.
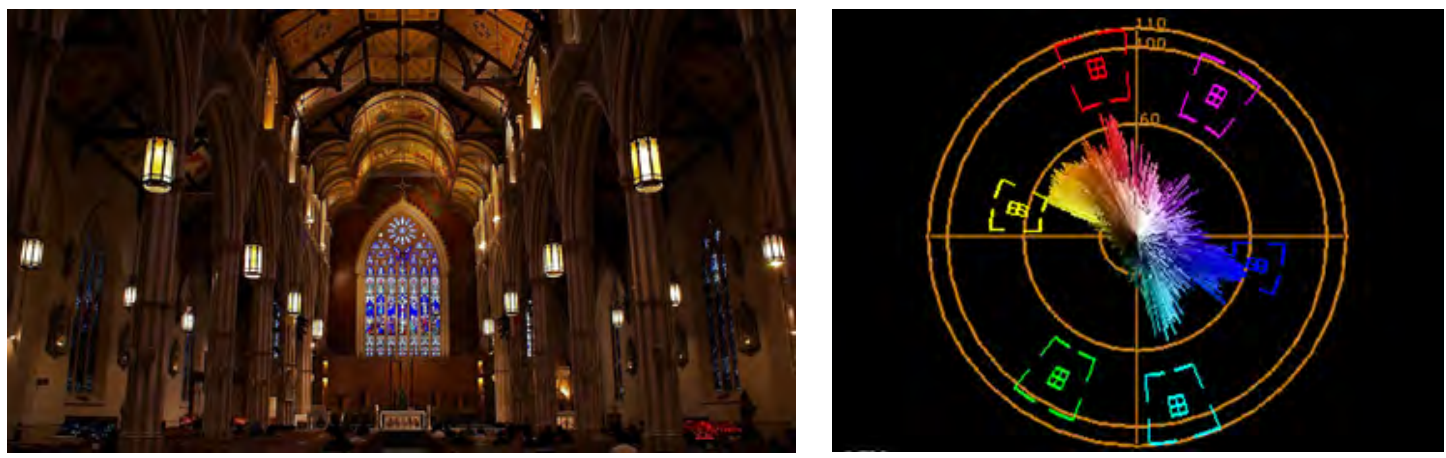

Fig. 41 - Catedral St Michael (Toronto) e Vectorscope 
No Adobe Photoshop é possível exibir a informação de uma cor por meio da ferramenta conta-gotas . Ao posicioná-la na imagem, pode-se verificar a cor exata de um pixel ou de uma área maior, obtendo-se a cor média de uma amostra em um determinado raio de pixels.

A figura 42 traz um fotograma do filme O Grande Hotel Budapeste (The Grand Budapest Hotel, 2013), de Wes Anderson, com dois posicionamentos da ferramenta contagotas.

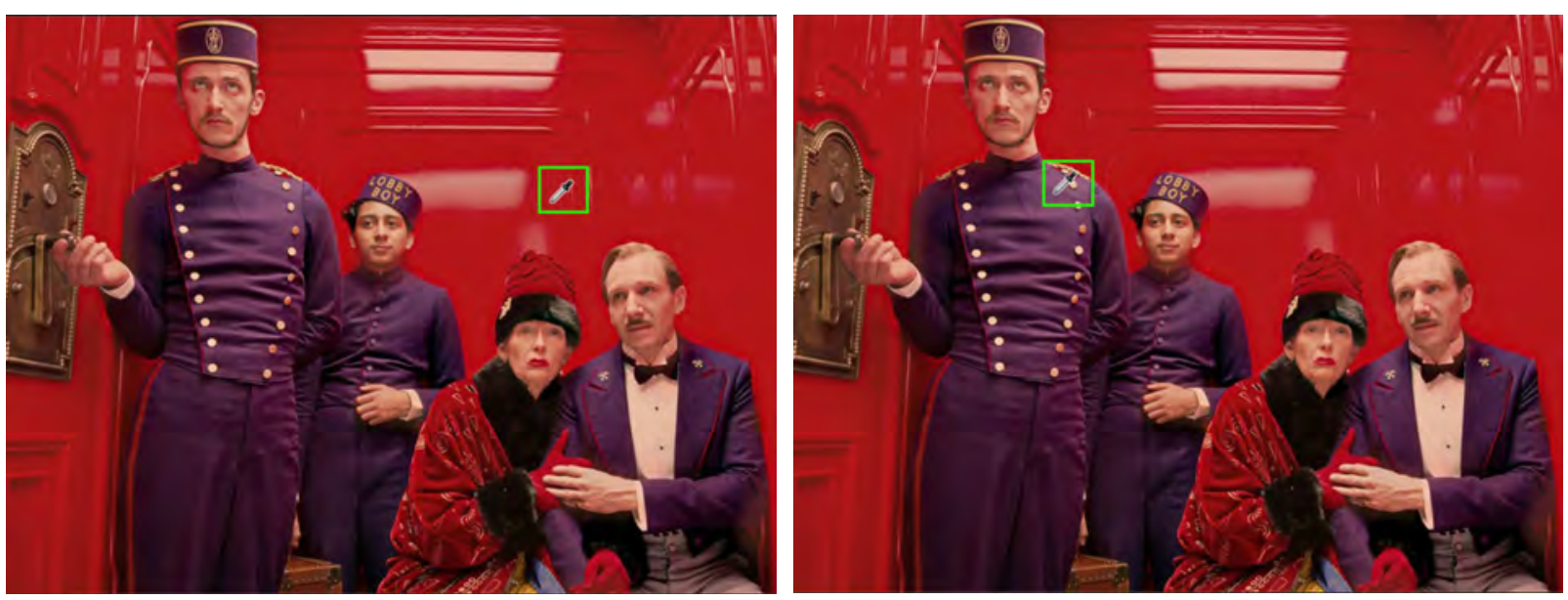

Fig. 42 - O Grande Hotel Budapeste (2013), Wes Anderson

Dentre os modos possíveis de exibição de cores no Photoshop, dois são úteis para a análise de filmes: HSL e RGB. O primeiro porque além do matiz, traz a leitura de saturação e brilho. O segundo, porque trata do sistema aditivo, formado pelas cores primárias da luz, e quando falamos em cinema estamos prioritariamente tratando da cor-luz.

Usando o modo de cores HSL, o matiz é especificado no campo de cores, como um ângulo de $0^{\circ}$ a $360^{\circ}$, que corresponde a um local no disco de cores. A saturação e o brilho são especificados como porcentagens (de 0 a 100\%).

A figura 43 apresenta as cores selecionadas pelo conta-gotas nos fotogramas da figura 42. À esquerda um vermelho, matiz posicionado a $359^{\circ}$ no disco de cores, com $89 \%$ de saturação e $72 \%$ de luminosidade. À direita, um matiz posicionado a $319^{\circ}$ no disco de cores, com $44 \%$ de saturação e $46 \%$ de luminosidade. 

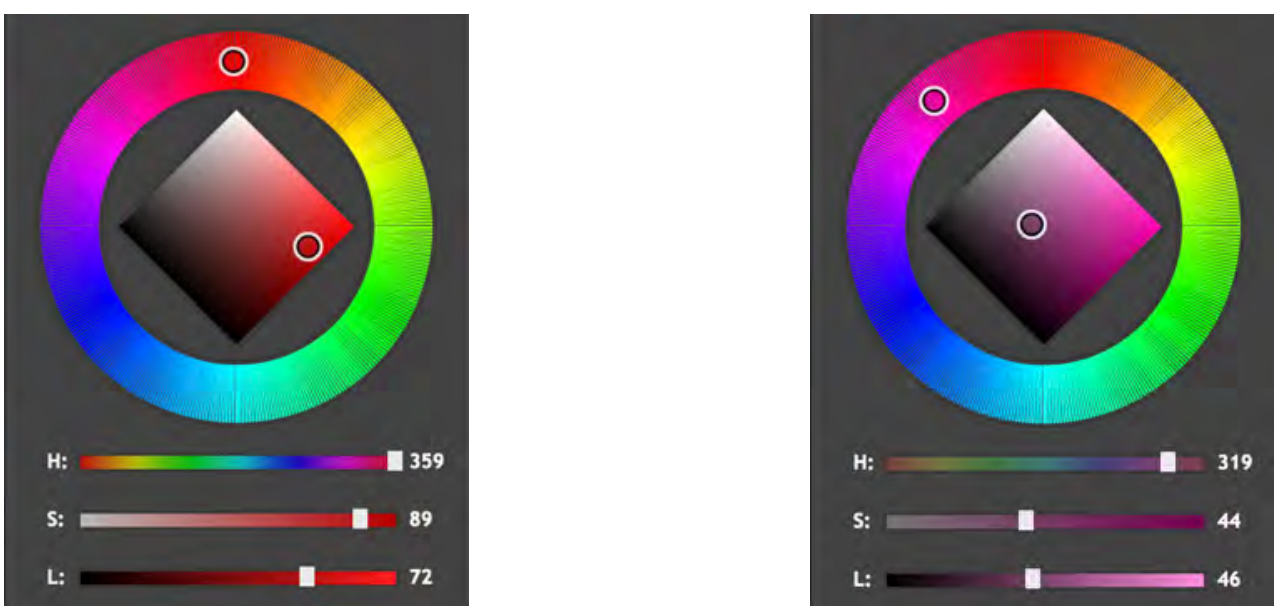

Fig. 43 - Análise de cores no modo HSL

O modo RGB utiliza o modelo RGB, atribuindo um valor de intensidade a cada pixel. Em imagens de 8 bits por canal, os valores de intensidade variam de 0 (preto) a 255 (branco) para cada um dos componentes de cores RGB (vermelho, verde, azul). É o modelo utilizado por monitores de computador para exibir cores. Isso significa que, ao trabalhar em modos de cor distintos do RGB, como CMYK, o Photoshop converte a imagem em RGB para exibição na tela. Embora o RGB seja um modelo de cores padrão, a faixa exata de cores representadas pode variar, dependendo do gamut utilizado.

No caso dos fotogramas da figura 42 , temos a seguinte leitura.
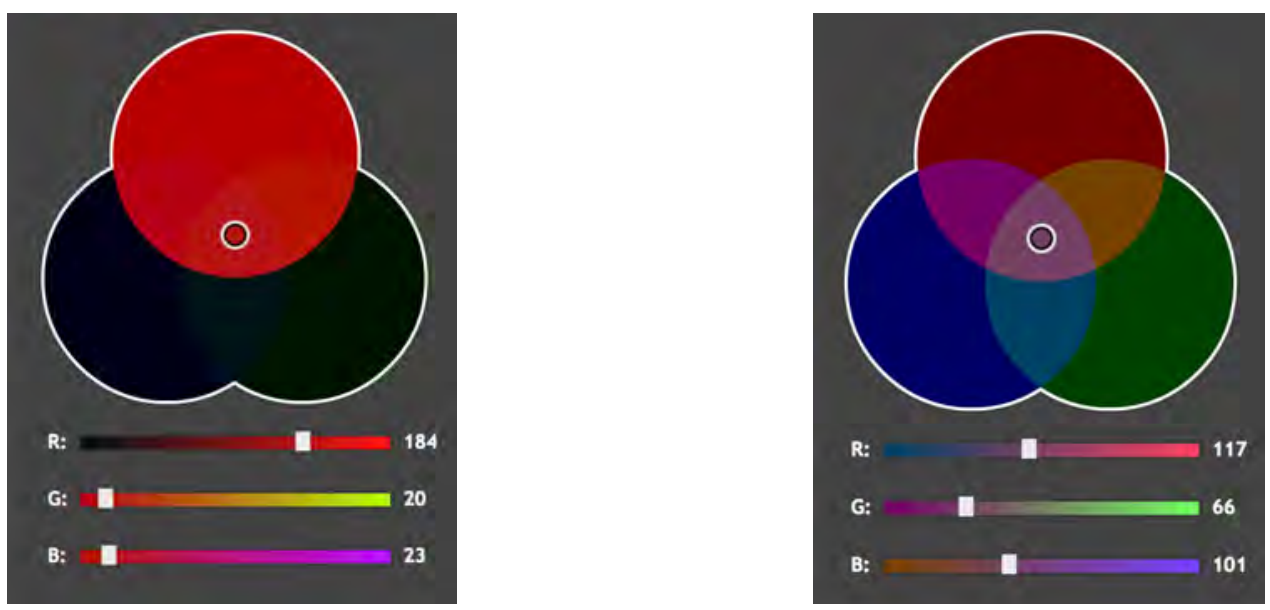

Fig. 44 - Análise de cores no modo RGB

Vemos, portanto, que o vermelho do elevador tem um valor $\mathrm{R}$ de 184 , um valor $\mathrm{G}$ de 20 e um valor B de 23. Já o roxo do uniforme do ascensorista tem valor de $\mathrm{R}$ de 117 , valor de G de 66 e valor de B de 101. Neste modo, quando os valores dos três componentes são iguais, o resultado é um tom de cinza. Quando o valor de todos os componentes é 255, o resultado é um branco puro e, quando o valor dos componentes é 0 , o resultado é um preto puro. 
O Photoshop online apresenta uma visualização de tabela de cores indexadas que permite uma avaliação do conjunto de cores existentes na imagem. A cor indexada é resultado de um processo de separação das cores em que as inúmeras tonalidades da imagem são reduzidas a um número limitado de cores. Ao converter em cores indexadas, o Photoshop cria uma tabela de busca de cores (CLUT, color lookup table), que armazena e indexa as cores da imagem. Ainda que este modo promova uma redução das cores originais para 256 cores, em imagens de 8 bits, é uma ferramenta importante para promover um comparativo entre imagens. A figura 51 traz a tabela de cores indexadas do fotograma da figura 48.

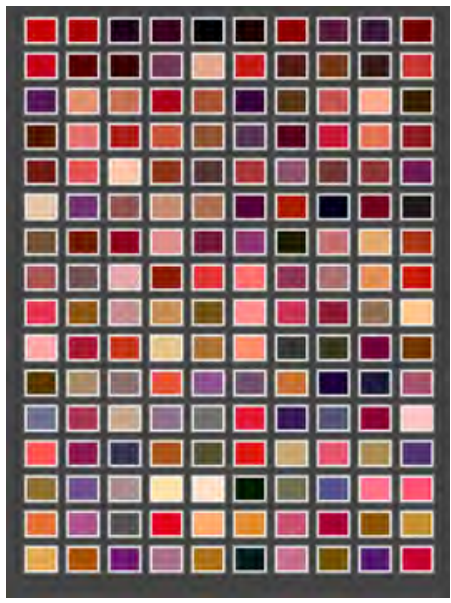

Fig. 45 - Modo de cores indexadas

As ferramentas e sistemas de padronização são necessários para a análise do fenômeno cromático, que comporta um alto grau de subjetividade. Apesar da percepção e avaliação das cores ser individual, algumas teorias são construídas a partir de postulados do caráter psicológico da cor.

Johann Wolfgang von Goethe (1749-1832), escritor e poeta dos séculos XVIII e XIX, publicou sua Teoria das cores (Zur Farbenlehre) em 1810. Distanciando-se da tendência dominante da época, o materialismo científico, Goethe não se ocupou da quantificação, mas priorizou em seu enfoque o elemento qualitativo. Ainda que sua teoria não se construa sobre alicerces matemáticos, possui um rigor de observação dos fenômenos cromáticos e suas conexões. Nesse sentido, opõe-se à teoria de Isaac Newton (1643-1727), publicada em 1672.

O texto principal de Goethe divide-se em seis partes:

\section{Cores fisiológicas}

II. Cores físicas

III. Cores químicas

IV. Perspectiva geral das relações internas 
V. Afinidades da Teoria das Cores com outras disciplinas

VI. Efeito sensível-moral das cores

$\mathrm{Na}$ primeira parte, trata dos fenômenos cromáticos que se relacionam à interioridade dos indivíduos, produzidos por condicionantes fisiológicos. Apesar de considerar que as cores pertencem ao universo subjetivo, Goethe afirma que elas se apresentam a indivíduos diferentes com as mesmas disposições, as mesmas ordenações. $\mathrm{Na}$ última parte, indica a atuação das cores na alma humana, antevendo questões que seriam consideradas posteriormente pela psicologia das cores. Ao afirmar que as cores possuem caráter próprio, entende que cada cor tem uma atuação característica sobre o psiquismo humano, provocando sensações e reações similares em diferentes indivíduos.

Este é o ponto de partida de teorias que se estabeleceram no campo das artes, comunicação visual, design e arquitetura. É o caso da base pedagógica para o ensino de cor na Bauhaus, escola fundada em Weimar em 1919, com uma visão pioneira e interdisciplinar das artes. Vários mestres da Bauhaus tinham interesse na teoria da cores, como Wassily Kandinsky, Paul Klee, Johannes Itten (1888-1967) e Josef Albers (1888-1976). Identificam-se elementos da teoria de Goethe, expressas de novas formas, nos métodos e procedimentos pedagógicos desses artistas.

Havia uma convicção entre eles de que a cor na composição poderia se buscada de forma objetiva. Itten acreditava na possibilidade de se atribuir às cores valores emocionais universais. Klee, por sua vez, referenciava a obra de Goethe mas era cauteloso em relação ao excesso de teorias. Acreditava que os efeitos emocionais das cores não eram passíveis de serem dissecados e analisados em tabelas e gráficos. Kandinsky acreditava que a cor influenciava diretamente a alma, e realizou testes para tentar identificar o significado psicológico de diferentes cores, experimento que resultou inconclusivo.

Ao tratar do papel expressivo que a cor desempenha no cinema, Jacques Aumont constata a "quase inexistência de uma teoria da cor". Segundo o autor, apesar de sua importância como valor plástico, a cor "só tem suscitado discursos metafóricos".

\footnotetext{
Metáfora psicológica, basicamente a do calor, que todos conhecem: o vermelho é cor quente, o azul é fria. Metáforas simbólicas que retomam, às vezes sem saber, equivalências antigas entre o vermelho e o sangue, o ouro e poder, o azul-marinho e o firmamento. Todas essas metáforas e outras, acham-se incansavelmente reproduzidas e combinadas na maioria das abordagens criadoras do domínio plástico, de Kandisnky em suas lições na Bauhaus a Eisenstein em seus ensaios sobre a montagem. Não se trata de desprezar o interesse potencial de tais comparações. Simplesmente, não podem valer para teorias (AUMONT, 1993, p. 284).
} 
A dificuldade na criação de uma teoria geral para a cor reside na complexidade e instabilidade de seu fenômeno, que só pode ser interpretado culturalmente, dentro de um determinado contexto. Apesar de Aumont invalidar tais discursos como verdadeiras teorias, as ideias de Eisenstein acerca das cores no cinema merecem destaque, uma vez que se afastam de uma psicologia universal da cor, atrelando conteúdos simbólicos à narrativa.

No texto "Movimento da cor", publicado na coletânea Cinematismo, Eisenstein trata a cor como um elemento dinâmico, um "dom plasticamente ligado ao tema". Afirma que não há ausência de cor nos filmes em preto e branco, uma vez que preto, branco e cinza são cores. $\mathrm{O}$ movimento do tema do filme está na luta que se estabelece entre dois princípios cromáticos: o preto e o branco, que em algum momento se entrecruzam para formar a cor cinza. Assim, ainda que eleja uma cor contínua para cada um de seus filmes, afirma que as "peripécias internas" do tema resultam em matizes de cor (EISENSTEIN, 1982, p. 452).

Nesse sentido, explica que o tom cinza dominante em $O$ Encouraçado Potemkin (1925) foi composto por três elementos do filme: a dureza das bordas do encouraçado, a suavidade dos nevoeiros "e um terceiro fato, que é como se reunisse os outros dois, tomando de um o brilho e de outro a suavidade: a variação da superfície do mar, filmada na mesma gama de cinza" (EISENSTEIN, 1982, p. 451).
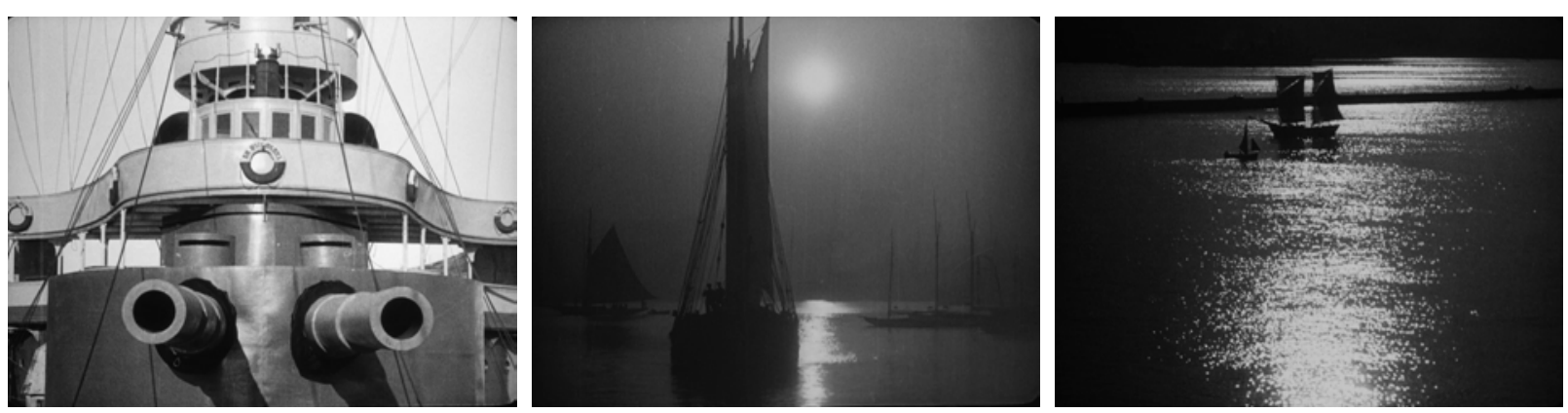

Fig. 46 - O Encouraçado Potemkin (1925), Sergei Eisenstein

O cinza no filme chega nos extremos, até fundir-se ao negro: nas jaquetas dos oficiais e nos negros quadros do alarme da noite. E, no branco, ao tomar-se a lona branca na cena do fuzilamento, as brancas velas dos barcos, que se acercavam velozmente do encouraçado, o voo dos gorros brancos dos marinheiros no final; no voo, parecido a um estalido, da falecida mortalha de lona, destroçada pelo impulso revolucionário do ano de 1905 (EISENSTEIN, 1982, p.451).
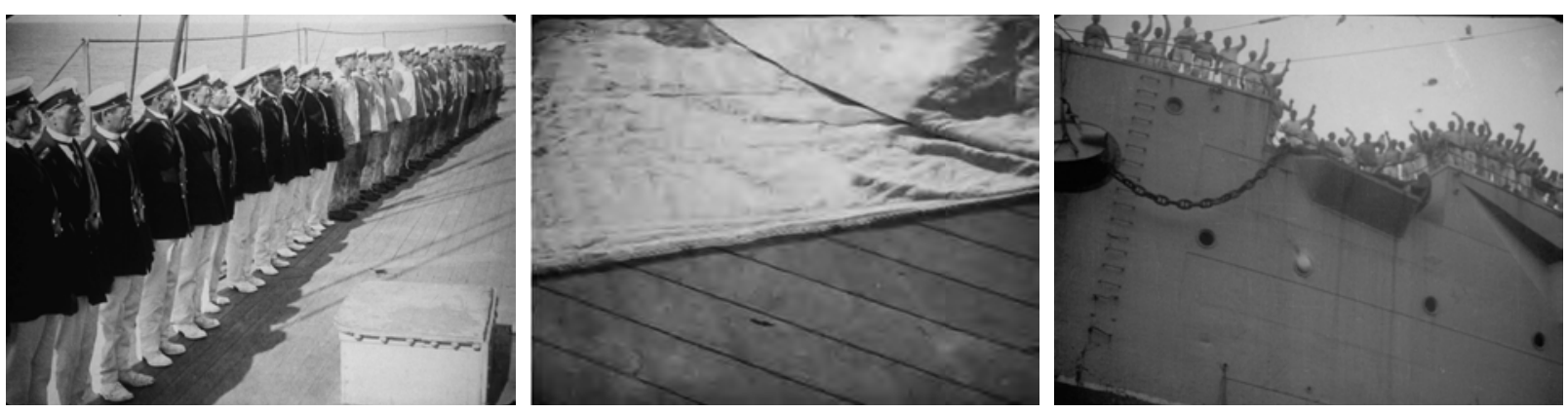

Fig. 47 - O Encouraçado Potemkin (1925), Sergei Eisenstein 
A segunda ideia fundamental de Eisenstein relaciona-se ao significado simbólico da cor, uma concepção metafórica da obra cinematográfica. No capítulo "Cor e significado", publicado em $O$ sentido do filme, analisa autores que contribuíram para a história da evolução dos significados simbólicos das cores e alerta para o erro de um sistema em que as cores agem por sua própria conta, em que lhes são atribuídos significados independentes e autossuficientes, abstraindo-se o fenômeno concreto, única fonte dos conceitos e associações. Desse modo, sugere evitar correlações absolutas entre cor e emoção, e entre cor e relações sociais, uma vez que esses sistemas nascem de conceitos pessoais que evoluem para significados atribuídos às cores. Eisenstein finaliza seu texto afirmando que:

\footnotetext{
Na arte, não são as relações absolutas as decisivas, mas as relações arbitrárias dentro de um sistema de imagens ditadas pela obra de arte em particular. O problema não é, e nem nunca será, resolvido por um catálogo fixo de símbolos de cor, mas a inteligibilidade emocional e a função da cor surgirão da ordem natural de apresentação da imagem colorida, coincidente com o processo de moldar o movimento vivo de toda a obra (EISENSTEIN, 2002, pp 99 e 100).
}

Outra questão importante a se observar na análise de filmes foi desenvolvida por Richard Misek (1962- ), professor da Universidade de Kent. Em seu livro Chromatic cinema, Misek evidencia a diferença entre o emprego da cor-superfície e da cor-luz na obra cinematográfica.

A cor-superfície é aquela proveniente da utilização de elementos pigmentados, como cenários e figurinos. É o que faz o diretor Jean-Luc Godard (1930) no filme A Chinesa (La Chinoise, 1967), fotografado por Raoul Coutard (1924-2016). À semelhança do que faz Henri Matisse (1869-1954) em O ateliê vermelho (1911), Godard estrutura o espaço fílmico por meio das cores. A cor, portanto, torna-se não apenas um elemento de composição e sim um elemento estrutural do espaço. No caso do filme de Godard, a cor é dada pela superfície dos objetos, que são fotografados com luz branca.
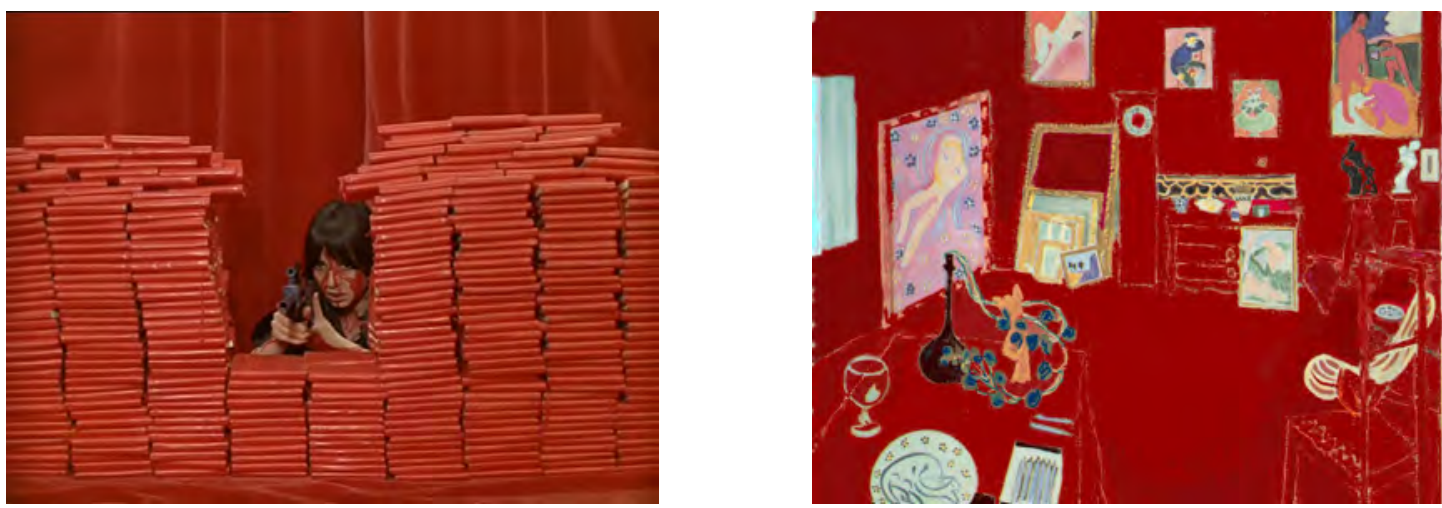

Fig. 48 - A Chinesa (1967), Jean-Luc Godard e $O$ ateliê vermelho (1911), Henri Matisse 
A cor-luz, por sua vez, constrói-se a partir dos aparatos de iluminação, do uso de refletores e gelatinas. Uma característica importante nesse tipo de procedimento é a possibilidade de utilização de fontes luminosas com diferentes matizes. Um exemplo de filme com essas características é Blade Runner: O Caçador de Androides (Blade Runner, 1982), de Ridley Scott, fotografado por Jordan Cronenweth (1935-1996).

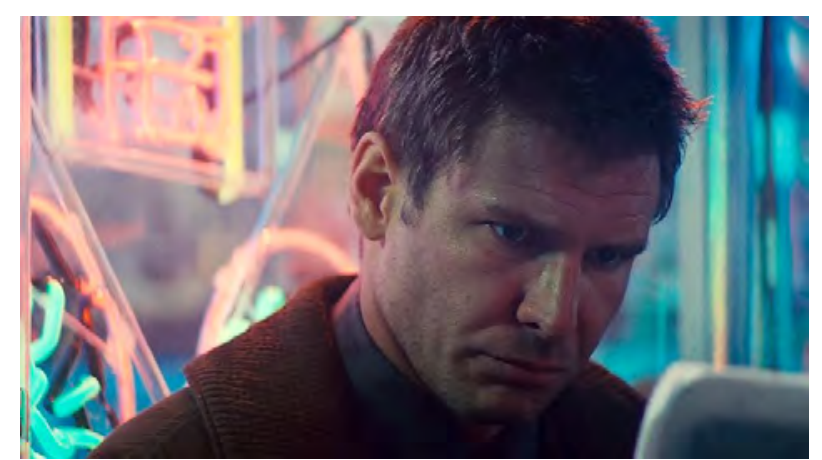

Fig. 49 - Blade Runner: O Caçador de Androides (1982), Ridley Scott

O trabalho de cor-luz é uma atribuição do diretor de fotografia em associação ao do colorista. Durante a captação do filme, o diretor de fotografia trabalha as várias temperaturas de cor e os filtros de efeito, responsáveis pela cor-luz fora do eixo CTO/CTB (laranja/azul). O colorista trabalha a cor da imagem como um todo na pós-produção, podendo também manipular separadamente matizes específicos.

O resultado final depende de uma combinação de elementos técnicos como, por exemplo: capacidade de registro de cor do sensor ou da película, balanceamento entre temperatura de cor de refletores e set up de câmera (ou característica da película), índice de reprodução cromática (IRC) das fontes luminosas.

O ser humano enxerga a luz natural como branca, desse modo, sua utilização no cinema contribui para a impressão de realismo na obra ficcional. Em Um Beijo Roubado (My Blueberry Nights, 2007), Won Kar-Wai e o diretor de fotografia Darius Khondji (1955- ) elaboram as cenas utilizando fontes diegéticas de diferentes matizes, sem contudo romper com o registro realista do filme. No fotograma da figura 50 é possível ver como as cores não são provenientes de superfícies pigmentadas mas sim de fontes luminosas brancas, amarelas, azuis, vermelhas, verdes e lilases.

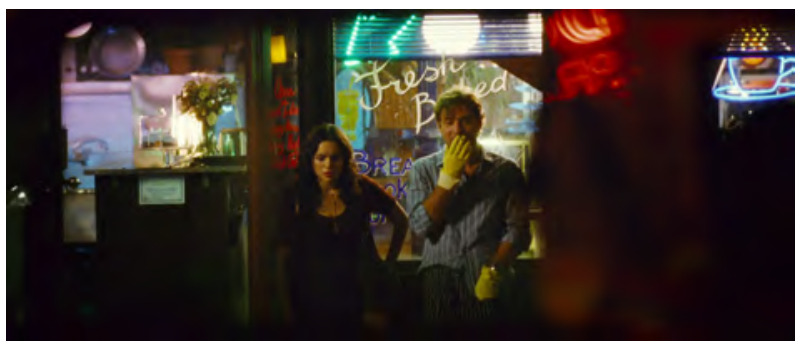

Fig. 50 - Um Beijo Roubado (2007), Won Kar-wai 
Existe ainda uma terceira possibilidade de uso da cor no cinema, não discutida por Misek, que é o processo de colorização em pós-produção. É o que faz o diretor de fotografia Walter Carvalho em O Filme da Minha Vida (2017), de Selton Mello (1972- ). O enredo gira em torno do personagem Tony, que na década de 1960 volta à sua cidade natal e descobre que o pai retornou à França, alegando sentir saudade de seus amigos e de seu país de origem. $\mathrm{O}$ filme tem um trabalho de colorização em pós que lhe confere uma tonalidade contínua, assemelhando-o à visualidade de filmes antigos, desgastados com o tempo.

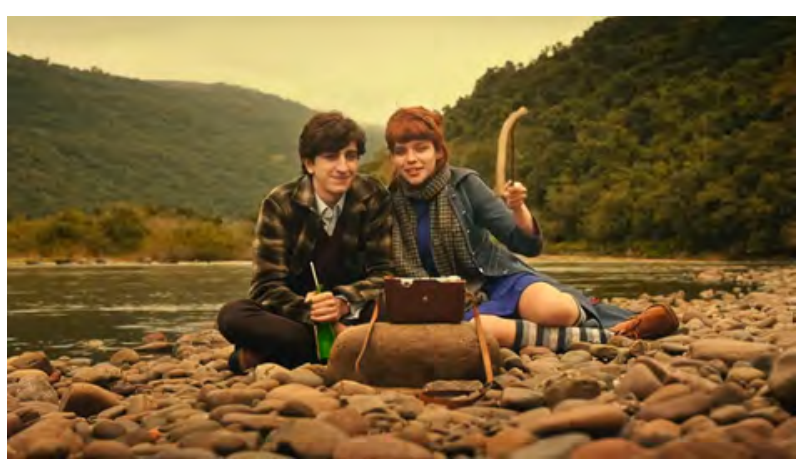

Fig. 51 - O Filme da Minha Vida (2017), Selton Mello

A pós-produção permite o movimento da cor-luz, um procedimento que rompe com o caráter estático da temperatura de cor das fontes. É o que faz o fotógrafo Vittorio Storaro (1940- ) no filme Roda Gigante (Wonder Wheel, 2017), de Woody Allen (1935- ). Ginny é uma garçonete casada com Humpty, operador do carrossel em um parque de Coney Island, e amante do jovem salva-vidas Mickey. Em um dos momentos do filme, Ginny tem uma conversa com sua enteada Carolina, que confessa estar vivendo um romance com Mickey. Durante a cena, a luz azulada que entra pela janela transforma-se em um forte alaranjado, marcando a transformação interior de Ginny ao descobrir que está sendo traída por seu amante.
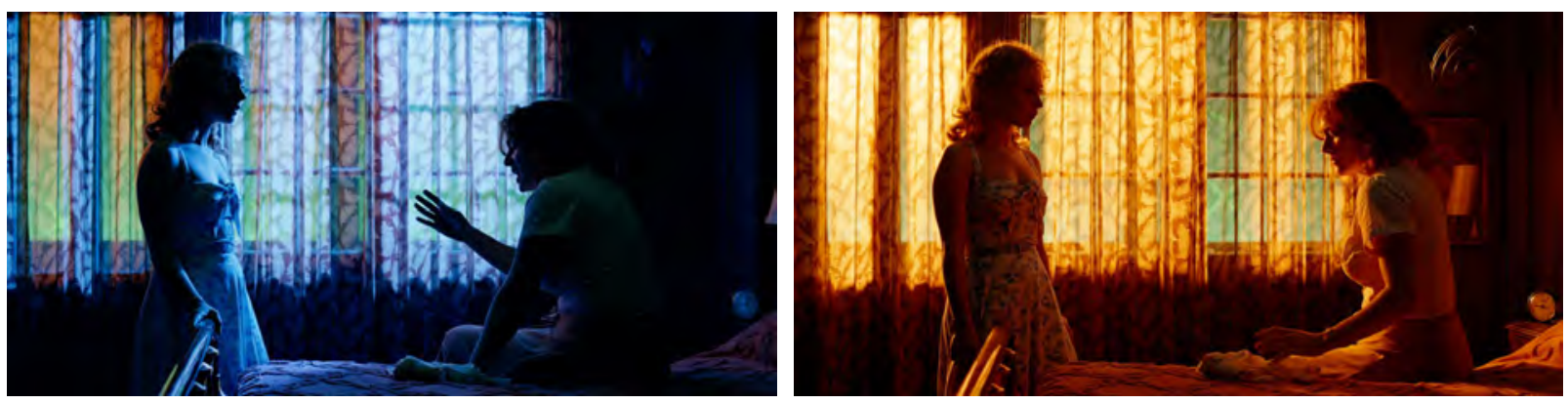

Fig. 52 - Roda Gigante (2017), Woody Allen

É o que ocorre nos créditos iniciais de Bagdad Café (Bagdad Cafe, 1987), de Percy Adlon (1935- ), fotografado por Bernd Heinl (1947- ). A mudança da cor e do contraste 
antecipam a transformação pela qual passará a personagem Jasmin, uma turista alemã que briga com o marido e é deixada em uma estrada do Arizona. Ao se refugiar em um postomotel chamado Bagdad Café, muda sua própria vida e das pessoas que habitam o local.
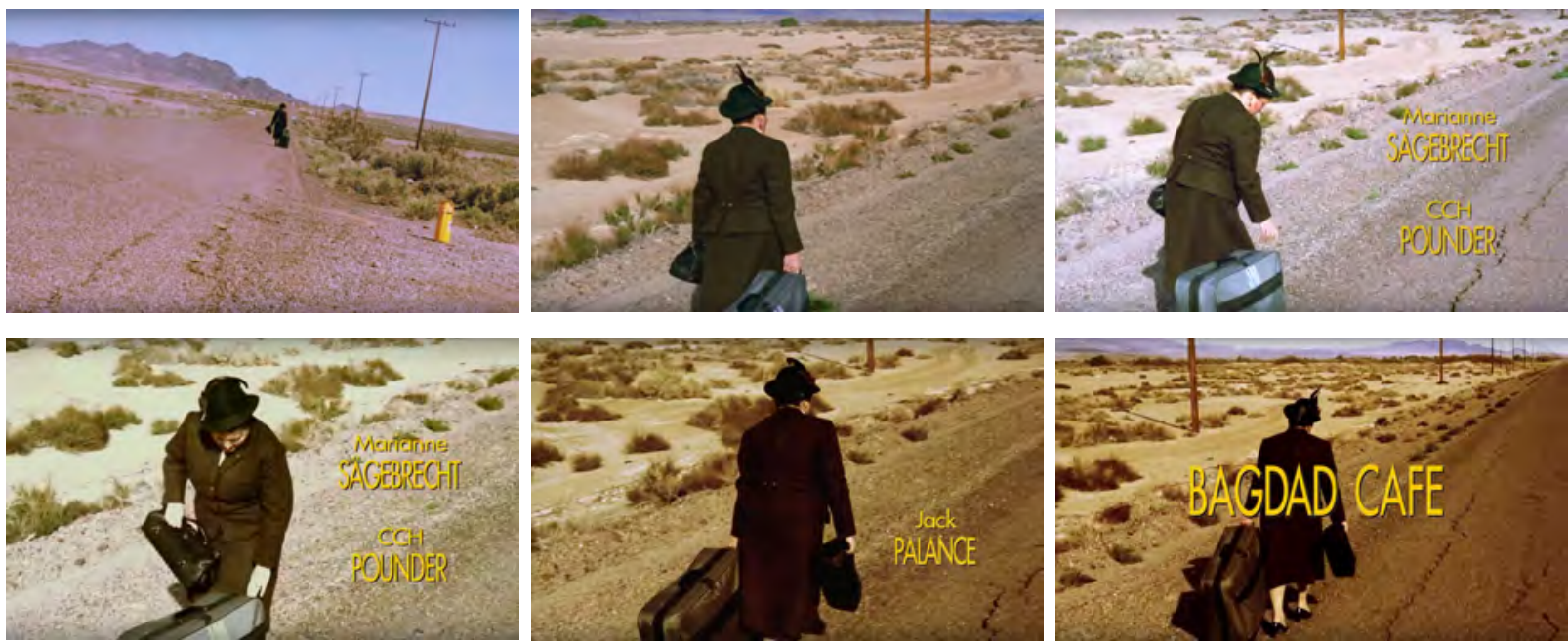

Fig. 53 - Bagdad Café (1987), Percy Adlon

Por fim, vale lembrar que um aspecto fundamental da utilização da cor no cinema resulta do caráter imersivo de sua exibição. Na sala de cinema a cor expande-se para além da superfície da tela, rompendo o limite do espaço fílmico criado pelo enquadramento e lançando-se para o espaço real. Desse modo, o cromatismo da imagem supera sua função como elemento da composição, permitindo que o espectador adentre a imagem. 


\section{IMAGEM TÉCNICA E O SISTEMA FOTOGRÁFICO}

As imagens técnicas, ou seja, as representações icônicas mediadas por aparelhos, não podem corresponder a qualquer duplicação inocente do mundo, porque entre elas e o mundo se interpõem transdutores abstratos (MACHADO, 2005, p. 05).

A rigor, todas as imagens são técnicas, uma vez que são produzidas por algum procedimento técnico. Entretanto, para o presente trabalho adotaremos a concepção de imagem técnica proposta pelo filósofo Vilém Flusser (1920-1991), aquela cuja relação entre sujeito criador e coisa percepcionada é mediada por um aparelho de codificação, um meio tecnológico passível de produzir imagens. O motivo para adotar tal definição apoia-se no fato da imagem cinematográfica ser produzida por câmeras, e para entender o ato criador do diretor de fotografia é necessário investigar não apenas os elementos plásticos, mas também os parâmetros técnicos com os quais ele deve lidar para imprimir uma imagem.

A imagem fotográfica resulta da transformação de uma quantidade de luz em uma organização qualitativa, que ocorre no interior da câmera. Desse modo, a codificação é externa ao agente humano, o que poderia equivocadamente levar a crer que o significado da imagem é impresso de forma automática e objetiva. Assim, imagem e mundo supostamente encontrariam-se no mesmo patamar, unidos por uma cadeia de processos óticos, químicos, mecânicos e eletrônicos, que produziriam cópias fiéis do real. A imagem fotográfica, portanto, não configuraria um símbolo, no sentido de se referir ao objeto fotografado por meio de uma associação de ideias, e em consequência, não careceria de deciframento.

Esta possibilidade existe, principalmente num momento em que muitos se contentam em "apertar botões", limitando a capacidade criativa às limitações de um software, de um LUT, de um conjunto de possibilidades estabelecidas a priori pelas configurações do equipamento. Entretanto, se pensarmos em imagens fotográficas produzidas com intencionalidade, tanto na captação quanto no processamento, sua objetividade é duplamente ilusória, uma vez que é realizada por um agente humano e não configura uma representação realista.

Trata-se de um processo em que apesar das habilidades manuais serem colocadas de lado, cabe ao olho, ao cérebro e "ao coração" (CARTIER-BRESSON, In: FONTCUBERTA, 2014, p. 223) a responsabilidade pelo resultado. É necessário que o agente transcodifique sua intenção em conceitos para o aparelho os transforme em imagens. Portanto, existe uma variável subjetiva no sistema, que age de forma intencional, sendo responsável pela tomada 
de decisões no sentido de um resultado. A câmera apenas registra a decisão tomada pelo agente.

Desse modo, apesar de sua aparente automaticidade, a imagem técnica pode configurar a codificação de conceitos particulares de um agente, e não uma representação objetiva da realidade. Segundo Flusser, fotografias são imagens de conceitos. O agente produz, manipula e armazena símbolos abstratos, cuja origem está em seu pensamento. Assim, quando contemplamos uma imagem fotográfica não vemos o "mundo", mas determinados conceitos relativos ao mundo.

A intermediação do processo artístico pela máquina também coloca em evidência questões sobre os conceitos que norteiam a construção dos aparatos, uma vez que as características técnicas de sua programação acabam por se materializar na produção das imagens. No caso da fotografia, a utilização de um determinado modelo de câmera digital, ou de um determinado negativo, imprime uma visualidade específica à imagem.

Esse fato pode ser evidenciado quando comparamos, por exemplo, um fotograma da cena inicial de $O$ Céu de Suely (2006), de Karim Aïnouz (1966- ), filmada em super-8, e outro de Ela (Her, 2013), de Spike Jonze, captado em 2K.

A cena de $O$ Céu de Suely tem uma textura pouco nítida e granulada, proveniente do registro em super-8. É possível simular essa visualidade em pós-produção, entretanto, o resultado obtido difere da efetiva captação nessa bitola. O filme Ela, por sua vez, tem uma imagem nítida, compatível com a resolução $2 \mathrm{~K}$ do sensor com que foi captada, a câmera Arri Alexa.
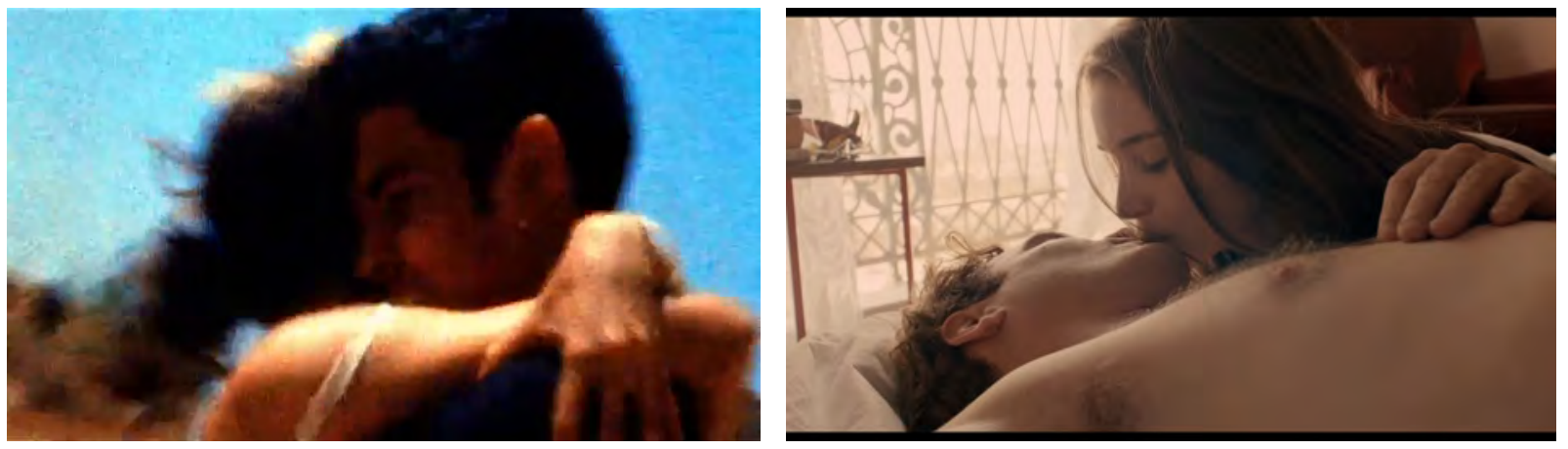

Fig. 54 - O Céu de Suely (esq) e Ela (dir)

Flusser chamou o complexo aparelho-operador de caixa preta e apontou a dificuldade de penetrar seu processo, no qual se amalgamam a intenção codificadora do agente e a programação da máquina (FLUSSER, 1985, p.11). Além disso, identificou a necessidade de "branquear" essa caixa, ou seja, explicitar os procedimentos construtivos dos aparatos 
tecnológicos para que seja possível manipulá-los na produção de resultados intencionais.

O ponto crucial de mediação entre sujeito e tecnologia situa-se no instante de criação da imagem. Portanto, para compreender a imagem técnica é necessário analisar os intervenientes objetivos e subjetivos do processo: o dispositivo tecnológico, suas potencialidades, características construtivas e variáveis do sistema; e o sujeito que cria, que progride entre o imaginário e o visual por meio de decisões sobre como utilizar o aparelho.

O presente trabalho não visa a compreensão dos processos mentais que levam agentes a fazer escolhas. Entretanto, a análise das variáveis objetivas na formação da imagem técnica, bem como da linguagem visual resultante deste processo, configuram importantes ferramentas na investigação de estilo, e uma forma possível de penetrar a caixa preta.

Para decifrar fotografias não preciso mergulhar até o fundo da intenção codificadora, no fundo da cultura, da qual as fotografias, como todo símbolo, são pontas de icebergs. Basta decifrar o processo codificador que se passa durante o gesto fotográfico, no movimento do complexo "fotógrafo-aparelho" (FLUSSER, 1985, p. 23).

Nos processos fotográficos analógicos e digitais, os princípios básicos da captação da imagem são semelhantes. O sistema é alimentado por uma quantidade de luz e a formação qualitativa da imagem ocorre por uma organização ponto a ponto, por meio da combinação de três variáveis de exposição: sensibilidade, diafragma e obturador.

A fotografia digital utiliza sensor em lugar do filme, obturador eletrônico em lugar do mecânico, pixels em lugar de sais de prata, mas tanto a fotografia analógica quanto a digital resultam da forma como as três variáveis são combinadas na formação da imagem. As câmeras cinematográficas apresentam os mesmos princípios de funcionamento das câmeras fotográficas, de modo que a análise das variáveis é análoga nos dois meios.

É importante notar que fotografar vai além de dominar técnicas e equipamentos. A técnica é importante na medida em que é utilizada para comunicar uma intenção e porque é determinante no resultado da imagem. A poética norteia o uso da técnica de forma expressiva, de modo a combinar as variáveis para a obtenção do resultado desejado. Segundo Flusser, é nessa manipulação da técnica que encontra-se a liberdade do fotógrafo.

Várias respostas apareceram: 1. o aparelho é infra-humanamente estúpido e pode ser enganado; 2. os programas dos aparelhos permitem introdução de elementos humanos não-previstos; 3. as informações produzidas e distribuídas por aparelhos podem ser desviadas da intenção dos aparelhos e submetidas a intenções humanas; 4. os aparelhos são desprezíveis. Tais respostas, e outras possíveis, são redutíveis a uma: liberdade é jogar contra o aparelho. E isto é possível (FLUSSER, 1985, p. 41). 
Entretanto, essa liberdade é limitada pela tecnologia, que acaba por criar o que o pesquisador William Crawford (1948- ) chamou de sintaxe fotográfica. Em termos linguísticos, a sintaxe configura um conjunto de regras que determinam as relações formais entre os constituintes da sentença, atribuindo-lhes uma estrutura e tornando possível a transformação de conceitos em discurso inteligível.

$\mathrm{Na}$ fotografia, a sintaxe é a combinação de elementos técnicos que acabam por limitar o que os fotógrafos conseguem comunicar. Trata-se do conjunto das relações químicas, óticas, mecânicas e eletrônicas de uma determinada tecnologia, que definem o range de possibilidades dentro do qual o fotógrafo irá trabalhar.

Para ilustrar a limitação trazida pela tecnologia, pensemos o caso do daguerreótipo, processo fotográfico criado no século XIX por Louis Jacques Mandé Daguerre (1787-1851). O daguerreótipo possuía uma baixa sensibilidade, o que demandava longos tempos de exposição e, consequentemente, a imobilidade do sujeito fotografado. Assim, era comum posicionar a pessoa retratada com a mão no queixo, sentada, e com um suporte na parte posterior da cabeça, de modo a minimizar seu movimento. Como resultado, grande parte dos retratados por daguerreótipos apresenta uma expressão rígida, decorrente da limitação do processo.

Nos dias de hoje, quando vemos um daguerreótipo, é comum associarmos a sisudez das pessoas retratadas à forma como se portavam à época. Entretanto, essa característica não é proveniente da personalidade dos retratados, mas da necessidade de posarem para a fotografia.

Desse modo, só podemos tomar a fotografia como um testemunho confiável de um período se levarmos em conta a sintaxe técnica em que foi produzida, caso contrário seremos compelidos a erros históricos, a ideias fora do contexto de uma tecnologia que opera seletivamente. Assim, existe uma relação entre a tecnologia e a forma como vemos o mundo, as fotografias trazem apenas uma versão da realidade.

Para prosseguirmos na investigação de estilo de cinematografia é necessário compreender o espaço sintático dentro do qual o diretor de fotografia toma suas decisões criativas, que basicamente ocorrem em dois momentos: na captação e na pós-produção.

Durante a captação as decisões concentram-se nos parâmetros de câmera, no desenho de luz e no movimento. Na pós-produção essas decisões referem-se à revelação do negativo e à manipulação da imagem por meio de softwares de correção de cor.

Neste capítulo analisaremos como é possível criar diferentes visualidades a partir da sintaxe fotográfica e do movimento. 


\subsection{Variáveis do sistema fotográfico}

O olho humano ajusta-se automaticamente às condições de luz de cada ambiente. $\mathrm{O}$ mesmo não ocorre com as câmeras, é necessário ajustar a quantidade de luz que a superfície fotossensível irá receber, dependendo do resultado que se pretenda obter. Esse processo é denominado exposição e determina a densidade da imagem.

A imagem fotográfica é, portanto, condicionada por uma relação quantitativa e qualitativa da luz. A quantidade de luz que entra no sistema é regulada por meio da exposição, que implica em uma determinante qualitativa à imagem.

A figura 55 traz três imagens com exposições distintas para uma dada quantidade de luz existente. A da esquerda está superexposta, há predominância de altas luzes e não há preto. A da direita está subexposta, não há brancos, a neve é cinza. A imagem central seria considerada a exposição correta, o que é um termo relativo, uma vez que o correto depende do resultado desejado. Desse modo, entenderemos por correta a exposição que zera o fotômetro.

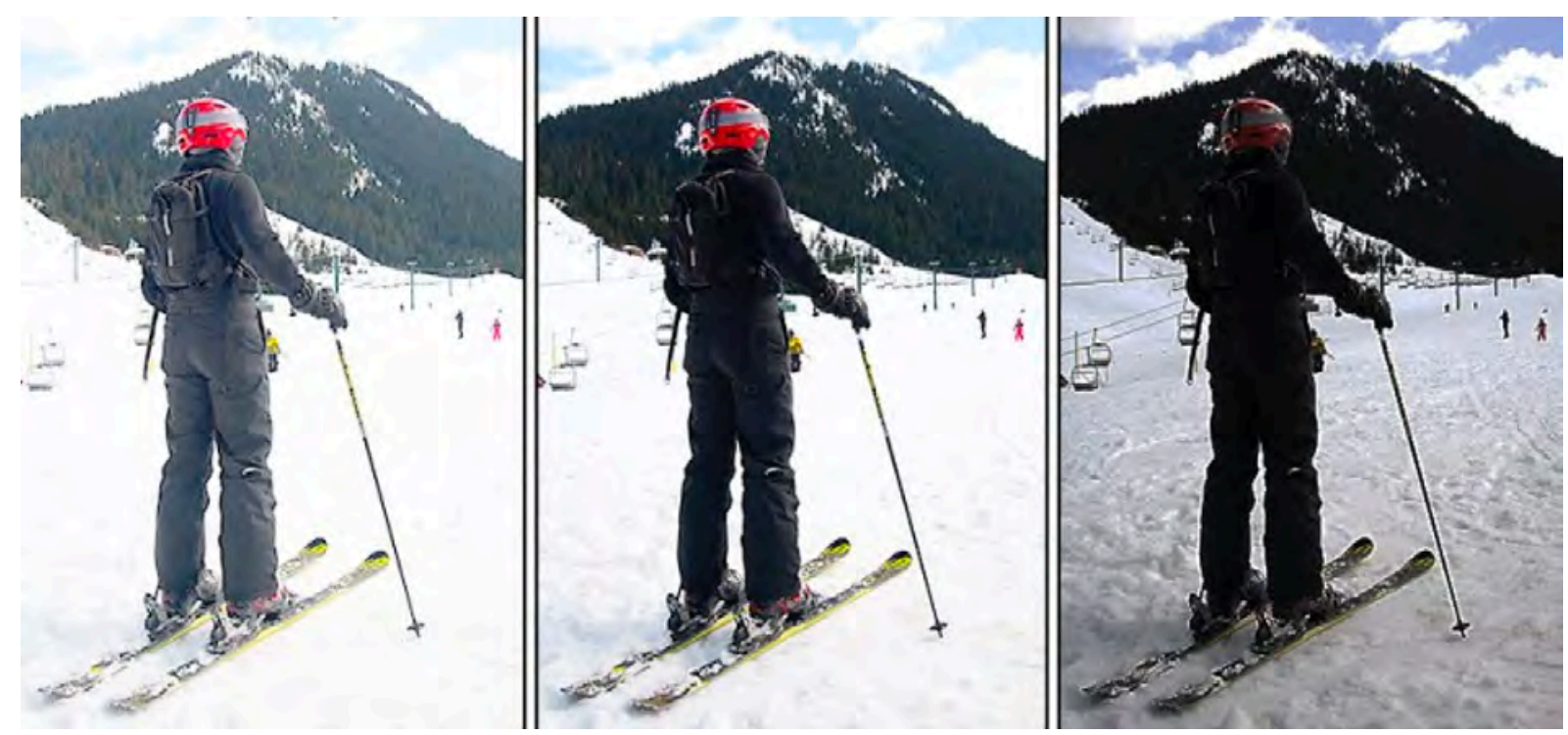

Fig. 55 - Diferentes exposições

(Fonte: http://ajustes.org.br/obturador-a-ferramenta-para-congelar-o-movimento/)

Em uma dada condição de luz, há três fatores que se relacionam para determinar a exposição: sensibilidade, obturador e diafragma. A forma como essas variáveis se combinam resulta em um tipo de visualidade.

Se pensarmos em uma grande entrada de luz no sistema é possível utilizarmos uma pequena sensibilidade (grão fino), obturador rápido (nitidez) e diafragma fechado (grande profundidade de campo). Mas nem sempre o objetivo do fotógrafo é maximizar o aproveitamento de luz no sistema. 
A forma de combinar as variáveis de exposição depende do resultado visual pretendido e do estilo pessoal do fotógrafo. Para entendermos as possibilidades que essas variáveis oferecem em termos de linguagem, analisaremos separadamente cada uma delas.

\subsubsection{Sensibilidade}

Refere-se à capacidade de absorção de luz das superfícies fotossensíveis. A escala utilizada para sua medição é o ISO (International Standard Organization), um padrão fisicamente definido como a inversa da entrada necessária para obter uma resposta predeterminada em um sistema. Ou seja, quanto maior a sensibilidade de um filme, menor o tempo necessário para a captação da imagem.

Os elementos fotossensíveis dos filmes são os haletos de prata, como mostra a figura 56. Quanto maior a área de absorção de luz, menor o tempo de exposição da imagem, assim, emulsões mais sensíveis tendem a possuir haletos maiores e menos dispersos. Por esse motivo, filmes mais sensíveis geralmente apresentam imagens mais granuladas.

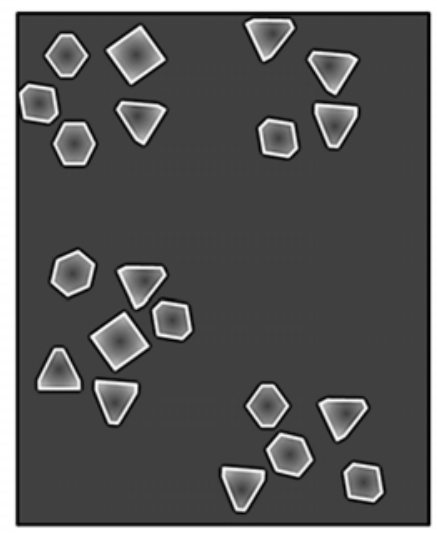

ISO 100

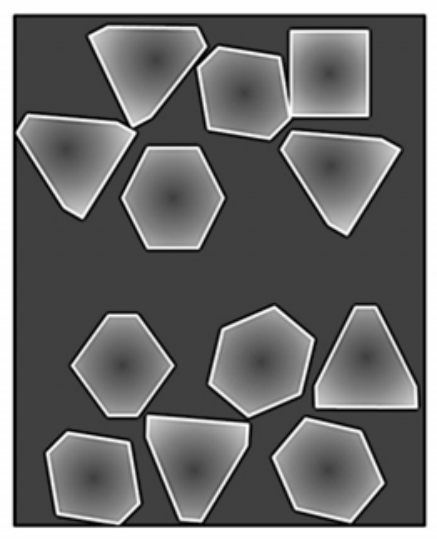

150400

Fig. 56 - Grãos em filmes de diferentes sensibilidades

(Fonte: http://cameraneon.com/tenha-em-mente/iso-granulacao-e-ruido-na-fotografia-digital-eanalogica/)

O processo exposição/revelação pode gerar imagens em que os grãos tornam-se mais visíveis. É o que acontece quando o negativo é sub-exposto e super-revelado, processo conhecido como "puxar" o filme. Na figura 57 temos um filme Kodak T-Max 3200 puxado para 6400. Isso significa que sua sensibilidade nominal é ISO 3200, mas foi exposto como ISO 6400 e revelado por mais tempo ou a uma temperatura mais alta. Nesse tipo de processo há um aumento de contraste da imagem e os haletos podem se aglomerar, tornando-se mais visíveis. O resultado é uma imagem granulada, inclusive nas áreas de alta luz, como no caso da parede branca da figura 57. 


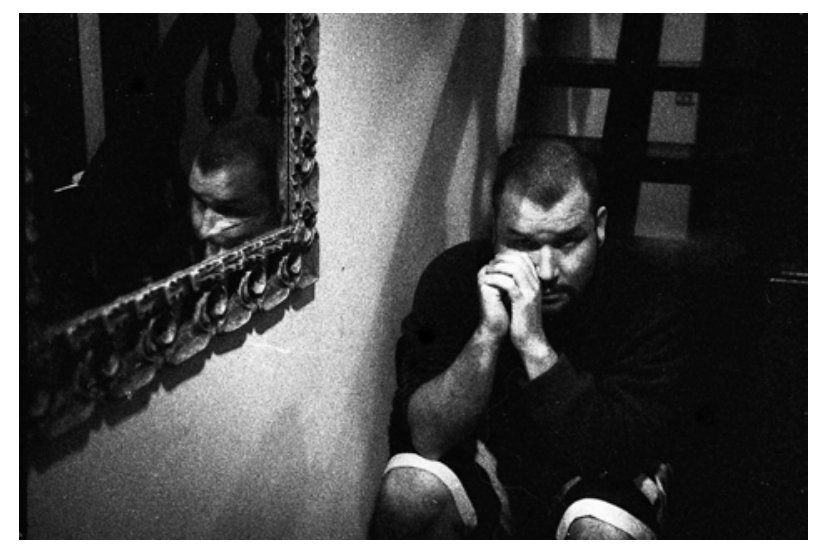

Fig. 57 - Na escada (2011), Lomocouple

Na fotografia digital, as câmeras possuem uma sensibilidade nominal. Entretanto, é possível variar a sensibilidade da captação. Quando a sensibilidade ajustada é maior que a nominal, simula-se o processo de puxar o filme: há uma subexposição compensada pela ampliação do sinal gerado pela luz nos fotorreceptores. A consequência dessa ampliação é o aparecimento de ruído eletrônico. $\mathrm{O}$ aumento da sensibilidade não interfere na resolução da imagem (relação entre a quantidade de pixels e tamanho do sensor) mas pode diminuir a sua qualidade em virtude do aparecimento de ruído, o que pode ser visto na figura 58.

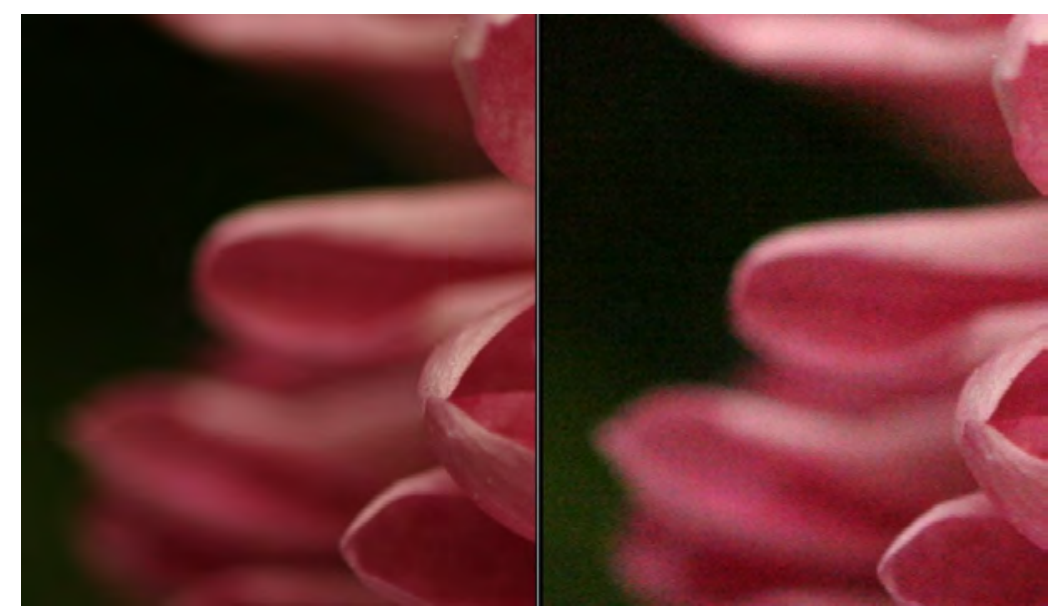

Fig. 58 - Perda de qualidade pelo aumento do ruído

(Fonte: https://fotografiaartistica.it/cose-liso-corso-di-fotografia/)

Grão e ruído são de naturezas distintas, o primeiro resulta de um fenômeno químico e refere-se ao tamanho e dispersão dos haletos nas emulsões, o segundo relaciona-se à ampliação do sinal eletrônico, e não com o número ou tamanho de fotorreceptores (pixels) presentes no sensor.

A tecnologia tem avançado na produção de equipamentos capazes criar imagens cada vez mais limpas e definidas, entretanto, grão e ruído podem ser utilizados de forma 
expressiva. É o caso de Julien Donkey-Boy (Julien Donkey-Boy, 1999), dirigido por Harmony Korine (1973- ) e fotografado por Anthony Dod Mantle (1955- ).

Trata-se do retrato de uma família americana disfuncional, afetada pela esquizofrenia do filho Julien. A história é contada a partir de seu ponto de vista, o que torna a narrativa aparentemente incoerente e pouco nítida. O filme foi captado em mini DV, portanto em standard definition, teve blow-up para $16 \mathrm{~mm}$ e cópias de exibição em $35 \mathrm{~mm}$. A sucessiva ampliação teve como resultado uma imagem extremamente granulada, não-realista, refletindo o estado interior dos personagens e uma visão de mundo longe dos padrões tidos como "normais". A figura 59 traz um fotograma da sequência em que o pai, interpretado por Werner Herzog (1942- ), droga-se com xarope para tosse, usando uma máscara antigás.

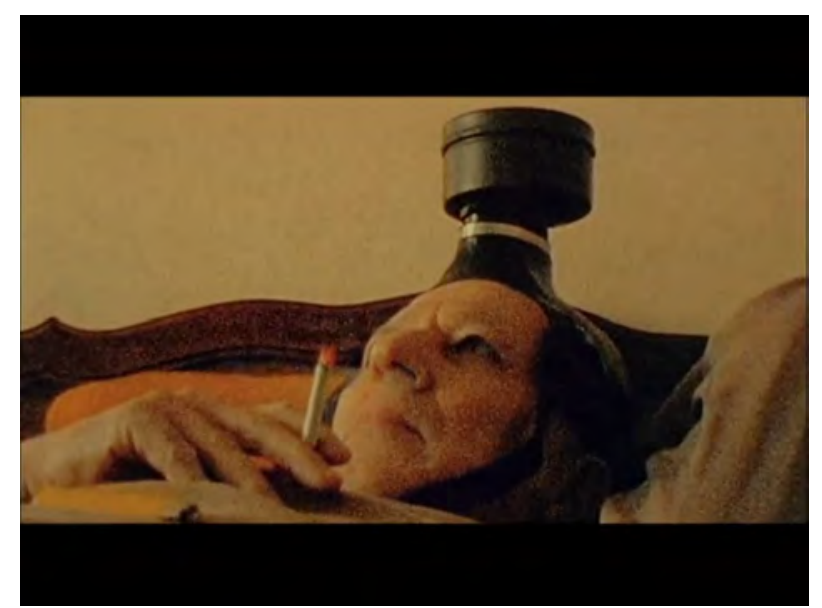

Fig. 59 - Julien Donkey-Boy (1999), Harmony Korine

\subsubsection{Obturador}

Trata-se de um dispositivo no interior da câmera cuja finalidade é controlar o tempo de exposição do filme. Funciona como uma cortina, cobrindo o sensor/filme enquanto não há exposição e abrindo-se rapidamente no momento da captação da imagem.

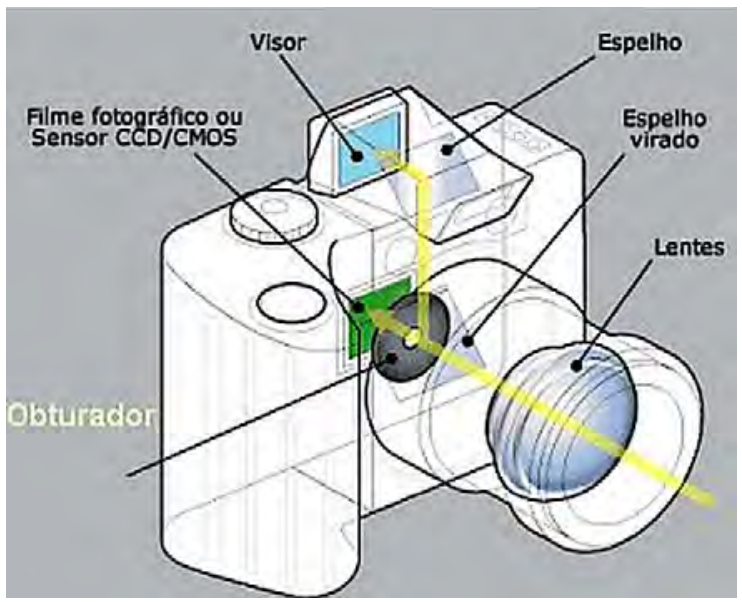

Fig. 60 - Mecanismo básico de funcionamento da câmera fotográfica

(Fonte: https://lfpress.blogspot.com/2011/11/entenda-um-pouco-sobre-as-cameras.html) 
A figura 60 mostra o mecanismo de funcionamento de câmeras fotográficas. Da luz que entra pela lente, uma parte vai para o visor e outra parte passa pelo obturador, que quando aberto permite a sensibilização do filme/sensor digital.

Em um obturador mecânico, como o da figura 61, a velocidade de disparo é medida em segundos ou frações de segundos e representa o tempo que o obturador fica aberto. Ao contrário dos obturadores utilizados em câmeras fotográficas, os utilizados na maioria das câmeras de vídeo com CCD/CMOS não é mecânico. As velocidades do obturador da câmera de vídeo representam simplesmente o tempo permitido para que a carga gerada pela ação de luz acumule-se eletronicamente no sensor.

As câmeras cinematográficas de película possuem basicamente o mesmo princípio de funcionamento das digitais, com algumas particularidades. O obturador dessas câmeras é um disco rotativo com uma seção removida, e sua abertura corresponde ao ângulo removido do disco de $360^{\circ}$. O maior parte das câmeras possui obturador de $180^{\circ}$ e algumas têm obturador variável, sendo possível alterar o ângulo de abertura.
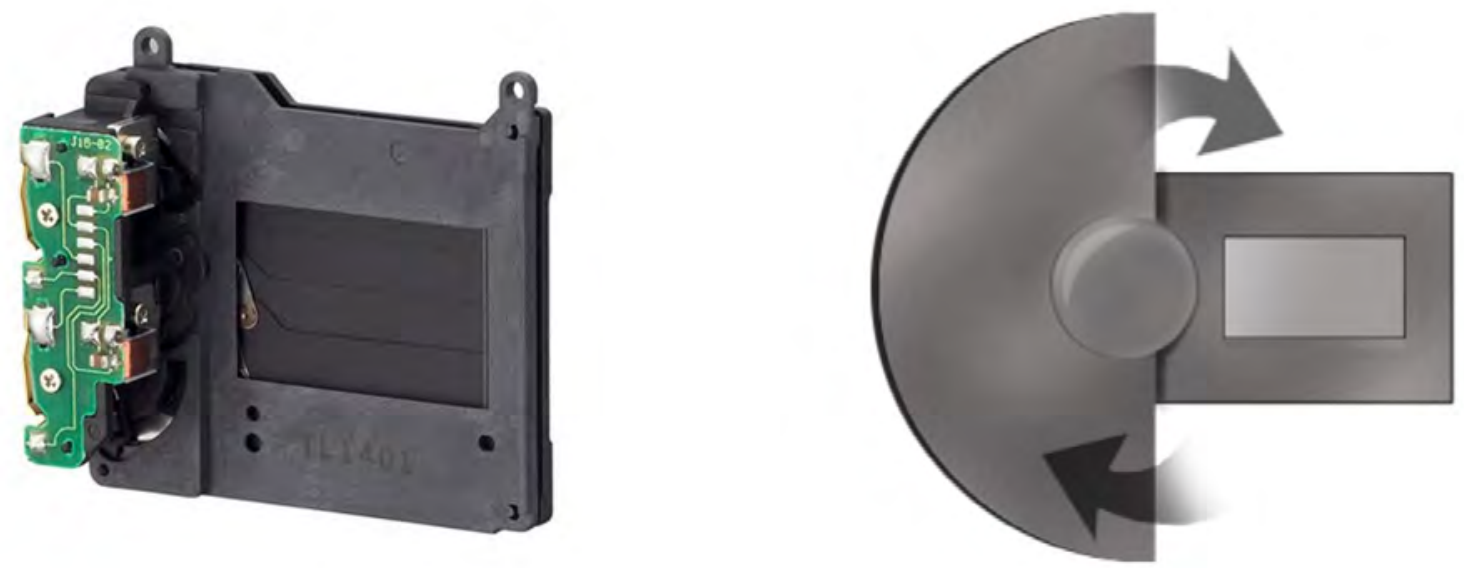

Fig. 61 - Obturador mecânico e Obturador de $180^{\circ}$

(Fonte: https://www.tecmundo.com.br/internet/8354-fotografia-diafragma-e-obturador-os-olhos-dacamera.htm)

É importante não confundir o frame rate da câmera com a velocidade do obturador. Frame rate refere-se ao número de fotogramas que a câmera captura por segundo. Nas câmeras cinematográficas, a captação padrão ocorre a uma taxa de 24 quadros por segundo, a mesma velocidade da projeção. No momento em que o filme é exposto, o obturador fica aberto e o negativo deve estar imóvel na janela da câmera para que não haja borrões na imagem. Quando o filme é transportado, o obturador se fecha para que não ocorra a exposição. Isso significa que o obturador leva $1 / 24$ de segundo para girar $360^{\circ}$, portanto, em uma câmera com obturador de $180^{\circ}$ cada frame é exposto durante metade desse tempo, ou 
seja 1/48 de segundo. Desse modo, é possível estabelecer uma equivalência entre ângulo e velocidade do obturador, conforme a tabela da figura 62.

\begin{tabular}{|c|c|}
\hline Ângulo do obturador & Velocidade do obturador \\
\hline 45 & $1 / 192$ \\
\hline 60 & $1 / 144$ \\
\hline 90 & $1 / 96$ \\
\hline 135 & $1 / 64$ \\
\hline 144 & $1 / 60$ \\
\hline 160 & $1 / 54$ \\
\hline 172,8 & $1 / 50$ \\
\hline 180 & $1 / 48$ \\
\hline 270 & $1 / 32$ \\
\hline 360 & $1 / 24$ \\
\hline
\end{tabular}

Fig. 62 - Equivalência entre ângulo e velocidade do obturador

Ao controlar o tempo de exposição da superfície fotossensível, o obturador acaba por determinar a nitidez do movimento impresso na imagem. Quanto mais rápido, mais nítida é a imagem, é o que mostram as figuras 63 e 64.

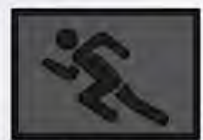

$1 / 8000$

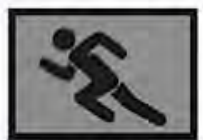

$1 / 160$

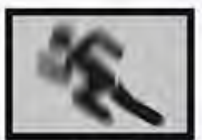

$1 / 30$

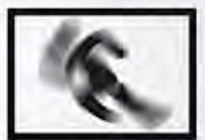

$1^{\prime \prime}$

Fig. 63 - Velocidade do obturador e nitidez do movimento

(Fonte: https://falandodefoto.com.br/obturador-da-camera-fotografica/)

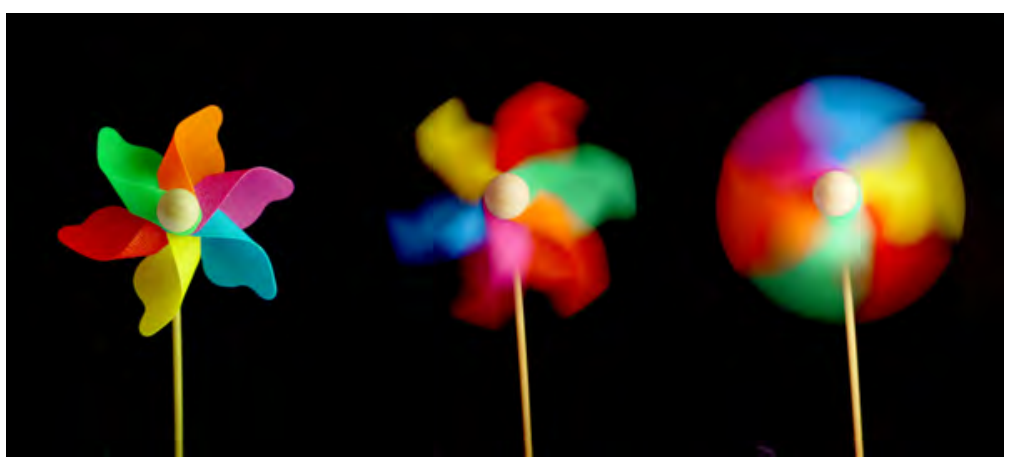

Fig. 64 - Velocidade do obturador e nitidez do movimento (Fonte: https://www.knowyourdslr.com/shutter-speed/)

O recurso de obturador mais rápido é utilizado por Steven Spielberg (1946- ) e o diretor de fotografia Janusz Kaminski (1959- ) em O Resgate do Soldado Ryan (Saving Private Ryan, 1998). Na cena do desembarque das tropas aliadas na Normandia, o obturador faz com que os tiros e explosões fiquem extremamente nítidos, o que traz um efeito de hiper- 
realismo à narrativa. Associado ao movimento ágil e constante da câmera, esse recurso provoca no espectador a sensação de estar na praia de Omaha, junto aos soldados, sendo alvejado pelo inimigo.
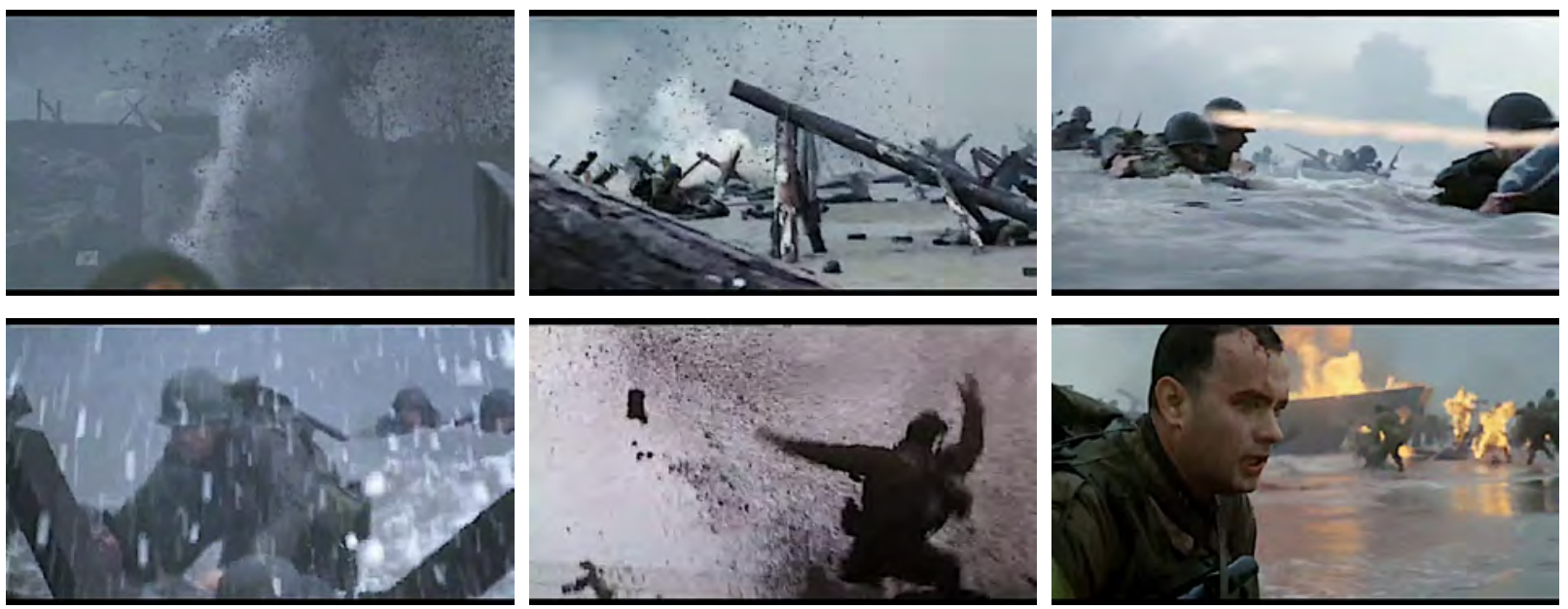

Fig. 65 - O Resgate do Soldado Ryan (1998), Steven Spielberg

\subsubsection{Diafragma}

A terceira variável de exposição fotográfica é o diafragma, mecanismo situado no interior da lente, que controla a quantidade de luz que chega à superfície fotossensível.
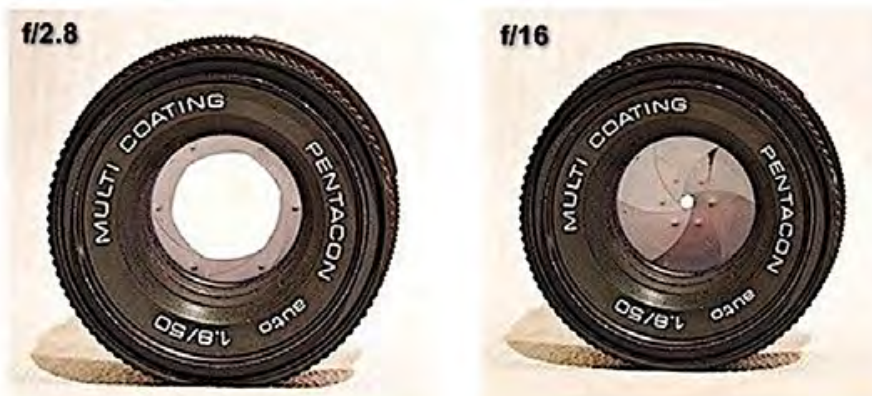

Fig. 66 - Diafragma

(Fonte: https://coreacao.wordpress.com/)

O diafragma é medido na escala $\mathrm{f}$, que corresponde à proporção entre o diâmetro de abertura da lente e sua distância focal. Quando há pouca luz no ambiente fotografado é necessário que a abertura do diafragma seja maior, para garantir a exposição. Quanto maior a abertura, menor o f-stop.

\section{f/1.01.4222.8 45.6811162232}

Fig. 67 - Escala f

$\mathrm{Na}$ escala de diafragma, cada stop para a direita representa metade da luz entrando no sistema, cada stop para a esquerda representa o dobro. Além de regular a quantidade de luz na exposição, o diafragma tem um papel qualitativo importante, uma vez que constitui um dos 
elementos determinantes da profundidade de campo. Trata-se da gama de distâncias em torno da distância focalizada na qual há nitidez aceitável. Portanto, por meio do diafragma é possível controlar não apenas a localização do foco, como também a quantidade de elementos que ficarão nítidos na imagem.

A profundidade de campo está diretamente relacionada à magnitude da imagem. Quanto menor o sensor ou bitola do filme, menor será a escala de reprodução do objeto fotografado e maior será a profundidade de campo. Além disso, ela é determinada pela abertura do diafragma, distância focal e distância focalizada. A distância focal é a distância ótica entre o centro da lente e o plano onde a imagem é focada dentro da câmera, isto é, o sensor ou o filme.

Comparando imagens produzidas com sensores de mesmo tamanho e expostas com o mesmo diafragma, terá maior profundidade de campo a que for captada com a lente de menor distância focal. O inverso ocorre com a distância focalizada, quanto mais próximo da lente estiver o plano de foco, menor a profundidade de campo.

Entretanto, se para um mesmo tamanho de sensor compararmos o resultado da captação de uma cena feita com a mesma distância focal e distância focalizada, terá maior profundidade de campo aquela captada com diafragma mais fechado. É o que mostra a figura 68.
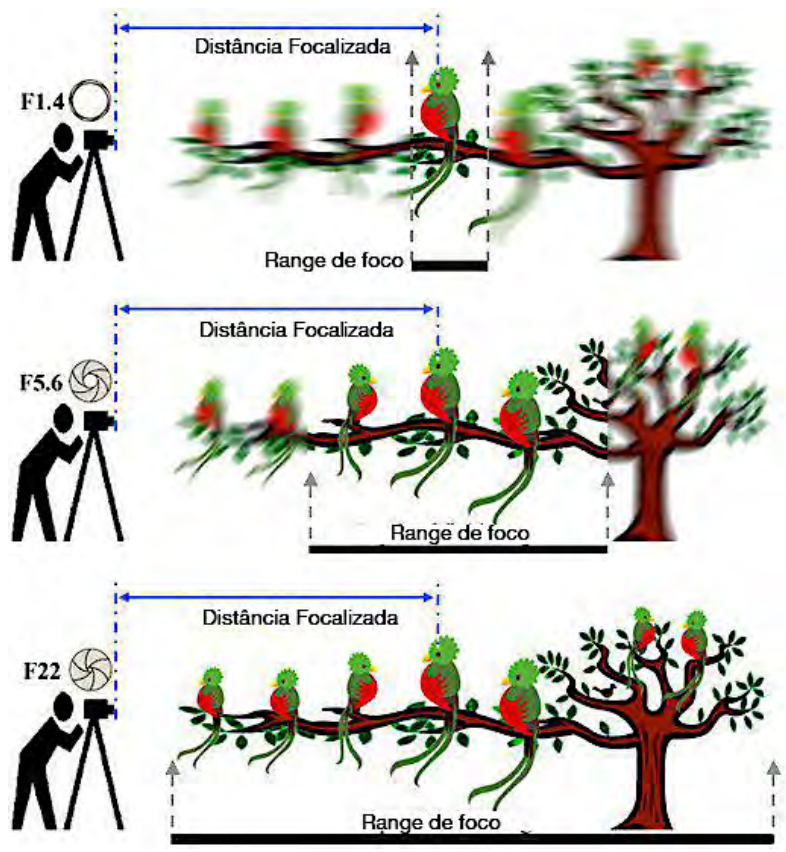

Fig. 68 - Abertura de diafragma e profundidade de campo

(Fonte: https://cinematography.com/index.php?/topic/75967-focus-and-focus-transition/)

A importância da profundidade de campo reside em seu resultado expressivo. A imagem cinematográfica é bidimensional, o aumento da profundidade de campo implica em 
ampliar a percepção do efeito perspectivo por meio de vários planos de ação dentro do mesmo enquadramento, permitindo a encenação em profundidade. Um exemplo clássico de utilização expressiva da grande profundidade é Cidadão Kane (Citzen Kane, 1941), de Orson Welles (1915-1985). Fotografado por Gregg Toland (1904-1948), o filme utiliza a profundidade de campo de modo a concentrar ações em um único plano, sem necessidade de muitos cortes. Desse modo, permite que o espectador realize sua própria decupagem, encontrando as linhas de ação dentro do quadro.

O fotograma da figura 69 pertence à cena em que Susan, esposa de Kane, tenta o suicídio. No primeiro plano há o frasco de remédio, o copo e a colher, no plano médio Susan está na cama desacordada, ao fundo Kane entra no quarto para socorrê-la. Em um filme com decupagem clássica a ação seria desenvolvida por meio de vários planos. Welles concentra o episódio em uma única tomada, de modo que o espectador percorra os elementos da ação e escolha em qual deles deter o olhar.

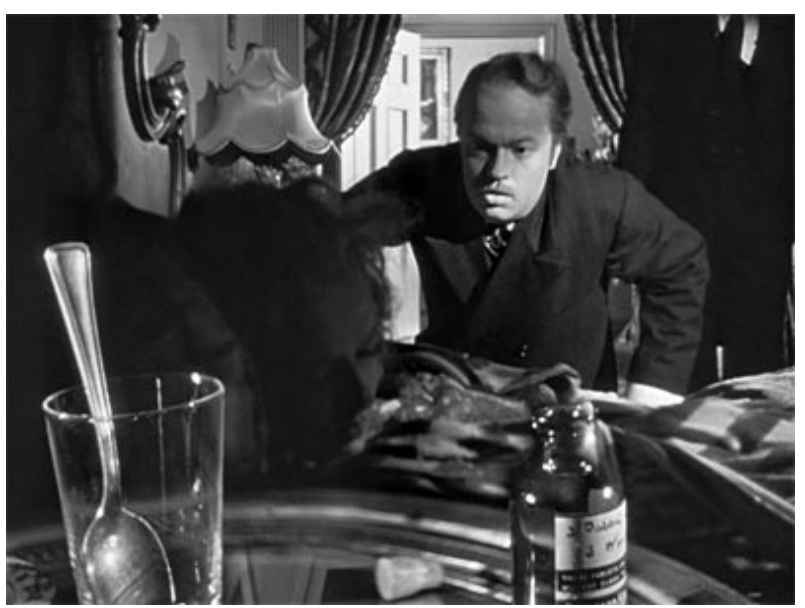

Fig. 69 - Cidadão Kane (1941), Orson Welles

Na época em que foi lançado, o filme recebeu elogios do crítico André Bazin (19181958) por incorporar as descobertas da decupagem, desenvolvida desde o cinema mudo, ao realismo do plano-sequência. Em Sobre a história do estilo cinematográfico, David Bordwell mostra que Bazin acreditava que a filmagem em profundidade era mais simples e mais natural, além de suscitar novas possibilidades dramatúrgicas: "construir tensão e criar um desempenho conjunto mais denso" (BORDWELL, 2013, p. 88).

Cidadão Kane corrobora as teses do realismo baziniano ao utilizar a profundidade de campo, respeitar o contínuo espaço-temporal do mundo cotidiano por meio dos planos longos, tornando a câmera invisível ao espectador e incentivando sua participação na construção da 
obra, uma vez que tem liberdade para "varrer o quadro em busca de informações importantes" (BORDWELL, 2013, p. 88).

Em sentido oposto, a pequena profundidade de campo pode ser utilizada expressivamente ao direcionar o olhar do espectador para um determinado elemento do quadro. Um exemplo é Barry Lyndon (Barry Lyndon, 1975), de Stanley Kubrick, fotografado por John Alcott, que ganhou o Oscar de melhor fotografia em 1976.

O enredo desenvolve-se na Inglaterra do século XVIII, época em que não existia luz elétrica, e a fotografia é trabalhada de modo a reconstruir a iluminação disponível naquele período. Inspirado pelas pinturas de William Hogarth (1697-1764), Kubrick decidiu captar as imagens com luz natural e velas, utilizando pouquíssimos refletores e lentes Cooke Speed Panchro e Zeiss Super Speed. As lentes Cooke, com abertura máxima f/2.0, possuem a característica de realçar cromaticamente as imagens captadas em baixa iluminação. As lentes Zeiss utilizadas no filme foram desenvolvidas em conjunto com a NASA para uso em estações espaciais, e possuíam abertura máxima f/0.7.
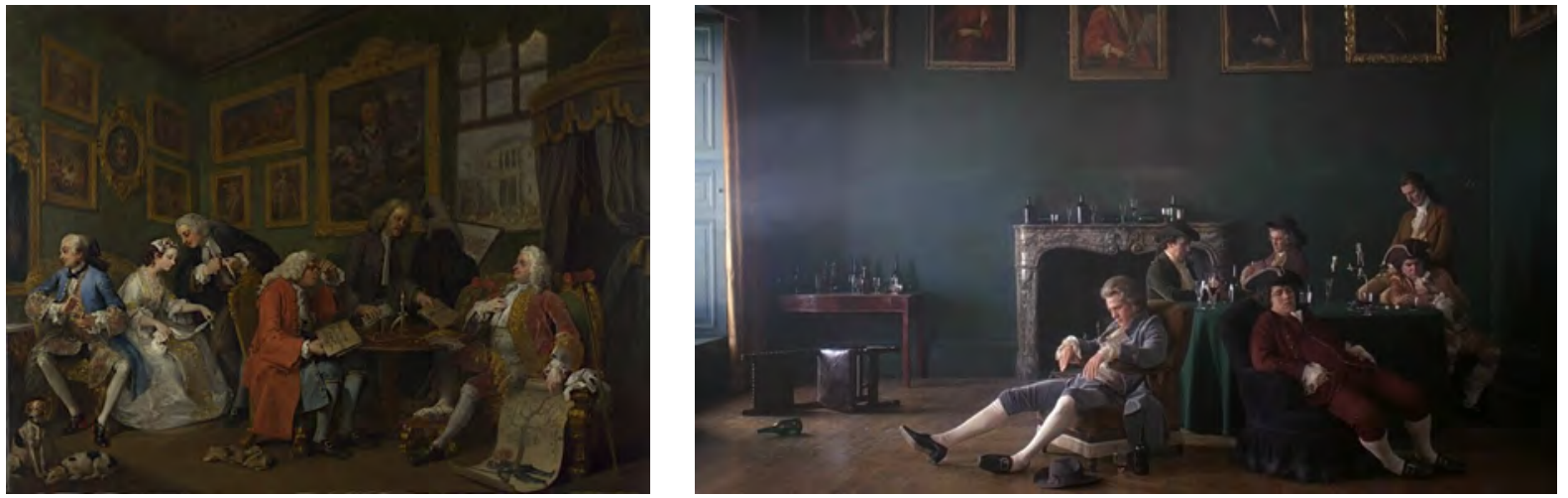

Fig. 70 - William Hogarth e Stanley Kubrick

O fotograma da figura 71 mostra o resultado da profundidade de campo em baixíssimas condições de luz, por meio da grande abertura do diafragma. O foco está no personagem da esquerda, o fundo, bem como os outros dois personagens (ainda que próximos da distância focalizada) encontram-se desfocados.

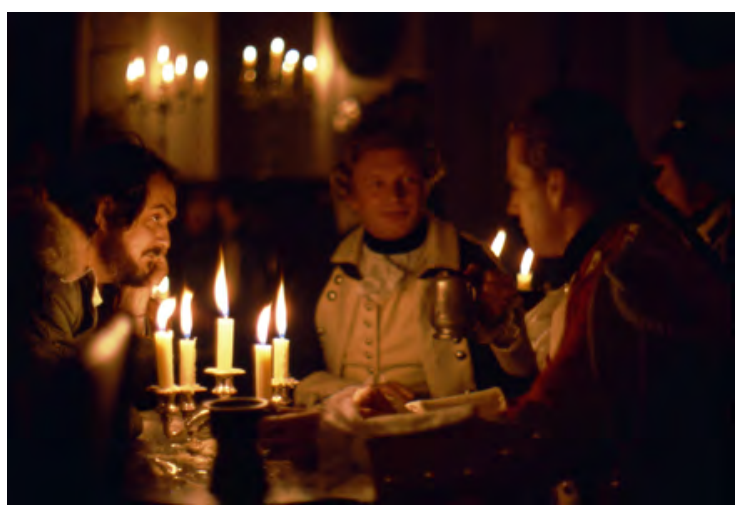

Fig. 71 - Barry Lyndon (1975), Stanley Kubrick 
O foco seletivo pode ser obtido não apenas por meio da abertura de diafragma mas também pela utilização de lentes especiais. O filme $O$ Escafandro e a Borboleta (Le Scaphandre et le Papillon, 2007), dirigido por Julian Schnabel (1951- ) e fotografado por Janusz Kaminski , utiliza lentes shift and tilt para contar a história pelo ponto de vista de um personagem vítima de AVC.

Essas lentes são basculáveis horizontal e verticalmente, de forma que fiquem inclinadas em relação ao plano do filme/sensor. Desse modo, é possível selecionar o foco em um objeto, mantendo desfocados outros objetos que estejam no mesmo plano.

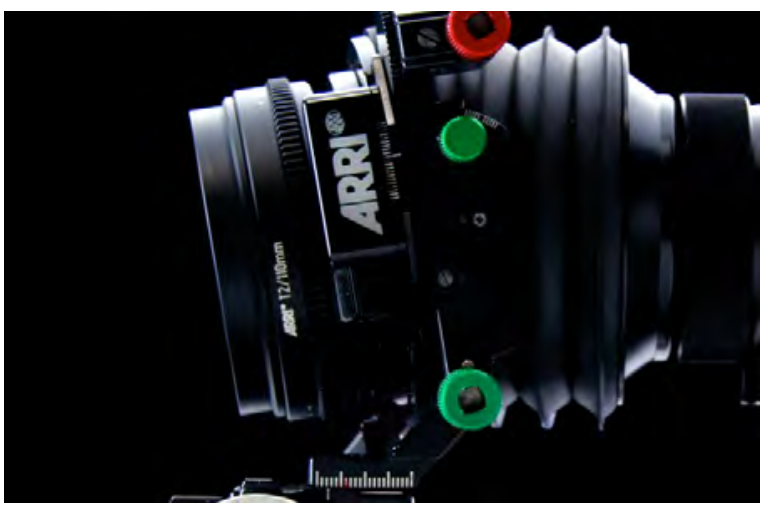

Fig. 72 - Lente Arri Shift \& Tilt

No filme de Schnabel, o publicitário Jean-Dominique Bauby tem sua vida modificada ao sofrer um acidente vascular cerebral. O personagem fica completamente paralisado, sendo apenas capaz de movimentar um dos olhos. Grande parte das imagens é filmada em planos subjetivos do personagem principal, cujo foco extremamente seletivo amplia-se gradativamente com a evolução de seu estado de saúde. Os fotogramas da figura 73 evidenciam o ponto de vista de Bauby.
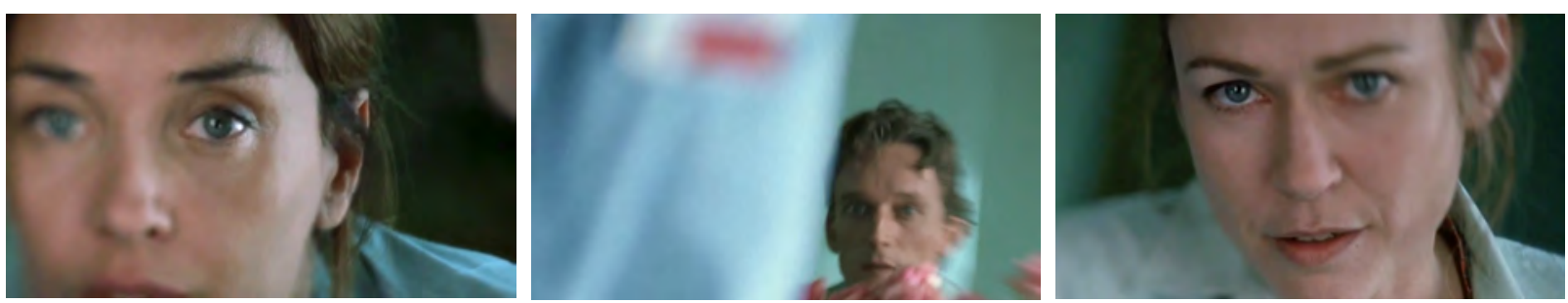

Fig. 73 - O Escafandro e a Borboleta (2007), Julian Schnabel

Resumindo as três variáveis de exposição e os resultados visuais que elas proporcionam, podemos observar o seguinte diagrama: 
ISO

Sensibilidade

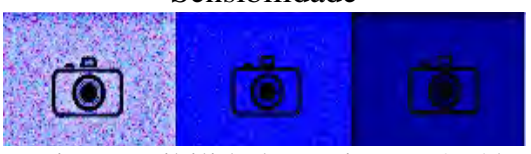

Maior sensibilidade, mais grão/ruído

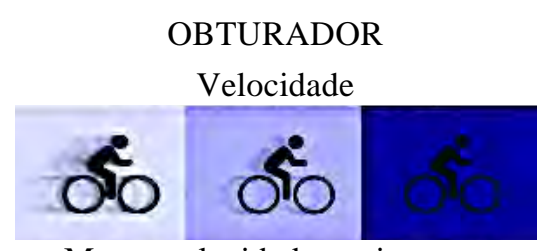

Menor velocidade, mais rastro
DIAFRAGMA

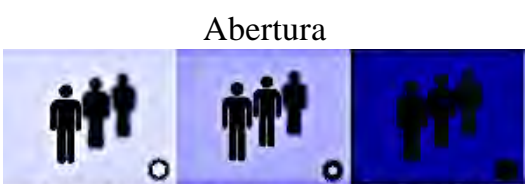

Maior abertura, menos profundidade de campo

Fig. 74 - Condições de luz e possibilidades de sensibilidade, obturador e diafragma (Fonte: https://fotourgrafe.wordpress.com/)

A quantidade de informação de um sistema fotográfico está diretamente relacionada com a quantidade de energia que entra no sistema. A energia é um dado quantitativo e a sintaxe fotográfica condiciona a produção de imagens em uma determinante qualitativa. Assim, maior quantidade de luz permite o uso de uma sensibilidade menor (grão mais fino), obturador mais rápido (menor blur) e diafragma mais fechado (maior profundidade de campo).

A forma como essas variáveis são combinadas a partir de uma dada quantidade de entrada de energia, permite a produção de imagens distintas. Cabe à variável subjetiva do sistema, o fotógrafo, determinar como utilizá-las para a criação de uma poética. Essas escolhas caracterizam seu estilo. 


\section{ESTRUTURA DA IMAGEM}

No documentário Iluminados (2007), de Cristina Leal, Walter Carvalho diz que "a colocação de uma câmera é a conquista de um território". Segundo o diretor de fotografia, para que a imagem comunique o que pretende, a câmera só pode estar em um lugar. E quando o fotógrafo encontra este lugar, "é como uma bandeira que se coloca".

O posicionamento da câmera, o ângulo que ela estabelece com os atores e objetos, a escolha da lente, a determinação do que estará em quadro e o que o que estará fora dele, a presença ou ausência de movimento, constituem algumas das decisões do diretor e do diretor de fotografia com relação à filmagem de um plano, que implicará em determinado resultado narrativo.

Existem três patamares de estrutura na construção da imagem: de onde vejo, o que vejo e como vejo. Esses patamares nada mais são do que a combinação dos elementos plásticos e técnicos na construção de uma visualidade.

\subsection{De onde vejo}

Trata-se do ponto de vista da cena, do ângulo segundo o qual a imagem é captada. A escolha desse ângulo é fundamental pois determina a perspectiva da imagem e tem implicações no sentido da narrativa. O ponto de vista deve ter uma razão de ser, para que não represente um esteticismo vazio.

A câmera pode estar situada na mesma altura do personagem (ângulo normal), como também acima (plongée) ou abaixo dele (contre-plongée). A plongée, ou câmera alta, transmite a impressão de esmagamento do personagem, uma vez que o espectador é posicionado acima do objeto. É o que vemos na figura 75 , imagem vencedora do prêmio da Asian Geographic Magazine de 2011. A fotógrafa Amy Helene Johansson (1973- ) documenta a viagem de uma mulher entre os vagões de um trem em Bangladesh. A fragilidade da mulher é reforçada pelo ângulo de tomada da imagem. 


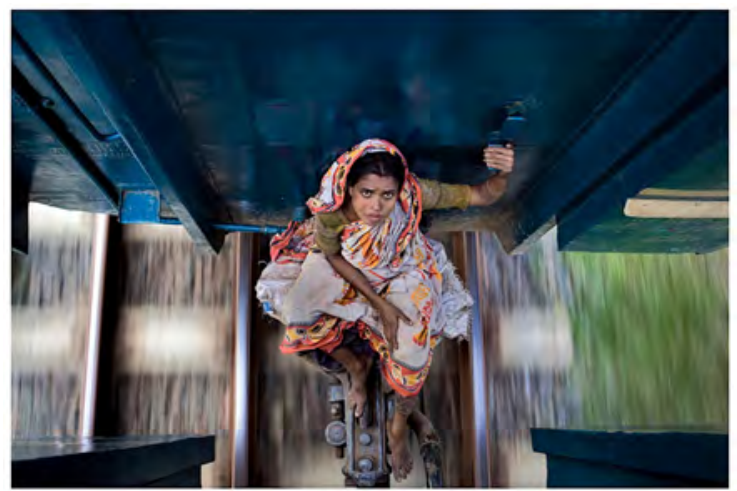

Fig. 75 - Unsafe journey (2011), Amy Helene Johansson

A contre-plongée define a situação inversa: a câmera fica abaixo do nível dos olhos dos personagens, voltada para cima, causando uma magnificação do que vemos. No filme Ivan, o Terrível - Parte II (Ivan Grozny, 1958), Eisenstein varia os ângulos de tomada de Ivan, demonstrando sua dualidade entre a posição de czar e seus conflitos pessoais.

Os fotogramas da figura 76 mostram duas tomadas distintas de Ivan. O da esquerda, captado em ângulo normal, aproxima o espectador de sua figura. Apesar de se tratar de um nobre, esse ângulo nos permite ver sua expressão facial, nos mostra Ivan mais como um ser humano - com suas dúvidas, angústias, sentimentos. O conflito entre o nobre e o homem, presente durante todo o filme, é enfatizado pelo ponto de vista da imagem. Já o fotograma da direita, em contre-plongée, mostra a imponência do czar, anulando o conflito e evidenciando seu poder.
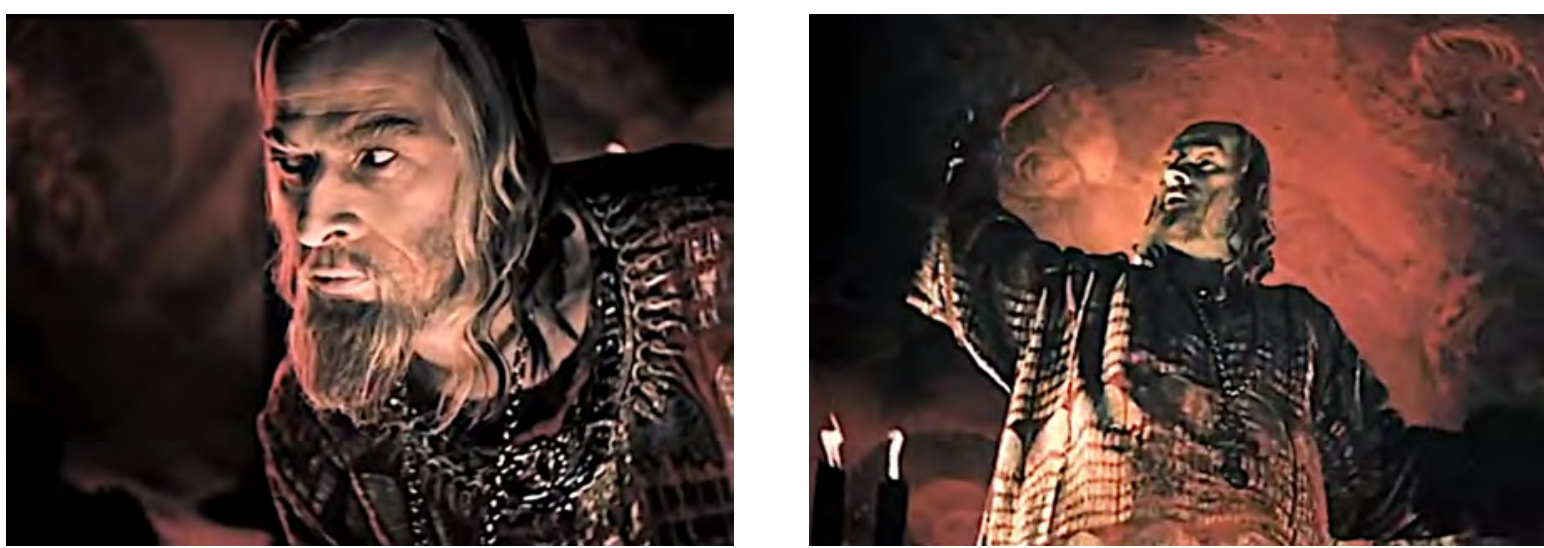

Fig. 76 - Ivan, o Terrível - Parte II (1958), Sergei Eisenstein

Na sequência de abertura de O Resgate do Soldado Ryan (Saving Private Ryan, 1998), Steven Spielberg deixa claro sob qual ponto de vista a história será contada. O primeiro plano é um detalhe da bandeira dos Estados Unidos, informando ao espectador que os eventos da guerra serão tratados pela ótica americana. Em seguida vemos o capitão Miller, já idoso, visitando o cemitério em que foram enterrados os combatentes da $2^{\mathrm{a}}$ Guerra 
Mundial. O último plano da sequência é um travelling in nos olhos do personagem, em ângulo normal, indicando que ele é o narrador e a testemunha ocular dos eventos que serão contados na sequência. A imagem de seus olhos faz a transição para a praia de Omaha, no momento do desembarque da tropa americana.
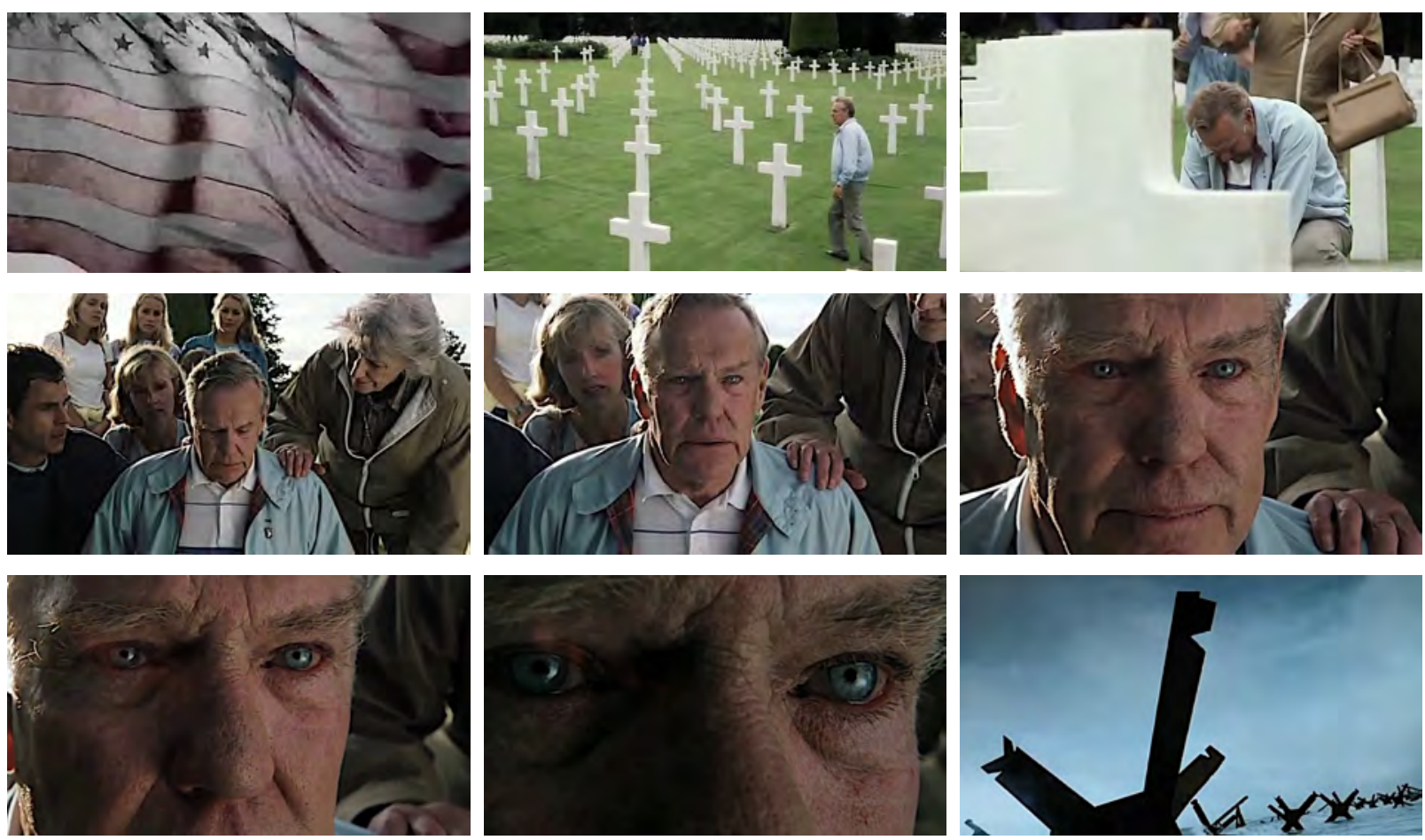

Fig. 77 - O Resgate do Soldado Ryan (1998), Steven Spielberg

\subsection{O que vejo}

Diz respeito ao que está dentro do quadro e ao tamanho do plano. Essa distinção não é apenas formal, cada plano possui uma capacidade narrativa, um conteúdo dramático próprio. Com relação ao tamanho do quadro, os planos se dividem em três grupos principais: planos gerais, planos médios e primeiros planos.

$\mathrm{Na}$ categoria de planos gerais temos:

1. Grande Plano Geral (GPG) - Aqui o ambiente é o elemento primordial, sendo o sujeito dominado pela situação geográfica. Objetivamente, a área do quadro é preenchida pelo ambiente, deixando uma pequena parcela do espaço para o personagem. Seu valor descritivo está na localização geográfica do sujeito e o seu valor dramático está no envolvimento do sujeito pelo ambiente. 


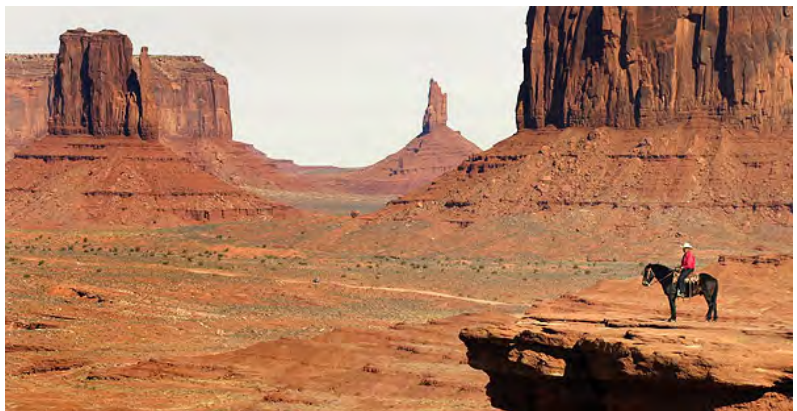

Fig. 78 - Monument Valley (2013), L Cowles Photography

2. Plano Geral (PG) - Neste enquadramento o ambiente ocupa uma menor parte, dividindo o espaço com o personagem. Tem grande valor descritivo, situa a ação e o homem no ambiente em que ocorre a ação, integrando-os. O dramático advém do tipo de relação entre o sujeito e o ambiente. O PG é utilizado para localizar o espaço da ação.

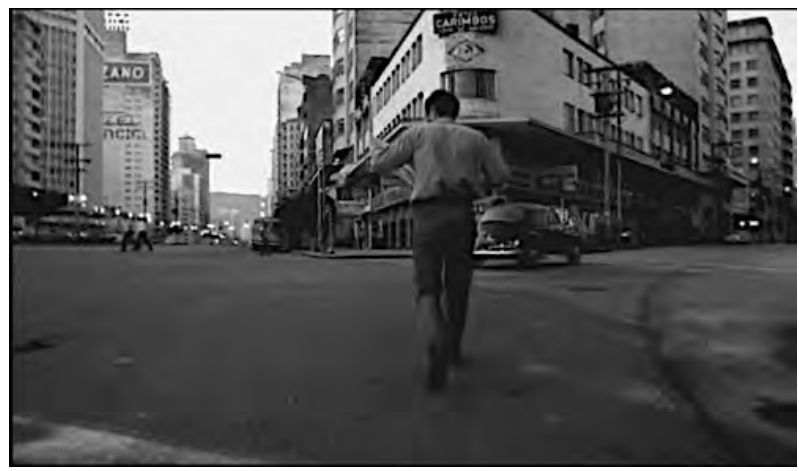

Fig. 79 - Bang-Bang (1971), Andrea Tonacci

3. Plano de Conjunto - É o que consegue captar um grupo de pessoas, enquadradas dos pés à cabeça. O diretor Luchino Visconti (1906-1976) utiliza com frequência os planos de conjunto nos salões de baile de O Leopardo (Il Gattopardo, 1963), fotografado por Giuseppe Rotunno (1923- ). Neste tipo de enquadramento os personagens existem, tanto por si mesmos como pelo grupo que formam, e o espaço é vasto bastante para que se movimentem, sendo possível estabelecer a relação entre eles.

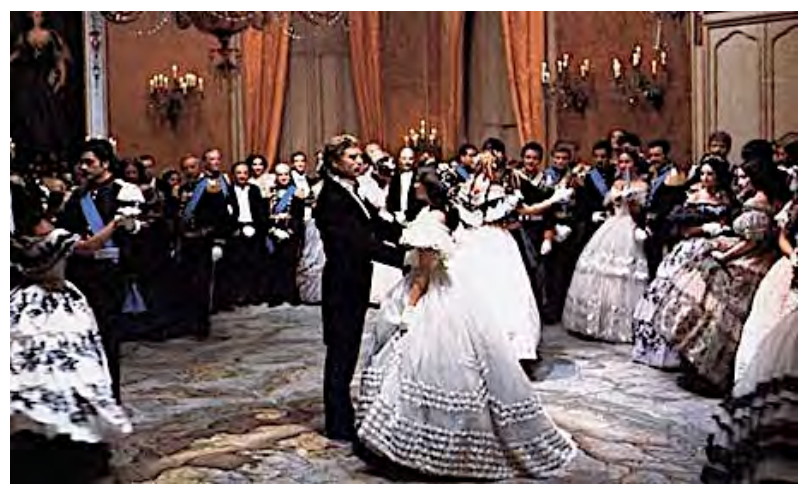

Fig. 80 - O Leopardo (1963), Luchino Visconti 
Existem dois tipos de planos na categoria dos planos médios.

4. Plano Americano - O personagem é enquadrado do joelho para cima, sendo possível visualizar sua expressão. Foi muito utilizado no gênero western para permitir a visualização das armas do personagem, geralmente dispostas na cintura. Um exemplo clássico é o de John Wayne (1907-1979) em No Tempo das Diligências (Stagecoach, 1939), do diretor John Ford (1894-1973), fotografado por Bert Glennon (1893-1967).

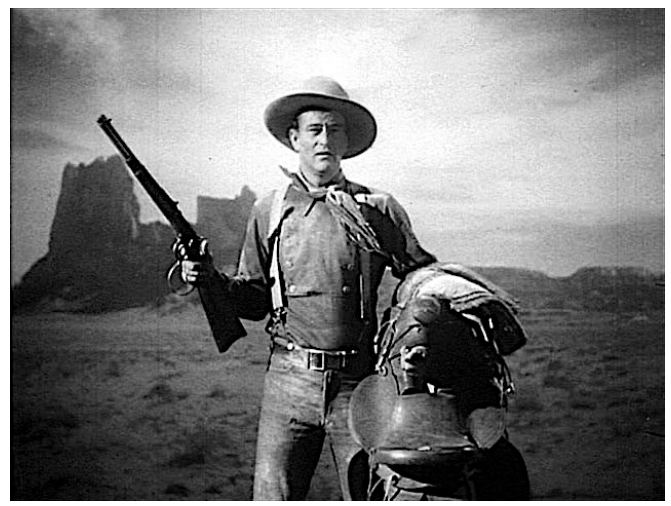

Fig. 81 - No Tempo das Diligências (1939), John Ford

5. Plano Médio (PM) - Enquadramento em que o personagem é filmado da cintura para cima, preenchendo o quadro. A câmera fecha o suficiente para filmar com clareza os gestos, expressões e movimentos do ator. Os PM costumam ser descritivos, uma vez que detalham a ação do personagem, diferindo dos PG que descrevem a situação geográfica onde este se encontra. A figura 82 traz um fotograma de Gladiador (Gladiator, 2000), de Ridley Scott, fotografado por John Mathieson (1961- ), em que é possível visualizar a expressão do personagem Commodus, deserdado por seu pai, o imperador Marco Aurélio.

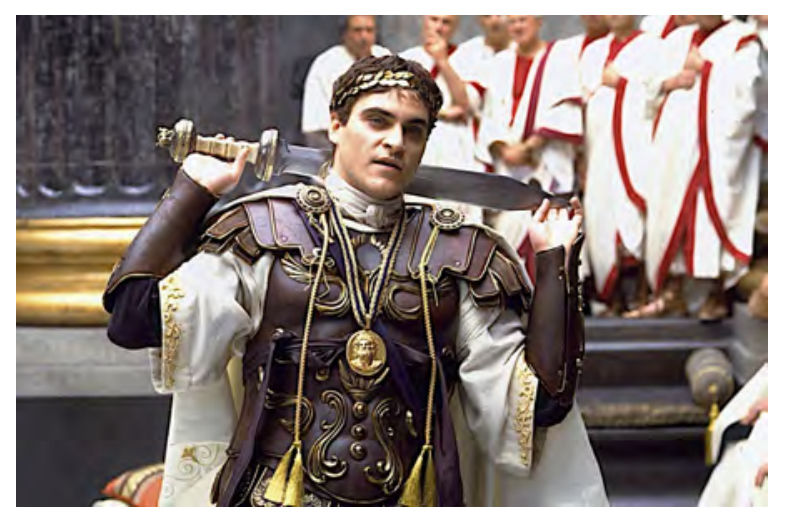

Fig. 82 - Gladiador (2000), Ridley Scott 
A última categoria de tamanho de enquadramento refere-se aos planos fechados, ou primeiros planos.

6. Primeiro Plano (PP) - Enquadra o rosto do personagem, permitindo visualizar sua expressão. Isola o sujeito do ambiente, portanto dirige a atenção do espectador. $\mathrm{O}$ diretor Ingmar Bergman (1918-2007) apontou a importância desse tipo de plano.

Há muitos diretores que esquecem que o rosto humano é o ponto de partida do nosso trabalho. Certamente, podemos nos dedicar à estética da montagem, podemos imprimir ritmos admiráveis a objetos ou naturezas mortas, mas a proximidade do rosto é, seguramente, a nobreza e a característica do filme. O mais belo meio de expressão do ator é seu olhar. O primeiro plano composto com objetividade, conduzido e representado com perfeição, é o meio mais poderoso de que o diretor dispõe para influenciar seu público, sendo também o critério mais seguro para avaliar sua competência ou sua insuficiência. A ausência ou abundância de primeiros planos caracteriza infalivelmente o temperamento do realizador e seu grau de interesse pelos homens (BETTON, 1987, p.32).

O fotograma da figura 83, é um exemplo de primeiro plano da atriz Audrey Tautou (1976- ) em O Fabuloso Destino de Amélie Poulain (Le Fabuleux Destin d'Amélie Poulin, 2001), de Jean-Pierre Jeunet (1953- ), fotografado por Bruno Delbonnel (1957- ).

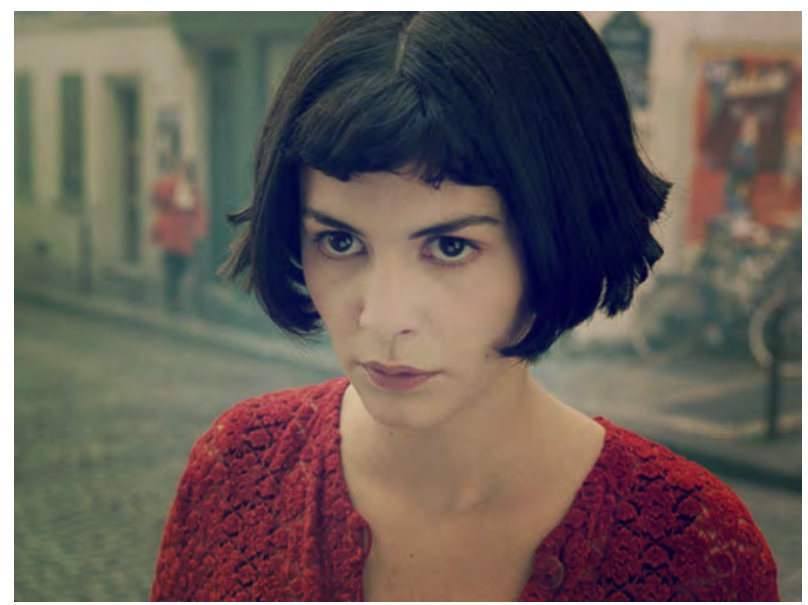

Fig. 83 - O Fabuloso Destino de Amélie Poulain (2001), Jean-Pierre Jeunet

7. Primeiríssimo Plano - Anula o cenário, enfatiza a expressão do ator, invade a psique do personagem. É o que mostra o fotograma de Matrix (Matrix, 1999), dirigido por Lana (1965- ) e Lilly (1967- ) Wachowski e fotografado por Bill Pope (1952- ). No filme, o personagem de Keanu Reeves (1964- ) é constantemente atormentado por sua dúvida sobre o que é real e o que é ilusório, conflito evidenciado pela utilização de primeiríssimos planos. 


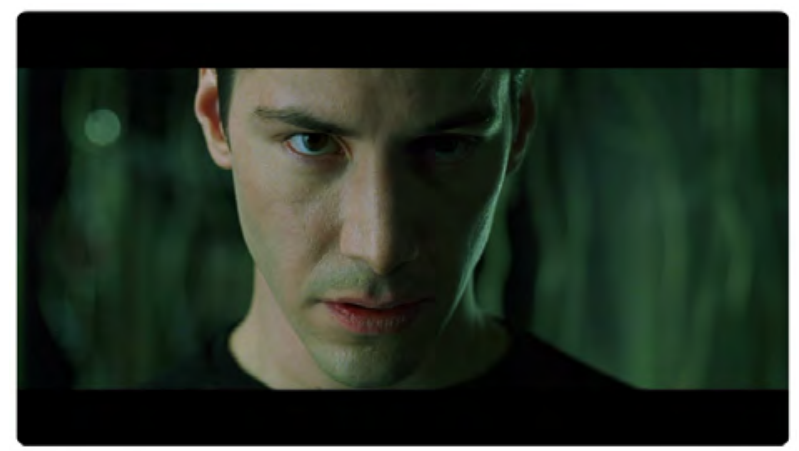

Fig. 84 - Matrix (1999), Lana e Lilly Wachowski

8. Plano Detalhe (PD) - Isola parte de um rosto ou de um objeto. É um plano de grande impacto pela ampliação que dá a um pormenor que não seria percebido em um plano mais aberto. O diretor Quentin Tarantino (1963- ) é conhecido pelos planos detalhe, muitas vezes sem função narrativa, mas que evidenciam seus gostos pessoais. É o caso dos planos dos pés de Uma Thurman (1974- ) em Pulp Fiction: Tempo de Violência (Pulp Fiction, 1994) e Kill Bill (Kill Bill, 2003), e de Bridget Fonda (1964- ) em Jackie Brown (Jackie Brown, 1997), filmes fotografados respectivamente por Andrezej Sekula (1954- ), Robert Richardson (1955- ) e Guillermo Navarro (1955-).

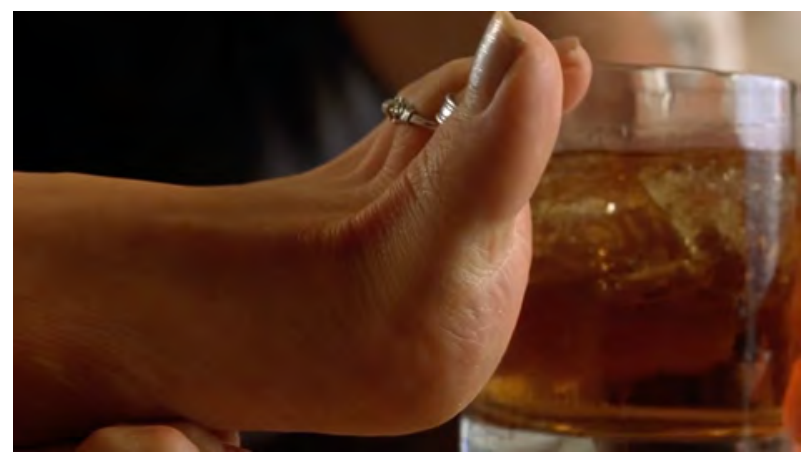

Fig. 85 - Jackie Brown (1997), Quentin Tarantino

É importante notar que a distância focal utilizada na construção do plano tem um efeito decisivo na linguagem. Isso deve-se ao ângulo de visão da lente, que resulta em maior ou menor magnificação da imagem. Quanto maior a distância focal, menor o ângulo de visão e maior a ampliação da cena.

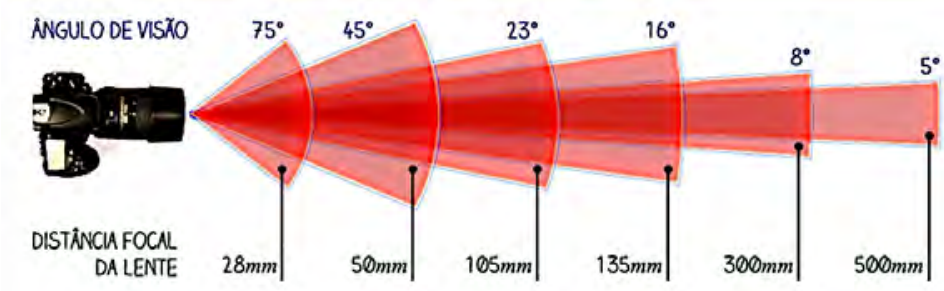

Fig. 86 - Ângulo de visão X Distância focal das lentes

(Fonte: http://cameraneon.com/acessorios/tipos-de-lentes-fotograficas-suas-funcoes-e-aplicacoes/) 
O olho humano captura a perspectiva de uma cena de forma única. Nas lentes fotográficas, as informações de escala, profundidade e relações espaciais dos objetos variam de acordo com a distância focal.

A figura 87 mostra o comparativo de uma cena fotografada com lentes distintas. $\mathrm{O}$ fundo está mais presente nas angulares do que nas teles, a profundidade de campo ajuda a isolar a figura do fundo e há uma distorção das formas nos ângulos extremos, tanto os mais abertos quanto os mais fechados. As angulares distorcem as formas dos primeiros planos e arredondam as linhas, as teles achatam a imagem e deixam as figuras mais largas.

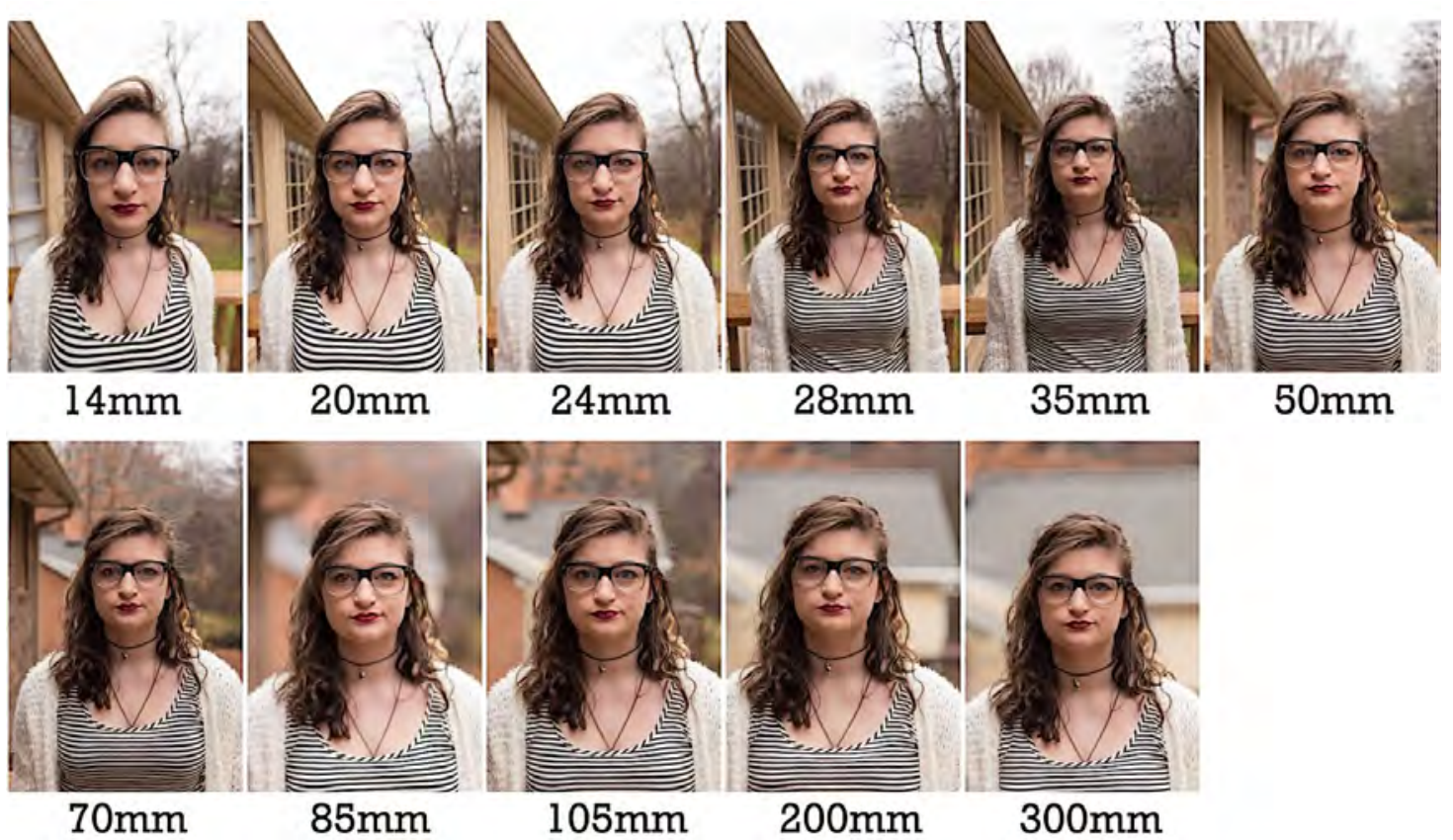

Fig. 87 - Comparativo entre lentes

(Fonte: https://picturestoryteller.com/2015/01/03/nikon-d750-best-portrait-lens/)

Com relação à distância focal, as lentes são classificadas em grandes angulares, lentes médias e teleobjetivas. Essa classificação não é absoluta, depende do tamanho do sensor da câmera ou da bitola do filme utilizado. Para um filme cinematográfico $35 \mathrm{~mm}$, a lente $35 \mathrm{~mm}$ é considerada normal, pois corresponde aproximadamente à medida da diagonal da bitola. Para cada formato, a lente normal é a que mais se aproxima da visão humana. As lentes cujas distâncias focais são inferiores à da normal são consideradas grandes angulares, as com distâncias focais superiores, são consideradas teleobjetivas.

Quando uma grande angular é utilizada em um primeiro plano ou plano médio, e portanto está muito próxima do personagem, percebemos algumas distorções de formas. É o que mostram os fotogramas de Inverno de Sangue em Veneza (Don't Look Now, 1973), de Nicholas Roeg (1928), fotografado por Anthony Richmond (1942- ). Em um plano médio de 
Donald Sutherland (1935- ), a grande angular faz com que um poste pareça inclinado para a direita. Um movimento de panorâmica acompanha o ator e no momento seguinte o mesmo poste parece inclinado para a esquerda.
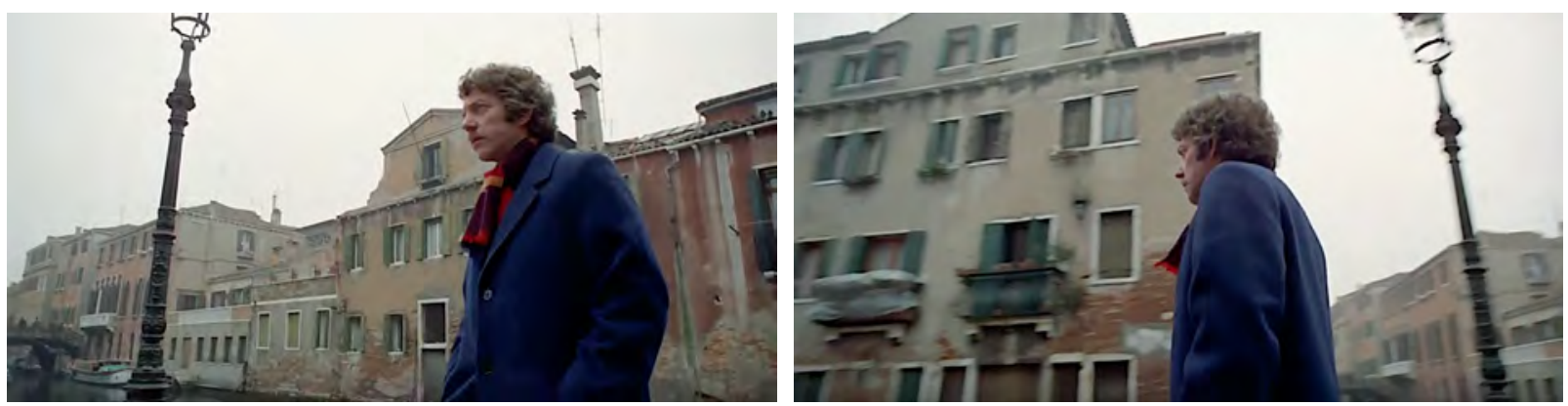

Fig. 88 - Inverno de Sangue em Veneza (1973), Nicholas Roeg

É importante elucidar que não é a distância focal sozinha que determina o tamanho do quadro, ela é apenas responsável pelo grau de magnificação da imagem. O tamanho do quadro resulta da combinação da distância focal com a distância de tomada da cena. Assim, um plano geral pode ser feito com uma grande angular próxima da ação, ou com uma teleobjetiva distante do assunto. Ambas resultam em planos gerais, mas com características distintas. A escolha da lente e o posicionamento de câmera trazem, portanto, implicações no estilo da imagem.

Podemos comparar como dois diretores fazem uso das distâncias focais na elaboração de planos gerais. Tomemos o caso de Paul Thomas Anderson (1970- ) nos filmes Magnólia (Magnolia, 1999), Sangue Negro (There Will Be Blood, 2007) - fotografados por Robert Elswit (1950- ) - e O Mestre (The Master, 2012), fotografado por Mihai Malaimare Jr. (1975). Comparemos com três filmes de David Fincher (1962- ): Seven: Os Sete Crimes Capitais (Seven, 1995), fotografia de Darius Khondji, Clube da Luta (Fight Club, 1999) e Garota Exemplar (Gone Girl, 2014), fotografados por Jeff Cronenweth (1962- ).
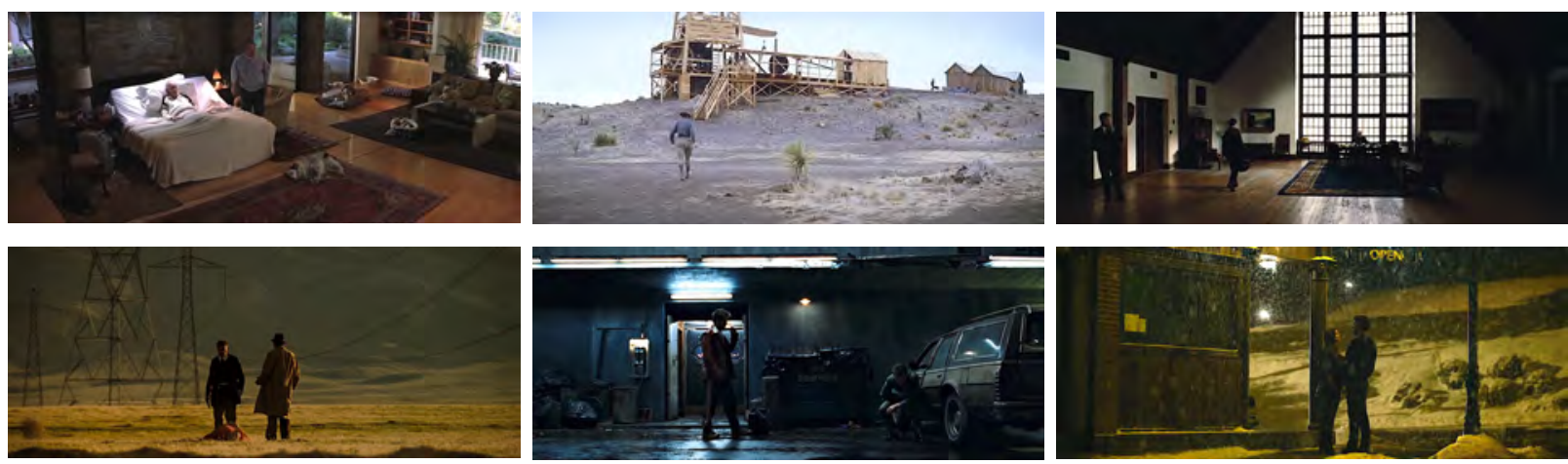

Fig. 89 - Paul Thomas Anderson (cima) e David Fincher (baixo) - Planos Gerais 
Nos fotogramas de Paul Thomas Anderson, filmados com lentes abertas, a figura humana aparece em escala muito menor do que o ambiente. Já nos fotogramas de David Fincher, filmados com lentes fechadas, a figura humana ocupa maior importância que o cenário, mesmo em se tratando de planos gerais. Portanto, a escala das figuras humanas em relação ao ambiente é construída de maneira distinta pelos dois diretores.

\subsection{Como vejo}

Neste patamar estão incluídos todos os elementos de linguagem provenientes de escolhas plásticas ou resultado das variáveis técnicas de exposição. Podemos elencar por exemplo o contraste luminoso, a profundidade de campo, o grão, o frame rate e o movimento.

Uma vez que parte desses elementos foram tratados anteriormente, explicitaremos neste item a velocidade e o movimento.

\subsubsection{Velocidade}

É a relação entre a taxa de captação da imagem e sua taxa de projeção. A velocidade de projeção é fixa em 24 fps (frames per second), desse modo, o que é captado em velocidade inferior torna-se acelerado na projeção, e consequentemente é chamado de câmera rápida, o contrário é o efeito de câmera lenta.

A variação de velocidade pode ter diversas funções na narrativa. A câmera rápida do coche do vampiro em Nosferatu (Nosferatu, Eine Symphonie des Grauens, 1928), de F. W. Murnau (1888-1931), sugere um poder sobrenatural ao personagem. Já em Koyaanisqatsi Uma Vida Fora de Equilíbrio (Koyaanisqatsi, 1982), de Godfrey Reggio (1940- ), a alteração de velocidade remete à vida frenética das cidades grandes.

O cineasta Dziga Vertov (1896-1954) utiliza a câmera lenta para retratar alguns eventos em detalhe em Um Homem com uma Câmera (Chelovek s Kino-Apparatom,1929), fotografado por Mikhail Kaufman (1897-1980). A velocidade ralentada pode ser um grande recurso expressivo, uma vez que amplia a duração do plano, enfatizando sua impressão no espectador. É o caso de Amor à Flor da Pele (Faa Yeung Nin Wa, 2000), de Won Kar-Wai, em que as tomadas de câmera lenta da Sra. Chan e seu vizinho reforçam a dramaticidade do amor platônico entre eles.

A velocidade também pode variar no interior de um mesmo plano, o que é conhecido como efeito rampa. Em O Informante (The Insider, 1999), o diretor Michael Mann (1943- ) e 
o diretor de fotografia Dante Spinotti (1943- ) filmam um personagem, que acaba de perder o emprego, atravessando o saguão da companhia rumo à porta de saída. Ao passar pela porta giratória a velocidade é ralentada, de modo que os movimentos do personagem desaceleramse. O efeito rampa na passagem da área interna para a área externa enfatiza o momento de transição, podendo remeter a um estado interno de relutância do personagem em deixar a empresa.

Uma cena rodada em velocidade normal pode causar a impressão de ter sido captada em câmera lenta. A utilização de uma lente muito longa associada a um movimento de aproximação pode causar a falsa impressão de câmera lenta, uma vez que o personagem aparentemente leva mais tempo para percorrer uma pequena distância. É o que ocorre em Tootsie (Tootsie, 1982), de Sydney Pollack (1934-2008), fotografado por Owen Roizman (1936- ), na primeira cena em que o ator Dustin Hoffman (1937- ) anda pela cidade vestido de mulher.

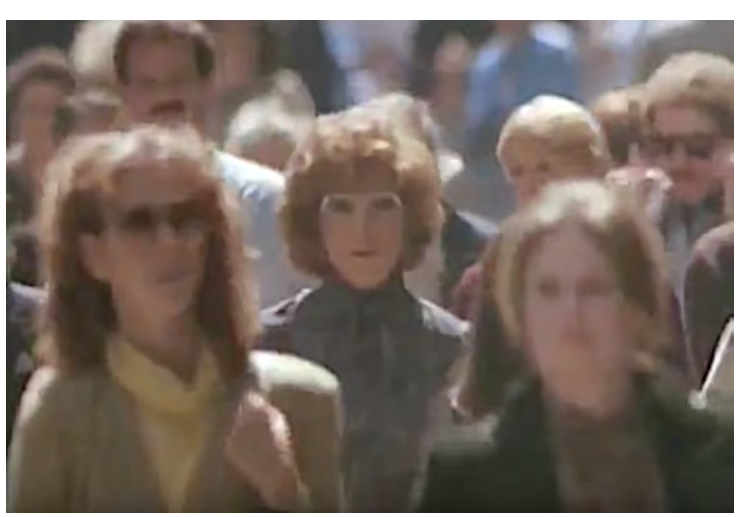

Fig. 90 - Tootsie (1982), Sydney Pollack

Em Ran (Ran, 1985), de Akira Kurosawa (1910-1998), a cena da batalha tem seu efeito dramático acentuado pela trilha sonora e pela montagem. Kurosawa retira o som direto e prolonga a duração por meio do corte, de forma que toda a crueldade da batalha é enfatizada, como se tivesse sido captada em câmera lenta.

\subsubsection{Movimento}

Nos textos de história do cinema existe um desacerto em estabelecer uma data precisa do seu nascimento. Apesar de muitos considerarem a primeira exibição dos irmãos Lumière (28 de dezembro de 1895) como um marco inicial, o pesquisador e professor Arlindo Machado (1949- ) afirma no livro Pré-Cinemas e Pós-Cinemas que invenções dos bricoleurs apenas marcam uma história técnica do meio, datando as primeiras exibições cinematográficas no período pré-histórico. Segundo Machado, nossos antepassados se 
aventuravam nos fundos das cavernas com o objetivo de fazer e assistir sessões de "cinema" (MACHADO, 2011, p.13).

As pinturas de Altamira, Lascaux e Font-de-Gaume foram gravadas de uma forma que à medida em que o observador se move, elas parecem se movimentar em relação a ele, produzindo um efeito de imagens animadas na caverna como um todo. Desse modo, segundo Machado, o homem pré-histórico já possuía a mente de um cineasta, apesar de utilizar os instrumentos de um pintor (MACHADO, 2011, p.14).

Em Sobre a história do estilo cinematográfico, David Bordwell afirma que a VersãoPadrão, percepção crítica do estilo cinematográfico desenvolvida nas primeiras décadas do século XX, acreditava que o movimento era a essência do cinema, caracterizando a especificidade do novo meio (BORDWELL, 2013, p.48). Essa visão não é compartilhada pelos atuais historiadores do cinema, uma vez que não é possível desconsiderar o fato de que o movimento já existia na pintura muito antes da invenção do cinematógrafo.

No quadro Snow storm: steam-boat off a harbour's mouth (1842), de William Turner (1775-1851), percebemos que apesar do movimento não estar presente de fato, ele está aí representado. A pintura de Turner é puro movimento das ondas, do barco. E esse não é um caso isolado na história da pintura.

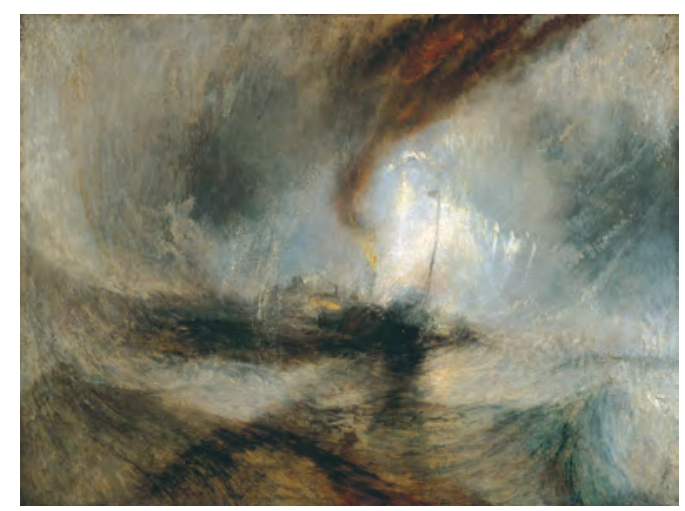

Fig. 91 - Snow storm: steam-boat off a harbour's mouth (1842), William Turner

No cinema, o imobilismo potencial criado pelo enquadramento pode ser compensado pelo dinamismo interno. O enquadramento pode ser imóvel sem que perca a dimensão do movimento na composição plástica.

Apesar do enquadramento configurar um limite para os elementos presentes na imagem, ele não é necessariamente estático. Há exemplos de enquadramentos que apresentam variações dinâmicas, como a íris dos filmes de D. W. Griffith (1875-1948), que se fecham para isolar um detalhe ou se abrem para mostrar o todo. O movimento de íris, que tornou-se parte do repertório de Griffith, foi criado por seu diretor de fotografia Billy Bitzer (1872- 
1944). Tentando resolver um problema de flare nas lentes, improvisou um dispositivo para evitar que os raios luminosos nelas incidissem diretamente. $\mathrm{O}$ dispositivo acabou sendo enquadrado pela lente e passou a ser utilizado para variar o espaço da tela, concentrando a atenção no centro da imagem. Outro exemplo de dinamismo do enquadramento é a tela múltipla de Abel Gance (1889-1991), que apresenta vários quadros simultaneamente, criando movimento pela justaposição das imagens.
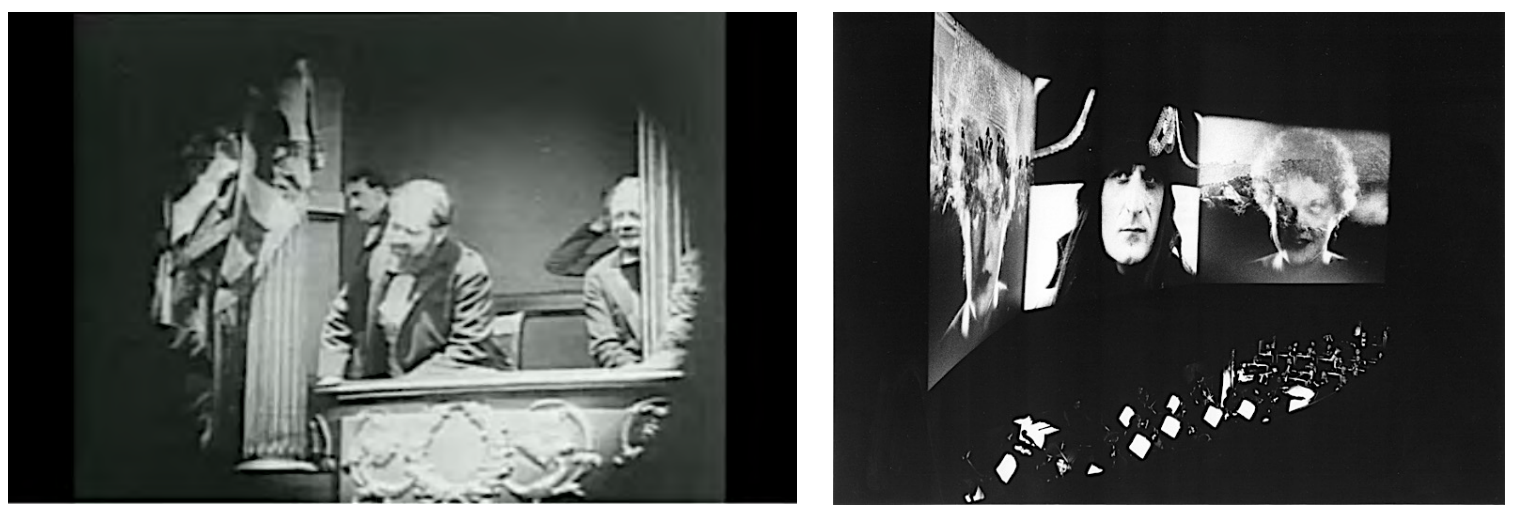

Fig. 92 - O Nascimento de uma Nação (1915), D. W. Griffith e Napoleão (1927), Abel Gance

Para não ser arbitrário, é preciso que o movimento tenha uma função narrativa: dirigir a atenção do espectador, revelar o espaço, reenquadrar, imprimir ritmo, entre outros.

Existem três tipos distintos de movimento: interno, ótico e de câmera.

O movimento interno é o que ocorre no interior do quadro, ainda que esse seja fixo. É o movimento dos personagens e da natureza. Ida (Ida, 2013), de Pawel Pawlikowski, é um exemplo de filme em que a força da ação acaba por ser acentuada pela ausência total de movimentos de câmera.

O diretor Akira Kurosawa utilizou o movimento interno de distintas formas em seus filmes. Na figura 93 vemos alguns tipos de elementos que se movem no interior de seus quadros: a chuva em Um Domingo Maravilhoso (Subarashiki Nichiyôbi, 1947), o fogo em Trono Manchado de Sangue (Kumonosu-jô, 1957), a chuva em primeiro plano em Rashomon (Rashômon, 1950), a neve vista pela janela em O Barba Ruiva (Akahige, 1965), o indivíduo em Yojimbo - O Guarda-Costas (Yôjinbô, 1961) e os leques do conjunto de personagens em Anatomia do Medo (Ikimono no Kiroku, 1955). O movimento interno é uma das assinaturas estilísticas de Kurosawa. 

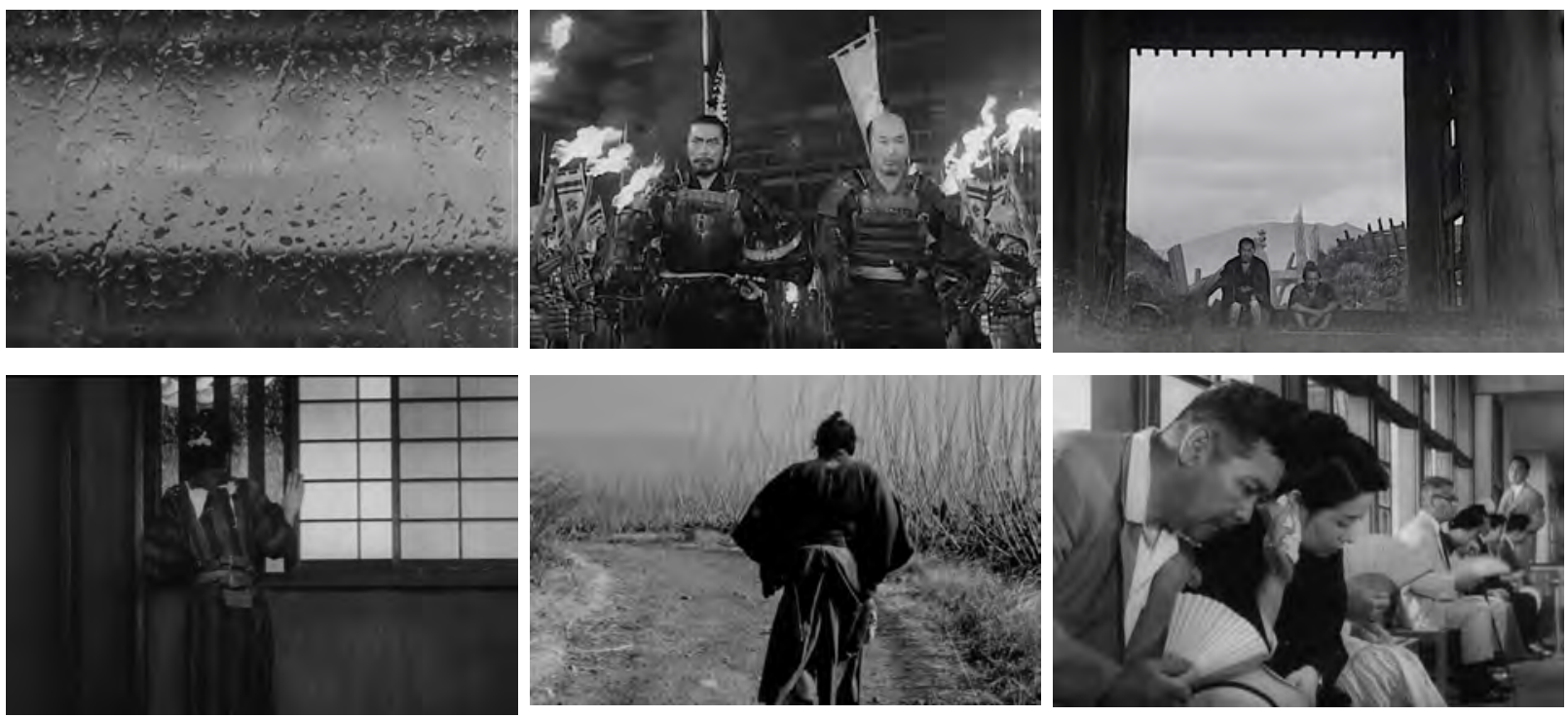

Fig. 93 - Movimento interno nos filmes de Kurosawa

O segundo tipo de movimento é o ótico, ou movimento de objetiva. Trata-se da abertura ou fechamento do campo da imagem por meio da variação de ângulos das lentes zoom. É o que faz Tarantino no filme Kill Bill (Kill Bill, 2003) ao utilizar um movimento de zoom in extremamente veloz, destacando o olhar da personagem vivida por Uma Thurman. Nesse tipo de movimento, a alteração das distâncias focais provoca, em um único plano, uma variação de escala de reprodução dos objetos e da profundidade de campo.
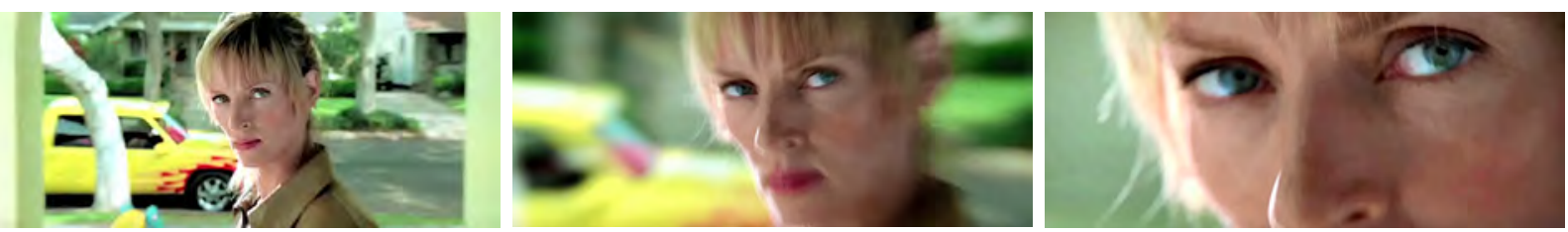

Fig. 94 - Kill Bill (2003), Quentin Tarantino

O terceiro tipo de movimento é o de câmera. Nesse caso pode ser apenas o movimento do corpo da câmera lateralmente (panorâmica horizontal ou pan) e verticalmente (panorâmica vertical ou tilt), ou o movimento do conjunto corpo de câmera mais suporte, como o travelling, grua, steadicam, drone, câmera na mão.

Assim como o movimento de zoom in, o travelling in tem a função de aproximar o espectador de um objeto ou personagem da narrativa. A diferença é que no travelling in não há variação de lentes, portanto a relação entre personagem e fundo, bem como a profundidade de campo, não se alteram de forma tão drástica. Essa diferença pode ser observada se compararmos os fotogramas das figuras 94 e 95. Ao contrário do que acontece em Kill Bill, no travelling in de Os Caçadores da Arca Perdida (Raiders of the Lost Arc, 1981), 
fotografado por Douglas Slocombe (1913-2016), é possível notar que mesmo no fotograma mais fechado, o fundo está presente e relativamente em foco.
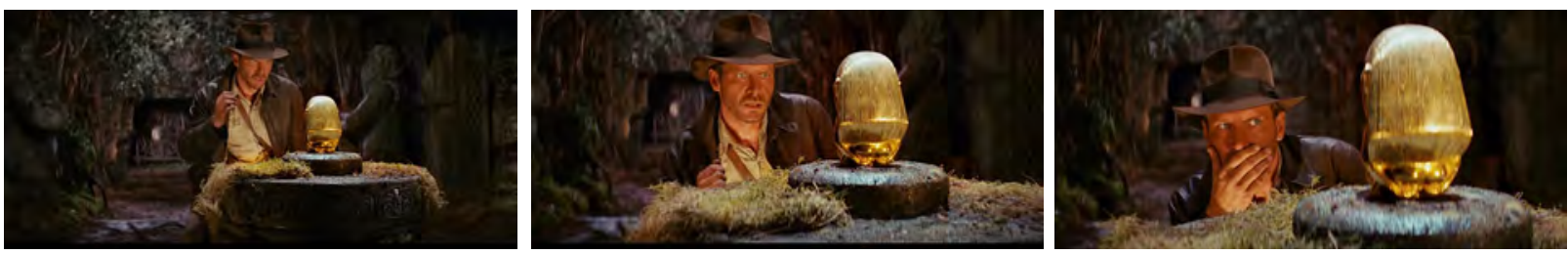

Fig. 95 - Os Caçadores da Arca Perdida (1981), Steven Spielberg

Os três tipos de movimento podem ser utilizados em um único plano. Um exemplo clássico é a combinação de movimento interno, travelling e zoom no filme Os Bons Companheiros (Goodfellas, 1990), de Martin Scorsese (1942), fotografado por Michael Balhaus (1935-2017). Essa combinação é chamada de efeito Vertigo, pois foi popularizado por Alfred Hitchcock (1899-1980) no filme de mesmo nome.

No diálogo entre Robert De Niro (1943- ) e Ray Liotta (1954- ), os personagens ocupam sempre a mesma porção do quadro. O fundo, entretanto, vai gradativamente se fechando, isolando os dois gangsters do mundo ao redor.
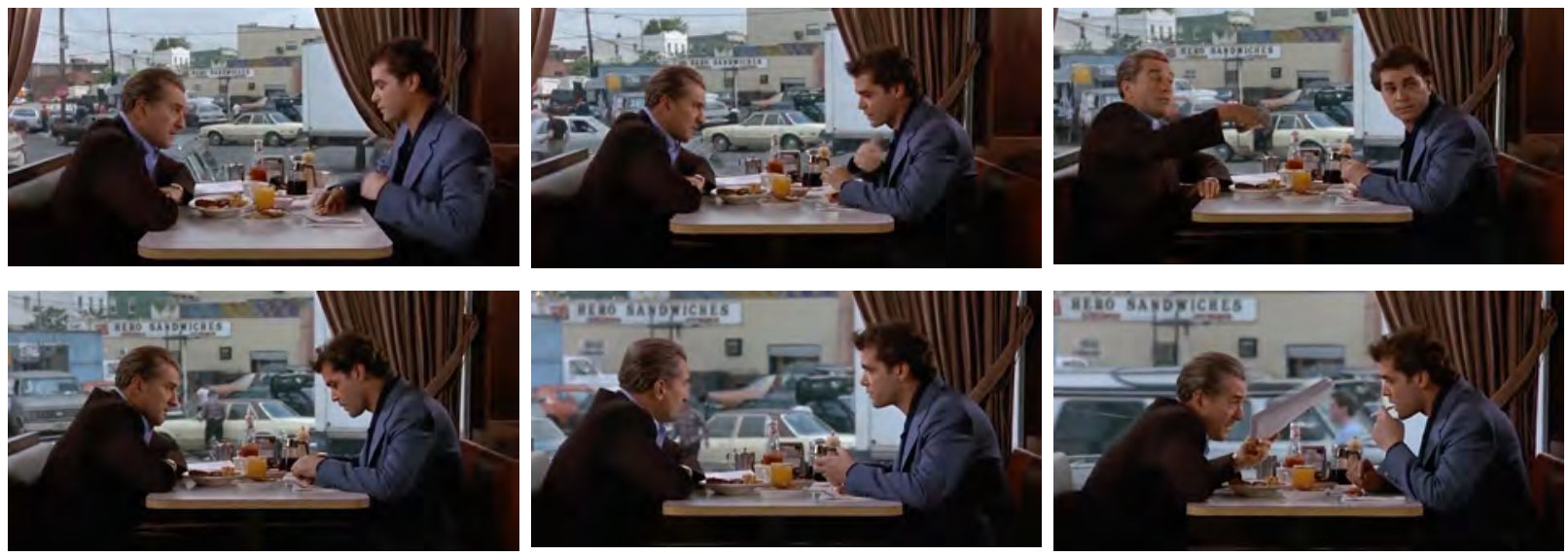

Fig. 96 - Os Bons Companheiros (1990), Martin Scorsese

Assim, o movimento permite variar objetos, corpos, dimensões e distâncias na imagem, e seu estudo é fundamental para a análise estilística de diretores de cena e diretores de fotografia, uma vez que dentre todas as decisões tomadas na realização de um filme, estes profissionais também participam das que concernem o movimento. 


\section{ANÁLISES}

O diretor de fotografia Walter Carvalho nasceu em 1947 em João Pessoa, Paraíba. Seu contato com o cinema iniciou-se precocemente. Ainda adolescente, mas já inclinado à pintura e ao desenho, Walter ajudava seu irmão, o cineasta Vladimir Carvalho (1935- ), nos sets de seus filmes. Na década de 1970 mudou-se para o Rio de Janeiro para estudar design gráfico na Escola Superior de Desenho Industrial, onde teve aulas de fotografia com Roberto Maia, fotógrafo de cinema.

Seu primeiro filme como diretor de fotografia foi Incelência para um Trem de Ferro (1972), dirigido por Vladimir Carvalho, pelo qual ganhou um prêmio na Jornada Internacional de Cinema da Bahia. Nas décadas de 1970 e 1980 trabalhou com diretores importantes, como Glauber Rocha (1939-1981), Ruy Guerra (1931- ) e Nelson Pereira dos Santos (1928-2018).

Em entrevista a João Vitor Leal, publicada na revista Cinémas d'Amérique Latine, Walter conta que no período das décadas de 1970 e 1980 o cinema brasileiro produzia majoritariamente pornochanchada e pós-chanchada, filmes populares sem preocupação com a qualidade artística. Entretanto, a Embrafilme, criada em 1969, possibilitou que os cineastas se reaproximassem de seus projetos pessoais, por meio de um grande fomento à produção.

\footnotetext{
Neste cenário, eu comecei a me inserir. Primeiro eu filmei alguns dias para o filme Que País é Este? (1977) que o Leon Hirszman dirigiu para a RAI. Depois eu fotografei um curta do Glauber Rocha sobre o escritor Jorge Amado, chamado Jorjamado No Cinema (1979). Comecei a ser chamado para fotografar filmes de outras pessoas, eu estava no meio desse "boom" muito interessante de política cultural com incentivo do governo. Eu estava, naquela época, mais dedicado a filmes documentários (CARVALHO in LEAL, 2012, p. 46).
}

O encontro com o diretor Walter Salles deu-se na década de 1980, quando trabalharam juntos em Krajcberg - O Poeta dos Vestígios (1987). Entretanto é Terra Estrangeira (1995), o filme seguinte em parceria com o diretor, que Walter Carvalho considera um divisor de águas em sua carreira de fotógrafo (LEAL, 2012, p. 48).

Terra Estrangeira é um dos filmes que marca o início da Retomada do Cinema Brasileiro, período em que o cinema nacional reconquistou público e ganhou visibilidade internacional, após a crise de estagnação na produção de longas-metragens ocorrida no início da década de 1990.

Os anos de crise tiveram início quando Fernando Collor de Mello (1949- ) tomou posse na presidência da República, em 1990, e extinguiu organismos estatais de fomento e 
fiscalização do cinema brasileiro: Embrafilme (Empresa Brasileira de Filmes), Fundação do Cinema Brasileiro e Concine (Conselho Nacional de Cinema).

O cinema nacional retomou seu curso a partir de 1995-1996 devido à criação de mecanismos de fomento por renúncia fiscal e investimento estatal direto. A Lei do Audiovisual, promulgada em 1993, previa a aquisição de Certificados de Investimentos Audiovisuais, abatidos no imposto de renda de empresas e/ou pessoas físicas. Previa também a possibilidade de empresas estrangeiras que mantinham negócios cinematográficos no país utilizarem até $70 \%$ do imposto devido ao Estado em coproduções com filmes brasileiros. Desse modo, distribuidoras estrangeiras passaram a ter incentivo para produzir e distribuir filmes nacionais, o que não garantiu, porém facilitou, o acesso das obras às salas de exibição.

Os mecanismos de renúncia fiscal encontraram um cenário em que o empresariado brasileiro carecia de tradição em investir no cinema nacional. Esse fato, aliado a uma política pública com objetivo de regionalizar e diversificar as obras cinematográficas, fez com que o Estado também fomentasse a atividade com recursos diretos, por meio de concursos públicos.

As novas formas de investimento trouxeram modificações significativas no modo de produção dos filmes nacionais e também em suas características estéticas. Em artigo para a Revista Alceu, a jornalista Maria do Rosário Caetano (1955- ) afirma que os filmes da primeira fase da Retomada "parecem acreditar na inserção do cinema brasileiro no mercado internacional. O discurso neoliberal, que prega a expansão de mercados, seduz boa parte dos realizadores" (CAETANO, 2007, p. 199). Nesse sentido, o professor e teórico Ismail Xavier (1947- ) identifica uma mudança na tendência à heroização do cineasta independente. "Mais aberto a parcerias, os realizadores tornam-se força maior na constituição de um polo de qualidade na produção" (XAVIER, 1999, p. 113), preocupando-se com o acabamento dos filmes.

Nesse período, profissionais que atuavam exclusivamente no mercado publicitário passaram a integrar as equipes de cinema, e com as novas fontes de recursos, puderam trazer equipamentos de ponta para as produções nacionais.

Essa conjunção de fatores teve como resultado uma melhoria na qualidade técnica dos filmes e a presença das obras em premiações internacionais, como a indicação de $O$ Quatrilho (1995), de Fábio Barreto (1957-2019), fotografado por Félix Monti (1938- ), ao Oscar de melhor filme estrangeiro.

Segundo Xavier, o aumento na produção de filmes a partir de 1993 caracterizou-se pela variedade, dificultando a definição de um estilo dominante com base em perfis estéticos e temáticos semelhantes. Desse modo, iniciou-se um período pautado pela diversidade, 
"supostamente distinto dos anteriores, marcados por tendências hegemônicas" (XAVIER, 1999, p. 113).

Xavier não identifica uma oposição entre cinema de autor e de mercado e atribui à nova forma de apoio à produção uma das causas favoráveis à diversidade existente no período. A Lei do Audiovisual criou o mecenato por meio da de renúncia fiscal, dando liberdade aos cineastas para produzirem filmes de arte ou de mercado, conforme suas convicções, sem pressão por retorno de bilheteria. Os filmes se pagavam antes de sua distribuição.

Com a desvalorização do Real a partir de 1998, após um período de quase seis anos de equiparação ao dólar, iniciou-se um questionamento sobre os altos valores das produções nacionais. "A nova realidade motivou os cineastas a apostarem em um cinema mais visceral. Ao invés de orçamentos inflados, filmes de baixo custo" (CAETANO, 2007, p. 204). Apesar da redução nos orçamentos, uma realidade de produção com equipamentos de ponta e técnicos qualificados já encontrava-se consolidada no país, o que manteve presente o cuidado no acabamento dos filmes.

Considerando que os filmes a partir da Retomada passam a ser realizados por meio de um modo de produção distinto, o que resultou em uma estética não homogênea, porém distinta dos filmes de períodos anteriores, o presente trabalho analisará os filmes fotografados por Walter Carvalho a partir de Terra Estrangeira, lançado em 1995.

As parcerias de Walter Carvalho com os mais importantes diretores do país resultaram em obras que ajudam a compreender a história recente do cinema brasileiro, sobretudo a partir da Retomada (LEAL, 2012, p.44).

Importante citar a parceria com Walter Salles (1956- ), que após Terra Estrangeira produziu Central do Brasil (1998), indicado ao Oscar de Filme Estrangeiro e ganhador do Urso de Ouro no Festival de Berlim em 1998, filme que projetou o nome de ambos no mercado cinematográfico internacional. Em entrevista a João Vitor Leal, Walter Carvalho fala sobre essa parceria:

Nosso encontro foi uma descoberta mútua. A minha formação como cinematógrafo e operador de câmera já estava sólida, eu já tinha certa facilidade pra andar com a fotografia no documentário. Ele tinha uma bagagem mais teórica, tinha estudado no exterior, mas ainda não tinha feito nenhum filme. Confiamos um no outro a ponto de, no filme do Krajcberg, eu viajar para filmar sem ele. Nossas bagagens se completaram no Terra Estrangeira. Sob o ponto de vista da imagem, ele tem a base do documentário: é a câmera na mão e o ator improvisando na rua. Também no Central do Brasil houve uma troca entre nós. Parte do filme se passa no Nordeste, minha terra natal. $\mathrm{O}$ Walter Salles promoveu uma volta minha à região. Ele era um garoto jovem, com uma ideia para um filme passado nesse lugar pouco conhecido por ele, mas ele estava acompanhado desse homem mais velho que conhecia a 
região. Nesse retorno eu filmei pela primeira vez em Cinemascope, capturando tudo em sua abrangência panorâmica. Isso deu força ao filme e contribuiu para sublinhar minha relação com o Walter (CARVALHO in LEAL, 2012, pp.49 e 50).

A parceria entre diretor de fotografia e diretor de cena é de grande importância na realização de um filme. Em muitos casos é difícil separar a contribuição de cada um para o resultado final da obra. Carvalho admite que muitos elementos nos filmes que fotografou tiveram sua contribuição direta:

\begin{abstract}
Através dos vários diretores com que eu trabalhei, mais de 50, eu fui descobrindo o que é ser diretor de cinema. Sem querer e sem me dar conta, aprendi o ofício da direção no próprio contato com esses colegas. E hoje eu percebo que, trabalhando como diretor de fotografia, eu acabei deixando nos filmes muitas coisas que seriam atitudes do diretor. Não falo isso por vaidade. Eu estava dando uma contribuição, em alguns momentos, que era muito mais do que a fotografia (CARVALHO in LEAL, 2012, p. 55).
\end{abstract}

O depoimento de Walter Carvalho aponta uma influência mútua no trabalho desses dois profissionais criativos, bem como a importância dos diretores de cena na construção de seu estilo próprio de filmar.

Para compreender a forma como Walter Carvalho imprime seu estilo às imagens, faremos um recorte de seu trabalho como diretor de fotografia em filmes de ficção para o cinema, de 1995 a 2017. Não serão abordados os filmes anteriores por entendermos que a retomada do cinema brasileiro é um momento divisor de águas no que se refere ao modo de produção de filmes no país, o que tem um reflexo direto na estética fílmica. Desse modo, analisaremos a fotografia dos seguintes filmes: Terra Estrangeira (1995), Central do Brasil (1998), Abril Despedaçado (2001), Lavoura Arcaica (2001), Madame Satã (2002), Heleno, o Príncipe Maldito (2011) e O Filme da Minha Vida (2017).

A ideia é abordar filmes de vários diretores, em uma tentativa de identificar elementos de composição e luz que se repetem, considerando que se tratam de contribuições diretas de Walter Carvalho às obras.

O foco das análises será a imagem, entretanto, não é possível deixar de lado elementos como roteiro, montagem, som e mis en scène, uma vez que a imagem desses filmes se constrói a partir da narrativa, do drama. Como veremos no decorrer da análise, Walter Carvalho não leva a imagem para o filme, mas encontra-a no roteiro, nos personagens e nas concepções do diretor. A partir de seu repertório, sensibilidade artística e conhecimento técnico, trabalha para revelar essa imagem latente e dar sentido ao filme. 


\subsection{Terra Estrangeira (1995), de Walter Salles e Daniela Thomas}

O filme inaugura a parceria entre Walter Carvalho e Walter Salles em filmes de ficção. Ganhador de vários prêmios, inclusive o troféu de prata Manaki Brothers, importante festival de fotografia da Macedônia, Terra Estrangeira aponta um fenômeno novo em nossa tradição cinematográfica: brasileiros que deixam o país para viver como imigrantes em outros países.

O enredo gira inicialmente em torno de duas histórias paralelas. Em São Paulo, Paco (Fernando Alves Pinto) e sua mãe (Laura Cardoso), descontentes com o contexto do país e com suas vidas pessoais, desejam mudanças: ele tentando uma carreira de ator e ela querendo retornar à Espanha, sua terra natal. Em Lisboa, Alex (Fernanda Torres) vive com Miguel (Alexandre Borges), um saxofonista sonhador e dependente de cocaína. Alex administra um cotidiano difícil, em uma situação de subemprego, e rejeita as contravenções de Miguel, que vive de contrabandos. A intenção de movimento dos personagens, presente nesse momento inicial, torna-se constante ao longo de todo o filme.

Paco perde a mãe, vítima de ataque cardíaco, ao ouvir a notícia do confisco da poupança efetuado pelo governo Collor. Com a vida colapsada, decide realizar o sonho materno de voltar à Espanha. Para custear a viagem leva um objeto contrabandeado até Lisboa, onde conhece Alex. Miguel é morto em uma operação de contrabando malsucedida. Daí por diante, Alex e Paco iniciam uma fuga sem rumo e um tumultuado romance.

O filme exprime a tristeza e a resistência de jovens em busca de um novo país, em meio ao caos da era Collor. É introspectivo, denso, com diálogos não coloquiais e a fotografia ao mesmo tempo traduz e reforça o estado de espírito tormentoso dos personagens. Não se enquadra em um único gênero: inicia como um melodrama, desenvolve-se como um policial e termina como um trágico road movie.

Sob o ponto de vista da imagem, o filme flerta com o documentário, utilizando câmera na mão e improvisação de atores. Essa escolha é fruto não apenas da experiência de Walter Salles como documentarista, mas também objetiva reforçar imageticamente a vida conflituosa dos personagens, por meio de uma câmera que nunca é estática, que acompanha suas intenções de movimento, e que respira o tempo todo, trazendo ao filme o sentido de vida real.

Foi filmado com uma câmera $16 \mathrm{~mm}$, mais leve, que permite mobilidade ao operador. A fotografia acompanha as variações de gênero e em termos de iluminação traz referências do cinema noir, cujo desenho de luz caracteriza-se por grande diferença entre os valores da luz principal e de preenchimento, o que determina o alto contraste da fotografia e a presença de sombras profundas. 
Os fotogramas da figura 97 evidenciam o desenho de luz com características noires. Alex e Paco têm seus rostos divididos entre a luz e a sombra. Paco é filmado com uma luz pontual, fazendo com que os demais elementos do quadro estejam imersos na escuridão. $\mathrm{O}$ plano do carro na estrada é filmado com uma luz de fundo intensa, em contraste com o primeiro plano em baixa luz.
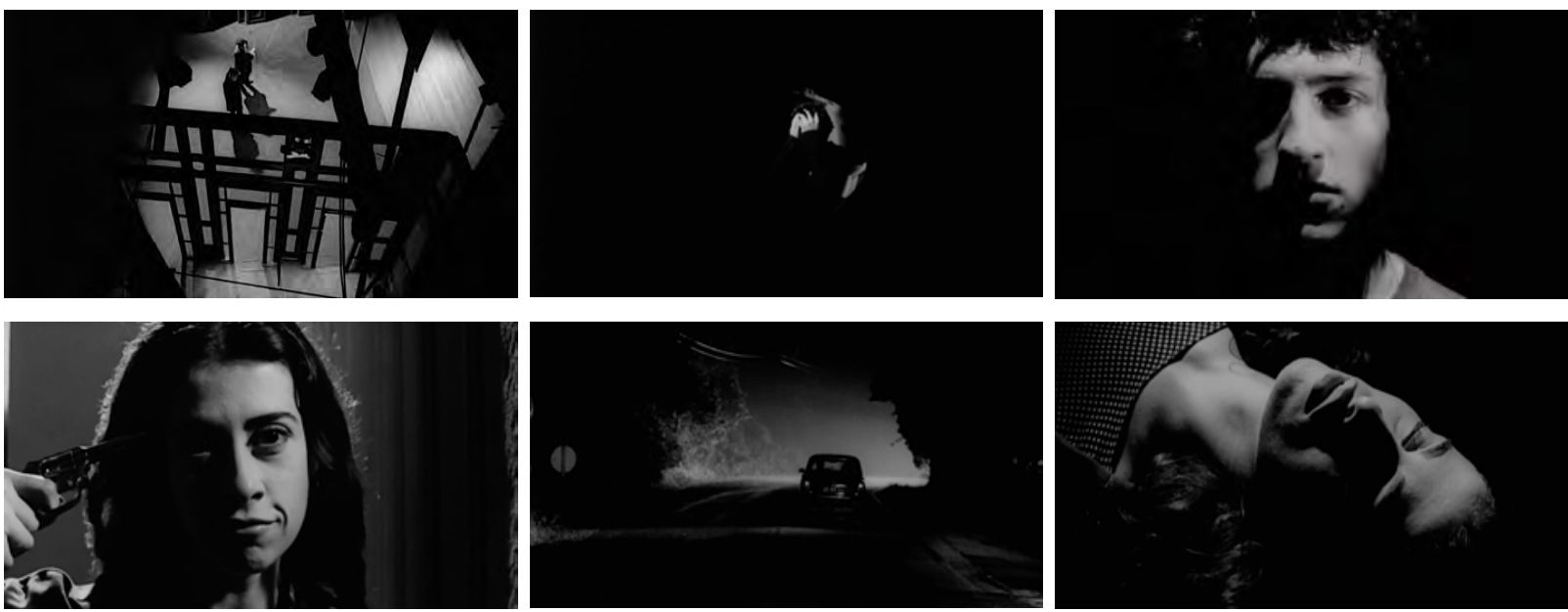

Fig. 97 - Terra Estrangeira (1995), Walter Salles e Daniela Thomas

O contraste também é explorado nos enquadramentos com janelas, em que a oposição entre luz externa e interna traduz visualmente a densidade dos sentimentos e os conflitos vividos pelos personagens.

Na figura 98, vemos dois momentos de Paco. À esquerda, no início do filme, em que seu conflito ainda não se estabeleceu, a luz interna equilibra-se com a luz externa. $\mathrm{O}$ preenchimento permite que sejam vistos detalhes do quarto e do corpo personagem. No fotograma da direita, quando Paco está em Lisboa desesperado e sem dinheiro, seu estado interior traduz-se pela falta de luz de preenchimento, que silhueta seu corpo em contraste com a luz externa. Abaixo de cada fotograma estão os histogramas das imagens. Nota-se que não existe muita diferença no número e na distribuição de pixels do lado esquerdo de cada histograma, o que demonstra haver pouca diferença nas luzes médias e baixas. A comparação dos lados direitos de cada histograma demonstra a diferença na quantidade de pixels das altas luzes. 

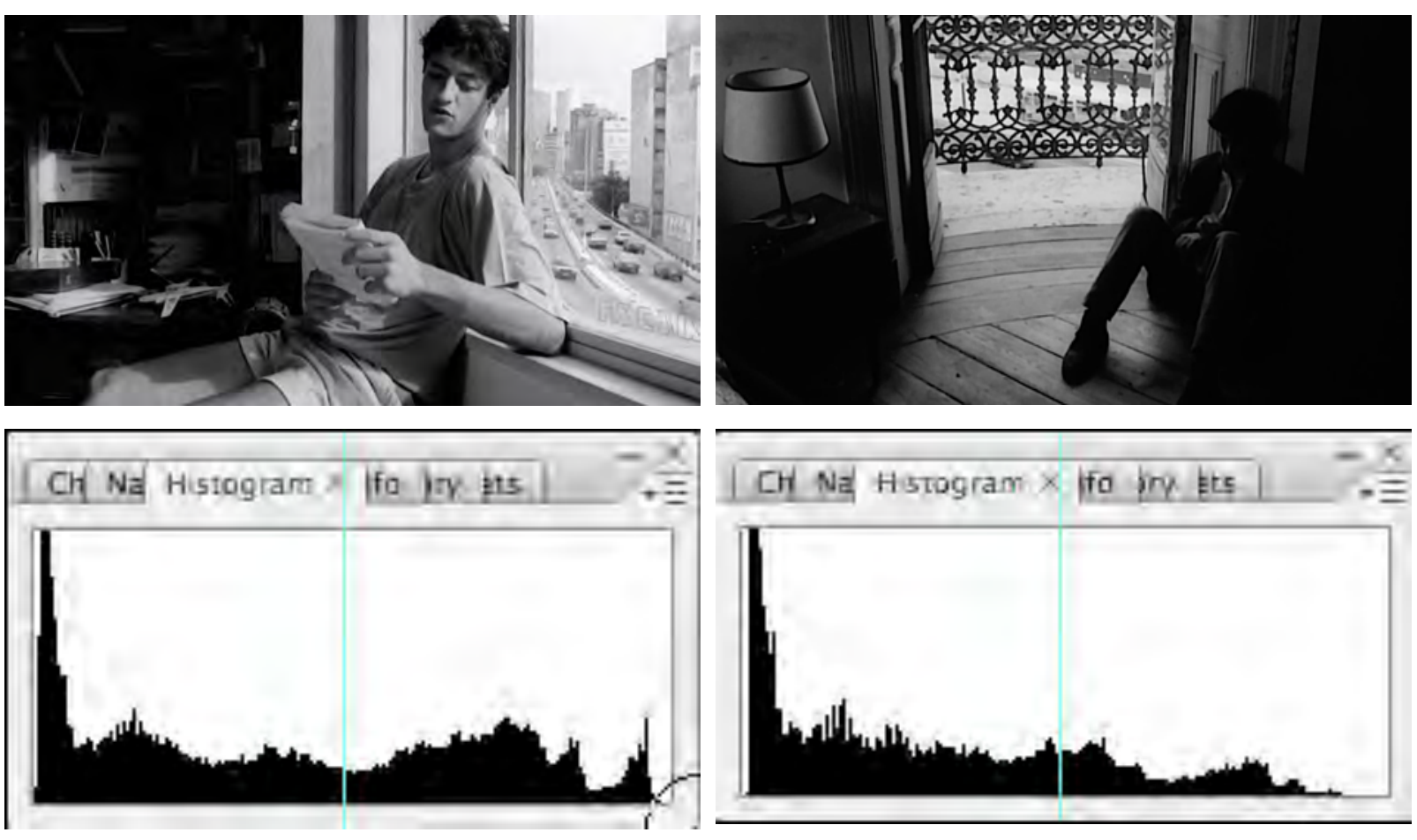

Fig. 98 - Terra Estrangeira (1995), Walter Salles e Daniela Thomas

O procedimento de estabelecer o contraste luminoso com base no momento do personagem é uma das características do trabalho de criação de luz de Walter Carvalho. No artigo Walter Carvalho: a fotografia além da fotogenia, afirma ser um erro levar uma luz para dentro de um filme. "Você tem que ler o roteiro sabendo que ali dentro, mesmo que não esteja escrito, tem uma luz, seu trabalho é descobrir qual é ela"(CARVALHO in LEAL, 2012, p. $51)$.

Nesse mesmo sentido, a opção pelo preto e branco em Terra Estrangeira, apoia-se na intenção de traduzir e reforçar o desalento vivido pelos personagens. Quando Walter Carvalho começou a atuar profissionalmente "o preto e branco estava em decadência" (CARVALHO in LEAL, 2012, p. 49). No final da década de 1960 e início dos anos 1970 a produção de filmes coloridos intensificou-se no Brasil, impulsionada pelo início das transmissões em cores pela TV e pelas atividades do laboratório Líder, em São Paulo. A recusa inicial de cineastas ao emprego da cor, tanto por motivos estéticos quanto pelo alto custo do processamento, foi perdendo força pouco a pouco, até que na década de 1980 a cor tornou-se hegemônica no cinema nacional.

A partir desse momento, a utilização do preto e branco passou a ser uma opção estética, muitas vezes para marcar imagens de época, flashbacks, em que a ausência de cor é associada à visualidade do passado. Não é o caso de Terra Estrangeira, em que os personagens vivem conflitos contemporâneos ao momento do lançamento do filme. A 
ausência de cor relaciona-se à ausência de esperança, de rumo, de perspectiva de vida dos personagens.

Como sua formação deu-se majoritariamente no cinema colorido, Walter Carvalho decidiu estudar o preto e branco para se preparar para as filmagens, em um processo que chamou de "descolorir-se".

Assisti a todos os filmes em preto e branco da Cinemateca do Museu de Arte Moderna do Rio de Janeiro, e fui muito marcado pelo trabalho do Giuseppe Rotunno (1923- ), diretor de fotografia italiano, sobretudo no Rocco e Seus Irmãos, dirigido por Luchino Visconti (1906-1976) em 1960. Lembro-me também da fotografia dos filmes do Kurosawa (1910-1998) e do Henri Alekan (1909-2001), grande fotógrafo francês que teve como um de seus últimos trabalhos o belíssimo Asas do Desejo (1987) do Wim Wenders (1945- ). E, claro, assisti a filmes brasileiros em preto e branco, de fotógrafos como o Fernando Duarte (1937- ), o José Medeiros (19211990) e o Ricardo Aronovich (1930- ). Para citar três que me marcaram, tem o $A$ Hora e a Vez de Augusto Matraga dirigido por Roberto Santos (1928-1987) em 1965, fotografado pelo Hélio Silva (1929- ); o Vidas Secas dirigido por Nelson Pereira dos Santos em 1963, fotogradado pelo José Rosa (1934- ); e o Deus e o Diabo na Terra do Sol dirigido por Glauber Rocha em 1964, fotografado pelo Waldemar Lima (1930-2012) (CARVALHO in LEAL, 2012, p. 55).

O preto e branco comporta amplas possibilidades em termos de composição tonal, podendo o fotógrafo optar pelo grande contraste, o que resulta em imagens com pouca pedominância de meios tons, ou pelo baixo contraste, em que a gradação de cinzas está presente na imagem.

Ao teorizar sobre os metódos de montagem, o cineasta Sergei Eisenstein fala sobre a montagem tonal, realizada a partir da tonalidades de luz, e o efeito emocional que provoca nos espectadores. É o que faz na sequência da neblina de O Encouraçado Potemkin (1925).

Trata-se de uma sequência de pausa dramática, que antecede o derramamento de sangue da escadaria de Odessa. O tom é dado pela imersão dos barcos, quase imóveis, em uma atmosfera esbranquiçada. Há predominância de cinzas, uma vez que a sequência não é sombria o suficiente para justificar o emprego das baixas luzes, tampouco vibrante a ponto de justificar a predominância das altas luzes.
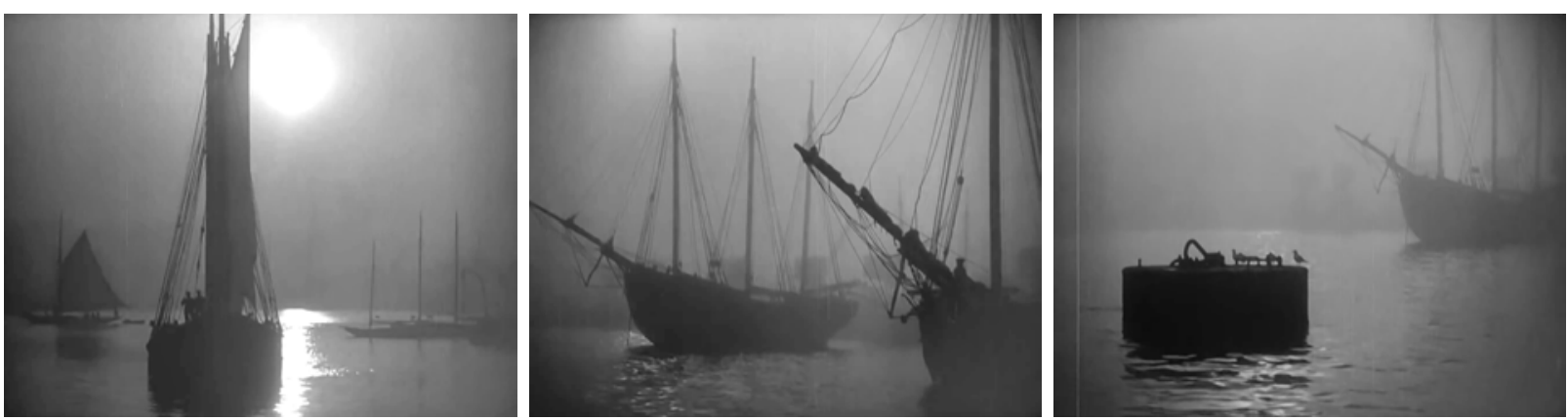

Fig. 99 - O Encouraçado Potemkin (1925), Sergei Eisenstein 
Em Terra Estrangeira, Walter Carvalho varia a composição tonal em função dos momentos dramáticos. Na figura 100 vemos dois fotogramas do início do filme e seus respectivos histogramas. Na imagem da esquerda, a mãe de Paco é retratada em uma ampla variedade de tons, que vão do cinza claro ao preto. Após sua morte, Paco vive um momento de grande dramaticidade, traduzido em uma imagem com predominância de tons que variam apenas do cinza médio ao preto.
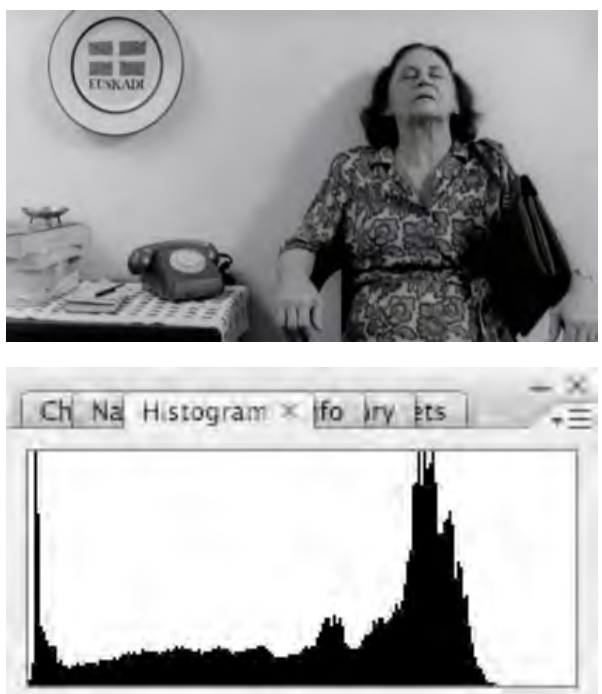
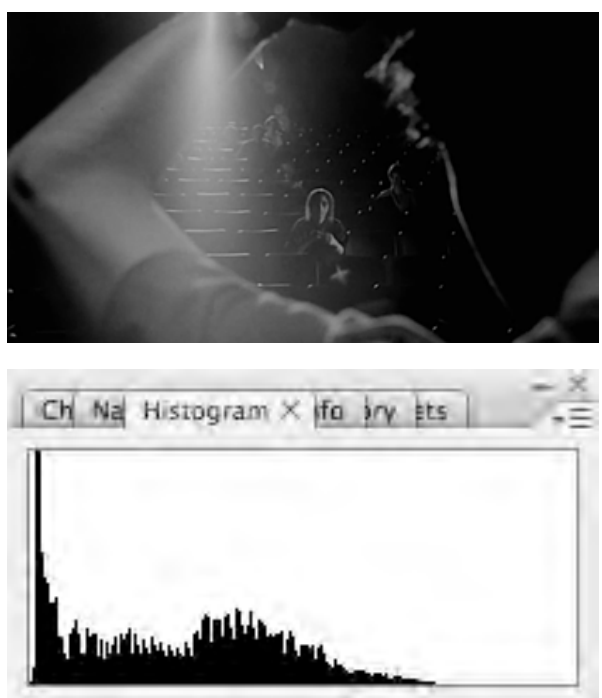

Fig. 100 - Terra Estrangeira (1995), Walter Salles e Daniela Thomas

Na figura 101, os fotogramas retratam dois momentos em Lisboa. Na imagem da esquerda há uma grande variação tonal e na da direita, que precede a fuga de Paco e Alex, o histograma concentra-se na zona de preto.
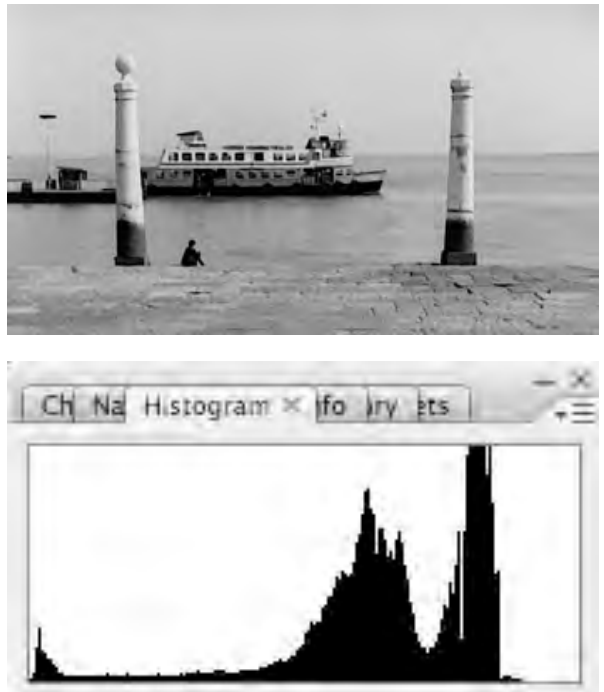
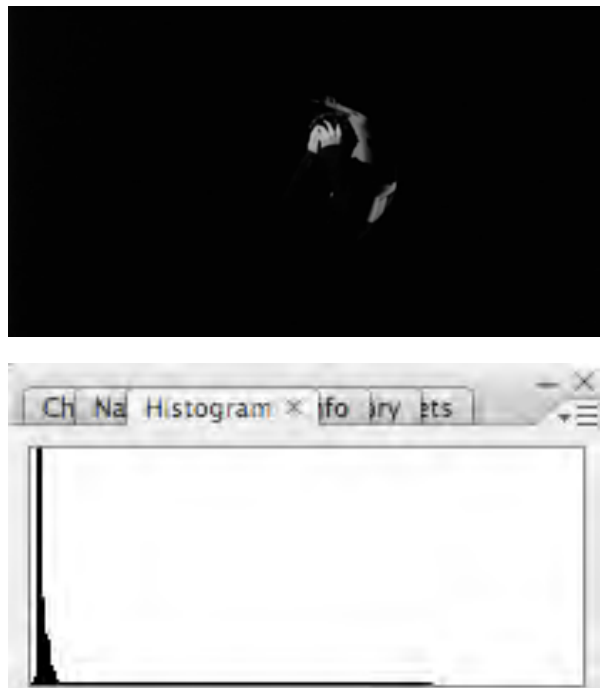

Fig. 101 - Terra Estrangeira (1995), Walter Salles e Daniela Thomas 
Mais para o final do filme, encontramos outros dois momentos em que a gradação de cinzas reflete a densidade dos conflitos. No fotograma da esquerda, Paco e Alex vivem um romance durante a fuga, e há predominância de cinzas médios e claros na imagem. À direita temos a cena final, após a morte de Paco, com predominância dos cinzas escuros e pretos.
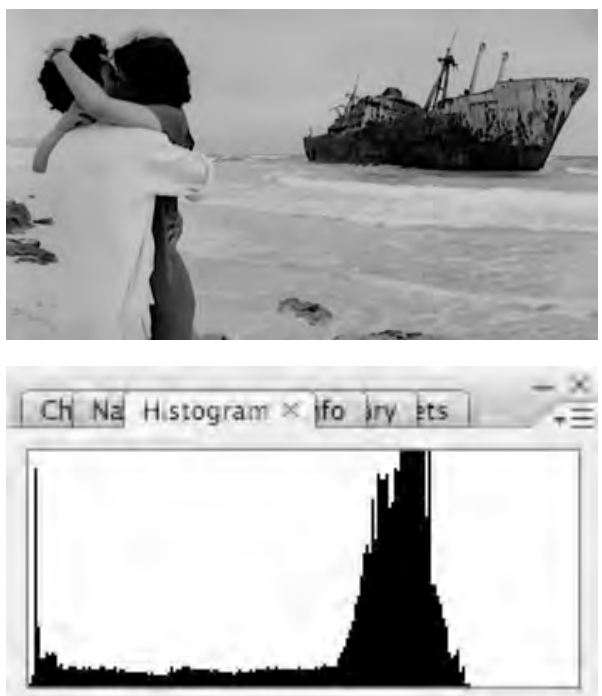
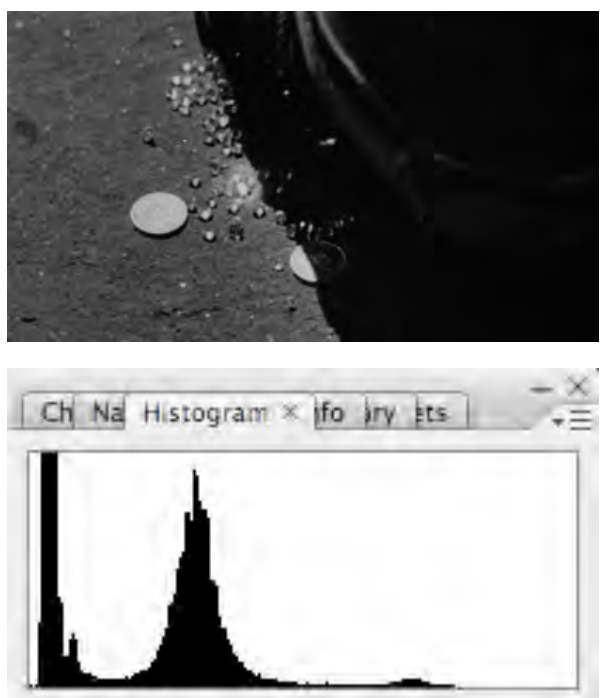

Fig. 102 - Terra Estrangeira (1995), Walter Salles e Daniela Thomas

Vale notar como os histogramas das três imagens de menor contraste assemelham-se, demonstrando que em momentos de pausa dramática há um mesmo tratamento com relação à composição tonal.
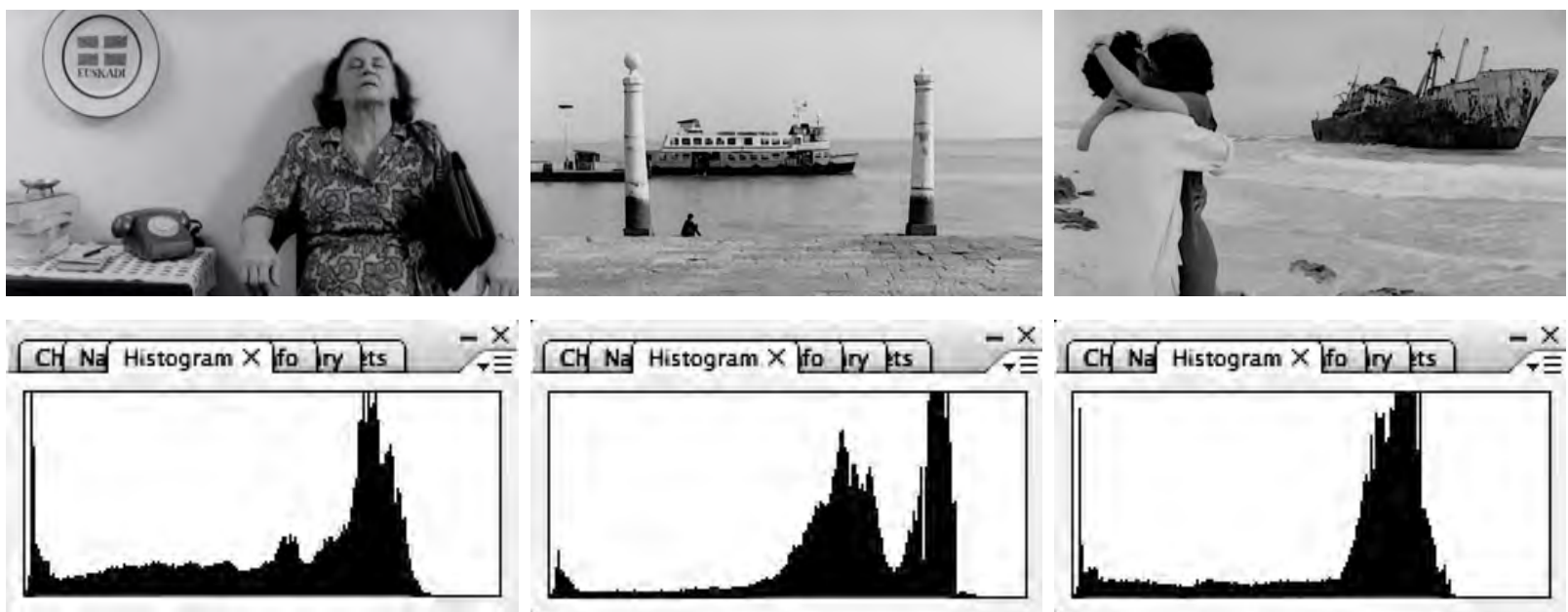

Fig. 103 - Terra Estrangeira (1995), Walter Salles e Daniela Thomas

Ao passo que em momentos de maior densidade dramática, mesmo havendo predominância de tons escuros, os histogramas apresentam composições distintas. Isso indica que a composição tonal leva em conta as nuances de intensidade dos conflitos. 

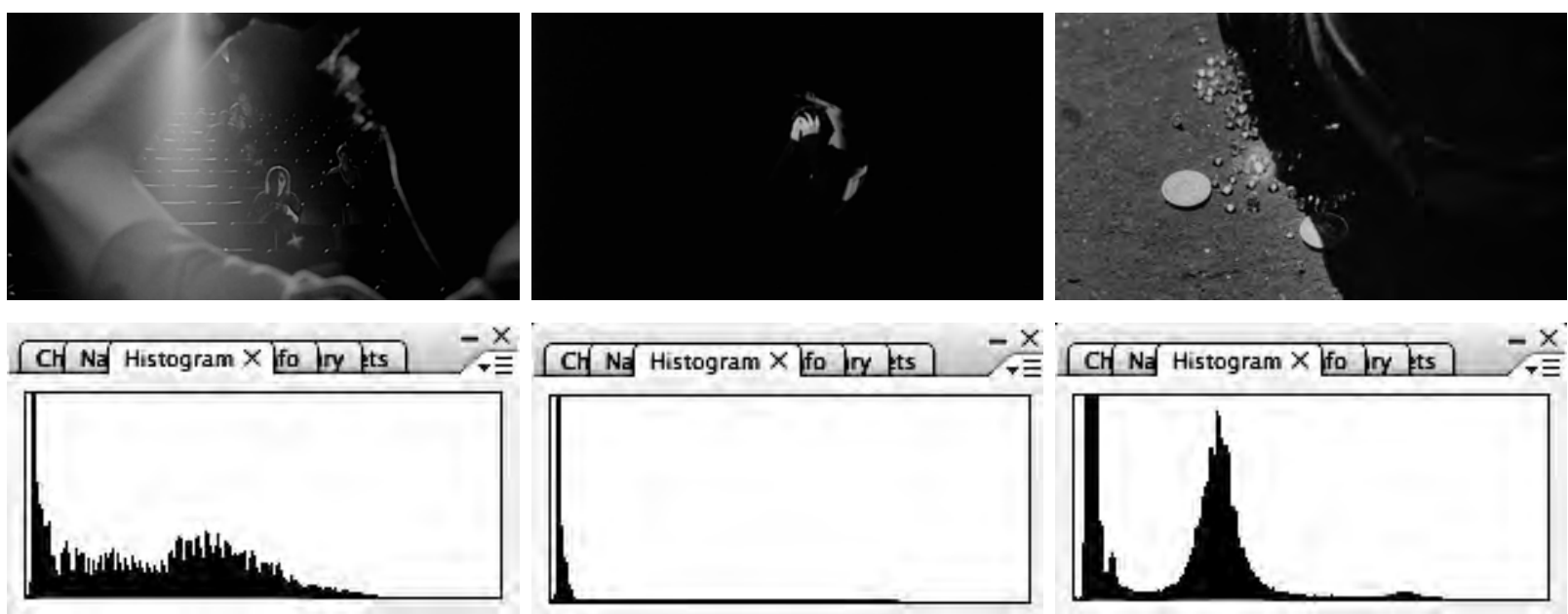

Fig. 104 - Terra Estrangeira (1995), Walter Salles e Daniela Thomas

Além da composição tonal, outros elementos de Terra Estrangeira encontram paralelo na teoria eisensteiniana, como, por exemplo, o tratamento gráfico das imagens.

A composição era uma ideia central no pensamento do cineasta soviético, que considerava o enquadramento como decisivo na construção da narrativa. Segundo a pesquisadora Maria Teresa Denser (1951-2013), Eisenstein introduz o pensamento gráfico no cinema, por meio da exploração de elementos como a linha, o círculo, o quadrado e o triângulo.

Em Terra Estrangeira, o espaço é criado por meio de formas bidimensionais, com ênfase nas linhas retas e curvas, como evidenciado na figura 105.
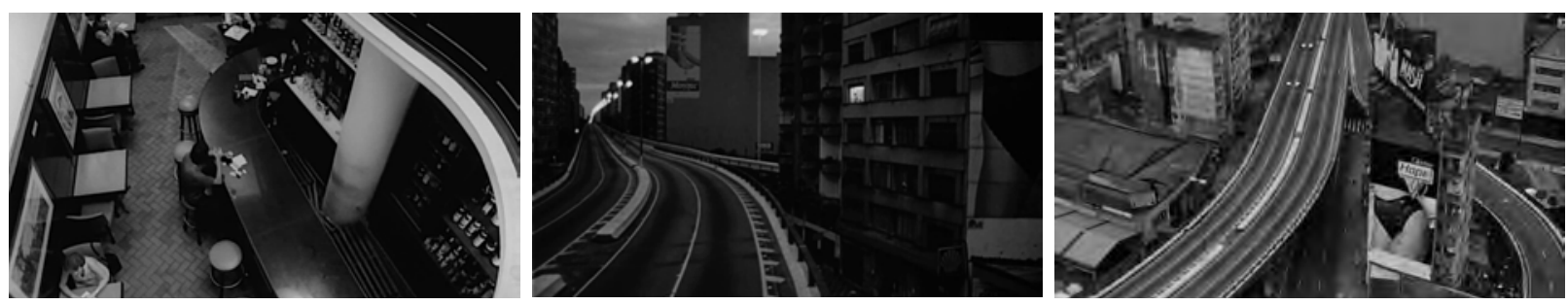

Fig. 105 - Terra Estrangeira (1995), Walter Salles e Daniela Thomas

Os enquadramentos variam entre a centralização e o deslocamento espacial dos personagens, aproveitando linhas e elementos do cenário.
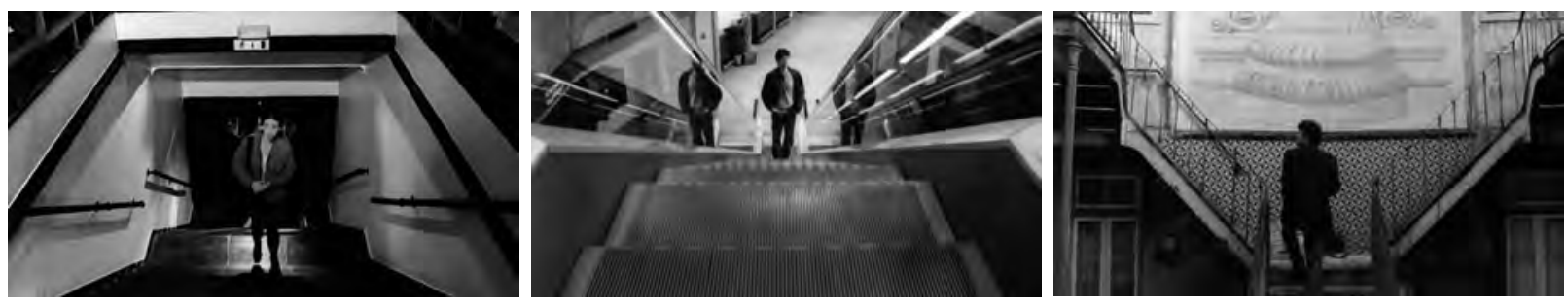

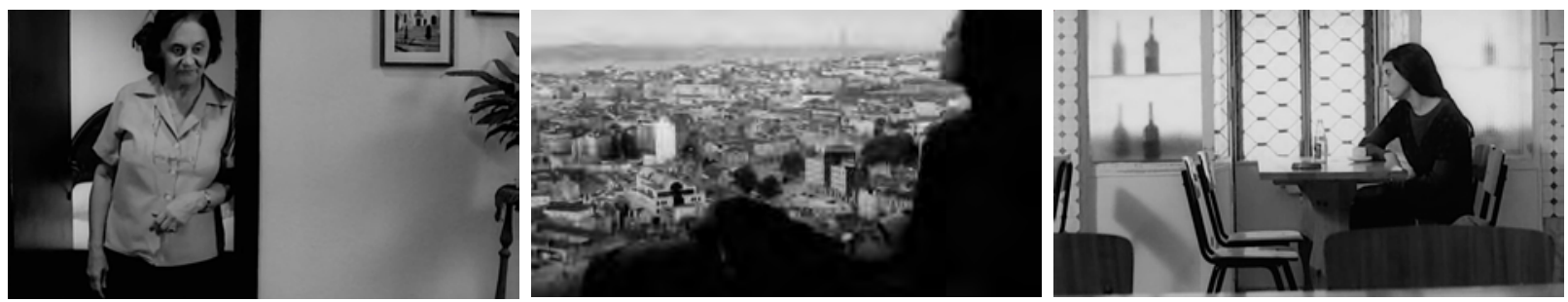

Fig. 106 - Terra Estrangeira (1995), Walter Salles e Daniela Thomas

O tratamento gráfico poderia ser considerado contrário à representação realista do espaço, uma vez que explorando a linha, elemento próprio ao desenho, estaria negando a terceira dimensão. Não é o que acontece em Terra Estrangeira, já que o desenho de luz e o enquadramento em profundidade garantem a dimensão de volume às imagens. Nesse sentido, também se aproxima do cinema de Eisenstein.

O princípio recorrente da construção estética do fotograma, observado nos filmes do diretor soviético, revela-se na construção em profundidade, interação dinâmica do primeiro plano e do fundo, que pode apresentar-se como a unidade dos dois, ou como sua nítida contraposição.

Em Terra Estrangeira, os enquadramentos em profundidade exploram elementos de cenário em primeiro plano e os vários planos até o fundo, como mostra a figura 107.

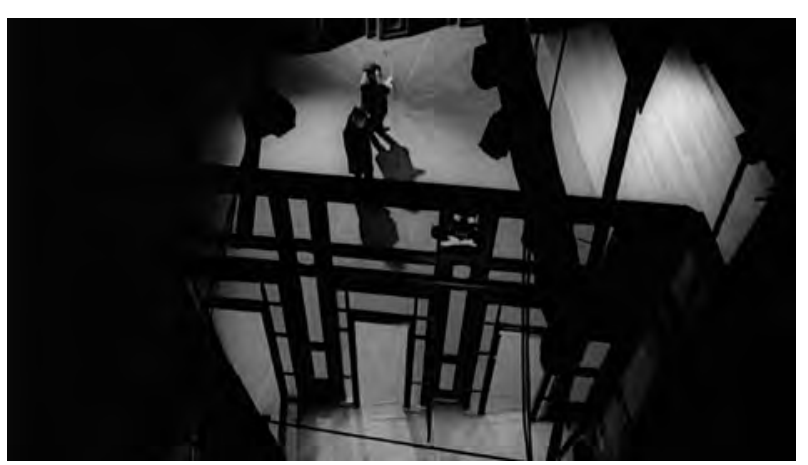

Fig. 107 - Terra Estrangeira (1995), Walter Salles e Daniela Thomas

A janela ao fundo é outro elemento de profundidade muito utilizado por Walter Carvalho, que prolonga a imagem ao exterior. Esse procedimento se repetirá em seus filmes posteriores. 

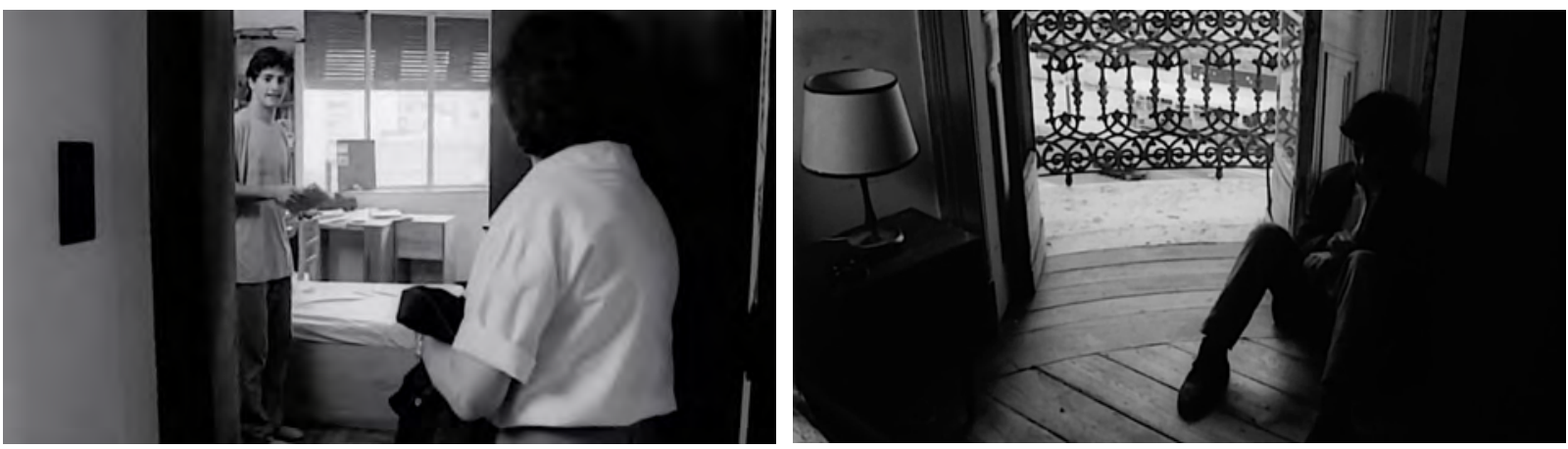

Fig. 108 - Terra Estrangeira (1995), Walter Salles e Daniela Thomas

A julgar pelas anotações de diversos anos, Eisenstein estudava a formação gradual da composição na arte pictórica, da qual surge a composição em profundidade no cinema. Experiências em A Greve (1924) não foram muito felizes pela falta da objetiva correspondente: a $28 \mathrm{~mm}$. Entretanto, cria a profundidade na imagem por meio do uso de diagonais e do claro/escuro, procedimento também utilizado por Walter Carvalho, como verificamos nos fotogramas da figura 109.
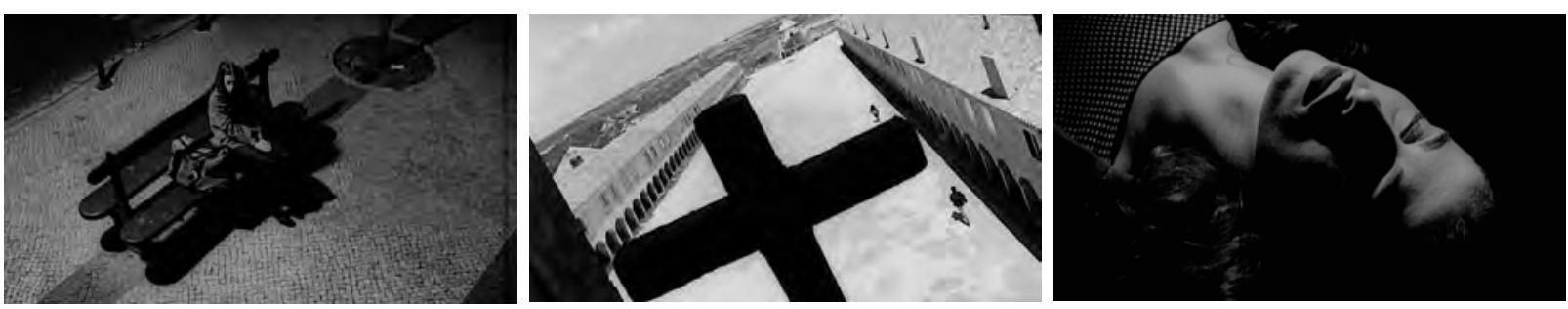

Fig. 109 - Terra Estrangeira (1995), Walter Salles e Daniela Thomas

Essa diagonalidade está presente não apenas em personagens sozinhos mas constantemente na relação entre eles.
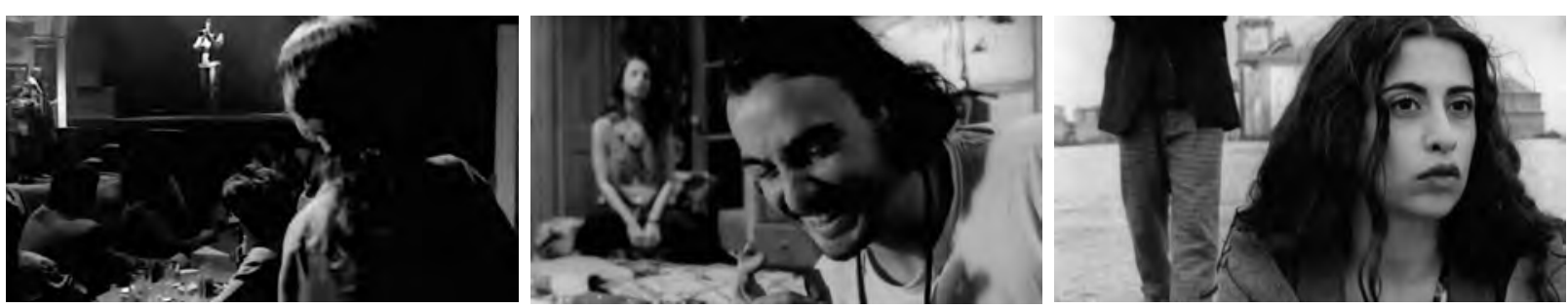

Fig. 110 - Terra Estrangeira (1995), Walter Salles e Daniela Thomas

Com relação à lente, Carvalho realiza a construção em profundidade de modo semelhante a Eisenstein.

O efeito da filmagem com uma objetiva $28 \mathrm{~mm}$ de distância focal, quando o objeto vertical se coloca diretamente frente ao mesmo e o foco está dirigido ao seu centro. Faz muito tempo (em 1927), que eu o defini capaz de criar um conflito entre o objeto e sua aparência (do mesmo modo que a câmera lenta e a câmera rápida criam um conflito entre o processo e o tempo de sua duração). Como se sabe, o efeito 
dessa objetiva se deve à redução de perspectiva dos objetos em profundidade, que é muitas vezes mais brusca e rápida que no olho normal. $\mathrm{O}$ olho percebe as reduções de acordo com as normas habituais e através disto recebe uma representação deformada do objeto. Os lugares planos se percebem como profundos. A mão, dirigida diretamente para a objetiva, parece incrivelmente grande, devido à colossal desproporção que existe entre seu tamanho e a figura catastroficamente reduzida de seu dono, correspondendo seu tamanho relativo à percepção do olho se estivesse a uma enorme distância. Fora de foco fica aquilo que está muito longe ou excessivamente perto (EISENSTEIN, 1982a, p. 195).

A comparação entre um fotograma de Ivan, o Terrível - Parte I e Terra Estrangeira ilustra esse procedimento. Em Ivan, Eisenstein enquadra o czar com a multidão que conclama sua volta a Moscou. Em Terra Estrangeira, de forma muito semelhante, a profundidade aparece no quadro em que Alex é vista com o navio encalhado ao fundo.
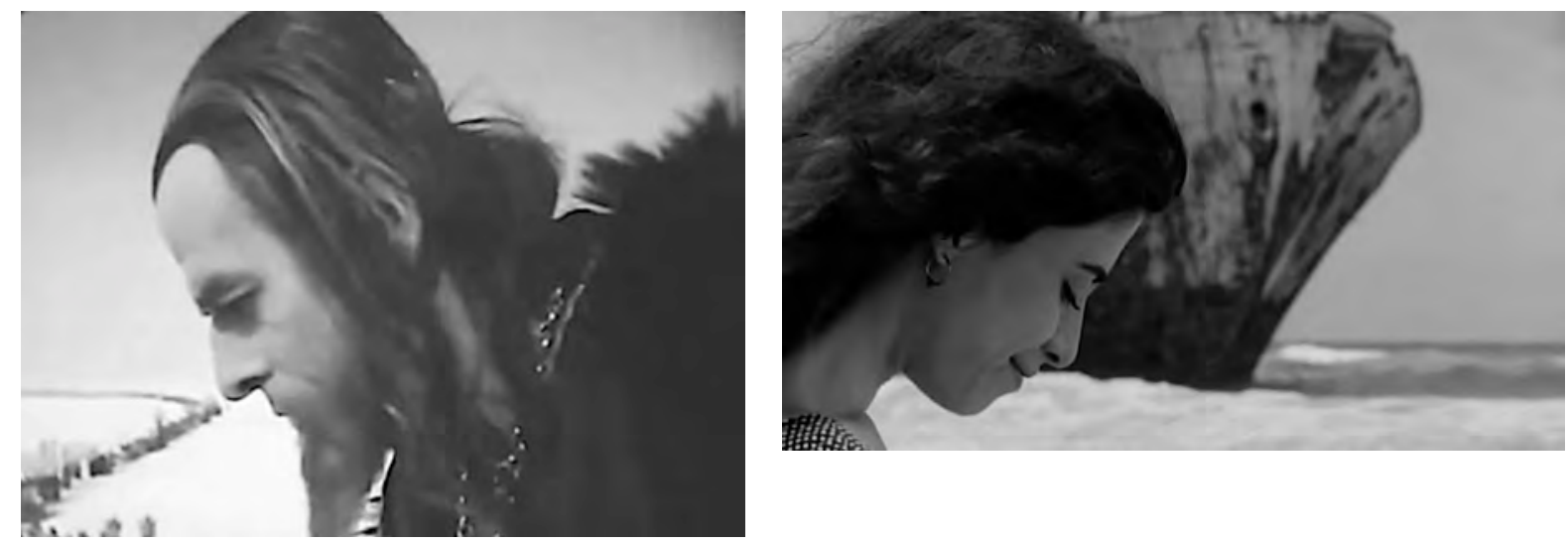

Fig. 111 - Ivan, o Terrível - Parte I (1944) e Terra Estrangeira (1995)

Outro momento eisensteiniano de Terra Estrangeira é o da morte do livreiro Pedro, que se dá metaforicamente pela imagem de seus óculos quebrados.

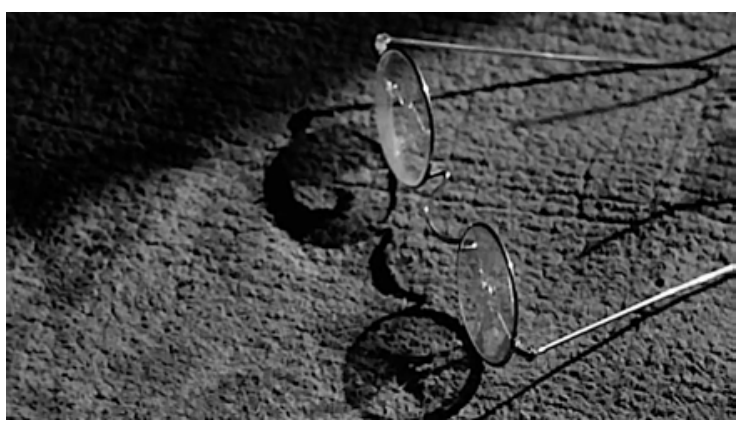

Fig. 112 - Terra Estrangeira (1995)

Essa imagem remete a dois momentos de O Encouraçado Potemkin (1925): a morte do médico do navio, cujos óculos são mostrados em detalhe após ele ser jogado ao mar, e o plano final da escadaria de Odessa, com o tiro que acerta os óculos. Sobre o plano metafórico, Eisenstein afirma ser "um elemento capaz de despertar no espectador a consciência e o sentimento do todo" (EISENSTEIN, 1969, p. 32). Desse modo, tanto em Terra Estrangeira 
quanto no Encouraçado Potemkin, os óculos trazem o significado da morte.
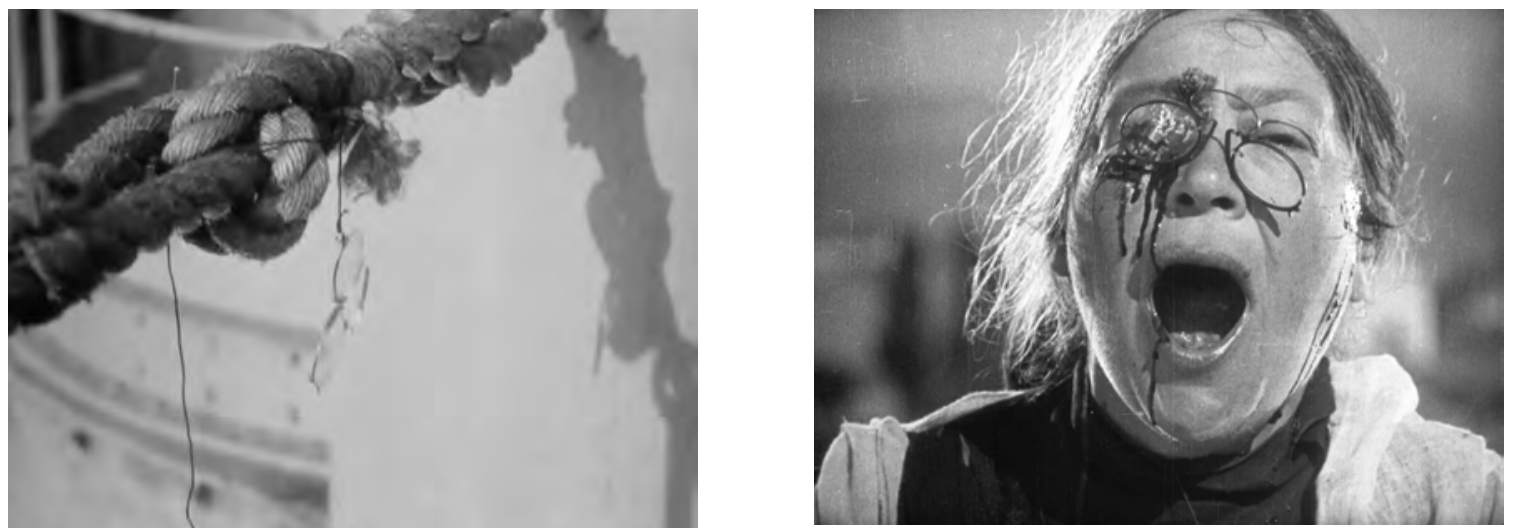

Fig. 113 - O Encouraçado Potemkin (1925), Sergei Eisenstein

A morte da mãe de Paco é vista de um enquadramento distante, em que os elementos do cenário dividem o quadro em três partes e o contraste se encarrega de emoldurar o momento dramático.
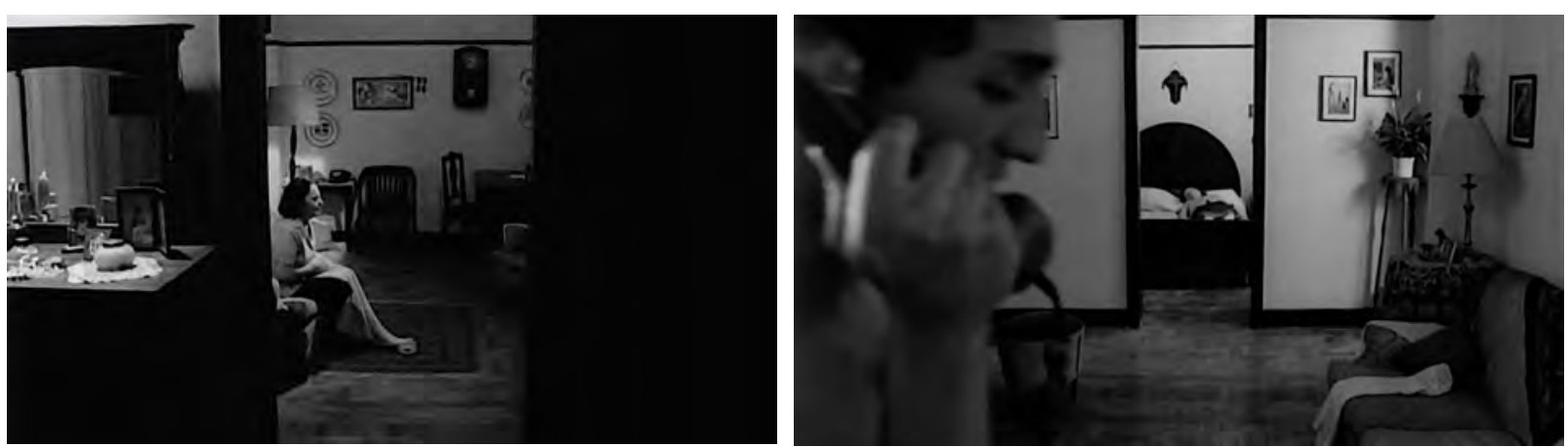

Fig. 114 - Terra Estrangeira (1995), Walter Salles e Daniela Thomas

A tripartição do quadro era utilizada com frequência por Eisenstein. Na figura 115 é possível verificar a semelhança de um dos enquadramentos de Terra Estrangeira com A Greve (1924).
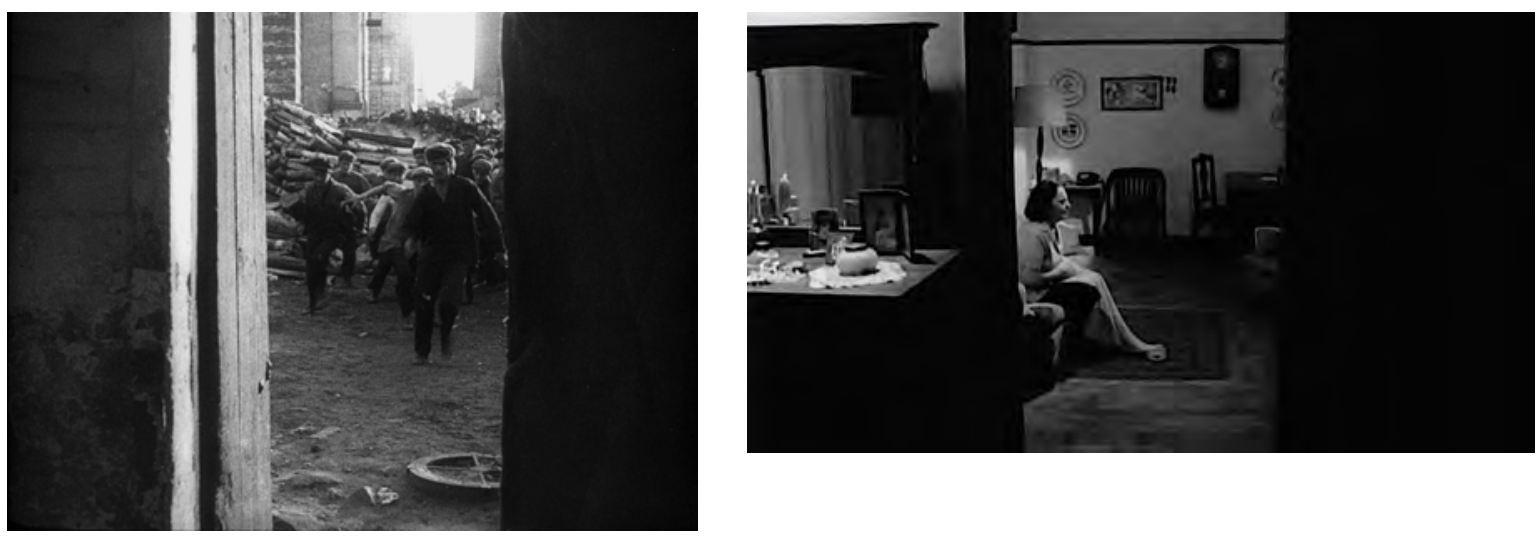

Fig. 115 - A Greve (1924) e Terra Estrangeira (1995) 
Trata-se do quadro dentro do quadro, procedimento que encontra paralelo na obra de Eisenstein e é empregado para filmar toda a sequência da morte da mãe até seu sepultamento, repetindo-se em filmes posteriores de Walter Carvalho.
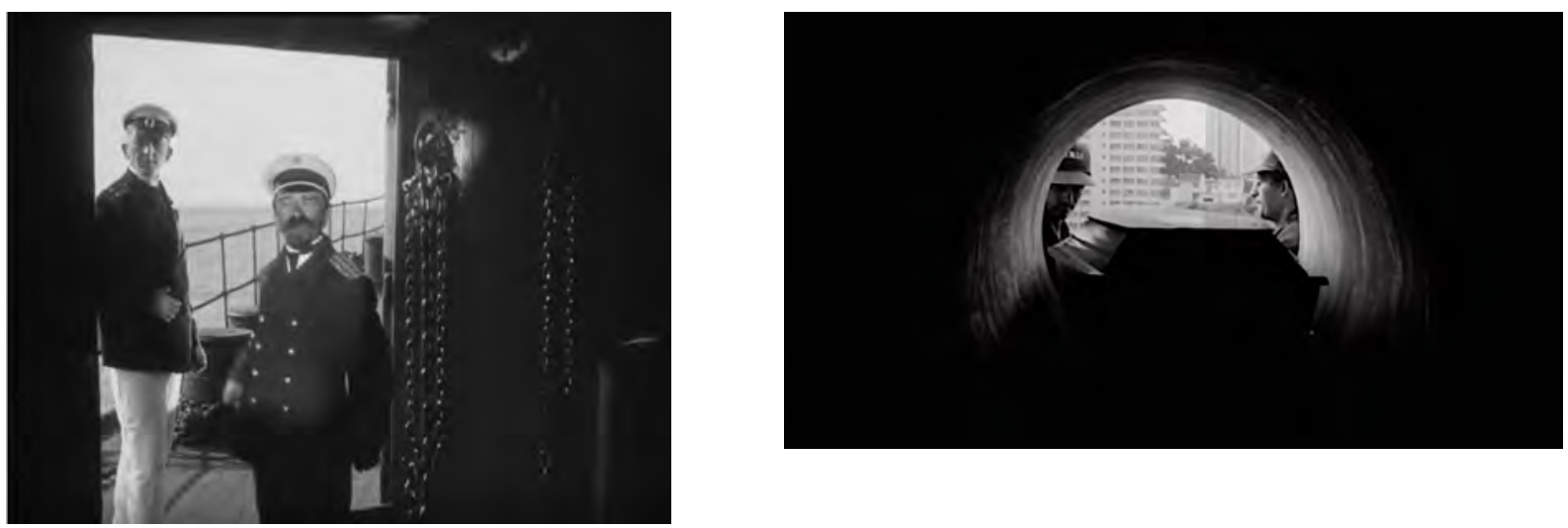

Fig. 116 - O Encouraçado Potemkin (1925) e Terra Estrangeira (1995)

O quadro dentro do quadro é criado por meio de elementos da paisagem, do cenário e até do corpo dos personagens.
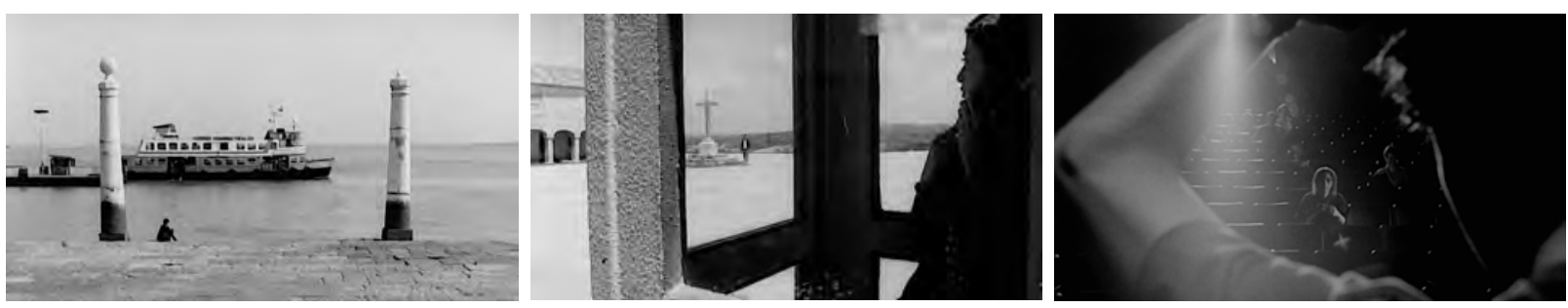

Fig. 117 - Terra Estrangeira (1995), Walter Salles e Daniela Thomas

Outro elemento poético constantemente utilizado por Walter Carvalho é a pequena profundidade de campo. Em $O$ pensamento gráfico no cinema: a construção $e$ a representação da imagem cinematográfica, Maria Teresa Denser identifica a pequena profundidade de campo como um traço do tratamento gráfico, que se opõe ao tratamento pictórico. "A técnica em que se obtém a profundidade de campo, característica do tratamento pictórico, quando usada de forma contrária, ou seja, com o achatamento da perspectiva, obtém-se o tratamento gráfico" (DENSER, 2008, p. 34). Assim, o gráfico estaria para o desenho e o bidimensional, assim como o pictórico estaria para a pintura e a impressão da tridimensionalidade. Ao dificultar a visualização do espaço, a pequena profundidade de campo torna a imagem plana, portanto gráfica.

O fotograma da figura 118, mostra Paco em Lisboa, sem dinheiro, ao tentar contatar Igor (Luís Melo) no Brasil. Paco está de costas para a câmera e o foco está na parte de trás de sua cabeça, o ambiente está desfocado, o que acentua o isolamento do personagem. Desse 
modo, o isolamento de Paco é traduzido visualmente pela profundidade de campo.

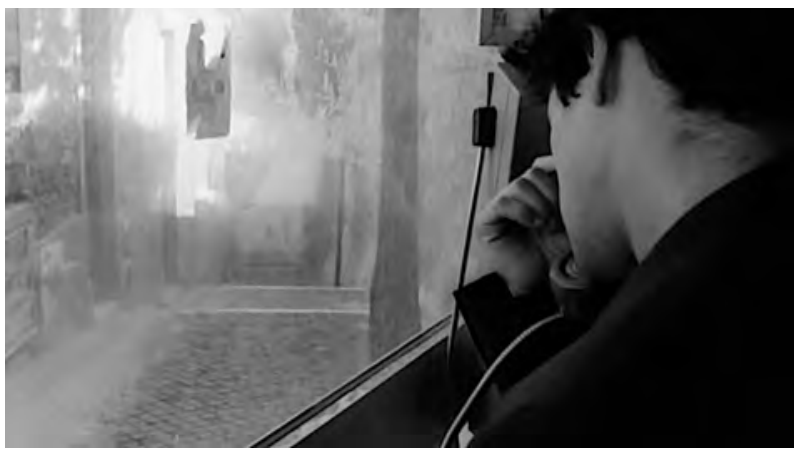

Fig. 118 - Terra Estrangeira (1995), Walter Salles e Daniela Thomas

Walter nem sempre utiliza o foco da maneira mais comum. Em geral, nos planos com pouca profundidade de campo opta-se por deixar o foco no personagem que fala. Walter Carvalho muitas vezes mantém o foco no personagem que ouve, ou que está mais ao fundo, como vemos na figura 119.

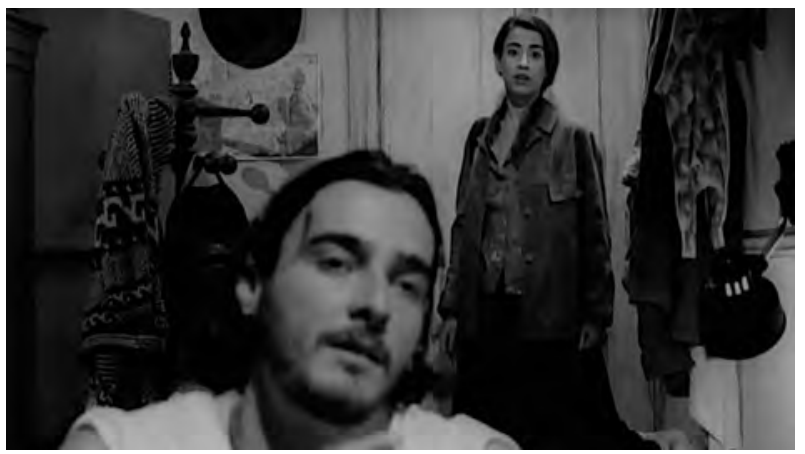

Fig. 119 - Terra Estrangeira (1995), Walter Salles e Daniela Thomas

Utiliza ainda o completo desfoque. É o caso do banho de Paco após sepultar a mãe, em que a imagem tem relação direta com a falta de foco interna do personagem. Apenas no final da cena há foco em Paco e na água que transborda do banheiro e inunda o apartamento. As imagens de San Sebastian e as fotos antigas da família são levadas pela água. A retomada de objetivo do personagem, que ocorre no momento seguinte, é representada imageticamente pela correção de foco.
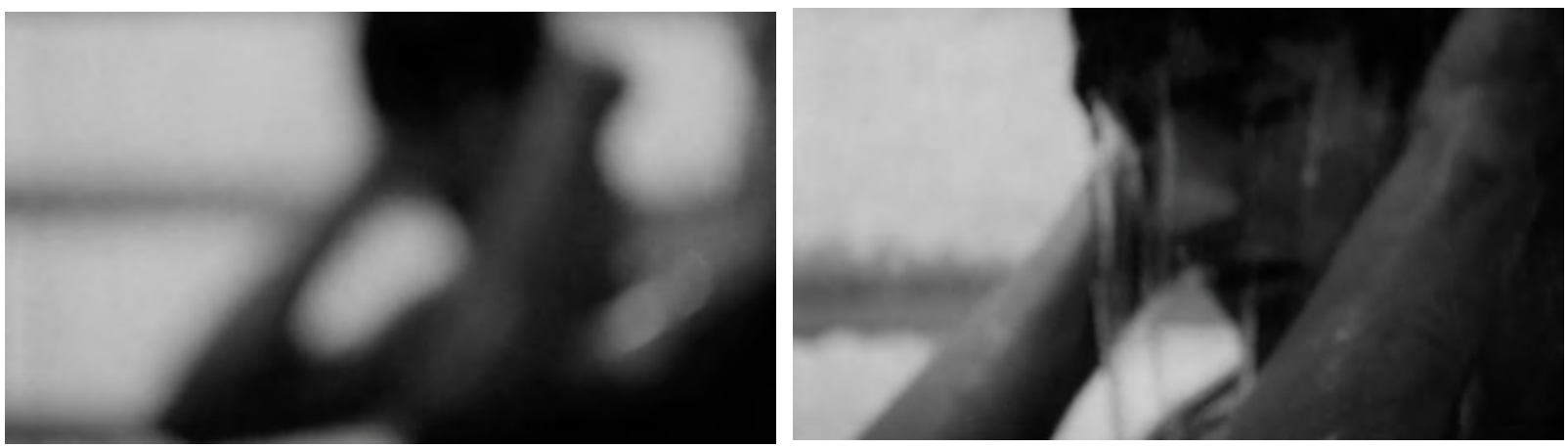

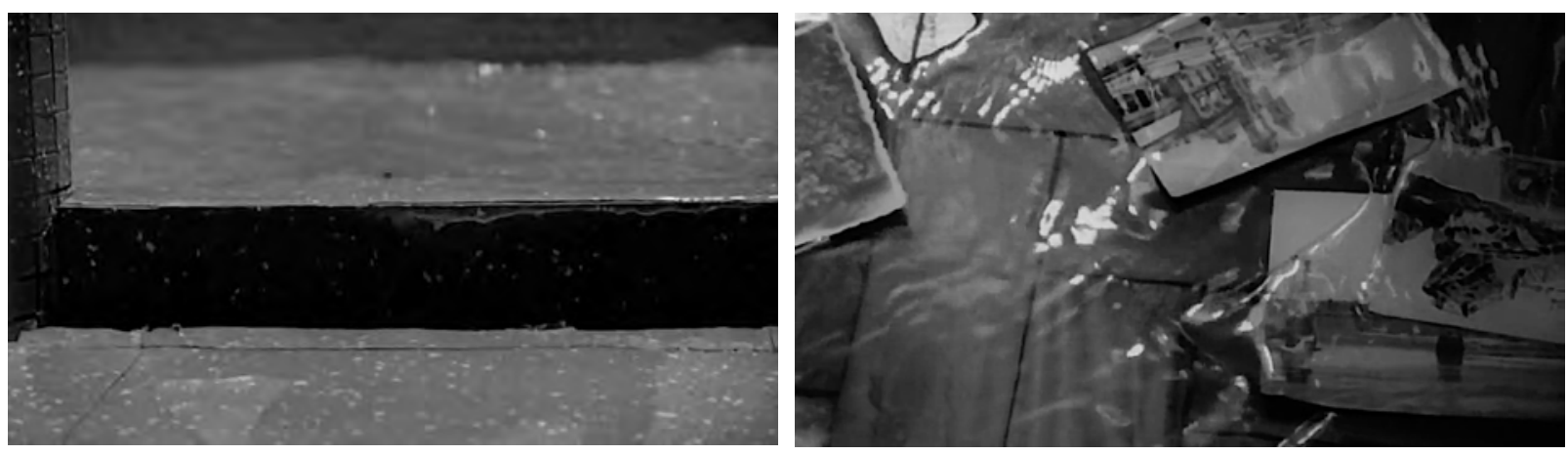

Fig. 120 - Terra Estrangeira (1995), Walter Salles e Daniela Thomas

Em Terra Estrangeira há um intercruzamento de narrativa e espaço. Os personagens se deslocam constantemente, tornando os espaços transitórios e reforçando o sentimento de ausência de abrigo.

Apesar do movimento interno ser constante, os movimentos de câmera, principalmente os de grua, intensificam-se a partir do momento em que Paco e Alex encontram-se pela primeira vez.
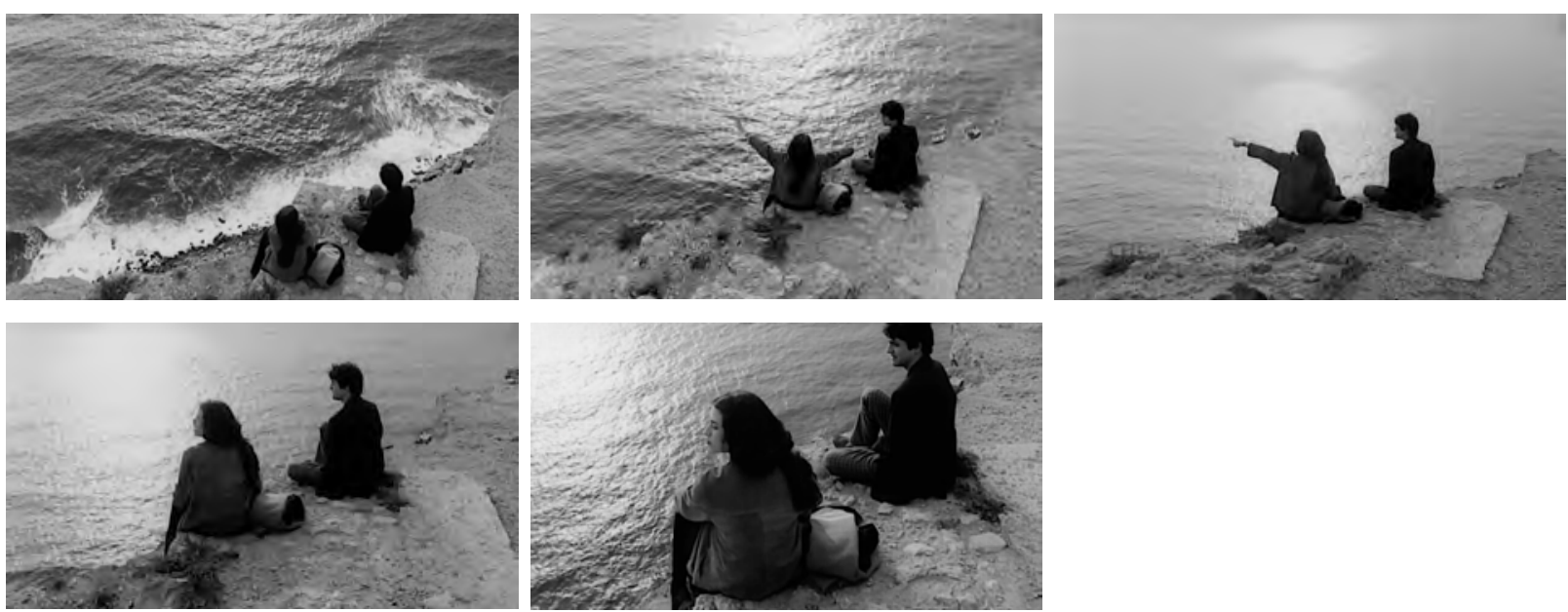

Fig. 121 - Terra Estrangeira (1995), Walter Salles e Daniela Thomas

Os movimentos são precisos, de modo que até os enquadramentos intermediários do movimento são composições balanceadas, como mostram os fotogramas da figura 122. 

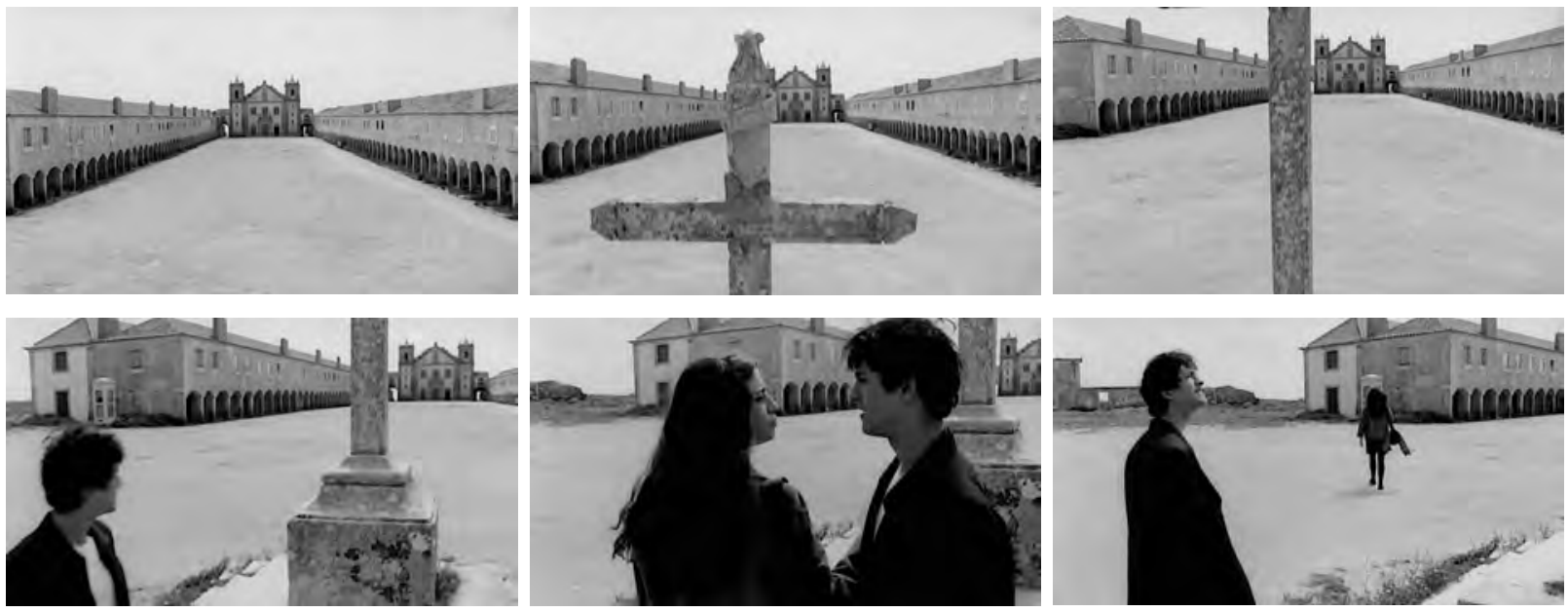

Fig. 122 - Terra Estrangeira (1995), Walter Salles e Daniela Thomas

A incapacidade de fixação dos personagens, reforçada pelo movimento constante dos atores e da câmera, suspende-se momentaneamente na imagem síntese do navio encalhado. A cena acontece em um raro momento de felicidade do casal. Paco observa a embarcação e a compara a "uma baleia que veio morrer na praia". Apesar dos personagens estarem em um momento cheio de esperança, a imagem do navio prenuncia o fracasso da tentativa de mudarem de vida.

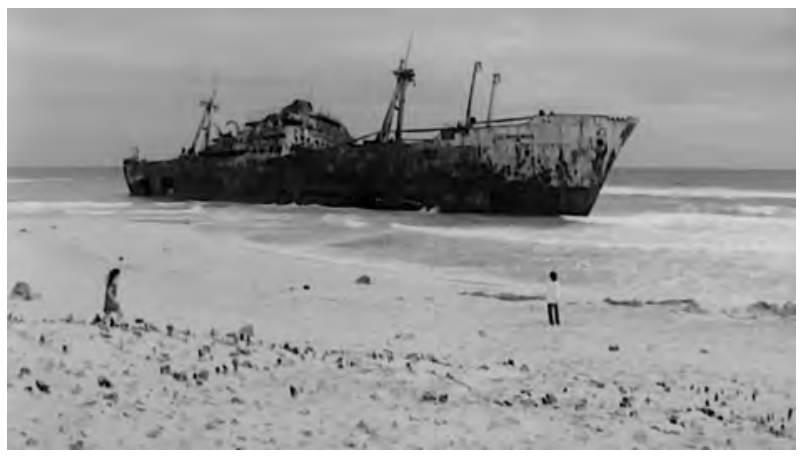

Fig. 123 - Terra Estrangeira (1995), Walter Salles e Daniela Thomas

No momento em que saem de Lisboa, o filme começa a explorar espaços amplos e lentes mais abertas, e os personagens começam gradativamente a se fundir com a paisagem.
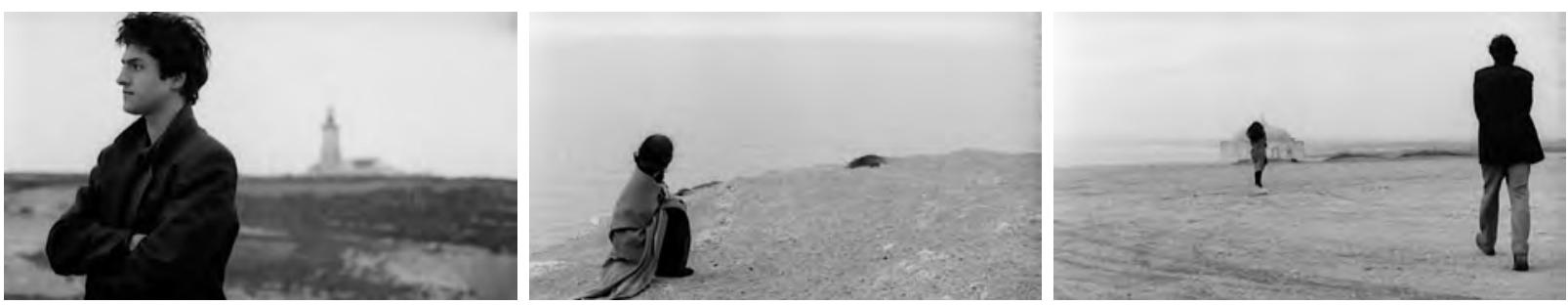

Fig. 124 - Terra Estrangeira (1995), Walter Salles e Daniela Thomas

A ampliação do espaço relaciona-se com a narrativa, com a possibilidade de fuga que 
experimentam os personagens, contrastando com os planos fechados dos dois primeiros terços do filme, em que muitas vezes os rostos dos personagens são encobertos ou divididos por elementos do cenário.
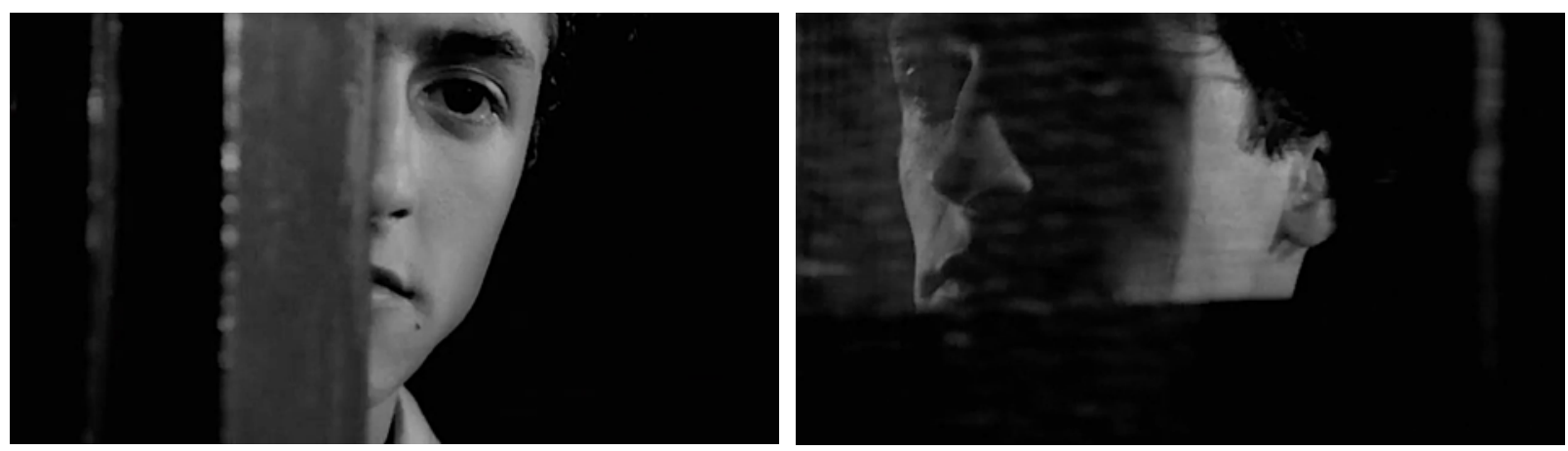

Fig. 125 - Terra Estrangeira (1995), Walter Salles e Daniela Thomas

Após a primeira noite em que Alex e Paco dormem juntos, há um plano que funciona como uma transição entre os espaços fechados e abertos. Inicialmente é enquadrada apenas a pintura de um homem atrás das grades. Paco então irrompe do interior e vai à procura de Alex.

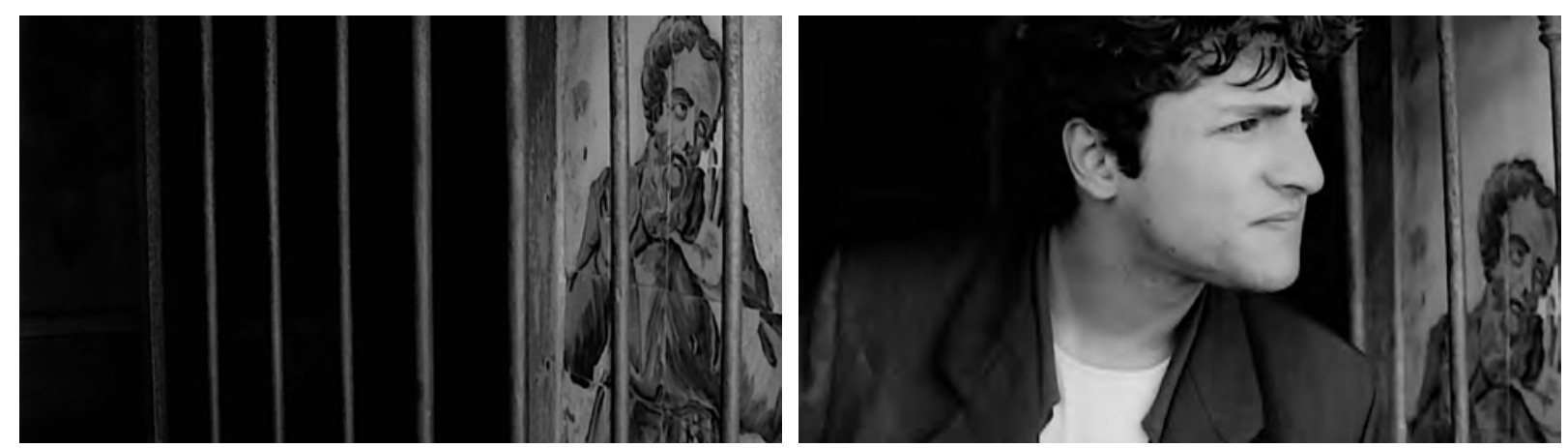

Fig. 126 - Terra Estrangeira (1995), Walter Salles e Daniela Thomas

Os grandes planos gerais vão se tornando cada vez mais frequentes, culminando em um plano aéreo do carro em alta velocidade rumo a San Sebastian, em que Paco e Alex não são mais identificáveis. Essa dispersão visual sintetiza a dispersão dos personagens, que ao longo do filme vão em busca de uma vida melhor em terras estrangeiras. 

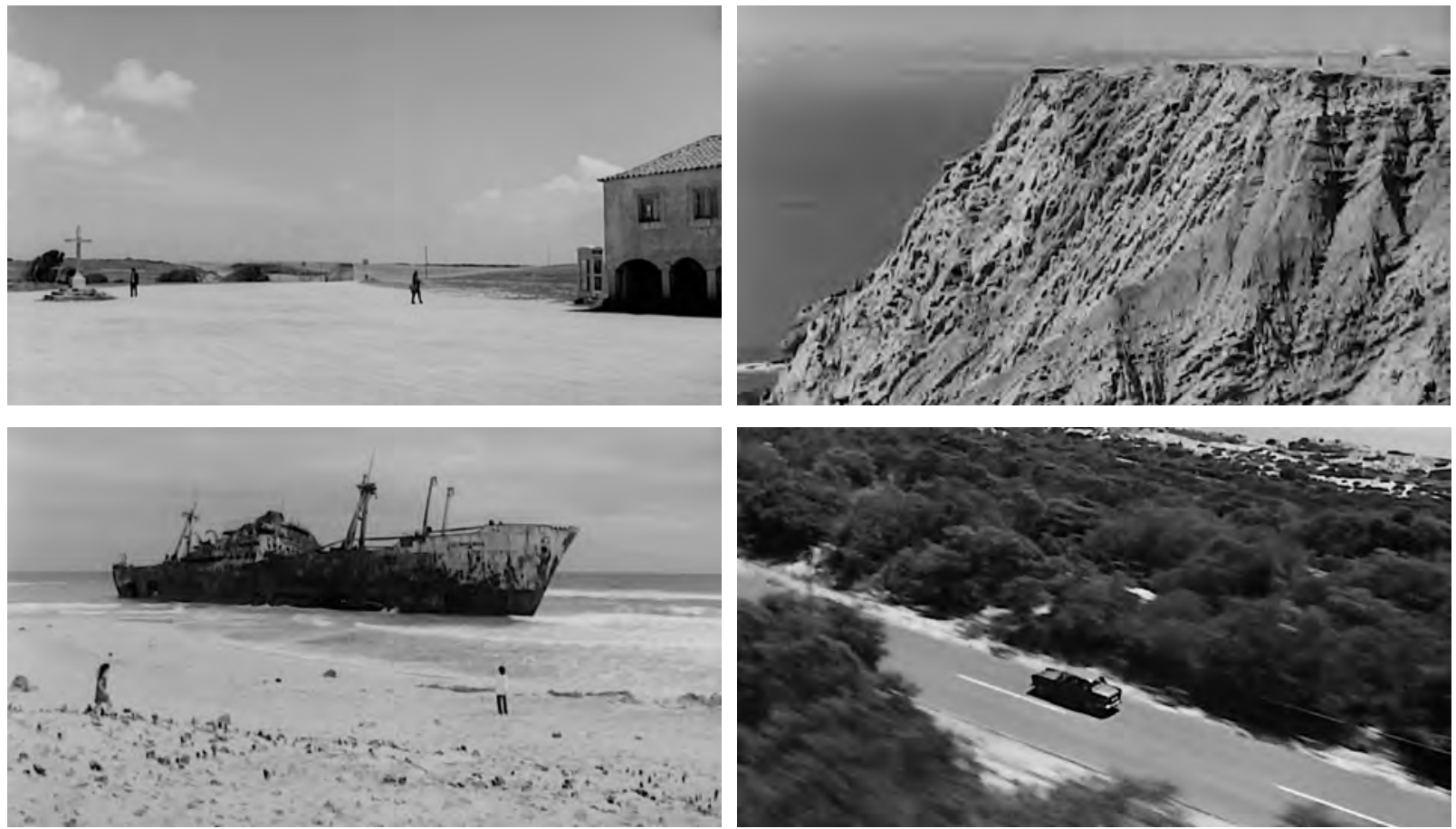

Fig. 127 - Terra Estrangeira (1995), Walter Salles e Daniela Thomas

Pode-se dizer que as semelhanças entre Terra Estrangeira e o cinema de Sergei Eisenstein extrapolam os limites do filme. A parceria que se estabelece entre Walter Carvalho e Walter Salles lembra a colaboração entre o diretor soviético e Eduard Tissé, fotógrafo da maioria de seus filmes.

Eisenstein conheceu Tissé no início dos anos 1920 e o convidou para fotografar $A$ Greve, seu primeiro longa-metragem. No momento em que iniciaram o longa, Eisenstein era um diretor estreante mas Tissé já trabalhava como diretor de fotografia desde 1914, possuindo uma ampla experiência como documentarista. Entre 1916 e 1918 filmou o front da Primeira Guera Mundial e posteriormente, entre 1918 e 1921, filmou 200 rolos sobre a revolução bolchevique para o Comitê Central de Filmes, organização estatal que gerenciou a produção cinematográfica nos primórdios da União Soviética. Do mesmo modo, Walter Salles era um diretor estreante ao encontrar Walter Carvalho, que ao filmar Terra Estrangeira já possuía uma sólida formação como fotógrafo.

No livro Reflexões de um Cineasta, Eisenstein dedica um capítulo à colaboração com seu diretor de fotografia.

Duvido que jamais tenha existido sincronização comparável àquela que me coloca em equivalência com Tissé no que se refere a ver, perceber e experimentar... Procuramos por todo lado sempre a mesma coisa. Nem o efeito de surpresa, nem o efeito decorativo, nem a estranheza do ângulo de tomada de cenas, mas somente o máximo de expressividade. E sempre a universalidade da imagem por trás do fenômeno filmado. Passo a passo, de mãos dadas, nós procuramos nosso método durante esses 
quinze anos na diversidade do real que desfilava diante de nossos olhos e em nossa reflexão meditativa e apaixonante da realidade; e o sucesso coroou as tendências e os elementos plásticos de nossos filmes onde conseguimos atingi-los (EISENSTEIN, 1969, p.189).

Walter Carvalho descreve seu encontro com Walter Salles como uma descoberta mútua, e afirma que suas bagagens se completaram. No caso da parceria Eiseinstein-Tissé, em que quase nenhuma documentação escrita chegou até nossos dias, é muito difícil precisar a contribuição de cada um para o resultado final das imagens. Já no caso de Walter CarvalhoWalter Salles, além dos depoimentos de ambos, a sequência de análises apontará elementos que o diretor de fotografia traz para os filmes. 


\subsection{Central do Brasil (1998), Walter Salles}

Central do Brasil é um filme sobre encontros e desencontros. O encontro central é entre Dora (Fernanda Montenegro) - uma professora aposentada, que trabalha na estação de trem Central do Brasil escrevendo cartas para pessoas que não sabem ler nem escrever - e Josué (Vinícius de Oliveira), um menino de nove anos que sonha encontrar seu pai. Após a morte da mãe de Josué, Dora e o menino iniciam uma jornada em busca do pai. A relação de Dora e Josué é inicialmente difícil, contudo, em meio aos percalços da viagem, nasce entre eles um sentimento de ternura e solidariedade.

Nesse segundo filme de ficção em parceria com Walter Salles, Walter Carvalho imprime uma visualidade distinta do filme anterior. Em Terra Estrangeira a construção da imagem observa certos preceitos eisensteinianos, a fotografia de Central do Brasil pauta-se na exploração de princípios clássicos de representação, a partir de uma narrativa contínua e crescente.

Segundo David Bordwell, a narrativa clássica caracteriza-se por apresentar

indivíduos definidos empenhados em resolver um problema evidente ou atingir
objetivos específicos. Nessa sua busca, os personagens entram em conflito com
outros personagens ou com circunstâncias externas. A história finaliza com uma
vitória ou derrota decisivas, a resolução do problema e a clara consecução ou não
consecução dos objetivos (BORDWELL, 2005, pp. 278 e 279).

No filme Central do Brasil, é possível verificar a presença dos elementos elencados por Bordwell. Os indivíduos definidos são Dora e Josué, que tentam resolver um problema específico: encontrar o pai do menino. Nessa busca, Dora e Josué entram em conflito entre si, com personagens que cruzam pelo caminho, com a falta de dinheiro e com as mudanças de endereço do pai, que acabam por prolongar a viagem. O problema é resolvido parcialmente, não localizam o pai mas localizam os irmãos de Josué, o que adia a união entre pai e filho mas abre a possibilidade de um encontro futuro.

A linearidade narrativa é outro elemento clássico do filme. Em Sertão Mar: Glauber Rocha e a estética da fome, Ismail Xavier trata da linearidade da decupagem clássica: "Acima de tudo é preciso fazê-las (as personagens) psicologicamente inteligíveis, localizar claramente seus dramas, dentro de uma representação que nos coloca as coisas em ordem e nos dá o conforto de sentir, passo a passo, a posse dos dados essenciais para o entendimento de tudo" (XAVIER, 1983, p. 47). 
Em Central do Brasil, cada momento do filme justifica e dá sentido ao momento anterior, de modo que o espectador consiga fazer uma leitura linear e unidimensional do conflito.

Um ponto importante a observar é o caráter alegórico do filme.

\begin{abstract}
Alegórico desde seu título e em toda a sua parábola de redenção moral, o contraponto a este espírito de vingança contra o mundo se constrói no motivo do encontro inesperado, agora entre uma velha dama indigna e uma figura de inocência. $O$ roteiro se assenta numa polarização entre bem e mal sem a qual a reviravolta final não teria o mesmo efeito. (XAVIER, 2001, p. 93).
\end{abstract}

A alegoria pode ser definida como expressão figurada de um pensamento ou de um sentimento, através da qual um objeto adquire outro significado. Opera por meio de fragmentos, que se reúnem para criar novos sentidos.

Identifica-se em Central do Brasil um duplo tratamento aos temas do filme, podendo classificá-lo como alegórico mas também realista. A questão da busca pelo pai, por exemplo, é realista no sentido da jornada que Dora e Josué fazem até Bom Jesus do Norte, mas alegórica pois ambos promovem uma jornada interior em busca de seus respectivos pais.

Central do Brasil trata de temas abordados pelo Cinema Novo, como a dualidade entre campo e cidade, a violência e o nordeste. O Cinema Novo também se utilizava da alegoria, entretanto, ao optar pelo melodrama como suporte narrativo, Walter Salles toma um caminho distinto das ideias cinemanovistas.

\begin{abstract}
O Cinema Novo conseguiu articular, pela primeira vez, uma "imagem do Brasil": densa, alegórica e estimuladora do pensamento sobre os problemas e as oscilações históricas - foi sua contribuição mais consistente e duradoura. Víamos pela primeira vez a nossa fisionomia diversa e a miséria crônica. Depois das experiências críticas de Glauber Rocha, Ruy Guerra, Nelson Pereira, tornou-se difícil "esconder" o Brasil. Essas imagens denotavam um estado de coisas que até então somente a literatura e a música tinham formulado mediante "imagens" (NOGUEIRA, 2013, p. 156).
\end{abstract}

Segundo Lisandro Nogueira, os diretores do Cinema Novo viam no melodrama um gênero que apazigua conflitos, constituindo um obstáculo para o aprofundamento das questões apresentadas nos filmes. É o que acontece em Central do Brasil, uma vez que temas como a religiosidade e a pobreza aparecem nas imagens como pano de fundo, sem que sejam verdadeiramente examinados.

A religiosidade aparece nos nomes de Josué, Jesus, Moisés e Isaías. Em César, caminhoneiro evangélico vivido por Othon Bastos (1933- ), ator de filmes importantes do Cinema Novo, tais como Deus e o Diabo na Terra do Sol (1964) e O Dragão da Maldade 
contra o Santo Guerreiro (1969), ambos dirigidos por Glauber Rocha (1939-1981). Aparece nas frases do caminhão de César, nos romeiros que Dora e Josué cruzam pelo caminho, nas igrejas, na procissão e na Casa dos Milagres de Bom Jesus do Norte.
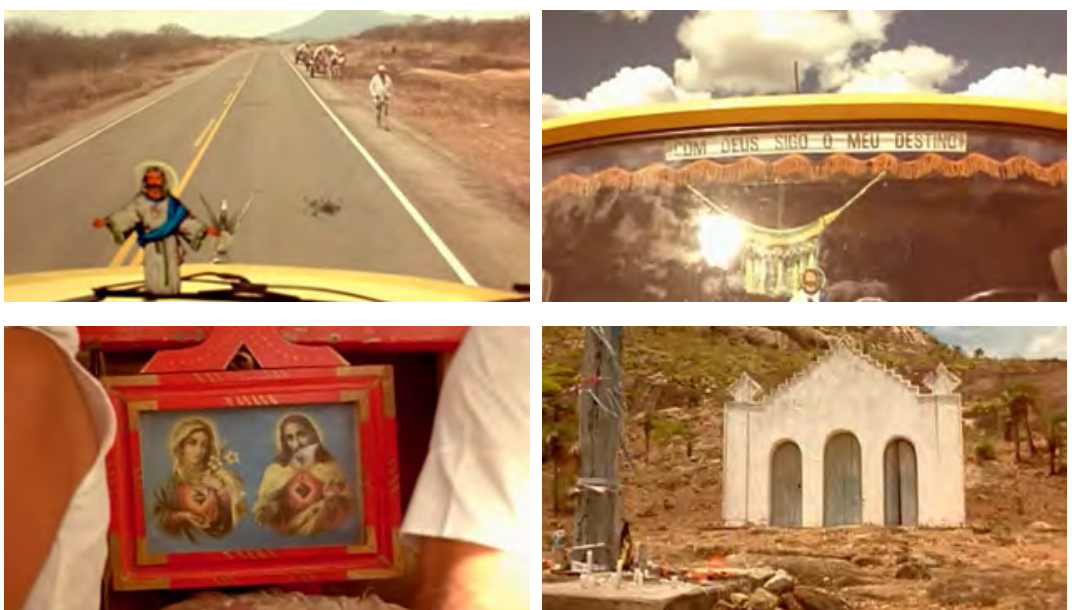

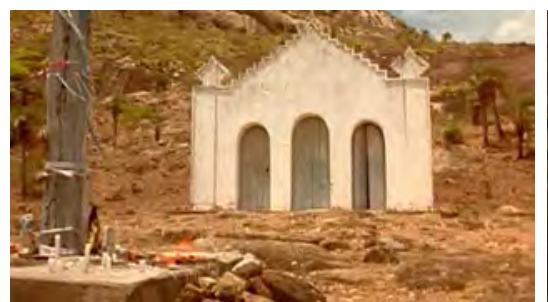

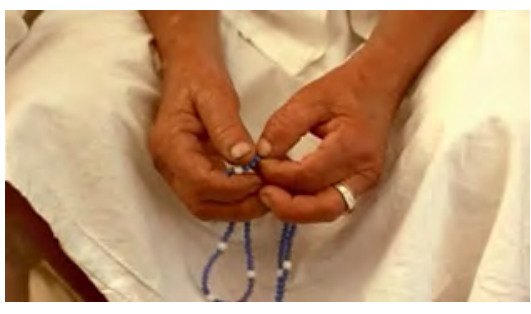

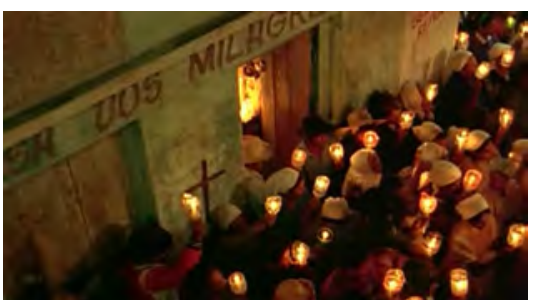

Fig. 128 - Central do Brasil (1998), Walter Salles

A pobreza está por toda parte, nos passageiros da Central do Brasil, na vida de Dora no Rio de Janeiro, mas principalmente na paisagem e nos rostos sofridos dos homens e mulheres do sertão. Entretanto, religião e pobreza são dados, não são questões discutidas pelo filme.
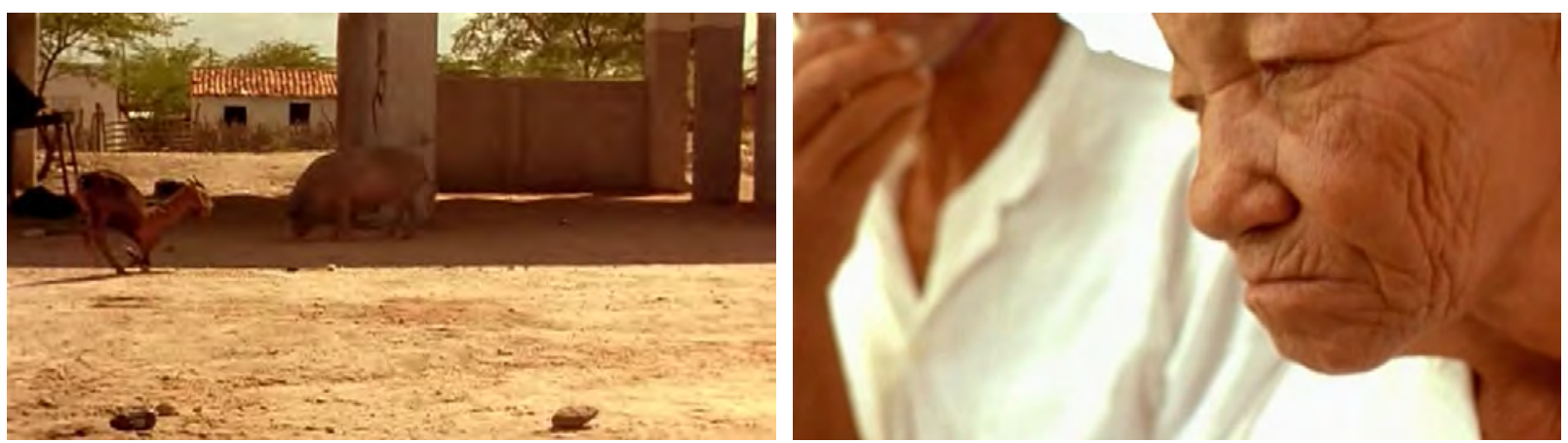

Fig. 129 - Central do Brasil (1998), Walter Salles

Antes de iniciar as filmagens, Walter Salles distribuiu um texto à equipe e ao elenco indicando quais seriam suas intenções com o filme, e descrevendo o que pretendia de cada um deles: "É necessário que, a partir de agora, estejamos todos olhando para a mesma direção".

As referências e opções narrativas de Walter Salles são respeitadas por Walter Carvalho na elaboração das imagens, mas como veremos a seguir, a contribuição do diretor de fotografia evidencia-se na forma como as imagens são criadas para construir o drama. 
Central do Brasil divide-se em duas partes distintas: o Rio de Janeiro e a estrada. Cada um desses espaços recebe um tipo de tratamento. No início do filme há predominância de planos internos, médios e fechados, que transmitem sensação de claustrofobia.

Em $O$ discurso cinematográfico: opacidade e transparência, Ismail Xavier explica que no desenvolvimento da linguagem cinematográfica "o uso do primeiro plano deu-se em função de uma necessidade denotativa - dar uma informação indispensável para o andamento da narrativa (XAVIER, p.23, 1984a)". Outra função do primeiro plano é apontada por Pedro Plaza Pinto no artigo Central do Brasil: enquadramento, montagem e narrativa: a de ser psicologia de personagens.

Os planos fechados de Central do Brasil revelam sua dupla função clássica: são utilizados para desenvolver a narrativa, bem como para captar ações e reações, de modo a pontuar visualmente o caráter dos personagens. Nesse sentido, uma das atribuições do diretor de fotografia acaba sendo primordial: a escolha das lentes. Enquanto Dora e Josué estão no Rio de Janeiro, os close-ups são filmados com teleobjetivas, que conferem grande magnitude aos personagens fotografados. A pequena profundidade de campo isola os personagens do espaço e dirige a atenção para seus dramas pessoais.
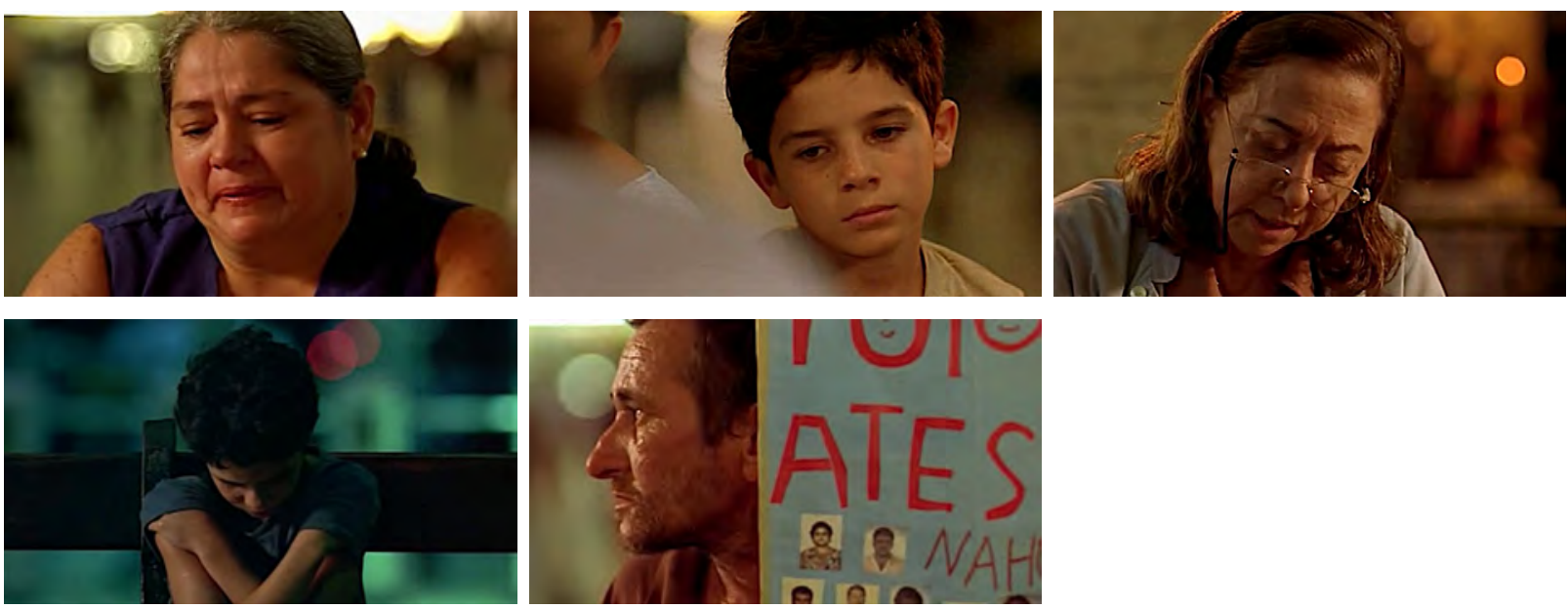

Fig. 130 - Central do Brasil (1998), Walter Salles

O plano geral da estação serve de contraponto, diluindo no espaço os dramas apresentados e tornando anônimas as pessoas que anteriormente ditaram suas cartas. 


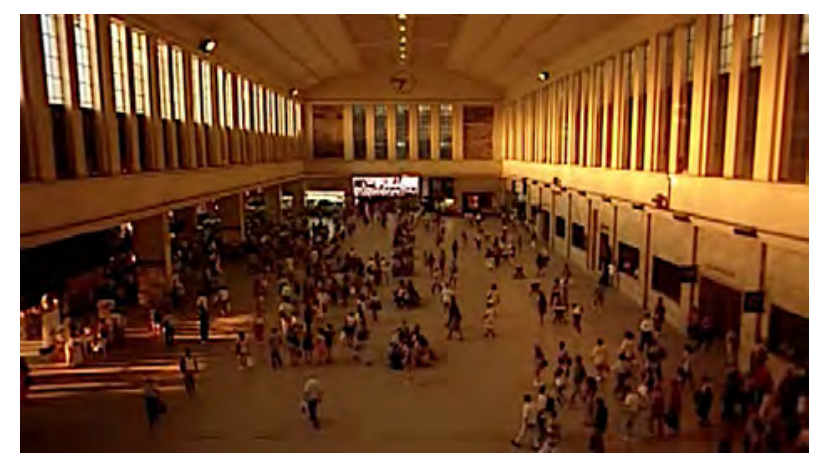

Fig. 131 - Central do Brasil (1998), Walter Salles

Além dos planos fechados de reações, são característicos da decupagem clássica os two-shots (planos médios de dois personagens), a centralização, a simetria e os over-theshoulders, planos com referência dos personagens no campo/contra-campo, como mostram os fotogramas da figura 132.
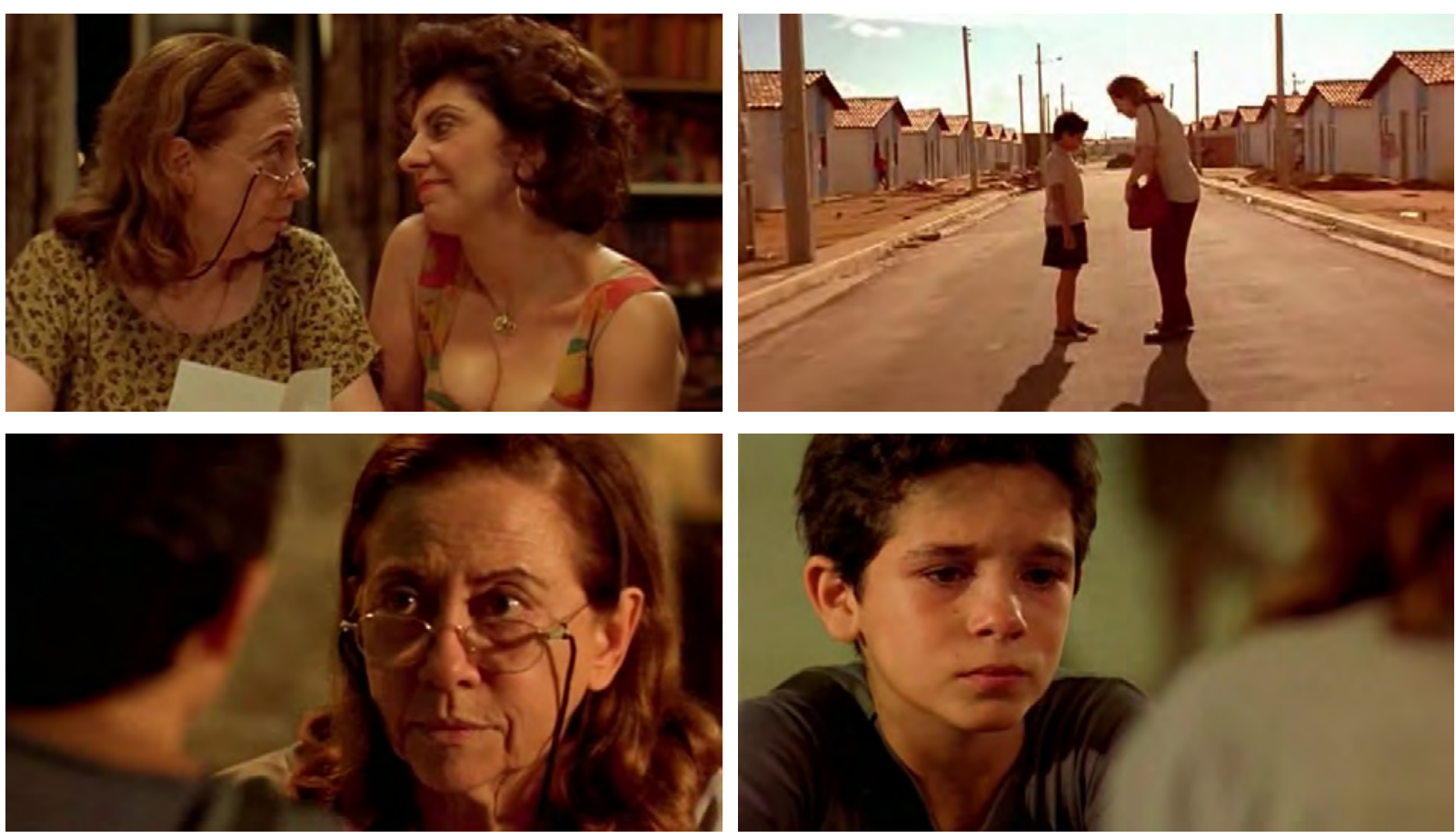

Fig. 132 - Central do Brasil (1998), Walter Salles

A presença de detalhes reforça o caráter melodramático da narrativa, é o caso das mãos dadas de Josué com a mãe e da metáfora do pião, objeto afetivo para o menino. Josué conta com muito orgulho que seu pai é carpinteiro, que faz casas, móveis e piões. É por causa da perda do pião que sua mãe acaba sendo atropelada. 

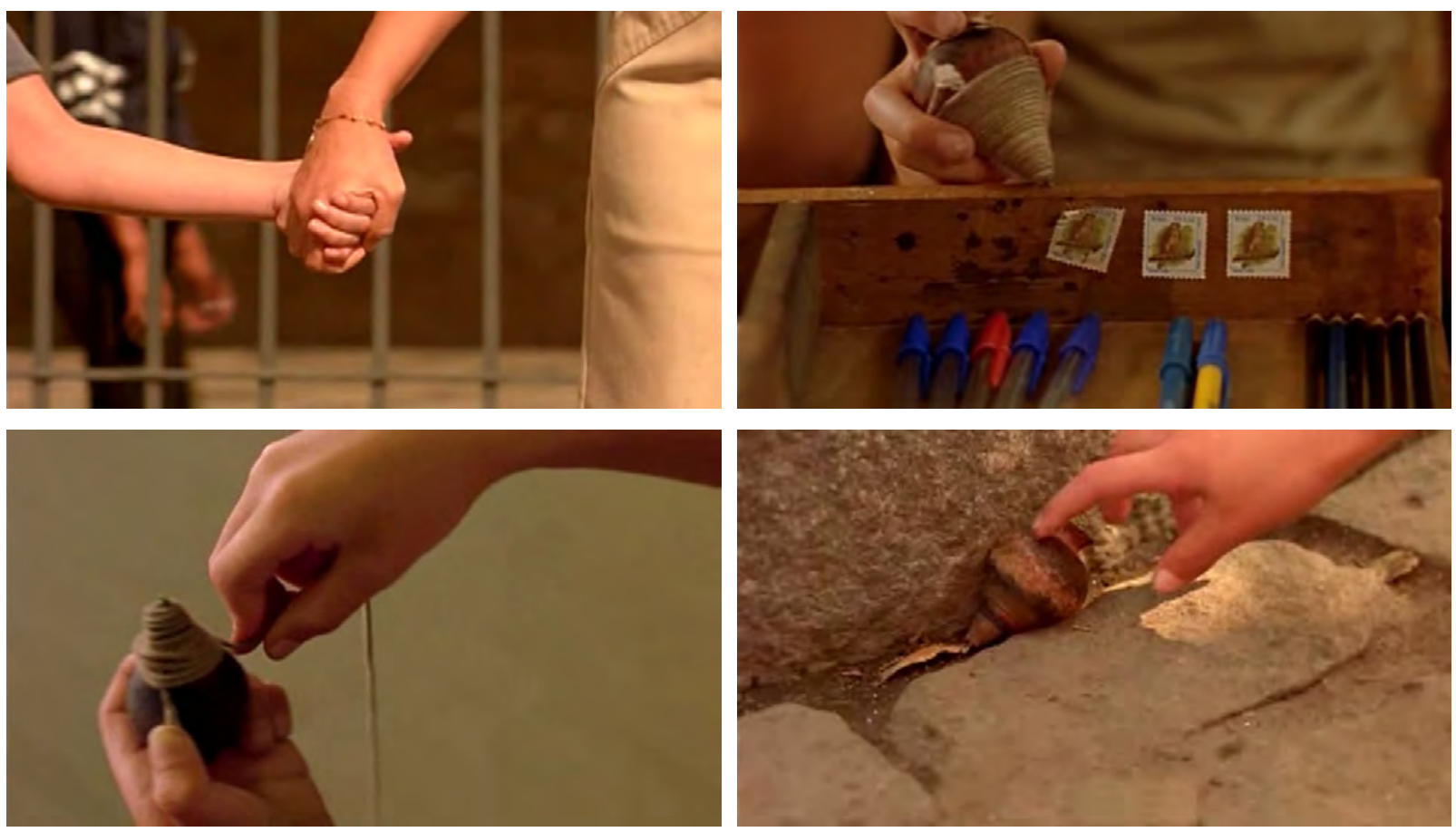

Fig. 133 - Central do Brasil (1998), Walter Salles

O lenço também é uma imagem metafórica e exerce papel importante na narrativa. Antes de ser atropelada, a mãe esquece o lenço na mesa de Dora. No momento da morte de Ana, Dora recolhe o lenço como se assumisse a maternidade de Josué.
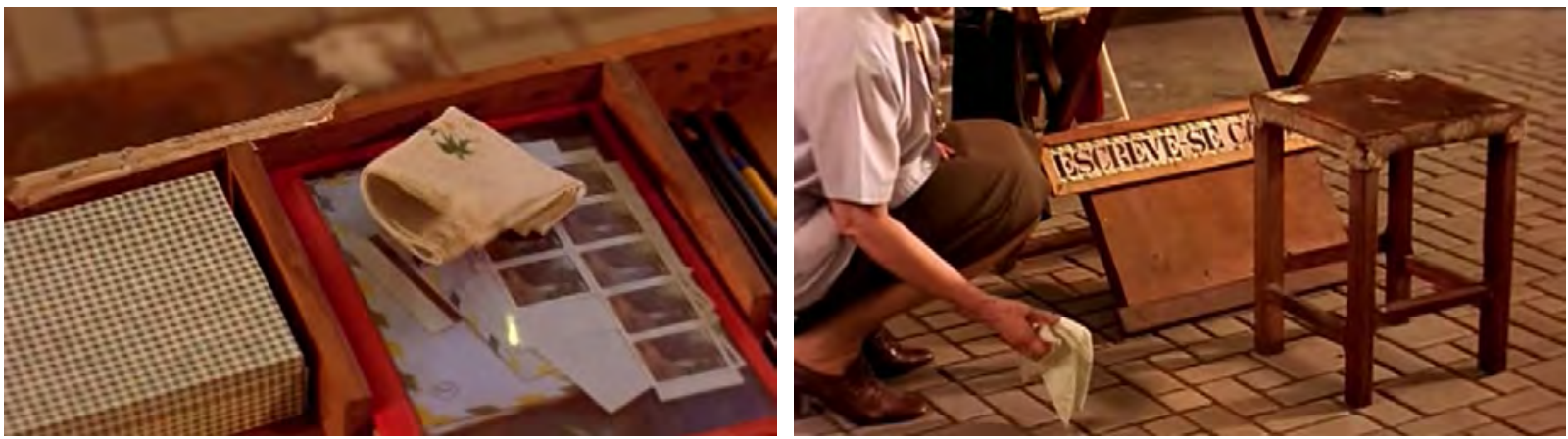

Fig. 134 - Central do Brasil (1998), Walter Salles

A principal distinção entre alegoria e metáfora refere-se à extensão do uso da linguagem simbólica em cada uma dessas figuras de linguagem. A metáfora é usada pontualmente e refere-se a termos isolados. A alegoria se dá na totalidade da narrativa, constituindo-se pela interligação de várias metáforas.

As metáforas do lenço (mãe) e do pião (pai), são encerradas na segunda parte do filme. A primeira quando Josué diz: "minha mãe sempre me dizia que meu pai ia me mostrar o sertão. Onde será que ela está agora? Você acha que fizeram um enterro direito pra ela?”. Então Dora entrega o lenço ao menino, que o coloca como um ex-voto em frente a uma 
igrejinha do sertão. A segunda metáfora se encerra quando o irmão de Josué, Moisés, carpinteiro como o pai, faz um pião para o menino. Nesse momento Josué recupera o pai por intermédio da família, dos irmãos.
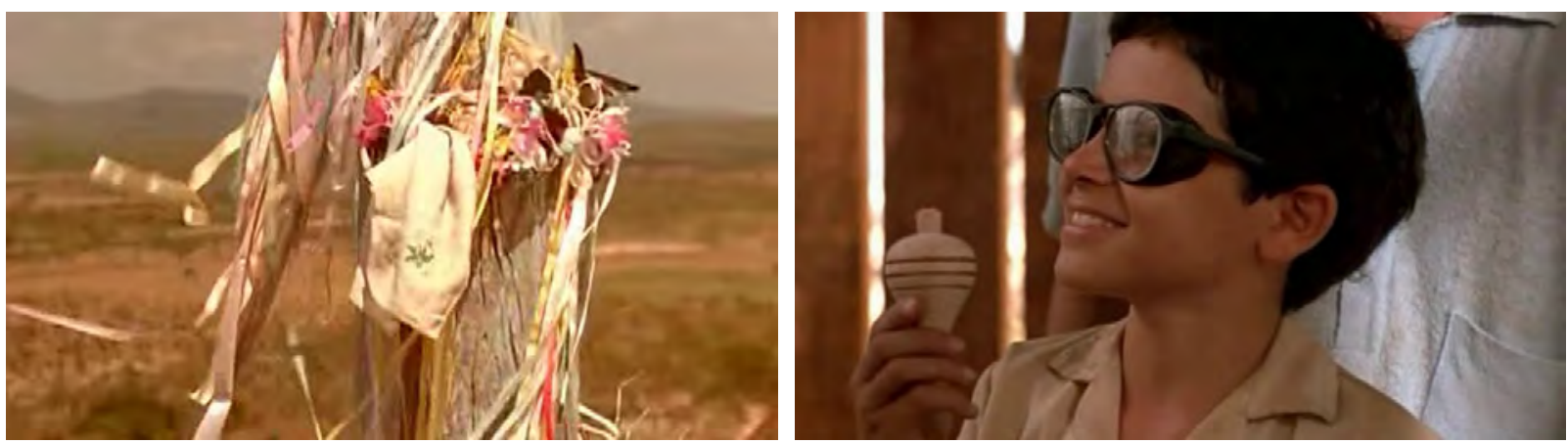

Fig. 135 - Central do Brasil (1998), Walter Salles

Há ainda a metáfora do lar, presente na pintura do prato que decora a casa de Dora. É um lar idealizado, uma casinha simples em uma paisagem rural. Josué encontra o lar real diferente do que imaginava: uma casa em um conjunto habitacional e sem a presença do pai, mas com o afeto presente na figura dos irmãos e a esperança de que o pai um dia retorne.
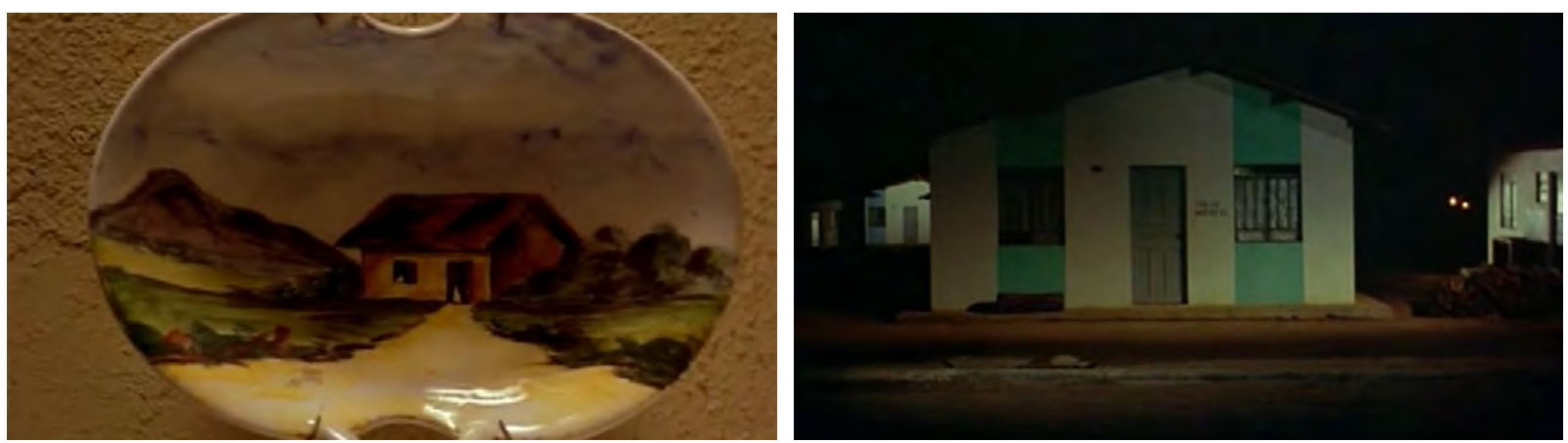

Fig. 136 - Central do Brasil (1998), Walter Salles

Na primeira parte do filme, os planos externos evitam enquadrar o céu e o horizonte, e as linhas e o fluxo de pessoas representam visualmente o caos urbano.
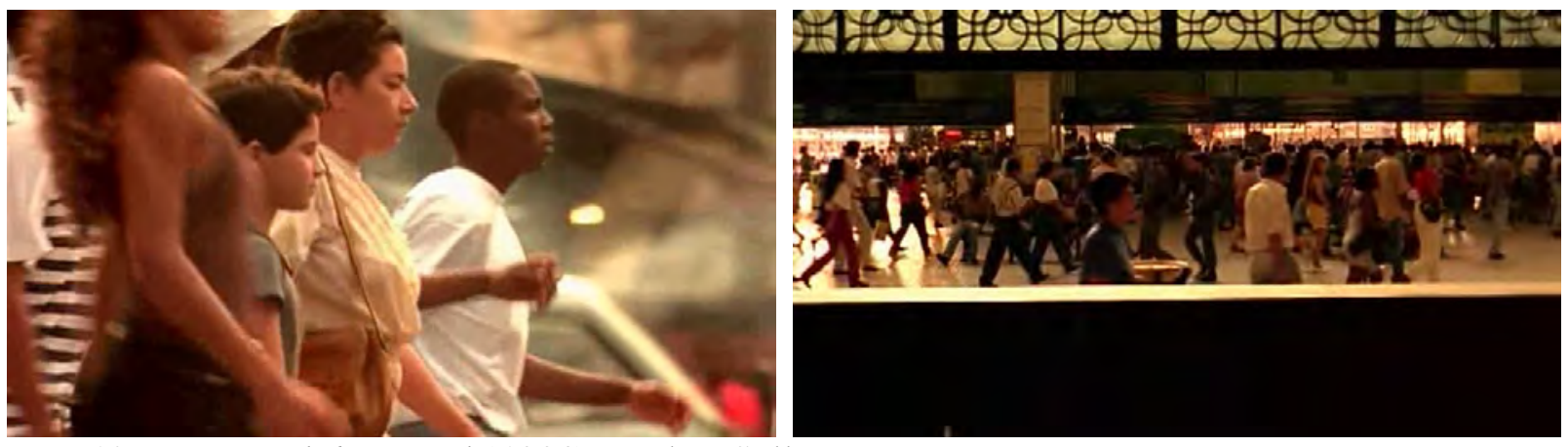

Fig. 137 - Central do Brasil (1998), Walter Salles 
A composição com uso de linhas confere um tratamento gráfico à imagem. As retas predominam e a verticalidade dos elementos do cenário estão muito presentes. O plano inicial, imagem da plataforma filmada com uma teleobjetiva, traz a verticalidade, que se repete no plano dos passageiros vistos pela grade de uma janela, no plano geral do saguão da estação e na chegada de Dora ao prédio onde mora.
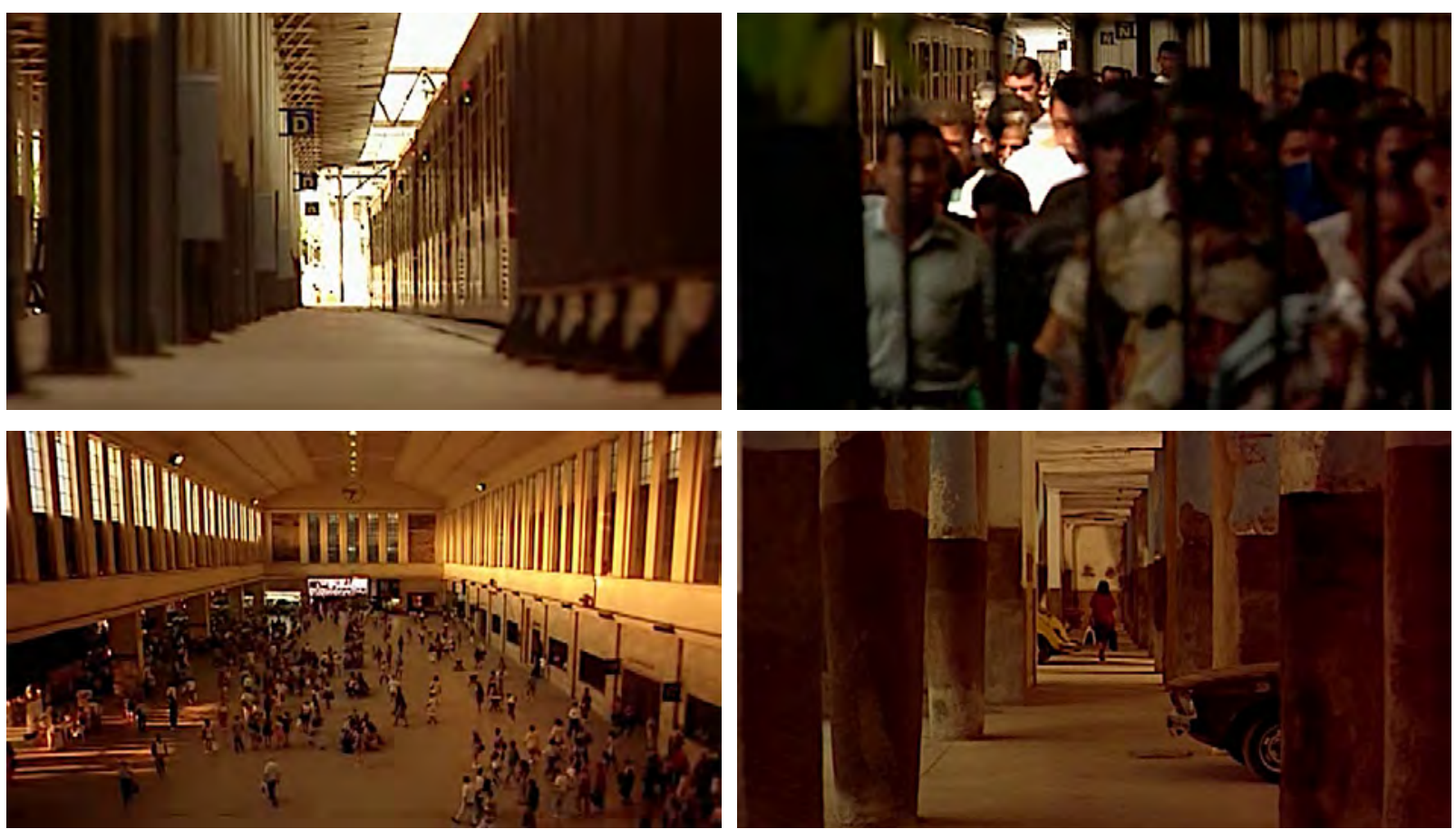

Fig. 138 - Central do Brasil (1998), Walter Salles

As curvas também são exploradas, ainda que em menor grau, como no fotograma em que Josué contempla os trilhos e no que aparece na janela do trem.
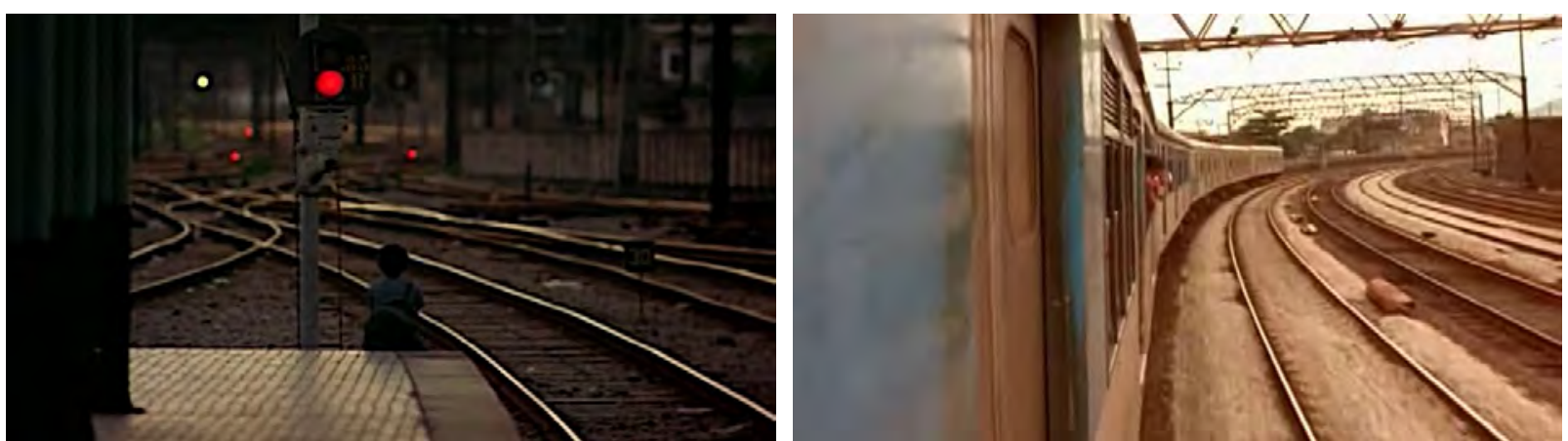

Fig. 139 - Central do Brasil (1998), Walter Salles

Uma novidade em relação ao filme Terra Estrangeira é que além das linhas concretas do cenário, Walter Carvalho explora a projeção de sombras como elementos gráficos, o que se vê nos fotogramas da figura 140 . 


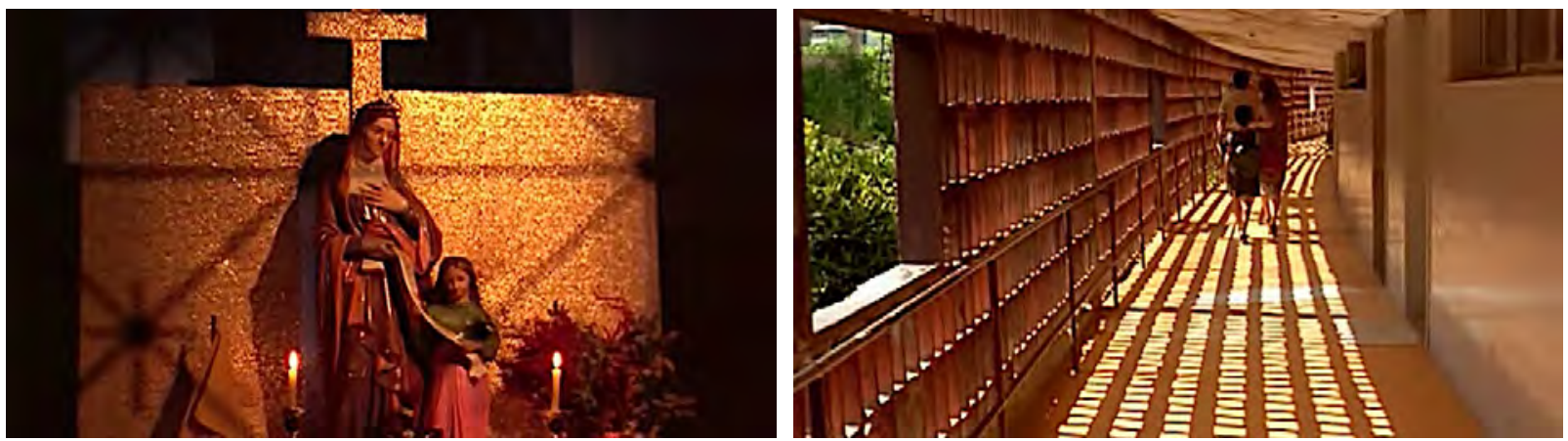

Fig. 140 - Central do Brasil (1998), Walter Salles

Por outro lado, intensifica-se a tomada do personagem intermediada por algum elemento do cenário, procedimento já empregado em Terra Estrangeira.
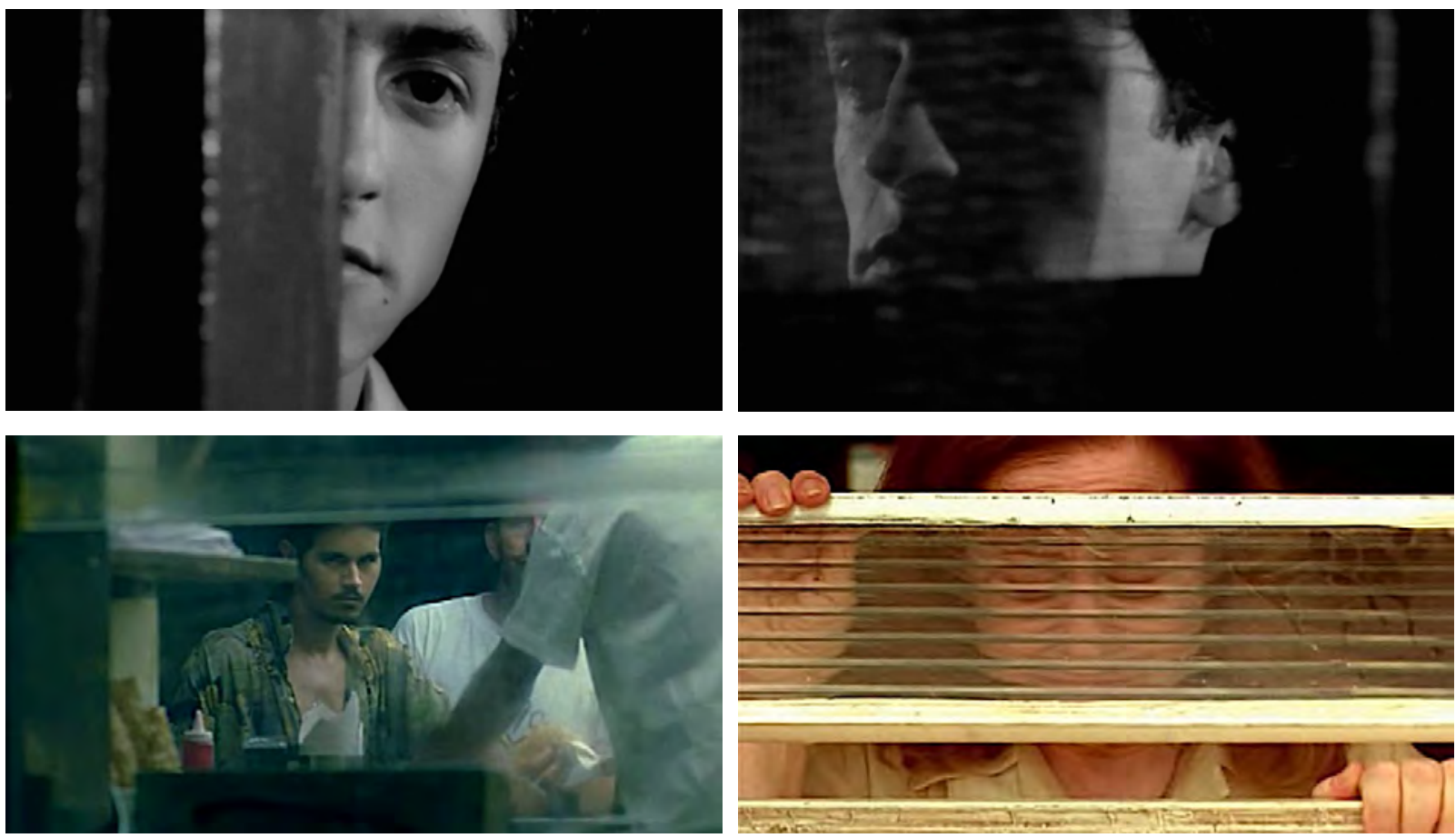

Fig. 141 - Terra Estrangeira (cima) e Central do Brasil (baixo)

Assim como a tripartição do quadro.
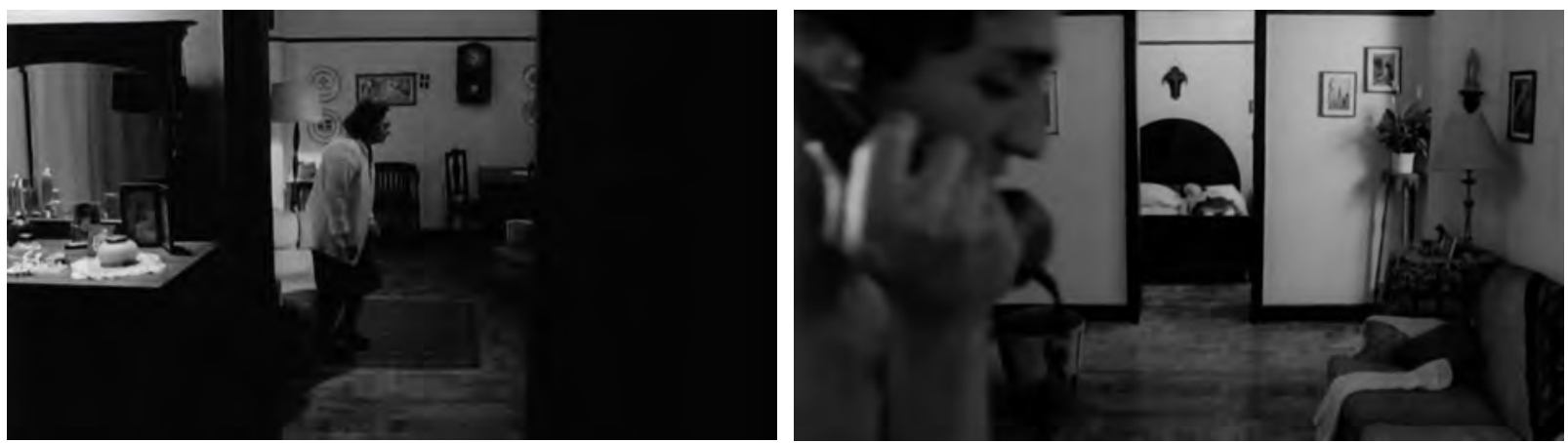


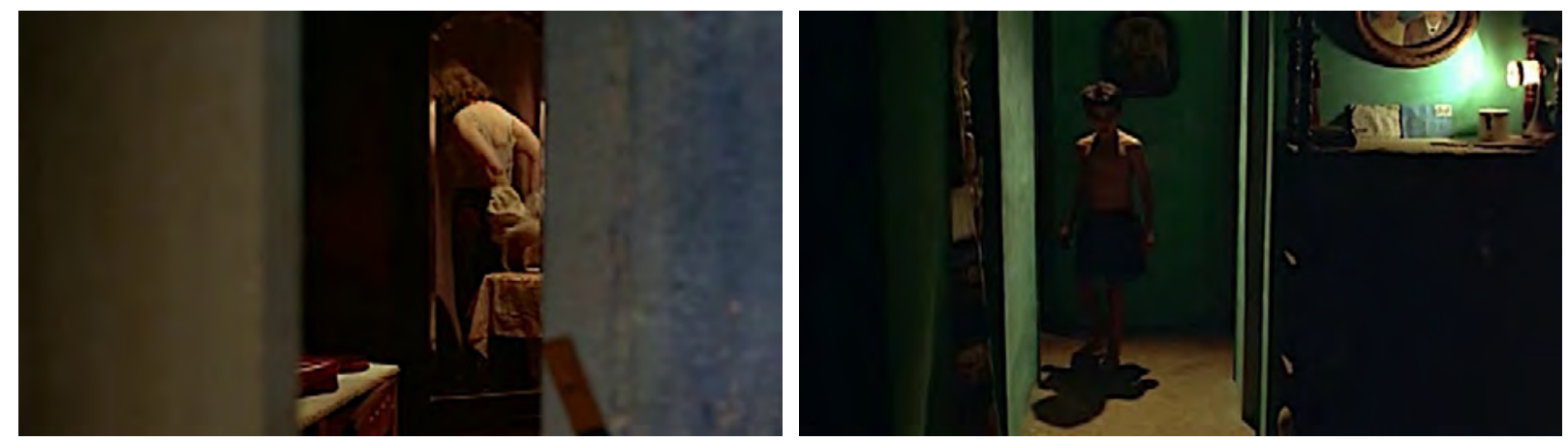

Fig. 142 - Terra Estrangeira (cima) e Central do Brasil (baixo)

Esse tipo de enquadramento, associado à iluminação do fundo, aumenta a profundidade do plano e equipara-se a Terra Estrangeira.
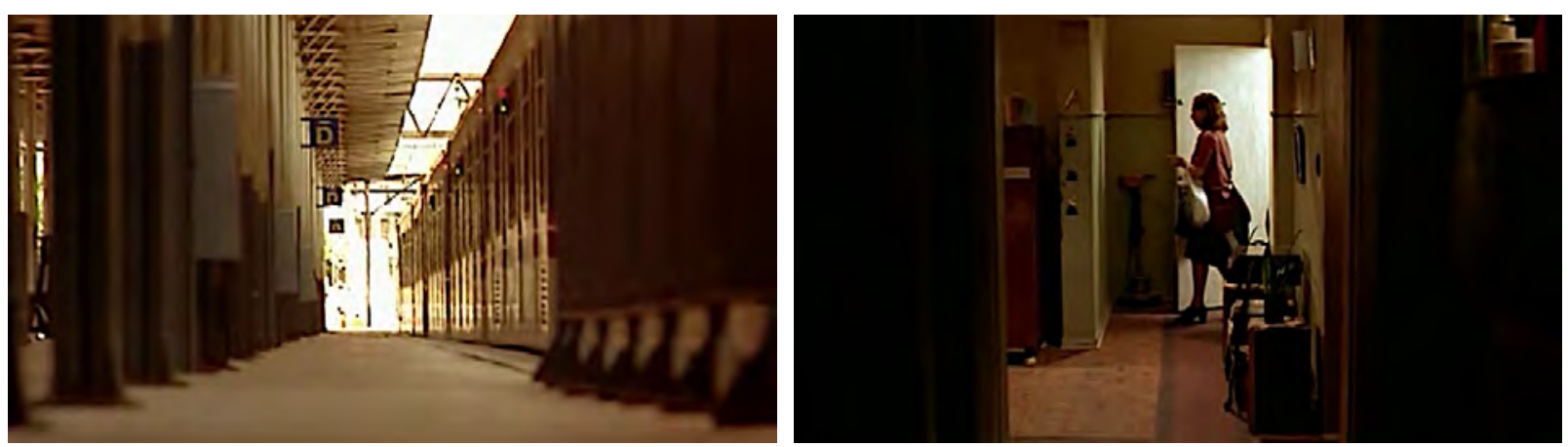

Fig. 143 - Central do Brasil (1998), Walter Salles

O quadro dentro do quadro é explorado como moldura e elemento de profundidade.

Neste caso, também são utilizados elementos não retangulares das próprias locações, como nos fotogramas da figura 144.

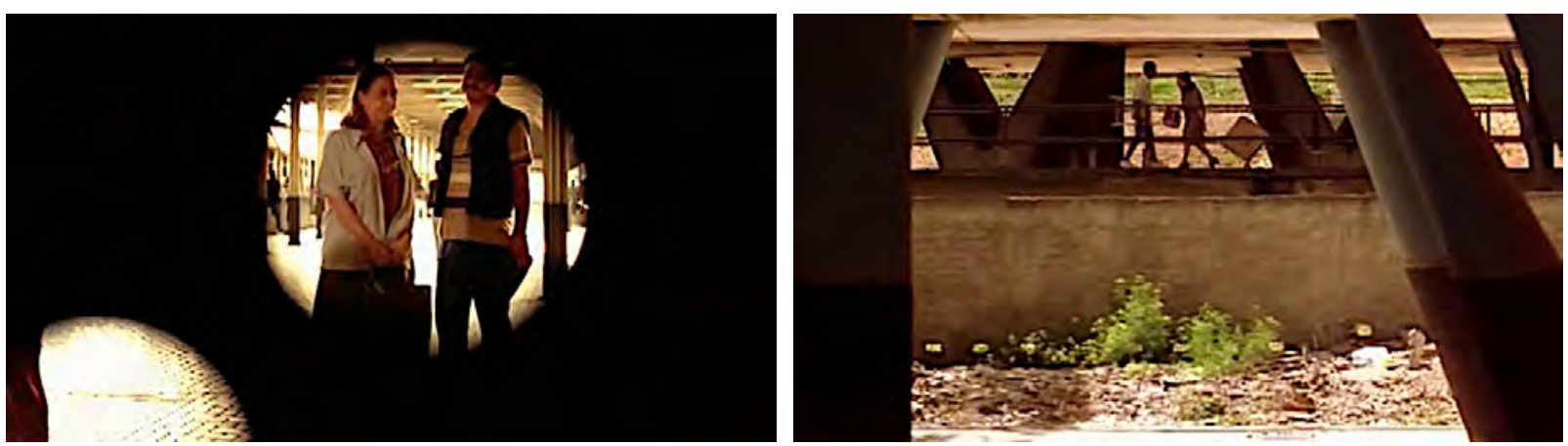

Fig. 144 - Central do Brasil (1998), Walter Salles

Os quadrados e retângulos são explorados nas janelas do apartamento, do conjunto habitacional, do trem, e funcionam como moldura da paisagem. 

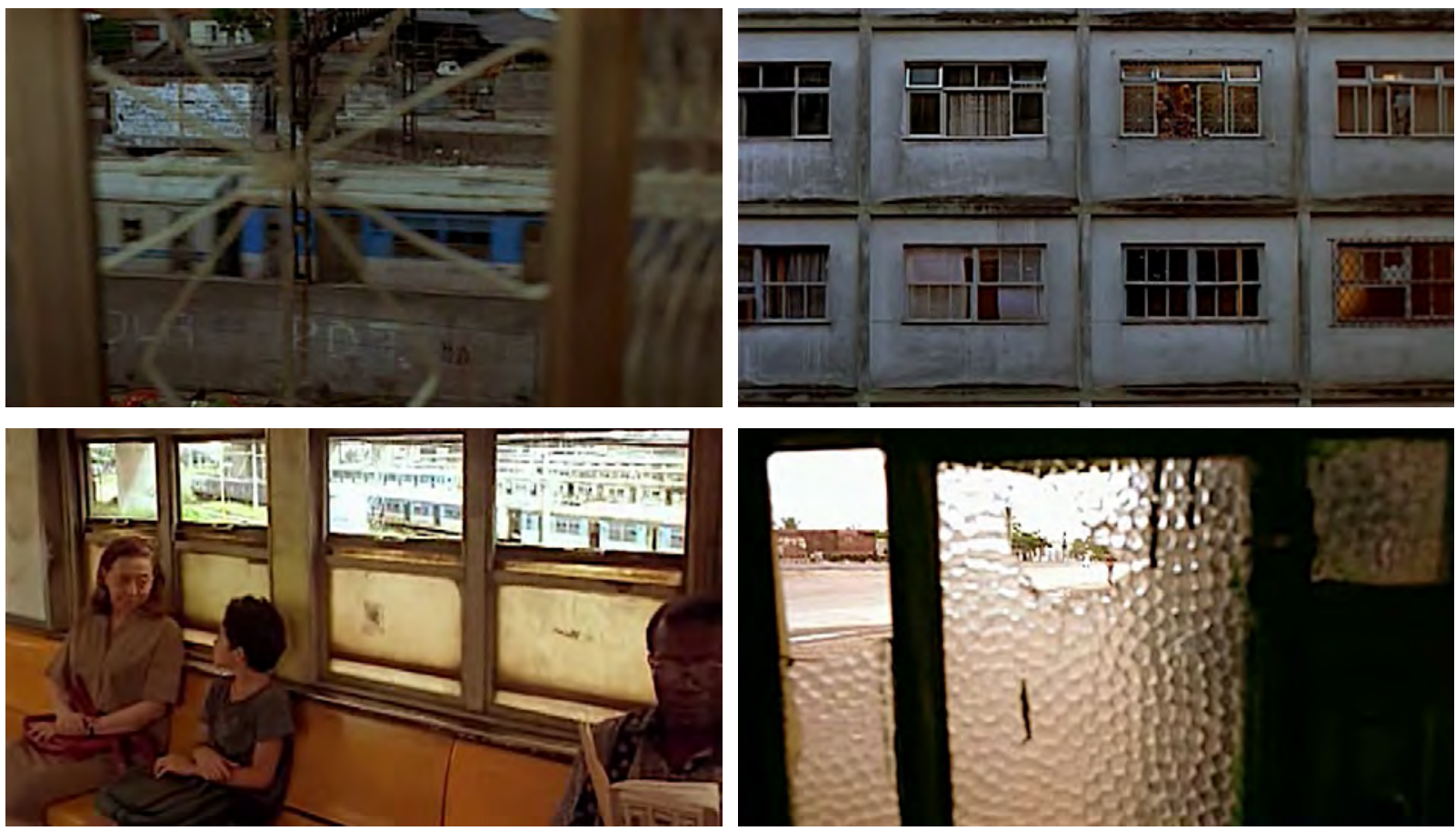

Fig. 145 - Central do Brasil (1998), Walter Salles

Entretanto, portas e janelas não são utilizadas apenas como molduras, mas também como solução dramática para marcar oposição ou integração entre espaços internos e externos.

No fotograma da esquerda (figura 146), são visíveis o espaço interno do trem e a plataforma da estação. Desse modo, a relação de olhar entre Dora e Josué, ou seja, a interação dos personagens, se dá por intermédio da janela. Já no fotograma da direita, que marca a chegada à casa de Jessé, apenas o interior é visível, o exterior resume-se à alta luz do sertão. Neste caso, os dois ambientes não se integram, a janela delimita o que é interno e o que é externo e promove a oposição entre o que pertence à família e o que é próprio do mundo.
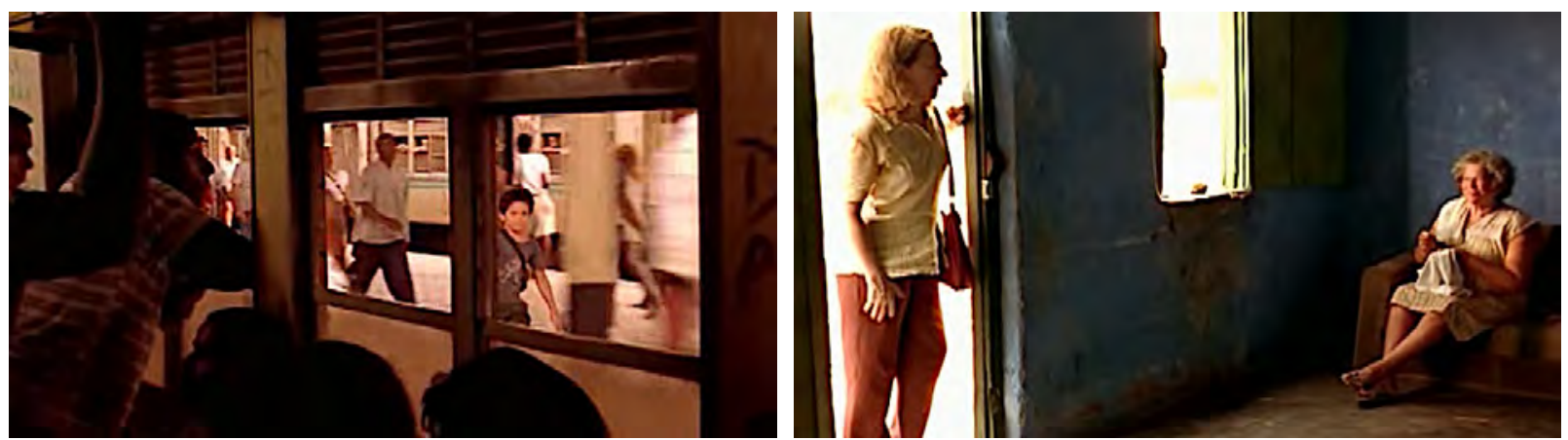

Fig. 146 - Central do Brasil (1998), Walter Salles 
À medida em que Dora e Josué se afastam do Rio de Janeiro, os quadros se ampliam e os planos fechados tornam-se mais pontuais, a imagem ganha horizonte.
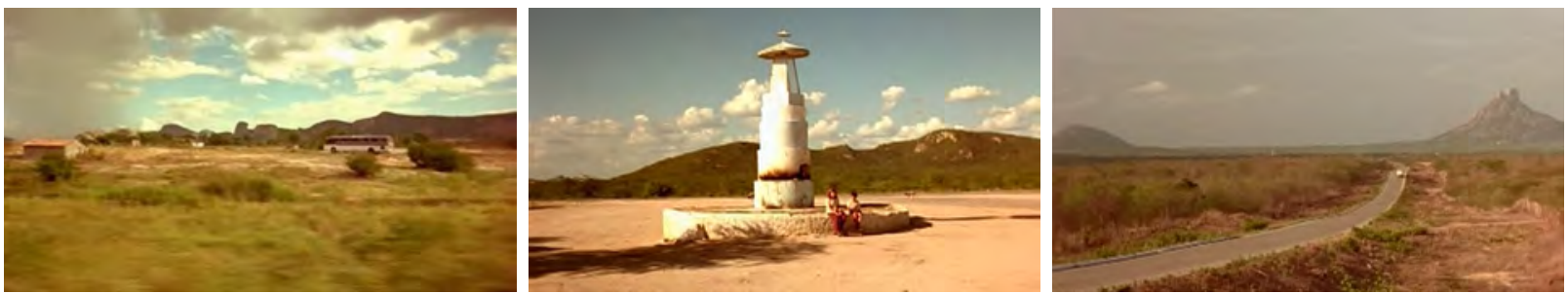

Fig. 147 - Central do Brasil (1998), Walter Salles

Os movimentos de grua tornam-se frequentes, como no plano sequência anterior à chegada a Bom Jesus do Norte. O plano inicia com a câmera na altura do menino e a paisagem do sertão ao fundo. Josué conduz o movimento até encontrar-se com Dora, num enquadramento em contre-plongée da montanha e do céu. A câmera fica fixa por alguns instantes enquanto travam um diálogo sobre a mãe. Finalmente os dois se levantam, descem o morro e a câmera os acompanha até o quadro final do sertão em plongée.
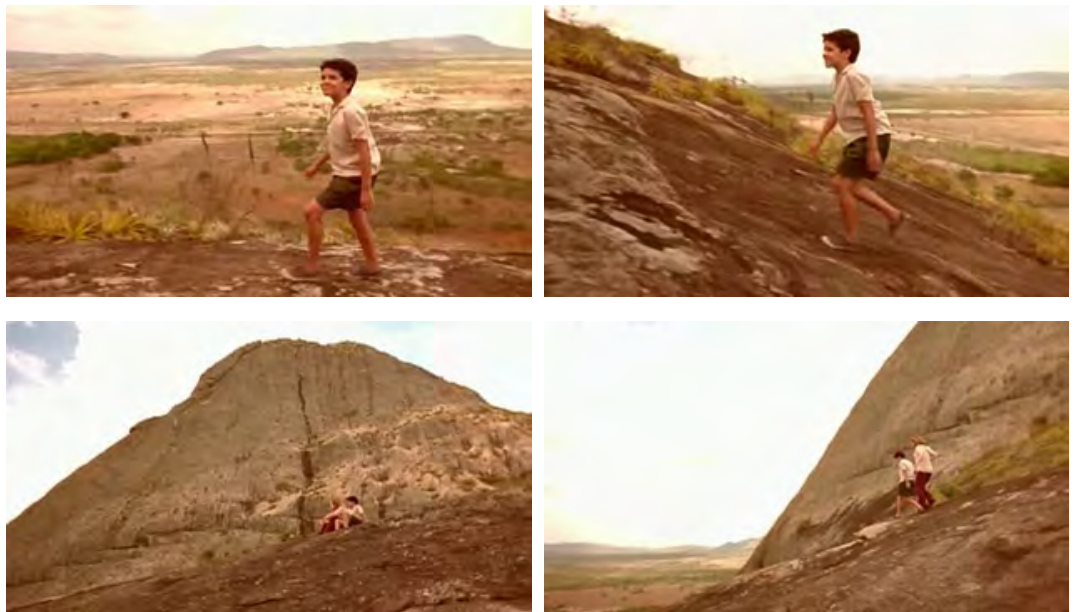

Fig. 148 - Central do Brasil (1998), Walter Salles

O segundo plano de grua acontece quando Dora e Josué chegam ao local em que acreditam ser a casa do pai do menino (figura 149). A câmera inicialmente encontra-se na altura dos personagens, que conduzem o movimento em uma panorâmica horizontal. Param por alguns instantes na porteira. O menino corre em direção à casa e a câmera sobe enquadrando os dois personagens e a casa ao fundo. 

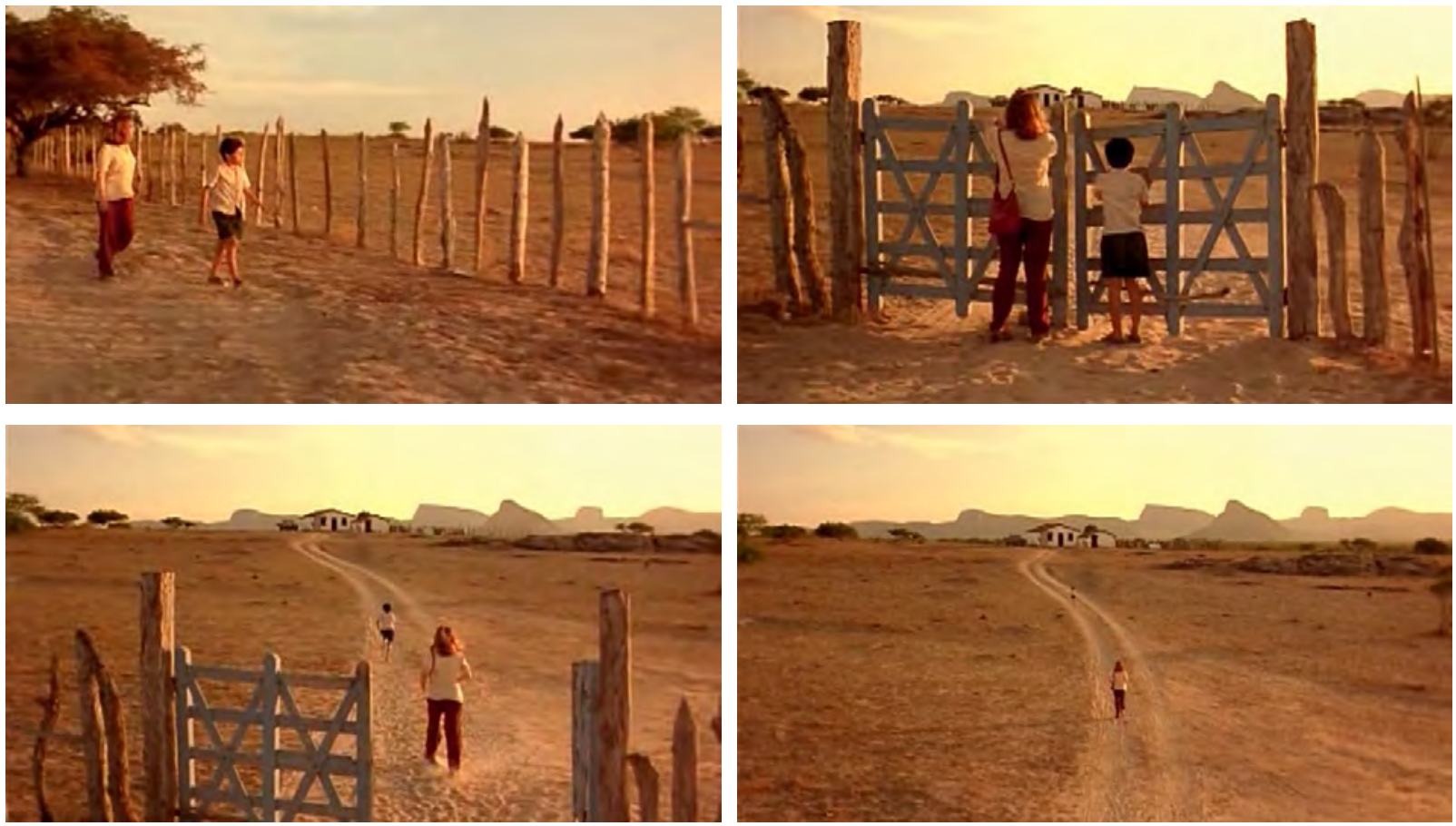

Fig. 149 - Central do Brasil (1998), Walter Salles

Ao final do plano, há uma articulação de montagem entre dois momentos disjuntos: a casinha pintada no prato de louça, vista no apartamento de Dora no início do filme, torna-se real na paisagem do sertão. A imagem cria a expectativa de resolução do conflito do filme, que acaba por se frustrar na sequência seguinte.
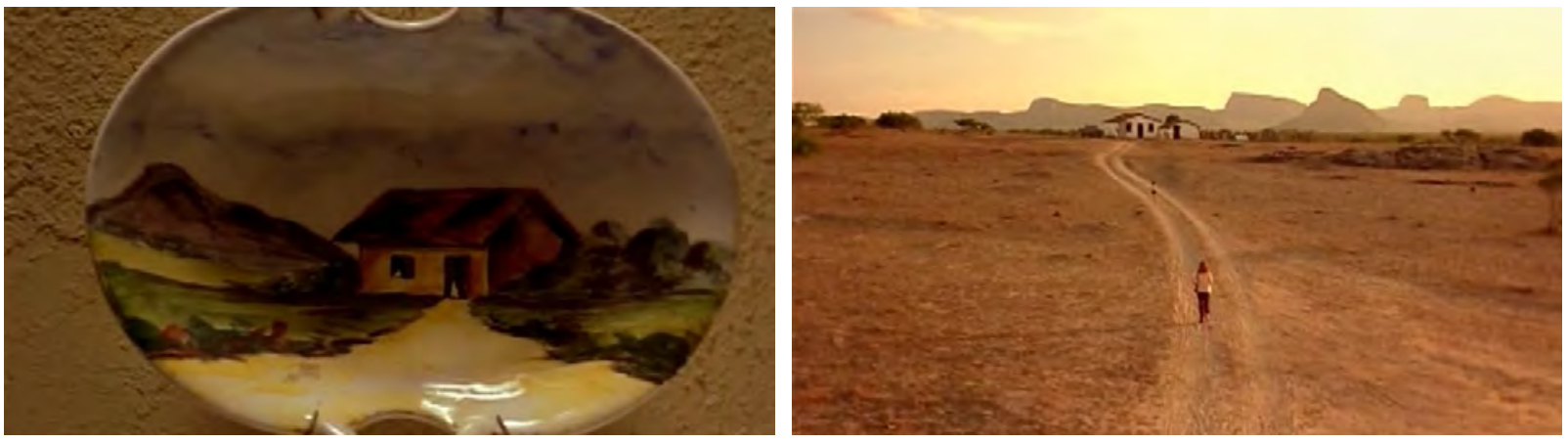

Fig. 150 - Central do Brasil (1998), Walter Salles

Quando Josué chega próximo à entrada da casa, suas expectativas estão no ápice. A câmera está ligeiramente abaixo da altura de seus olhos, enquadrando-o contra o céu. Seu rosto se transforma quando percebe a presença de um menino, a música também se transforma, acentuando a mudança de expectativas de Josué. A outra criança é filmada de um ângulo normal. Inicia-se uma troca de olhares entre os meninos, filmada em campo/contracampo com a câmera em movimento e conduzida pelo movimento dos dois. 
O campo/contracampo é um dos pilares de linguagem do filme clássico. Trata-se da decomposição do espaço, de modo que seja possível observar campos opostos, articulando-se dois interlocutores ou um personagem que olha e o alvo de seu olhar.

Na cena da chegada à casa, o movimento e o campo/contra-campo estabelecem ao mesmo tempo o conflito e a identidade entre os meninos. O duelo de olhares cria um efeito de suspense à trama, pois momentaneamente há a expectativa de que a outra criança seja filha de Jesus.
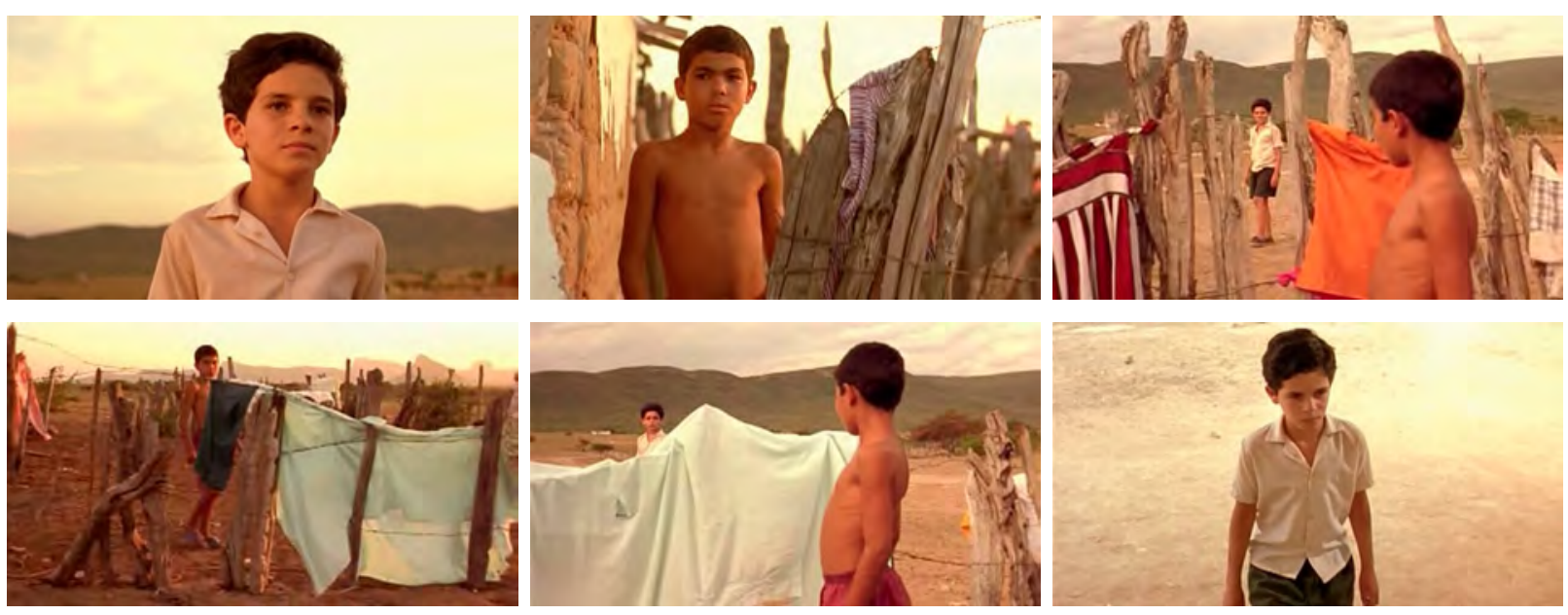

Fig. 151 - Central do Brasil (1998), Walter Salles

O suspense se mantém na cena seguinte, até descobrirem que o pai não mora mais ali. A cena é pontuada pelos primeiros planos de Josué, ao estilo do cinema de David Wark Griffith. Segundo Ismail Xavier, uma das características de Griffith era oferecer mais tempo ao ator nos planos fechados. "Foi um mestre na definição do momento de expectativa, do contraste entre perplexidade e vivência plena de um instante decisivo, demonstrando a notável força do cinema na elaboração cênica do 'a ponto de' e do conflito dramático expresso em olhares e pequenos movimentos" (XAVIER, 1984b, p.76).

Josué entra na casa e enquanto aguarda a chegada do pai vemos a expectativa do encontro estampada em seu rosto. Uma ventania precede a entrada de Jessé, Josué vira-se para olhar e um travelling in fecha ainda mais o quadro em seu rosto. Ele então se movimenta para tentar ver o pai entrar em casa e um novo travelling in captura sua reação. Dora explica o motivo de estarem ali e Jessé pergunta se ele é um bom menino. Dora responde que sim e Josué esboça um sorriso. Ao descobrir que aquele não é seu pai, seus olhos se enchem de lágrimas. Jessé conta que Jesus vendeu a casa e bebeu todo o dinheiro, nesse momento Josué abaixa a cabeça e sai da casa. 

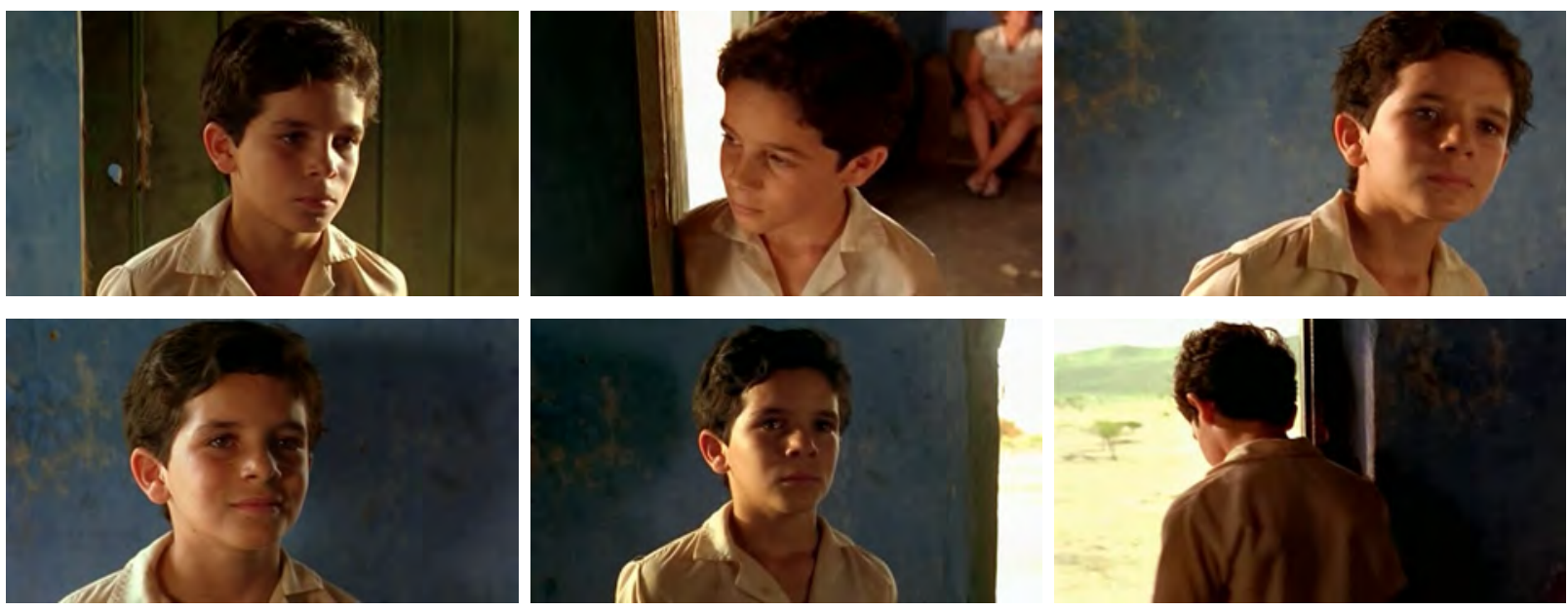

Fig. 152 - Central do Brasil (1998), Walter Salles

A frustração do menino é vista em seu distanciar lento, por meio de um plano emoldurado pela porta da casa. A câmera observa o menino de costas, afastando-se cabisbaixo. Vale lembrar que o suspense em Griffith é elaborado com base nas ameaças à família, e o diretor opõe os espaços internos (próprios ao lar) dos espaços externos (de onde provêm as situações e pessoas ameaçadoras). Em seu movimento, Josué parte novamente para a estrada, em desalento por não ter encontrado o acolhimento da família.

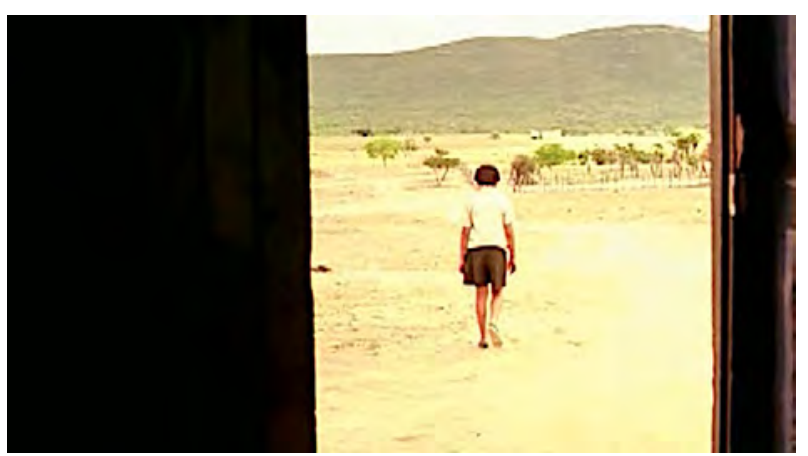

Fig. 153 - Central do Brasil (1998), Walter Salles

Dora e o menino dirigem-se ao endereço fornecido por Jessé. Trata-se de um conjunto habitacional, que é apresentado em um novo movimento de grua (figura 154). Dessa vez, o horizonte do sertão é substituído pela uniformização das casas, marcando um retorno ao universo massificado e serial do início do filme. 

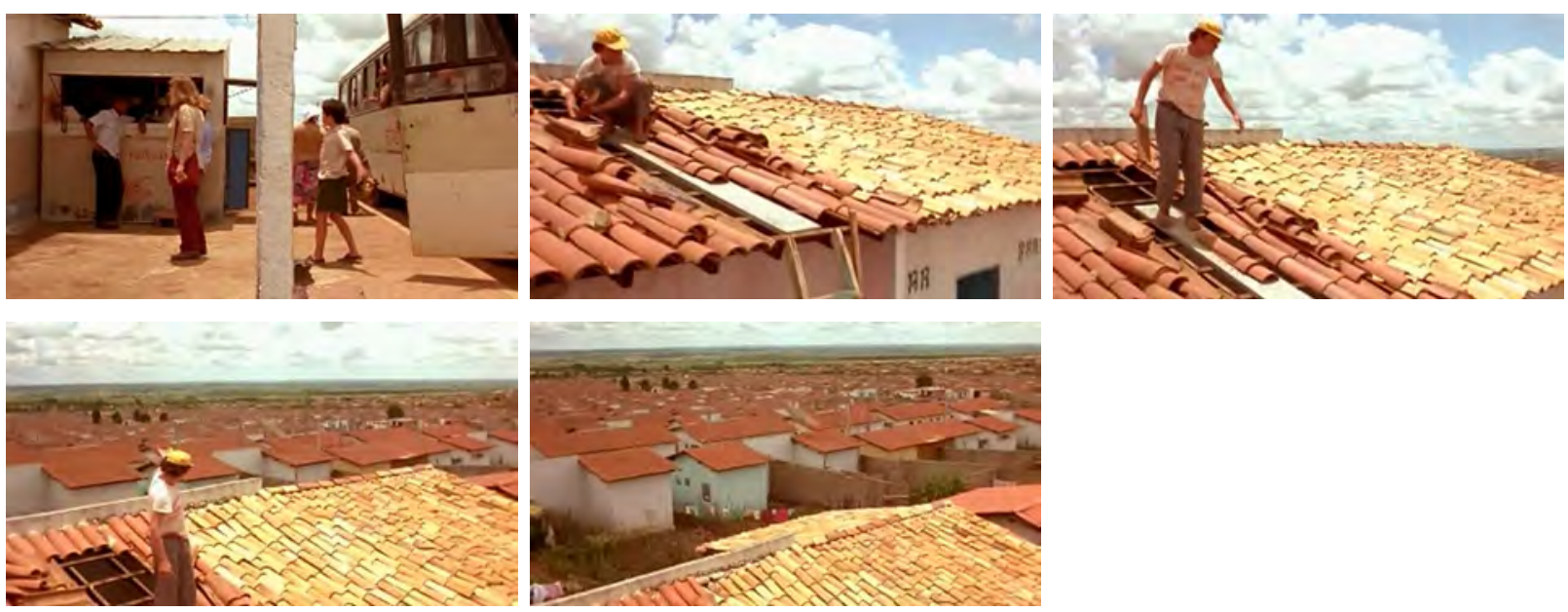

Fig. 154 - Central do Brasil (1998), Walter Salles

O universo claustrofóbico do interiores do Rio de Janeiro retorna ao filme, como vemos nos enquadramentos da casa dos irmãos de Josué. Mas o afeto familiar é mais forte que a desindividualização da Vila do João.

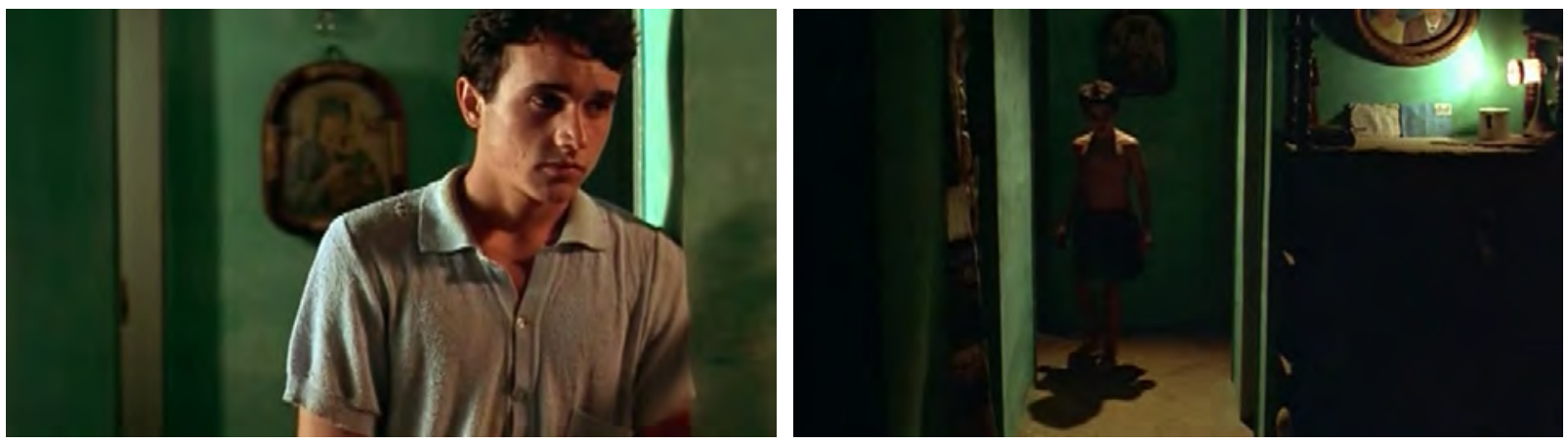

Fig. 155 - Central do Brasil (1998), Walter Salles

A ampliação do espaço na segunda parte do filme resulta da alteração das lentes, que traduzem uma mudança no comportamento de Dora: ela passa a olhar para o mundo e para o outro. Nesse movimento, Dora deixa de ser agente, de deter o poder sobre o destino das pessoas (mandar ou não as cartas), para ser transformada pelas circunstâncias e personagens que encontra.

A utilização de objetivas mais abertas modifica a profundidade de campo ao longo da narrativa. Vale comparar as cartas ditadas na estação de trem, como as da linha superior da figura 156, com as ditadas ao Santo (linha inferior), num momento em que Josué percebe que a habilidade de Dora poderia lhes render algum dinheiro. No primeiro caso, não é possível ver o saguão da estação. No segundo caso, a cidade e as pessoas ao fundo tornam-se presentes. 

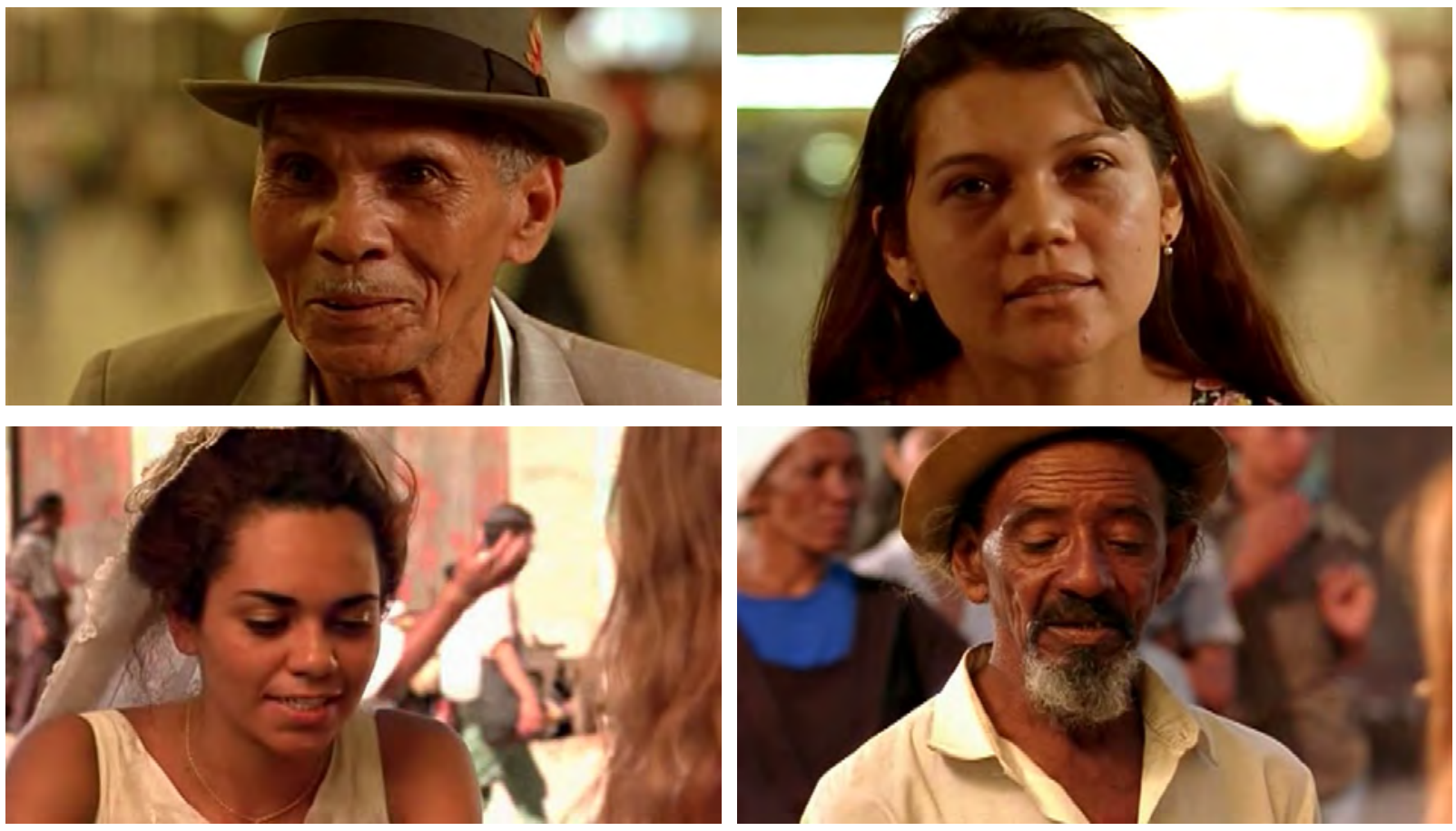

Fig. 156 - Central do Brasil (1998), Walter Salles

Com o aumento da profundidade de campo, os personagens tornam-se parte integrante do espaço e com ele interagem. Nota-se que o aumento da profundidade não tem a ver apenas com a alta luz do nordeste, uma vez que até em cenas noturnas, filmadas com pouca luz, o ambiente é visível. Por meio da escolha das lentes, Walter Carvalho promove a integração entre personagens e espaço.
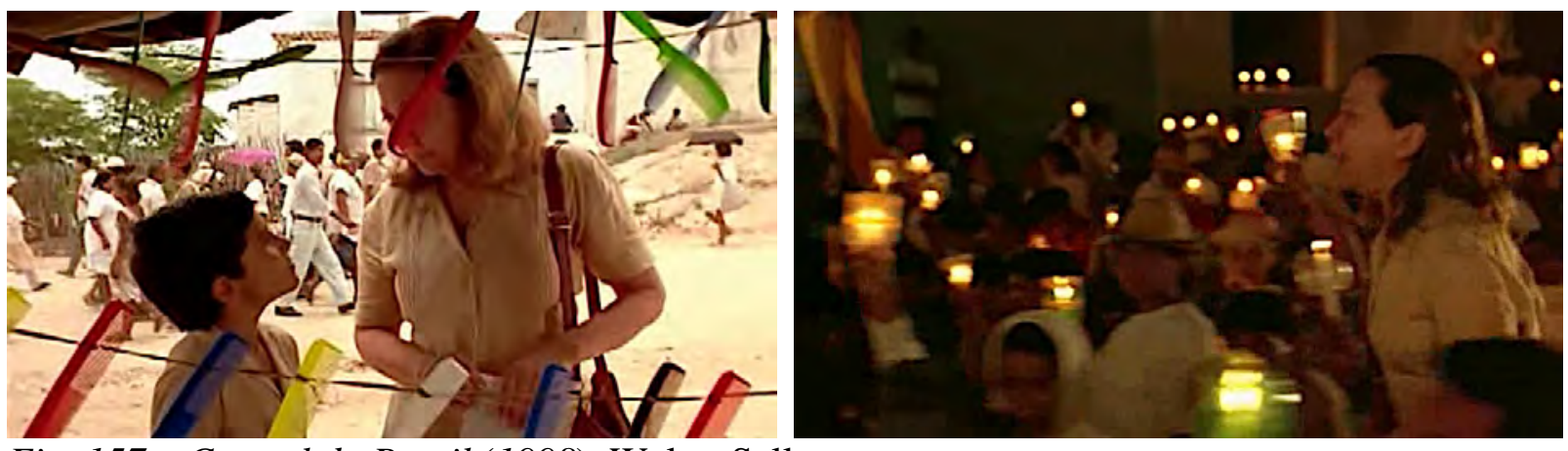

Fig. 157 - Central do Brasil (1998), Walter Salles

Desse modo, o foco é trabalhado expressivamente em função da narrativa e do momento dos personagens. No início do filme, a profundidade de campo confere um tratamento gráfico aos quadros, enfatizando o caráter bidimensional da imagem. Posteriormente, as imagens recebem um tratamento pictórico, uma vez que a terceira dimensão se faz presente. 
A iluminação também se transforma ao longo do filme. No início as fontes são suaves e não pontuais, o que resulta em sombras pouco acentuadas.
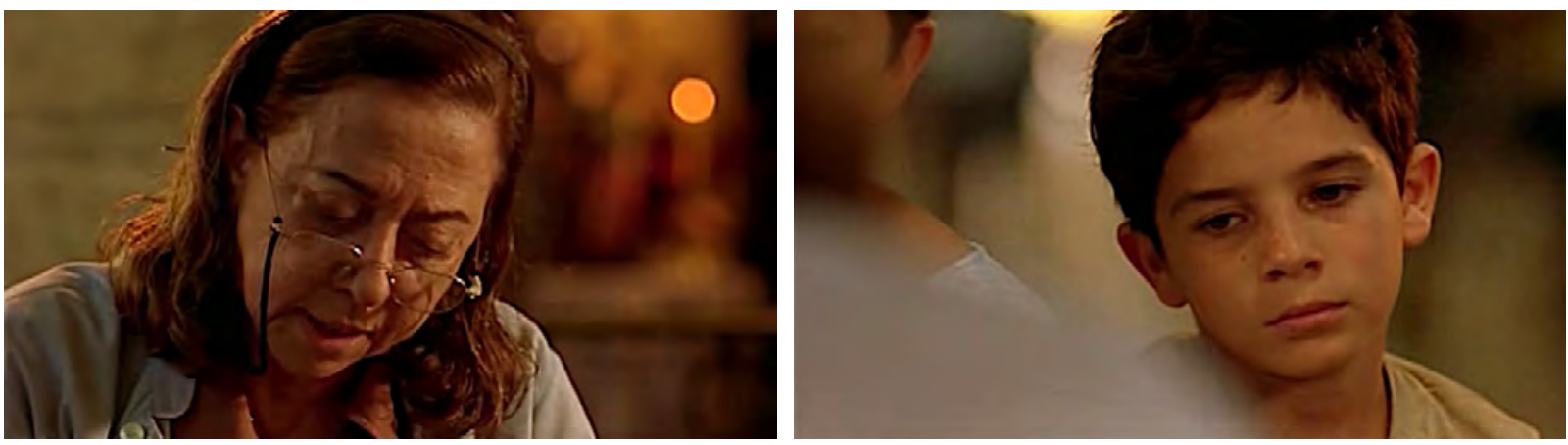

Fig. 158 - Central do Brasil (1998), Walter Salles

O contraste acentua-se com a exploração da alta luz do nordeste.
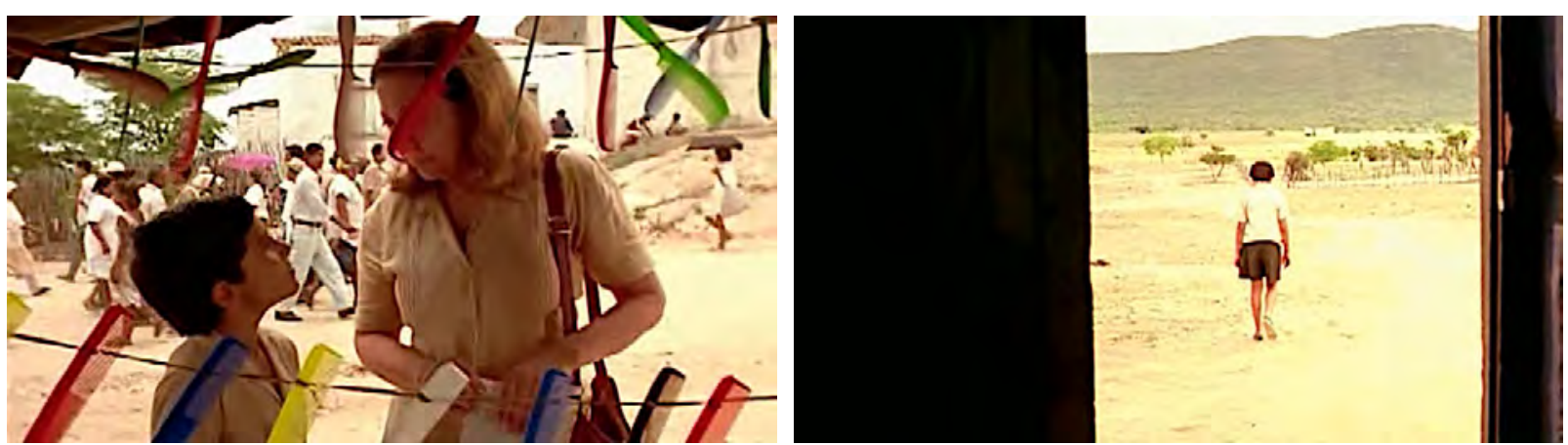

Fig. 159 - Central do Brasil (1998), Walter Salles

Durante a viagem a luz torna-se recortada, principalmente com a utilização de velas como fontes diegéticas.
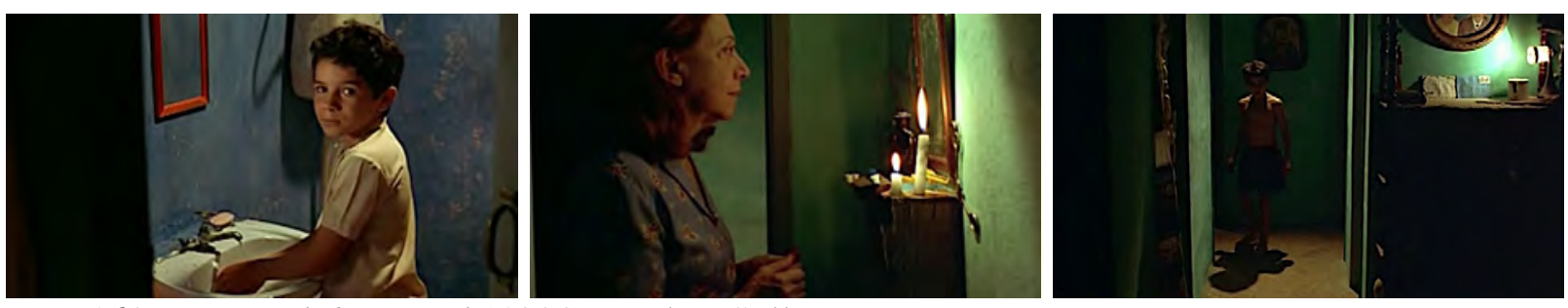

Fig. 160 - Central do Brasil (1998), Walter Salles

A iluminação com velas é um dos pontos altos do filme, como na cena da procissão, em que Walter Carvalho utilizou refletores apenas na fachada da igreja e centenas de velas nas mãos dos figurantes para iluminar os atores e a ação. 

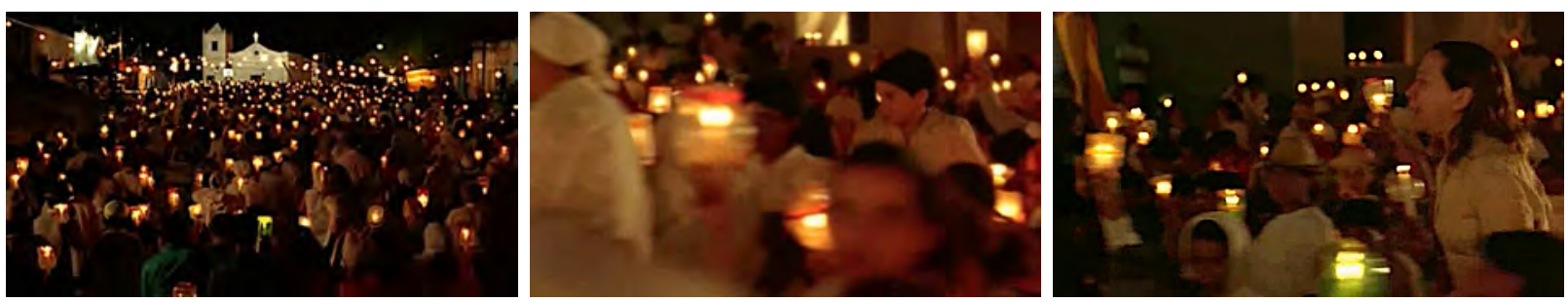

Fig. 161 - Central do Brasil (1998), Walter Salles

As velas têm importante papel na cena da Casa dos Milagres, em que Dora sucumbe ao esgotamento físico e mental. Ali ocorre a virada da personagem, o desmaio é o ápice de sua trajetória de purgação, em um movimento típico do melodrama. A cena é criada por meio da montagem paralela, mais um elemento clássico utilizado na estrutura narrativa do filme.

Após correr atrás de Josué no meio da multidão, Dora entra na Casa dos Milagres. Do lado de fora a comoção dos peregrinos aumenta, o calor das orações é apresentado paralelamente ao ambiente interno, com planos do rosto de Dora e do ambiente repleto de velas. O giro e o estouro dos fogos de artifício marcam o momento de maior tensão dramática de Dora, que culmina em seu desmaio.
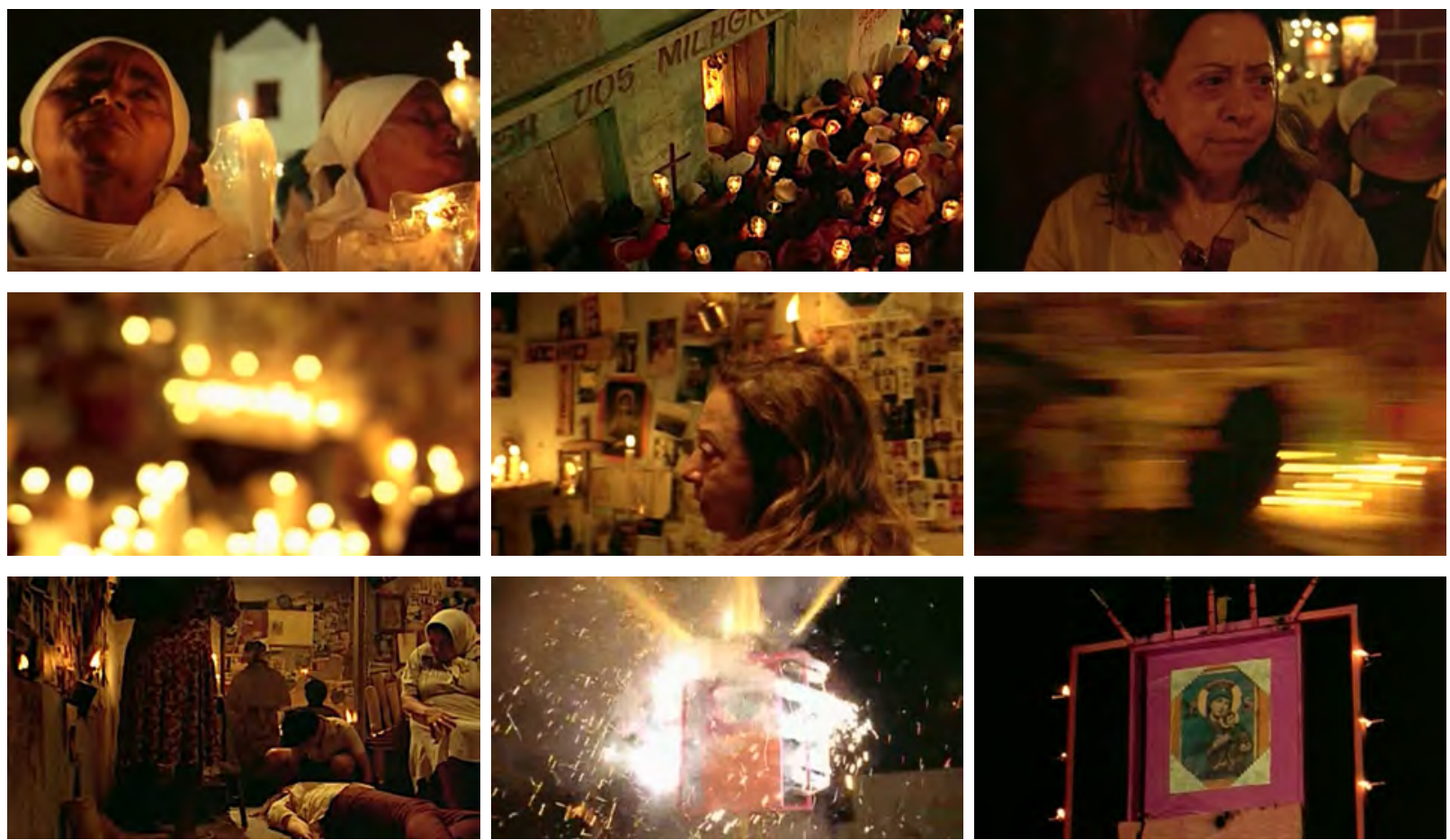

Fig. 162 - Central do Brasil (1998), Walter Salles

O recomeço da personagem é marcado pela tela preta e um longo fade in para a cena em que Dora repousa no colo de Josué, semelhante à imagem da Pietà invertida. A escultura de Michelangelo (1475-1564) retrata o momento em que Maria ampara o corpo do Cristo após a crucificação. No caso de Dora, trata-se da morte simbólica, no sentido da 
transformação de seu caráter. A câmera fixa e a serenidade dos personagens marcam o retorno ao equilíbrio.

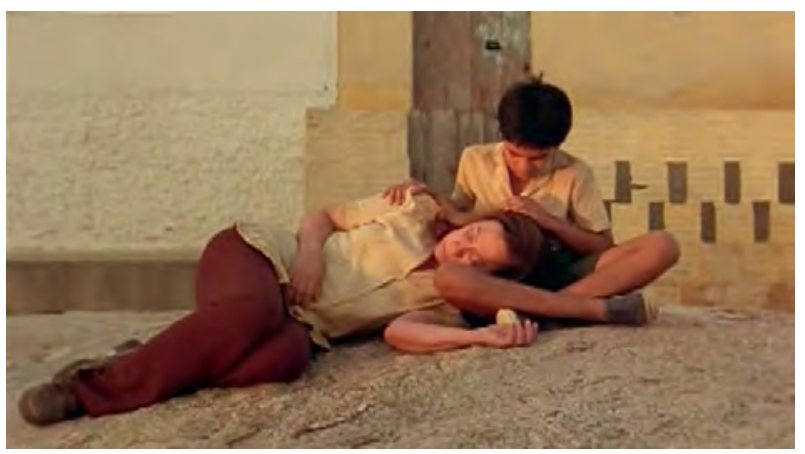

Fig. 163 - Central do Brasil (1998), Walter Salles

Assim como o tratamento do espaço e da iluminação, a cor do filme apresenta dois momentos. É trabalhada na cor-pigmento, por meio de cenários, objetos e figurinos; na corluz, por meio de fontes luminosas; e na cor-pós, que uniformiza a tonalidade do filme.

$\mathrm{Na}$ primeira parte do filme, pigmentos e temperaturas de cor das fontes luminosas trabalham em conjunto, com predomínio de ocres, beges, cinzas e marrons. Há um certo monocromatismo, de forma que o contraste não se estabelece por meio de matizes muito distintos, mas na variação de tons dentro de matizes semelhantes.

É o que vemos na figura 164, em dois momentos de Dora no Rio de Janeiro. Tanto na estação de trem quanto no apartamento, a paleta é reduzida e a temperatura de cor trabalha em conjunto com os pigmentos.
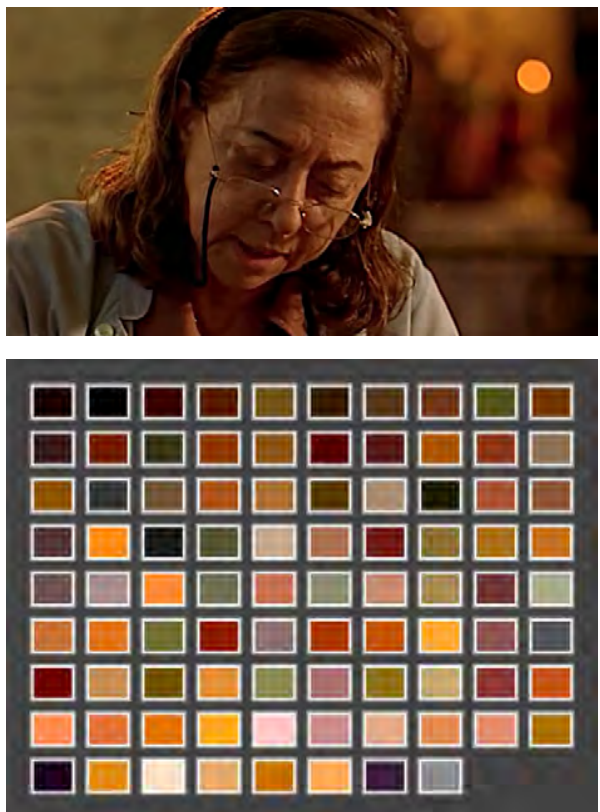
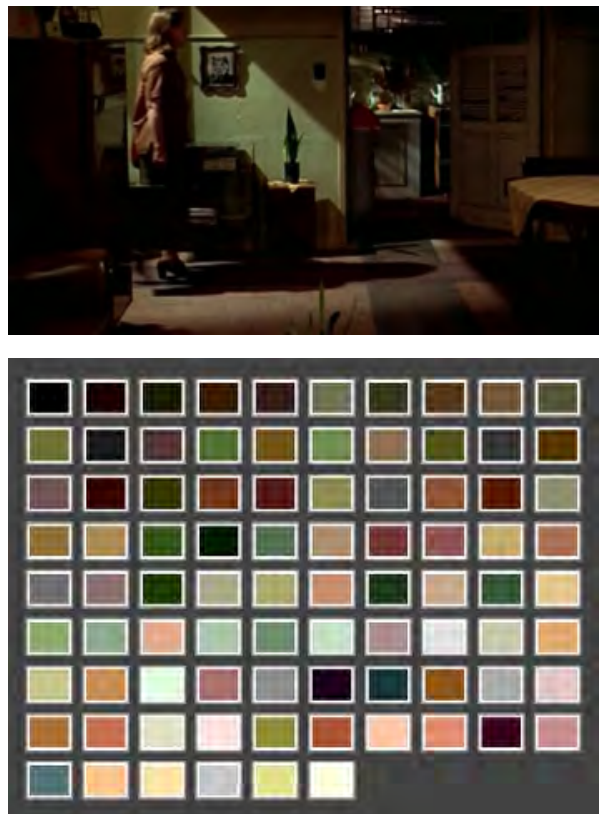

Fig. 164 - Central do Brasil (1998), Walter Salles 
À medida em que o filme ganha a estrada, não apenas a imagem se amplia como também ganha novos matizes. A transição de cores entre o Rio de Janeiro e o sertão é marcada pelos ocres, presentes na terra do sertão.

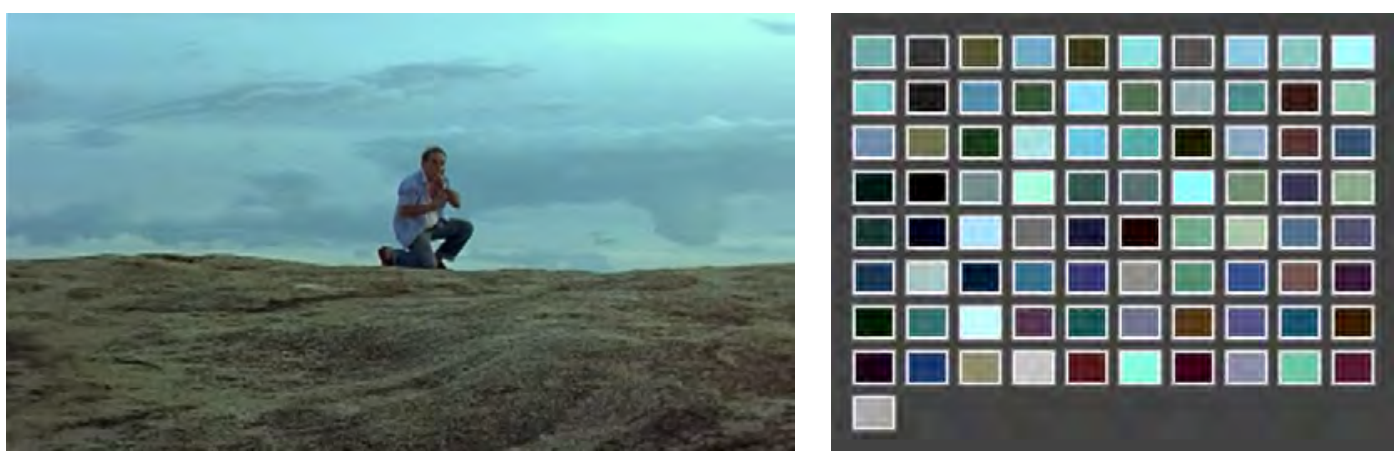

Fig. 165 - Central do Brasil (1998), Walter Salles

No fotograma da figura 166 percebe-se o contraste de matizes entre cor-pigmento, que aparece no cinza-ocre do chão (esquerda), e cor-luz, advindo da temperatura de cor azul (direita).
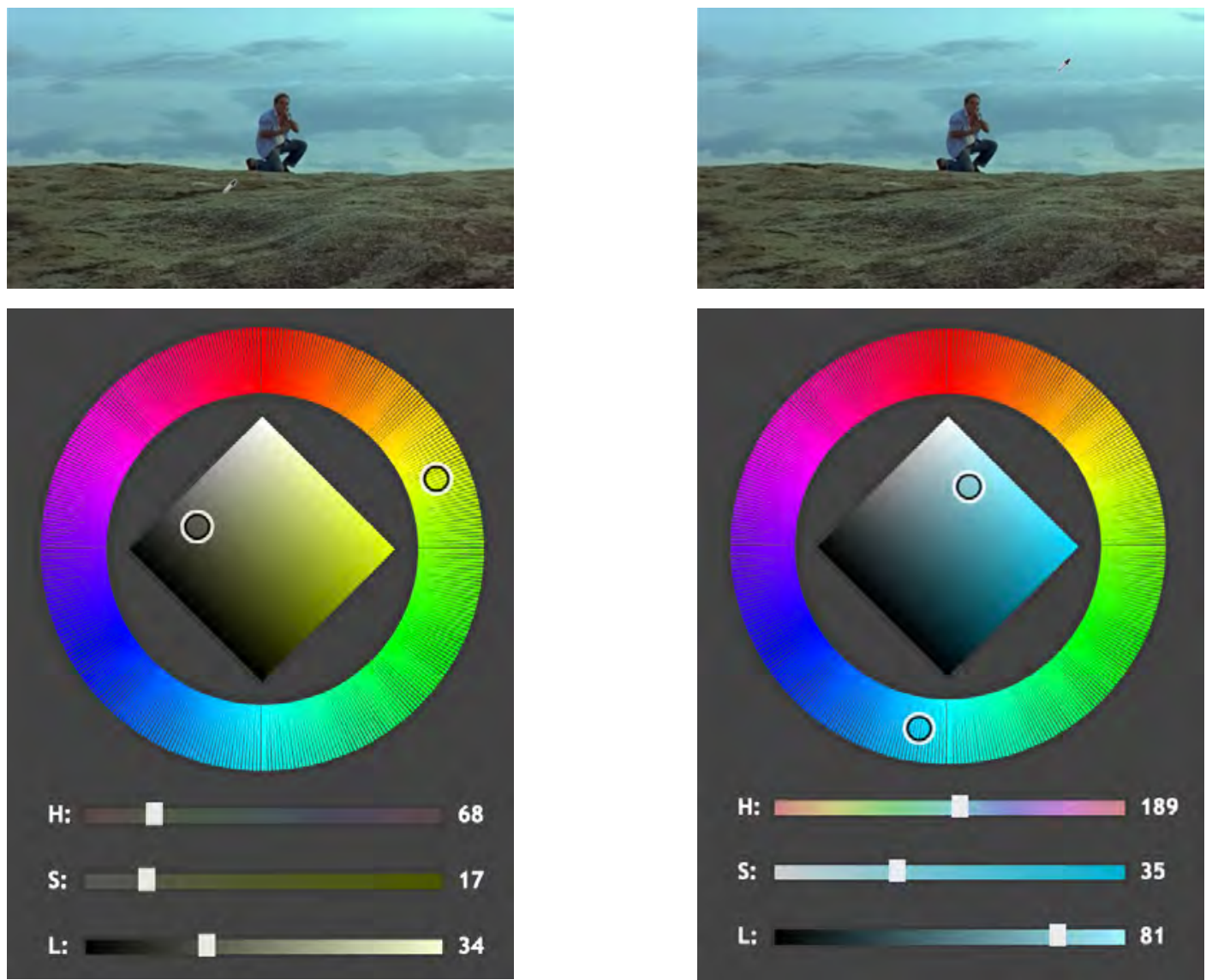

Fig. 166 - Central do Brasil (1998), Walter Salles 
O contraste entre cor-pigmento e cor-luz também está presente na casa de Jessé, em que o azul da parede (esquerda) difere da fonte alaranjada que ilumina a mulher sentada (direita).
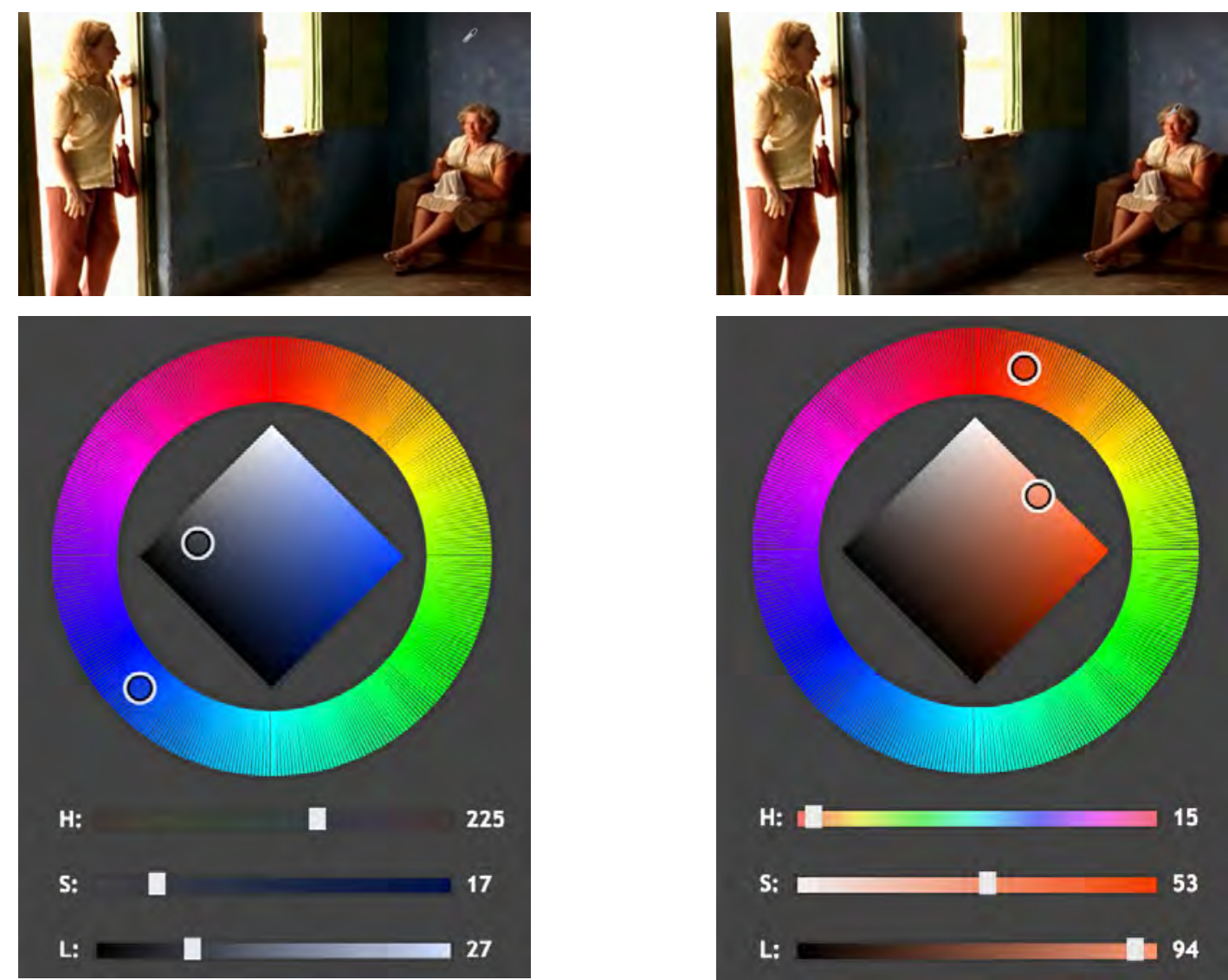

Fig. 167 - Central do Brasil (1998), Walter Salles 
O vermelho é a cor que liga as duas partes do filme, e se intensifica quando Dora vai ao banheiro do restaurante da estrada e decide passar um batom. Nota-se em relação aos fotogramas do Rio de Janeiro uma significativa ampliação da paleta.

Uma das referências para criar a cor do sertão vem de $O$ Dragão da Maldade Contra o Santo Guerreiro (1969), dirigido por Glauber Rocha e fotografado por Affonso Beato (1941). Nesse filme, a dupla buscou criar um colorido tropical por meio da alta saturação de cores primárias, estética que ficou conhecida como Tropicolor. A cor era utilizada para ressaltar e afirmar a luz solar intensa e a realidade do sertão nordestino.

Comparando fotogramas de Central do Brasil e de O Dragão da Maldade Contra o Santo Guerreiro é possível verificar a semelhança no tratamento cromático.
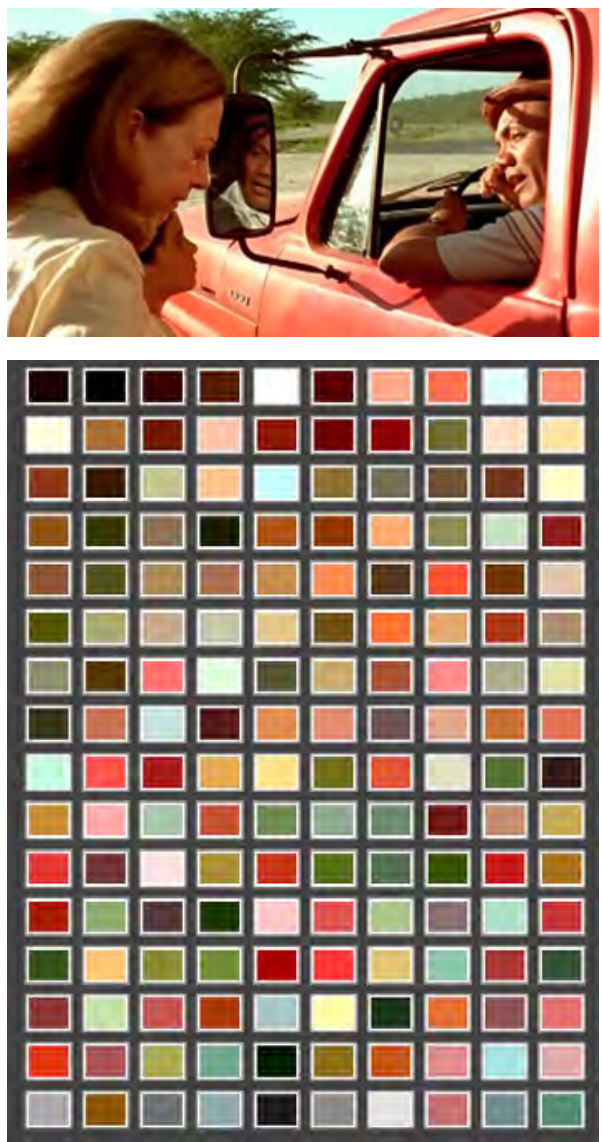
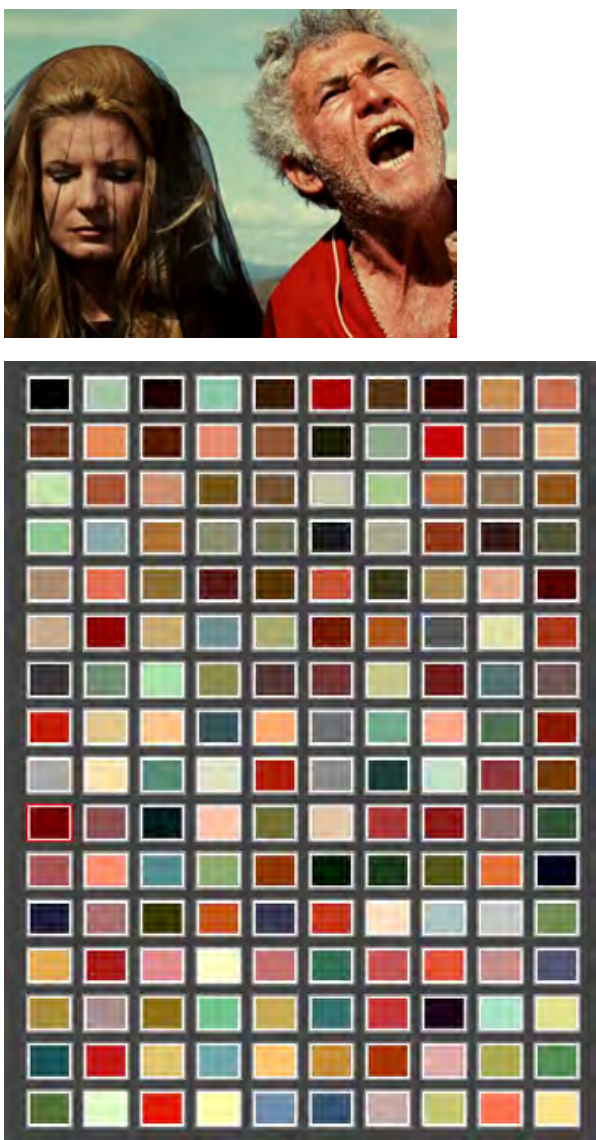

Fig. 168 - Central do Brasil (esq) e O Dragão da Maldade Contra o Santo Guerreiro (dir) 
O verde é a cor que marca a casa dos irmãos de Josué, num momento do filme em que o contraste entre luz (direita) e pigmento (esquerda) ainda se faz presente, como podemos ver na cena em que Dora se prepara para sair.
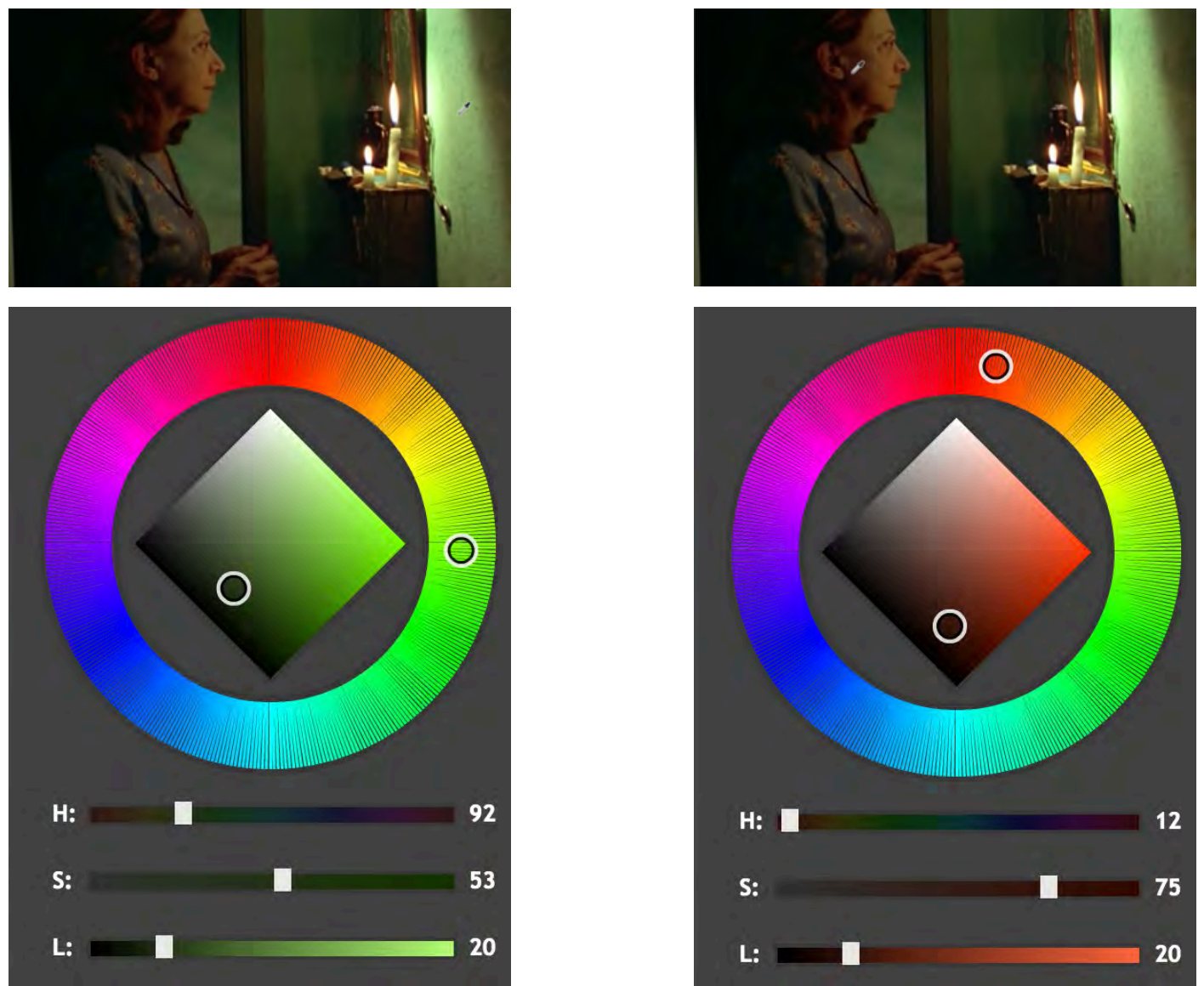

Fig. 169 -Central do Brasil (1998), Walter Salles 
Quando Dora deixa a casa para voltar ao Rio de Janeiro, o contraste entre luz e pigmento desaparece. $\mathrm{O}$ vestido (esq) tem um matiz muito semelhante ao azul do amanhecer (dir).
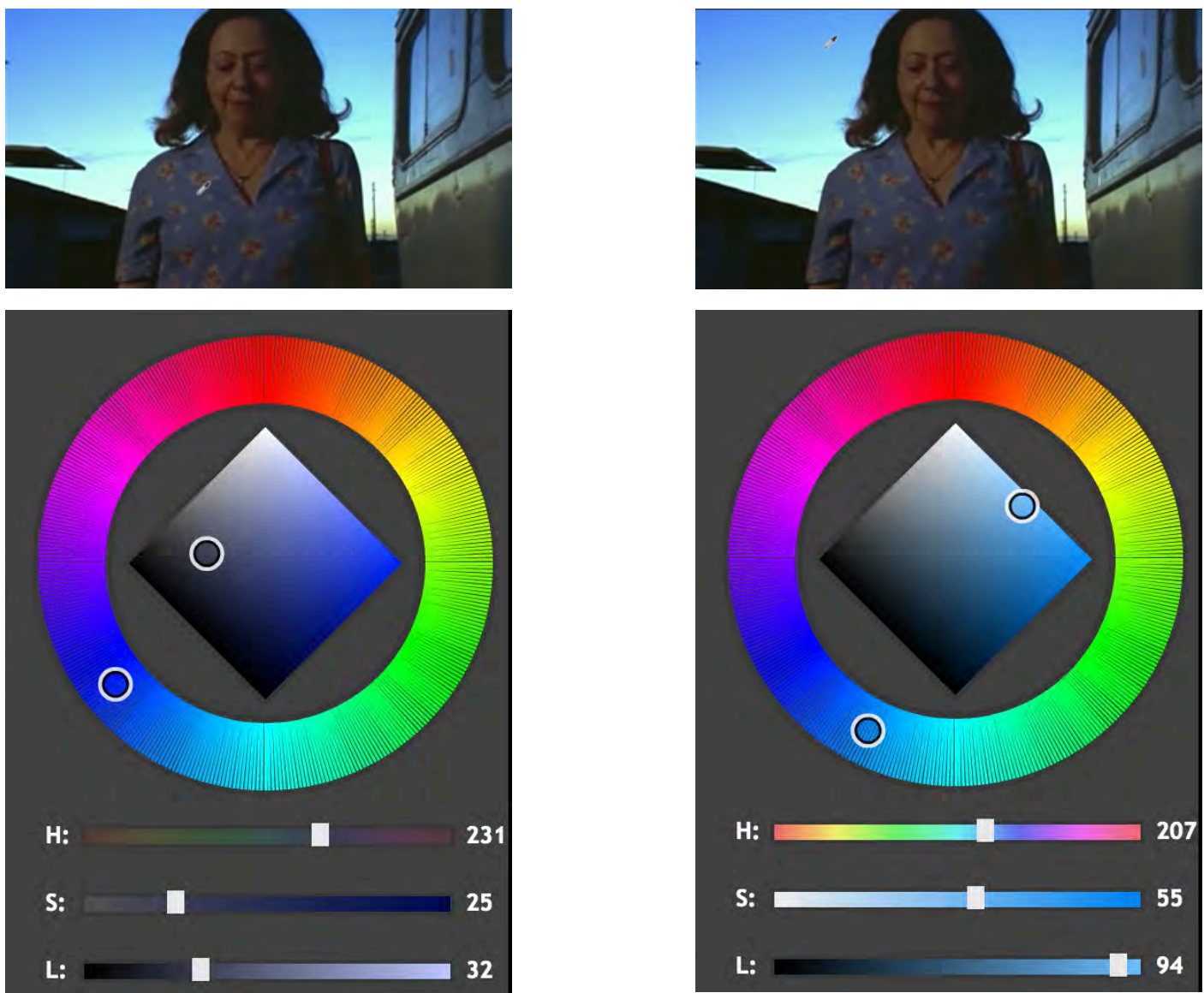

Fig. 170 - Central do Brasil (1998), Walter Salles

Dora decide partir e deixar Josué com seus irmãos, mas antes de ir embora acaba por consertar um desencontro promovido pelo destino. Coloca a carta de Ana Fontenele ao lado da de Jesus de Paiva, promovendo um encontro simbólico entre o casal. Trata-se de uma das últimas metáforas do filme: os dois terminam lado a lado, como no retrato que marca sua união.
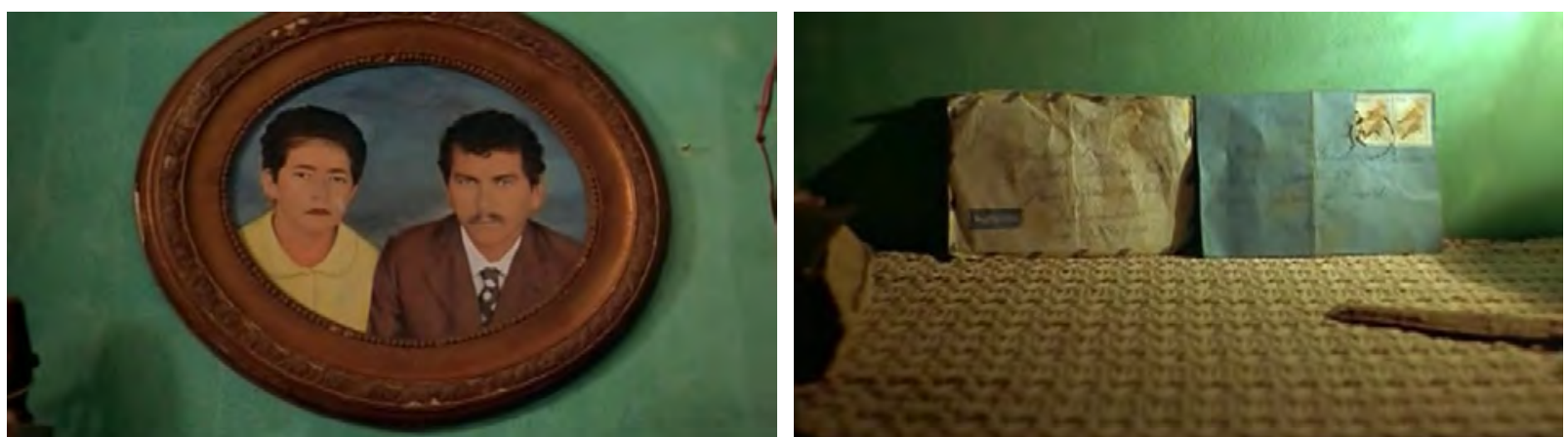

Fig. 171 - Central do Brasil (1998), Walter Salles 
O encontro entre Dora e Josué também é selado por um retrato. O gesto fotográfico, capaz de eternizar um instante, aparece como o elo da ligação entre os dois. Assim como Ana e Jesus, Dora e Josué permanecem juntos no retrato com a estátua de Padre Cícero. A fotografia é tirada quando conseguem dinheiro com o negócio de escrever cartas para o Santo, no dia seguinte à mudança de caráter de Dora.
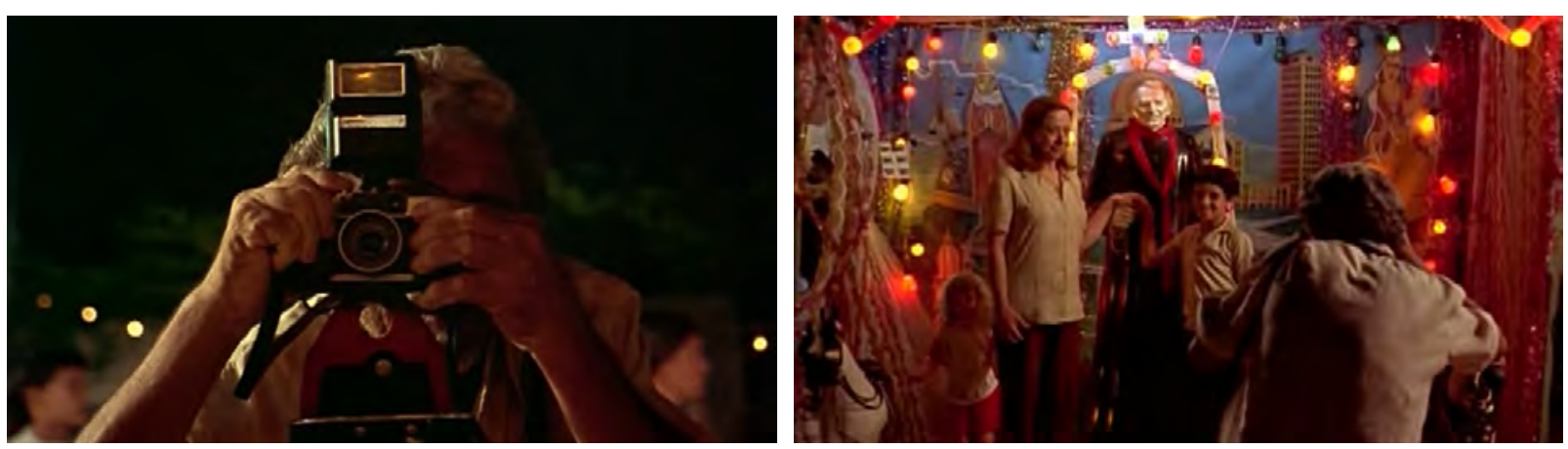

Fig. 172 - Central do Brasil (1998), Walter Salles

A fotografia é observada ao mesmo tempo pela mulher e pelo menino, em espaços disjuntos, e promove a ligação entre ambos. Reitera as metáforas da presença do outro, apresentadas pelo lenço e pelo pião. É o ápice da emoção proveniente dos recursos narrativos.
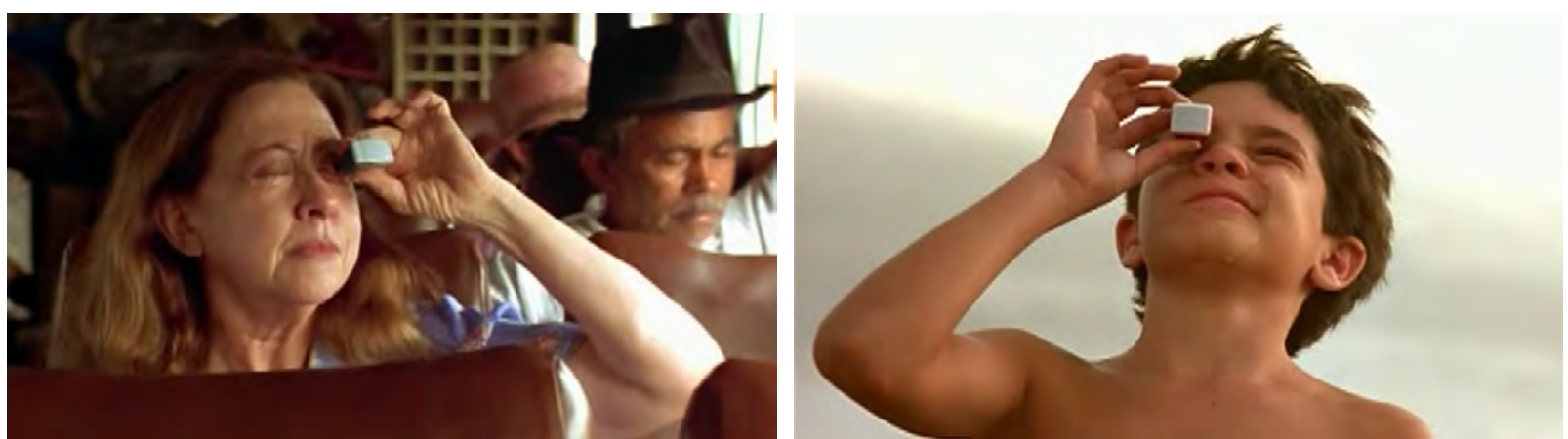

Fig. 173 - Central do Brasil (1998), Walter Salles

A imagem que ambos observam é invertida, assim como a cena da pietà. A jornada do menino em busca do pai acaba por ser a jornada de Dora pela libertação de si mesma, e esse espelhamento pode ser observado na relação entre "imagem real" e "imagem fotográfica".
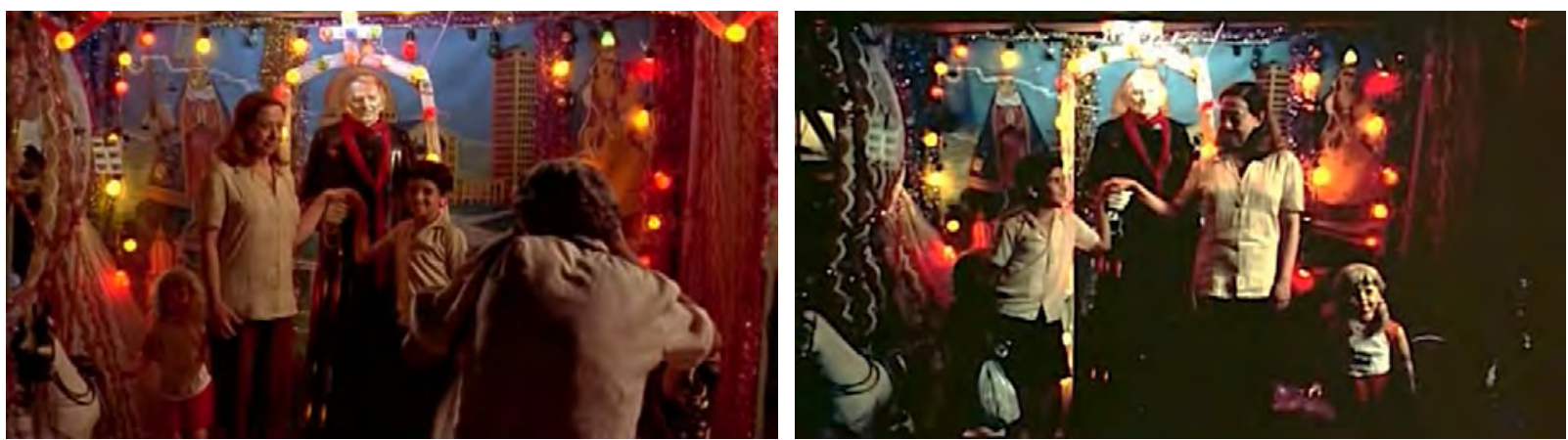

Fig. 174 - Central do Brasil (1998), Walter Salles 


\subsection{Lavoura Arcaica (2001), Luiz Fernando Carvalho}

Lavoura Arcaica é o primeiro longa-metragem dirigido por Luiz Fernando Carvalho (1960- ). O enredo gira em torno de André (Selton Mello), que resolve fugir da fazenda onde mora graças à forte vigilância moral e os valores tradicionais de seu pai, e para esquecer a paixão que nutre por sua irmã Ana (Simone Spoladore). O roteiro é constuído a partir do encontro entre André e seu irmão Pedro (Leonardo Medeiros), que tenta levá-lo de volta para casa. Com uma narrativa não linear, o tempo oscilante entre passado e presente tem por base o fluxo de pensamento de André, não a lógica da ação.

A imagem foi concebida a partir de uma parceria entre Luiz Fernando e Walter Carvalho, que estudaram juntos as referências de luz e enquadramentos. O filme trata a questão de identidade e pertencimento de André, e esses dilemas, assim como os dos outros personagens, são trabalhados pela fotografia. A preocupação principal de Luiz Fernando Carvalho era "trazer o mundo interno do personagem para o primeiro plano" (CARVALHO, 2002, p. 79). Nesse sentido, a imagem não desempenha apenas um papel estético, mas ao materializar visualmente a atmosfera emocional dos personagens, acaba por estruturar a narrativa do filme.

A cena inicial é um exemplo desta materialização. Criada a partir de planos próximos do corpo de André, enquanto o rapaz se masturba, a cena penetra a intimidade do personagem. Entretanto, a pequena profundidade de campo e a baixa intensidade de luz não permitem que o espectador veja com clareza o que se passa.
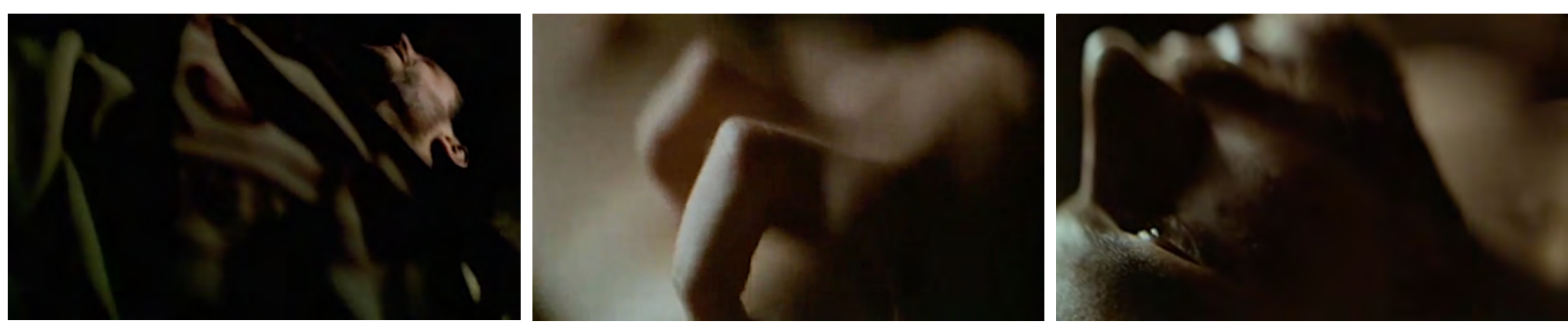

Fig. 175 - Lavoura Arcaica (2001), Luiz Fernando Carvalho

Os conflitos familiares, que embora sentidos não são encarados pelos personagens, norteiam a criação de enquadramentos com elementos em primeiro plano, que dificultam a visão.
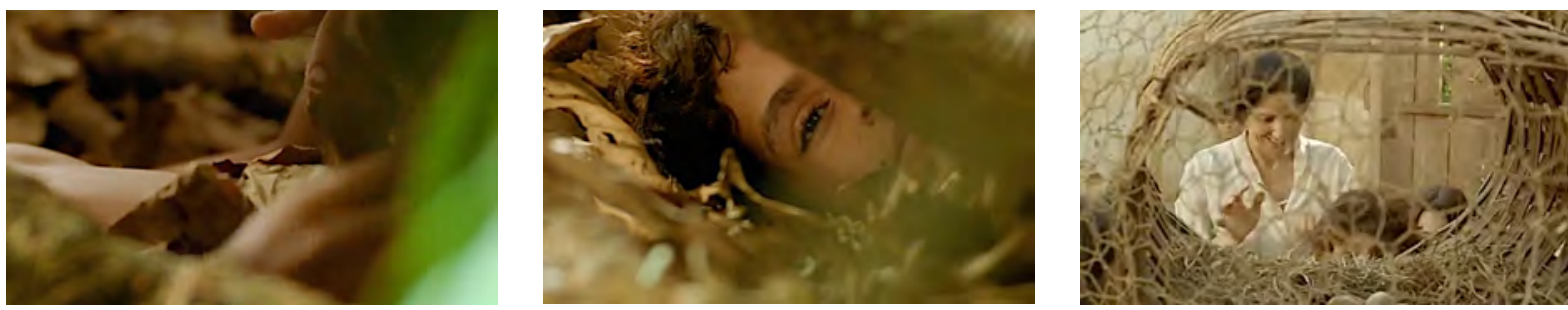

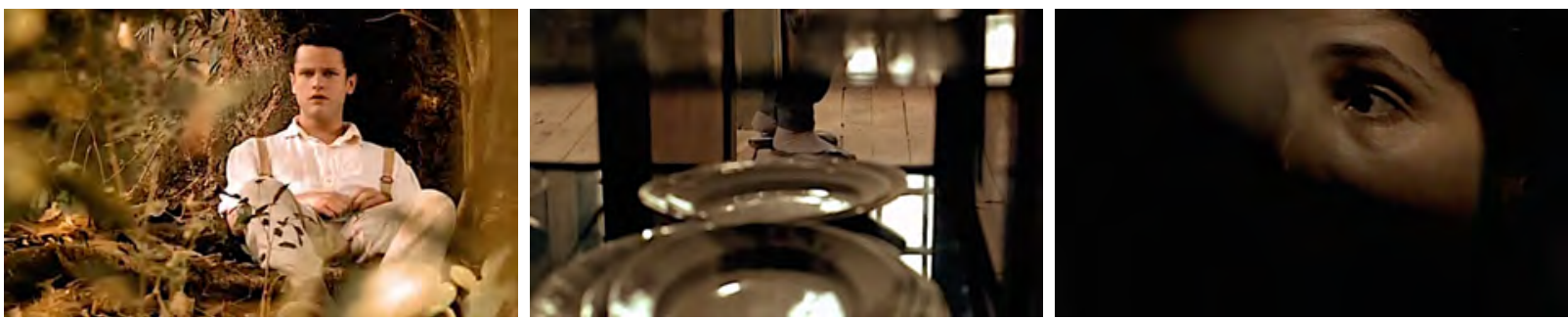

Fig. 176 - Lavoura Arcaica (2001), Luiz Fernando Carvalho

Nesse mesmo sentido, o desfoque é utilizado como elemento metafórico, da realidade que embora presente, não pode ser vista tão claramente. É o caso da festa no bosque, do diálogo entre Pedro e André, das irmãs desfocadas atrás das velas, e da prostituta ao se vestir, cuja imagem beira a abstração.
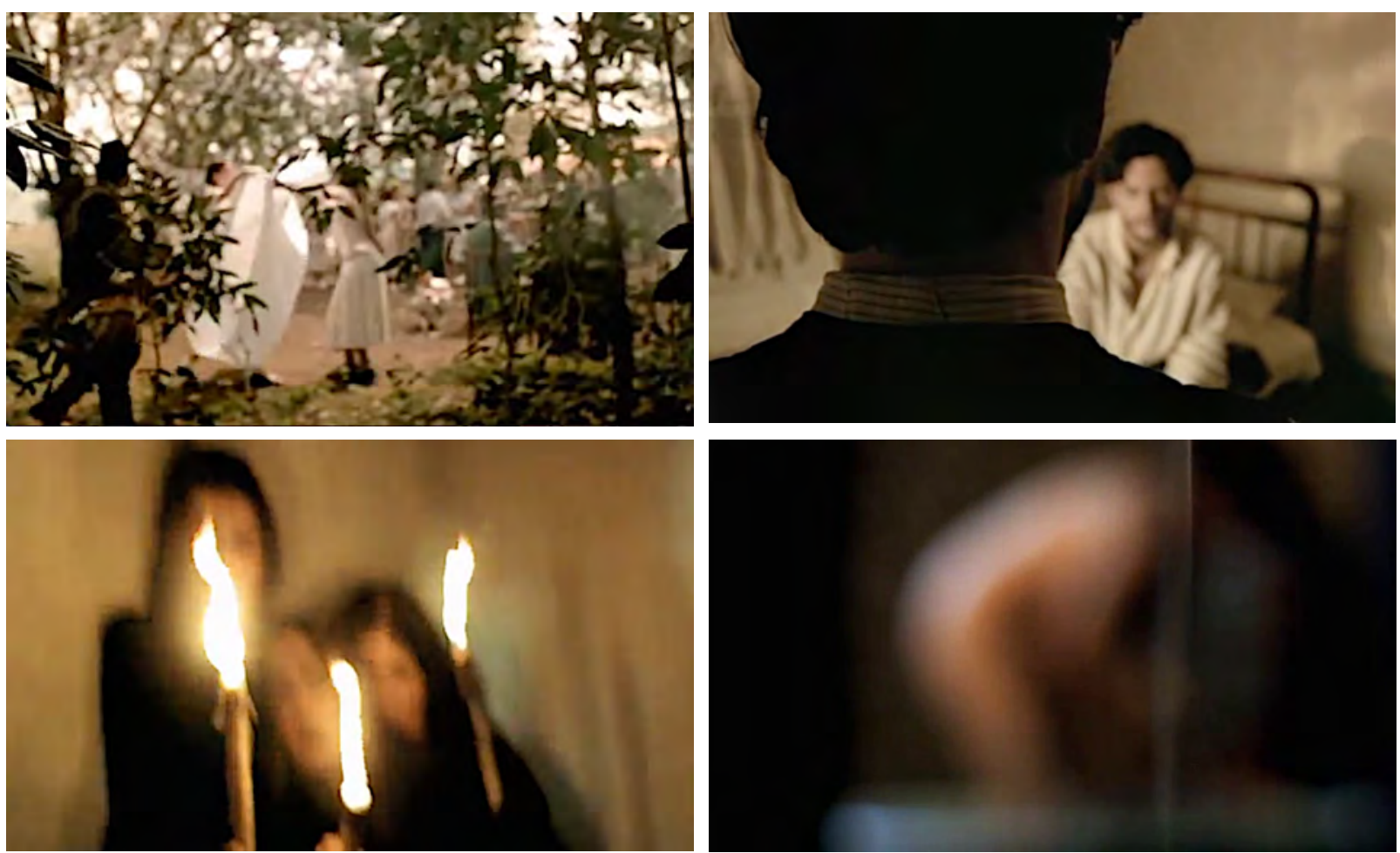

Fig. 177 - Lavoura Arcaica (2001), Luiz Fernando Carvalho

A dualidade familiar criada pelos modelos patriarcal e matriarcal é apresentada no momento da refeição, com a voz off de André e a imagem dos que aniquilaram suas individualidades pela submissão ao pai (dir) e os que contestam sua autoridade pelo comportamento desviado (esq).

"Eram esses os nossos lugares à mesa na hora das refeições ou na hora dos sermões: o pai à cabeceira; à sua direita, por ordem de idade, vinham primeiro Pedro, seguido de Rosa, Zuleika e Huda; à sua esquerda vinha a mãe, em seguida eu, Ana e Lula, o caçula. O galho da direita era um desenvolvimento espontâneo do tronco, desde as suas raízes. Já o da esquerda trazia o estigma de uma cicatriz, como se a mãe, que 
era por onde começava o segundo galho, fosse uma anomalia, uma protuberância mórbida, pela carga de afeto."
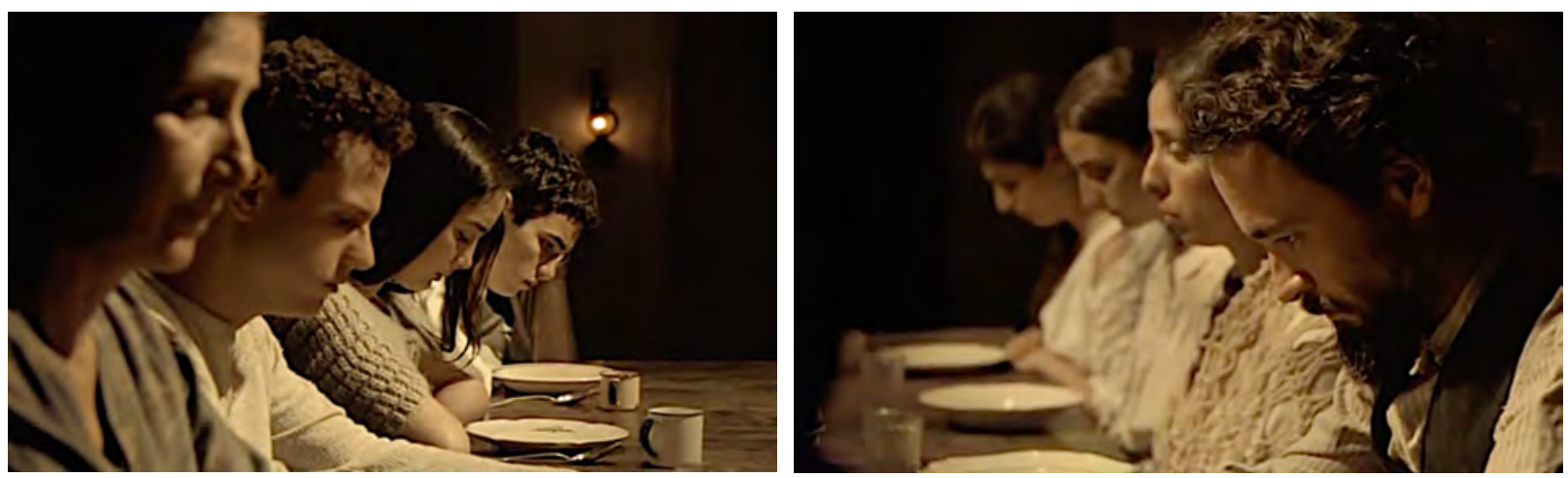

Fig. 178 - Lavoura Arcaica (2001), Luiz Fernando Carvalho

Essa dualidade está presente na iluminação, que é construída a partir de referências da pintura barroca, estilo que permeou a arte na Europa entre o final do século XVI e início do século XVIII. A pintura barroca apresenta particularidades dos locais em que se desenvolveu, entretanto, algumas características são recorrentes, como o forte conteúdo emocional e a presença marcante de luzes e sombras. As contradições interiores de André e das personalidades dos membros da família traduzem-se em oposição entre luz e sombra e no contraste entre claro e escuro.

A antítese é a principal figura de linguagem utilizada, marcando tratamentos distintos para passado e presente, bem como para as figuras da mãe e do pai, no que tange desenho de luz, cor, saturação e contraste. A antítese rege o uso metafórico da luz e o tratamento dos contrastes humanos presentes no filme.

Lavoura Arcaica é um filme que lida com a memória dos personagens e a luz dessa memória constrói-se a partir de referências pictóricas e da memória de Walter Carvalho.

No Lavoura Arcaica, eu baseei toda a parte da infância do personagem principal, em uma frase que eu li no livro do Raduan Nassar, no livro a partir do qual o filme foi feito. Ele escreveu "como era boa a luz da infância". Isso me remeteu direto à minha infância. Eu passava férias no interior e via as minhas tias fazendo pão, acho que tive uma infância parecida com a personagem do ponto de vista da família. Ao ler o Raduan é que eu recordei que a luz da infância é mais solar, transparente, demarca mais o horizonte. Com isso em mente é que eu comecei a trabalhar os filtros e a maneira de expor. Já a luz do pai desse personagem era uma luz tenebrosa, que eu fui construindo a partir de pinturas de Rembrandt (CARVALHO in LEAL, 2012, p.9).

A luz da infância de André é clara, diurna e relaciona-se ao afeto da mãe. 

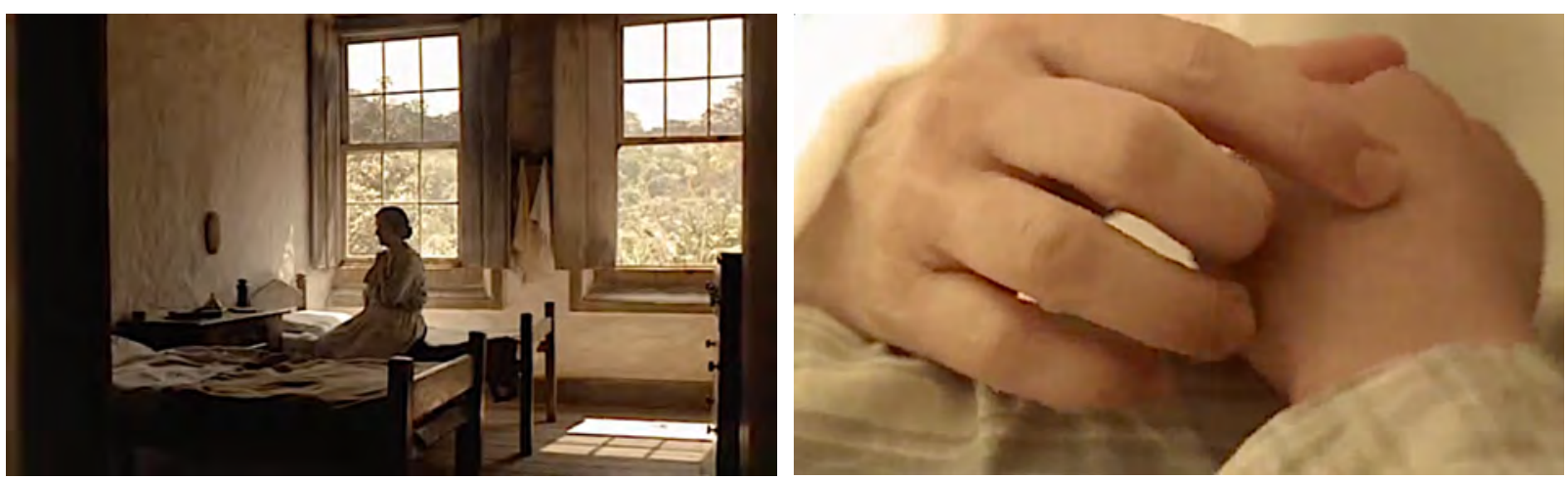

Fig. 179 - Lavoura Arcaica (2001), Luiz Fernando Carvalho

André narra em off a memória dessa luz boa, enquanto as imagens apresentam a claridade da casa.

Era boa a luz doméstica da nossa infância, o pão caseiro sobre a mesa, o café com leite e a manteigueira, essa claridade luminosa da nossa casa e que parecia sempre mais clara quando a gente vinha de volta lá da vila, [...] (Nassar, 2014, p.25).

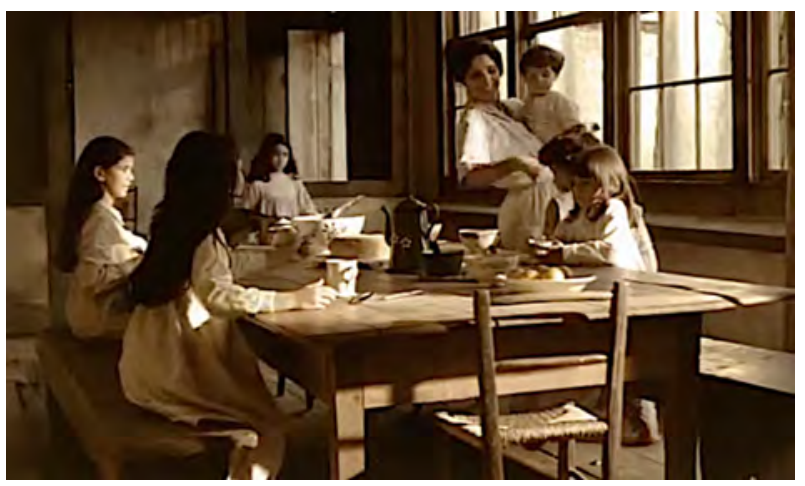

Fig. 180 - Lavoura Arcaica (2001), Luiz Fernando Carvalho

Metaforicamente, a luz boa também marca o momento do orgasmo dos irmãos, por meio da imagem de André menino pulando em direção ao sol.
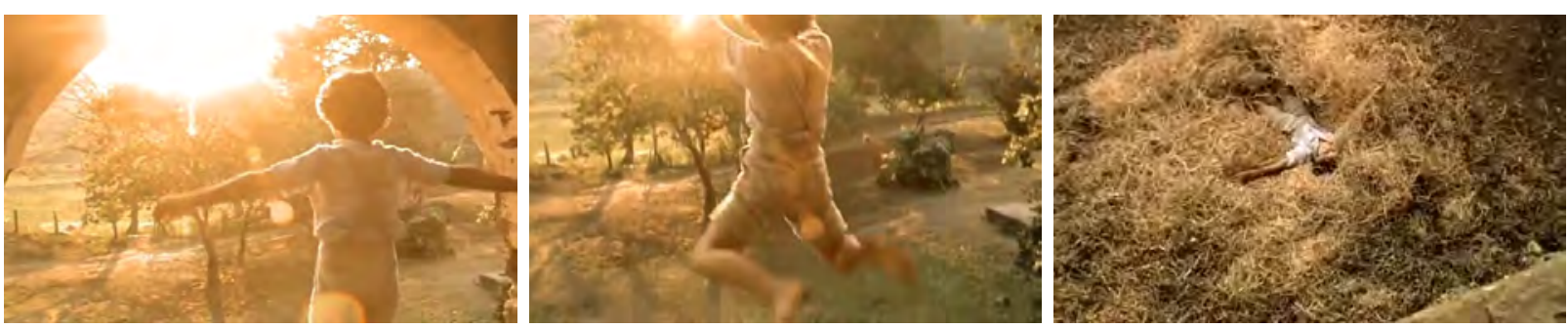

Fig. 181 - Lavoura Arcaica (2001), Luiz Fernando Carvalho

Mas a claridade também tem uma conotação negativa para o personagem, quando se refere em termos luminosos à ternura de seu irmão Pedro: "foram seus olhos plenos de luz em cima de mim que me fizeram envenenado" (NASSAR, 2014, p.15). André afirma que o 
excesso de claridade começa a perturbá-lo: “essa claridade que mais tarde passou a me perturbar, me pondo estranho e mudo no mundo" (NASSAR, 2014, p.26). Na sequência há uma mudança de intensidade de luz até que a imagem desmaterializa-se, tornando-se apenas um clarão.

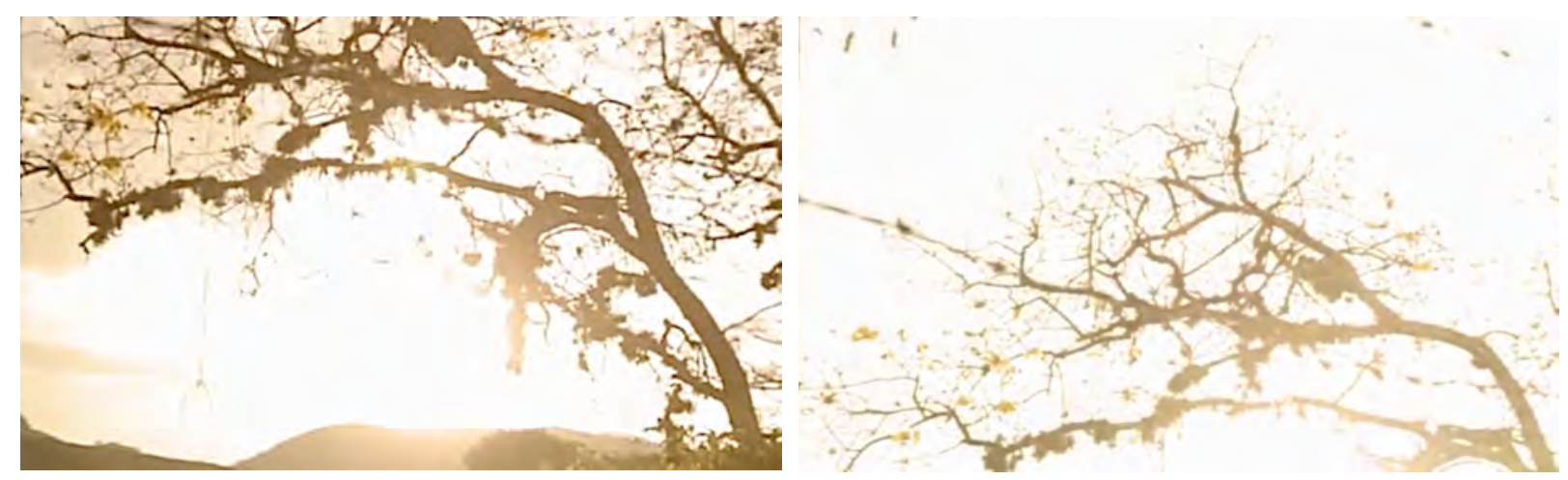

Fig. 182 - Lavoura Arcaica (2001), Luiz Fernando Carvalho

Por outro lado, quando André foge da fazenda, entra em um túnel sem luz. A transição entre os dois momentos de vida do personagem é estabelecida em termos luminosos. André parte da claridade, associada à vida na fazenda, para a escuridão que representaria seu futuro longe da família.

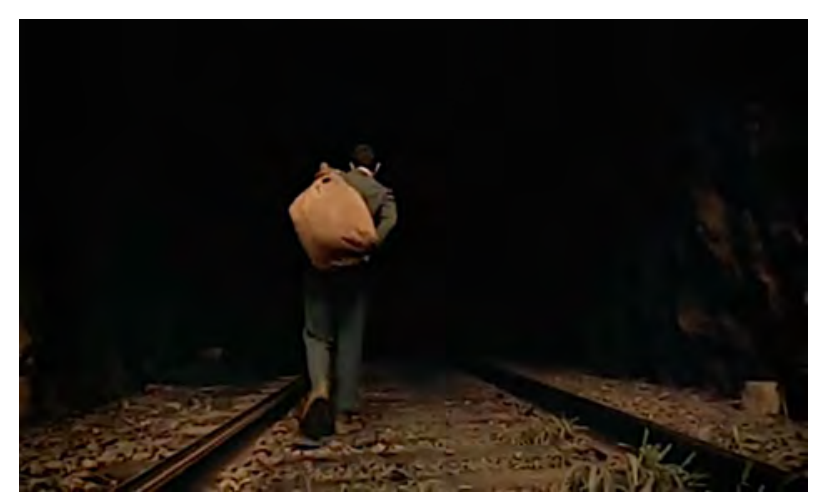

Fig. 183 - Lavoura Arcaica (2001), Luiz Fernando Carvalho

Desse modo, a fotografia de seu momento na pensão é marcada por pretos profundos e alto contraste, à semelhança das pinturas de Caravaggio (1571-1610). O alto contraste representa visulamente o conflito do personagem, que mesmo distante da família se mantém presente.

Uma das características do pintor é a utilização de luz e cor em primeiro plano, sobre um fundo escuro. $\mathrm{O}$ foco, portanto, recai sobre os personagens retratados, evidenciando seus sentimentos por meio das expressões em seus rostos. Em Lavoura Arcaica, a preocupação de Luiz Fernando Carvalho em evidenciar o mundo interno do personagem é resolvida por meio da luz e pelos primeiros planos. 

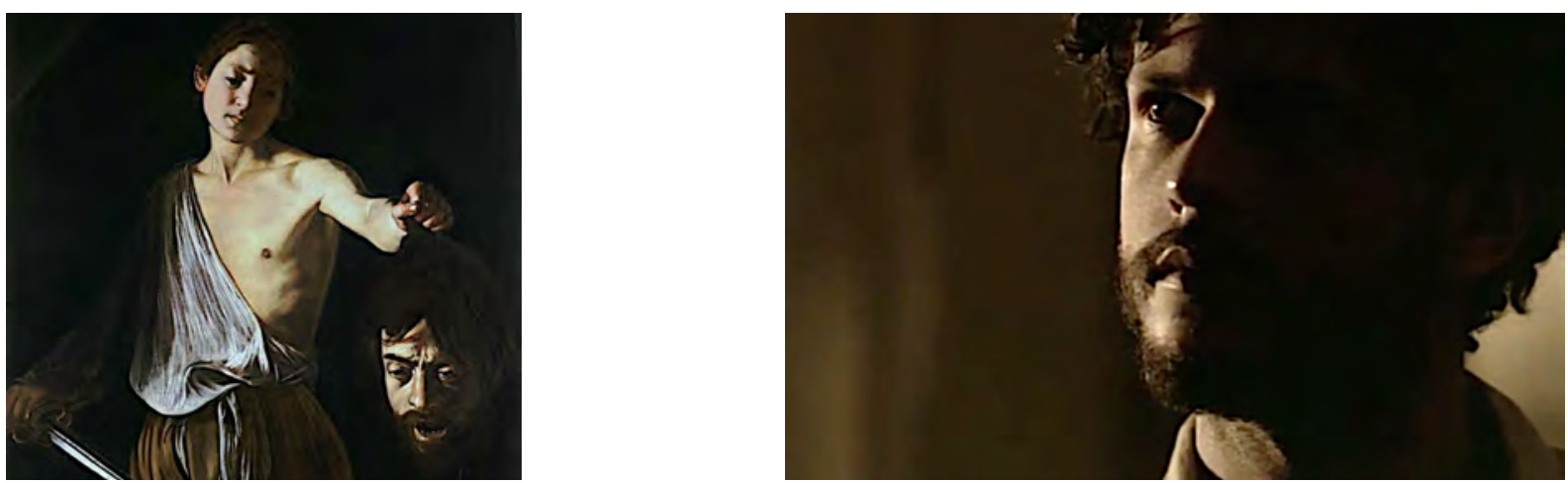

Fig. 184 - David com a cabeça de Golias (1610), Caravaggio e Lavoura Arcaica (2001), Luiz Fernando Carvalho

André fala de seu processo psíquico em termos luminosos e a dualidade claro/escuro da imagem apoia-se no contraste desejo/razão, amor/punição, afetuosidade da mãe/rigidez do pai.

E me lembrei que a gente sempre ouvia nos sermões do pai que os olhos são a candeia do corpo, e que se eles eram bons é porque o corpo tinha luz, e se os olhos não eram limpos é que eles revelavam um corpo tenebroso, e eu ali, diante de meu irmão, respirando um cheiro exaltado de vinho, sabia que meus olhos eram dois caroços repulsivos, mas nem liguei que fossem assim, eu estava confuso, e até perdido [...] eu estava era escuro por dentro, não conseguia sair da carne dos meus sentimentos (NASSAR, 2014, p.13).
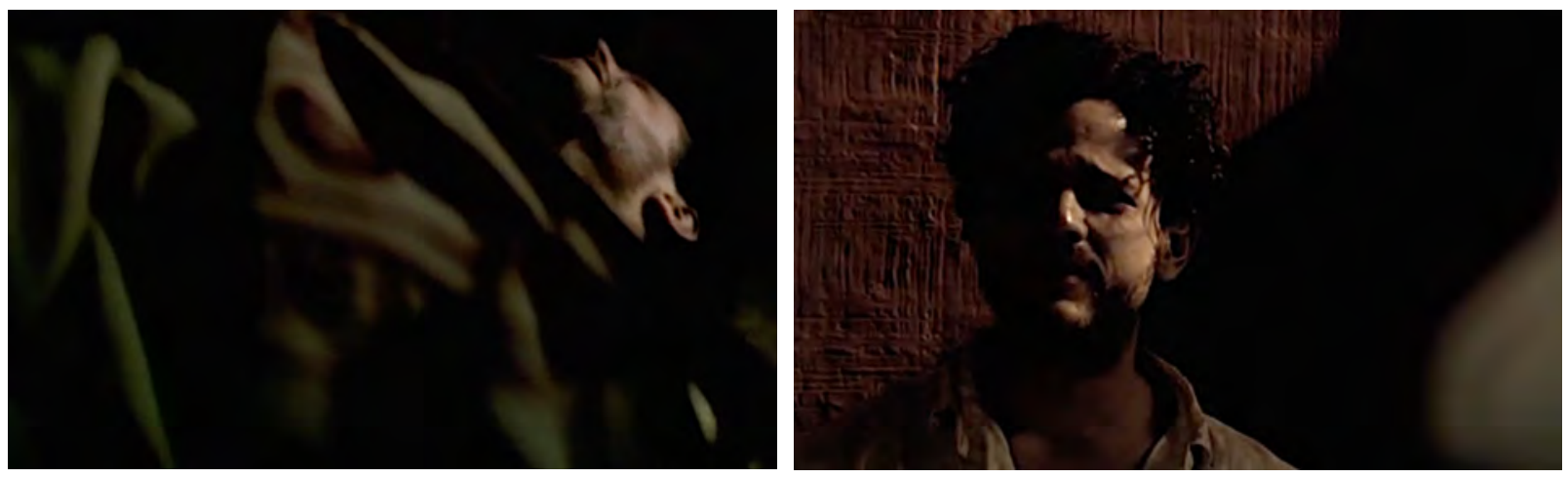

Fig. 185 - Lavoura Arcaica (2001), Luiz Fernando Carvalho

Luiz Fernando Carvalho conta que utilizou como referência "a pintura tenebrista espanhola, com uma grande predominância dos fundos negros e presença dos dourados, que também dialogam com Rembrandt, e as figuras alongadas de El Greco" (CARVALHO, 2002, p. 101). O tenebrismo é um estilo de pintura com grande ênfase no claro/escuro, apresentando contastes intensos entre luzes e sombras. Entre seus expoentes mais conhecidos encontram-se Caravaggio, José de Ribera (1591-1652), Adam de Coster (1583-1643) e posteriormente Georges de La Tour (1593-1652). A semelhança entre a figura do pai e o auto retrato de El Greco (1541-1614) em idade mais avançada evidencia a referência ao pintor. 

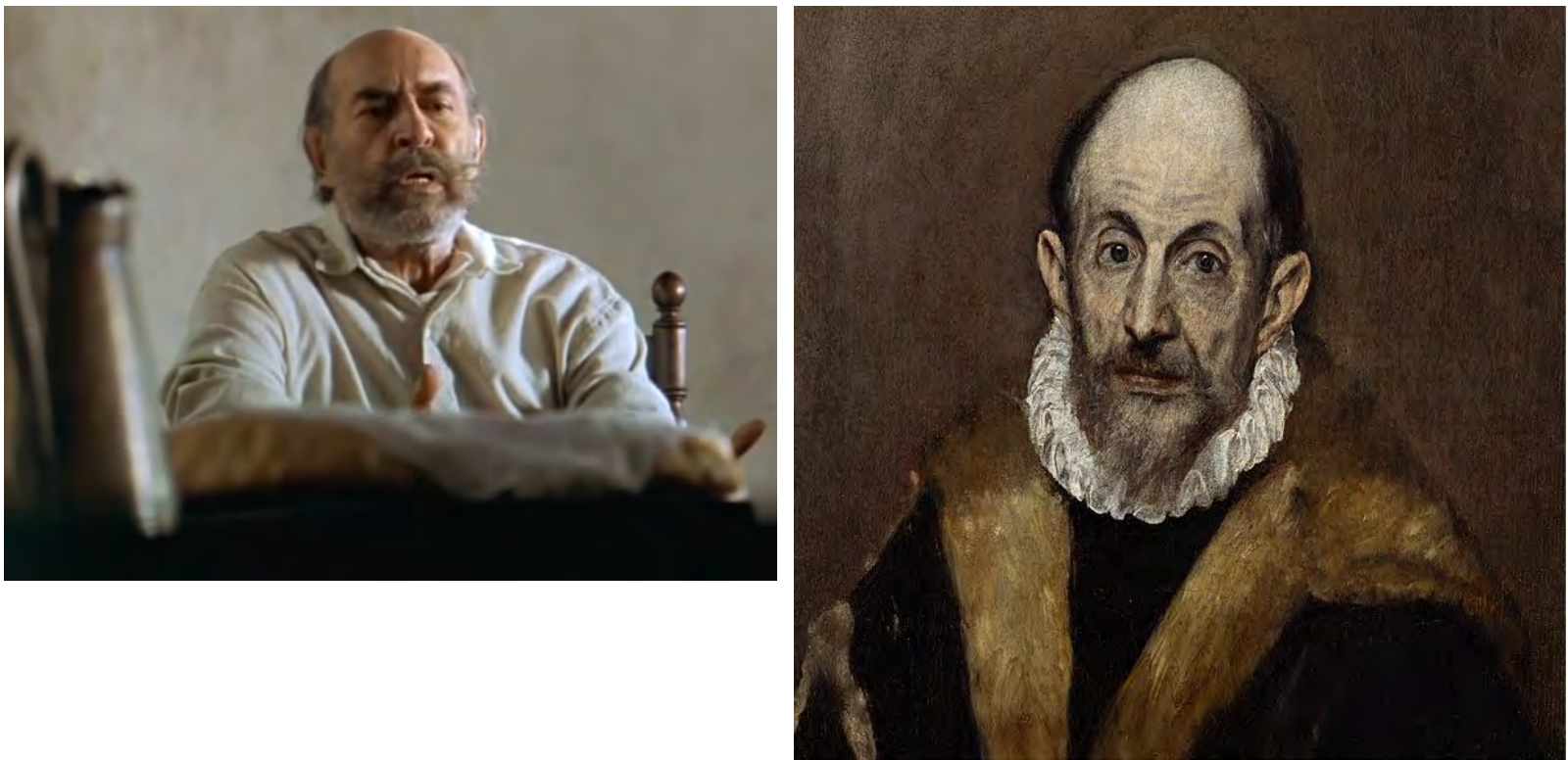

Fig. 186 - Lavoura Arcaica (2001) e Auto retrato de El Greco (1600)

A luz do pai é trabalhada a partir de um dos recursos estéticos do tenebrismo, que é o de iluminar as cenas com uma fonte única de luz bem marcada, que pode vir de uma janela ou da luz de uma vela. O detalhe de uma lamparina sendo acesa, sem aparente função narrativa, marca a iluminação utilizada para o pai.

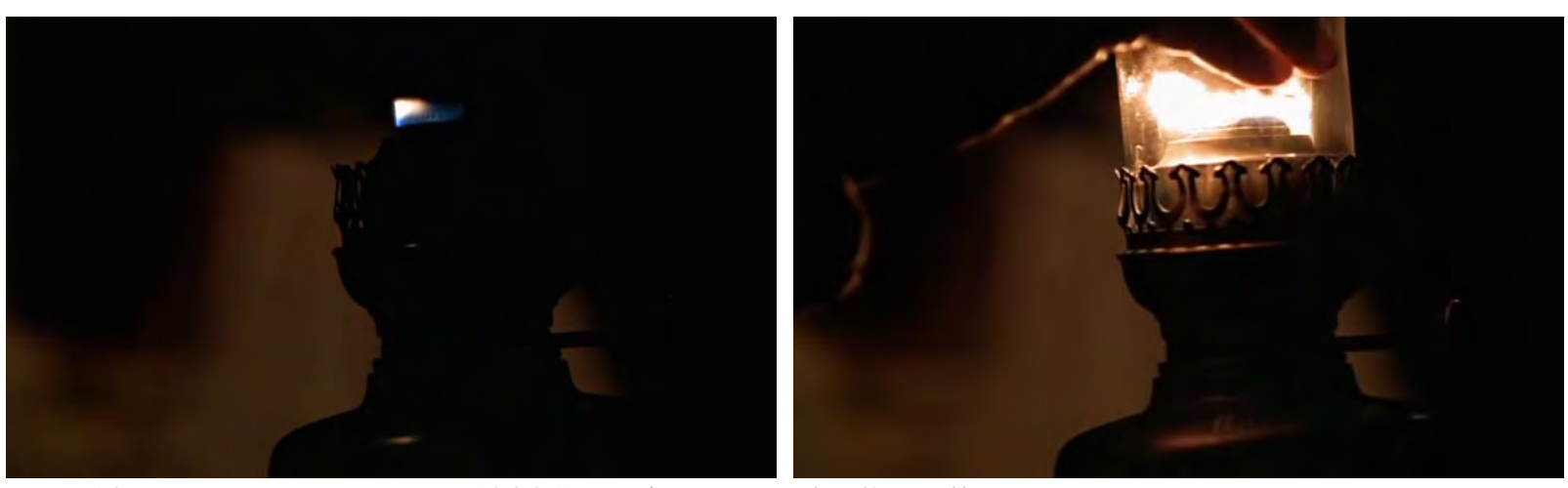

Fig. 187 - Lavoura Arcaica (2001), Luiz Fernando Carvalho

É o que se pode ver na figura 188, a atmosfera sombria do momento da refeição, comparada à luz de $O$ recém nascido (1648), de Georges de La Tour. Observa-se a semelhança entre os histogramas das duas imagens. 

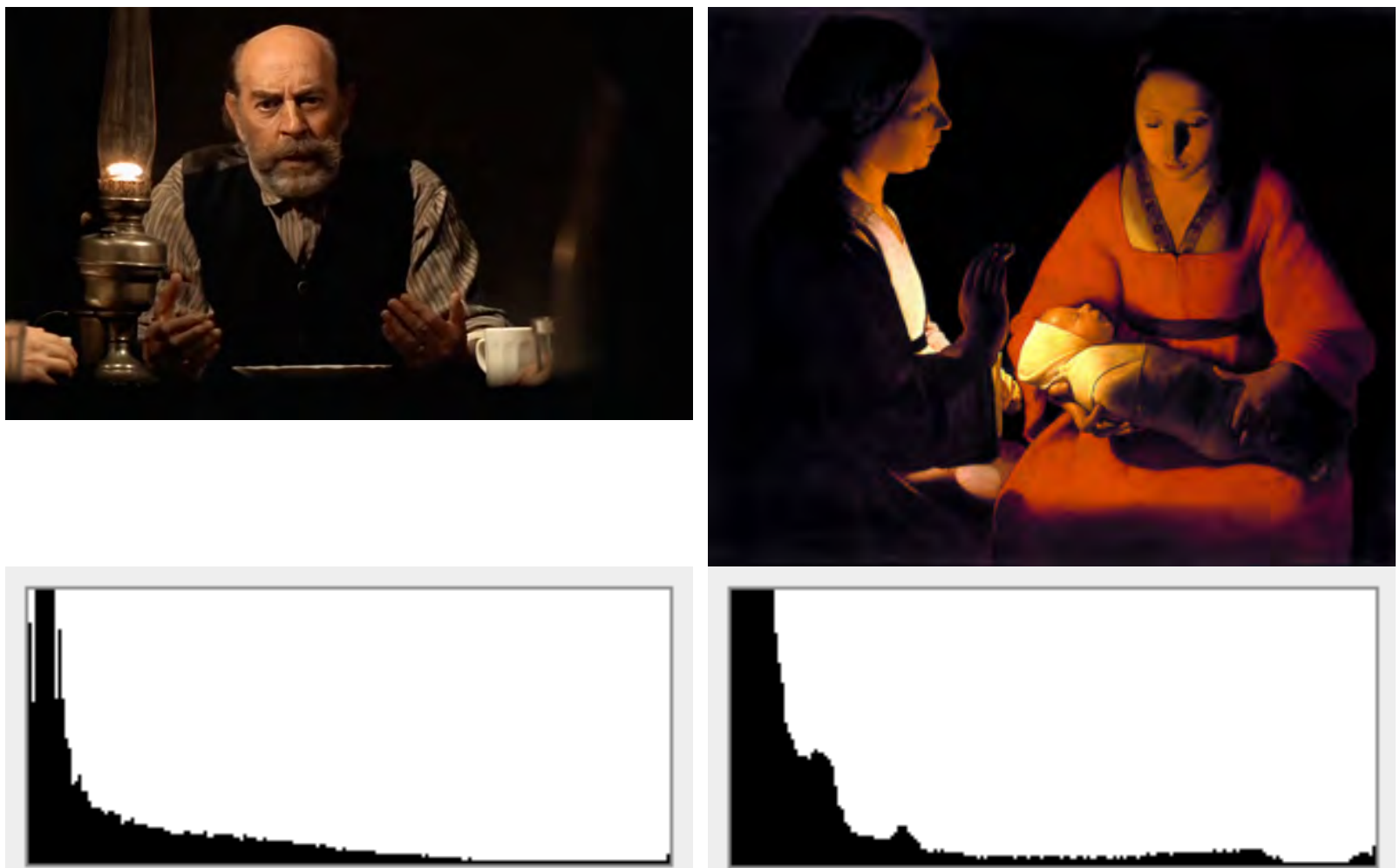

Fig. 188 - Lavoura Arcaica (esq) e O recém nascido (dir)

Além das velas, Walter Carvalho utiliza as janelas como fontes. A luz das janelas é filmada de duas maneiras: ora ilumina diretamente o interior (figura 189) ora é filtrada pelas cortinas, projetando sombras e desenhos nas parede e no teto dos ambientes (figura 190).
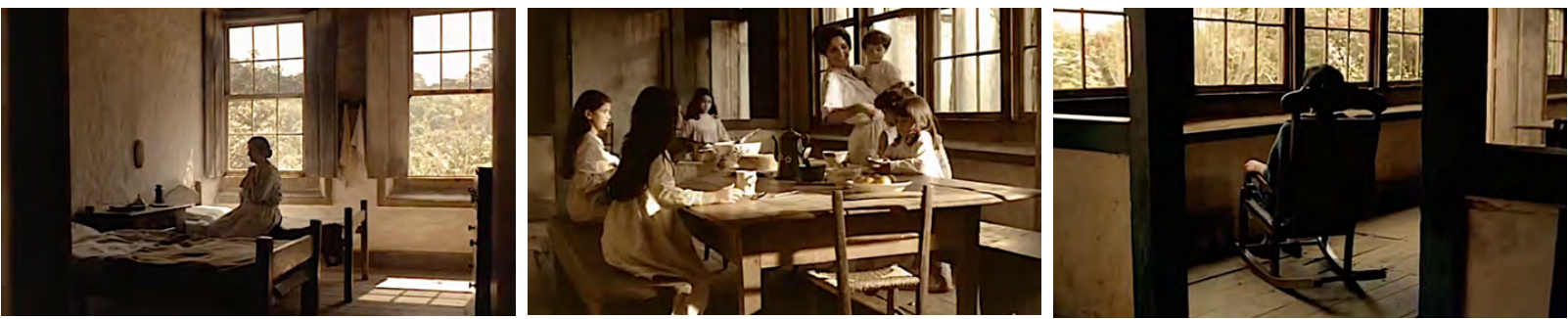

Fig. 189 - Lavoura Arcaica (2001), Luiz Fernando Carvalho
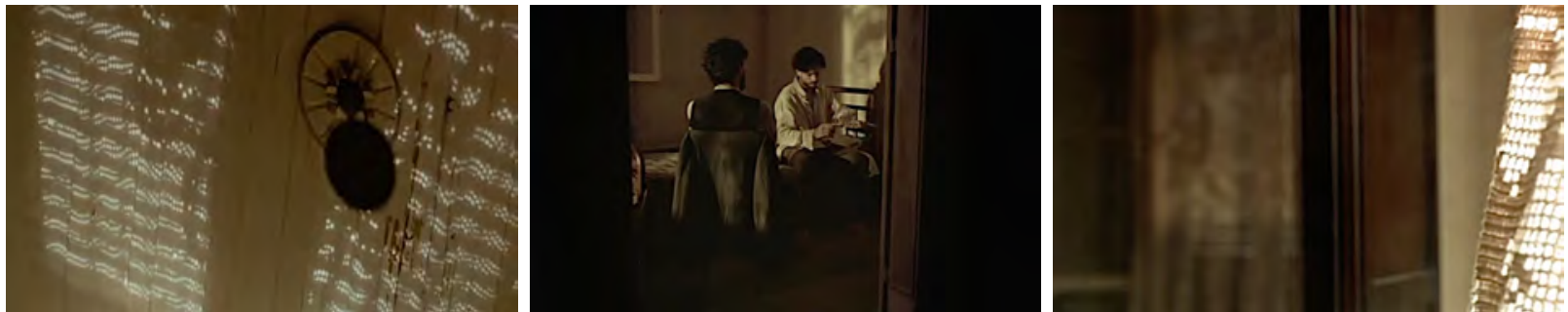

Fig. 190 - Lavoura Arcaica (2001), Luiz Fernando Carvalho

$\mathrm{Na}$ sequência que precede o incesto, a passagem do tempo é marcada pela transformação da luz que vem da janela. As mulheres da casa tiram a mesa e deixam apenas o 
prato de André, que esteve ausente da refeição. A luz começa a mudar, sendo possível ver um raio de sol que ilumina o canto inferior esquerdo do quadro. A mãe e as irmãs dedicam-se aos seus afazeres, entrando e saindo de quadro, enquanto o sol vai invadindo a sala de jantar. Ana surge em quadro e vai até o lugar do irmão. Fica parada por alguns instantes, sua mão banhada pelo sol que entra da janela, até que começa a retirar os utensílios de André.
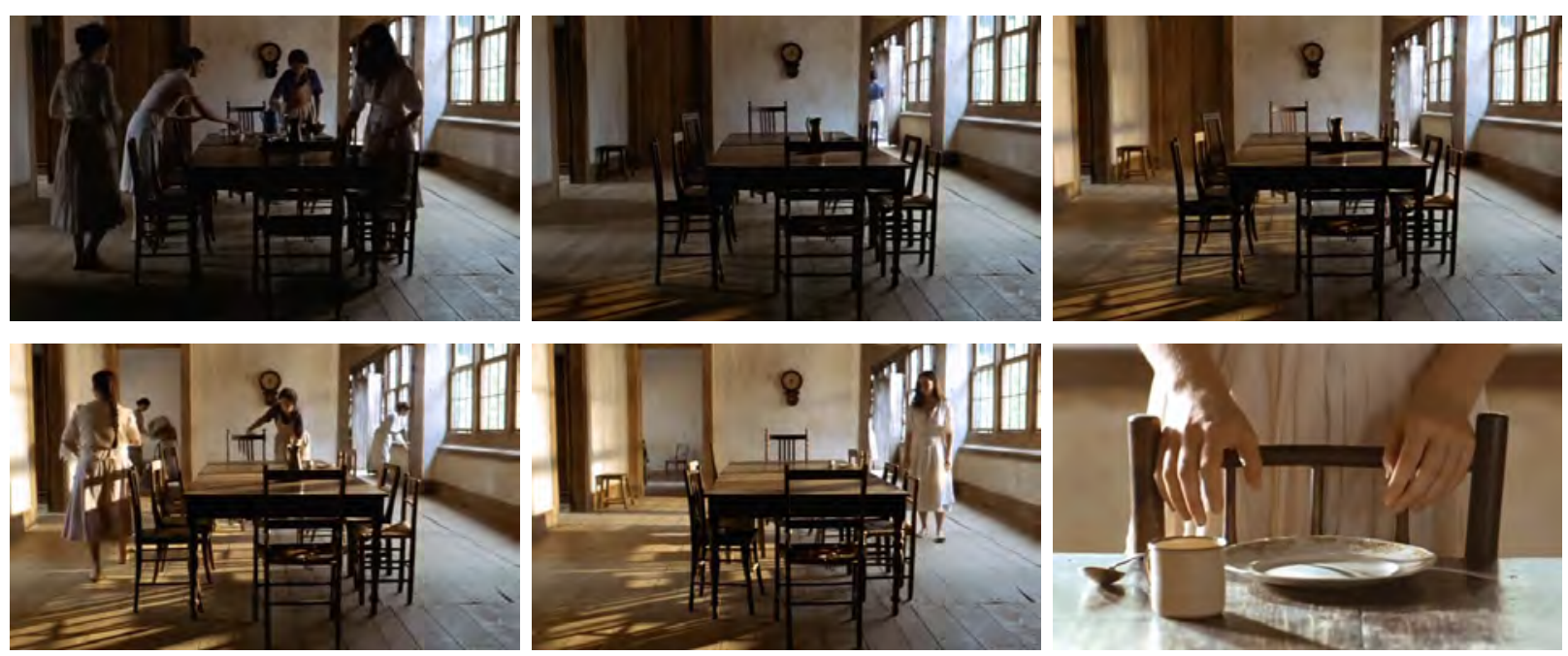

Fig. 191 - Lavoura Arcaica (2001), Luiz Fernando Carvalho

No caso das sombras projetadas, há dois momentos disjuntos que tratam do êxtase de André e se relacionam pela luz. No primeiro deles, o personagem ainda menino fala sobre sua percepção de Deus enquanto a luz da janela projeta sua sombra na parede.

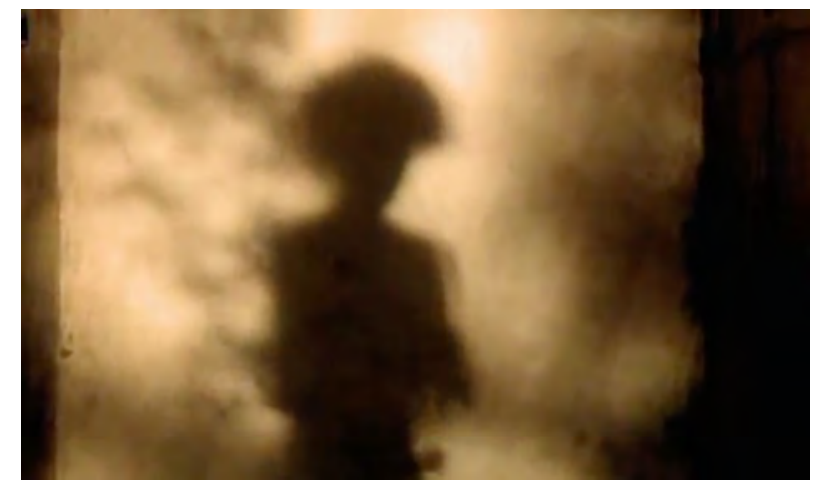

Fig. 192 - Lavoura Arcaica (2001), Luiz Fernando Carvalho

Trata-se de um momento de êxtase religioso, que precede a cena do seu levitar: "e assim que eu levantava, Deus estava na minha frente em cima do criado mudo. E era um Deus que eu podia pegar com as mãos e que enchia meu peito de menino e eu entrava na igreja feito um balão". André voa até a capela e aterrissa na entrada. 

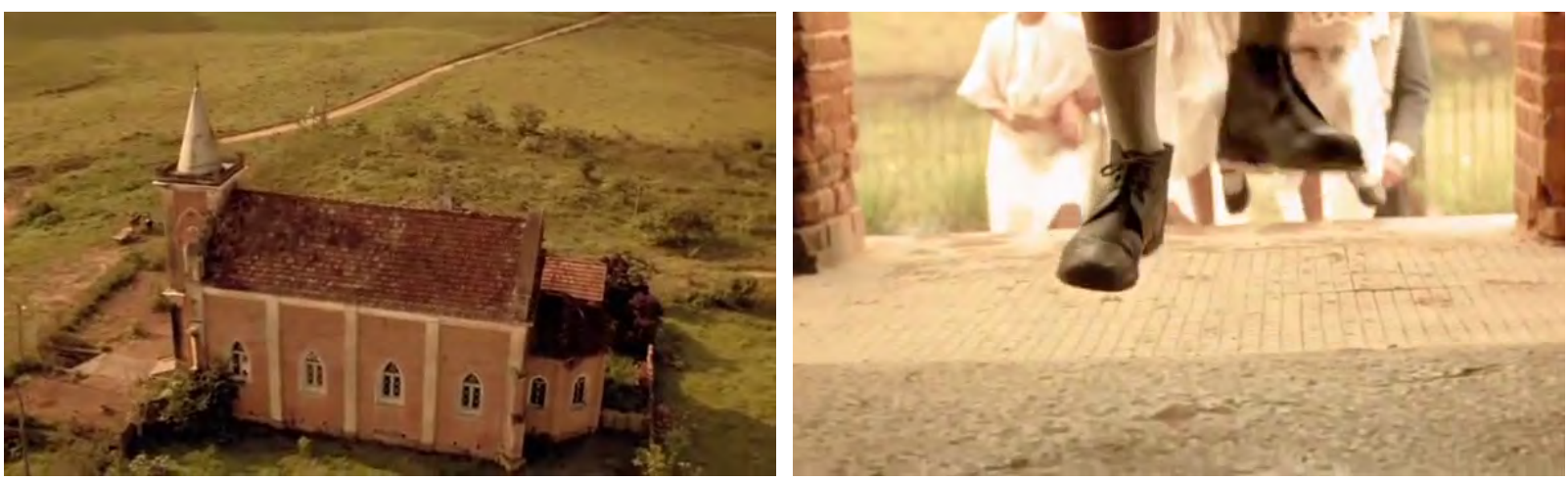

Fig. 193 - Lavoura Arcaica (2001), Luiz Fernando Carvalho

O segundo momento acontece após a consumação do incesto, quando André encontra Ana na capela. Ao contrário da cena da infância, em que o êxtase religioso o faz levitar, o êxtase carnal o traz para o chão, para a concretização dos desejos. Está escuro e André entra na capela andando.

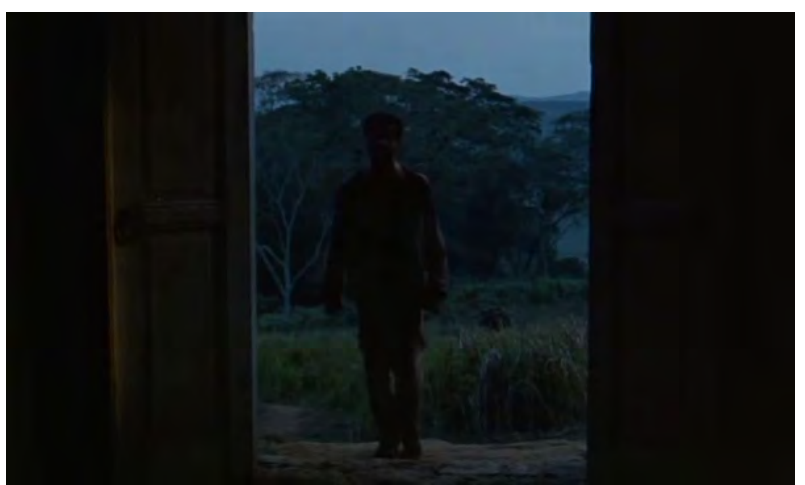

Fig. 194 - Lavoura Arcaica (2001), Luiz Fernando Carvalho

As velas projetam sua sombra na parede enquanto diz: "te amo, Ana. Escute, é só o que te peço. Foi um milagre o que aconteceu entre nós, querida irmã. Descobrimos que somos tão conformes em nossos corpos e que vamos em nossa união continuar a infância, sem mácula para nossos brinquedos, sem trauma para nossa história”. As sombras, portanto, marcam dois momentos de comunhão do personagem: a comunhão com o divino e a comunhão com o humano.
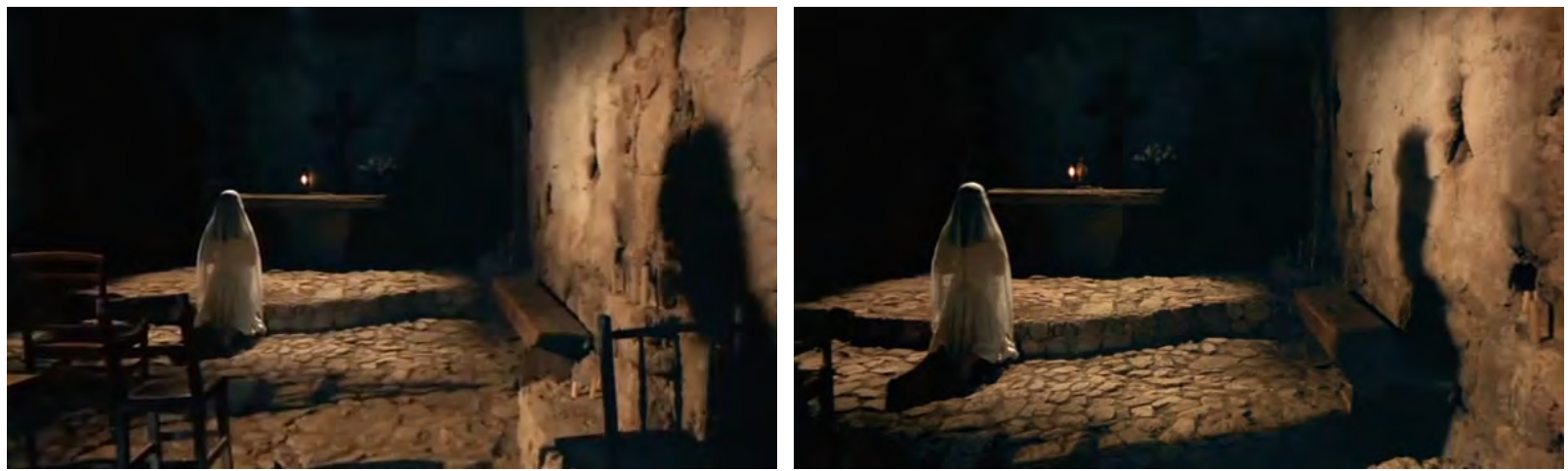

Fig. 195 - Lavoura Arcaica (2001), Luiz Fernando Carvalho 
Como em Central do Brasil, as janelas funcionam não apenas como fontes luminosas, mas como molduras, produzindo quadros dentro do quadro.
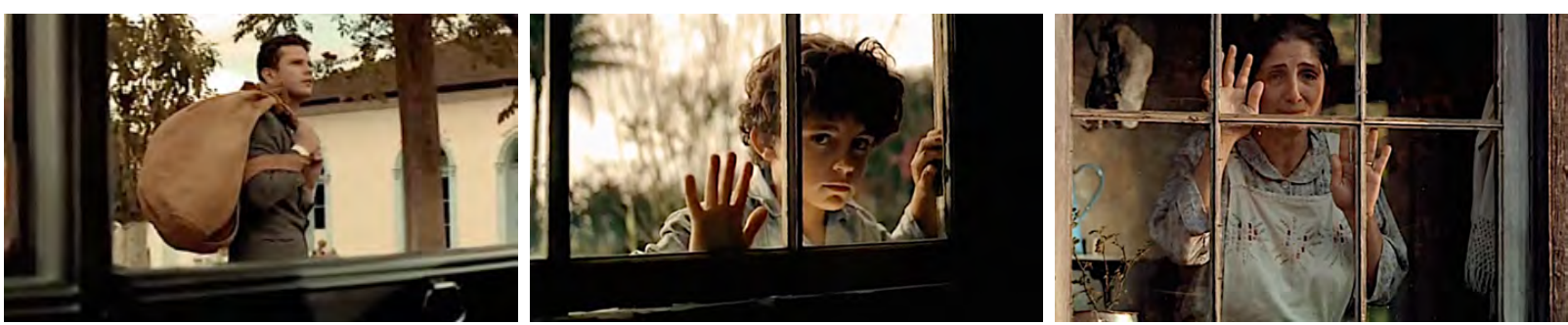

Fig. 196 - Lavoura Arcaica (2001), Luiz Fernando Carvalho

Outros elementos orgânicos também funcionam como molduras: cercas, árvores, o próprio corpo dos personagens.
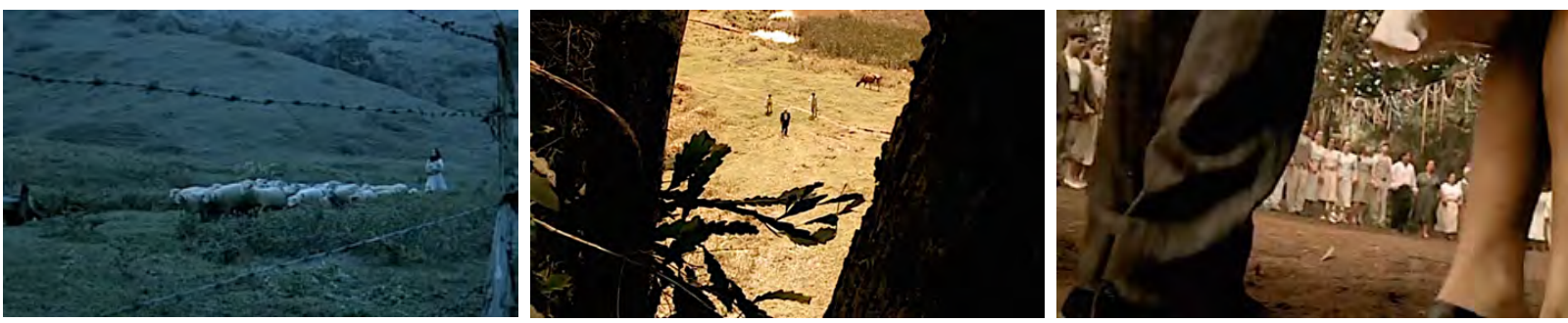

Fig. 197 - Lavoura Arcaica (2001), Luiz Fernando Carvalho

A divisão do quadro verticalmente em três partes aparece, porém com menor frequência que nos filmes anteriores.
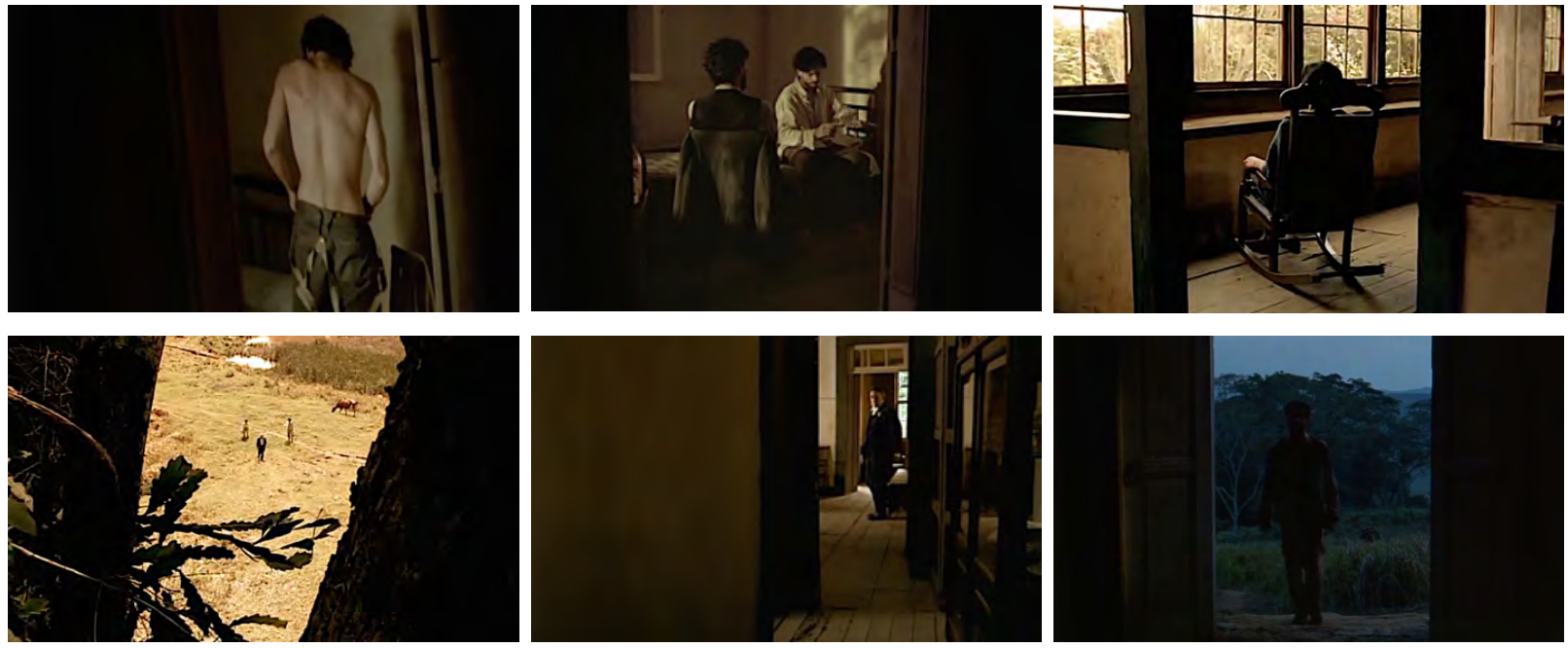

Fig. 198 - Lavoura Arcaica (2001), Luiz Fernando Carvalho 
Como em Terra Estrangeira, as diagonais são exploradas na disposição dos personagens.
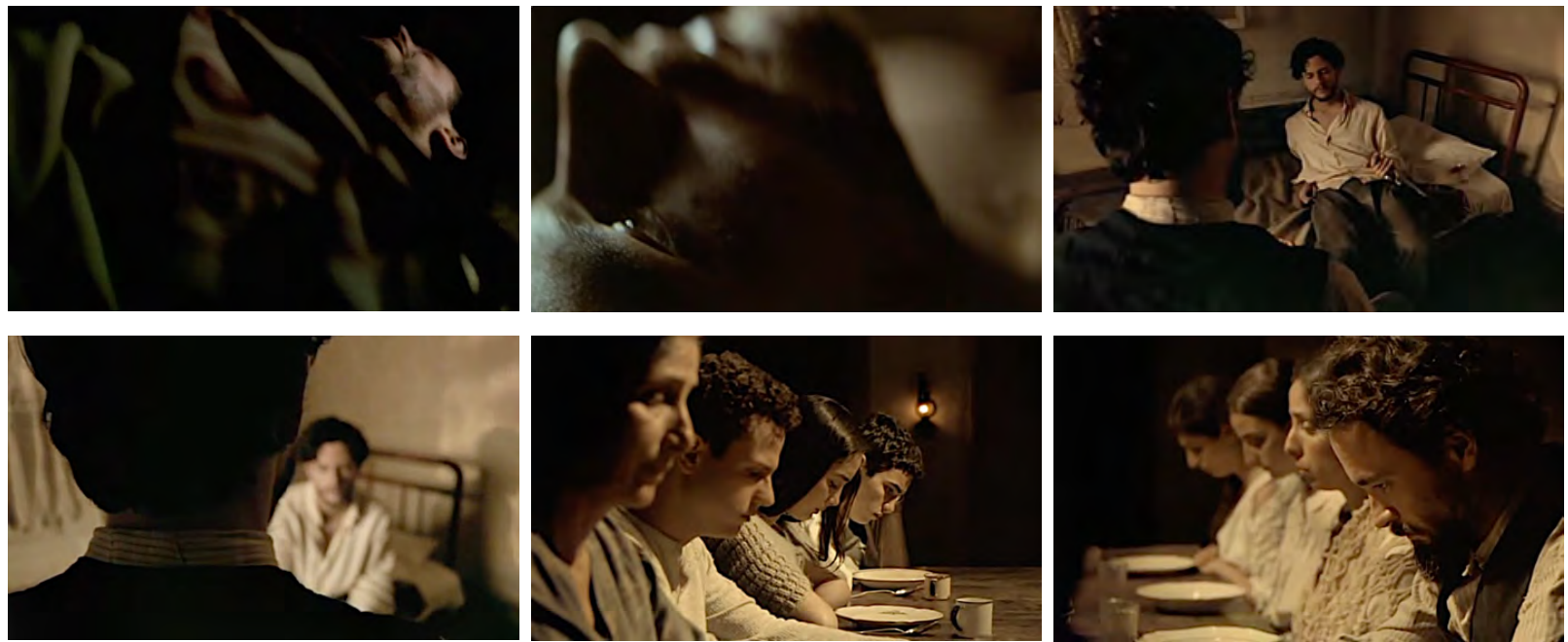

Fig. 199 - Lavoura Arcaica (2001), Luiz Fernando Carvalho

Além dos contrastes, Lavoura Arcaica é um filme de detalhes. Os planos muito fechados não são utilizados para explicar a narrativa mas sim para evidenciar os sentimentos dos personagens e suas relações. É o que ocorre na primeira sequência do filme, em que André é apresentado ao espectador: o detalhe associa-se à pequena profundidade de campo, à iluminação, ao som e à ação para retratar o conflituoso personagem. É também o que ocorre na cena da parábola do faminto, em que as mãos contraídas expressam o sentimento de André em relação ao pai.
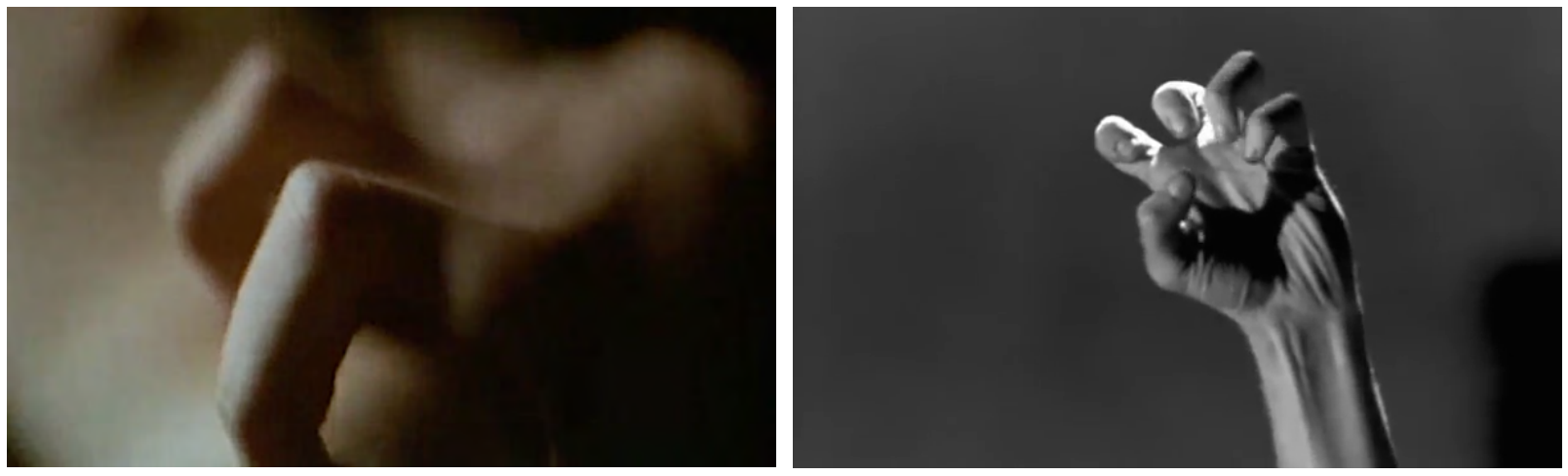

Fig. 200 - Lavoura Arcaica (2001), Luiz Fernando Carvalho

Os detalhes dos pés e mãos de André marcam o desejo do personagem pela irmã, como pode ser visto na figura 201. 

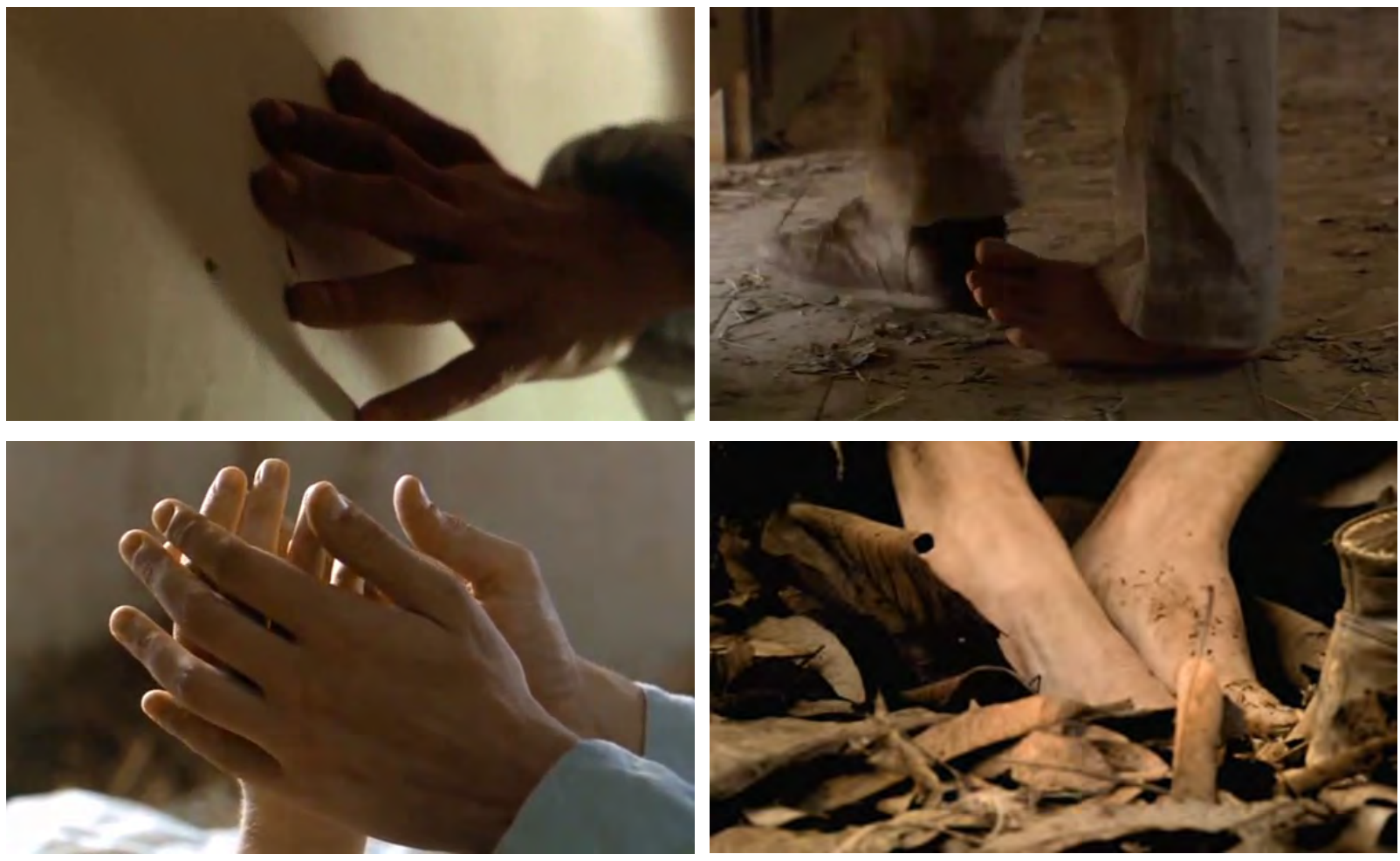

Fig. 201 - Lavoura Arcaica (2001), Luiz Fernando Carvalho

O detalhe também aparece na relação afetuosa de André com a mãe, no abraço de Pedro ao sair em busca do irmão mais novo, nas mãos dos membros da família unidas por um nó, na disposição dos lugares à mesa.
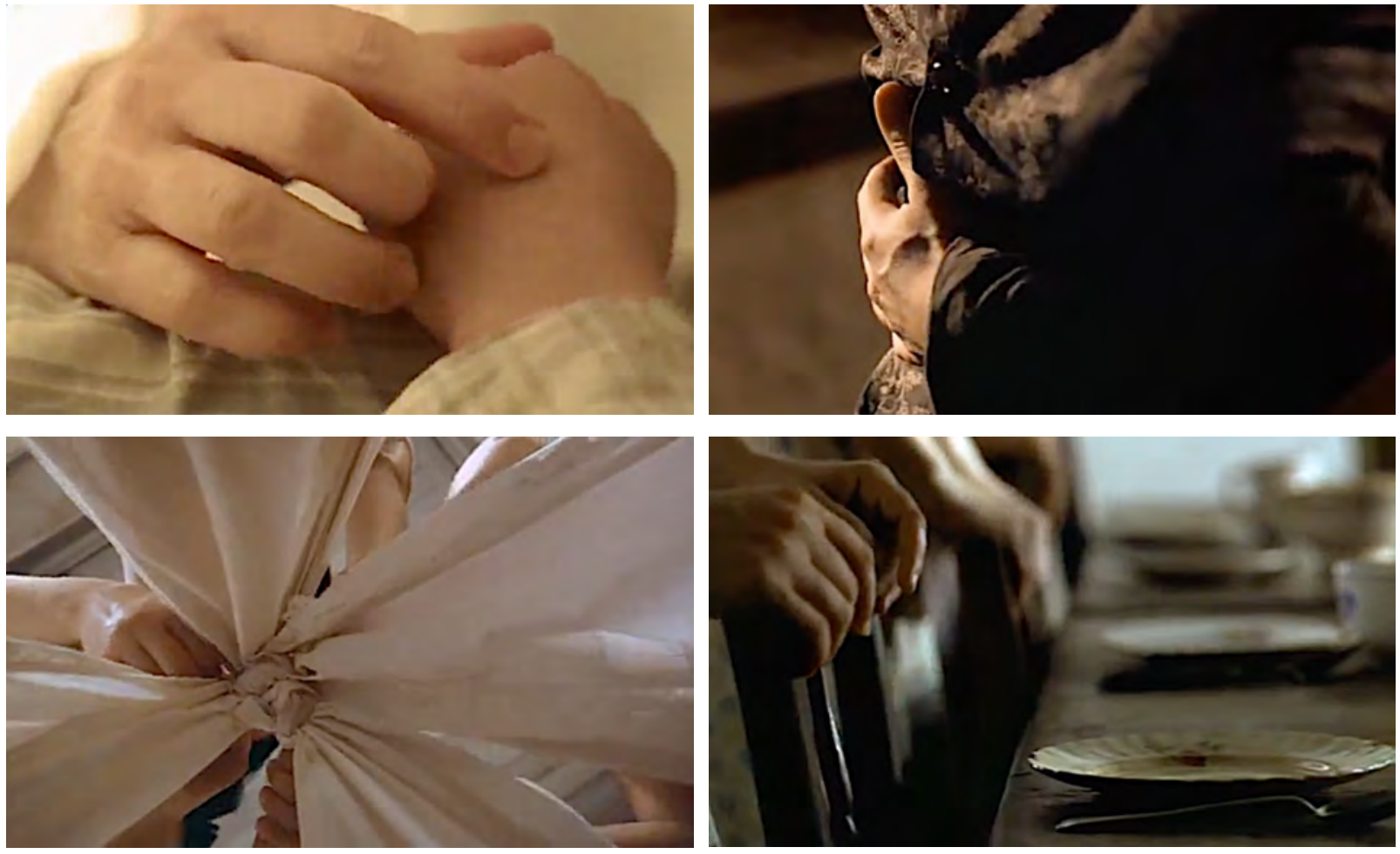

Fig. 202 - Lavoura Arcaica (2001), Luiz Fernando Carvalho 
Além da troca de afeto, o ênfase nas mãos traz a dimensão do trabalho cotidiano e do ritual de austeridade da família, descrito por André.

"Vou puxando desse feixe de rotinas, um a um, os ossos sublimes de nosso código de conduta: o excesso proibido; o zelo uma exigência; condenado como vício, a prática constante contra o desperdício, apontado sempre como ofensa grave ao trabalho (...) e também uma escola de meninos artesãos, defendendo de adquirir fora o que pudesse ser feito com nossas próprias mãos. E uma lei ainda mais rígida, dispondo que era lá mesmo, na fazenda, que deveria ser amassado nosso pão. Nunca tivemos outro em nossa mesa que não fosse o pão de casa, e era na hora de repartilo, que concluíamos três vezes ao dia o nosso ritual de austeridade, sendo que era também na mesa, mais que em qualquer outro lugar, onde fazíamos de olhos baixos o nosso aprendizado da justiça".
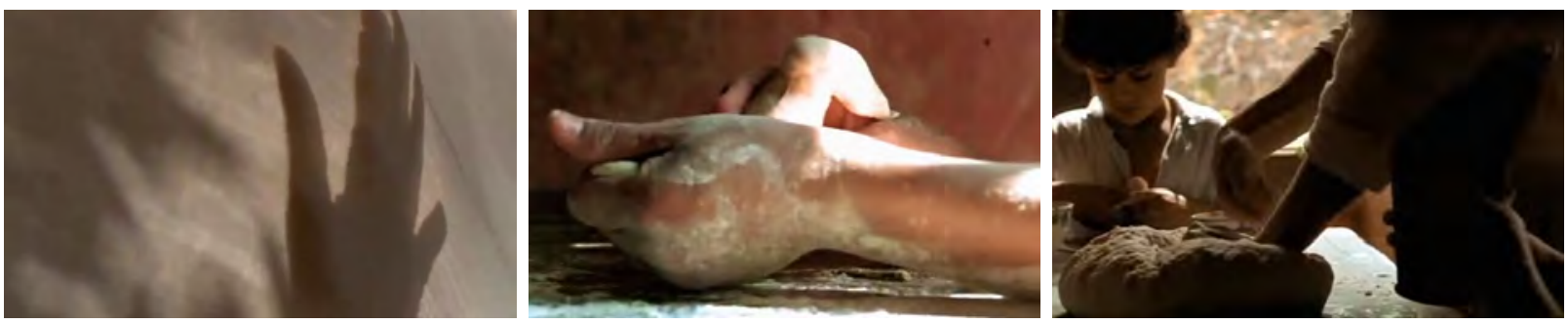

Fig. 203 - Lavoura Arcaica (2001), Luiz Fernando Carvalho

Os primeiros planos dos rostos são muito utilizados, e com o mesmo objetivo dos planos-detalhe: enfatizar as emoções. É o caso do plano em que André toca seu rosto no espelho, do diálogo entre os irmãos, do momento em que mãe e filho se olham através da janela, da despedida silenciosa e distanciada da mãe, da despedida de Ana através dos olhares.
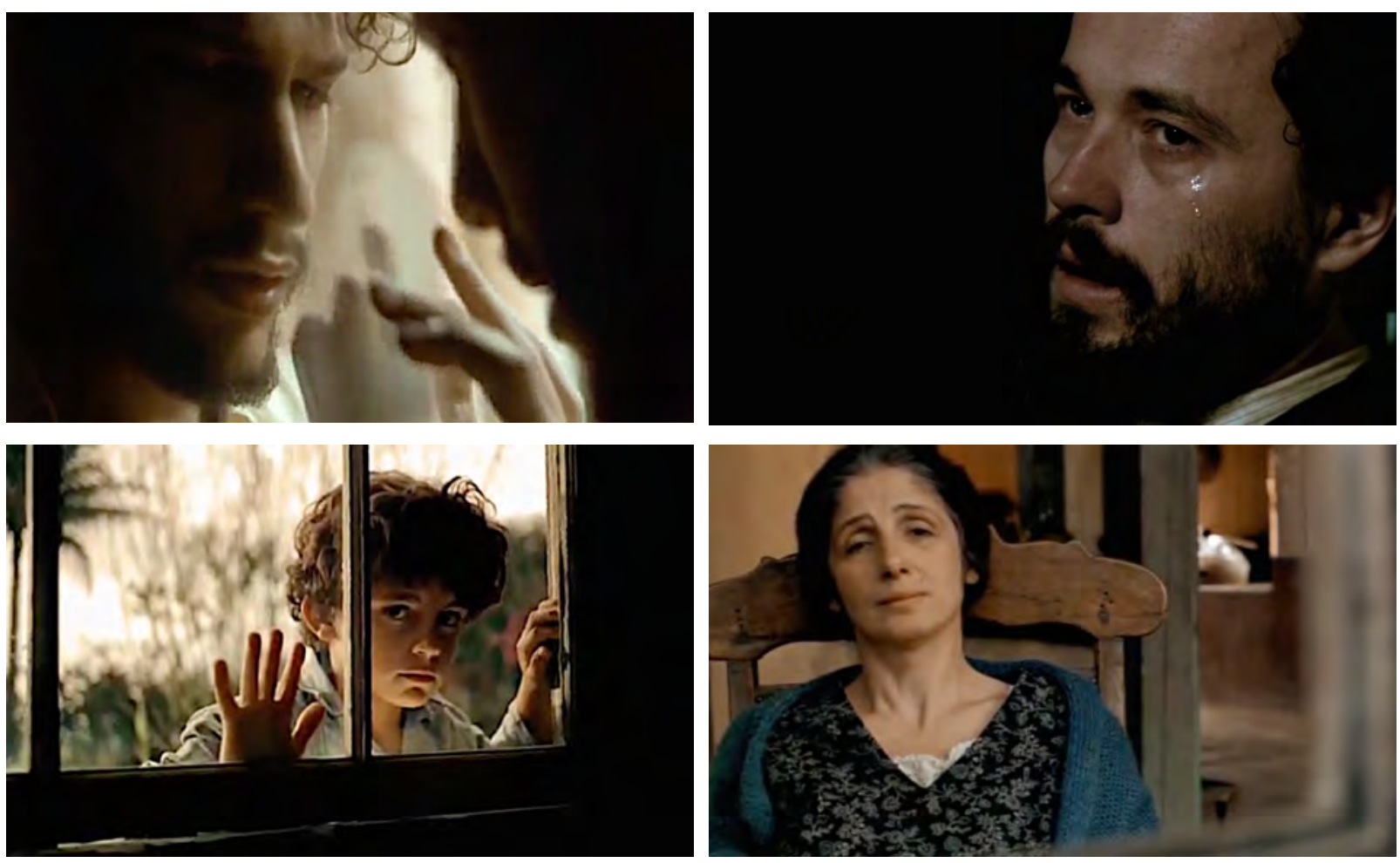

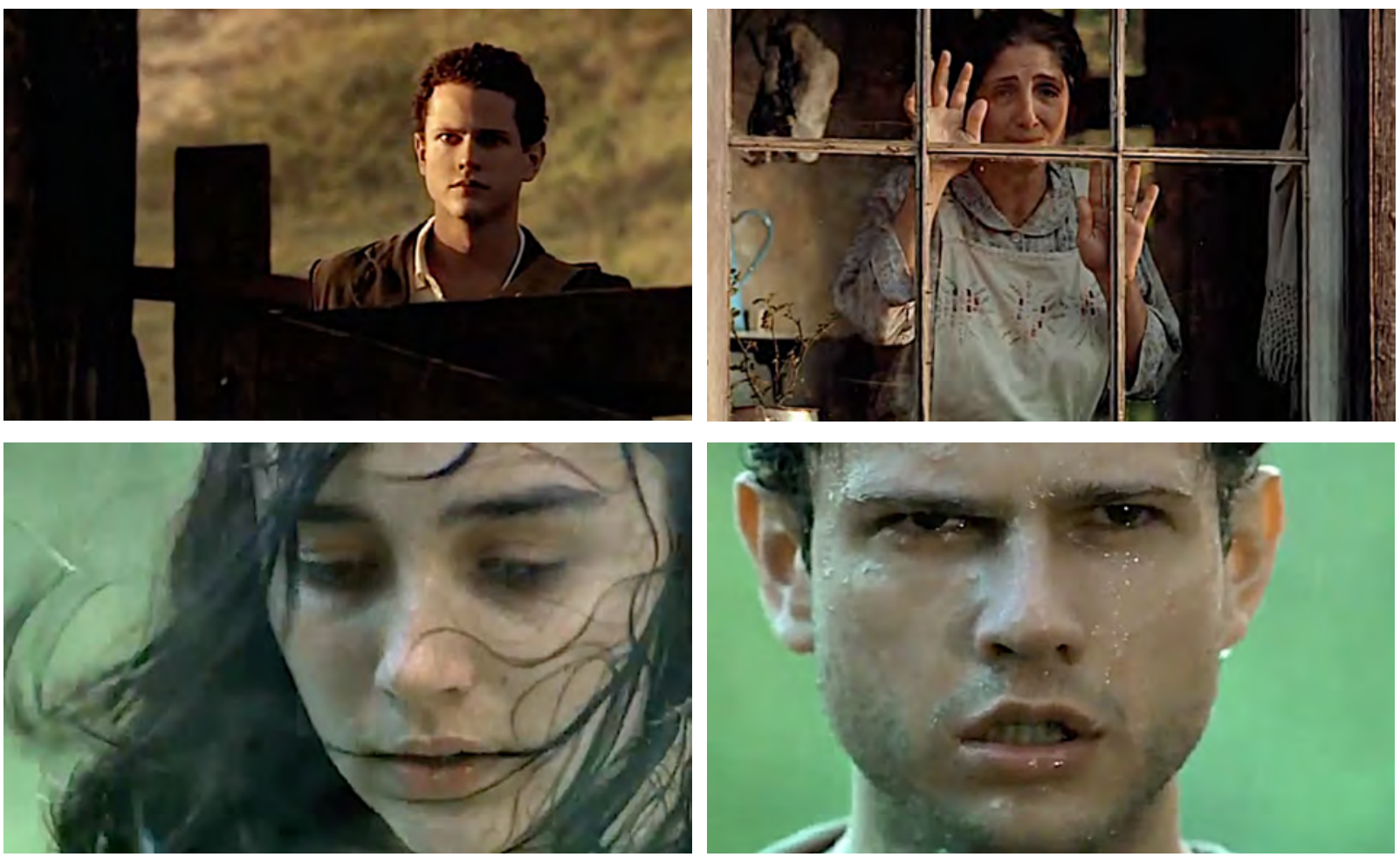

Fig. 204 - Lavoura Arcaica (2001), Luiz Fernando Carvalho

Há primeiros planos que se assemelham a enquadramentos de filmes anteriores de Walter Carvalho, como é possível ver nos fotogramas da figura 205, comparando-se um plano de Terra Estrangeira ao plano em que André menino observa sua irmã.
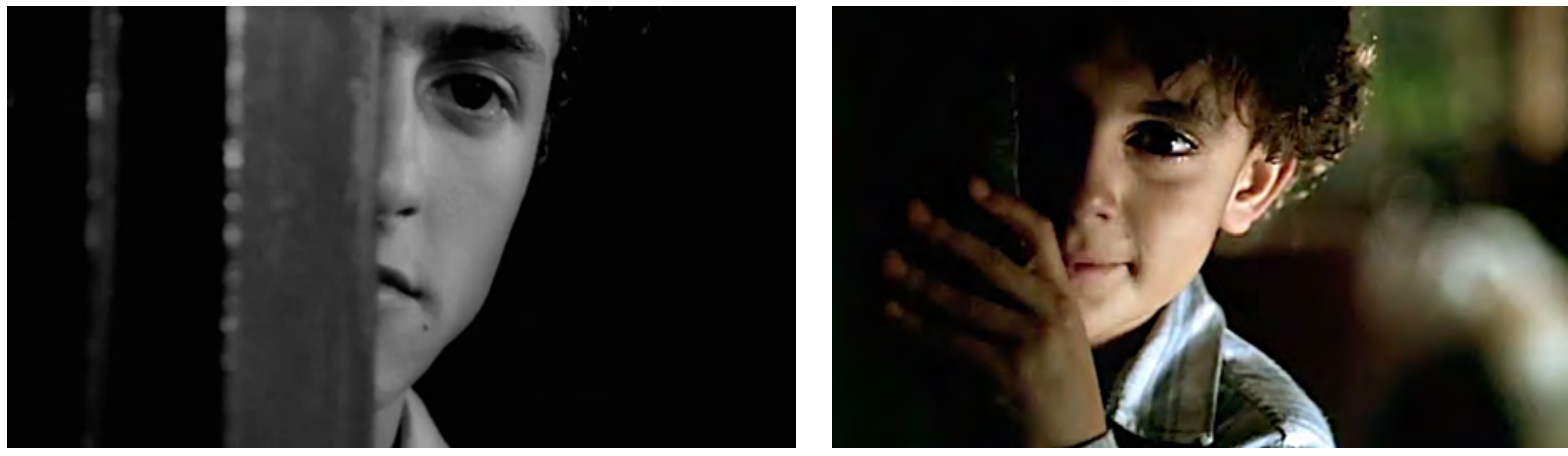

Fig. 205 - Terra Estrangeira (esq) e Lavoura Arcaica (dir)

As sutilezas de Lavoura Arcaica são enfatizadas pelos movimentos suaves de câmera. O erotismo está presente não apenas no incesto que move o enredo, mas na lentidão da câmera, que perscruta os personagens. É o caso da cena inicial, em que a câmera percorre o corpo de André, dos pés que se afundam nas folhas e da sequência em que Ana se isola pela falta do irmão (figura 206). 

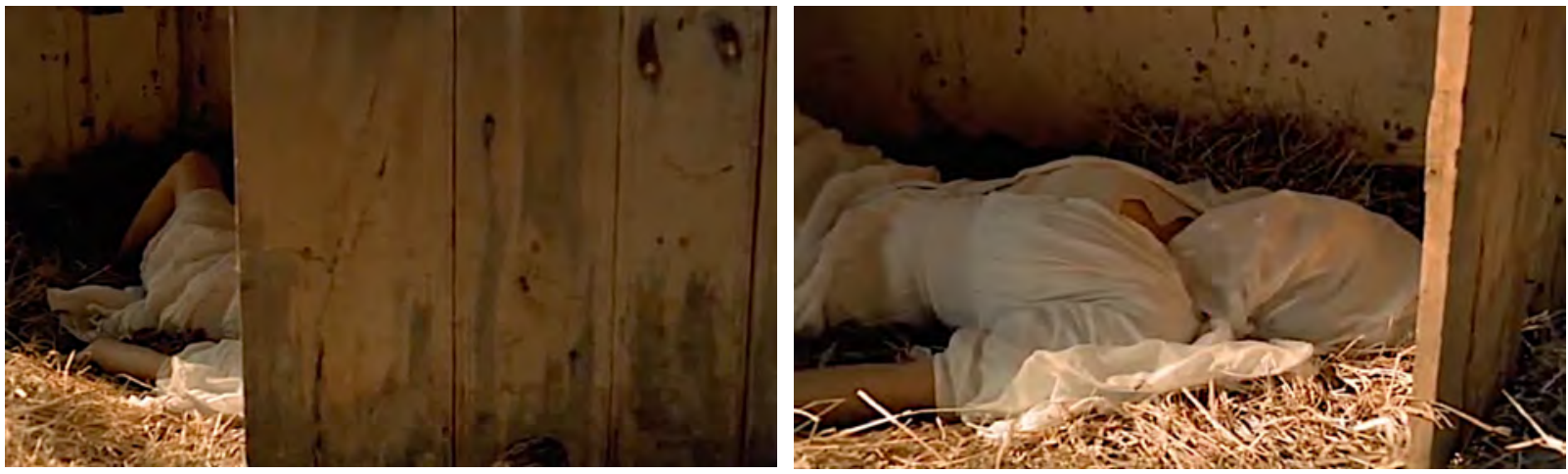

Fig. 206 - Lavoura Arcaica (2001), Luiz Fernando Carvalho

Mesmo nas sequências em que a conotação erótica não está presente, o movimento é lento, marcando o ritmo da vida na casa. E o caso do travelling in da mãe na cadeira de balanço, seguido da subjetiva da personagem que olha a janela, da grua que observa pai e filhos no campo, do detalhe das mãos dos que sentam à mesa.
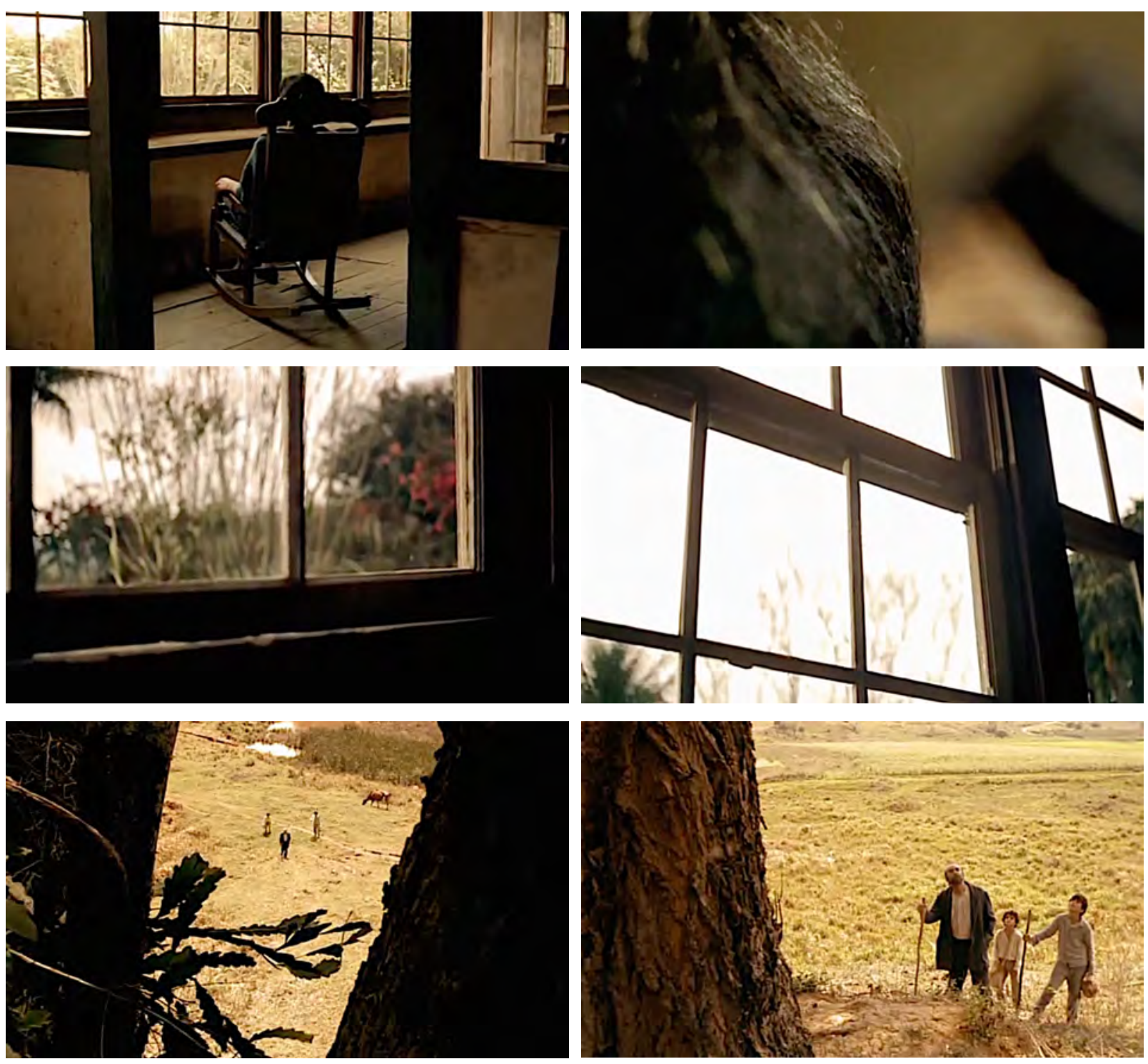

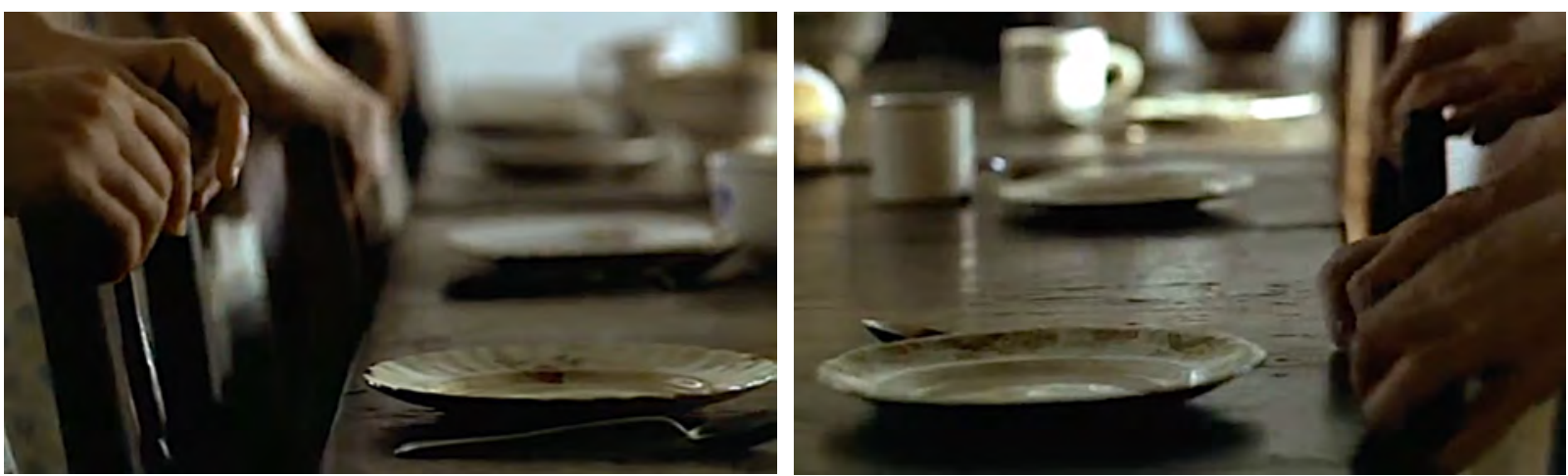

Fig. 207 - Lavoura Arcaica (2001), Luiz Fernando Carvalho

Assim como a luz, a cor tem tratamento diversificado durante a narrativa. A predominância de marrons, ocres, dourados e pretos profundos, tanto na cor-pigmento quanto na cor-luz do filme, vem das referências pictóricas utilizadas pelo diretor e pelo diretor de fotografia. A luz das velas traz o dourado e o alaranjado de inspiração tenebrista, porém com matizes menos saturados que Central do Brasil.
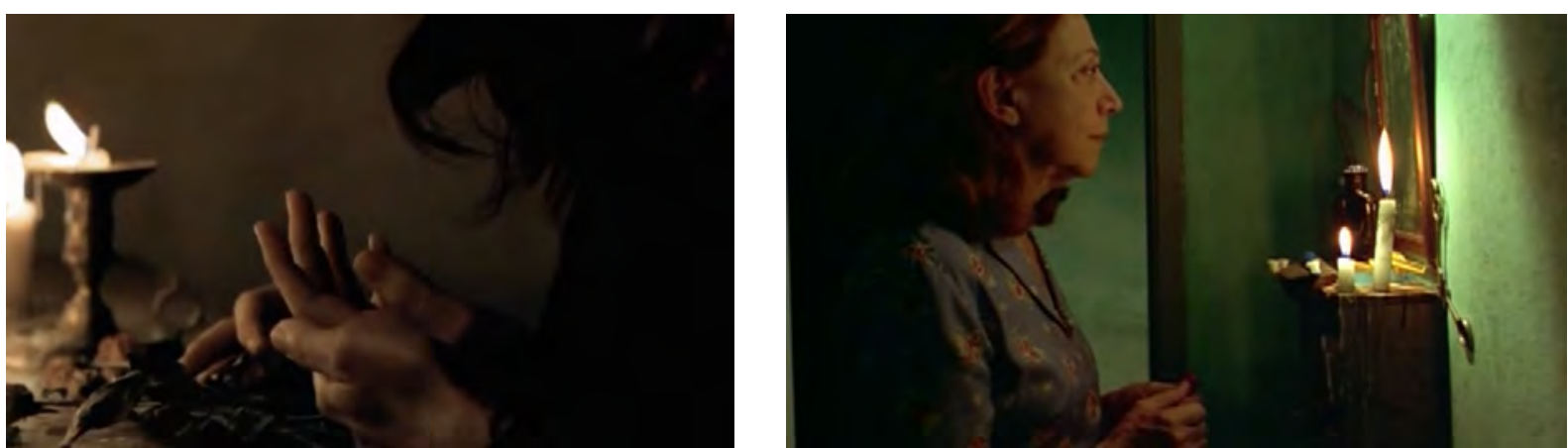

Fig. 208 - Lavoura Arcaica (esq) e Central do Brasil (dir)

As cenas do quarto de pensão apresentam a paleta mais reduzida do filme. Trata-se do longo diálogo entre os irmãos, que conduz as memórias de André. O conflito entre os dois personagens e suas personalidades muito distintas garantem uma polarização que se traduz em uma pequena gama de matizes.
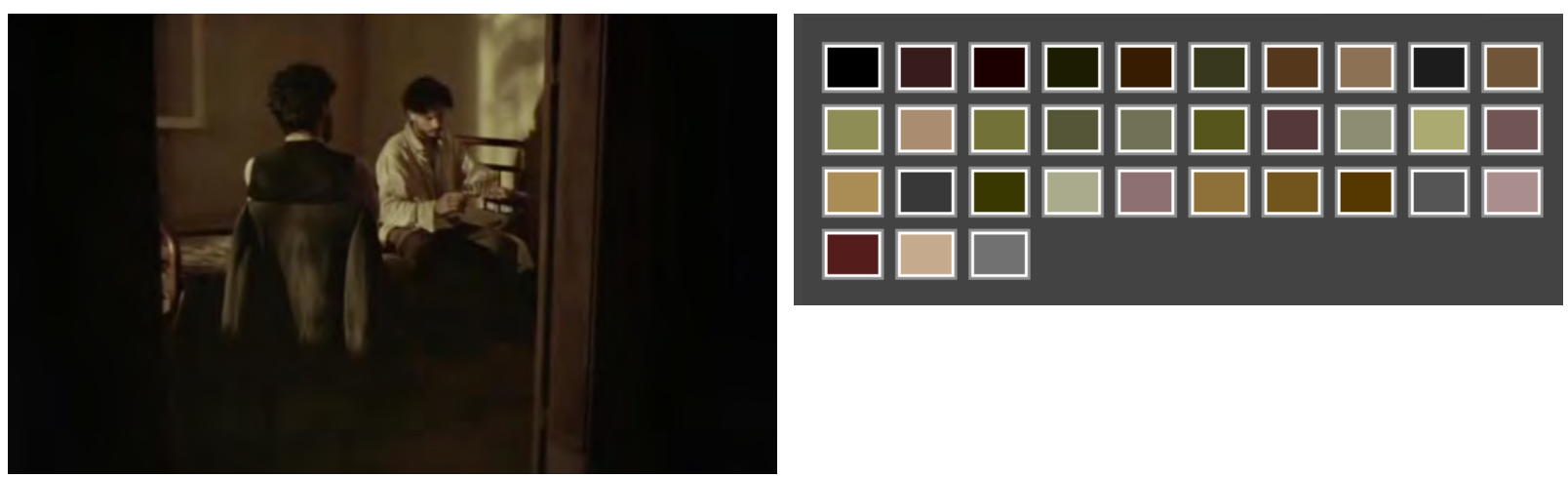

Fig. 209 - Lavoura Arcaica (2001), Luiz Fernando Carvalho 
As cores que revelam o mundo interno do pai são distintas das utilizadas para a mãe. Observa-se uma gama maior de matizes, cores mais saturadas e a presença de pretos, evidenciando o mundo interior intenso do pai, em contraste com a aparente leveza da mãe.
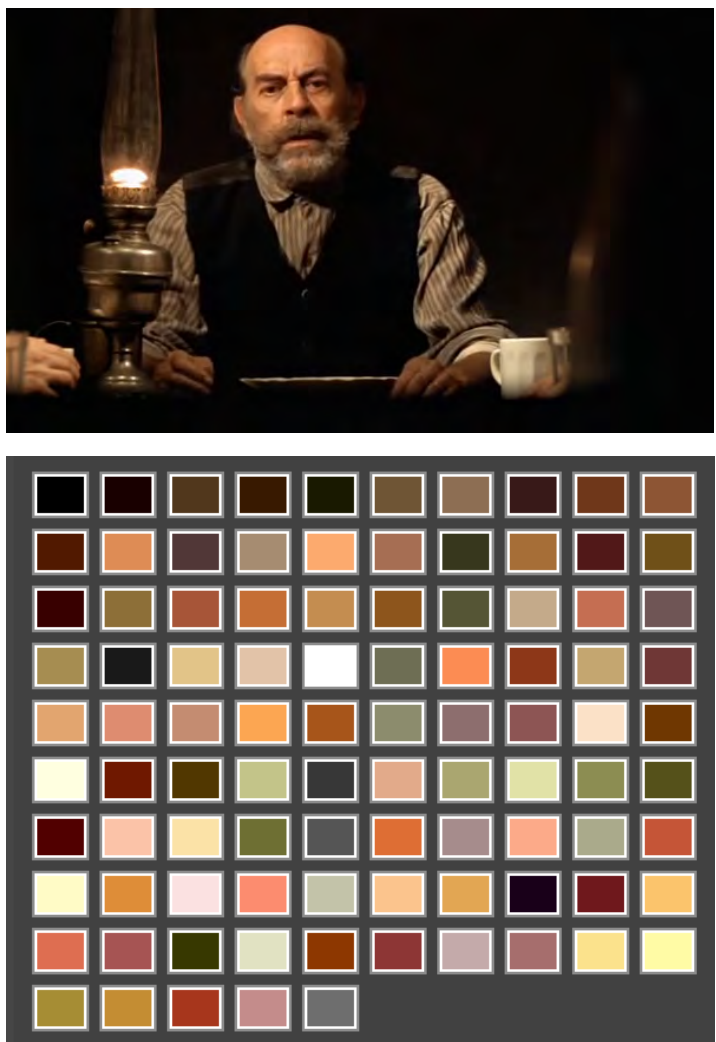
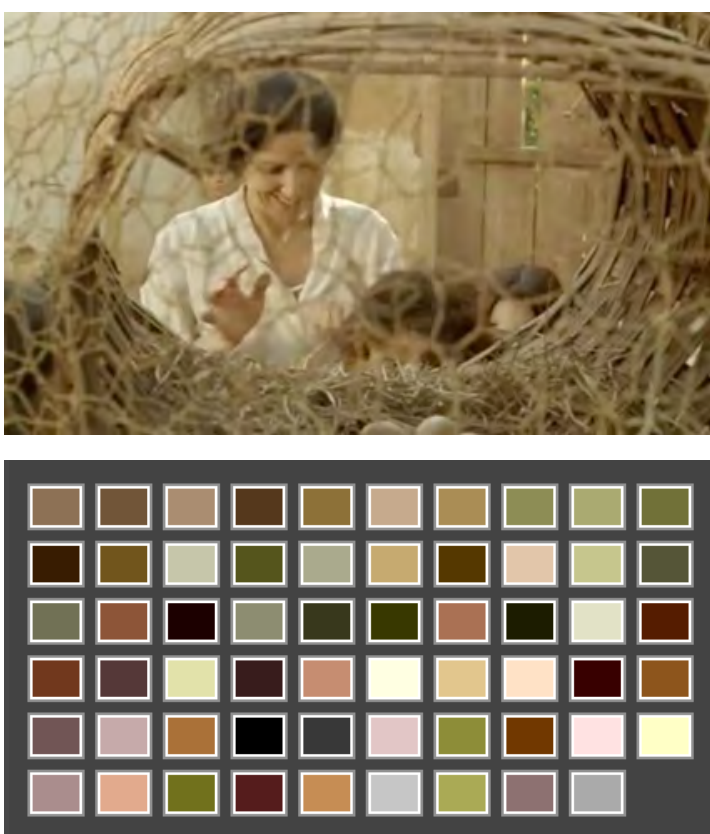

Fig. 210 - Lavoura Arcaica (2001), Luiz Fernando Carvalho

Contudo, a paleta utilizada para a mãe transforma-se ao longo do filme, principalmente na saturação dos matizes. Na figura 211, o fotograma da esquerda apresenta um momento da infância de André e o da direita, seu retorno à casa da família. Nota-se uma diferença de matizes e um aumento na saturação, resultando na diminuição de tonalidades intermediárias. Essa diferenciação no tratamento das cores apresenta uma dupla função: diferenciar a imagem da memória da imagem do tempo presente e marcar a intensidade dramática de cada um dos momentos. A intensificação dos sentimentos maternos traduz-se em termos cromáticos. 

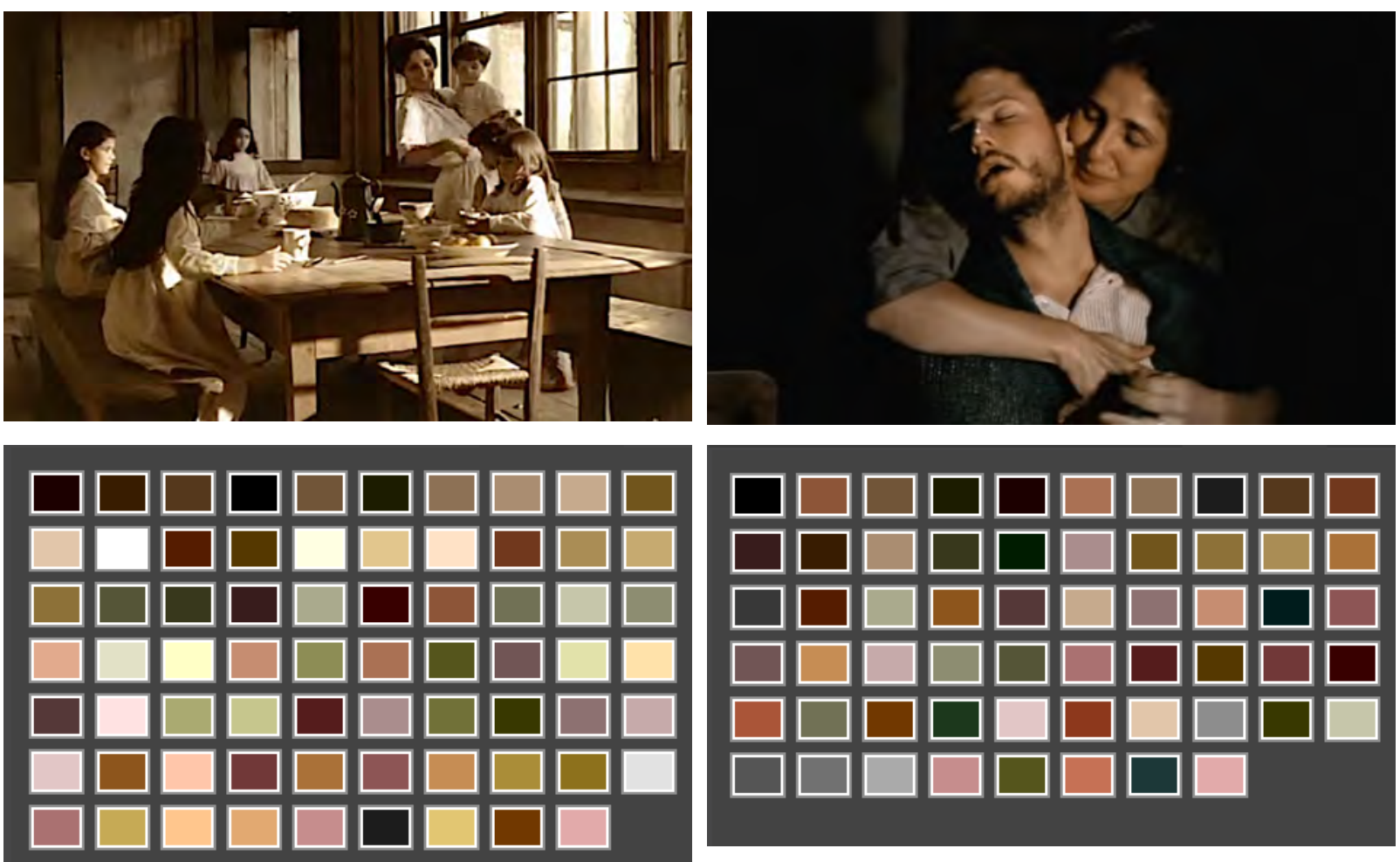

Fig. 211 - Lavoura Arcaica (2001), Luiz Fernando Carvalho

A personagem Ana é a que traz a maior variação cromática do filme. Apesar de um comportamento retraído na maior parte das cenas, seu cromatismo demonstra uma riqueza interna diferente dos demais personagens. Além dos dourados, que a igualam aos outros membros da família, a ela são reservados os tons de azul e verde, que garantem uma identificação com os elementos da natureza.
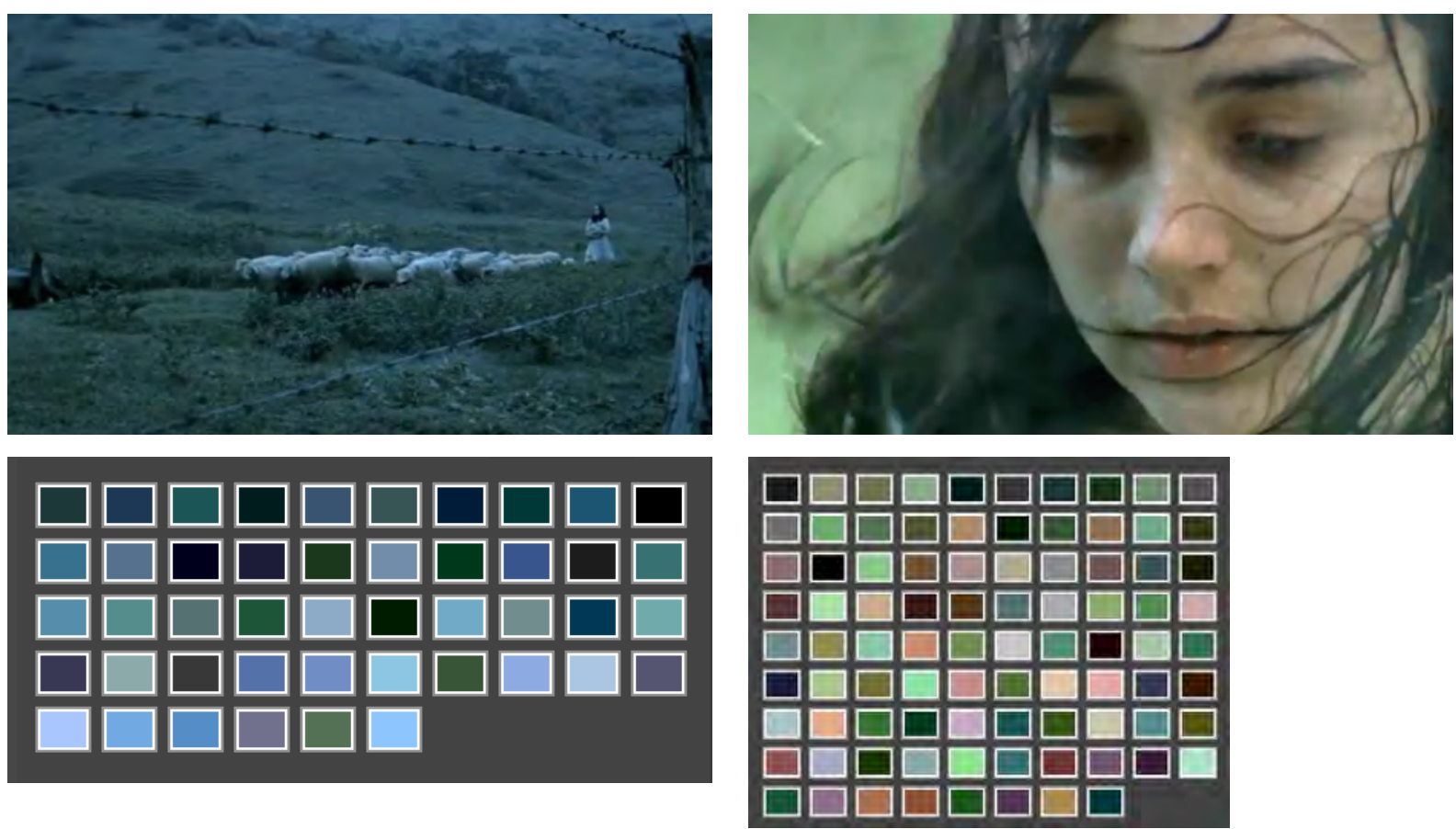

Fig. 212 - Lavoura Arcaica (2001), Luiz Fernando Carvalho 
Sua aproximação aos elementos da natureza é enfatizada pelas metáforas da pomba e da flor. $\mathrm{O}$ incesto é montado em paralelo com a cena em que André menino captura uma pomba e depois a deixa livre. Após a consumação do ato, vemos uma flor branca que desabrocha com as gotas de orvalho, e finalmente as nuvens banhadas pela luz solar, com a revoada dos pássaros.
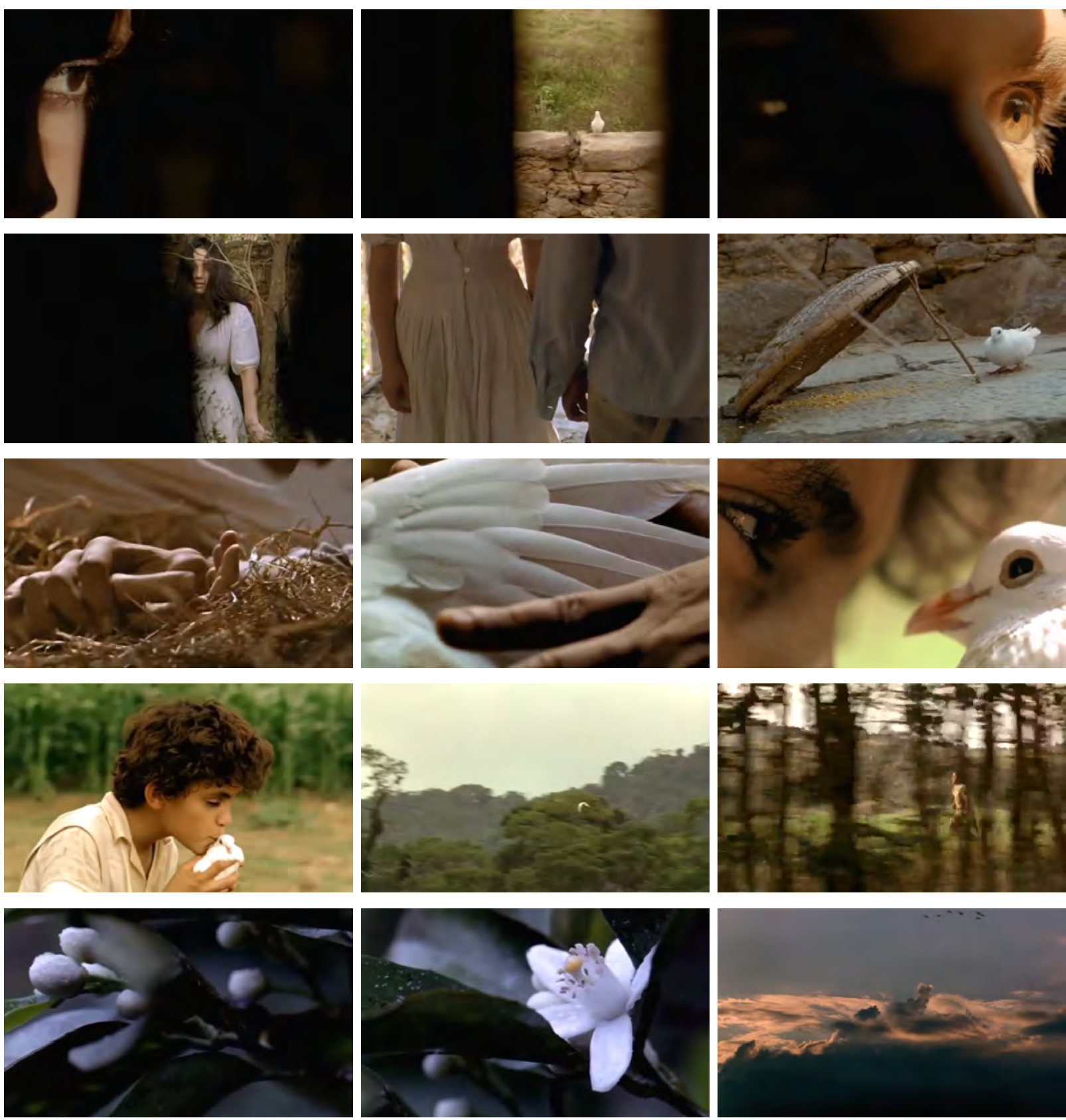

Fig. 213 - Lavoura Arcaica (2001), Luiz Fernando Carvalho

No início do filme, Ana é apresentada ao espectador em uma cena de dança. Trata-se de uma personagem complexa, que carrega ao mesmo tempo a pureza, evidenciada nos 
elementos brancos, e a sedução, presente nos dourados e laranjas. Após o retorno de André, Ana pega da caixa do irmão os objetos presenteados por prostitutas e se veste com eles para dançar na celebração pelo retorno. É importante notar como a paleta se altera em relação à da dança inicial, havendo redução de matizes e de saturação. A luz quente dá lugar à luz branca, marcando a transformação no comportamento de Ana.
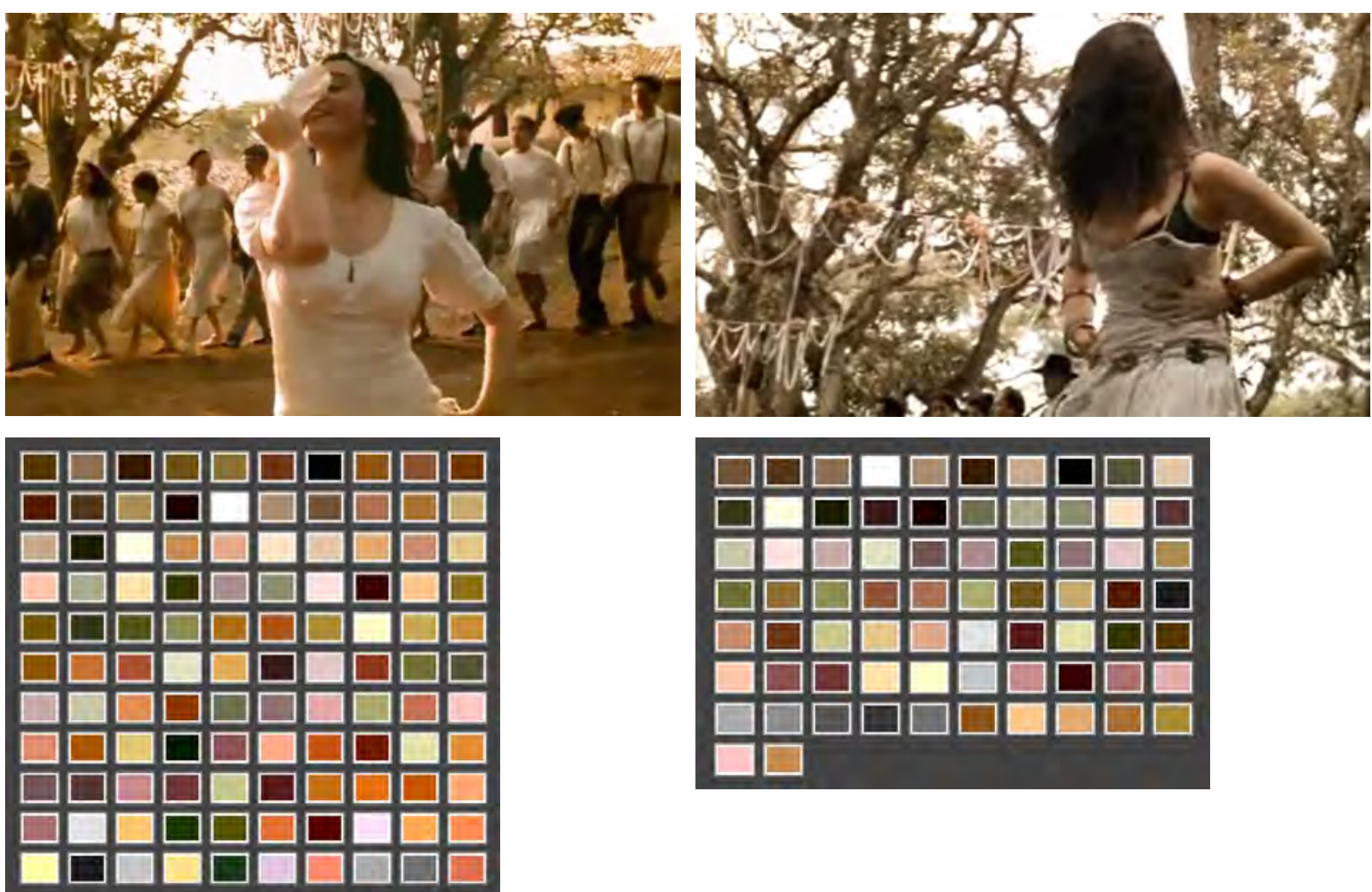

Fig. 214 - Lavoura Arcaica (2001), Luiz Fernando Carvalho

Sobre os objetos das prostitutas, André fala ao irmão: "o filho manda entre os presentes um pesado riso de escárnio". Mas é Ana quem, por meio de sua dança, debocha da rigidez de comportamento e da austeridade familiar. É dela o riso de escárnio, que desestrutura a família e marca sua libertação.

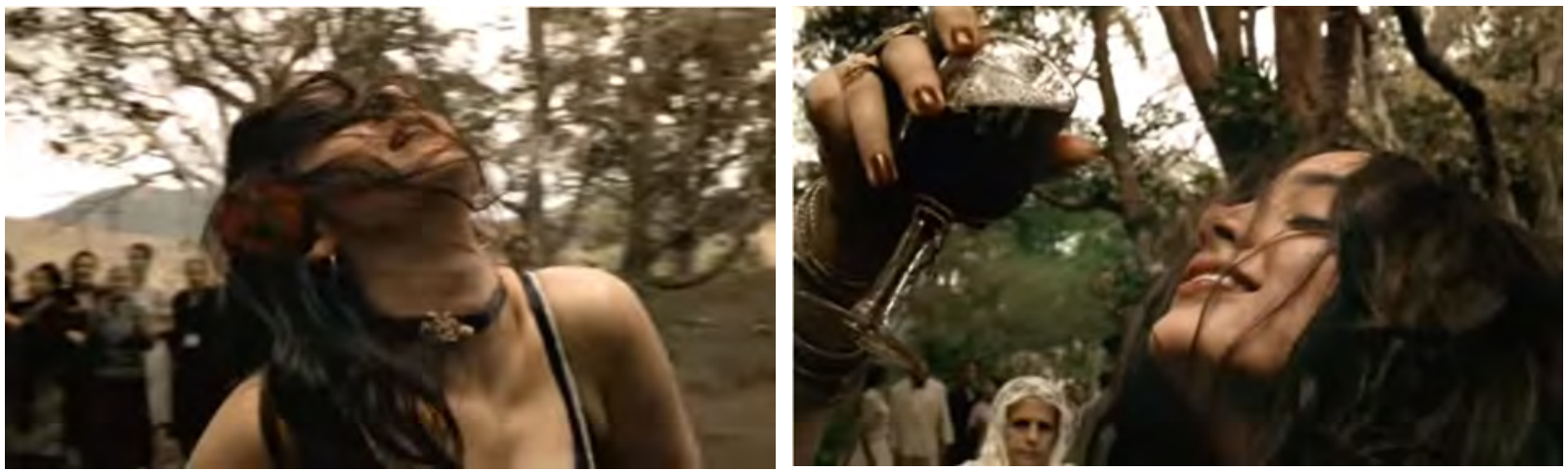

Fig. 215 - Lavoura Arcaica (2001), Luiz Fernando Carvalho 


\title{
4.4. Abril Despedaçado (2001), Walter Salles
}

Baseado no livro homônimo do escritor albanês Ismail Kadaré (1936- ), o filme tem como tema central a inexorabilidade do tempo e do destino. O enredo gira em torno da luta entre duas famílias no sertão da Bahia, que se configura em um interminável ciclo de vingança e morte, perdurando por várias gerações.

A história trata do momento em que Tonho (Rodrigo Santoro) vinga a morte do irmão mais velho e torna-se jurado de morte. É concedida uma trégua até a lua cheia seguinte, mas durante esse período, o jovem de vinte anos aparentemente não conhecerá nada além do cotidiano árido que viveu até então. A vida da família de Tonho transita entre a bolandeira, o tacho de rapadura, o destino, e nada mais.

Em entrevista à Associação Brasileira de Cinematografia, Walter Carvalho fala sobre a procura da bolandeira e das locações para o filme.

\begin{abstract}
Um ano antes das filmagens, Walter (Carvalho) e o $1^{\circ}$ assistente de câmera, Lula Carvalho, fizeram uma viagem de $4.000 \mathrm{Km}$ pelo sertão nordestino começando na Bahia, e passando por Pernambuco, Rio Grande do Norte, Ceará e Paraíba, em busca de uma bolandeira. Ele contou que no livro não é uma bolandeira, a fazenda dos Breves tinha uma outra atividade, mas o diretor Walter Salles assistiu a um documentário chamado "A bolandeira" de Vladimir Carvalho e disse "eu quero isso no filme, por que é a marca do tempo, eu vou fazer um filme sobre o tempo". "O Waltinho queria um sertão de Vidas Secas e acabei encontrando uma ruína de bolandeira e segui caminho procurando essas locações mais áridas que o Walter queria. No Ceará perto de Assaré, o Lula, que tava comigo, viu a fazenda que está no filme. Alguma coisa o atraiu, ele ficou encantado e começou a fotografá-la de tudo quanto é jeito. E aí o Cássio Amarante, diretor de arte, viu aquela fazenda e resolveu que seria a fazenda dos Breves e reproduziu a fazenda absolutamente igual por fora e o interior dela ele fez em função da decupagem do Walter (Salles)." Walter Carvalho e seu filho Lula fizeram mais de 100 filmes fotográficos nessa viagem pelo sertão nordestino. Essa fase de pré-produção, em que o fotógrafo pesquisa as locações é fundamental para o filme, pois é nela que ele obtém informações valiosas que podem gerar novas ideias para a fotografia (ASSOCIAÇÃO BRASILEIRA DE CINEMATOGRAFIA, 2002).
\end{abstract}

A imagem da bolandeira permeia toda a narrativa. Os enquadramentos da casa e da família dos Breves privilegiam a bolandeira em todos os seus ângulos, evidenciando seu papel central.
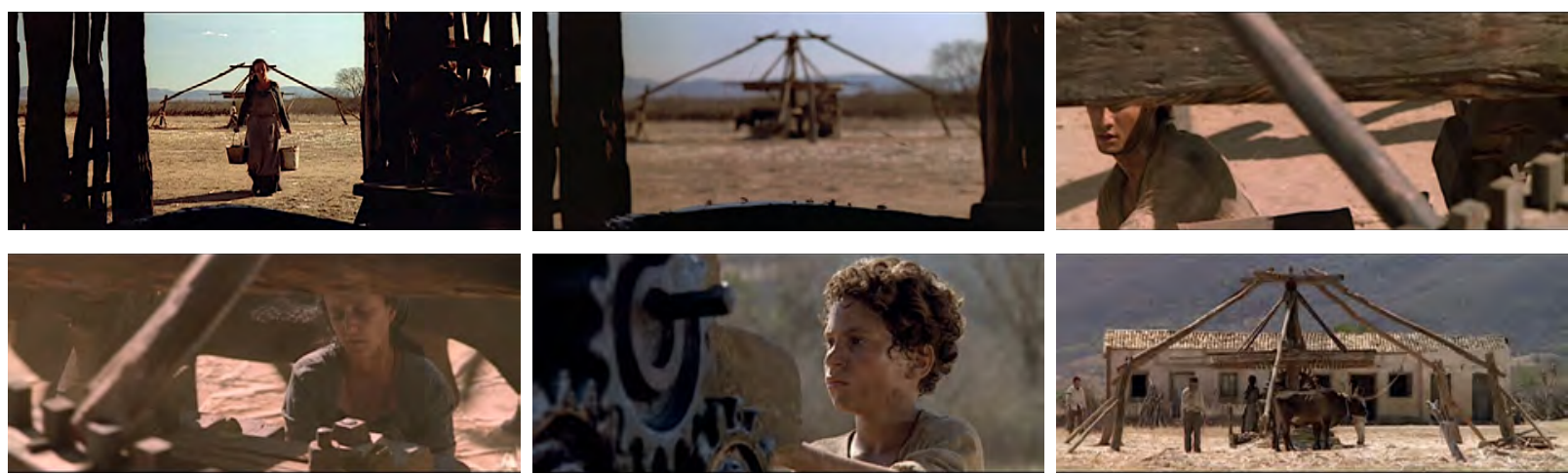

Fig. 216 - Abril Despedaçado (2001), Walter Salles 
Além dos estudos fotográficos realizados por Walter Carvalho, a desnatadeira do filme O Velho e o Novo (Staroye i Novoye, 1929), de Sergei Eisenstein, norteou a construção da bolandeira, como se pode ver na figura 217.
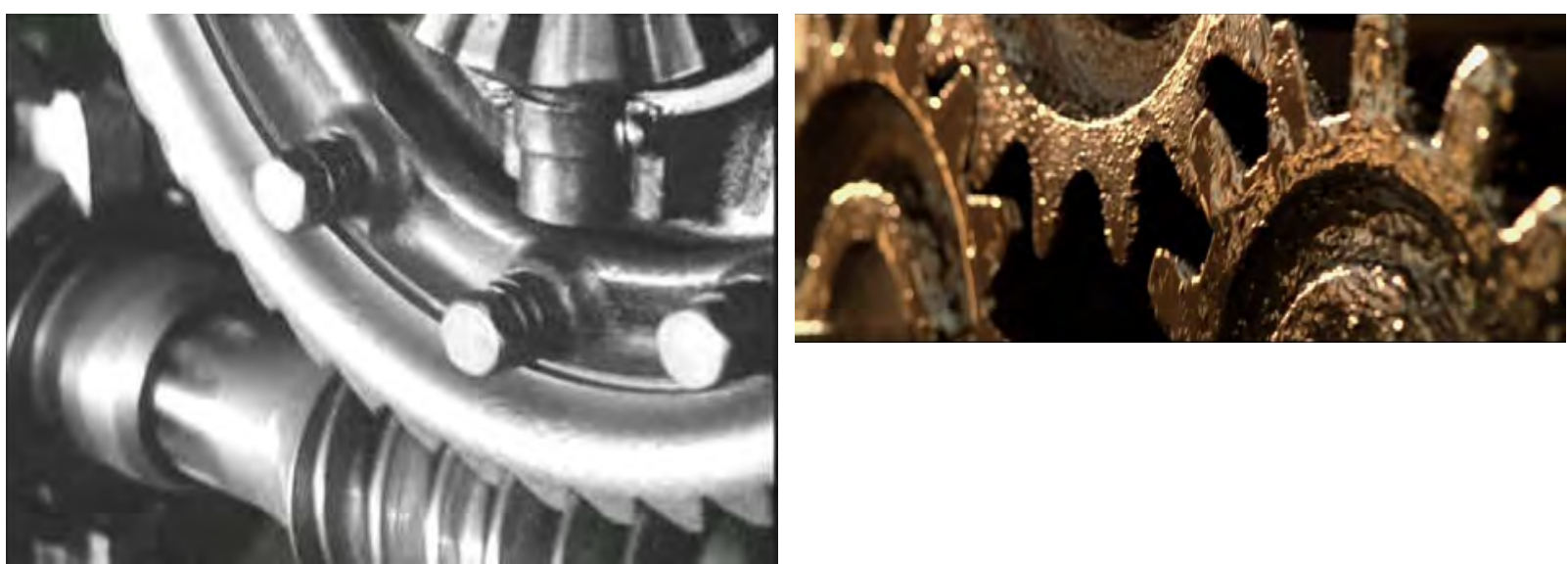

Fig. 217 - O Velho e o Novo (esq) e Abril Despedaçado (dir)

Inicialmente a bolandeira é vista de cima, em seu movimento circular, metaforeando o destino da família Breves.

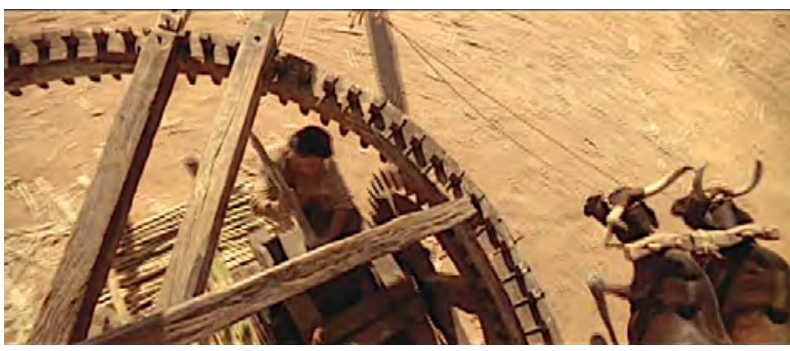

Fig. 218 - Abril Despedaçado (2001), Walter Salles

O pai toca os bois e determina o ritmo do trabalho e da vingança. Os demais membros da família são enquadrados entre as engrenagens, como se delas fizessem parte.
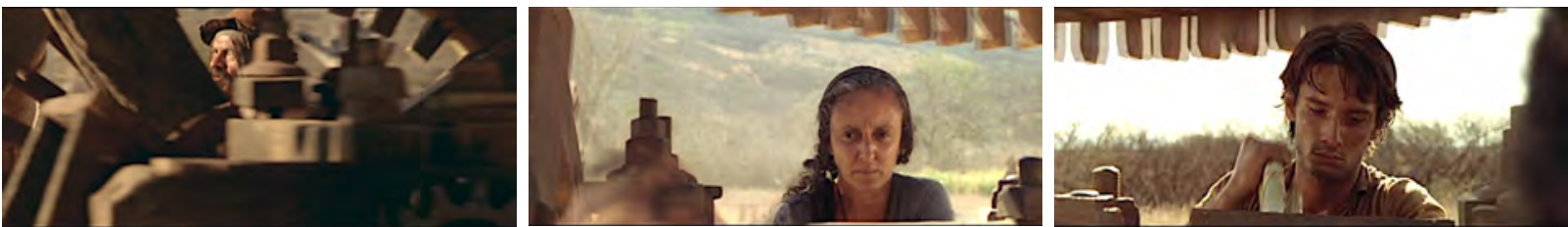

Fig. 219 - Abril Despedaçado (2001), Walter Salles

O espaço é elemento determinante na vida dos personagens. $\mathrm{O}$ calor, a seca e o sertão promovem o isolamento das famílias do Vale das Almas. Abril Despedaçado é um filme de poucos diálogos, de silêncios, e de imagens criadas em função do mundo interno dos personagens. Walter Carvalho conseguiu, por meio dos enquadramentos e da luz, imprimir 
nos personagens as características do espaço, mostrando ao espectador a dimensão da falta de perspectivas em que vivem esses indivíduos.

Além da bolandeira, outros elementos de Abril Despedaçado dialogam com as imagens de $O$ Velho e o Novo. O sofrimento dos trabalhadores rurais, o boi que é levantado quando cai exausto no chão (Fig. 220), a luta de Pacu entre o velho (código moral que lhes impõe um destino imutável) e o novo (sua ideia libertária do destino). Durante o período de concepção do filme, Walter Salles usou referências de Eisenstein para conferir a Abril Despedaçado uma qualidade de filme mudo. Desse modo, priorizou imagem ao invés de diálogo, e tornou o ambiente árido um elemento formador da dureza dos personagens.
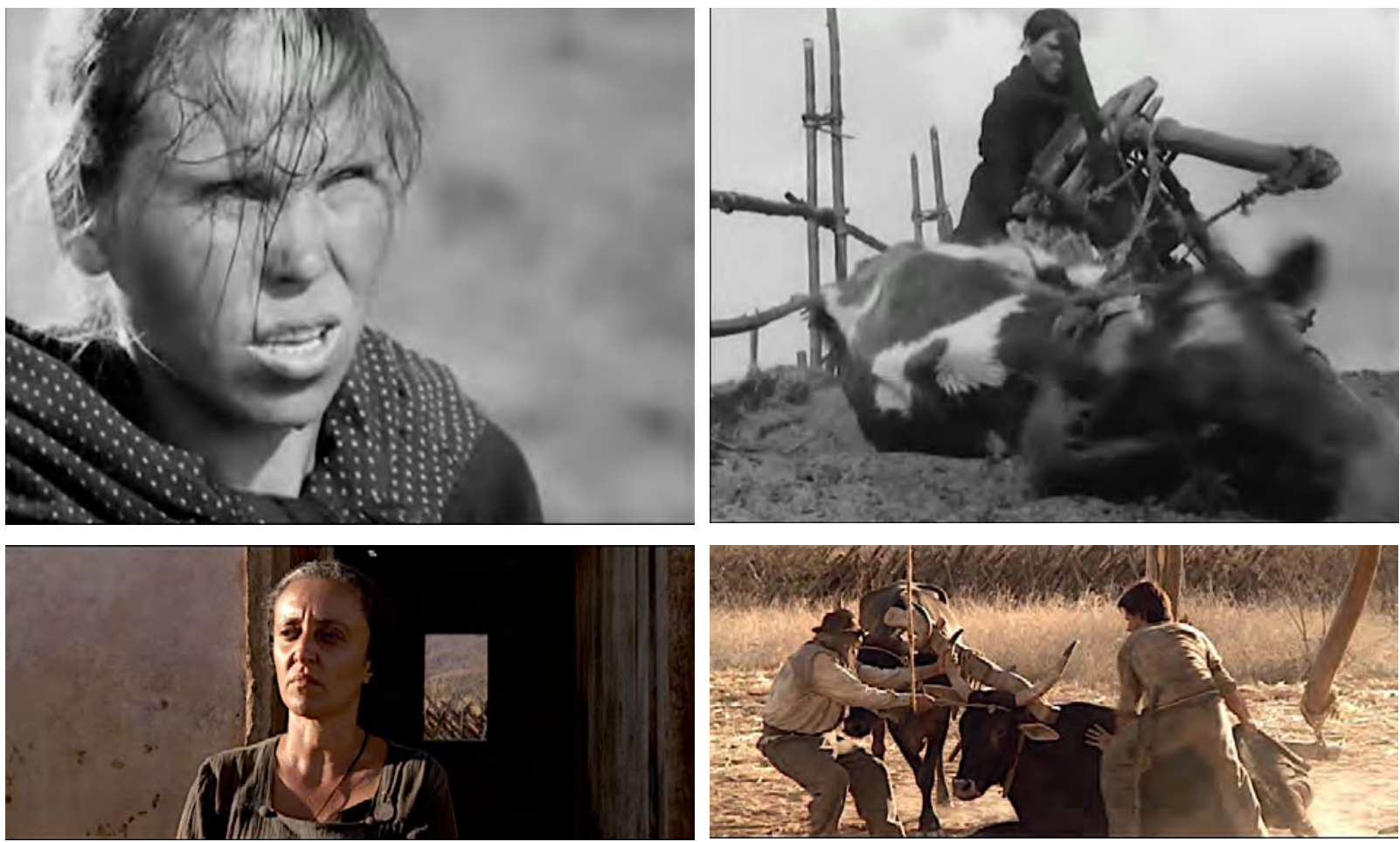

Fig. 220 - O Velho e o Novo (cima) e Abril Despedaçado (baixo)

O tempo é outro elemento crucial à trama. O periodo de trégua marca a vida de Tonho, que se esvai. A passagem do tempo intensifica o desespero crescente de Tonho e é representada físicamente pela imagem do relógio, pela bolandeira, pela lua, pela camisa manchada de sangue, que amarela com o passar dos dias, e pela oposição entre dia e noite. A espacialização do tempo já é indicada no título do filme: despedaçar, que é próprio do espaço, é aplicado ao tempo, ao mês de abril.

O primeiro momento de espacialização do tempo acontece no início do filme, com a família Breves reunida em torno da camisa manchada de sangue. O pai anuncia: "O sangue começou a amarelar", indicando a proximidade da vingança. 

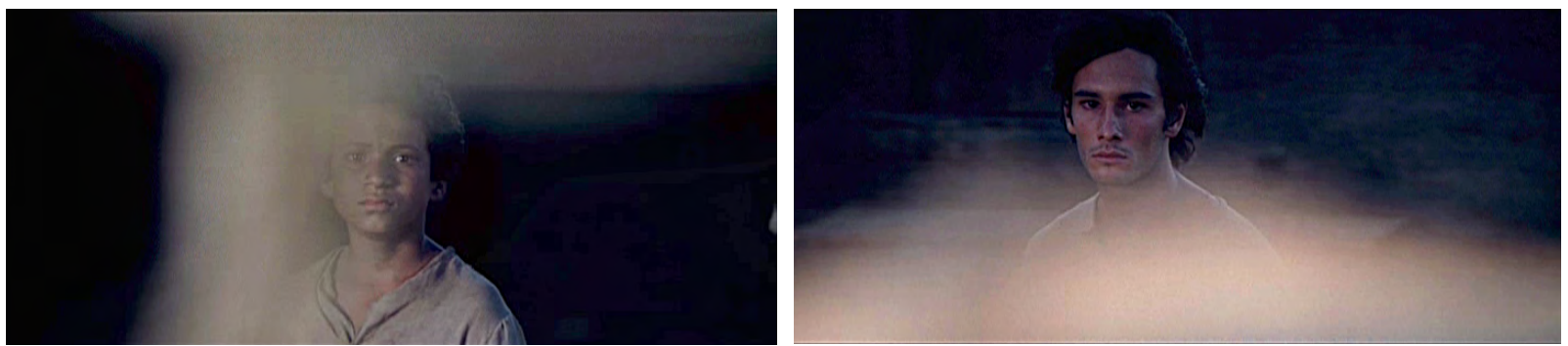

Fig. 221 - Abril Despedaçado (2001), Walter Salles

Segundo Pedro Butcher e Anna Luiza Müller, no livro Abril Despedaçado: história de um filme, a bolandeira foi concebida para marcar a passagem do tempo, suas engrenagens se comparam às de um relógio primitivo que gira no sentido anti-horário, como se o tempo rodasse para trás. O tempo que retroage remete ao curto período de vida que resta a Tonho, marcado pela fala do patriarca da família Ferreira: “Tu tá vendo aquele relógio ali? Cada vez que ele marcar mais um, mais um, mais um... Ele vai tá te dizendo: menos um, menos um, menos um".

Esse movimento do tempo que retroage remete à primeira parte do filme A Greve (Stachka, 1925), de Eisenstein, cujos fotogramas podem ser vistos na figura 222. O letreiro diz: "Tudo está calmo na fábrica" (1). O letreiro seguinte traz uma informação adicional: “Tudo está calmo na fábrica - Mas" (2). Na sequência, há um plano de detalhe da palavra "Mas", que em russo é "Ho" (3). As letras se movem e se sobrepõem, deixando de configurar uma palavra e tornando-se elementos geométricos (4). Há então a fusão do círculo com uma imagem da fábrica em que uma roda gira em sentido horário (5). No plano seguinte dois operários estão em frente à roda, que agora gira em sentido anti-horário (6). As duas próximas imagens estão verticalmente invertidas e rodam de trás para frente. Na primeira delas (7) um homem pisa em uma poça d'água, quando sai de quadro a água se estabiliza e vemos a imagem da fábrica. Na imagem seguinte (8), também filmada a partir do reflexo na água, os homens andam de costas, o que demonstra que o plano foi inserido de trás para frente. Desse modo, Eisenstein mostra como a calmaria da fábrica é apenas aparente, fazendo isso por meio de planos gráficos, explorando o movimento circular e o tempo que retroage. 

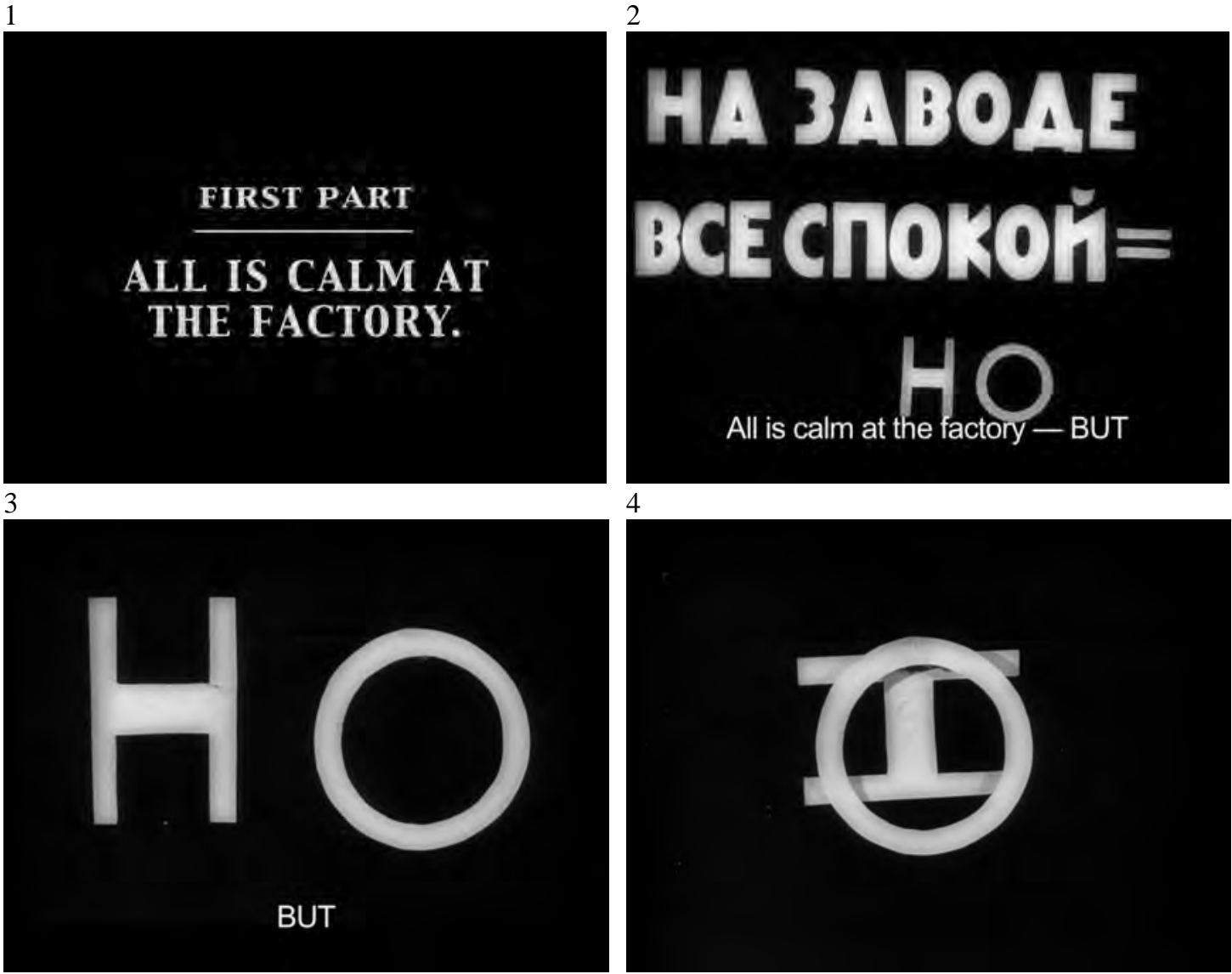

5

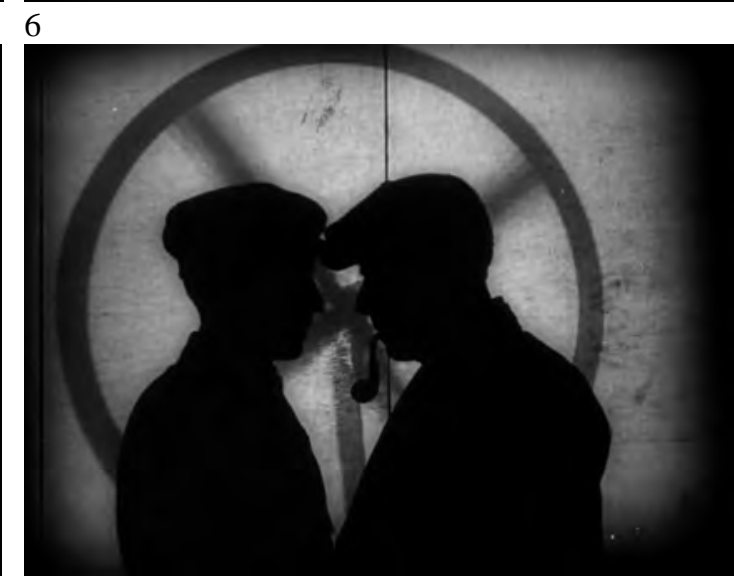

7

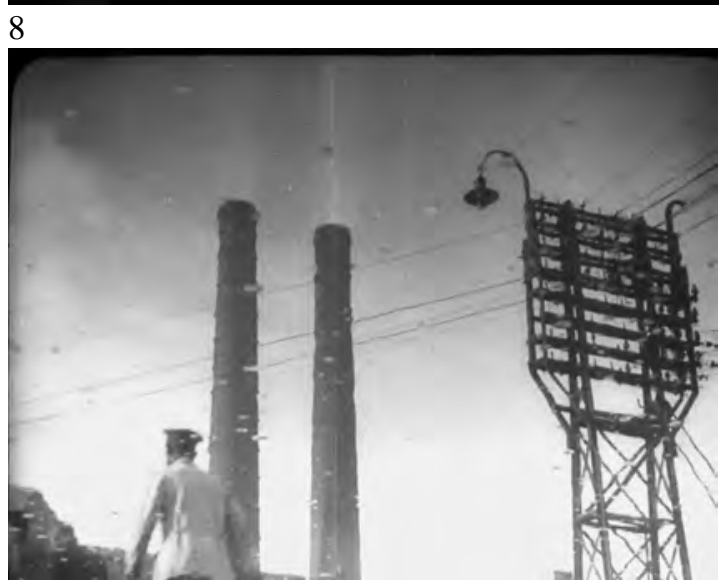

Fig. 222 - A Greve (1925), Sergei Eisenstein 
Tonho rebela-se aos poucos contra seu destino, encorajado por Pacu, seu irmão mais novo, e inspirado por uma dupla de artistas circenses que chega à cidade. Os irmãos passam, cada um a seu modo, a questionar a lógica da violência e da tradição.

É Pacu quem traz a mudança de paradigma dos Breves e promove a libertação de seus destinos incontestáveis e inevitáveis. O menino adquire consciência da situação em que se encontram, o que verbaliza em uma das cenas: "a gente é que nem os bois: roda, roda e nunca sai do lugar" (SALLES, MACHADO e AÏNOUZ, 2002, p.208).

Observando os bois da bolandeira, que andam em círculos sozinhos, mesmo sem estarem presos à engrenagem, Pacu entende a necessidade de romper com o destino inexorável do irmão e dele próprio. A cena é filmada com o horizonte desfocado, indicando a impossibilidade de enxergar além. Desse modo, a falta de perspectiva de uma outra realidade, além do destino familiar, é impressa na imagem.
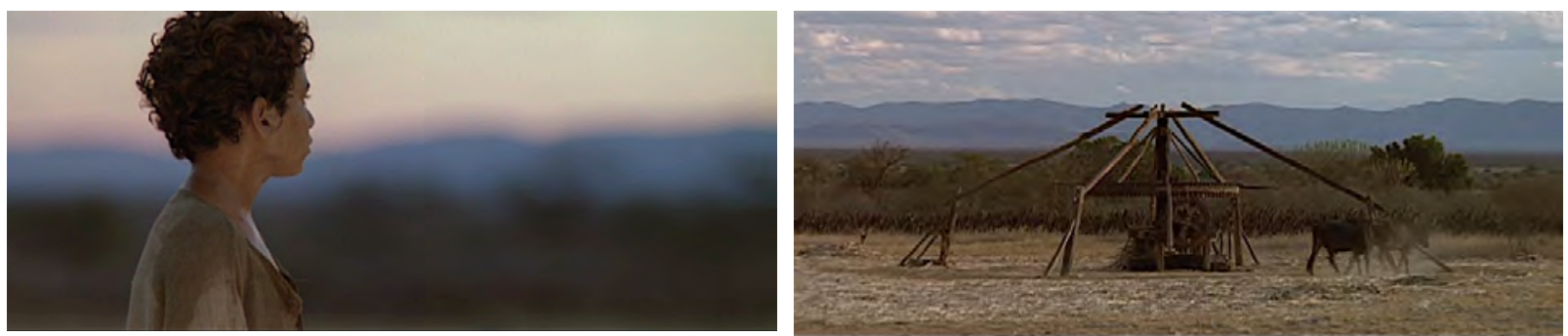

Fig. 223 - Abril Despedaçado (2001), Walter Salles

O paralelo entre os animais e os Breves é reforçado pela imagem de Tonho carregando a canga, peça que prende os bois à bolandeira, como se o personagem fosse tal qual os animais, que rodam mecanimente sem possibilidade de questionar seus destinos.

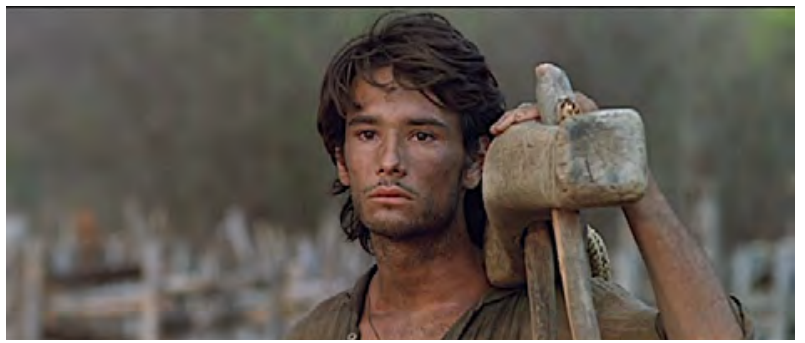

Fig. 224 - Abril Despedaçado (2001), Walter Salles

Outros elementos circulares, como a roda da charrete, são referências ao ciclo da vingança e do destino. O movimento circular de Clara na corda marca a passagem do tempo, ela inicia o movimento durante o dia e encerra ao anoitecer. 

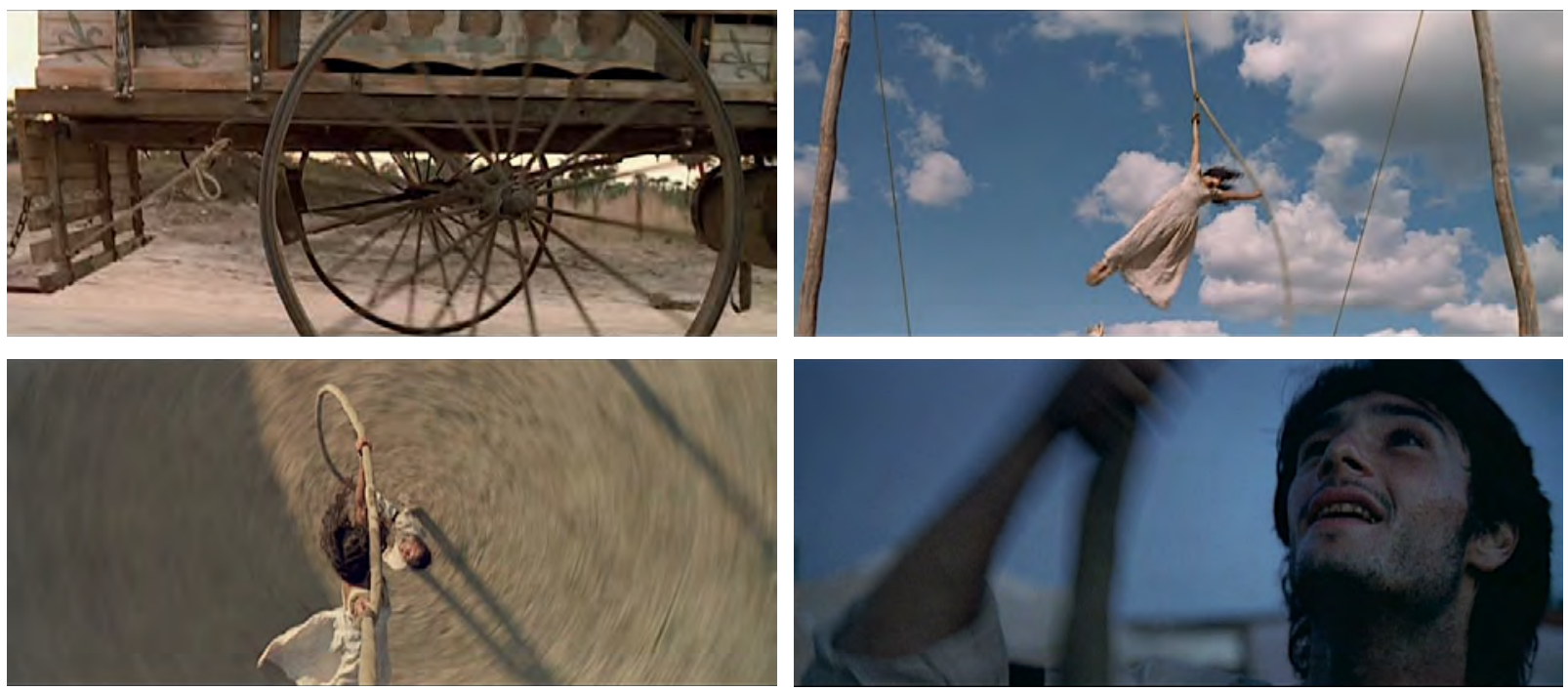

Fig. 225 - Abril Despedaçado (2001), Walter Salles

A morte de Pacu chega a ser um ato de rebeldia, porque mais do que proteger o irmão, sua atitude rompe com a tradição da vendetta, uma realidade aparentemente imutável, prédeterminada antes de seu nascimento.

A cor e o contraste exercem papel relevante para marcar a vida dos personagens. As cores alternam-se entre ocres e azuis e são provenientes dos elementos espaciais. O trabalho de temperatura da cor-luz e da pós produção da imagem faz com que os tons de pele se fundam às cores do espaço, tornando indissociável o homem da natureza que o cerca. É o caso do fotograma em que a pele de Pacu se iguala à terra da fazenda.

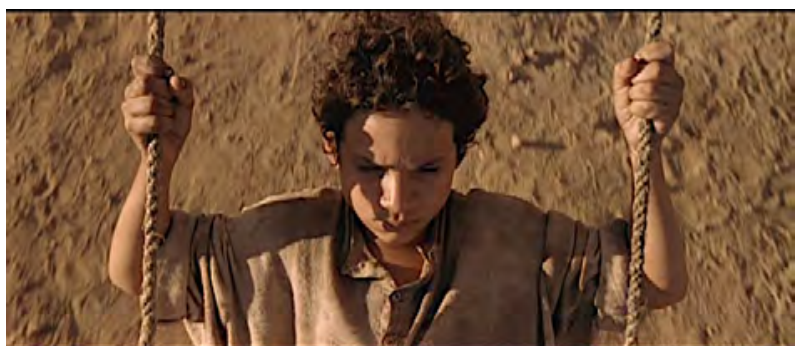

Fig. 226 - Abril Despedaçado (2001), Walter Salles

Os azuis estão presentes:

no céu
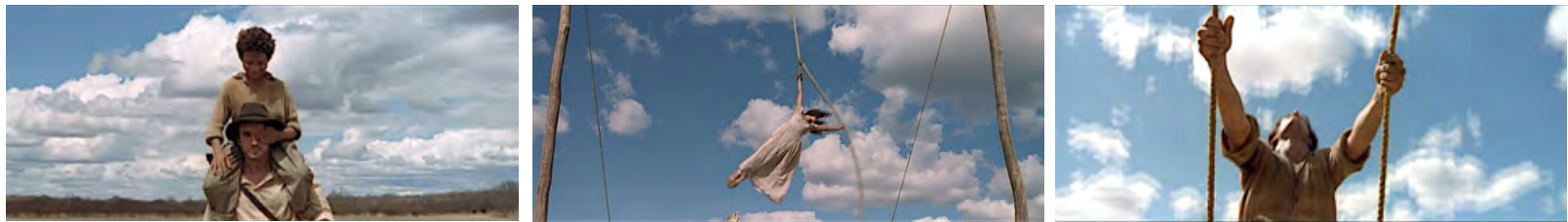

Fig. 227 - Abril Despedaçado (2001), Walter Salles 
e na noite
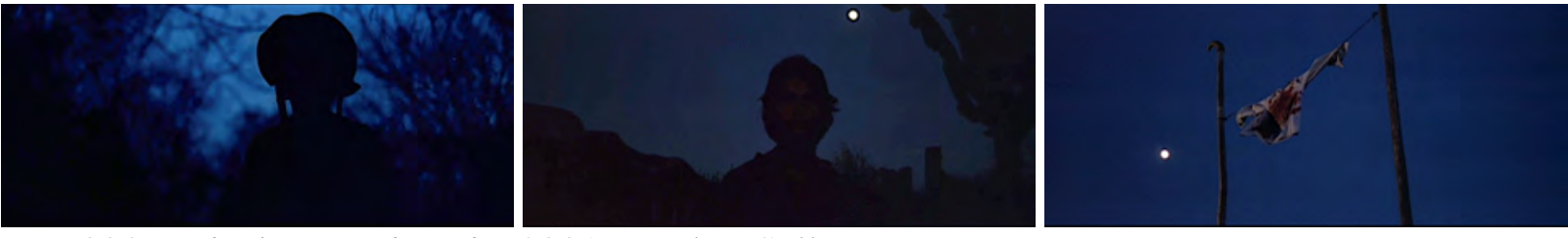

Fig. 228 - Abril Despedaçado (2001), Walter Salles

Os marrons, ocres e alaranjados, por sua vez, aparecem em elementos como:

a terra
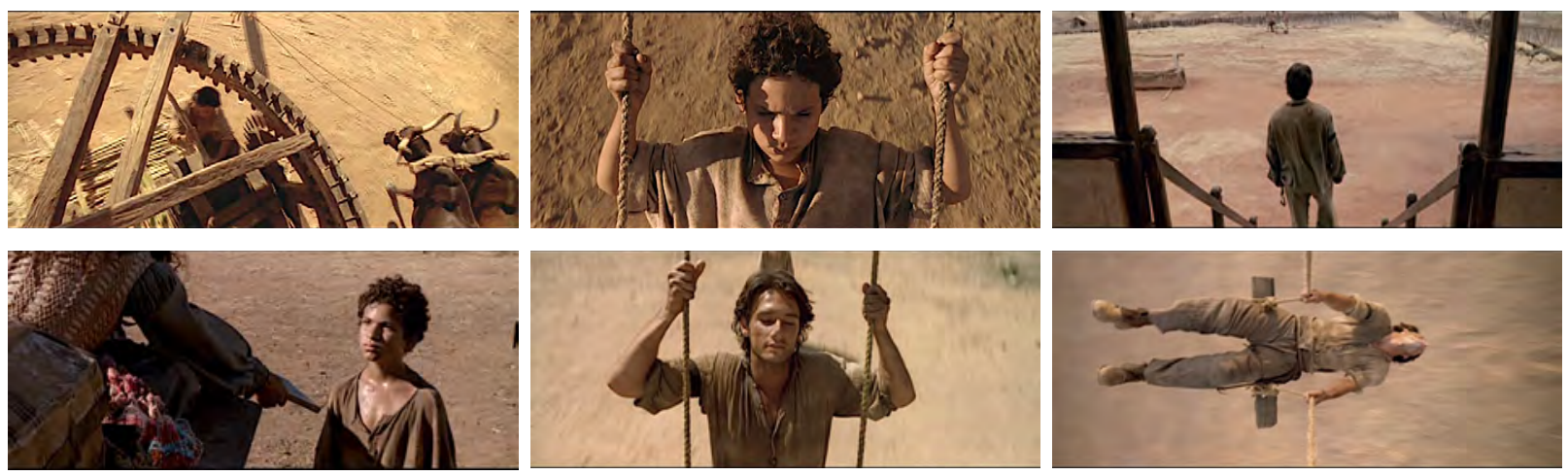

Fig. 229 - Abril Despedaçado (2001), Walter Salles

o sol
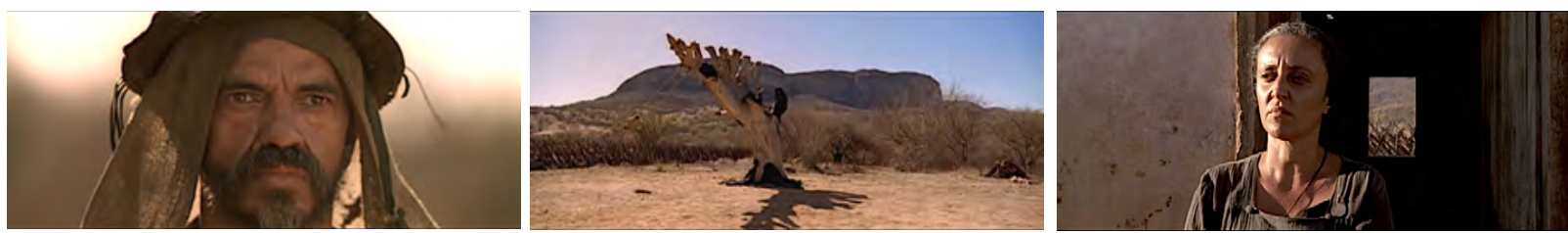

Fig. 230 - Abril Despedaçado (2001), Walter Salles

e o fogo
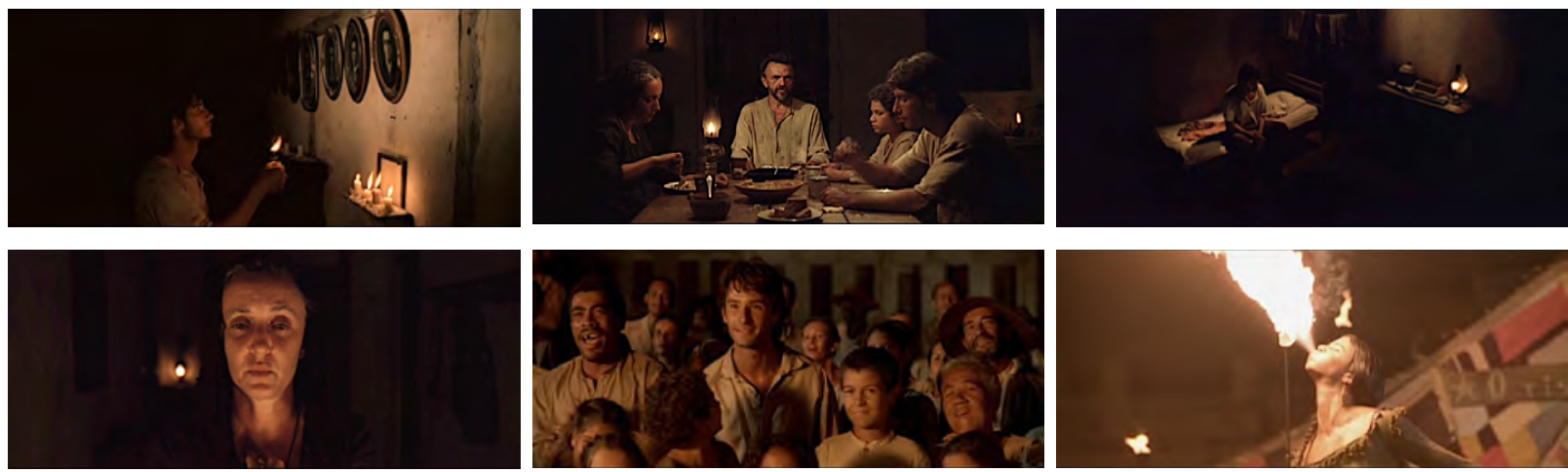

Fig. 231 - Abril Despedaçado (2001), Walter Salles 
Vermelhos e amarelos referem-se ao sangue.
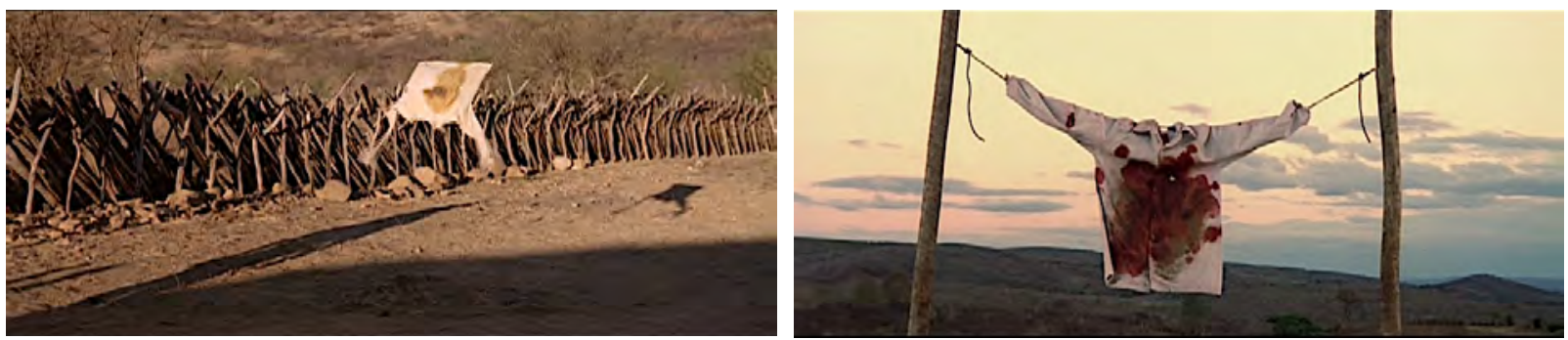

Fig. 232 - Abril Despedaçado (2001), Walter Salles

O contraste da iluminação é alto, tanto nas cenas diurnas quanto nas noturnas, marcando a dureza dos personagens e a presença constante da morte, associada aos pretos profundos. Em entrevista à Associação Brasileira de Cinematografia, Walter Carvalho conta como o diretor o instruiu sobre as imagens.

Antes do filme começar o Walter (Salles) fez um texto sobre o perfil de cada departamento, desde o livro, a direção dos atores, sobre a fotogrfia ele diz assim: vejo a fotografia árida e seca, como a geografia que cerca a casa dos Breves, áspera, em que uma parte do quadro sempre deverá estar às escuras. A presença constante da morte, mesmo de dia. Não há doçura, os rostos e os elementos do quadro são recortados, a escala cromática vai dos ocres ao negro denso, com alguns pontos de cor, principalmente o sangue, que deve ser de um vermelho vivo. A câmera não deve se revelar, não deve exibir-se e sim potencializar. A câmera objetiva é um quadro em que aquilo que deve ser visto convive sempre com aquilo que não se consegue ver, aquilo que se teme: a morte. Os personagens transitam da luz para a sombra, nela mergulham ou dela emergem (ASSOCIAÇÃO BRASILEIRA DE CINEMATOGRAFIA, 2002).

Como podemos verificar nos fotogramas da figura 233, Walter Carvalho utiliza enquadramentos de portas e janelas para marcar o trânsito dos personagens entre luz e sombra, e à semelhança dos enquadramentos de Central do Brasil e Lavoura Arcaica, para criar molduras, aumentar a profundidade da imagem e explorar o contraste da luz exterior e interior.
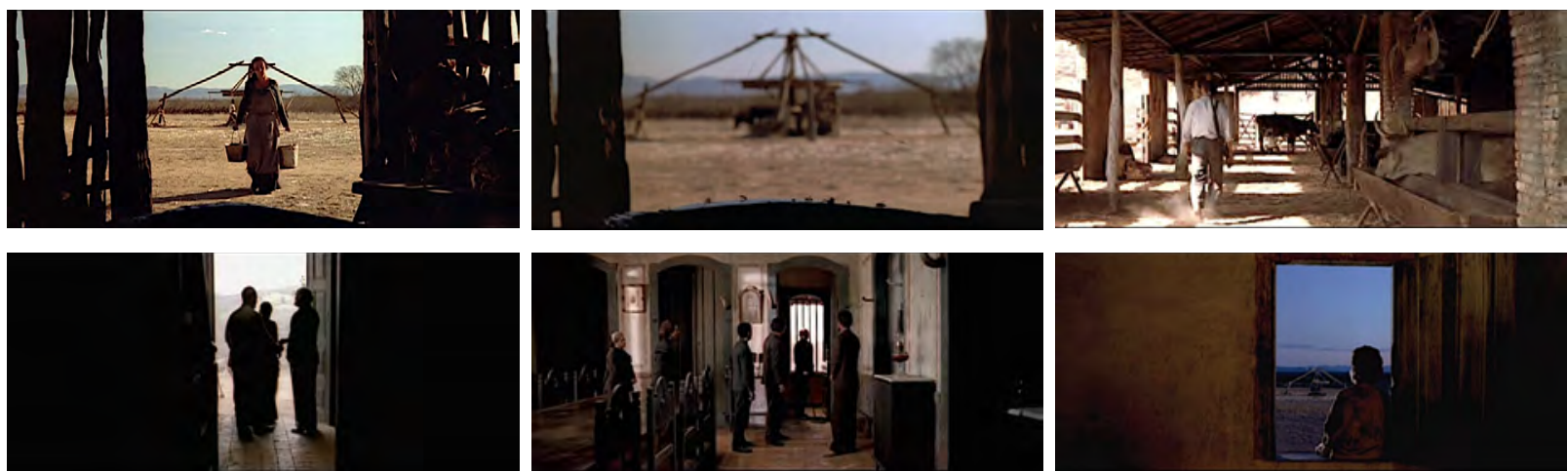

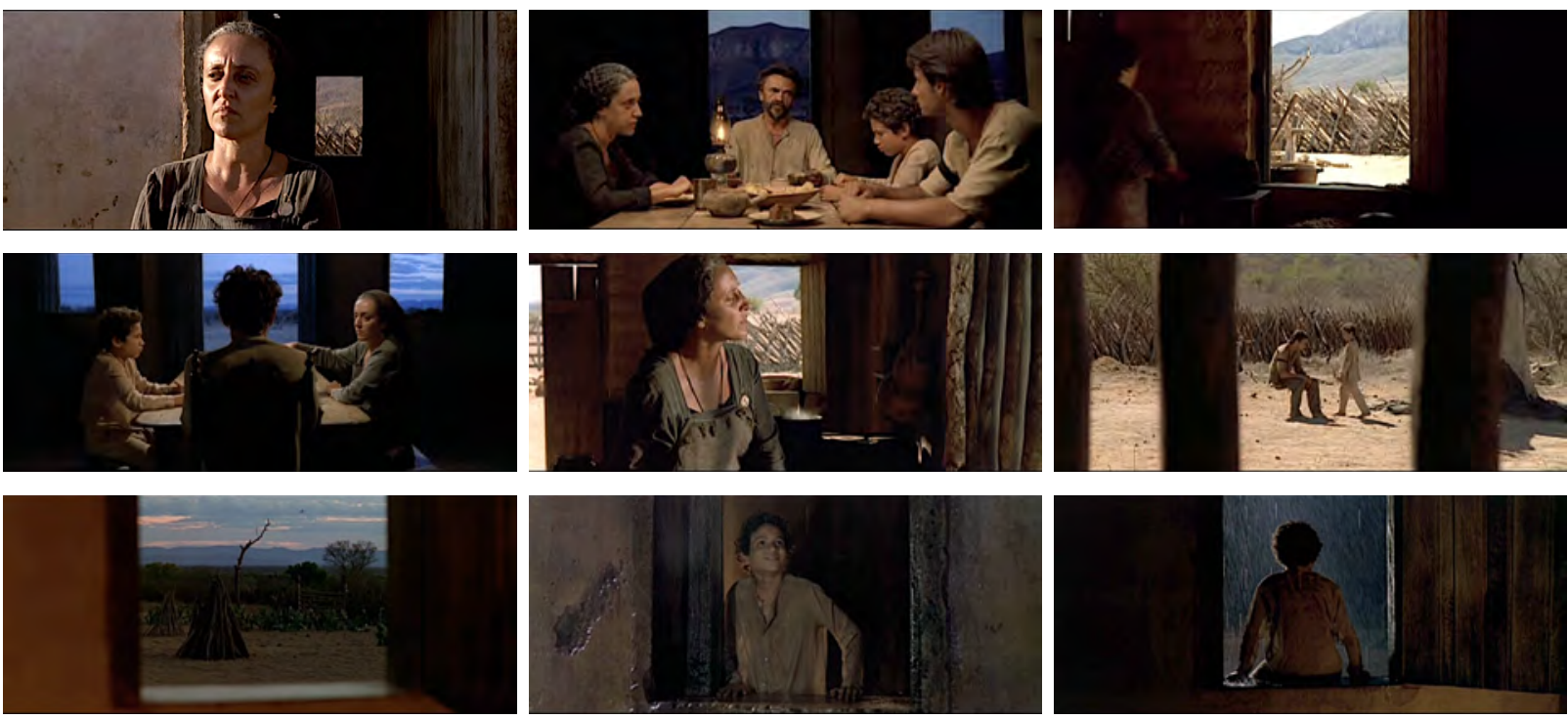

Fig. 233 - Abril Despedaçado (2001), Walter Salles

Na análise de Central do Brasil, mostramos a similaridade desse tipo de quadro com um fotograma de A Greve, de Eisenstein. O filme $O$ Velho e o Novo, referência para Abril Despedaçado, também privilegia essa forma de enquadrar, como vemos na figura 234. Entretanto, de forma distinta de Central do Brasil, Abril Despedaçado não promove uma oposição entre o exterior (mundo) e o interior (família), mas integra os ambiente como se o interior fosse um prolongamento do espaço externo, reforçando a influência da geografia na psique dos personagens.

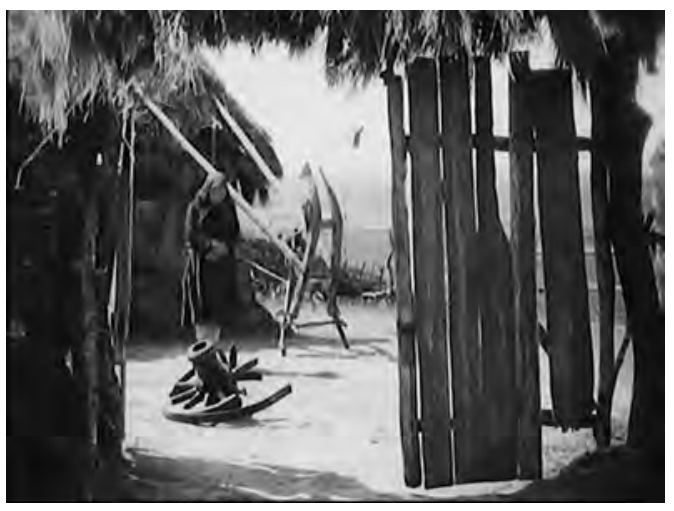

Fig. $234-O$ Velho e o Novo (1929), Sergei Eisenstein

É possível ainda traçar um paralelo entre esse procedimento empregado na fotografia de Abril Despedaçado e a imagem de Rastros de Ódio (The Seachers, 1956), de John Ford (1894-1973), fotografado por Winton C. Hoch (1905-1979), com personagens transitando entre a luz e sombra e a interação entre exterior e interior. 

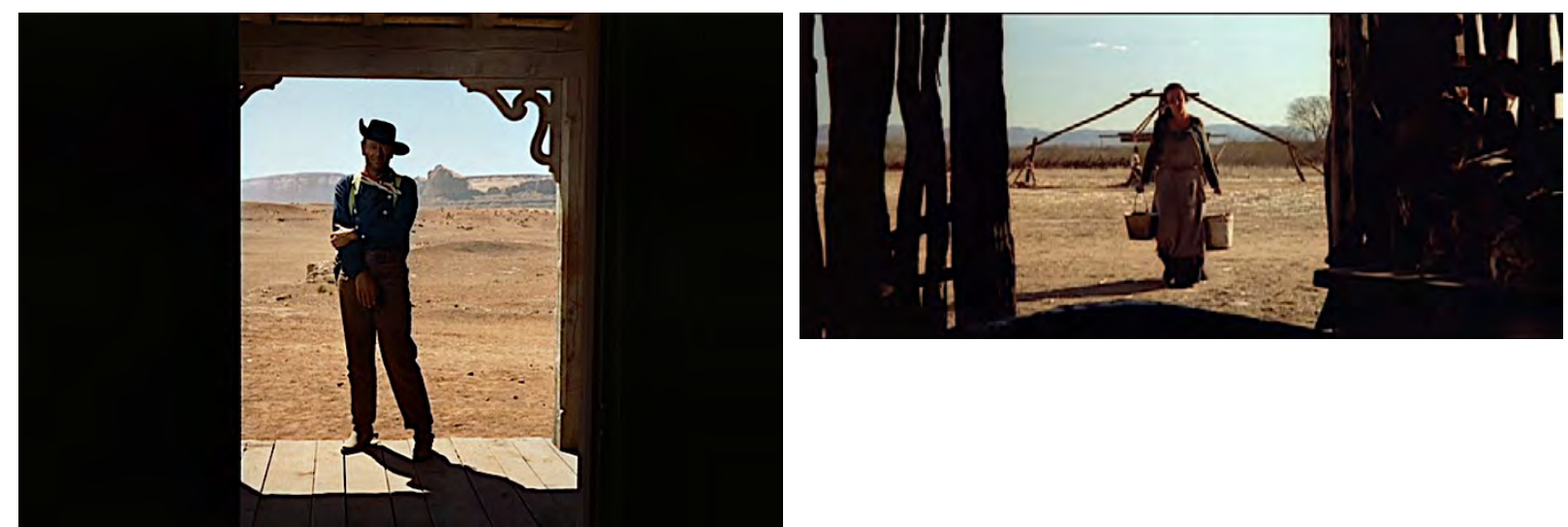

Fig. 235 - Rastros de Ódio (esq) e Abril Despedaçado (dir)

A utilização de grandes planos gerais, que privilegiam o espaço em detrimento do indivíduo, é uma característica do gênero western encontrada em Abril Despedaçado.
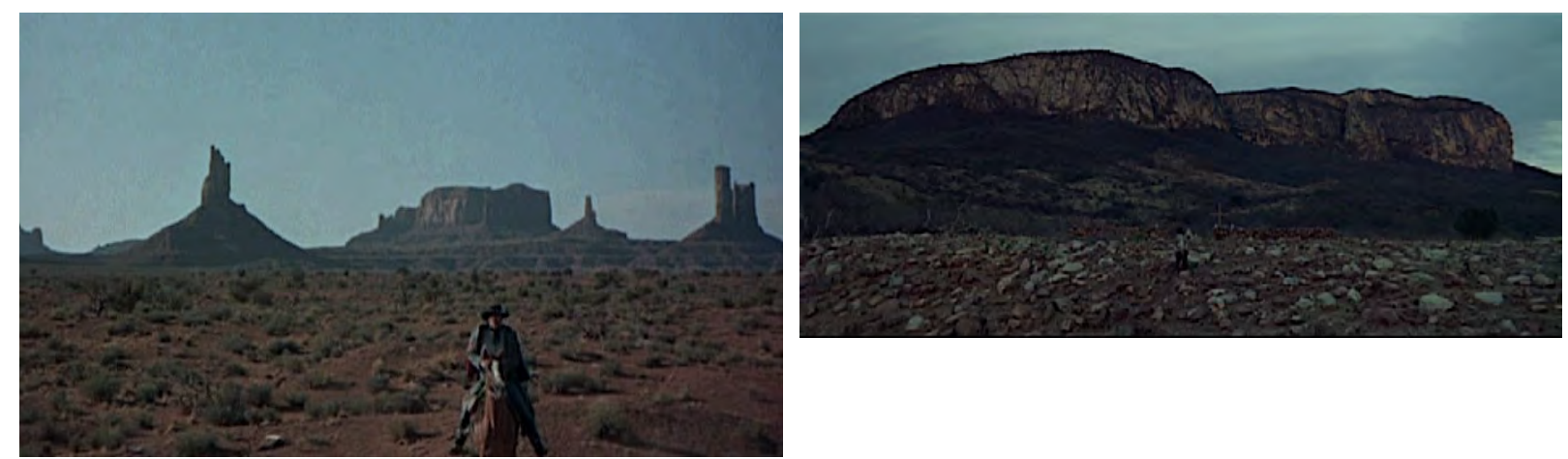

Fig. 236 - Rastros de Ódio (esq) e Abril Despedaçado (dir)

Nesse tipo de enquadramento, o ambiente é o elemento primordial. Tem valor descritivo pois localiza geograficamente o sujeito, e no caso específico do filme, demonstra o isolamento das famílias do Vale das Almas. O valor dramático do grande plano geral está no envolvimento do sujeito pelo ambiente, elemento explorado por Walter Salles na construção dos personagens, e enfatizado pela luz, pelas cores e pelo contraste.
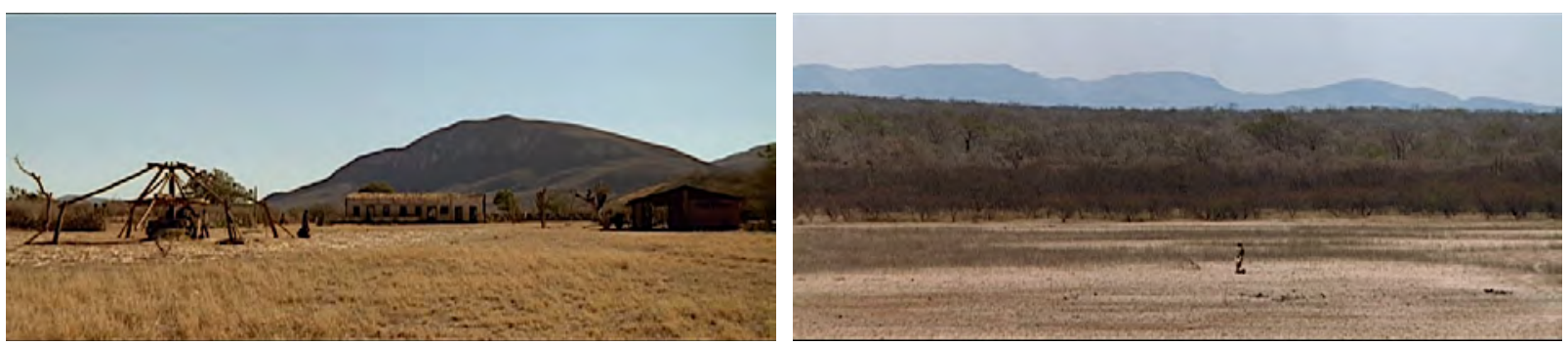

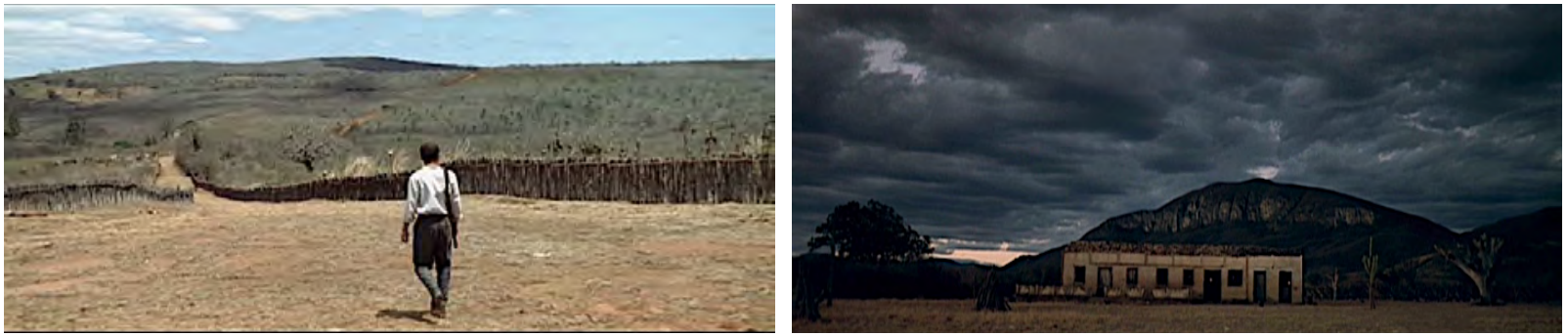

Fig. 237 - Abril Despedaçado (2001), Walter Salles

A morte de Inácio, irmão mais velho de Tonho, remete aos duelos dos westerns, com o plano fechado dos personagens contra o céu, o tiro em um grande plano geral e a subjetiva de Pacu vendo o assassino.

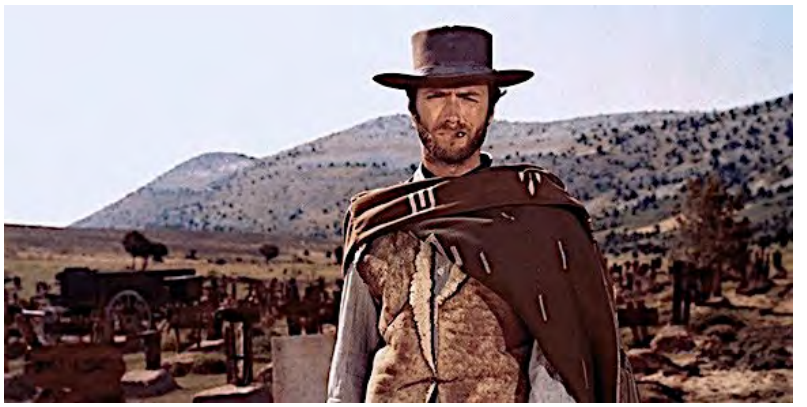

Fig. 238 - Três Homens em Conflito (1966), Sergio Leone
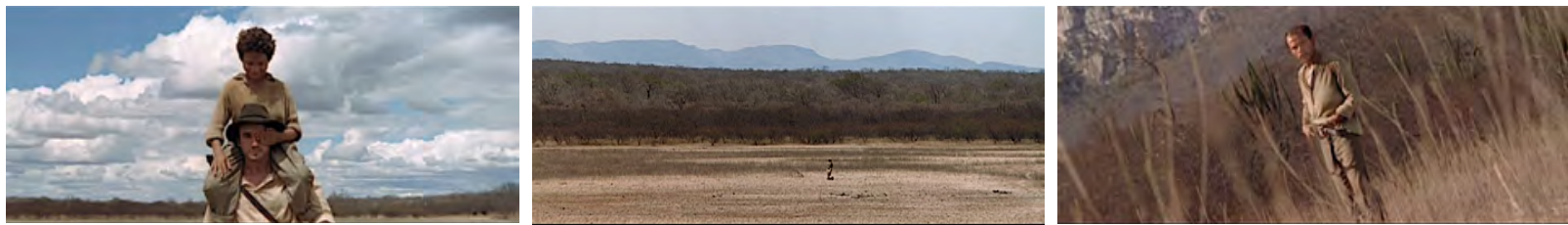

Fig. 239 - Abril Despedaçado (2001), Walter Salles

Muito em razão dos planos gerais, da luz abundante e das referências fílmicas para a criação da fotografia, é grande a profundidade de campo de Abril Despedaçado. Nos filmes anteriores, Walter Carvalho explora mais o desfoque. Entretanto, em Abril Despedaçado há alguns planos com foco seletivo, como os dos fotogramas da figura 240 , em que a camisa de Inácio serve de cortina para a imagem de Tonho e Pacu.
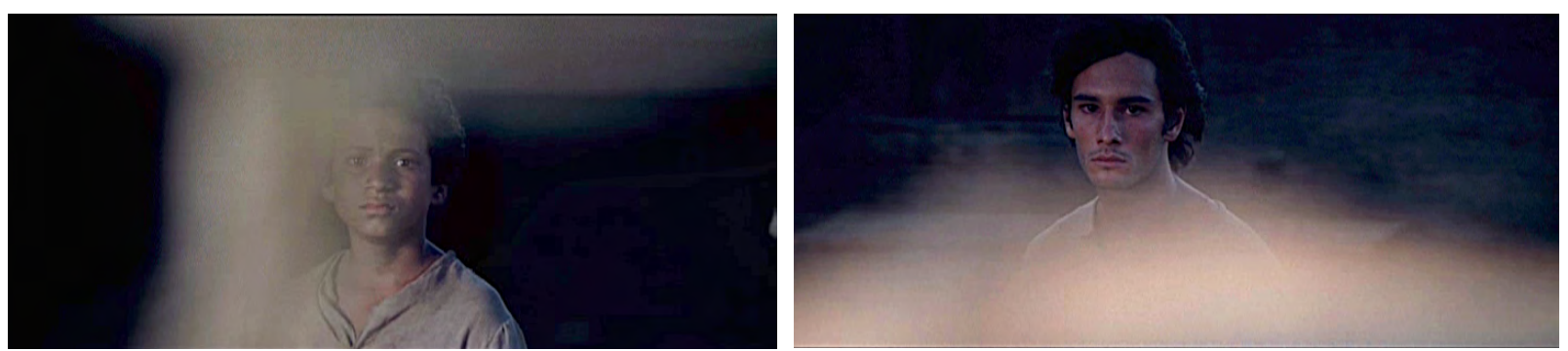

Fig. 240 - Abril Despedaçado (2001), Walter Salles 
Há também os planos que mostram a cruz do túmulo de Inácio e a bolandeira desfocadas, o plano em que Pacu observa os bois em um quadro com o horizonte totalmente desfocado, e o momento em que o pai entra em foco ao olhar a camisa amarelada de Inácio. É importante notar que a opção pela grande ou pequena profundidade de campo se dá em função da narrativa, e que a presença ou ausência de foco é utilizada expressivamente, uma característica recorrente na fotografia de Walter Carvalho.
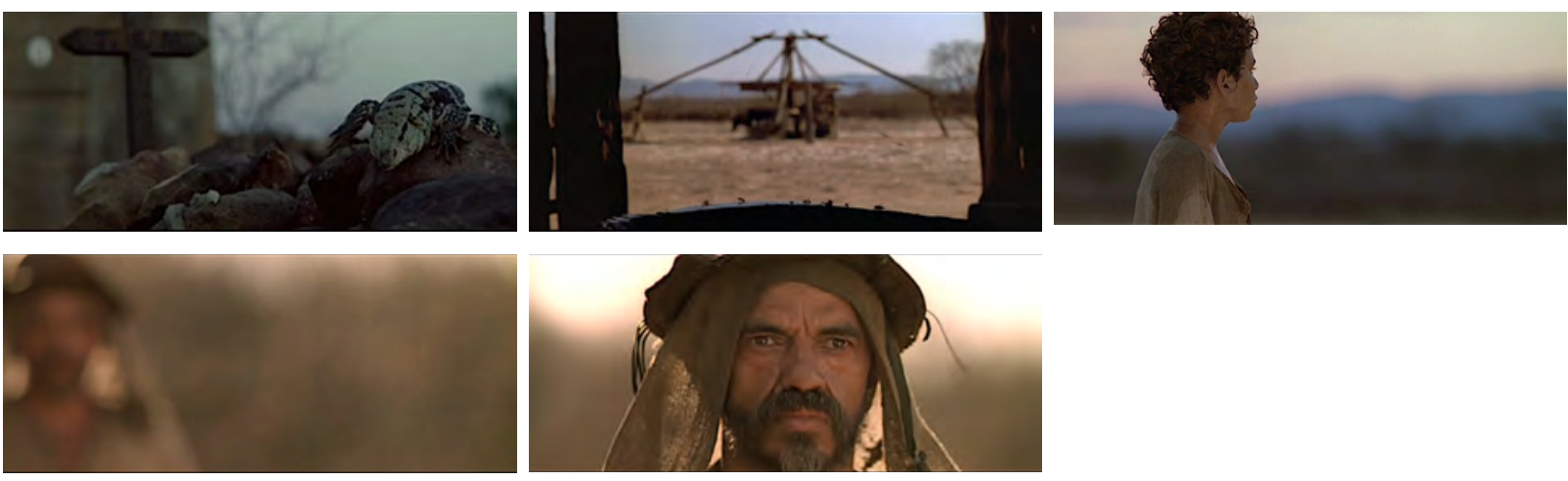

Fig. 241 - Abril Despedaçado (2001), Walter Salles

Na sequência da vingança de Tonho, Walter Carvalho enquadra os personagens com elementos do cenário em primeiro plano, procedimento utilizado em Central do Brasil e Lavoura Arcaica, é o caso da vegetação da caatinga e das madeiras do curral.
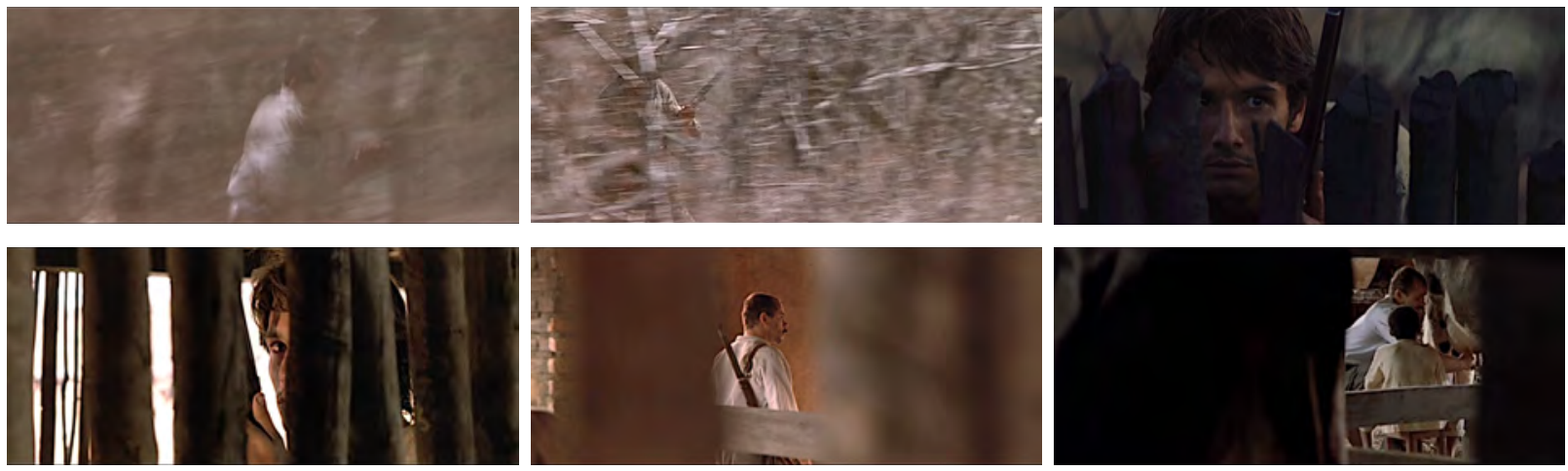

Fig. 242 - Abril Despedaçado (2001), Walter Salles

A perseguição na caatinga guarda certa semelhança com Rastros de Ódio (fig. 243), principalmente em relação ao ambiente e suas cores. 

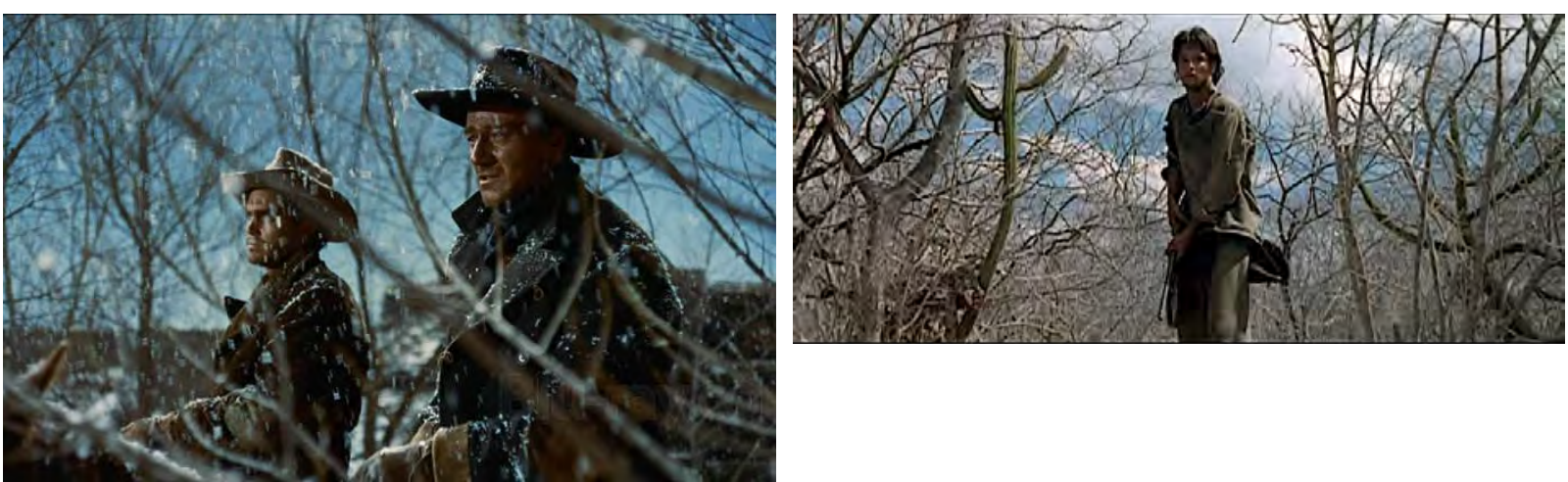

Fig. 243 - Rastros de Ódio (esq) e Abril Despedaçado (dir)

No que tange o movimento de câmera e dos personagens, a perseguição lembra o plano de Lavoura Arcaica em que André menino corre atrás da pomba liberta. Entretanto, no plano de Abril Despedaçado, a câmera mais veloz e a vegetação densa resultam num efeito em que pouco se pode ver do personagem, aumentando a tensão do espectador.
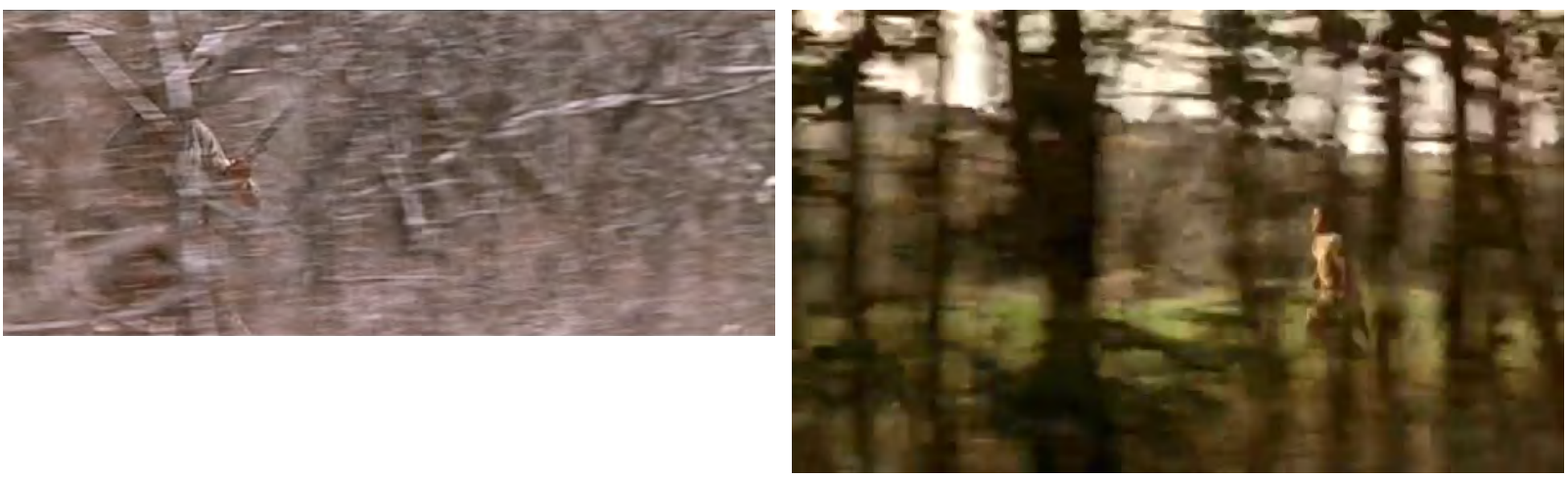

Fig. 244 - Abril Despedaçado (esq) e Lavoura Arcaica (dir)

Walter Carvalho conta que a cena só foi possível porque utilizou uma câmera leve (Aaton 35 III), que o permitiu correr em alta velocidade com a câmera na mão, e que não alterou obturador para melhorar a nitidez da imagem.

Não mexi (no obturador), imagina você correndo no meio da caatinga com aqueles galhos secos na frente, com uma lente $100 \mathrm{~mm}, 135 \mathrm{~mm}, 200 \mathrm{~mm}$, já dá um 'strobe' (efeito de flicagem na imagem), a ponto do Waltinho (Walter Salles, o diretor), que estava na outra câmera, achar que tinha perdido o ator, mas não, tava lá, só que não dava para ver. E eu tinha a mesma sensação, às vezes eu ficava catando o cara dentro do quadro e o cara tava lá no meio (ASSOCIAÇÃO BRASILEIRA DE CINEMATOGRAFIA, 2002).

A câmera leve e compacta também auxiliou a captação de imagens em posições e movimentos de difícil execução, como no alto da bolandeira, no balanço e na corda. 

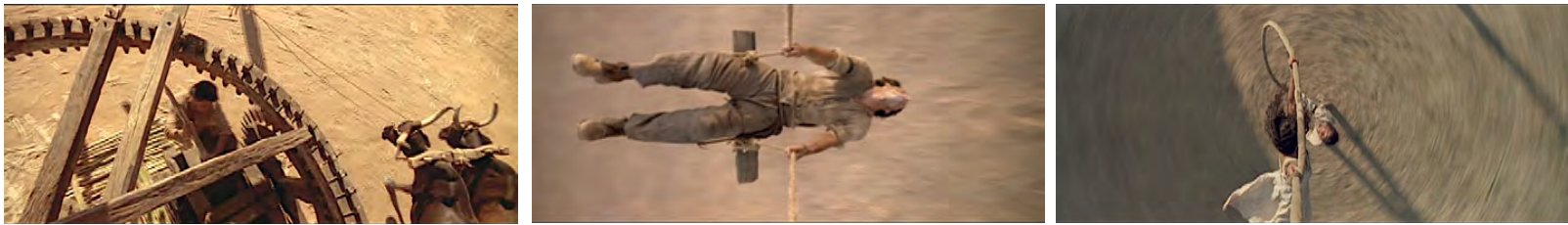

Fig. 245 - Abril Despedaçado (2001), Walter Salles

Com relação à iluminação, Walter Carvalho trabalhou com um refletor para cada grande elemento do cenário, como o pátio, a bolandeira, a casa. Colocou os refletores no alto de guindastes, filtrados por difusores. "Era como se a luz estivesse vindo dos astros mesmo, uma coisa muito longe, chegava apagada, chegava ausente, e eu trabalhei com essa ausência o tempo inteiro" (ASSOCIAÇÃO BRASILEIRA DE CINEMATOGRAFIA, 2002).

$\mathrm{O}$ conceito de luz ausente está relacionado ao espaço em que vivem os personagens. O isolamento da família Breves e a falta de luz elétrica justificam o fato da luz ter origem na natureza. O local em que a família produz rapadura é um exemplo do trabalho de iluminação que simula a luz solar, penetrando o ambiente apenas pelas pequenas janelas e frestas do barracão.
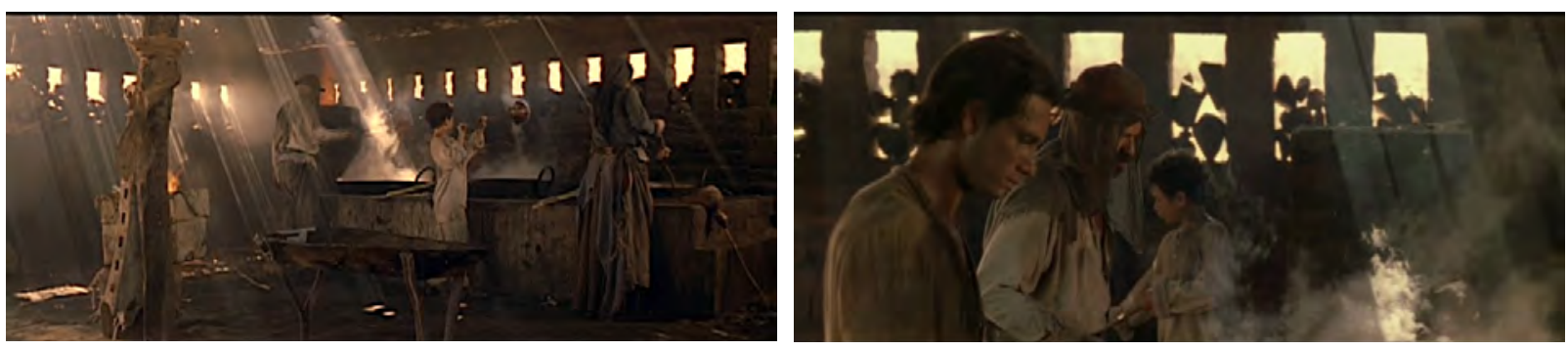

Fig. 246 - Abril Despedaçado (2001), Walter Salles

Tal conceito também aparece na iluminação com velas, utilizadas com frequência por Walter Carvalho, que constituem fontes luminosas diegéticas de algumas cenas de Abril Despedaçado. Apesar da utilização de refletores para reforçar a pequena intensidade luminosa, as velas simulam e justificam a origem da luz.
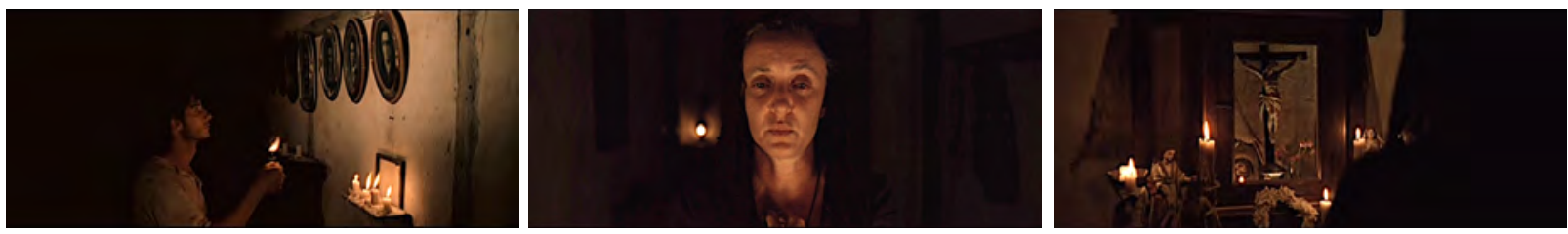

Fig. 247 - Abril Despedaçado (2001), Walter Salles

Ao empregar um único refletor para cada elemento do cenário, Walter Carvalho faz com que a luz venha de uma única direção, com pouco ou nenhum preenchimento, o que garante os pretos profundos, de forma semelhante ao trabalho de luz em Lavoura Arcaica. 

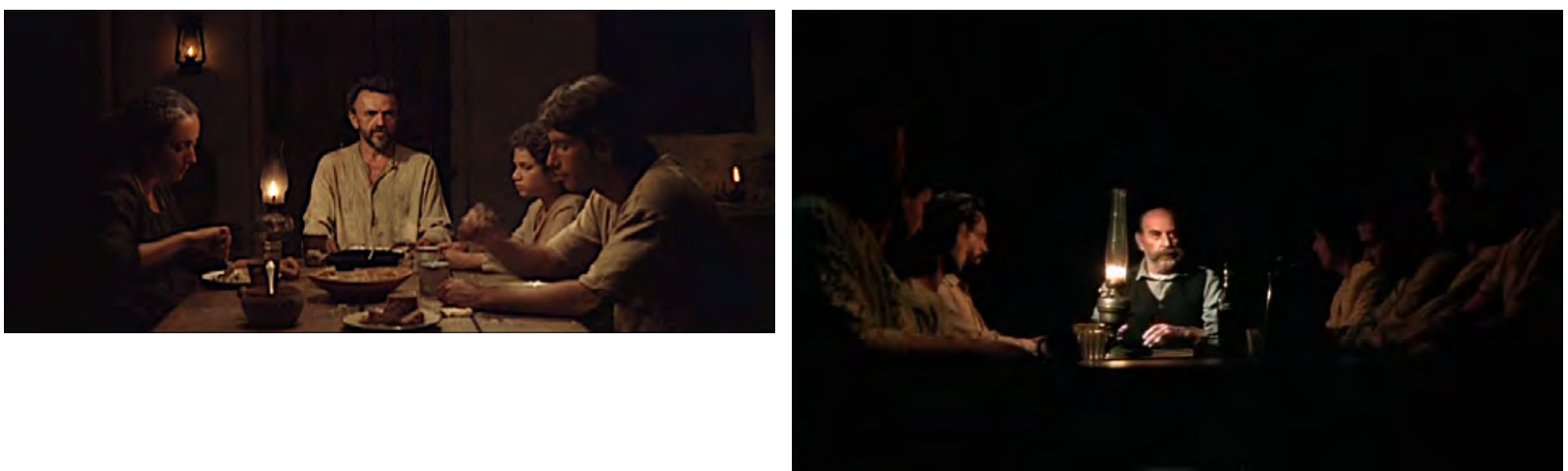

Fig. 248 - Abril Despedaçado (cima) e Lavoura Arcaica (baixo)

Entretanto, se eliminarmos a crominância dos fotogramas, é possível verificar uma pequena diferença entre os dois filmes. Abril Despedaçado possui mais nuances de cinza que Lavoura Arcaica, o que lhe confere um contraste menos radical.
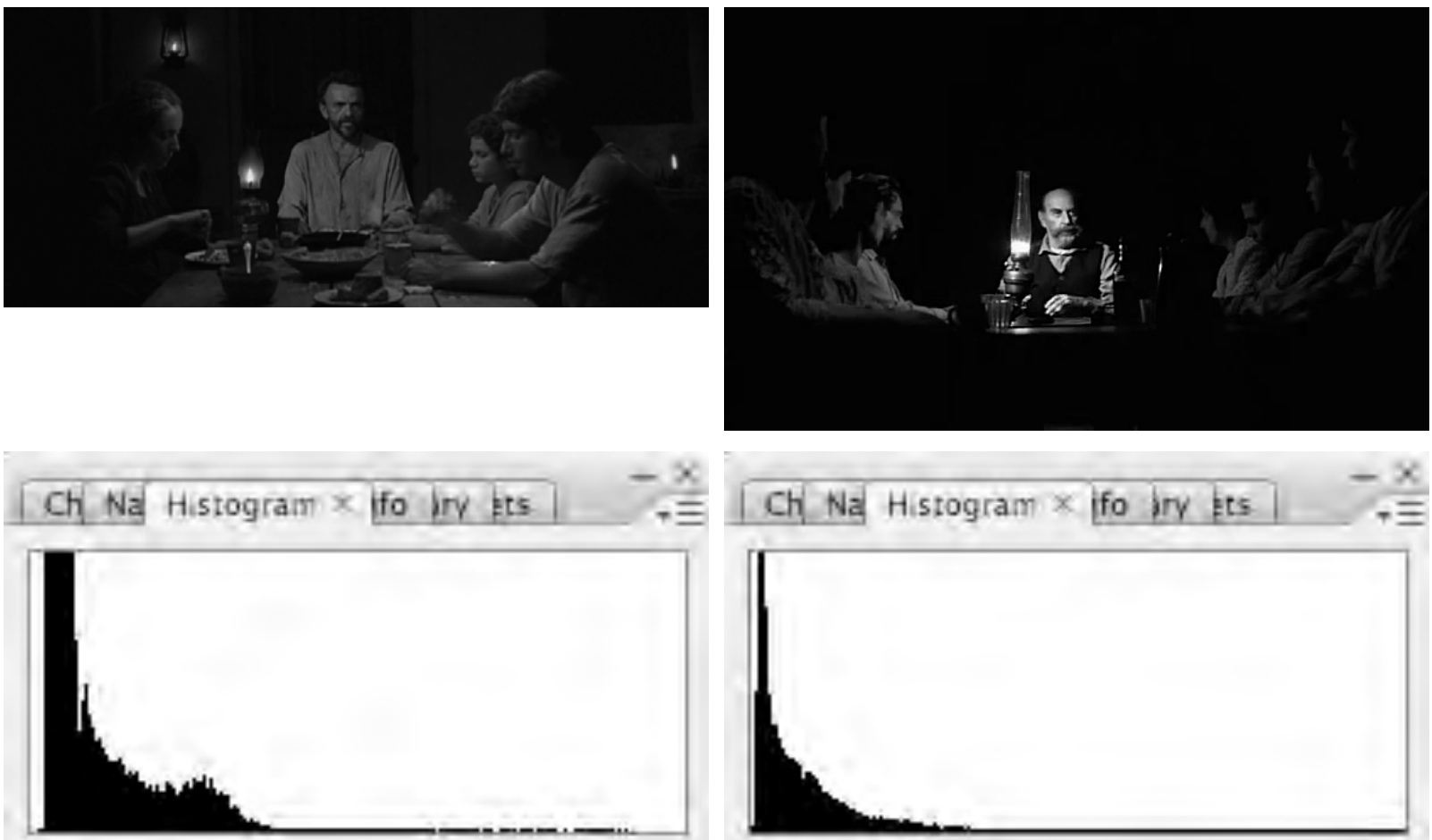

Fig. 249 - Abril Despedaçado (cima) e Lavoura Arcaica (baixo)

Apenas no final do filme, quando Tonho segue para a praia, os contrastes diminuem e a cor se altera.
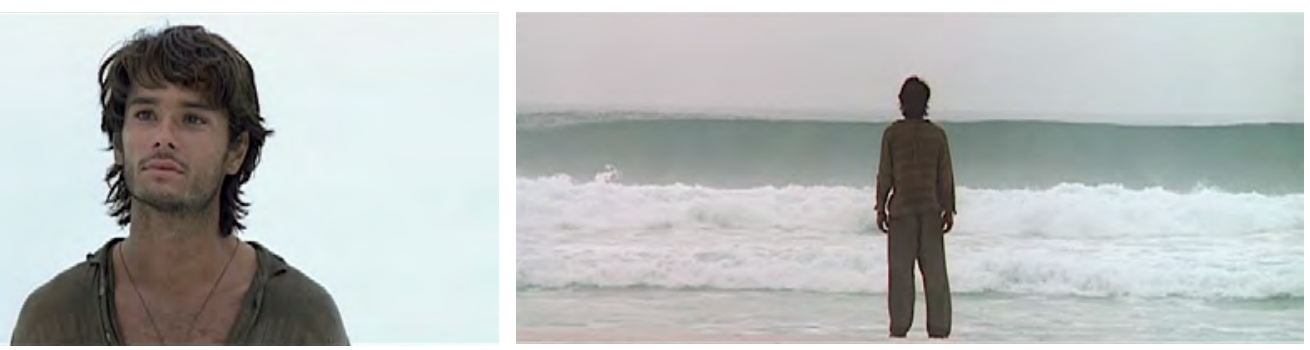

Fig. 250 - Abril Despedaçado (2001), Walter Salles 
A predominância de baixas luzes dá lugar às médias e altas luzes, os pretos, ocres e azuis são substituídos por brancos e tons de verde.

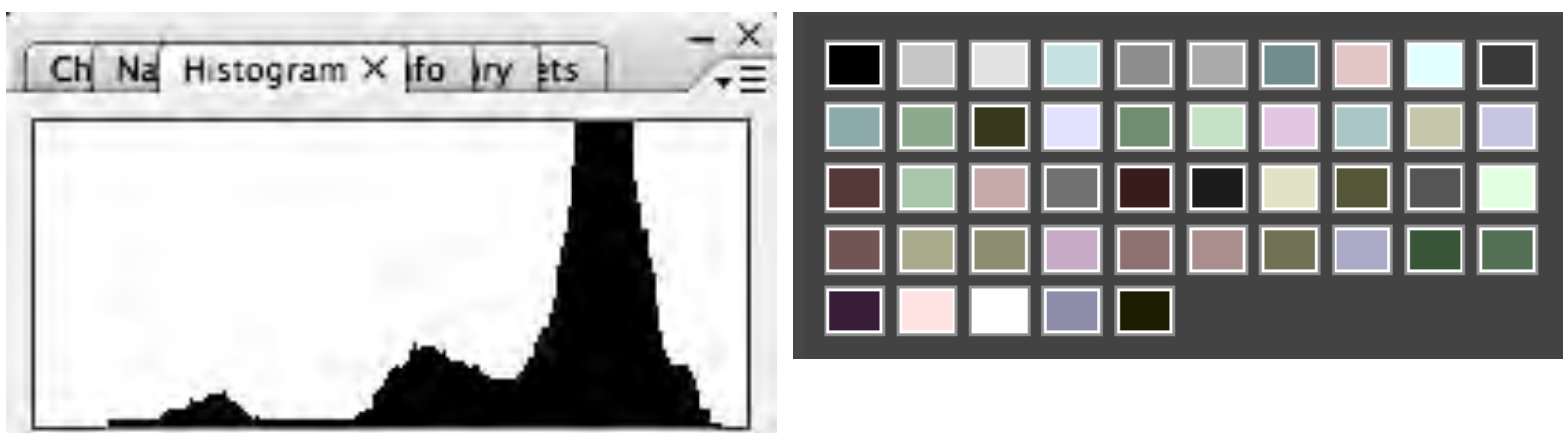

Fig. 251 -Abril Despedaçado, histograma e paleta do plano final

O mar, que era o sonho de Pacu, representa os novos horizontes, as novas perspectivas de Tonho. O movimento interno do personagem, o sertão que vira mar, traduz-se fotograficamente pela cor e pelo contraste. 


\subsection{Madame Satã (2002), Karim Aïnouz}

Primeiro longa-metragem do diretor Karim Aïnouz, Madame Satã retrata um curto período da vida de João Francisco dos Santos (1900-1976), personagem do submundo carioca, interpretado por Lázaro Ramos. O ano é 1932, momento anterior à transformação de João Francisco em Madame Satã, um mito no bairro da Lapa nos anos 1940.

João Francisco nasceu no interior de Pernambuco, filho de escravos recém-libertos, e ainda adolescente foi para o Rio de Janeiro, onde conviveu com prostitutas e boêmios da Lapa. Tornou-se famoso localmente e passou a frequentar as páginas policiais dos jornais devido a pequenos golpes e prostituição.

Em artigo publicado na Revista Universitária do Audiovisual, Geisa Rodrigues Leite da Silva, professora de comunicação da Universidade Federal Fluminense, trata do contexto em que viveu Madame Satã:

O Estado brasileiro do início do século XX iniciava um processo de modernização ainda sem saber lidar com elementos marginais à racionalidade e à moral que configurariam uma "sociedade moderna". No caso, ex-escravos, descendentes, imigrantes e toda uma população analfabeta e beirando a miséria que habitava um mundo à parte. Um exterior difícil de ser controlado e compreendido. Na contramão dos acontecimentos e excluída do processo social, essa população marginalizada, constituída em grande parte por negros e migrantes, criou códigos e normas próprios, com seus personagens e atores sociais (SILVA, 2009).

O filme, contudo, não é uma cinebiografia. Trata da intimidade do homem, de sua personalidade, de sua condição de negro, pobre, analfabeto e homossexual, bem como de sua rebeldia contra a exclusão. Poderíamos dizer que é uma narrativa "de dentro para fora", parte da força do personagem contra os limites que lhe são impostos, para finalmente tocar na violência que o oprime.

Desse modo, o roteiro afasta-se da biografia oficial de João Francisco, baseia-se em relatos dos que o conheceram. Os personagens que contracenam com ele são todos fictícios: Tabu (Flávio Bauraqui), a prostituta Laurita (Marcélia Cartaxo), Renatinho (Felippe Marques), a filha adotada, entre outros. Segundo Aïnouz,

De cara, eu não queria construir um personagem folclórico, estereotipado. Quando você folcloriza, você se distancia, trivializa, banaliza. Isso não me interessava e sim realizar um filme que fosse uma experiência no sentido de ficar tão colado ao personagem que entrasse nele, na sua intimidade, no seu cotidiano, na sua raiva, na sua doçura. Tampouco queria fazer um filme épico porque o personagem é Madame Satã descontruindo a cena multifacetado, não queria torná-lo um herói distante [...]. Também não queria um filme biográfico, porque de um modo geral, no cinema, as "biografias" são lineares, e a experiência dele não é linear. [...] Optei por fazer um recorte da vida do personagem e desenhá-lo verticalmente. O modelo biopic não seria justo (com o personagem) - seria empobrecer uma experiência tão exuberante e plural (AÏNOUZ, 2003, p. 183). 
Esteticamente, Madame Satã potencializa as tensões abordadas pelo roteiro. Trata-se da fotografia mais radical de Walter Carvalho desde o início da Retomada, uma vez que o diretor de fotografia explora os limites dos procedimentos técnicos. Assim como o personagem e sua grande complexidade, a fotografia foge do comum e de padrões estabelecidos, como veremos na análise de enquadramentos, profundidade de campo, desenho de luz, contraste e revelação de negativos. Não se pode dizer que a fotografia de Madame Satã traduz o personagem. Neste filme, fotografia e personagem encontram-se intrinsecamente unidos, um não existe sem o outro.

Madame Satã inicia com um close de João Francisco no momento de sua prisão. Em seguida, o filme mostra sua vida pessoal até ser preso. A escolha de fazer um filme que privilegia a intimidade reflete um recorte de distanciamento do mito, da imagem conhecida do personagem. A narrativa é elaborada a partir de imagens, que de forma sensorial, corporal, afetiva, permitem sentir o personagem. Para atingir esse objetivo, a fotografia é construída sobre quatro pilares: enquadramentos fechados, desfoque, alto contraste e luz marcada.

Os enquadramentos fechados tentam aproximar o espectador da psique dos personagens, por meio de seus corpos. É um filme de detalhes, que privilegia olhares, expressões, partes do corpo e nem sempre os rostos. O protagonista não raro é parcialmente enquadrado, o que contribui para enfatizar sua condição de não caber no mundo.
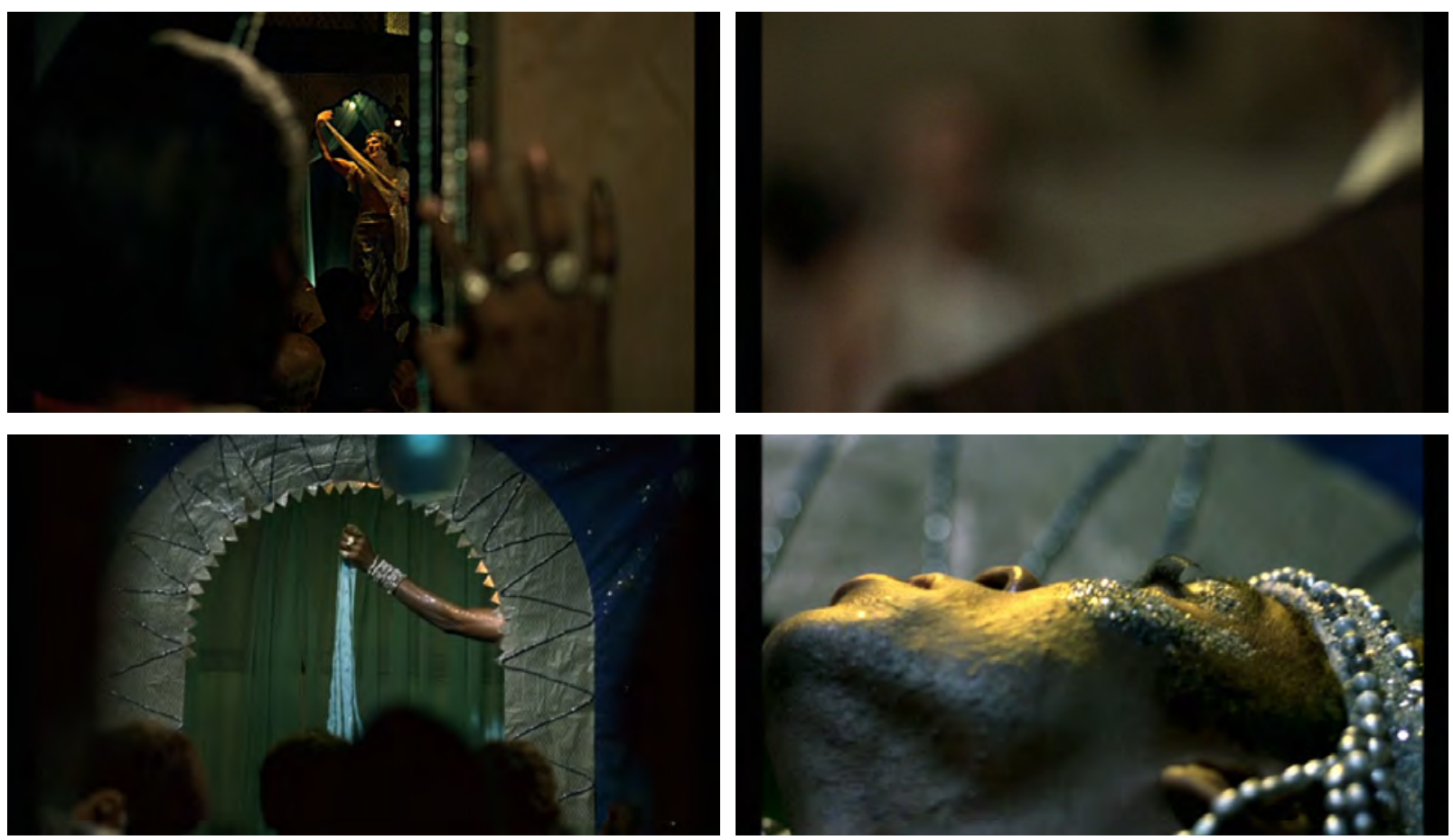

Fig. 252 - Madame Satã (2002), Karim Aïnouz 
Os planos gerais acontecem prioritariamente em ambientes externos, como no caso da praia, da fachada da casa, do esconderijo de João e da prisão.
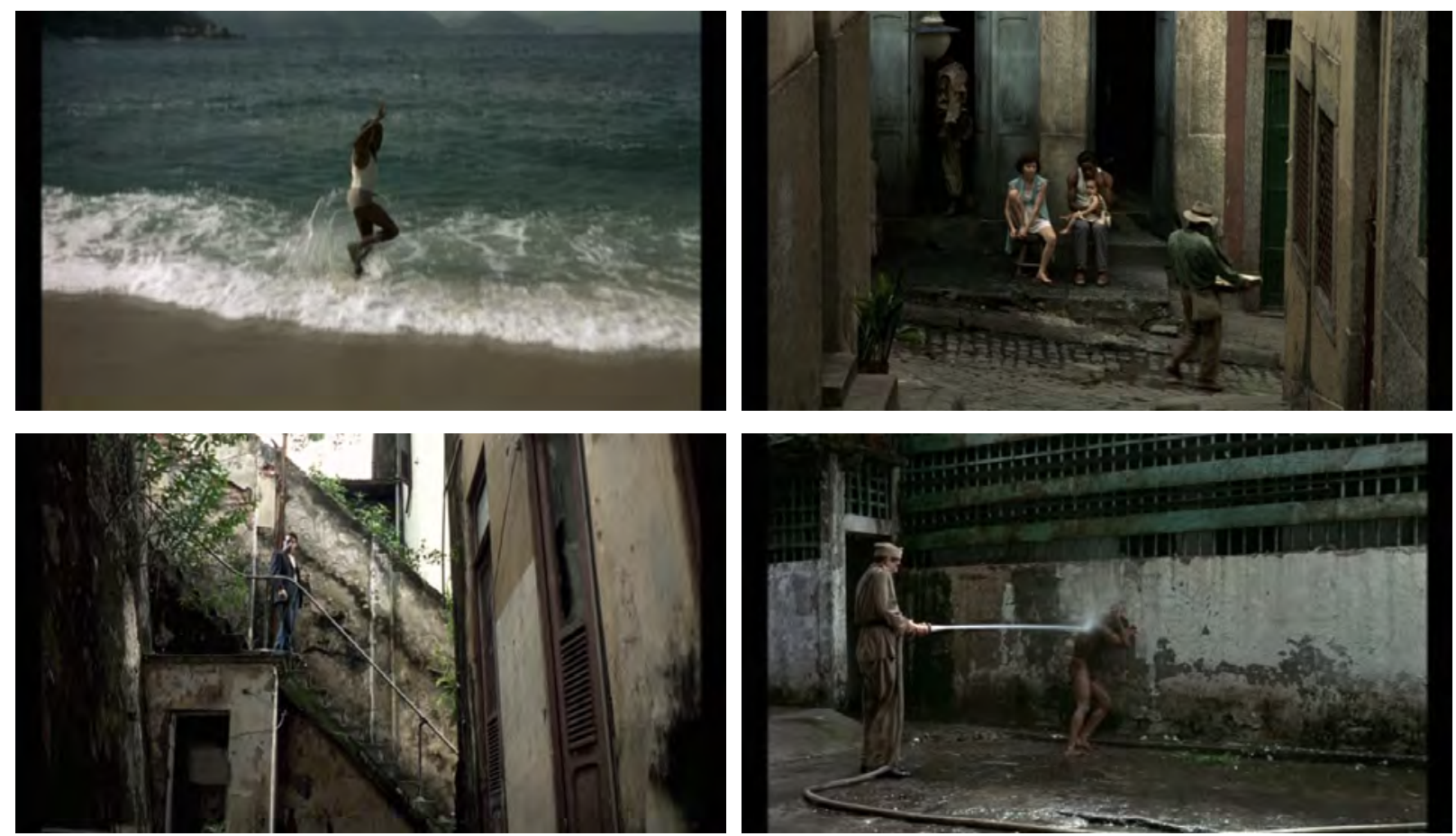

Fig. 253 - Madame Satã (2002), Karim Aïnouz

Cumpre observar que esses planos abertos não possuem a magnitude dos planos gerais de Abril Despedaçado (fig. 254), em que o ambiente exerce papel determinante na vida dos personagens. Em Madame Satã o ambiente é contexto, não um elemento primordial.

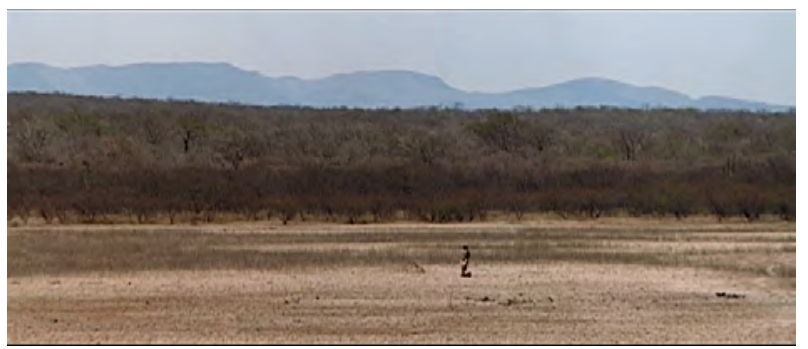

Fig. 254 - Abril Despedaçado (2001), Walter Salles

Há outros planos abertos que, graças à pouca iluminação, não contribuem para que se veja muito da cena. Esses planos traduzem a atmosfera noturna do bairro da Lapa, reforçando seu papel de contexto para a narrativa. 

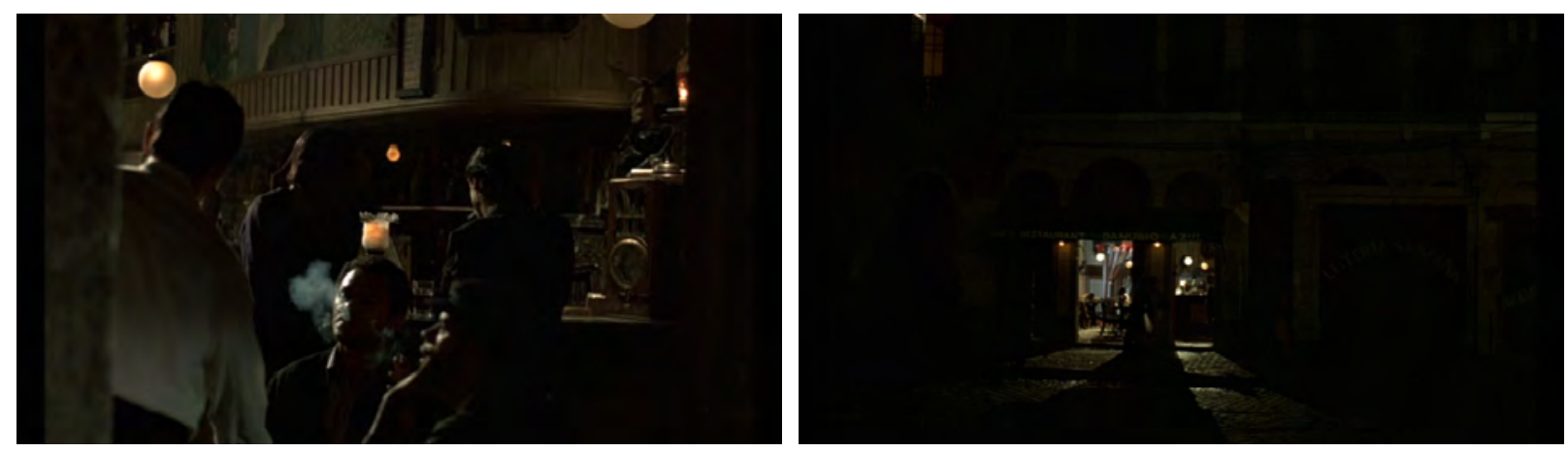

Fig. 255 - Madame Satã (2002), Karim Aïnouz

Há ainda os planos que, embora abertos, têm a imagem restrita a uma pequena porção do quadro pela inclusão de elementos em primeiro plano. Desse modo, tornam-se fechados não pela escolha da lente mas pela composição, como podemos perceber nos fotogramas da figura 256 .
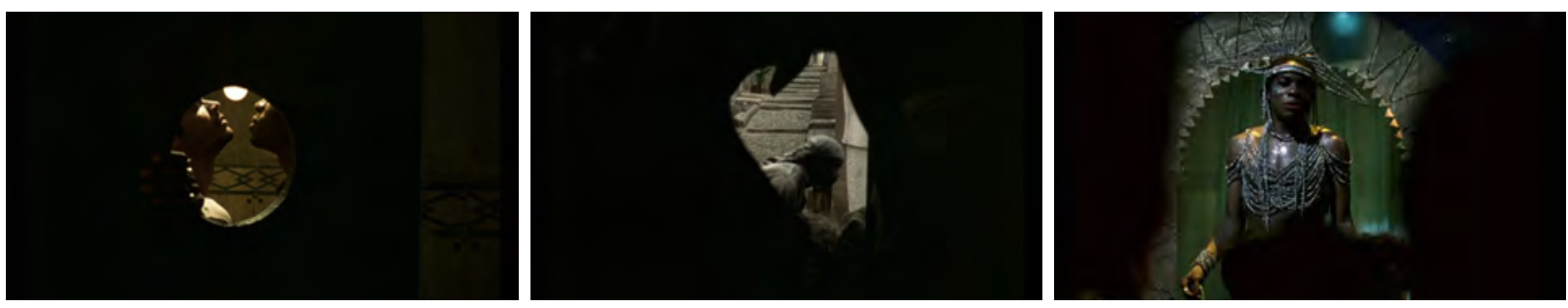

Fig. 256 - Madame Satã (2002), Karim Aïnouz

A divisão vertical do quadro em três partes e concentração da imagem iluminada no centro, procedimento utilizado por Walter Carvalho em filmes anteriores, é utilizada com muita frequência em Madame Satã. Trata-se de uma variação do procedimento mostrado anteriormente, em que a composição fecha o plano criado por uma lente aberta.
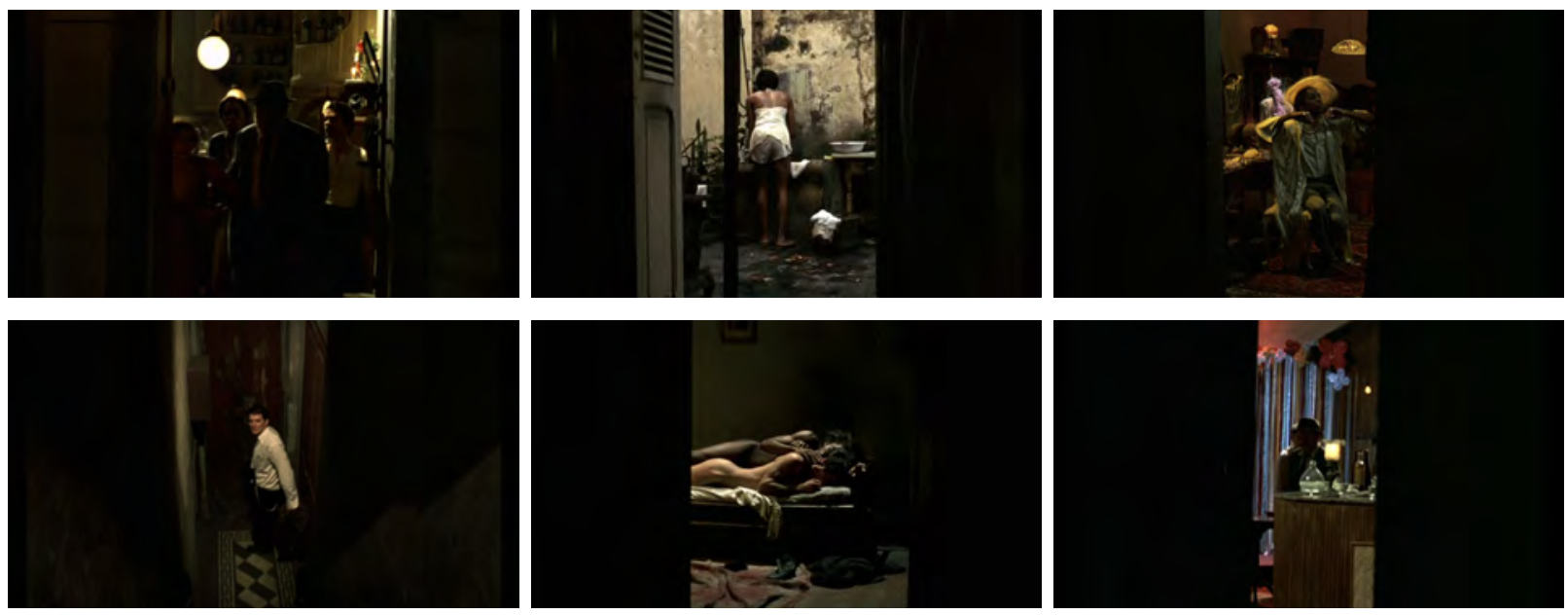

Fig. 257 - Madame Satã (2002), Karim Aïnouz 
Entretanto, nota-se uma diferença em relação ao uso da tripartição em filmes anteriores, como Central do Brasil e Abril Despedaçado. Nestes dois casos, a alta luz concentra-se no exterior dia, que contrasta com o preto profundo das áreas internas. Assim, a diferença de luz conduz o olhar de dentro para fora, do ambiente interno para o mundo.

No caso de Madame Satã, com raras exceções, a área iluminada está em um ambiente interior, contrastando com outro ambiente interno mais escuro ou com o exterior noite. Desse modo, a luz conduz o olhar do "interno para o mais interno". Walter Carvalho ilumina a intimidade dos personagens, dando ênfase a seus sentimentos e ações em detrimento do ambiente que os cerca. Assim, a fotografia dirige o olhar do espectador para o íntimo, tanto pela câmera próxima aos corpos quanto pela câmera distante, porém centrada na ação, ou ainda pela iluminação.

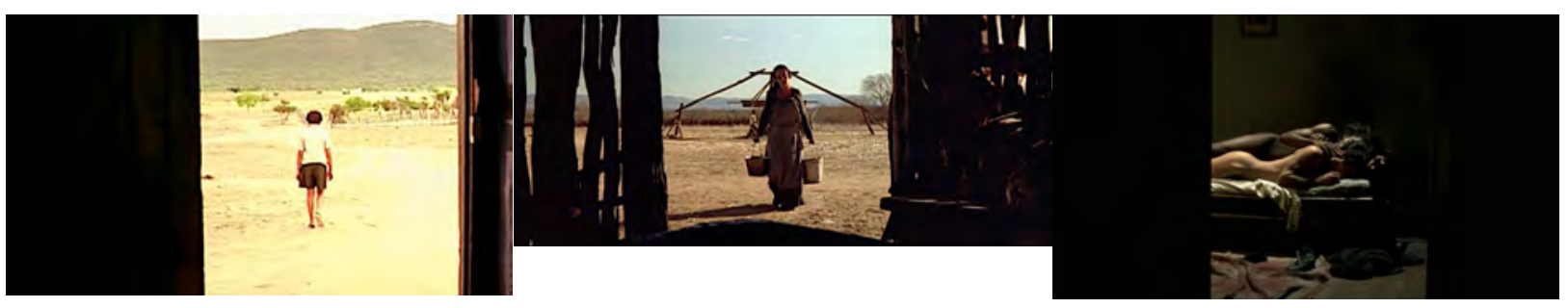

Fig. 258 - Central do Brasil, Abril Despedaçado e Madame Satã

O enquadramento utilizando espelhos é outro meio de focar a intimidade dos personagens. Além de ser um procedimento estético que emoldura e fecha o quadro, os espelhos tratam da relação entre o corpo e sua imagem.
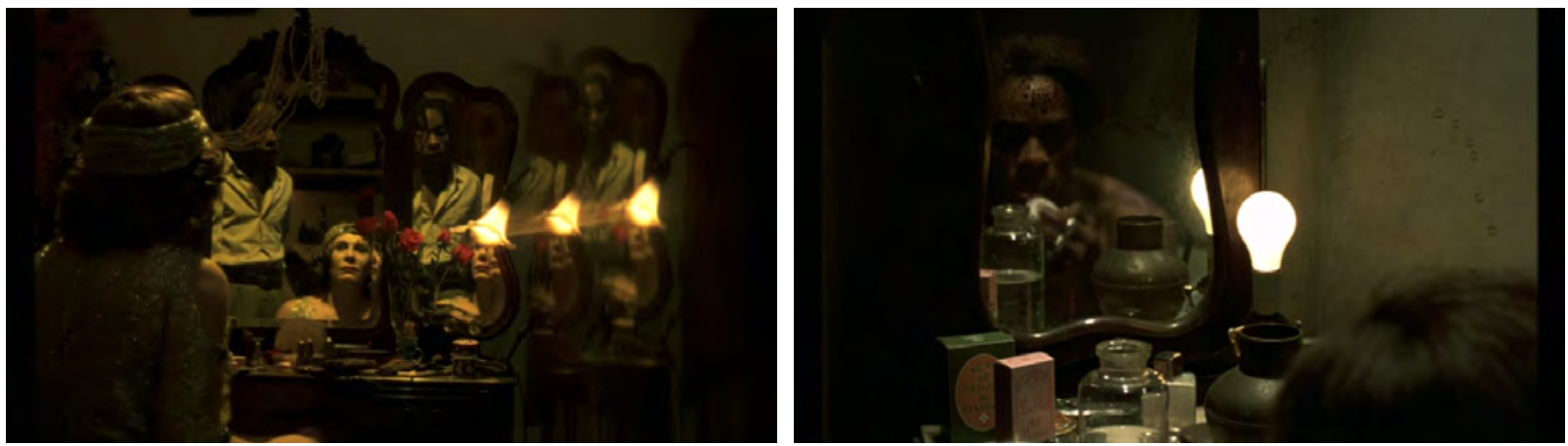

Fig. 259 - Madame Satã (2002), Karim Aïnouz

João Francisco busca materializar seu gênero por meio do corpo, através de roupas, gestos e olhares, que são explorados pela fotografia em planos de detalhes. Identificamos a face travesti do personagem nas cenas dos shows ou nas que representam esses momentos, como o espelhamento na artista Vitória, e também na cena em que declama um texto em frente ao espelho, que constitui um marco na construção da identidade de Madame Satã. 
O personagem está em casa e declama um texto de sua autoria, semelhante ao do show de Vitória no cabaré, mas com elementos de seu universo pessoal.

Vivia na maravilhosa China, um bicho tubarão bruto e cruel que mordia tudo e virava tudo em carvão. Pra acalmar a fera, os chinês fazia todo dia uma oferenda com sete gato-maracajá que ele mordia antes do pôr do sol. No ímpeto de pôr fím a tal ciclo de barbaridades chegou Jamacy, uma entidade da floresta da Tijuca. Ela corria pelos matos e avoava pelos morros. E Jamacy virou uma onça dourada de jeito macio, de gosto delicioso. RRRRRRR (imita a onça). E começou a brigar com o tubarão por 1001 noites. No final, a gloriosa Jamacy e o furioso tubarão já estavam tão machucados que ninguém sabia mais quem era um e quem era outro. E assim, eles viraram uma coisa só. RUARRR! (imita a onça de novo).

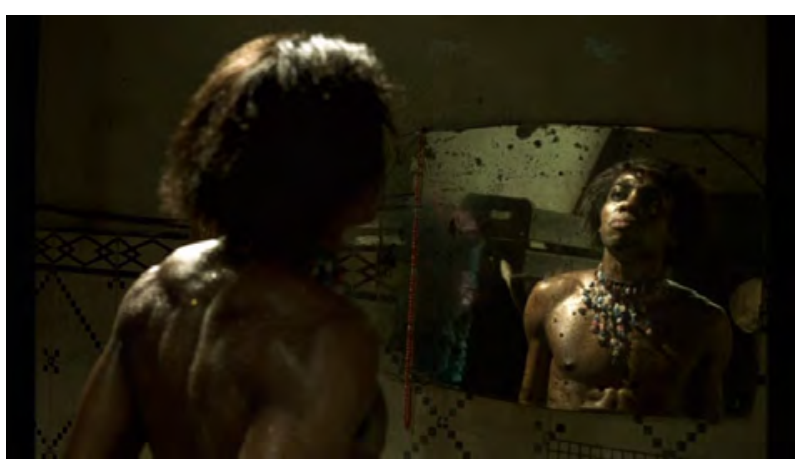

Fig. 260 - Madame Satã (2002), Karim Aïnouz

Neste momento, o personagem incorpora a ambiguidade entre o masculino (o tubarão agressivo) e o feminino (a onça macia), em um texto sobre ele, por ele e para ele. Jamacy acolhe e funde os dois gêneros em seu corpo, o que é visto por meio do corpo real e do espelho. Trata-se da metamorfose do personagem do duplo em um, da fusão do sonhos e desejos que habitam seu corpo na imagem que exterioriza e pode ser vista no espelho.

A questão do corpo e do desejo é trabalhada em alguns elementos do filme que remetem à obra de Wong Kar-wai, cineasta que trata dessa temática. Kar-wai tem como influência os filmes de Pedro Almodóvar (1949- ), mas nem sempre lida de forma explícita com essas questões, ao contrário do cineasta espanhol.

Em Almodóvar o corpo é exagero e o sexo é fácil e fluido. Amor à Flor da Pele (In The Mood For Love, 2000), de Kar-wai, é um filme que trata a sensualidade de forma contida, os protagonistas se encontram nas escadas e mal se tocam, vivem um erotismo proibido, subversivo, rebelde. Contudo, antes de chegar a essa sensualidade velada, Wong Kar-wai trabalhou com o corpo e os sentimentos de forma explícita em Felizes Juntos (Happy Together, 1997), filme fotografado por Christopher Doyle, que conta com protagonistas homossexuais, vivendo abertamente sua paixão no submundo de Buenos Aires. 


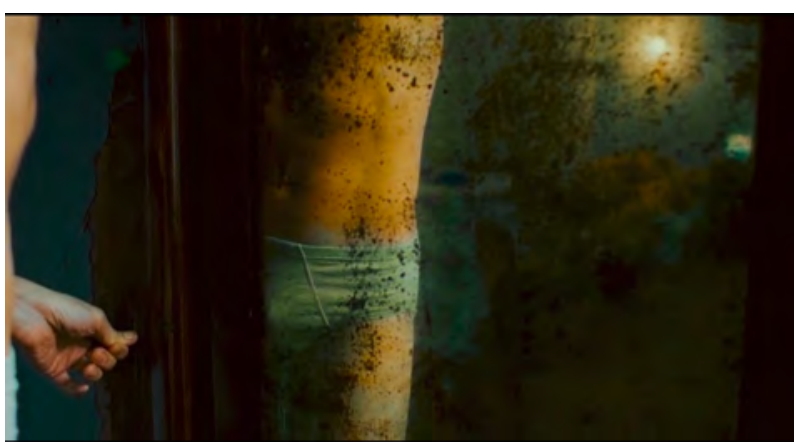

Fig. 261 - Felizes Juntos (1997), Wong Kar-wai

O corpo velado (dentro das regras) e o corpo transgressor são duas formas de tratar um objeto que é central no cinema. Assim como Amor à Flor da Pele, Madame Satã é um filme sobre o corpo, sobre o desejo, sobre as pulsões, mas não de forma velada. João Francisco dá vazão à raiva, ao sexo, ao desejo, ao feminino, ao masculino, seu corpo é retratado na contração dos músculos, na materialidade de suas paixões. Contudo, os detalhes do corpo alternam entre o encolhimento e a expansão do corpo de João Francisco, e por meio deste contraste é que o personagem mostra-se presente no mundo.

Aïnouz trabalha o submundo e a corporeidade de forma mais próxima a Feliz Juntos, mas utiliza elementos visuais presentes em Amor à Flor da Pele, como os planos de escada, que permeiam toda a narrativa.
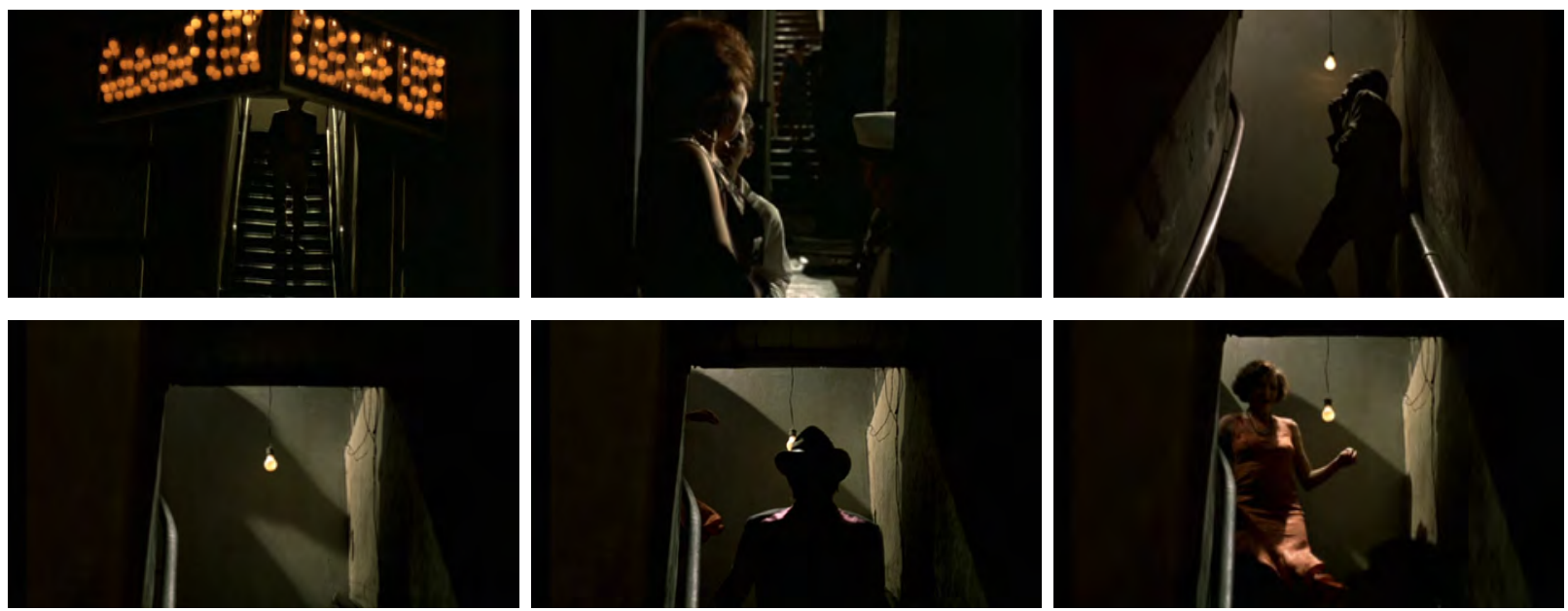

Fig. 262 - Madame Satã (2002), Karim Aïnouz

$\mathrm{Na}$ escada os corpos são vistos ora por inteiro, ora em planos mais fechados, em momentos de simples passagem e também de sedução. A figura 263 mostra dois momentos de Madame Satã filmados de forma semelhante a Amor à Flor da Pele. 

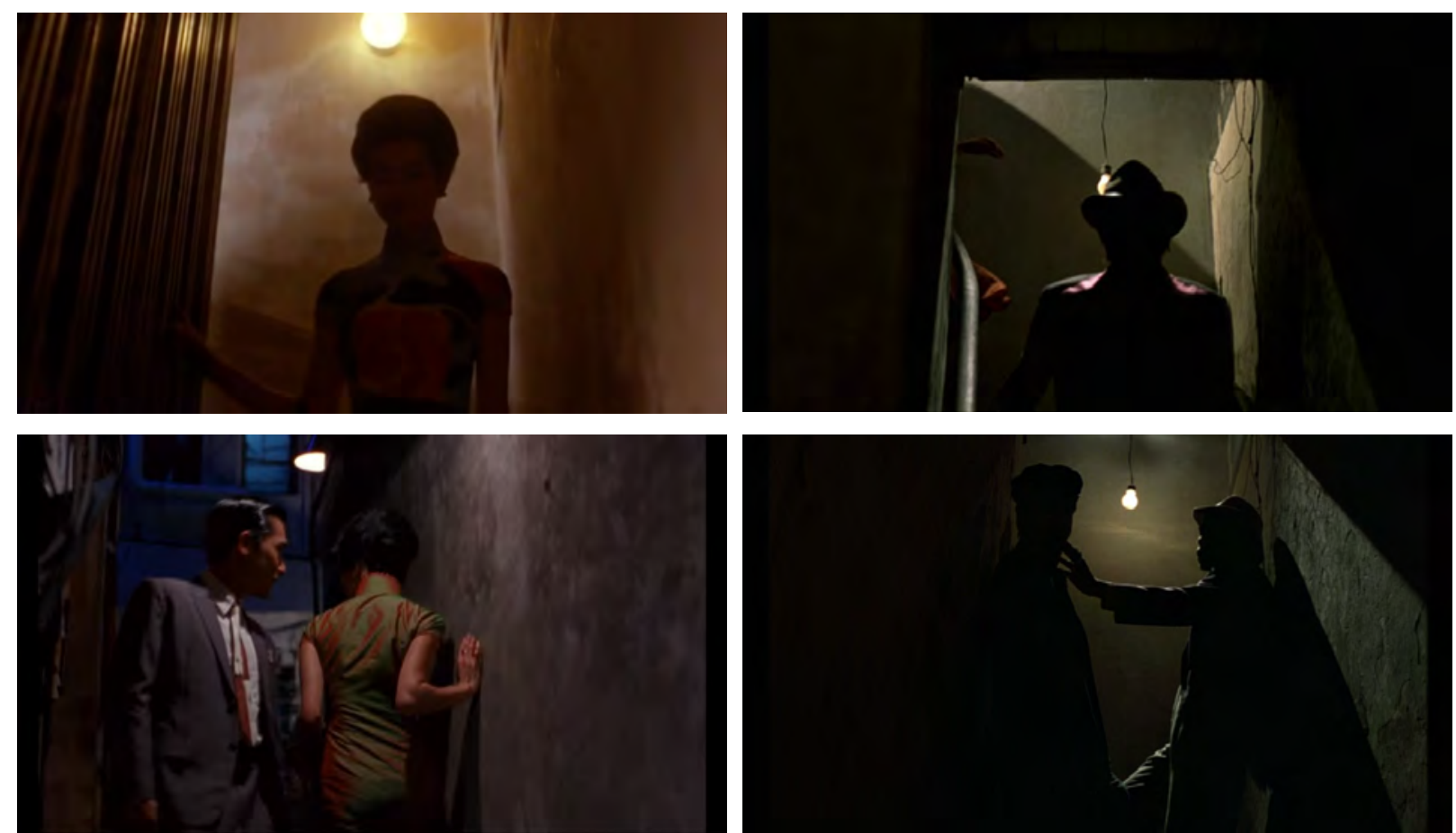

Fig. 263 - Amor à Flor da Pele (esq.) e Madame Satã (dir.)

Nos detalhes sutis dos corpos, a personagem de Mrs Chan e de João Francisco também traçam paralelos.
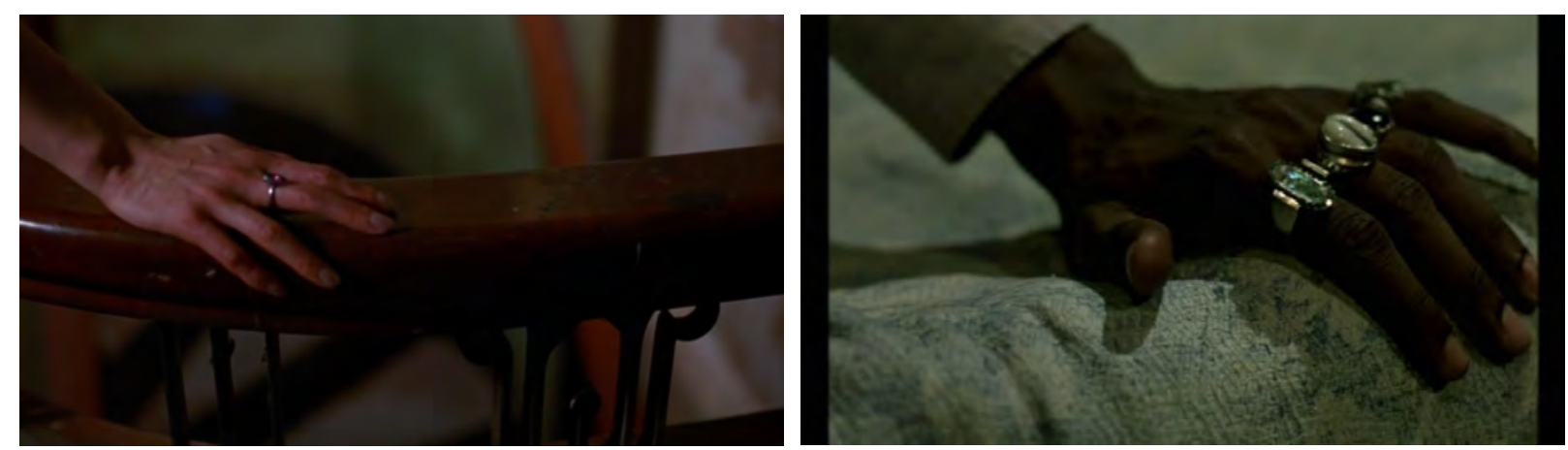

Fig. 264 - Amor à Flor da Pele (esq.) e Madame Satã (dir.)

Além dos enquadramentos fechados, a revelação do negativo utilizando a técnica bleach bypass realça o corpo e principalmente a pele negra do protagonista de Madame Satã. O bleach bypass consiste em pular o branqueador no momento da revelação, tendo como resultado uma imagem com redução na saturação cromática, intensificação no contraste das áreas de luz e sombra e aumento de granulação. Como é possível verificar na figura 265, as altas luzes tornam-se mais intensas e os pretos aprofundam-se, gerando um contraste no corpo do personagem. 


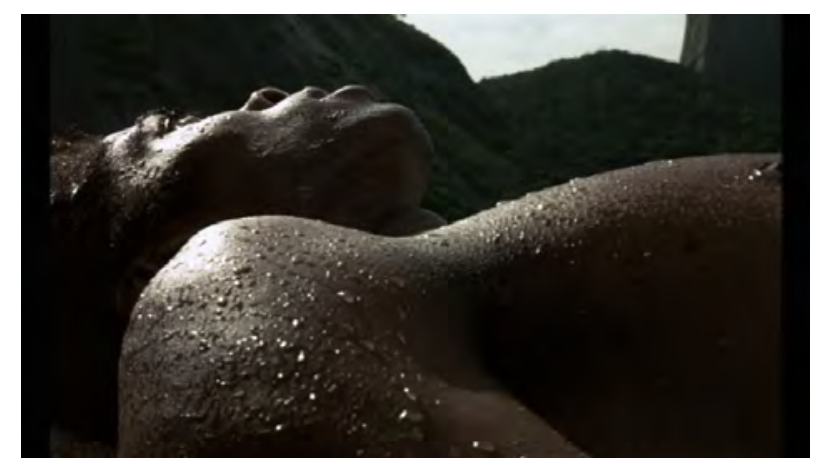

Fig. 265 - Madame Satã (2002), Karim Aïnouz

A figura 266 é um exemplo de como a revelação baixa a saturação da maioria dos matizes.
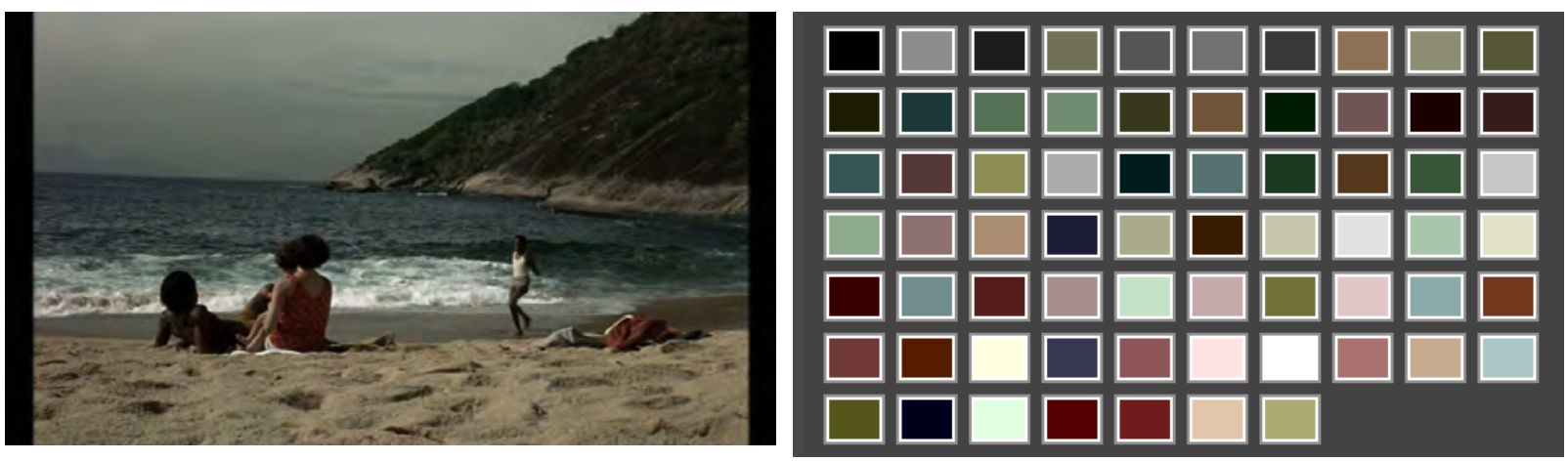

Fig. 266 - Madame Satã (2002), Karim Aïnouz

A visualidade criada por esse tipo de revelação dialoga com a textura ruidosa do cinema marginal, e dialoga com o corpo e a personalidade marginal de João Francisco. Portanto, longe de ter um efeito puramente estético, o bleach bypass está intimamente atrelado ao personagem principal e ao seu contexto.

O filme tem muitas cenas noturnas e personagens negros. Para que o bleach bypass tivesse efeito no contraste, Walter Carvalho tinha o desafio de criar altas luzes nesses ambientes escuros. Para isso utiliza dois procedimentos: enquadra as fontes de luz do ambiente e ilumina os personagens com luz marcada.
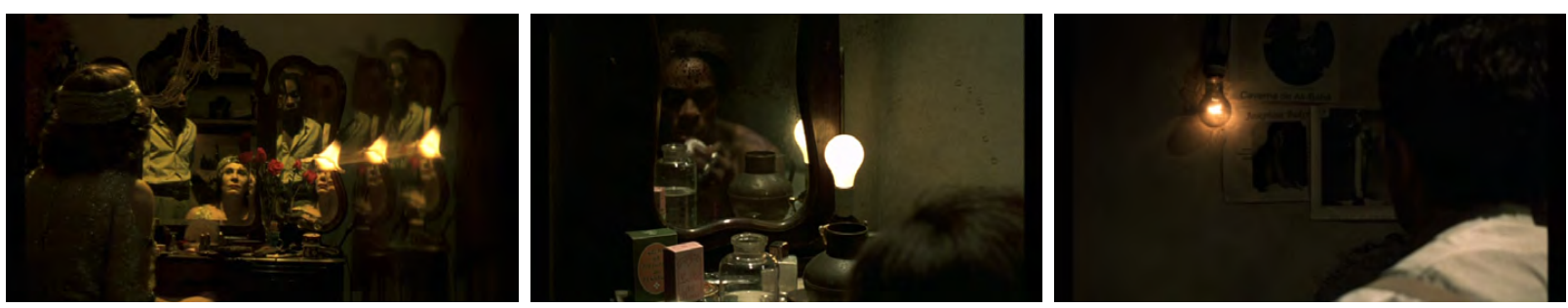

Fig. 267 - Madame Satã (2002), Karim Aïnouz

As fontes luminosas estão presentes em muitos planos, algumas vezes constituem o único elemento do quadro. 

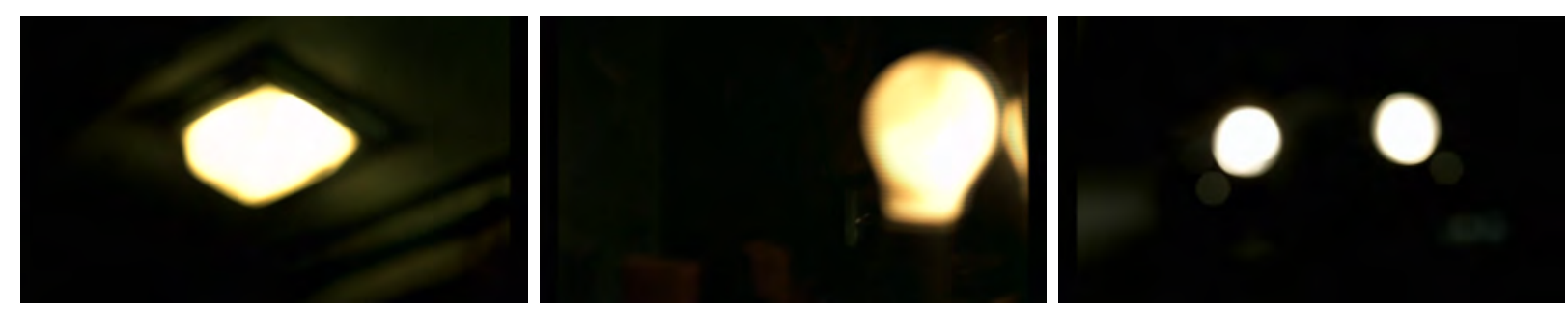

Fig. 268 - Madame Satã (2002), Karim Aïnouz

Assim como as escadas, o enquadramento das fontes encontra paralelo na obra de Won Kar-wai.
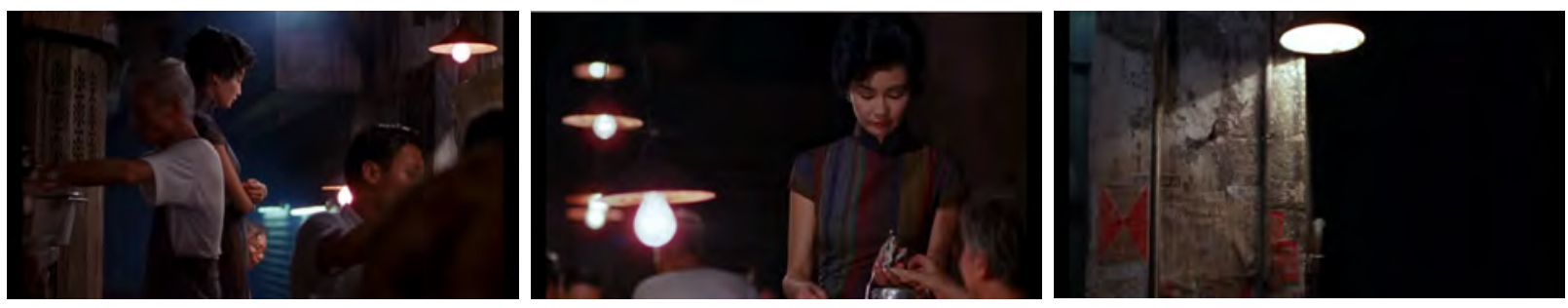

Fig. 269 - Amor à Flor da Pele (2000), Wong Kar-wai

Para evidenciar o que a presença da fonte de luz faz com o contraste, basta compararmos os histogramas de uma imagem com e sem a fonte. No fotograma original há um registro de alta luz, ainda que pequeno, como pode ser visto na parte direita do histograma. No segundo fotograma, com a retirada da fonte luminosa, o histograma concentra todos os seus pontos nas médias e baixas luzes.
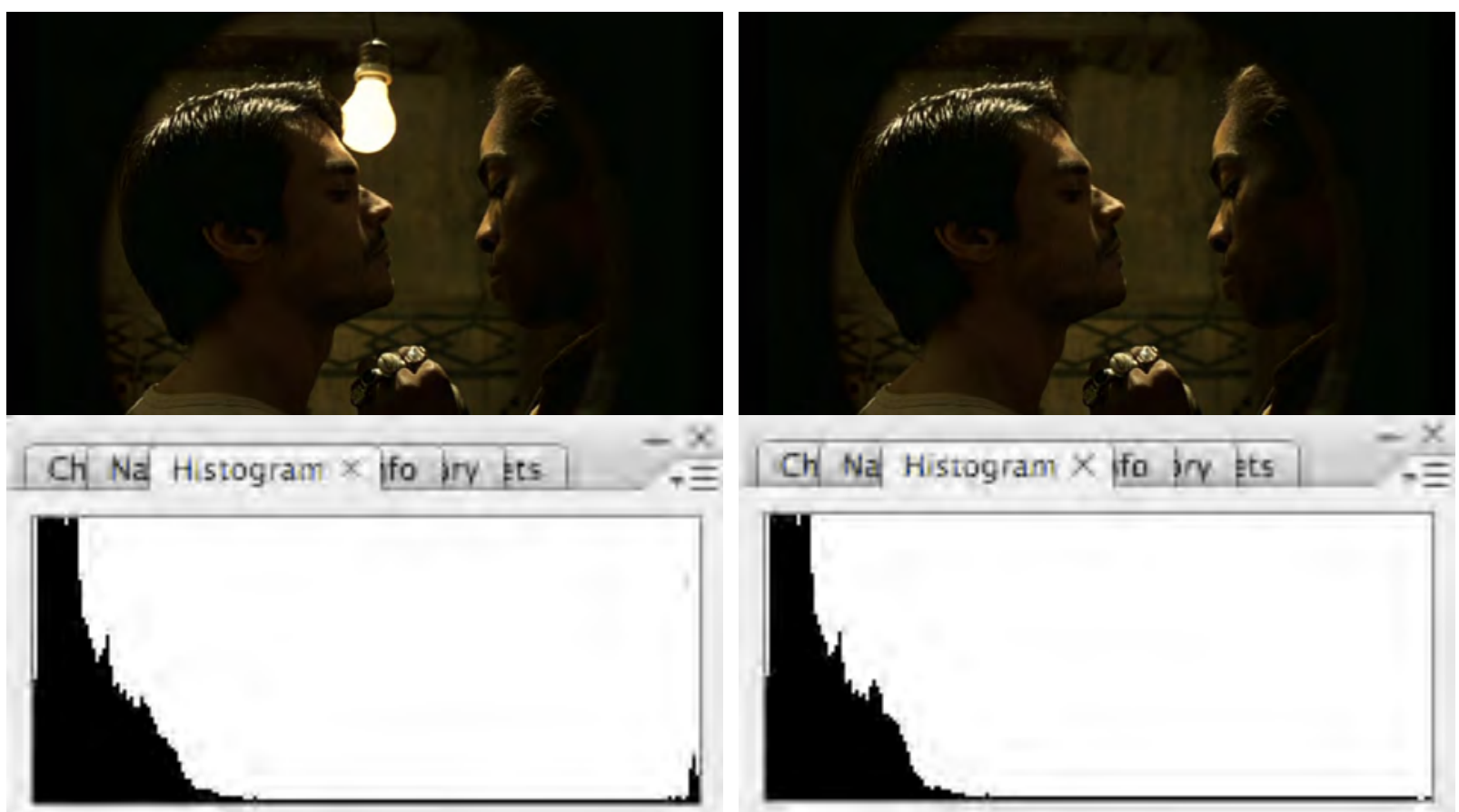

Fig. 270 - Madame Satã (2002), fotograma original e sem a fonte de luz 
O segundo procedimento utilizado para gerar contraste na imagem é o desenho de luz com fontes marcadas, que cria pontos de alta intensidade na pele dos personagens. Esses pontos são fundamentais para o contraste luminoso no corpo, que é acentuado pelo bleach bypass. Assim como o enquadramento, o contraste traduz a personalidade não linear de João Francisco, que alterna momentos de doçura e reações explosivas.
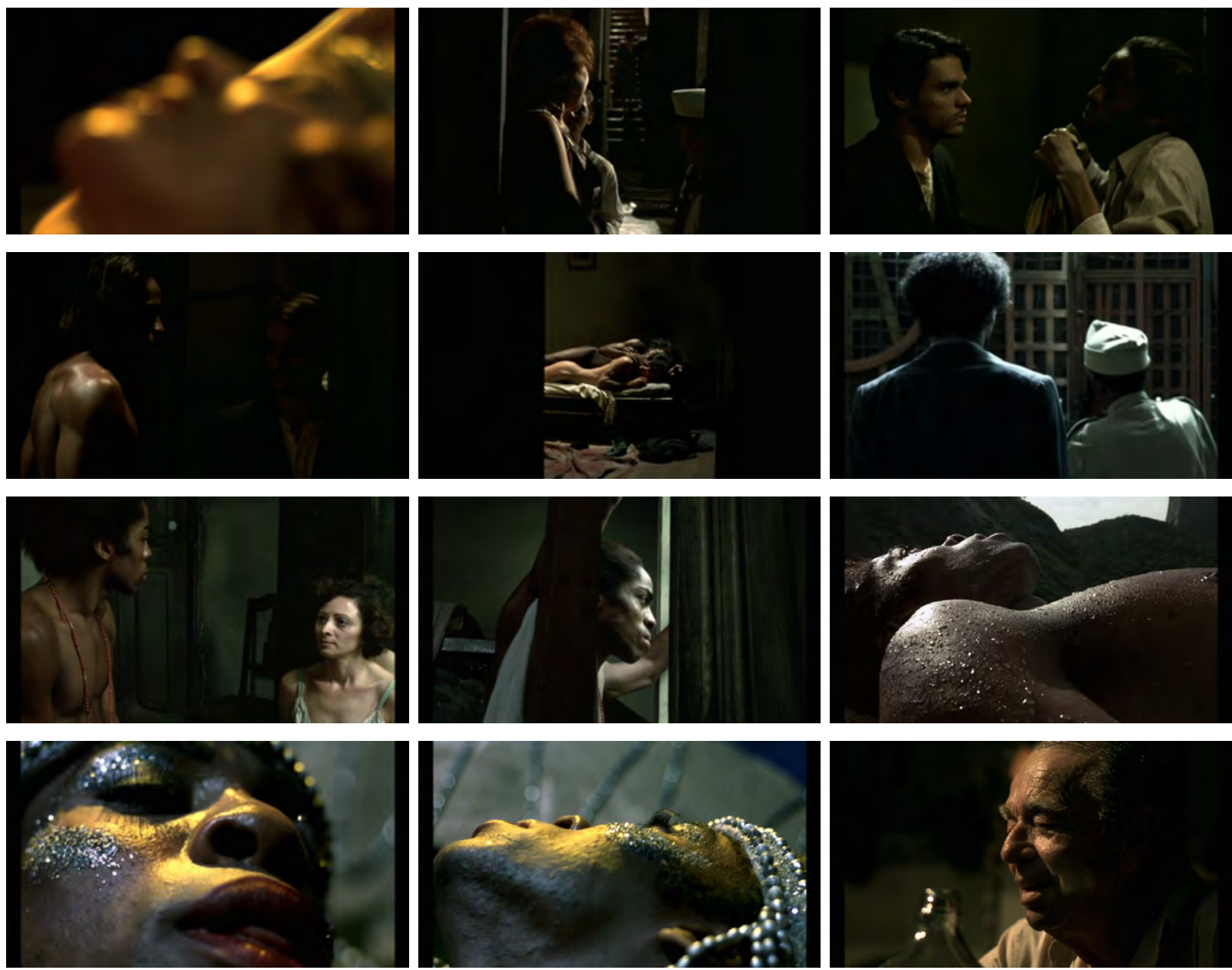

Fig. 271 - Madame Satã (2002), Karim Aïnouz

As fontes posicionadas ao alto e com pouca ou nenhuma difusão, geram sombras marcadas no rosto dos personagens, como se pode ver no primeiro plano de Laurita (figura 272). Esse tipo de iluminação é evitado por muitos fotógrafos por criar sombras na parte inferior dos olhos, mas é explorado por Walter Carvalho, que foge do efeito embelezador da fotografia, e faz um desenho de luz coerente com o ambiente em que vivem esses personagens. 


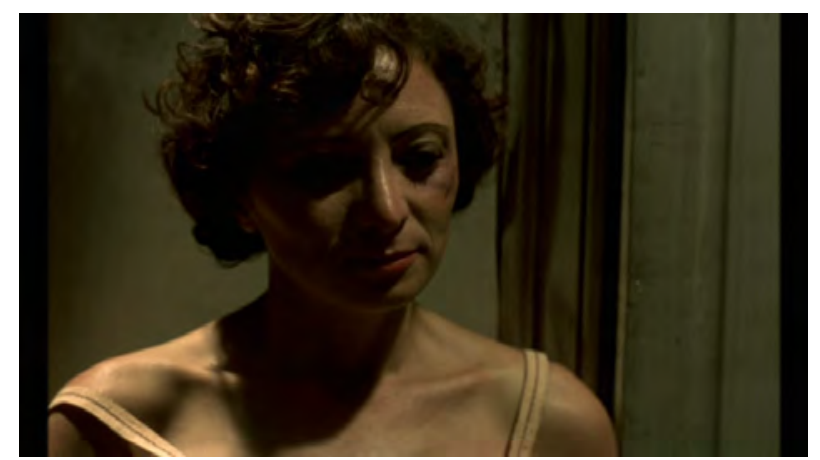

Fig. 272 - Madame Satã (2002), Karim Aïnouz

Outra característica do desenho de luz de Madame Satã é o de, por vezes, não iluminar o personagem mas sim um elemento do cenário, de modo que o personagem torna-se visível pelo contraste com o ambiente.
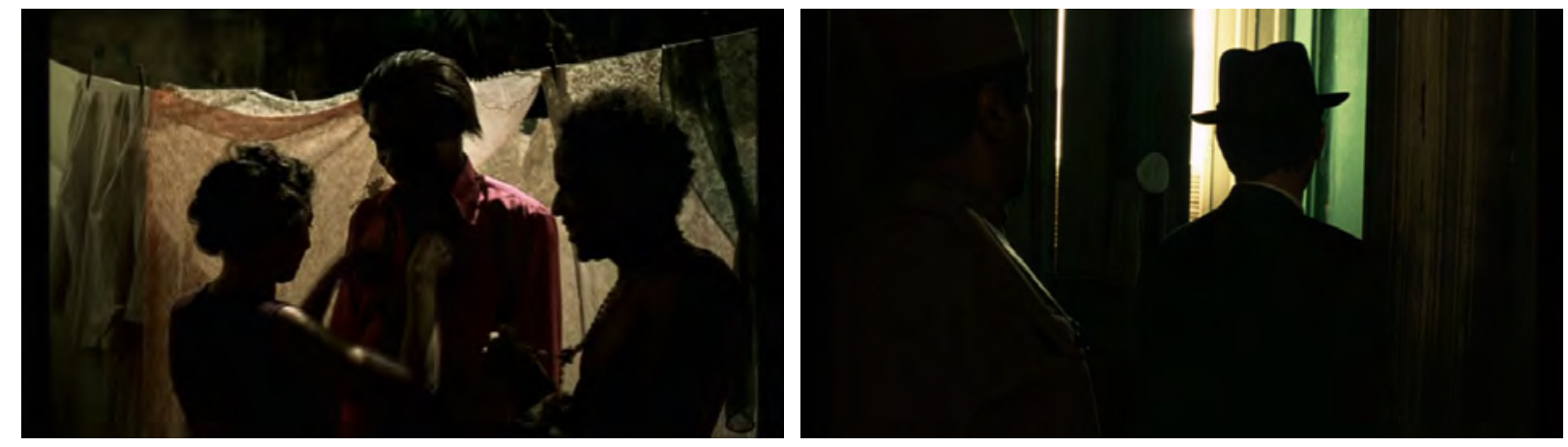

Fig. 273 - Madame Satã (2002), Karim Aïnouz

Com relação ao foco, Walter Carvalho enfatiza em Madame Satã um procedimento que já havia trabalhado em filmes anteriores. Em geral, em situações de pequena profundidade de campo, opta-se por colocar o foco no personagem que fala ou que ocupa a maior porção do quadro, alternando-se o foco entre os personagens, no caso de um diálogo, e acompanhando um personagem que se movimenta. Esse tipo de convenção não é sempre respeitado por Carvalho, que em Madame Satã, radicaliza o uso da pequena profundidade e faz planos completamente desfocados.
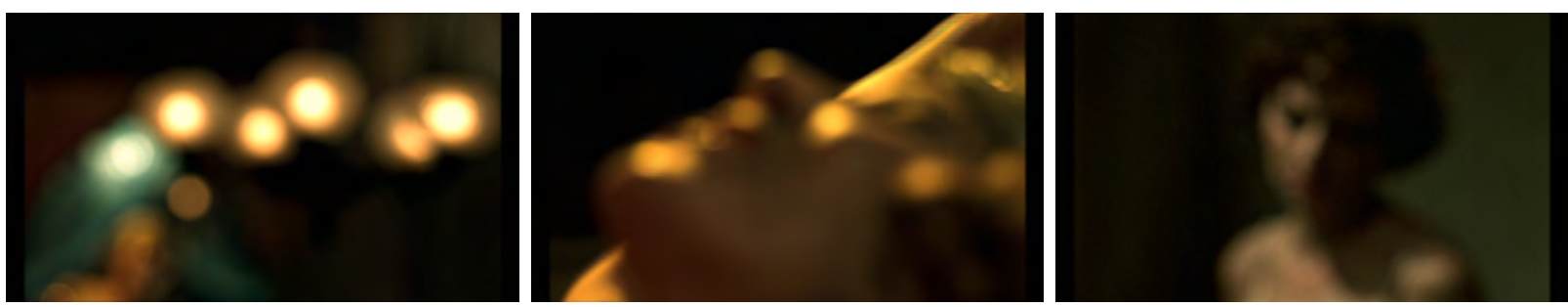

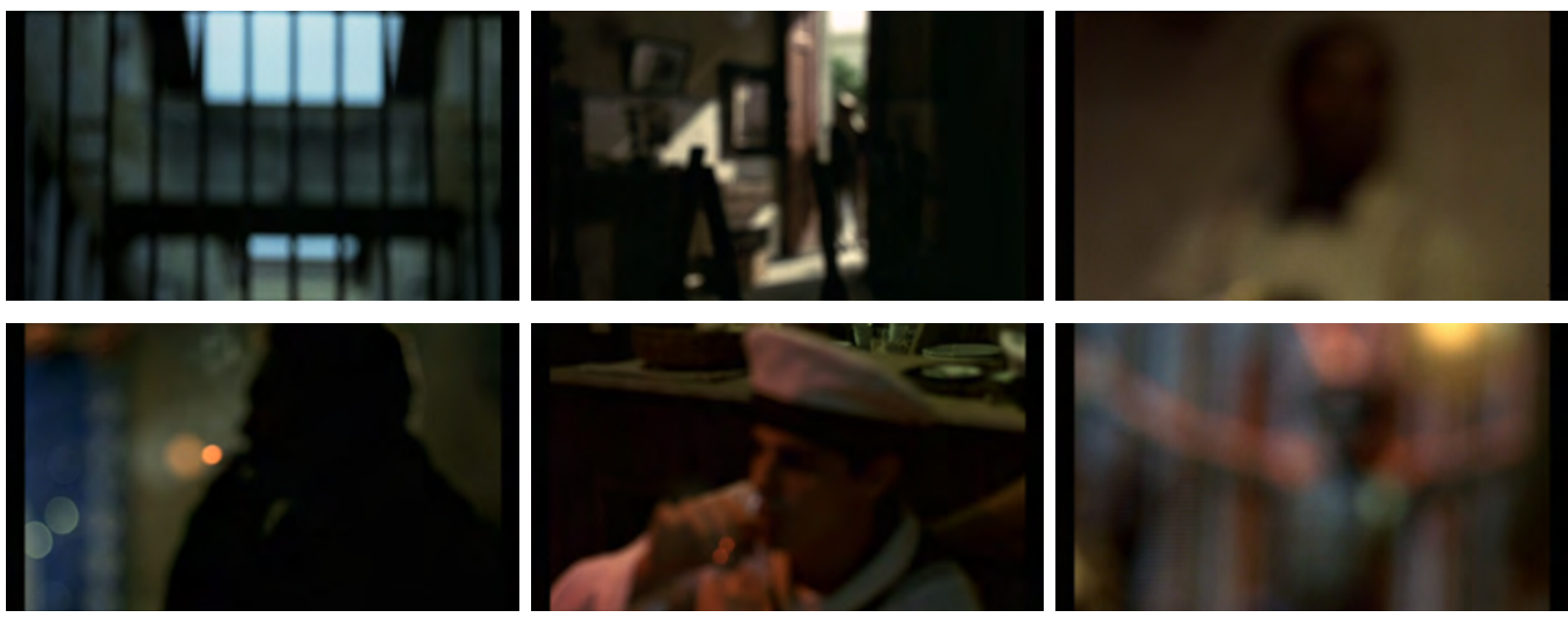

Fig. 274 - Madame Satã (2002), Karim Aïnouz

Em outros planos, deixa a correção de foco bastante evidente, como nos créditos iniciais do filme, em que o plano inicia desfocado e depois de alguns segundos há a correção.
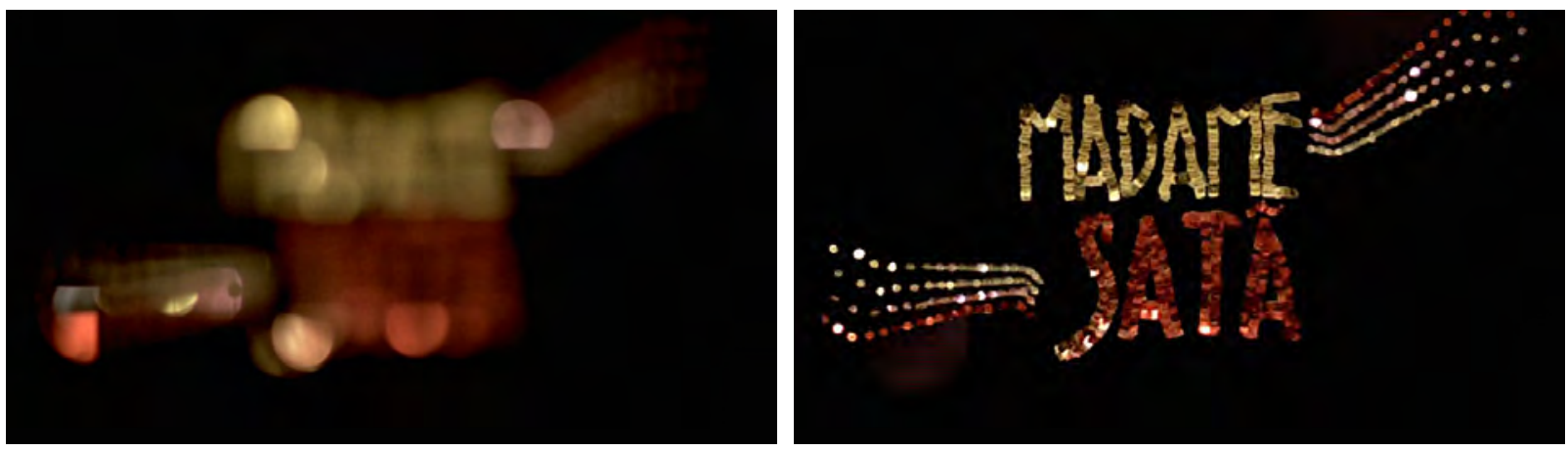

Fig. 275 - Madame Satã (2002), Karim Aïnouz

É também o caso dos fotogramas apresentados na figura 276.
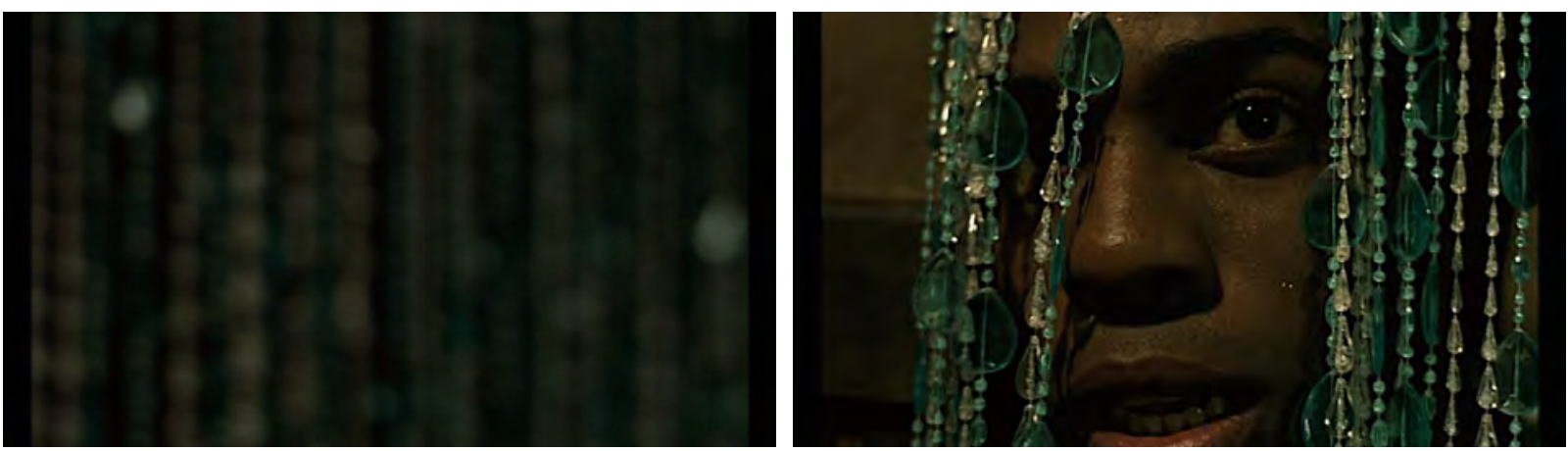

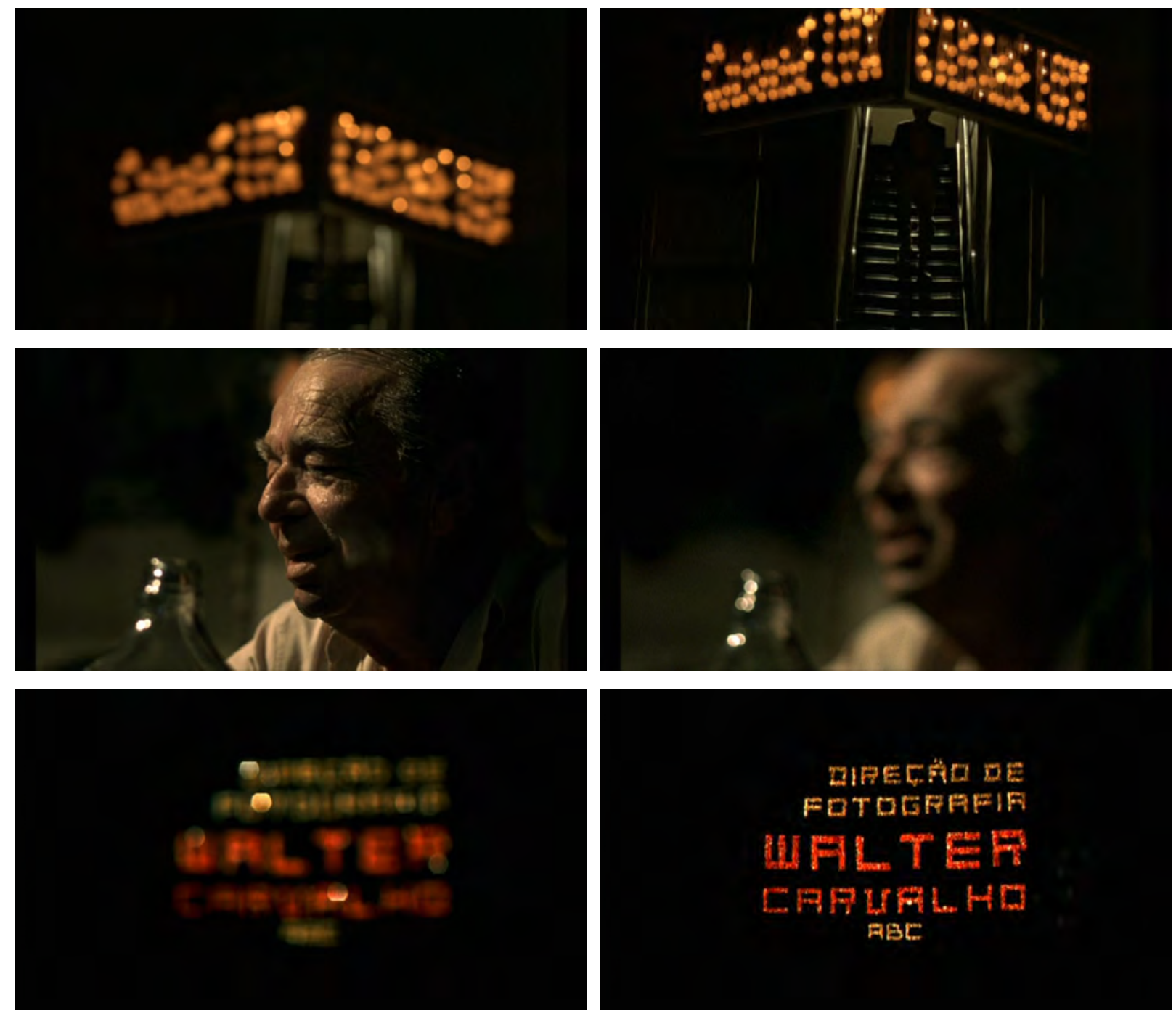

Fig. 276 - Madame Satã (2002), Karim Aïnouz

Utiliza ainda a não correção. Nesse caso, o foco é estabelecido na posição final do personagem que se move ou entra em quadro, ficando o início da cena desfocado.
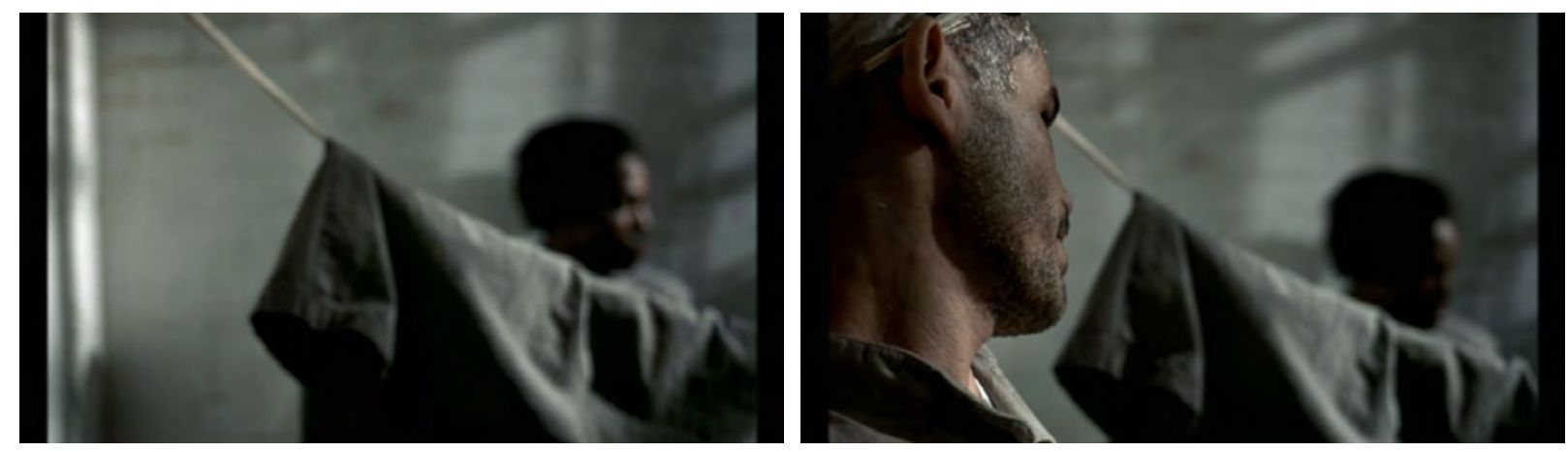

Fig. 277 - Madame Satã (2002), Karim Aïnouz

Na sequência após João e Laurita serem barrados em uma boate, a alternância de foco evidencia a contrariedade e o isolamento de João Francisco. 

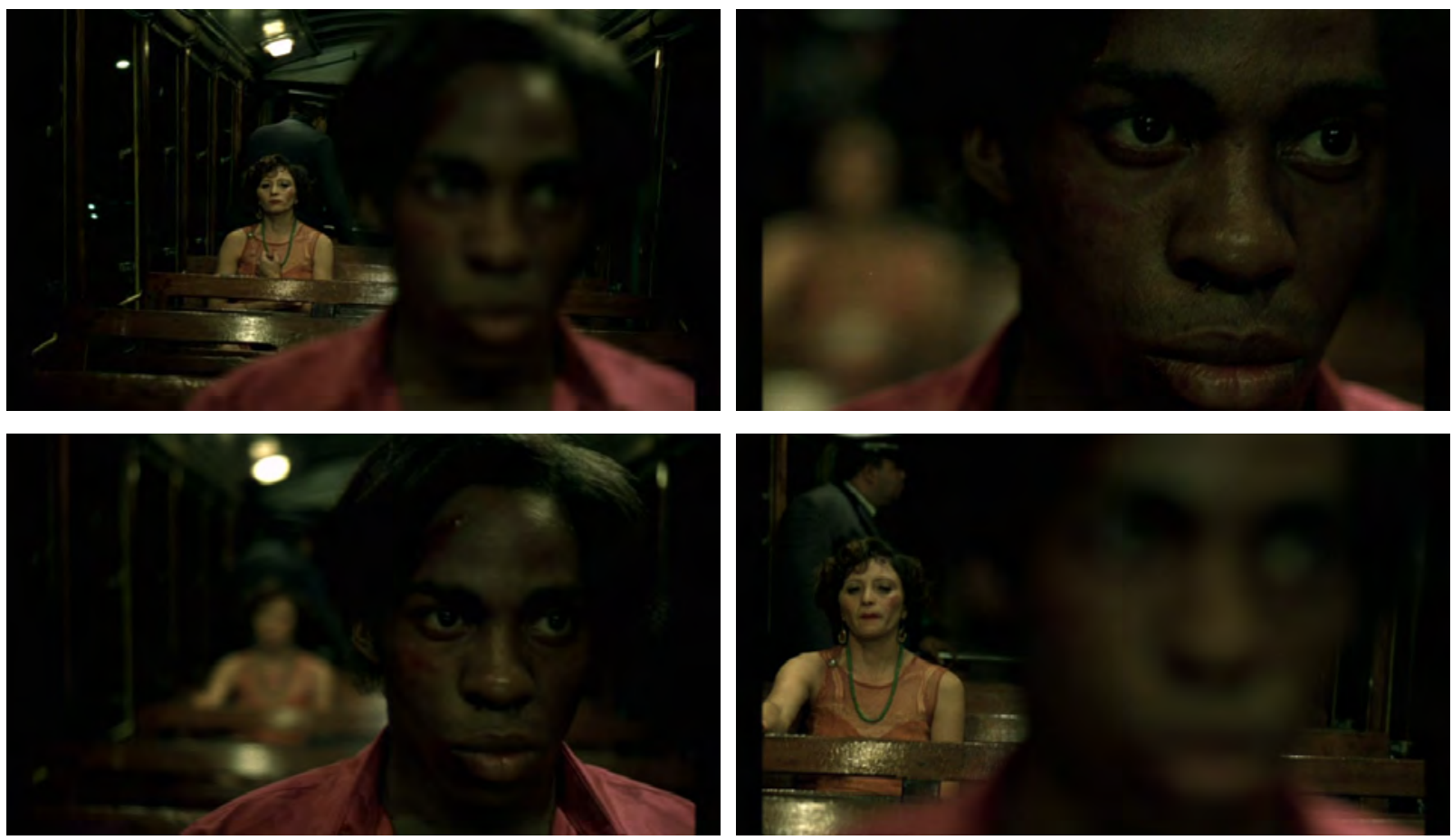

Fig. 278 - Madame Satã (2002), Karim Aïnouz

Portanto, por meio dos enquadramentos, desfoque, desenho de luz, contraste e revelação de negativos, Walter Carvalho contribui para a construção do personagem, para retratar o homem que, posteriormente, viria a ser conhecido como Madame Satã.

O mito não é o ponto de interesse do filme de Karim Aïnouz, o homem que precede o mito é construído intimamente pelo trabalho do ator, do diretor, do diretor de arte e do diretor de fotografia.

O filme termina no baile dos Caçadores de Veados, em 1942. João Francisco ganha o concurso de fantasias com uma roupa inspirada no filme Madam Satan (1930), do diretor americano Cecil B. DeMille (1881-1959), fotografado por Harold Rosson (1895-1988). João Francisco sai de cena para dar lugar ao personagem Madame Satã.
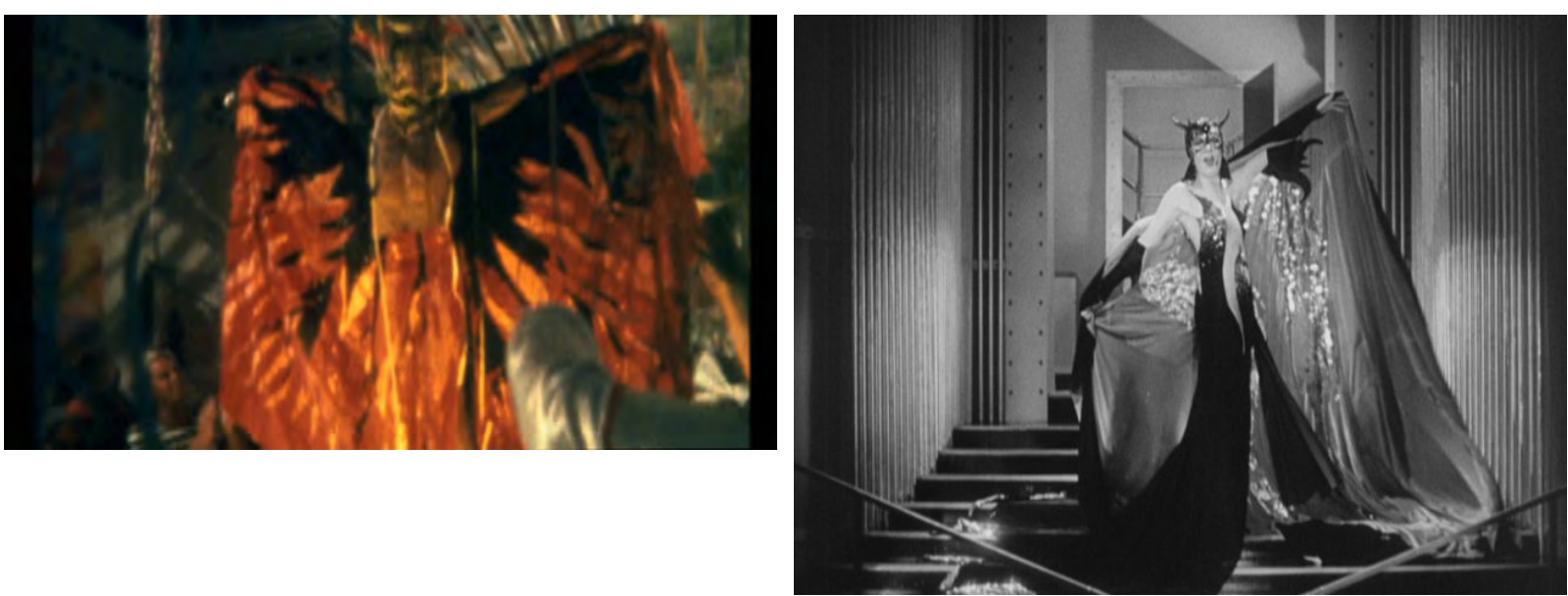

Fig. 279 - Madame Satã, de Karim Aïnouz (esq.) e de Cecil B. DeMille (dir.) 


\subsection{Heleno (2011), José Henrique Fonseca}

Assim como Madame Satã, Heleno baseia-se em um personagem real: Heleno de Freitas (1920-1950), jogador de futebol brasileiro atuante na década de 1940. Entretanto, ao contrário do filme de Karim Aïnouz, centrado na intimidade de João Francisco dos Santos, Heleno é uma cinebiografia sobre o mito do jogador, interpretado por Rodrigo Santoro.

Heleno de Freitas era conhecido por seu temperamento explosivo e pelo desregramento. Abusava de álcool, cigarro, drogas e tinha uma vida amorosa agitada. Contraiu sífilis ainda na juventude, doença que o levou à morte precocemente, após alguns anos de internação em um sanatório localizado em Barbacena, Minas Gerais.

O filme tem poucas cenas de futebol, focando na vida e na personalidade de Heleno. Contudo, esse retrato do jogador é feito de "fora para dentro", vemos suas atitudes mas o filme não busca investigar suas motivações internas.

A fotografia de Walter Carvalho é coerente com esse território mítico, lendário, do personagem. Com o advento das películas coloridas, a captação em preto e branco deixou de ser uma imposição técnica e tornou-se uma escolha pela abstração da cor. Em Heleno, a opção pelo preto e branco adequa a imagem ao registro de época, mas também afasta o personagem do real, uma vez que a cor pertence ao mundo natural, ao verossímil, ainda que possa ser trabalhada de forma não realista na fotografia.

O filme inicia com um close-up de Heleno já bem doente, seguido de imagens de recortes de jornais colados na parede, que são arrancados e comidos pelo jogador. O contraste entre o homem e o mito se estabelece nessa sequência de abertura.
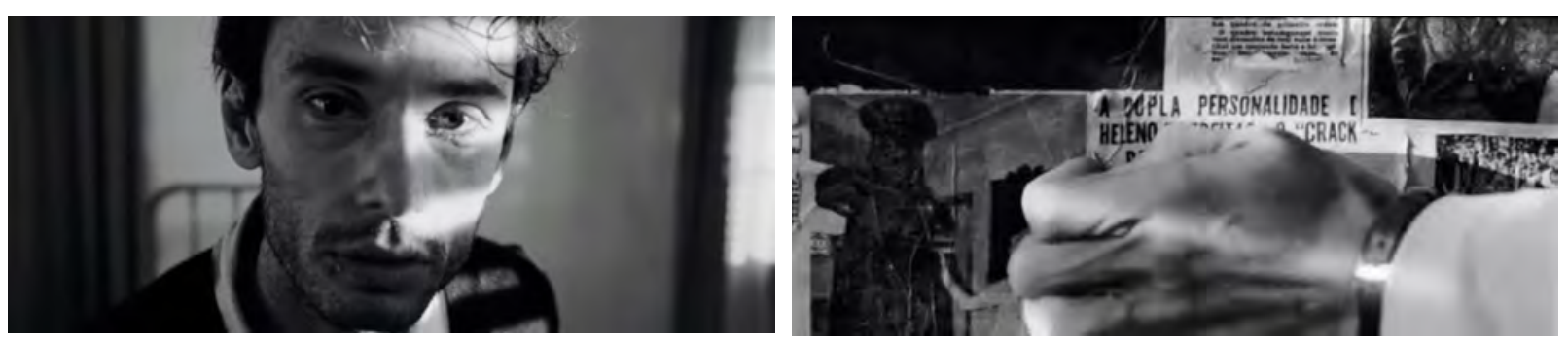

Fig. 280 - Heleno (2011), José Henrique Fonseca

Em seguida, há a cena da entrada em campo do time do Botafogo, um exemplo de como os personagens são retirados do mundo real. $\mathrm{O}$ alto contraste e o fundo branco sem detalhes eliminam o ambiente, capturando os atletas no vazio. No enquadramento final da cena, Heleno está sozinho, com a estrela do clube em seu peito. Esta é uma imagem que sintetiza Heleno, que o define como uma estrela solitária, e a partir desse momento o filme se desenvolve para mostrar a trajetória do personagem. 

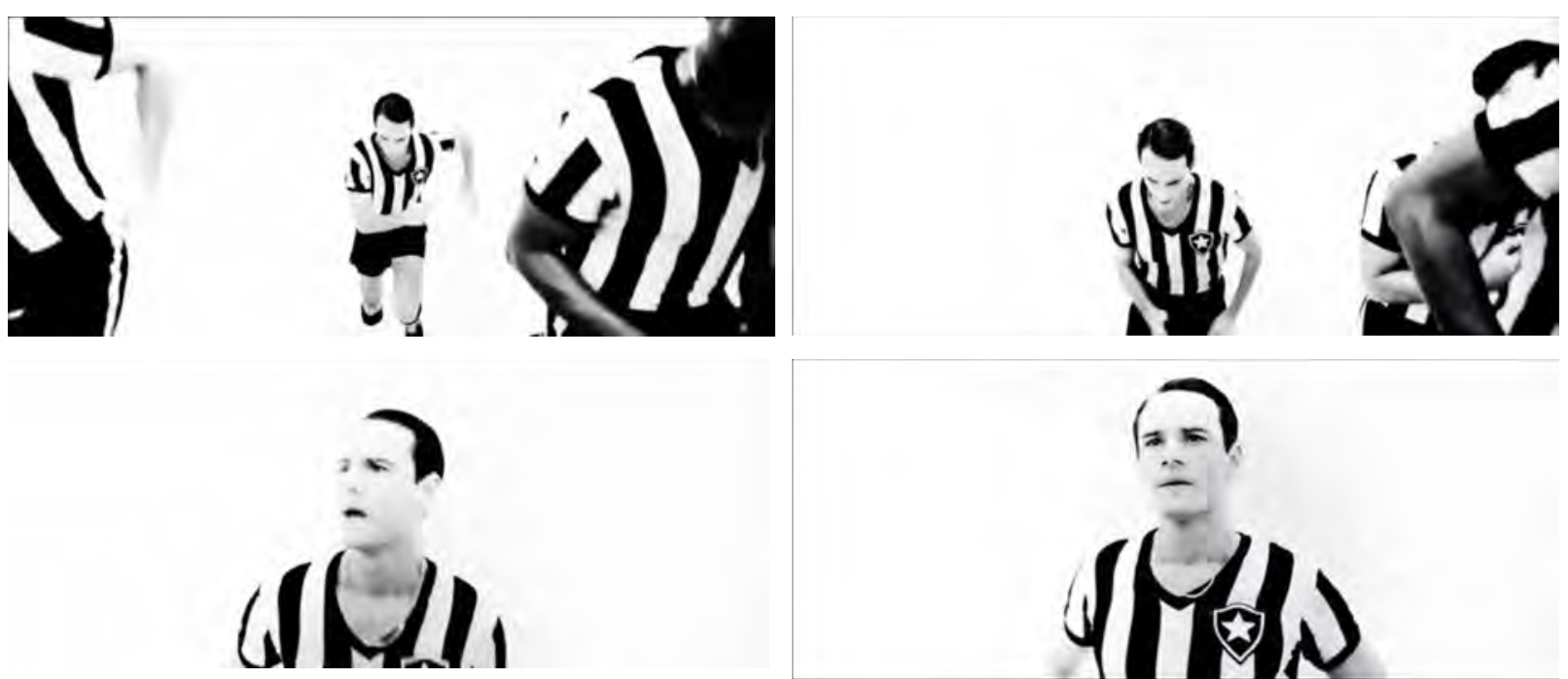

Fig. 281 - Heleno (2011), José Henrique Fonseca

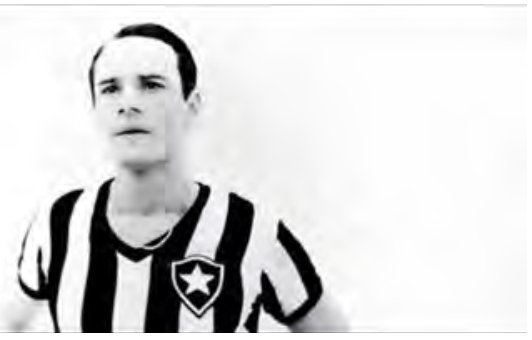

Seu comportamento de estrela aparece no relacionamento com os demais jogadores do time, Heleno sente-se superior a todos. Em um dos diálogos, ao digirir-se aos companheiros, diz: "O fato é que quando o sujeito é um perna de pau, não adianta xingar, gritar com a mãe, ele não vai mudar. Então eu prometo, pelo bem do grupo, que quando um de vocês me deixar com vergonha em campo, eu vou disfarçar e continuar jogando”.

A imprensa da época estimulava a construção do mito. No fotograma da figura 282, primeiro recorte de jornal que vemos no quarto em Barbacena, Heleno é retratado como se fosse a própria seleção brasileira.

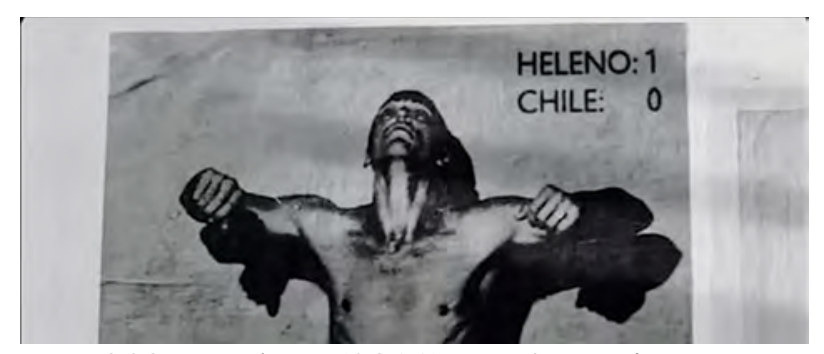

Fig. 282 - Heleno (2011), José Henrique Fonseca

A cena em que jogador treina na Argentina é outro exemplo de desambientação. Apesar da sequência iniciar-se com a indicação "Buenos Aires, 1948", a imagem mostra Heleno envolto na névoa, como se chutasse a bola em um lugar suspenso no tempo e no espaço. 


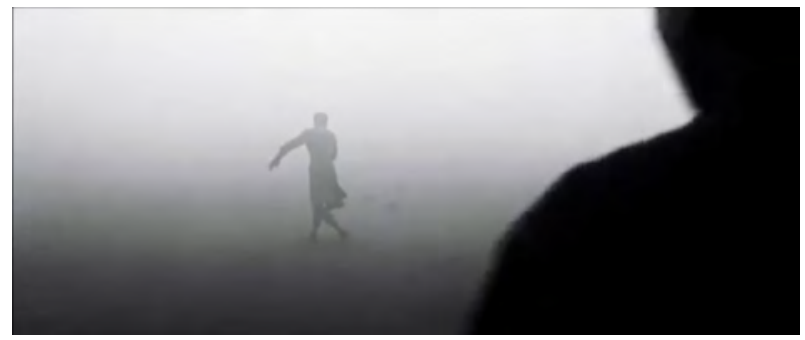

Fig. 283 - Heleno (2011), José Henrique Fonseca

Portanto, a supressão do ambiente e o preto e branco acabam reforçando a imagem lendária do jogador.

Graças à sua personalidade, Heleno era chamado de Gilda, uma comparação à personagem temperamental vivida por Rita Hayworth (1918-1987), no filme de 1946, dirigido por Charles Vidor (1900-1959) e fotografado por Rudolph Maté. Em Heleno, a cantora Diamantina (Angie Cepeda) é caracterizada como Gilda.
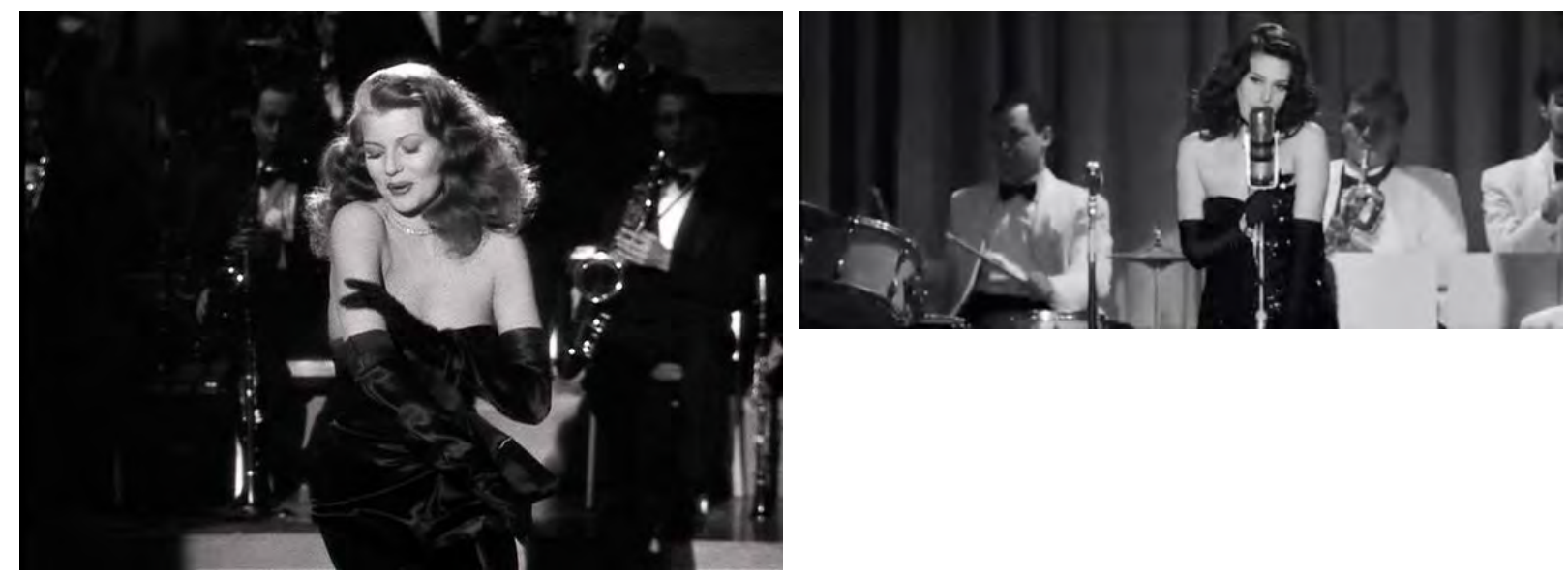

Fig. 284 - Gilda (esq) e Heleno (dir)

Contudo, as semelhanças ao filme de Vidor não se limitam à caracterização de Diamantina. Pode-se dizer que tanto na estrutura narrativa quanto na visualidade, Heleno tem inspiração noire, categoria de filmes a que pertence Gilda.

Em O outro lado da noite: filme noir, Antonio Carlos Gomes de Mattos (1939- ), professor de História do Cinema Americano da PUC-RJ, elenca as características desses filmes. Segundo o autor, não há consenso em relação à natureza do noir, podendo ser chamado de movimento, ciclo, gênero, estilo ou estrutura narrativa.

A expressão filme noir, cunhada por críticos franceses após a Segunda Guerra Mundial, designa um conjunto de filmes policiais norte-americanos, produzidos a partir de meados da década de 1940. Apresentam em comum as narrativas em primeira pessoa, psicológicas e pessimistas, enfatizando rostos, comportamentos, diálogos com frases precisas 
e incisivas, presença de femmes fatales, anti-heróis, personagens de caráter questionável e ausência de final feliz. Contrastando com os filmes de cunho otimista produzidos na década de 1930, os filmes noirs retratam uma sociedade distante do sonho americano de sucesso, e dominada por personagens fracassados.

Algumas dessas características estão presentes na estrutura narrativa e construção de personagens de Heleno. A começar pelo próprio Heleno de Freitas, craque problemático, com muitos vícios, psicologicamente instável, que não corresponde à imagem tradicional de um atleta. A narrativa em primeira pessoa, por meio de voz over, traçando estados mentais, pontos de vista subjetivos e retrospectos do protagonista, também configuram características noires ao filme.

Um tipo de personagem frequente no noir é o da mulher doméstica, que compreende e perdoa o herói, e se opõe à figura da mulher fatal. Em geral, essas mulheres domésticas são associadas à natureza, a ambientes abertos e iluminados. É o caso de Silvia (Alinne Moraes), esposa de Heleno.
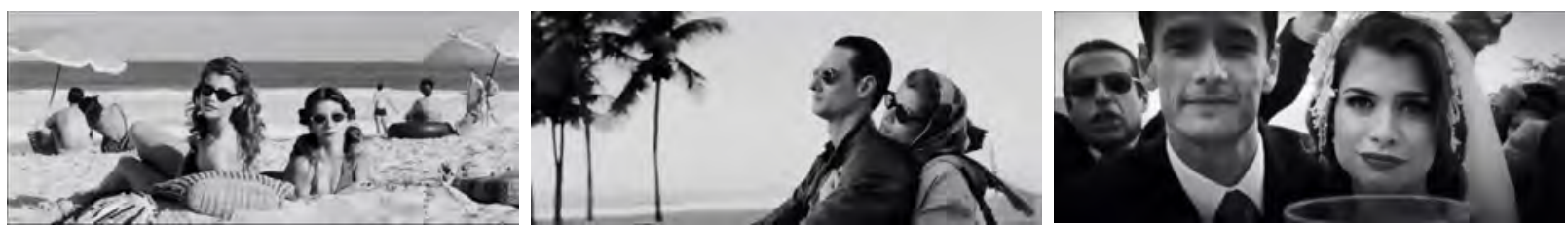

Fig. 285 - Heleno (2011), José Henrique Fonseca

O filme também conta com acessórios tipicamente noirs, como cigarros, bebidas e armas de fogo.
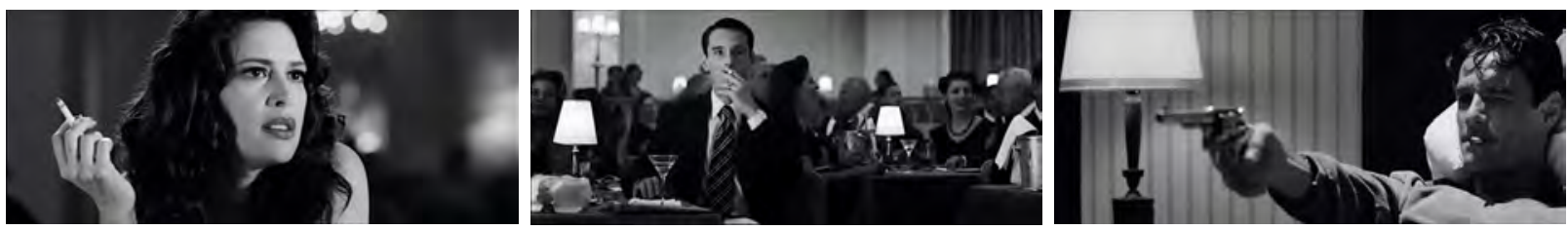

Fig. 286 - Heleno (2011), José Henrique Fonseca

E com planos abertos, em que várias ações acontecem em um mesmo quadro, como no caso da figura 287.

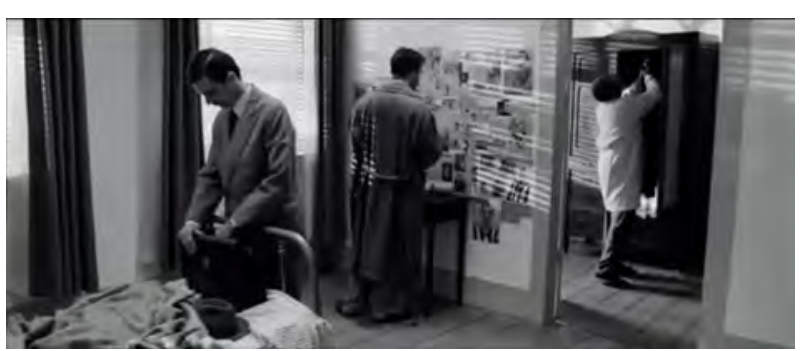

Fig. 287 - Heleno (2011), José Henrique Fonseca 
A primeira análise das imagens do noir foi feita por Janey Ann Place (1946- ) e Lowell Peterson (1936- ), e publicada na revista Film Comment em 1974. Neste artigo, os autores tratam da visualidade que une os filmes da categoria, constatando que a atmosfera criada pelos elementos visuais está instrinsecamente ligada à personalidade e à conduta dos personagens. Place e Peterson apontam um desenho de luz caracterizado por grande diferença entre os valores da luz principal e de preenchimento, o que determina a presença de sombras profundas e o alto contraste da fotografia. A luz dura, com pouca ou nenhuma difusão, é utilizada em close-ups, incluindo aí os das atrizes principais. Tradicionalmente as atrizes eram mostradas de seus melhores ângulos e sempre com luz atenuada, imprimindo um aspecto de suavidade e vulnerabilidade à imagem.

Comparando-se um fotograma de Heleno com o de um filme da década de 1930, é possível perceber a diferença no desenho de luz. No fotograma da direita, retirado de Our Betters (1933), de George Cukor (1899-1983), fotografado por Charles Rosher (1885-1974), o rosto da atriz Constance Bennett (1904-1965) é iluminado pela luz principal que entra pela esquerda de quadro. As sombras projetadas em seu rosto são atenuados por uma luz de preenchimento que entra pela direita de quadro, com uma intensidade menor, porém com valor próximo ao da luz principal. No caso do fotograma de Heleno (esq), percebe-se uma diferença maior entre os valores da luz principal e de preenchimento, com um lado do rosto da atriz marcado pela sombra.
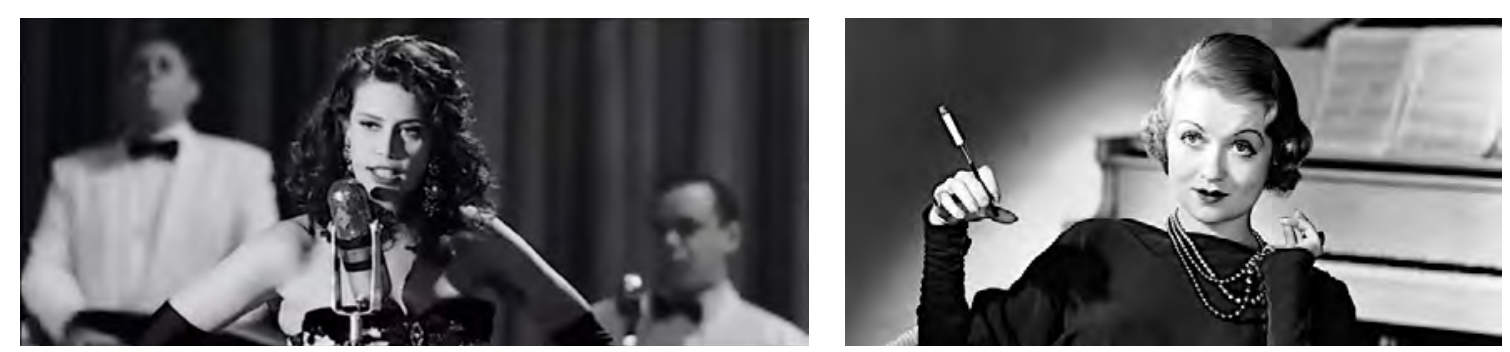

Fig. 288 - Heleno (esq) e Our Betters (dir)

Além do contraste, no cinema noir o posicionamento tradicional da luz principal, a quarenta e cinco graus da câmera, dá lugar a posições variadas: acima ou abaixo do rosto, a noventa graus da câmera ou até a iluminação apenas por contraluz, siluetando os atores. É o que vemos nos fotogramas da figura 289.

$\mathrm{Na}$ imagem da esquerda, a luz principal é o contraluz (posicionado a cento e oitenta graus da câmera), na imagem da direita, a luz principal encontra-se a noventa graus da câmera. Ao invés da tradicional luz de três pontos, o rosto do ator é iluminado por apenas um ponto de luz. 

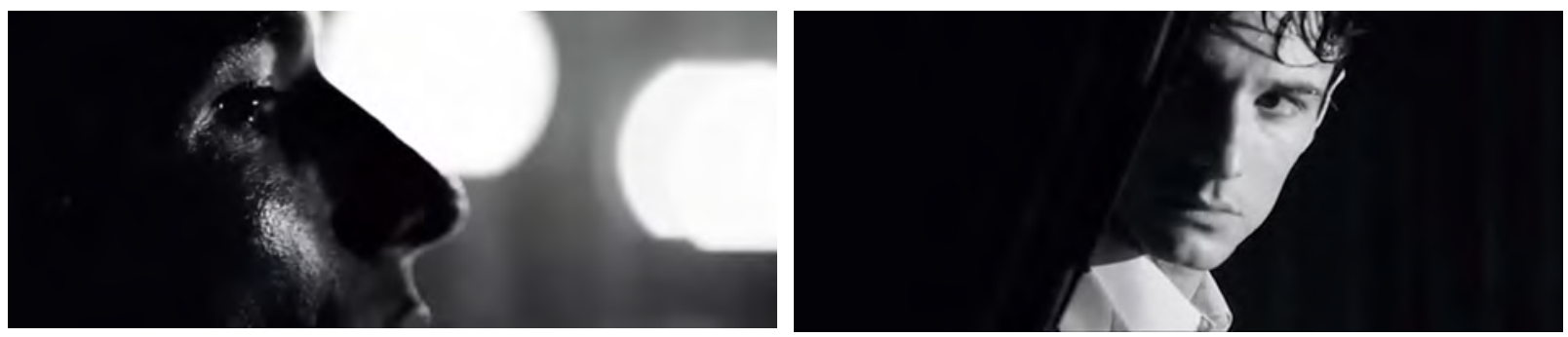

Fig. 289 - Heleno (2011), José Henrique Fonseca

Há ainda pontos de luz nos rostos dos personagens, como no fotograma de No Silêncio da Noite (In a Lonely Place, 1950), dirigido por Nicholas Ray (1911-1979) e fotografado por Burnett Guffey (1905-1983), em que Humphrey Bogart (1899-1957) tem um ponto de alta luz na lateral de seu olho esquerdo. Trata-se de uma luz aparentemente mal afinada, ou sobrando de um refletor, causando certo estranhamento. No fotograma da direita, ao contrário da luz de Bogart, é possível compreender de onde vem a luz projetada no rosto de Heleno, vem do exterior e é filtrada por uma cortina, janela ou veneziana. Contudo, ainda que tenham suas origens justificadas pela geografia da cena, as manchas de luz conferem um aspecto sombrio ao personagem, acentuando a aparência causada pela doença.
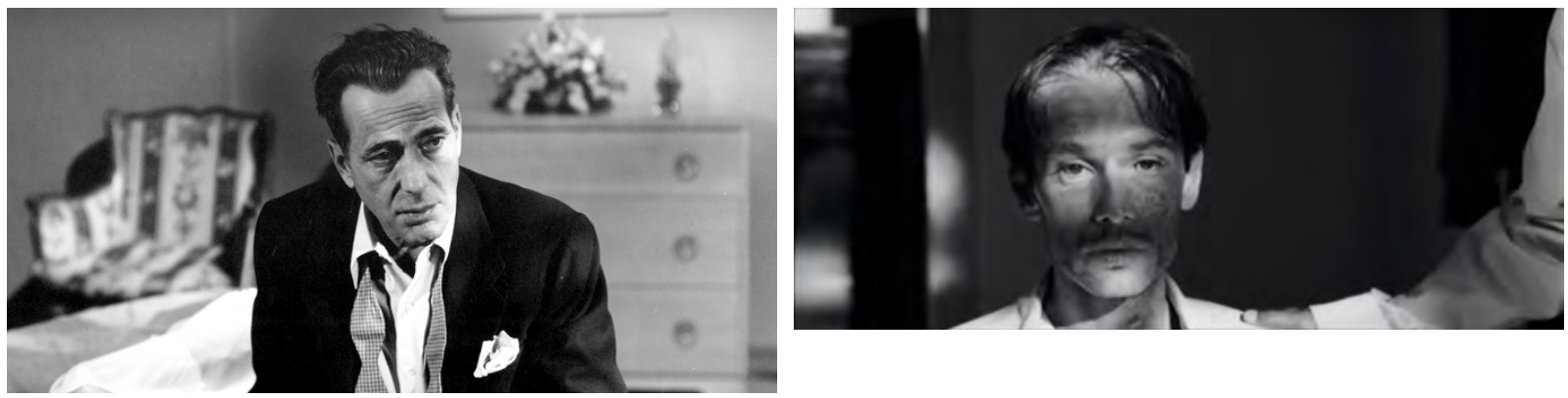

Fig. 290 - No Silêncio da Noite (esq) e Heleno (dir)

Com relação aos enquadramentos, a composição no cinema noir é pensada de modo a inquietar e desorientar o espectador, apoiando-se na desorientação vivida pelos personagens. Elementos em primeiro plano auxiliam na composição irregular, principalmente no que tange a ocupação do espaço pelos atores. É o que se vê na figura 291. Nas duas primeiras imagens, os personagens ficam confinados na metade esquerda do quadro. Na terceira imagem, a composição é ainda mais irregular, um elemento do primeiro plano atrapalha a visão, Heleno está deslocado horizontalmente e parece não caber em quadro.
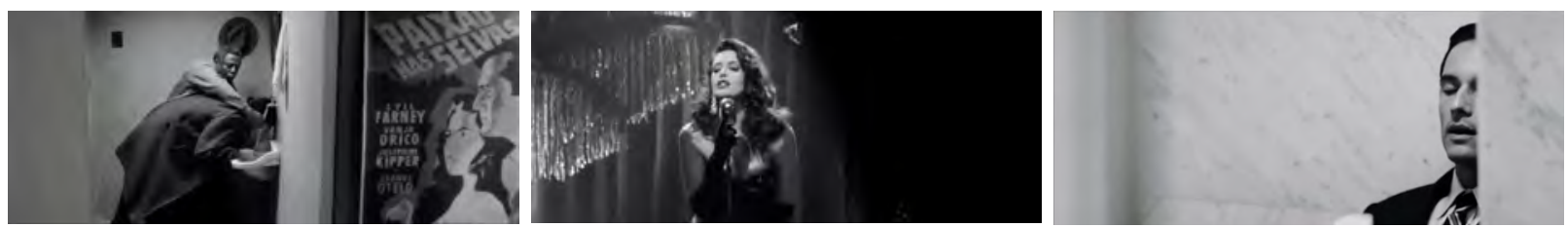

Fig. 291 - Heleno (2011), José Henrique Fonseca 
Reflexos em espelhos são comuns, representando simbolicamente o ego fragmentado ou a imagem idealizada do personagem. Heleno é constatemente enquadrado por meio de espelhos.
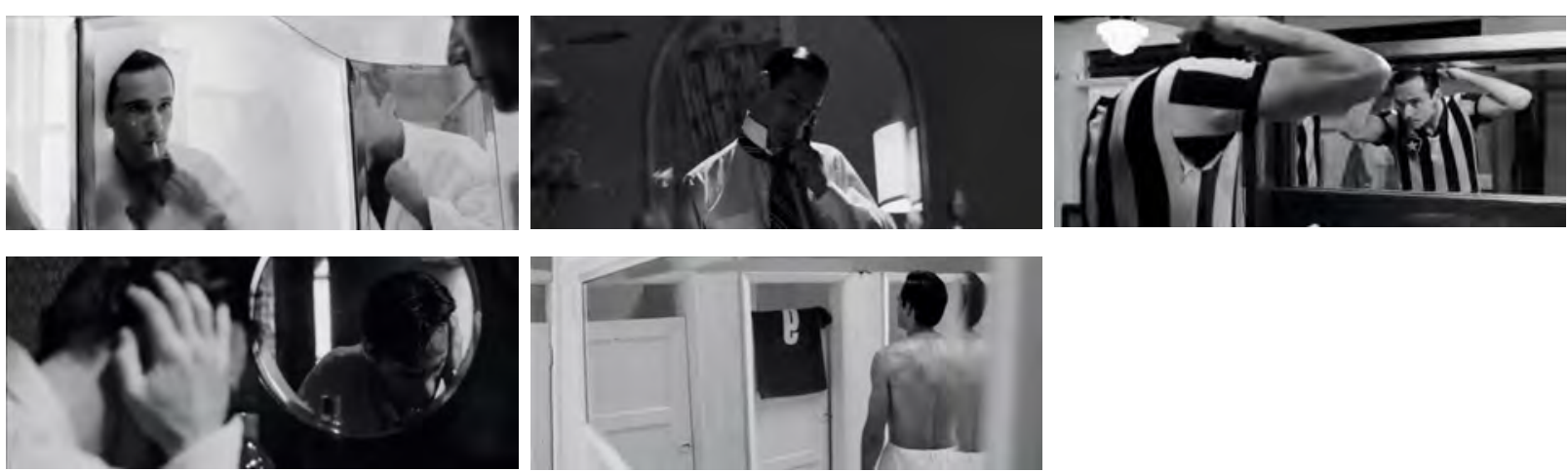

Fig. 292 - Heleno (2011), José Henrique Fonseca

Elementos do cenário tais como portas, janelas, escadas, são enquadrados em primeiro plano, conferindo um aspecto claustrofóbico à cena. Linhas horizontais, verticais e diagonais isolam personagens mesmo em quadros abertos. Neste fotograma de No Silêncio da Noite, as linhas verticais e horizontais separam os dois personagens e encerram a mulher ao fundo, em uma moldura dentro do quadro. $\mathrm{O}$ olhar estabelece uma linha diagonal, que os une novamente.

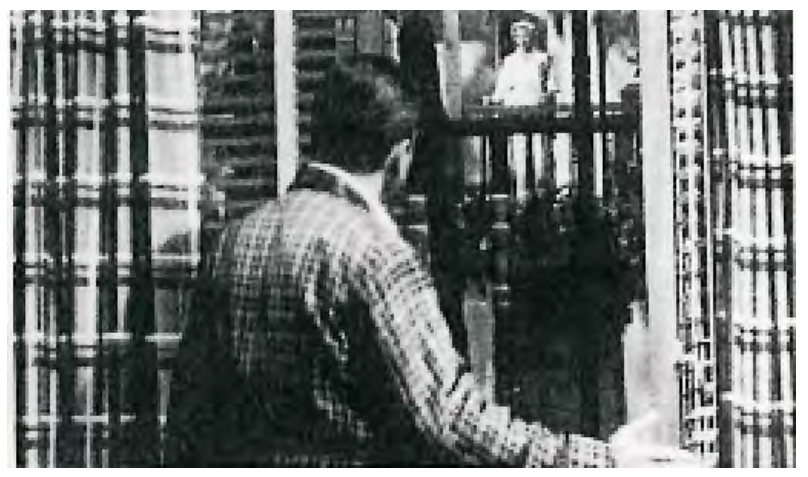

Fig. 293 - No Silêncio da Noite (1950), Nicholas Ray

Em Heleno, enquanto o jogador está lúcido e atuante na profissão, as linhas do cenário são aproveitadas para criar enquadramentos gráficos e precisos. A grande profundidade de campo é explorada, de forma que seja possível ver com clareza o ambiente.
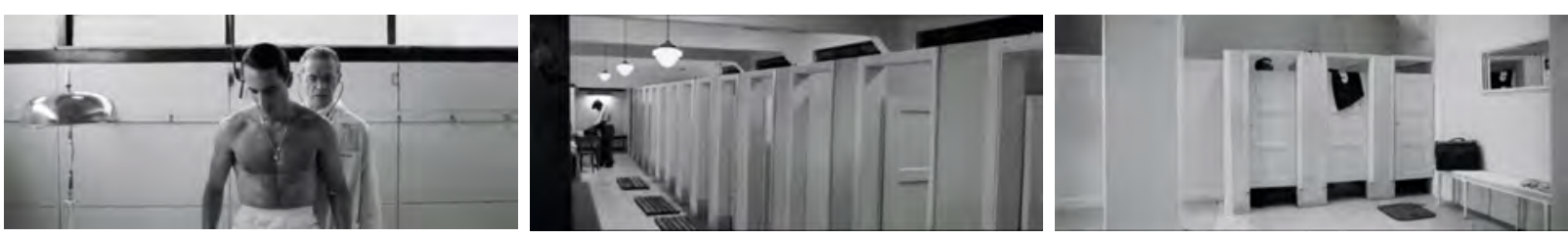

Fig. 294 - Heleno (2011), José Henrique Fonseca 
Essa precisão desaparece com o aumento da perturbação de Heleno. Exploram-se tomadas em contre-plongée, bem como a pequena profundidade de campo e um desenquadramento do personagem, que passa a não mais caber em quadro. É o tipo de desorientação pretendida na composição noire.
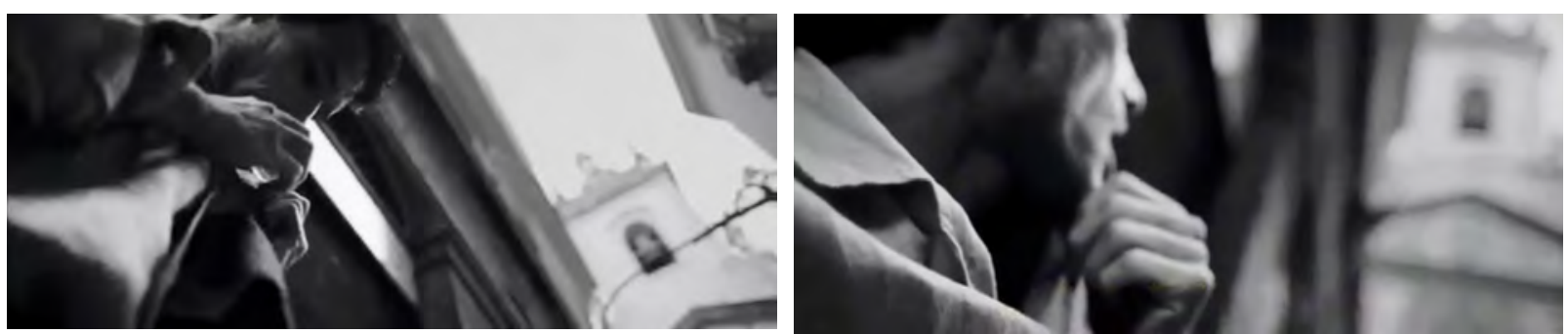

Fig. 295 - Heleno (2011), José Henrique Fonseca

A câmera plongée, também muito comum no filme noir, é utilizada nas cenas em que Heleno não está bem. Trata-se de um ângulo que achata o personagem e por isso é comumente utilizado para reforçar seu sofrimento.
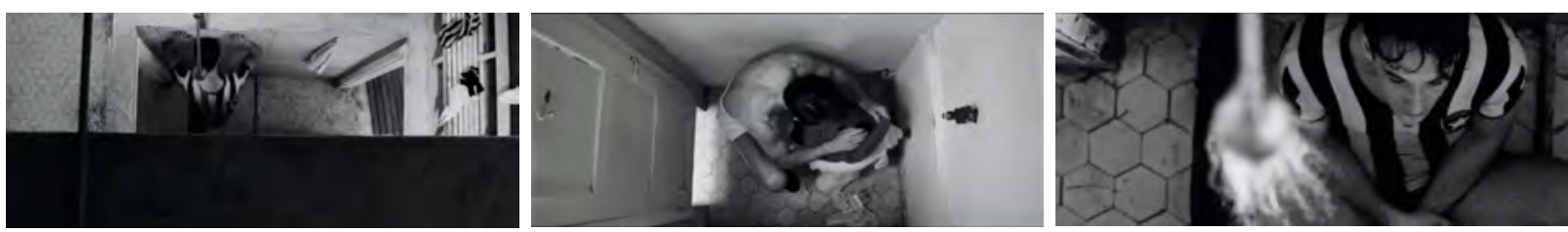

Fig. 296 - Heleno (2011), José Henrique Fonseca

A utilização de plongée e contre-plongée em uma mesma cena evidencia o conflito entre Heleno e o técnico do time. O técnico é filmado de baixo para cima, o que enfatiza seu poder sobre o jogador. Heleno é filmado de cima para baixo, o que dá pistas de que seus excessos começam a fazer efeito em sua falta de condição física para treinar.
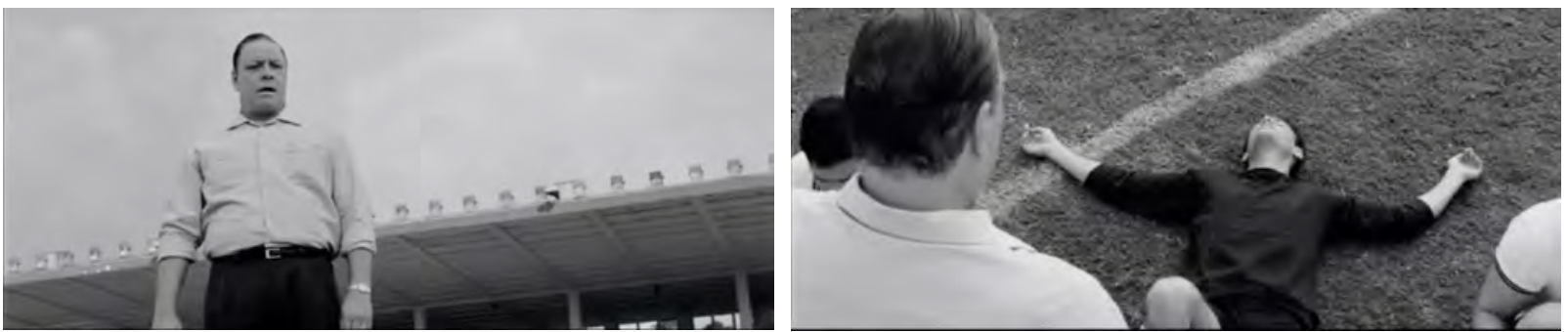

Fig. 297 - Heleno (2011), José Henrique Fonseca

Quando Heleno já se em contra em Barbacena, as linhas passam a ter função de grades, que separam o mundo externo do interno e intermediam a visão do jogador doente. 

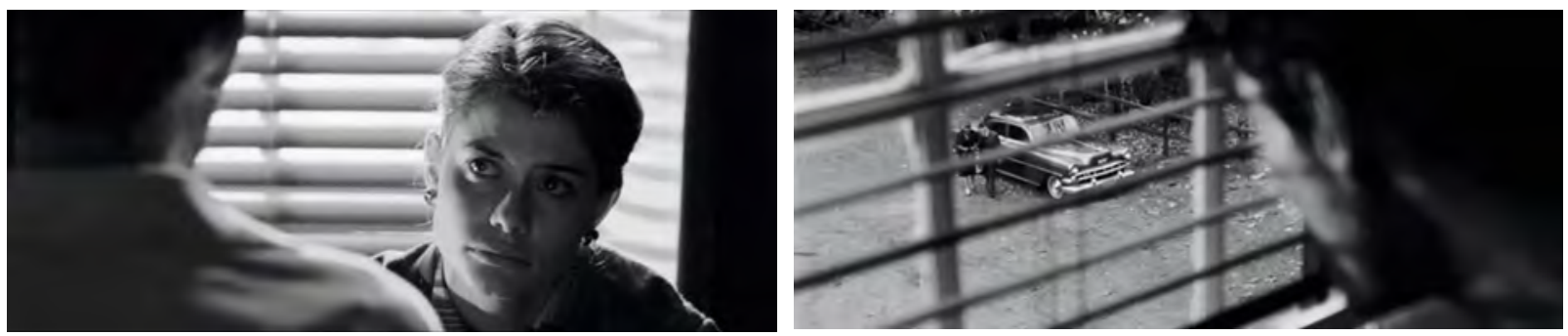

Fig. 298 - Heleno (2011), José Henrique Fonseca

A oposição entre exterior e interior também se dá pela iluminação filtrada pela janela, que cria linhas e manchas no rosto e corpo de Heleno. A iluminação filtrada por venezianas é mais um traço noir presente no filme.
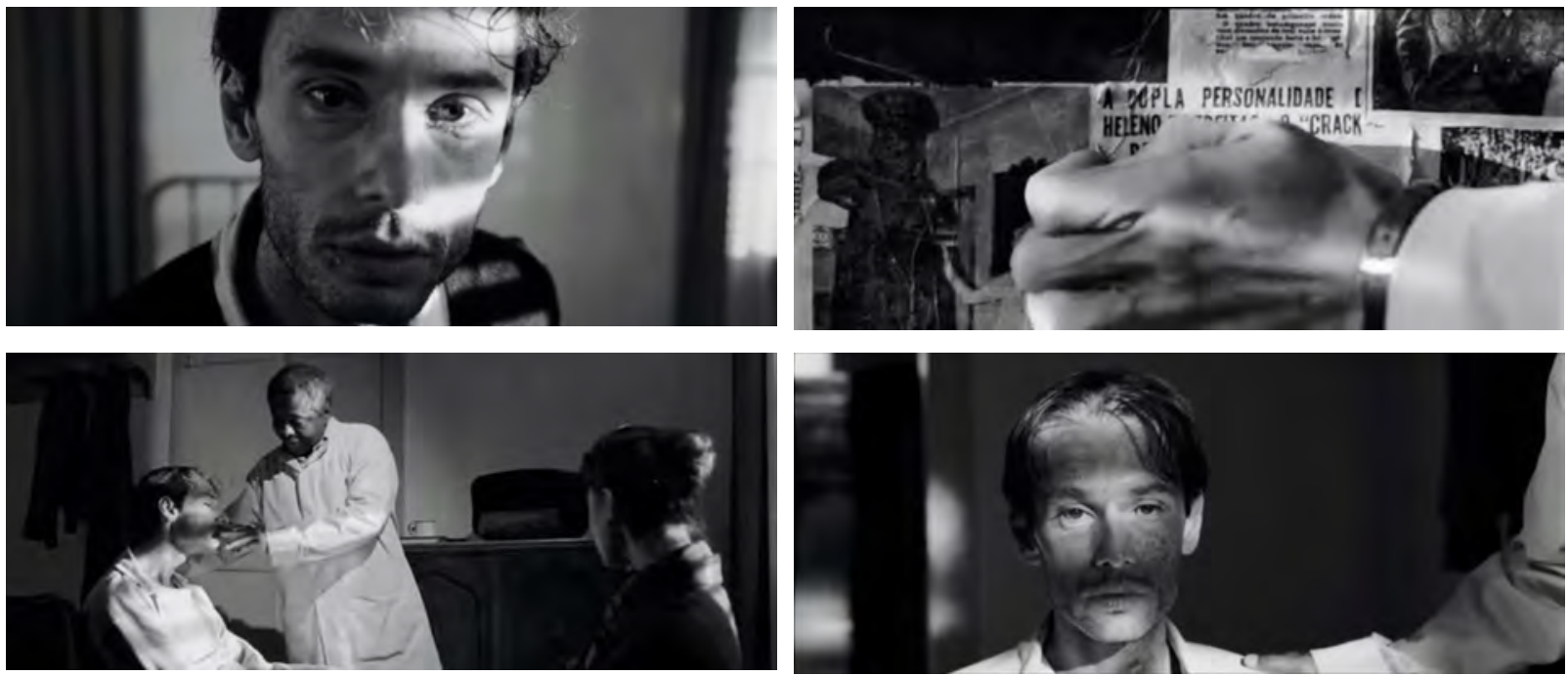

Fig. 299 - Heleno (2011), José Henrique Fonseca

Uma vez estabelecidos os paralelos com o cinema noir, é importante mostrar como Heleno traz referências de outros filmes fotografados por Walter Carvalho, como por exemplo, Terra Estrangeira (1995).

Em Terra Estrangeira a captação em preto e branco tem um sentido que difere do de Heleno. Walter Carvalho conta no documentário Iluminados (2007), de Cristina Leal, que quando se preparava para filmar Terra Estrangeira, passou por um processo de se descolorir, em uma tentativa de ver o mundo em preto e branco. Esse processo descreve também o momento dos personagens do filme de Walter Salles, em que a ausência de cor tem ligação com o desalento por eles vivido. O preto e branco, portanto, traduz seus estados de espírito. Já em Heleno, as imagens descoloridas ligam-se ao mito e aos registros da época em que viveu o jogador. A ideia de fazer a fotografia em preto e branco partiu de Walter Carvalho, que teve que convencer o diretor, o produtor e o distribuidor, de que a imagem sem cor era a que mais se adequava ao filme. 
Com relação aos equadramentos, é possível verificar a aproximação entre os dois filmes. Na figura 300 vemos quadros semelhantes para descortinar os olhares dos personagens em close-up (esq), e também para revelar o que os personagem enxergam (dir).
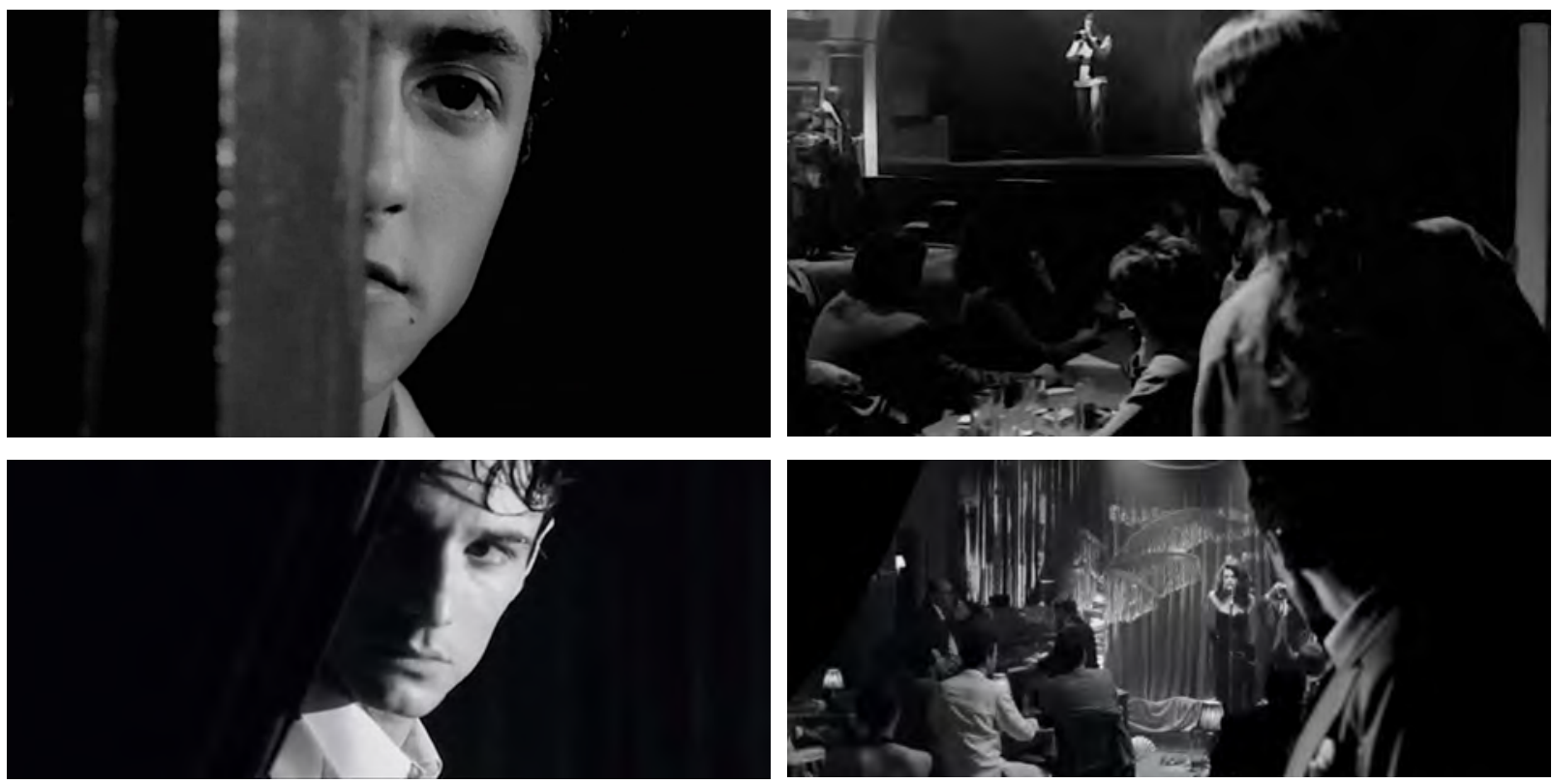

Fig. 300 - Terra Estrangeira (cima) e Heleno (baixo)

A tripartição vertical do quadro, procedimento utilizado em Terra Estrangeira, encontra paralelo em Heleno. Esse tipo de enquadramento cria impressão de profundidade no plano mas também um distanciamento da cena.
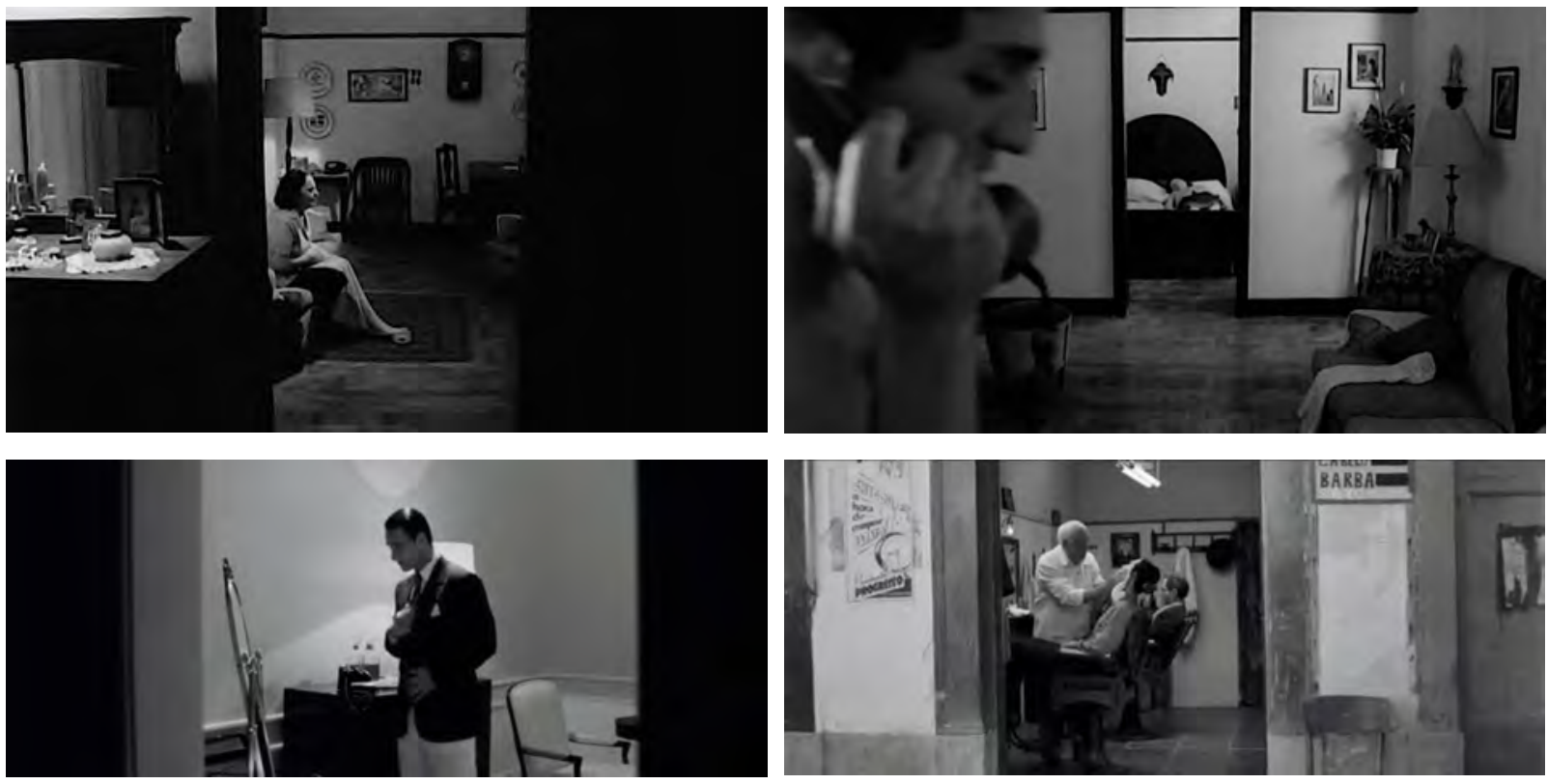

Fig. 301 - Terra Estrangeira (cima) e Heleno (baixo)

O quadro dentro do quadro, procedimento que emoldura internamente a imagem, enfatizando algum de seus elementos, é empregado nos dois filmes. Walter Carvalho utiliza 
espelhos, elementos do cenário e até do corpo dos personagens para criar molduras. É o que vemos na figura 302, em que o plano é emoldurado pelo braço de Paco (esq) e pelo braço de Diamantina (dir), levando a atenção à pessoa sentada na plateia.
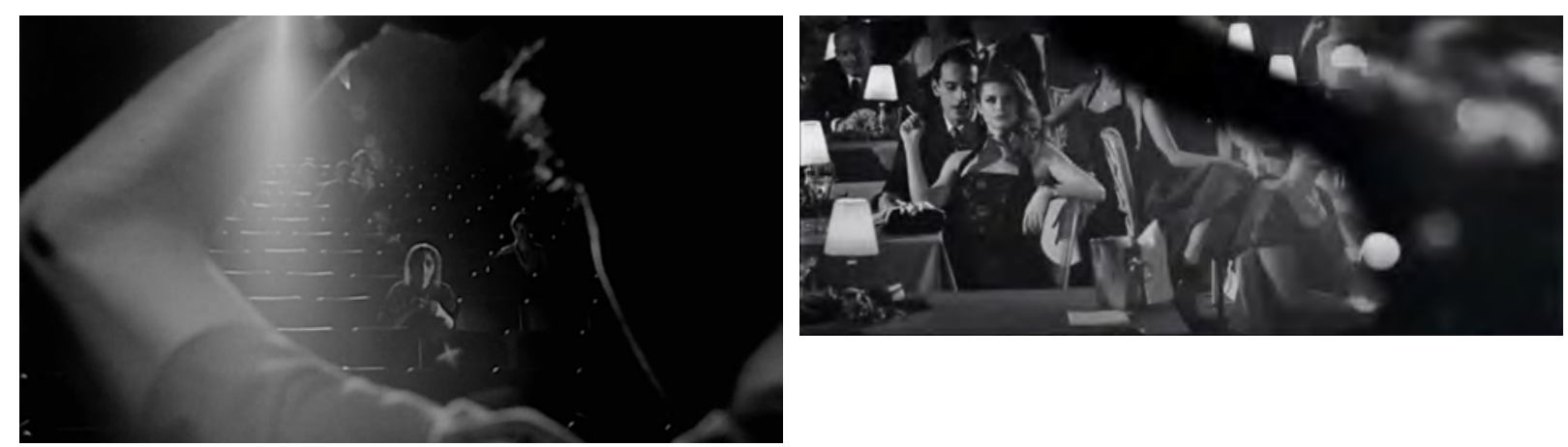

Fig. 302 - Terra Estrangeira (esq) e Heleno (dir)

Ainda com relação ao corpo, é importante notar a diferença entre os filmes Madame Satã e Heleno. No primeiro caso, a câmera cola-se ao corpo do personagem, utilizando-se lentes mais abertas e próximas dos atores. As emoções são, portanto, capturadas de perto. No caso de Heleno temos um olhar afastado, a câmera observa mas não participa da ação. A distância entre câmera e ator tem um impacto fundamental na relação entre o espectador e o personagem. No caso de Madame Satã, a proximidade configura uma tentativa de capturar o personagem "de dentro para fora", portanto, de compreender o homem. O distanciamento de Heleno leva a uma captura "de fora para dentro", o foco, portanto, é a imagem do personagem, o mito.
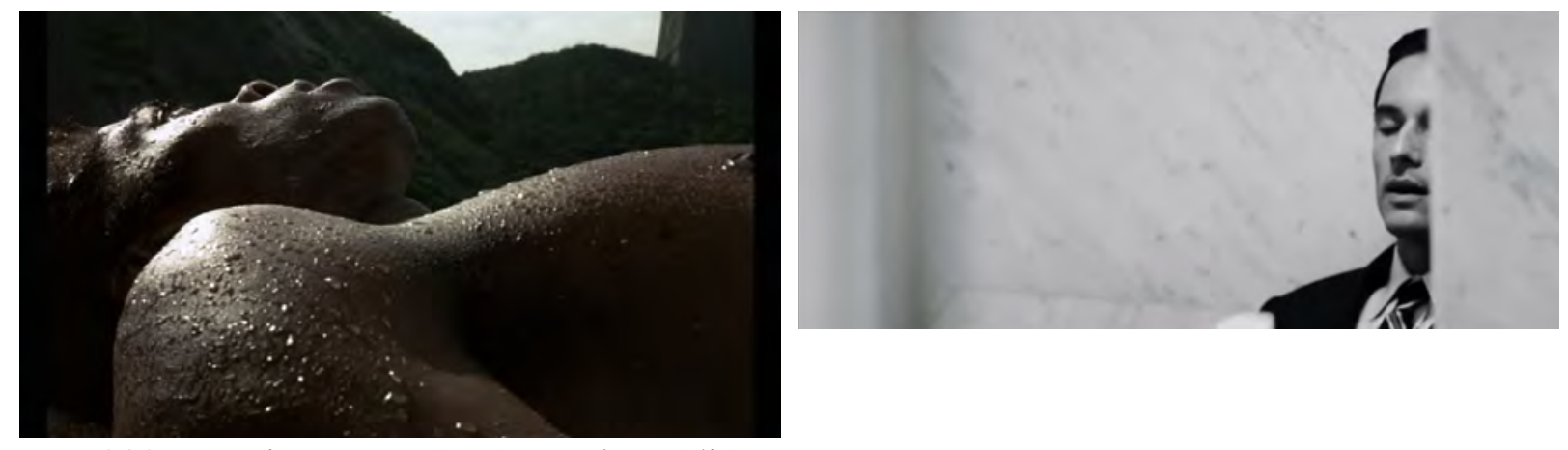

Fig. 303 - Madame Satã (esq) e Heleno (dir)

Mas Heleno não é feito apenas de distanciamentos, há também planos muito fechados nos personagens. Há dois tipos de close-ups extremos no filme: os que mostram o rosto dos personagens, e as tomadas de costas, em que a atenção volta-se ao ambiente. No primeiro caso, a intenção é evidenciar estados emocionais do personagens, como nos dois fotogramas da figura 304. 

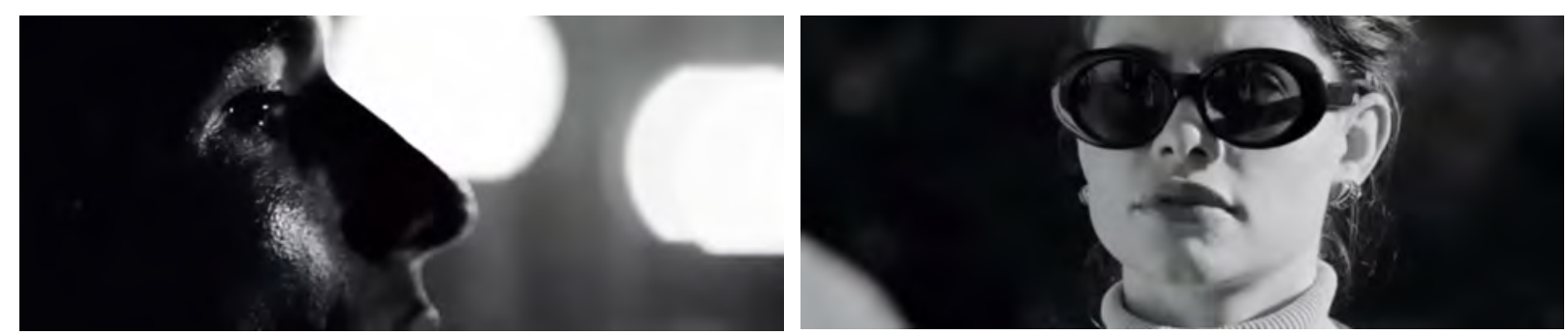

Fig. 304 - Heleno (2011), José Henrique Fonseca

No segundo caso, o extremo close-up mostra Heleno observando o horizonte desfocado, dando-nos a ideia de não ser possível ver o que há pela frente. O horizonte sem foco também remete ao seu futuro e à incapacidade de ver as consequências de seus atos e de seu modo de vida.
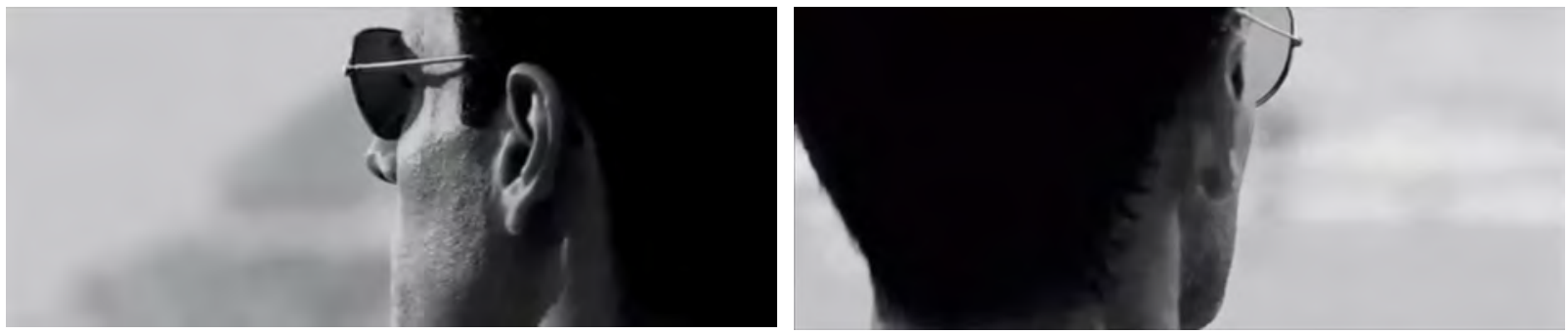

Fig. 305 - Heleno (2011), José Henrique Fonseca

Ë uma forma de utilizar o desfoque expressivamente, assim como fez reiteradamente em Madame Satã (2002), e em Abril Despedaçado (2001), na cena em que o menino Pacu toma consciência da necessidade de romper com o destino de sua família e sacrificar-se para poupar a vida do irmão.

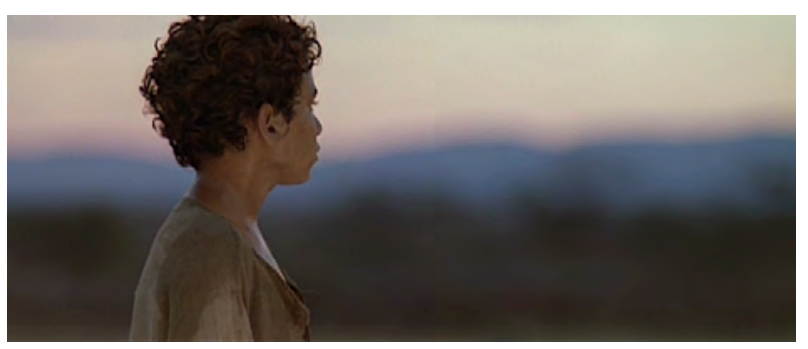

Fig. 306 - Abril Despedaçado (2001)

O movimento de câmera também é utilizado por Walter Carvalho de forma expressiva. Um dos grandes sonhos de Heleno era jogar no Maracanã. Já no final da carreira, atuando na Colômbia, o jogador tentava voltar a um time brasileiro para realizar seu sonho. Foi convidado a atuar no America, clube carioca que Heleno não julgava estar à sua altura, mas a única oportunidade de retornar ao Brasil, visto que os grandes clubes haviam lhe fechado as portas. 
O ano era 1951, Heleno estava fora de forma e os primeiros sinais dos distúrbios mentais causados pela sífilis começavam a aparecer. Entretanto, julgava-se ainda o grande craque do futebol brasileiro. No dia 4 de novembro entrou em campo no Maracanã, em uma partida contra o São Cristóvão.

No filme, a cena da partida de futebol é precedida pelo áudio de uma das entrevistas do jogador. O repórter pergunta o que ele esperava naquele dia. Heleno responde: espero nascer de novo.

Na biografia Nunca houve um homem como Heleno, Marcos Eduardo Neves (1975- ) conta que Heleno entrou em campo e se deslumbrou com a imensidão do estádio, o que teria intensificado suas perturbações. O craque pairava em campo, esquecendo-se do jogo que acontecia ao seu redor, sendo expulso após vinte minutos, por ofender os próprios companheiros. O filme retrata o deslumbramento de Heleno por meio de um movimento circular em torno do personagem, primeiro em plano médio e por fim em um plano fechado em seu rosto. Ele está só em campo e é filmado em contre-plongée diante de um estádio gigantesco. O filme traz mais uma vez o personagem suspenso no tempo e no espaço. O que vemos ali não é uma reconstituição da partida, mas a derradeira imagem que o jogador deixou para o mundo. Seus irmãos, que estavam no estádio, decidiram que era a hora de interditá-lo.
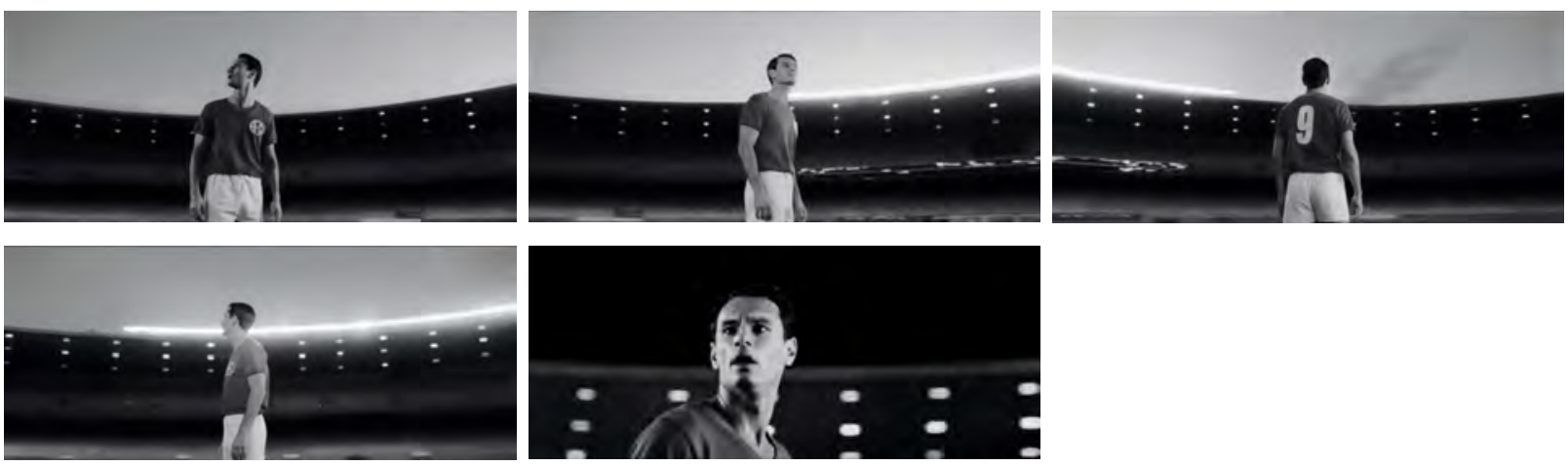

Fig. 307 - Heleno (2011), José Henrique Fonseca

A cena do início do filme, em que Heleno entra em campo em um fundo branco, é então retomada. Agora ele está nú e fora de foco, corre em direção à câmera até ser enquadrado em um plano fechado (figura 308). 

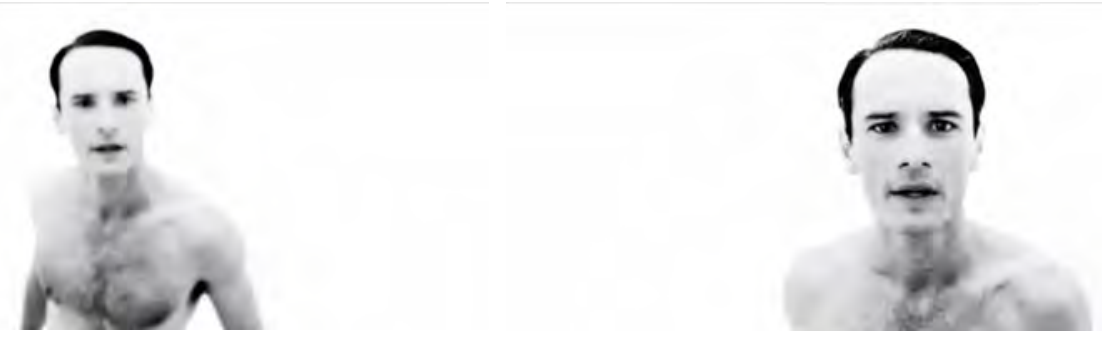

Fig. 308 - Heleno (2011), José Henrique Fonseca

Em seguida, Heleno desperta de seu sonho e está em Barbacena. Vemos imagens de Heleno jogando profissionalmente e com seus companheiros de sanatório, enquanto ouvimos suas palavras finais.

Glória. Não é bom? Até hoje eu não entendo direito o que foi que eu fiz. Eu sei que me vi cercado por aquele bando de urubús, e tudo o que eu queria era marcar um gol. Fui me equilibrando entre eles, silenciosamente, meu peito estufado, cheio de mim, e eu flutuei. Só me deixei explodir naquele chute seco, com raiva, urrando. Acho que todo jogador de futebol deveria assistir uma ópera antes de entrar em campo, pro sangue subir à cabeça. Eu não acredito em futebol sem o sangue fervendo, sem a faca entre os dentes. O jogador morre pensando na torcida. Eu não consigo imaginar alguém jogando futebol sem ser pela torcida. No juízo final, os satisfeitos e os covardes vão ser os primeiros a se retirar. Alguém pode achar que alguma coisa que eu fiz é impossível, mas não existe impossível para mim. Não sou jogador de futebol, sou a própria vontade de jogar, eu sou a gana em forma de gente. Eu sou.

O discurso de Heleno sintetiza sua trajetória e seu comportamento. Também aponta uma necessidade de ser amado e reconhecido pela torcida. Ainda que mostre seus últimos dias, dominado pela doença, o filme não mostra a morte de Heleno. Morre o homem mas não o mito. Os mitos são eternos e conjugam seus verbos no presente. Esta é a razão da frase que encerra o filme: eu sou. 


\subsection{O Filme da Minha Vida (2017), Selton Mello}

Baseado no livro Um Pai de Cinema, do escritor chileno Antonio Skármeta (1940- ), O Filme da Minha Vida é o terceiro longa-metragem dirigido por Selton Mello.

O enredo é ambientado nos anos 1960, em uma cidade fictícia no sul do Brasil, e conta a história de Tony (Johnny Massaro), um jovem que retorna à casa da família após um período de estudos na capital. Narrado em primeira pessoa por Tony, o ponto central de $O$ Filme da Minha Vida é a ausência do pai, que parte dizendo voltar à França, sua terra natal, e passa dois anos sem dar notícias à família.

Além da ausência do pai, o filme trabalha outros conflitos que orbitam a vida de Tony - descobertas amorosas e sexuais, início da vida adulta - e personagens com quem estabelece importantes relações: Luna (Bruna Linzmeyer), Petra (Bia Arantes) e Paco, personagem vivido pelo próprio diretor, que acaba tornando-se uma figura paterna na ausência do pai de Tony.

O cinema desempenha um papel relevante no filme, há referências tanto no título do livro que deu origem ao roteiro, como no próprio título do filme, que deixa claro ao espectador que ele não estará diante da vida de Tony mas sim do filme sobre a vida de Tony. É a mesma questão colocada pelo pintor surrealista René Magritte (1898-1967) ao criar o quadro Isto Não é Um Cachimbo (Ceci N’Est Pas Une Pipe, 1929).

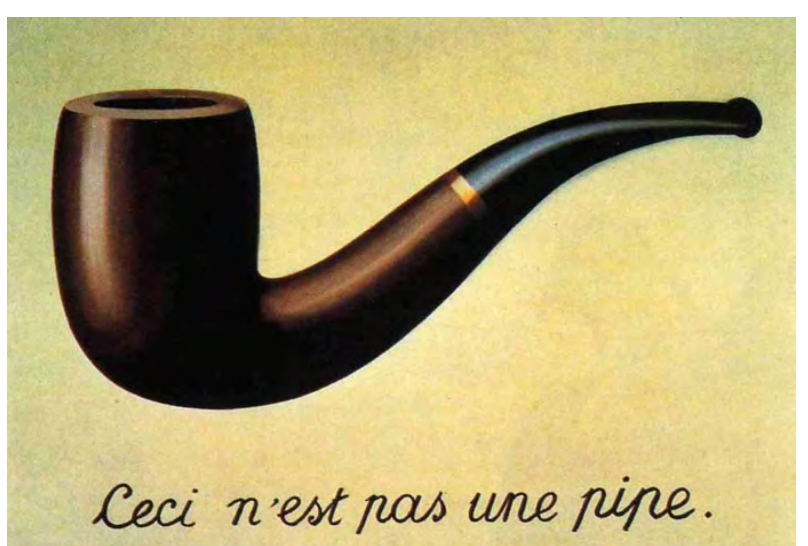

Fig. 309 - Isto Não é Um Cachimbo (1929), René Magritte

Magritte aponta para a diferença entre o objeto e sua representação, ou seja, o quadro não é o cachimbo, apenas uma imagem que representa um cachimbo. Do mesmo modo, Selton Mello distingue a vida de sua representação na obra cinematográfica, fornecendo a todo momento, elementos metalinguísticos que remetem à representação, como se Tony quisesse lembrar o espectador: isto não é minha vida, é o filme da minha vida. No mesmo sentido, Walter Carvalho concebe a imagem em constante referência à linguagem fotográfica, 
que é a base da captação da imagem fílmica.

A primeira referência ao cinema, tanto na imagem quanto na narração em off, está na cena de abertura, que é de uma paisagem vazia com a linha do trem. Tony diz: "antes eu só via o início e o fim dos filmes. O início, pra conhecer a história, e o fim eu gostava de assistir porque o fim é sempre bonito, né? Quem disse isso não fui eu, foi meu pai." Neste momento o trem entra em quadro em um movimento curvilíneo, e Tony continua: "depois eu entendi que o meio é tão importante quanto o início e o fim”. Assim, o personagem nos convida a entrar na narrativa.

Em termos de imagem, a metalinguagem está presente no trem, uma referência aos primórdios do cinema: o filme A Chegada de um Trem à Estação (1896), dos irmãos Lumière.
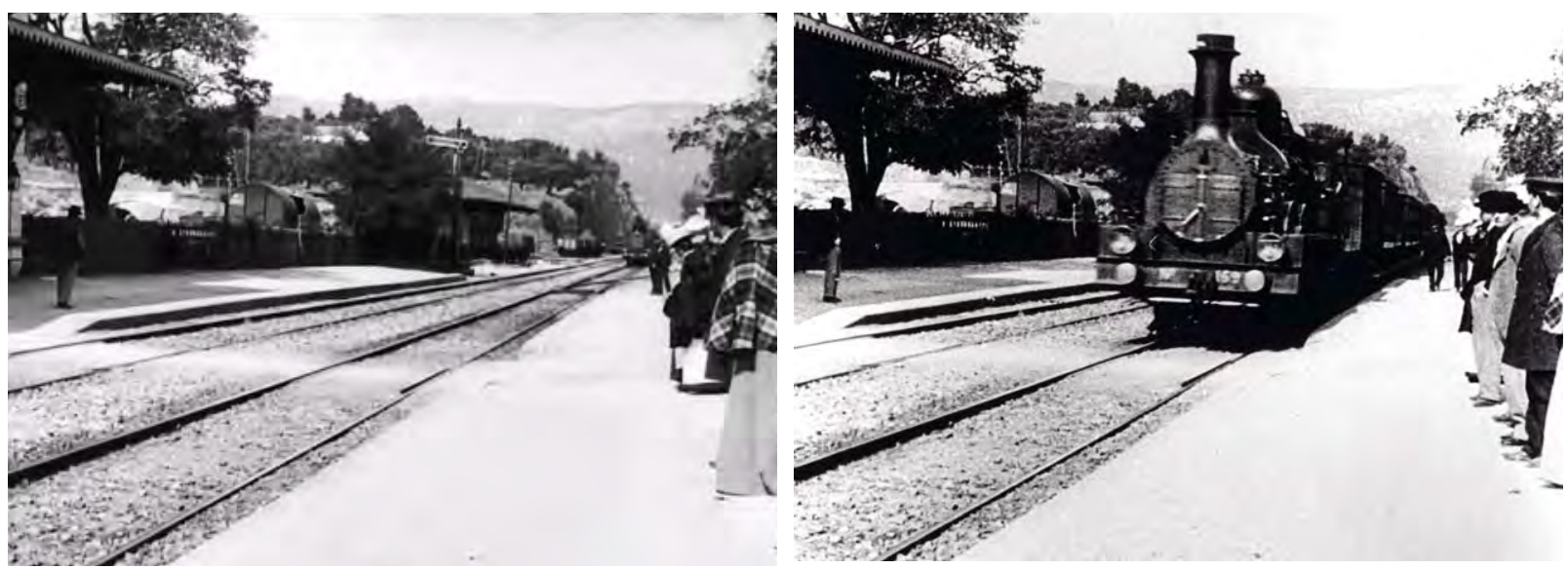

Fig. 310 - A Chegada de um Trem à Estação (1896), Irmãos Lumière

Apesar de muitos acreditarem que o filme tenha feito parte da primeira exibição do cinematógrafo em Paris, em 1895, há evidências de que sua exibição pública tenha sido posterior. O programa do evento lista dez filmes, mas não A Chegada de um Trem à Estação. O IMD (Internet Movie Database), site de referência sobre obras e profissionais do cinema, informa que sua exibição ocorreu apenas em 1896.

De qualquer modo, o filme é uma das obras iniciais do cinema, e sua importância não é apenas histórica, reside também na escolha da composição fotográfica, particularmente no uso do movimento do trem ao longo da diagonal, o que aumenta a impressão de profundidade da imagem. Nesse sentido, aponta para dois elementos fundamentais da criação da imagem cinematográfica: a profundidade no plano (espaço fílmico) e o movimento. Como veremos mais adiante, O Filme da Minha Vida também trabalha questões do espaço e do movimento, além de tocar na questão do tempo, outro elemento cinematográfico.

No artigo O trem na paisagem: um olhar materialista sobre o cinema de Lumière, o 
pesquisador Marcelo Carvalho descreve os momentos iniciais do filme:

\begin{abstract}
Reparemos no início do filme, em que o fundo da imagem toma quase todo o quadro, preenchendo-o com um vazio monótono. Vemos a plataforma, um pouco de céu, o pequeno aglomerado indiviso de corpos amontoando-se à direita do quadro, enfim, todo um cenário compondo o quadro como fundo de imagem. Uma paisagem desumanizada, autônoma, onde o pequeno aglomerado de corpos move-se sobre o eixo vertical de suas próprias pernas, como árvores que balançam ao vento, parte do fundo indiferente da imagem. Um fundo em movimento em que algo como uma percepção pura ("quase" imagem-percepção) se faz presente, o cenário em si, a última fase da paisagem da pintura tal como identificada por Rilke. Num dado momento, algo começa a tomar forma à direita do quadro, a locomotiva, a bela máquina, rival do cinema pelo status de maior invenção da Revolução Industrial. Do fundo da imagem, vindo da própria paisagem autônoma e emancipada, descolandose dela numa bela diagonal, crescendo sobre o cenário como uma gota de tinta que cai e se espalha sobre a água, vemo-la invadir a cena, tomar o quadro, realizando-se em primeiro plano (o móvel já se colocava em movimento nesse filme...) (CARVALHO, 2012, p. 91).
\end{abstract}

Tal descrição do filme dos Lumière caberia à abertura de $O$ Filme da Minha Vida, como é possível verificar nos dois fotogramas a seguir: "reparemos no início do filme, em que o fundo da imagem toma quase todo o quadro, preenchendo-o com um vazio monótono. Enfim, todo um cenário compondo o quadro como fundo de imagem. Uma paisagem desumanizada, autônoma, como árvores que balançam ao vento, parte do fundo indiferente da imagem (esquerda). Num dado momento, algo começa a tomar forma à esquerda do quadro (direita), a locomotiva, a bela máquina, rival do cinema pelo status de maior invenção da Revolução Industrial”.
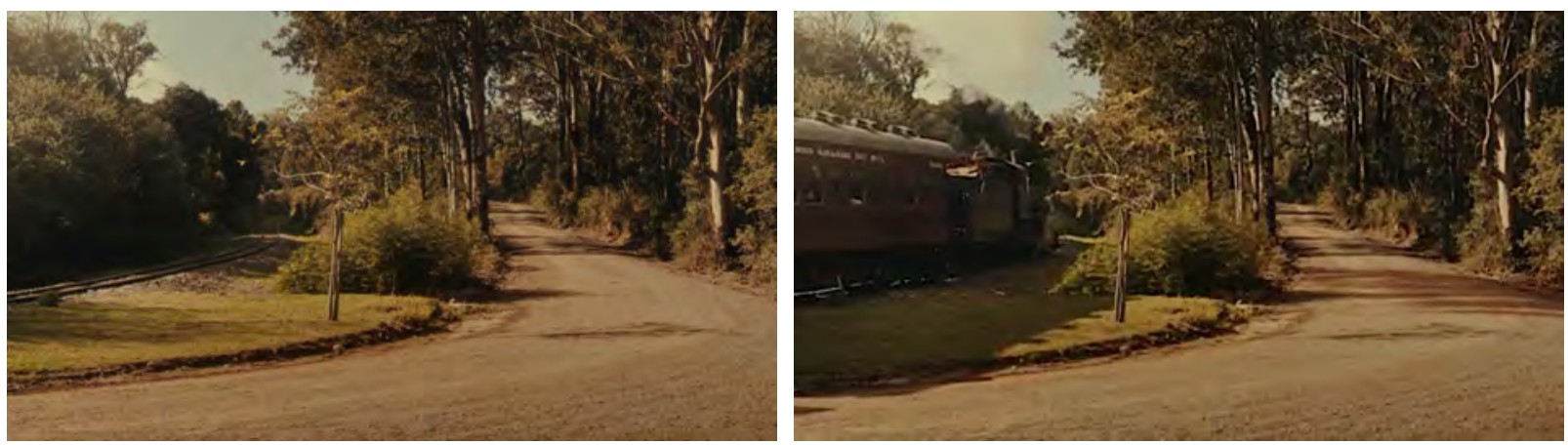

Fig. 311 - O Filme da Minha Vida (2017), Selton Mello

Assim, já de início, o diretor faz a ponte com o nascimento do cinema.

Com relação ao espaço, é importante notar o papel desempenhado pelo ambiente. Além da cena inicial, há vários planos gerais em que as paisagens contextualizam ações e conflitos, e nas quais os personagens aparecem imersos, como vemos na figura 312. 

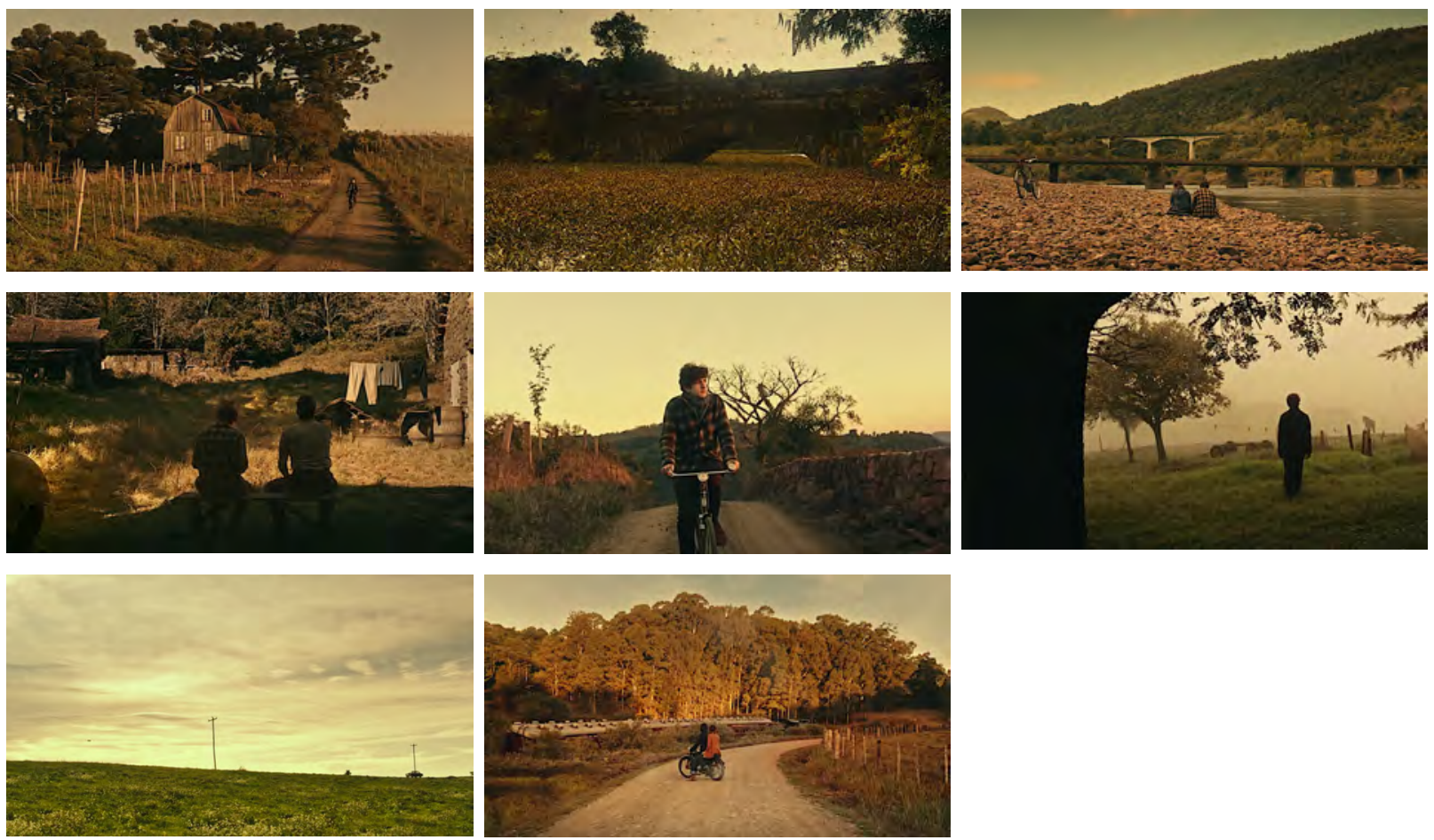

Fig. 312 - O Filme da Minha Vida (2017), Selton Mello

Os conflitos vividos por Tony estão ligados ao lugar. A cidade de Remanso representa sua raíz, o lar, a família, e desse modo, desempenha importante papel no conflito vivido pelo personagem. A importância do lugar é estabelecida logo na primeira imagem do filme, que traz a paisagem com a linha do trem.

Para que o ambiente esteja presente na imagem, Walter Carvalho utiliza, além de planos abertos, uma profundidade de campo que pemite a visualização desse espaço fílmico. Nos planos de menor profundidade o desfoque é sutil, sem o radicalismo empregado, por exemplo, em Madame Satã. Vale lembrar que a imagem de Madame Satã é elaborada com base nas emoções e na personalidade do personagem principal, e que o filme foge ao determinismo de que o contexto explique todas as atitudes desse personagem.

Na figura 313, vemos à esquerda um fotograma de Madame Satã, que não possui foco em nenhum ponto da imagem. À direita há um fotograma de O Filme da Minha Vida, em que o foco é estabelecido no personagem Paco, em primeiro plano, e todo o resto do enquadramento encontra-se desfocado. Comparando o desfoque dos dois fotogramas, nota-se que em Madame Satã a imagem chega a ser quase abstrata, enquanto em $O$ Filme da Minha Vida o ambiente é visível mesmo desfocado. Como o ambiente é importante para o enredo e para a vida dos personagens, não existe isolamento, mesmo desfocado o ambiente está presente. 

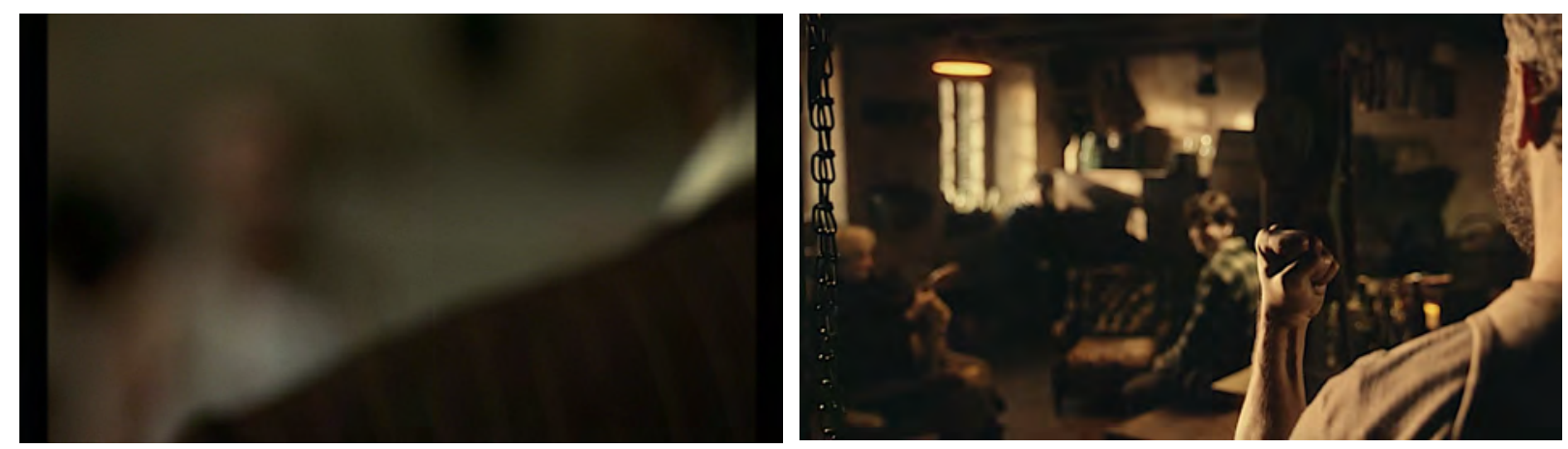

Fig. 313 - Madame Satã (esq) e O Filme da Minha Vida (dir)

O posicionamento do foco no primeiro plano, principalmente na nuca do personagem, é muito semelhante a Redemoinho (2016), dirigido por José Luiz Villamarim (1963- ) e fotografado por Walter Carvalho, como podemos verificar na figura 314.

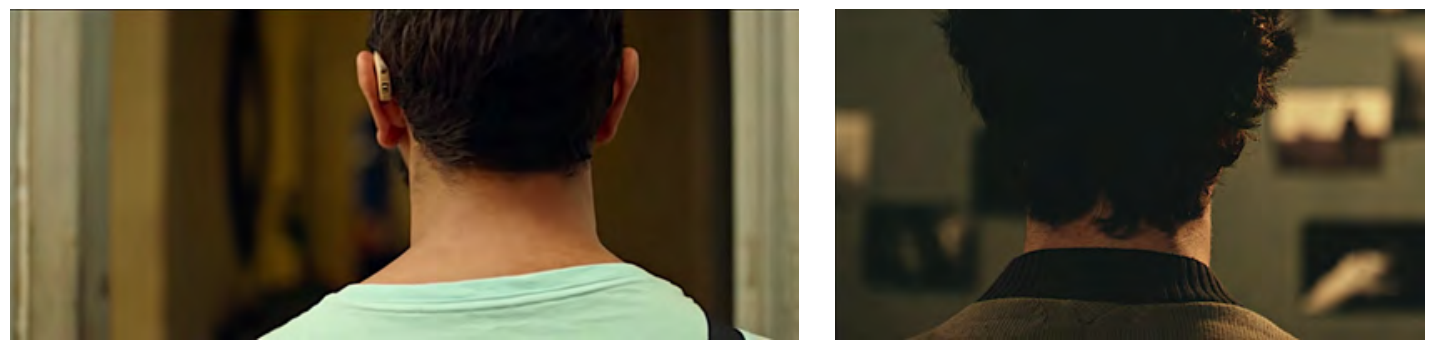

Fig. 314 - Redemoinho (esq) e O Filme da Minha Vida (dir)

Quando a profundidade de campo é pequena, o foco é estabelecido no ponto de destaque do plano. Chama a atenção a forma como Luzimar, em Redemoinho, e Tony, em $O$ Filme da Minha Vida, conduzem o foco em seus corpos, apesar do ambiente estar desfocado. Os dois personagens lidam com conflitos ligados ao lugar que habitam, ambos estão diante de segredos que são revelados ao longo do filme, e imageticamente são tratados de forma semelhante.

É o que acontece no momento em que o pai decide encontrar Tony, o foco está nele e todo o ambiente encontra-se desfocado. Não há clareza sobre o que acontecerá ao tomar essa decisão, assim como não há definição na imagem que está à sua frente.

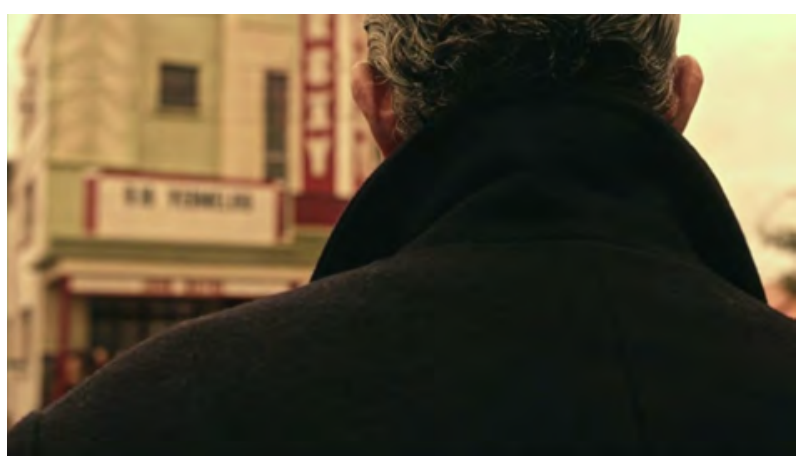

Fig. 315 - O Filme da Minha Vida (2017), Selton Mello 
Ao saber que Petra é mãe de Jean, Tony perde seu foco. Ele vira de costas e vai em direção ao ambiente desfocado, fundindo-se a ele. É o mesmo procedimento utilizado no plano em que sua mãe olha para o horizonte, na esperança de ter notícias do marido.

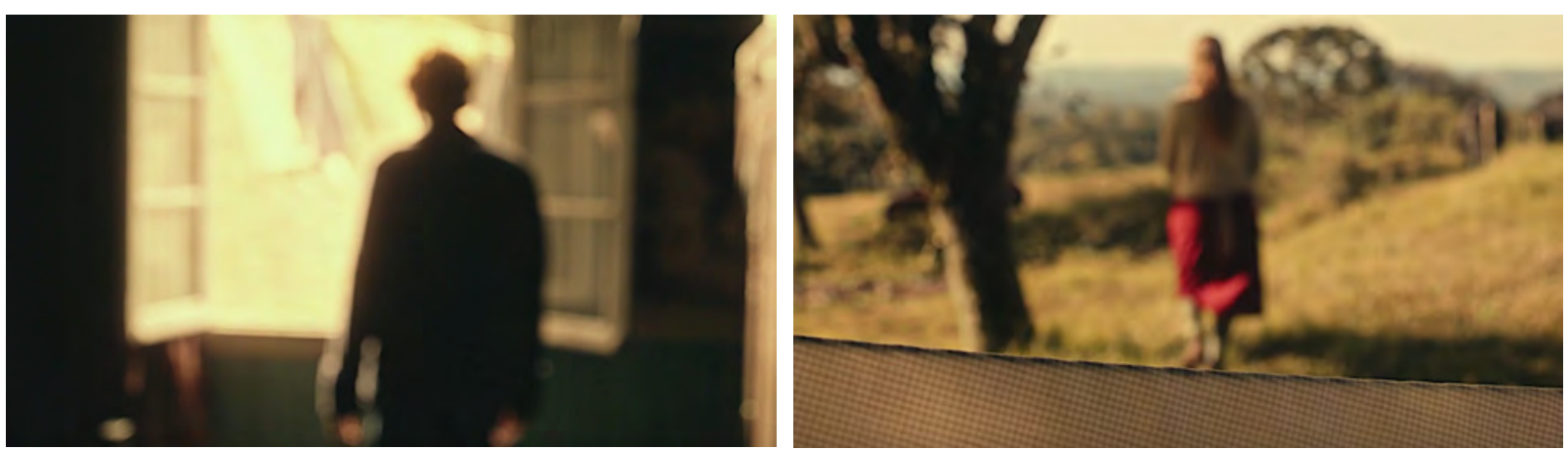

Fig. 316 - O Filme da Minha Vida (2017), Selton Mello

Além do foco, as janelas constituem outro elemento importante na delimitação do espaço fílmico. Remetem ao ato de enquadrar, uma vez que o dispositivo da câmera cinematográfica que delimita o quadro é denominado janela. Na figura 317 podemos ver doze fotogramas em que a cena é enquadrada por janelas, quer sejam das casas, do trem, do automóvel ou da sala de projeção.
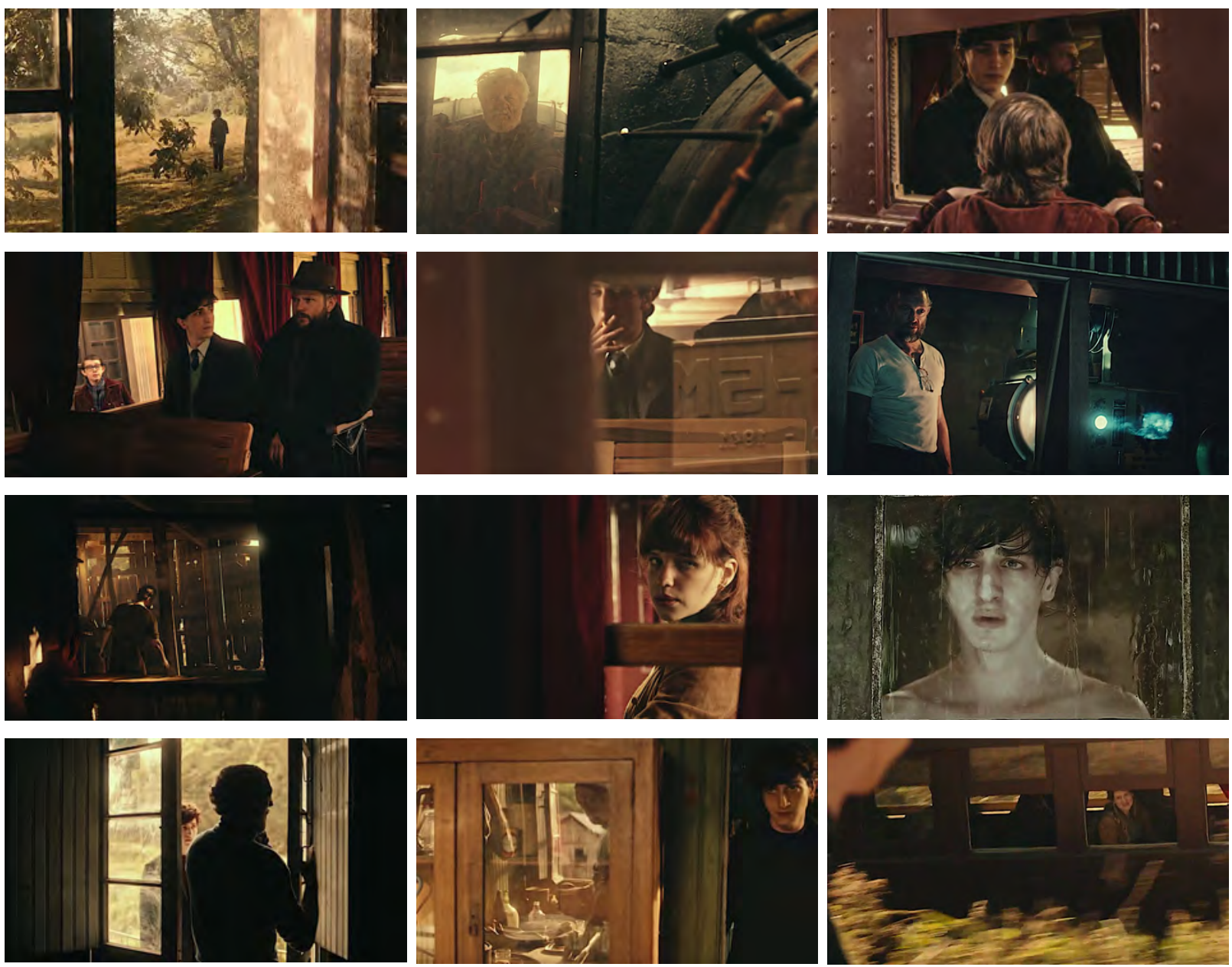

Fig. 317 - O Filme da Minha Vida (2017), Selton Mello 
As janelas reenquadram o que a janela da câmera inicialmente enquadrou, o que produz imagens mais fechadas dos que a lente utilizada produziria. É o que se pode ver no fotograma a seguir, em que o maquinista do trem ocupa uma porção menor do que a metade do quadro, limitado pela janela do vagão.

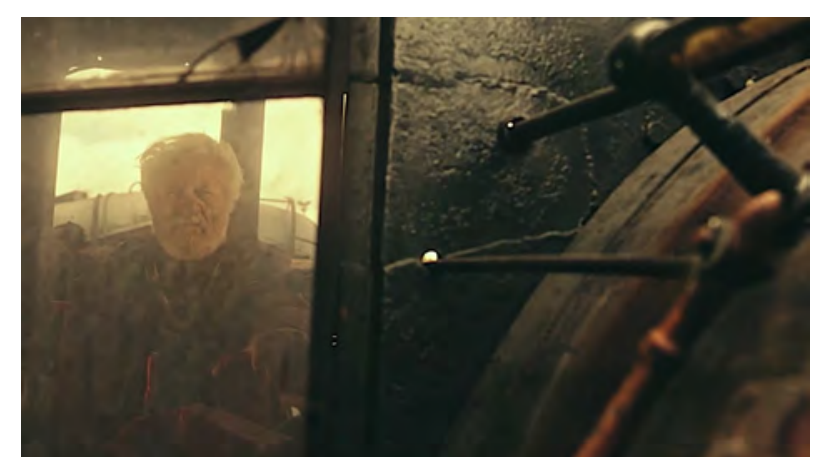

Fig. 318 - O Filme da Minha Vida (2017), Selton Mello

As janelas também remetem à projeção cinematográfica e, portanto, ao pai, projecionista do cinema local.
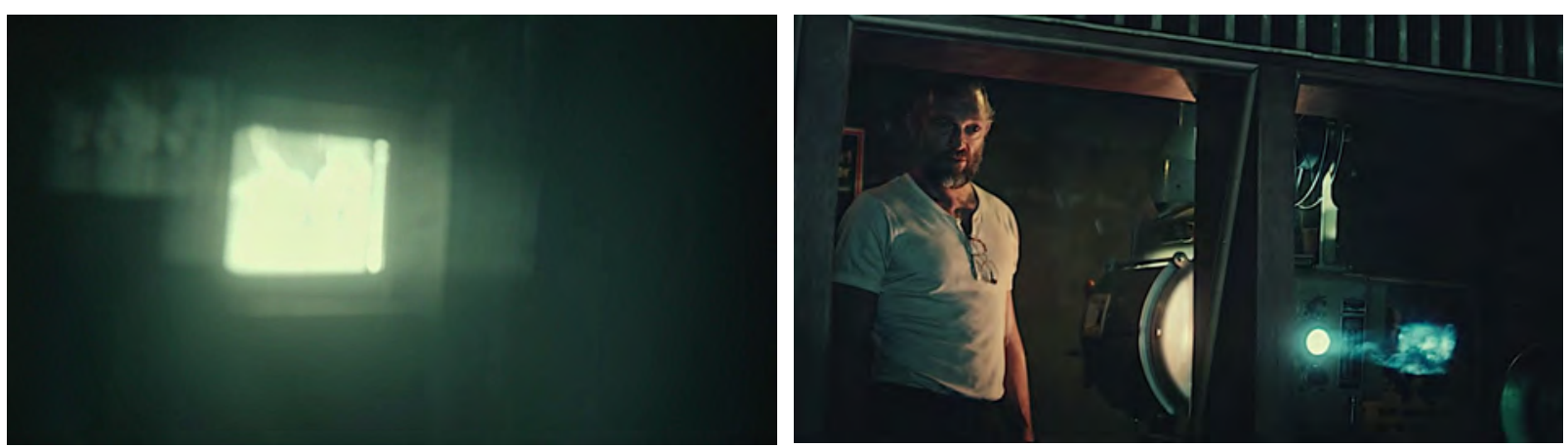

Fig. 319 - O Filme da Minha Vida (2017), Selton Mello

Podemos definir tecnicamente o cinema como uma sucessão de imagens fixas, positivas e translúcidas projetadas em uma tela, o que provoca a sensação de movimento contínuo. Na projeção ótica, um feixe de luz transpassa a imagem da cópia, que é ampliada por uma lente.

Os sistemas de captura e projeção da imagem são similares, compatíveis e padronizados. A captação se dá por meio da câmera cinematográfica e a projeção, por meio de um projetor que funciona de forma análoga à câmera. Uma das diferenças entre a câmera e o projetor é a trajetória da luz pelo sistema. A câmera é dotada de de um sistema de lentes que possibilta a entrada de luz para sensibilização do filme. O sistema de lentes do projetor funciona em conjunto com a lâmpada interna e tem a função de promover a saída de luz, projetando a imagem do fotograma para fora do sistema, em um percurso inverso ao da câmera. 


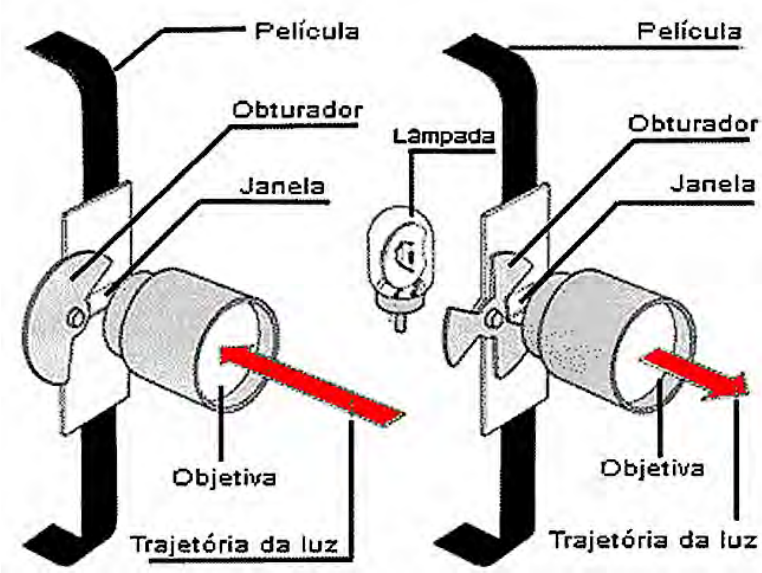

Fig. 320 - Trajetória da luz na câmera (esq) e no projetor (dir)

(fonte: http://www.mnemocine.com.br/index.php/cinema-categoria/28-tecnica/145-principioscine)

Assim, tanto câmera quanto projetor são dotados de lente, obturador e janela, sendo este último o dispositivo que limita o quadro a ser impresso ou projetado.

Além das janelas em primeiro plano, que emolduram a imagem à semelhança da janela de câmera, há as que estando ao fundo da imagem, iluminam a cena por trás, à semelhança da janela do projetor, como os fotogramas da figura 321.
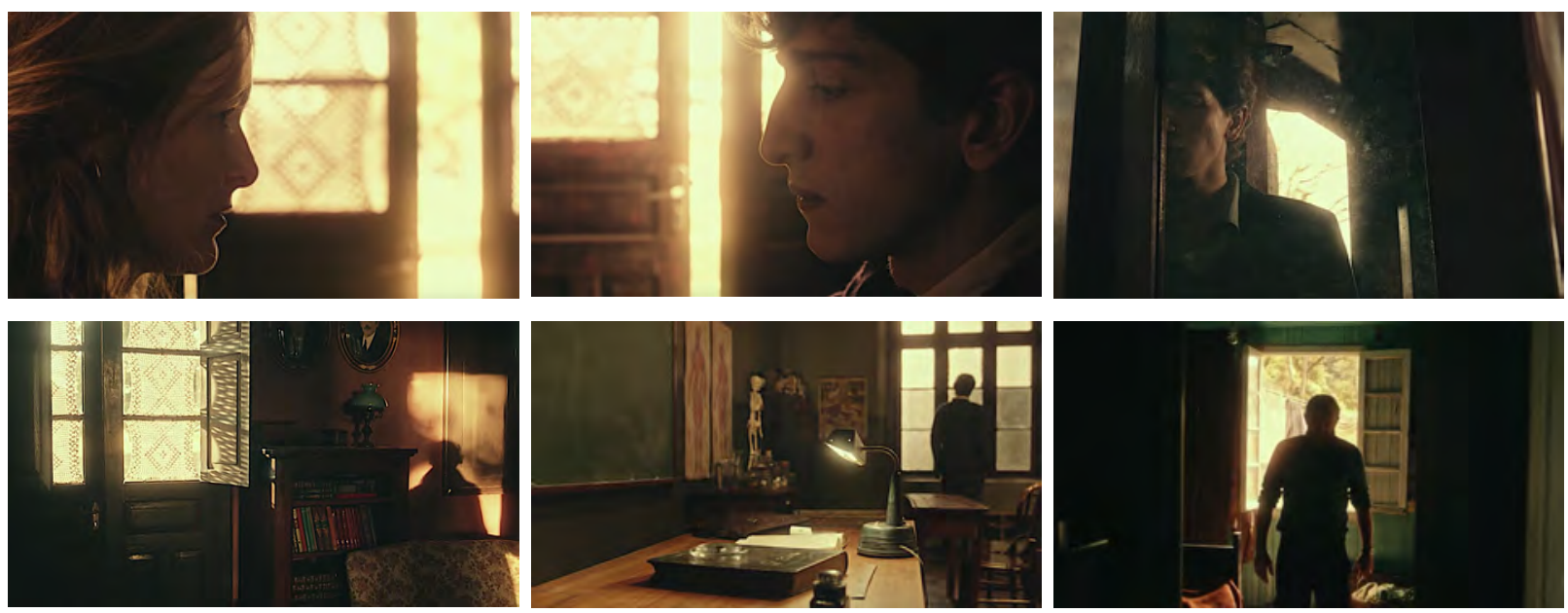

Fig. 321 - O Filme da Minha Vida (2017), Selton Mello

As janelas iluminadas recortam os objetos e personagens em primeiro plano, separando-os do fundo, de modo a aumentar a impressão de profundidade da imagem. Se traçarmos um paralelo entre esses quadros e os elementos do projetor, poderíamos considerar que a lâmpada estaria do lado de fora da janela e os personagens em primeiro plano seriam as projeções dos fotogramas do filme. Assim, essas imagens assemelham-se à visão de um espectador posicionado atrás da tela de projeção, como demonstra a figura 322. 


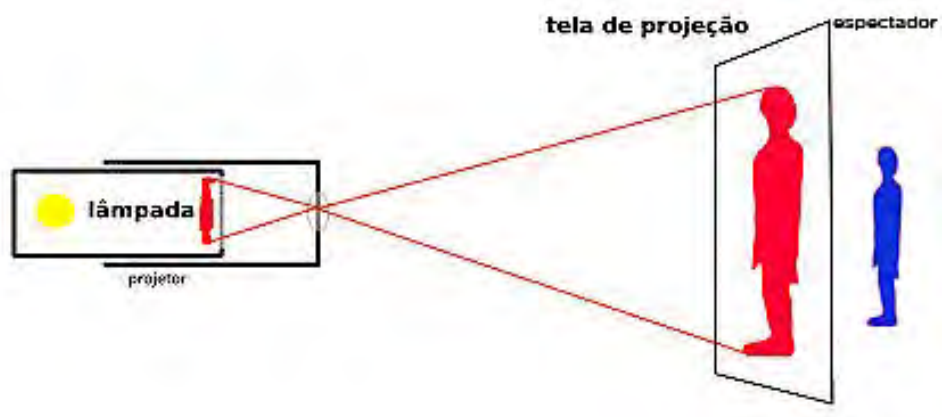

Figura 322 - Ponto de vista do espectador atrás da tela

(fonte: http://portaldoprofessor.mec.gov.br/fichaTecnica.html?id=30463)

A janela e o trem traçam um paralelo com o espectador do cinema. É possível comparar a visão de um passageiro que observa a paisagem pela janela de um trem em movimento, ao de um espectador que assiste à projeção de um filme.

Em seu artigo sobre os Lumière, Marcelo Carvalho fala da relação entre o trem e o cinema.

Talvez não haja imagem mais forte para o cinema do que a imagem desse trem paradigma das maravilhas industriais surgidas no século XIX - libertando-se da inexistência e, ao mesmo tempo, liberando todos os corpos retesados no canto do plano com a ventania produzida com sua chegada na estação (CARVALHO, 2012, p. 96).

O trem colocou os corpos em movimento, a uma velocidade jamais antes experienciada pelo homem. Esses corpos em movimento passaram a observar a paisagem de um novo ponto de vista, tendo a dimensão da paisagem em movimento.

De acordo com a física, o movimento é sempre um conceito relativo, pois depende de um referencial. Desse modo, o movimento ou o repouso dependem da ótica de quem observa e/ou do referencial adotado.

A paisagem do lado de fora de um trem está em repouso relativo a um observador fixo, contudo, é uma imagem em movimento para um observador que se move. Da mesma forma a imagem cinematográfica, composta de fotogramas fixos, que adquirem movimento relativo por meio da projeção. No primeiro caso, o espectador se move, no segundo caso é a imagem que se move.

Nesse sentido, na cena final, em que a mãe de Tony parte de trem para encontrar o marido, o que ela vê da janela pode ser comparado a um filme da cidade que está deixando. Assim como Tony vê a imagem em movimento da mãe que parte. 


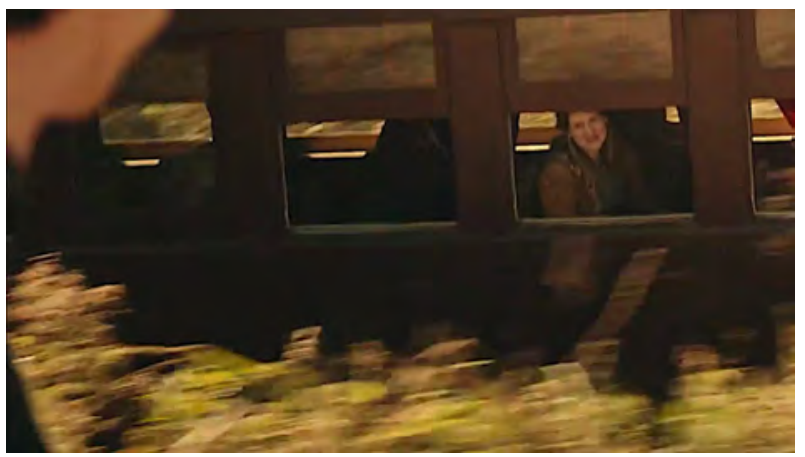

Fig. 323 - O Filme da Minha Vida (2017), Selton Mello

Além das janelas, outros elementos do filme emolduram os enquadramentos, criando a impressão de profundidade na tela plana. Como podemos verificar na figura 324, árvores, folhas, espelhos, paredes e até o corpo dos personagens servem de moldura, à semelhança dos filmes anteriores fotografados por Walter Carvalho.
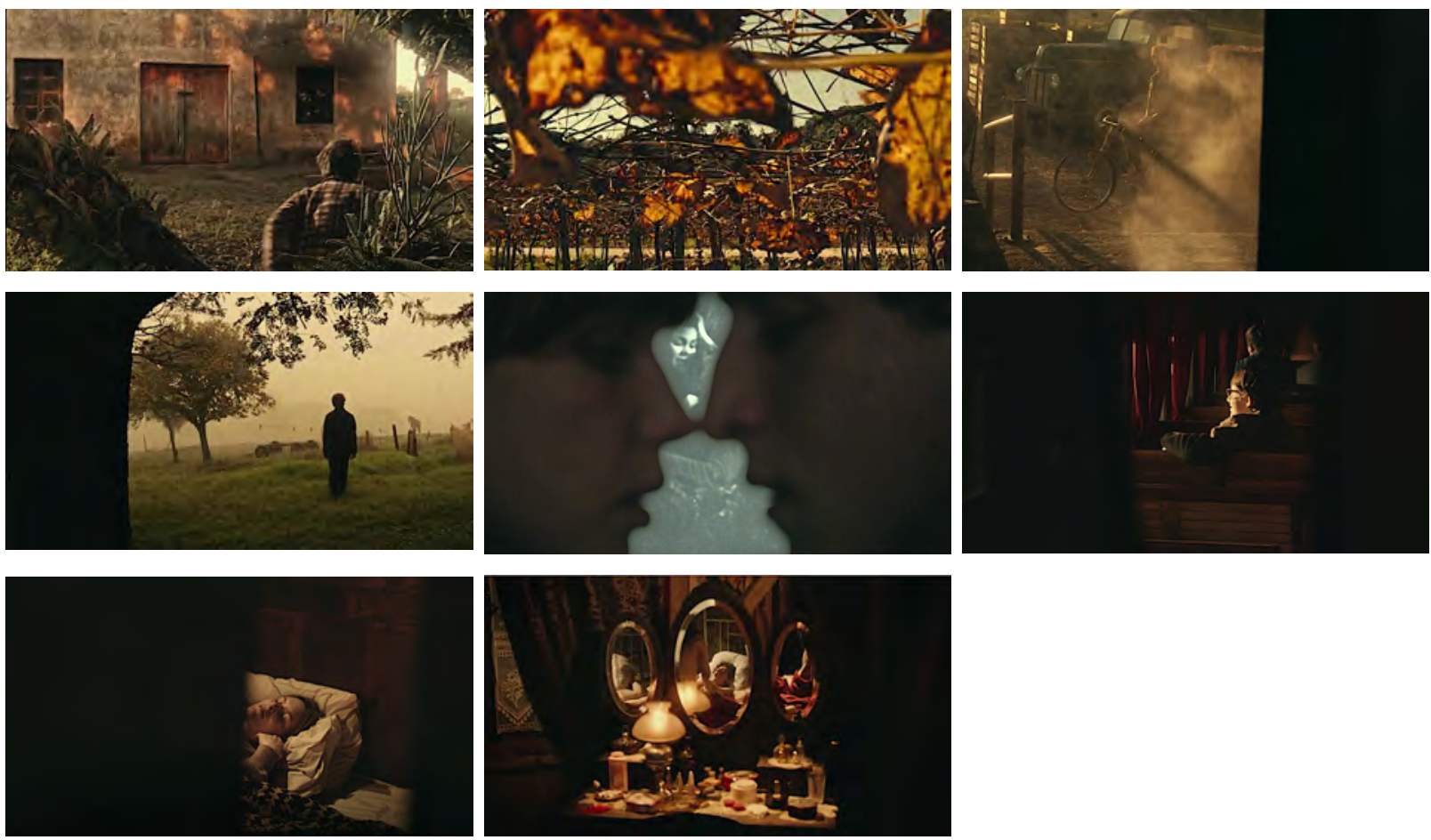

Fig. 324 - O Filme da Minha Vida (2017), Selton Mello

O enquadramento em profundidade, que dialoga com o cinema de Eisenstein, é utilizado em Terrra Estrangeira e em O Filme da Minha Vida. Esse tipo de enquadramento permite relacionar a figura com o fundo, personagem com ambiente. Em Terra Estrangeira existe a metáfora entre Alex e o barco encalhado, em $O$ Filme da Minha Vida a relação entre o cinema e o pai de Tony se estabelece no enquadramento em profundidade. 

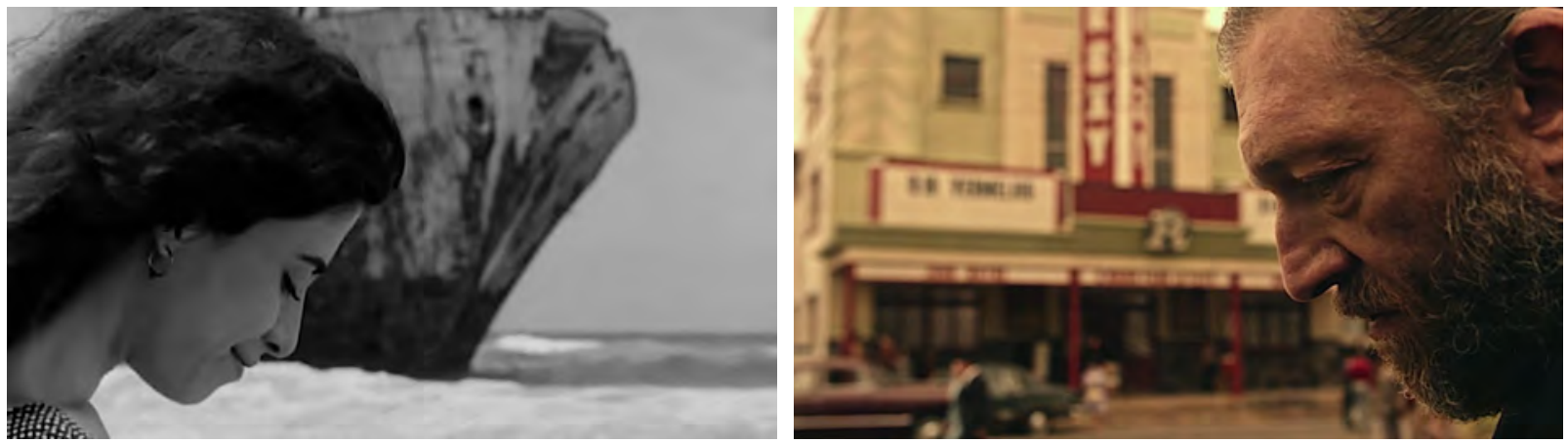

Fig. 325 - Terra Estrangeira (esq) e O Filme da Minha Vida (dir)

Além de Eisenstein, os enquadramentos do filme dialogam com o cinema de dois outros diretores. A cena em que Paco e Tony almoçam na cidade vizinha, pouco antes de irem ao cinema em que seu pai trabalha, encontra paralelo em $O$ Grande Hotel Budapeste (The Grand Budapest Hotel, 2014), de Wes Anderson.
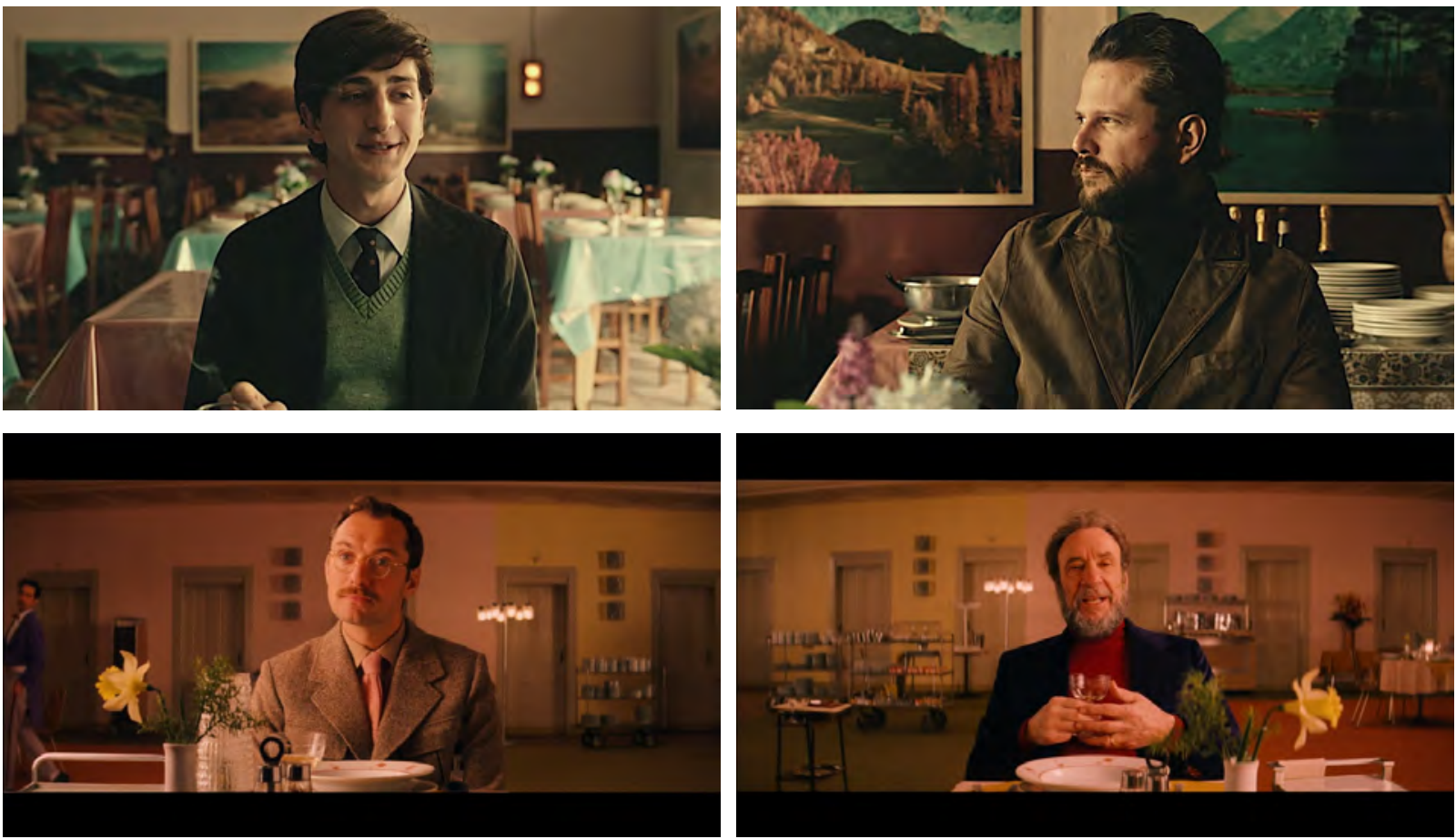

Fig. 326 - O Filme da Minha Vida (cima) e O Grande Hotel Budapeste (baixo)

Wes Anderson é conhecido pelo uso da simetria e da centralização nos enquadramentos. A visualidade de seus filmes caracteriza-se por uma atmosfera pouco realista trazida pela composição rigorosamente pensada, saturação de cores e trabalho corporal dos atores. O diretor evidencia a representação, em detrimento do registro realista.

Em O Filme da Minha Vida, a cena do restaurante precede a revelação de que o pai de Tony está na cidade. Até esse momento não sabemos onde ele está, tampouco sabemos que Paco conhece seu paradeiro e, portanto, está enganando Tony. 
Paco está representando, e tenta dissuadir Tony de ir ao cinema, onde poderá descobrir a verdade sobre o pai. A cena tem uma atmosfera desconfortante e a imagem colabora para isso. Os atores estão rigidamente enquadrados em planos centralizados, as cores do figurino estão presentes também no ambiente, como nas toalhas de mesa e nos quadros, o que funde os personagens ao restaurante. A atuação parece engessada, os atores pouco se movem.

Essa atmosfera de desconforto, criada pela relação entre personagens e espaço, é reforçada na tomada geral. O plano que enquadra lateralmente os dois atores, assemelha-se a um momento crucial do filme Os Bons Companheiros (Goodfellas, 1990), dirigido por Martin Scorsese.
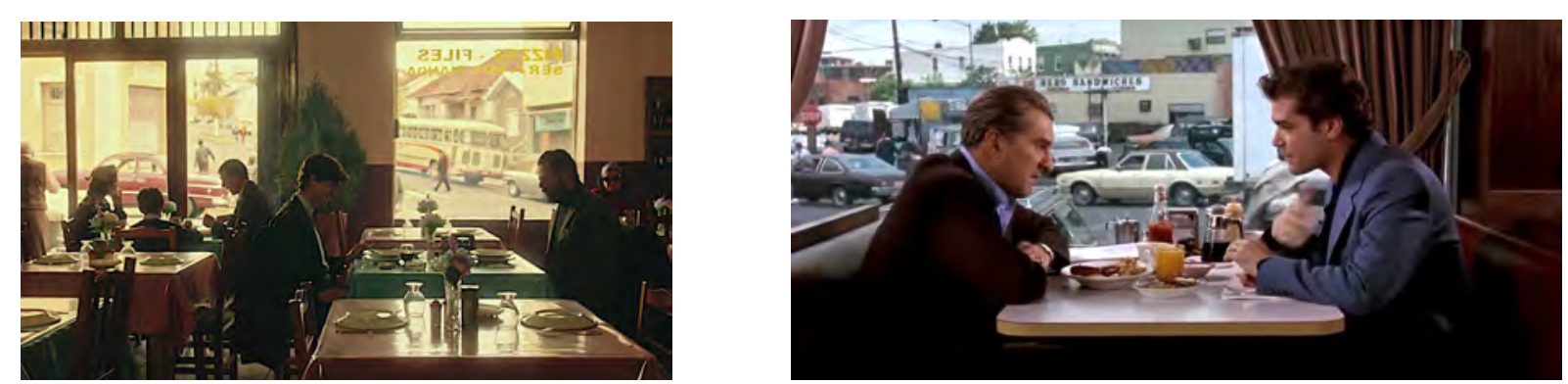

Fig. 327 - O Filme da Minha Vida (esq) e Os Bons Companheiros (dir)

Nesta cena, o personagem de Ray Liotta percebe que se for para onde o companheiro indica, ele será morto. Desse modo, a cena representa um rompimento, o final do relacionamento entre eles. O diretor de fotografia Michael Ballhaus e Scorsese criaram um plano que conjuga movimento de travelling out com movimento de zoom in, de modo que o quadro não se altera mas o fundo muda completamente. Quando a lente se fecha, o fundo torna-se cada vez mais presente. Esse plano, que ficou conhecido como efeito vertigo, traz suspense e estranhamento à imagem, uma vez que muitos espectadores sentem que algo muda mas não se dão conta do que realmente está mudando.

Em O Filme da Minha Vida o efeito vertigo não é utilizado, mas a semelhança com o plano de Os Bons Companheiros prenuncia o rompimento entre Tony e Paco. A presença da cidade, evidenciada pela janela, também aponta para a importância que o lugar representará neste rompimento.

Ainda no que tange a relação entre personagens e espaço fílmico, há paralelos que podem ser traçados com Lavoura Arcaica. Após a partida de Tony para a capital, há uma elipse temporal e, em seguida, seu retorno a Remanso. A volta de Tony acontece em uma subjetiva de dentro do trem, do túnel escuro para o horizonte claro. A chegada de Tony assemelha-se à partida de André, personagem de Selton Mello em Lavoura Arcaica. 

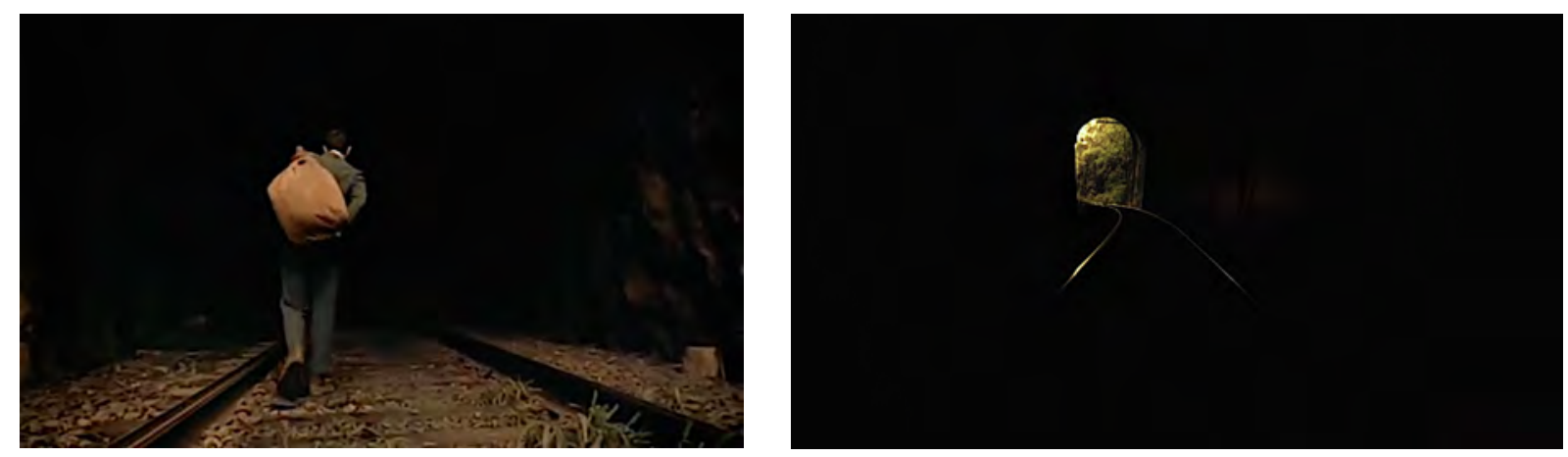

Fig. 328 - Lavoura Arcaica (esq) e O Filme da Minha Vida (dir)

A linha do trem é o caminho que leva André para longe de sua família e traz Tony para perto de sua mãe. $\mathrm{O}$ futuro incerto de André é marcado pela entrada no túnel escuro, em que não se pode ver o horizonte. Tony diz que o dia de sua partida foi uma festa, mas que não pode dizer o mesmo sobre seu retorno. Assim como a imagem de Lavoura Arcaica, o túnel escuro prenuncia tempos não muito felizes que Tony deverá atravessar. Contudo, a imagem aponta para uma luz no horizonte, um desfecho positivo para o personagem e sua família.

O túnel aparece também no momento em que Tony, ao descobrir o paradeiro do pai, retorna a Remanso. Desta vez não há horizonte, a entrada no túnel é seguida da tela preta.
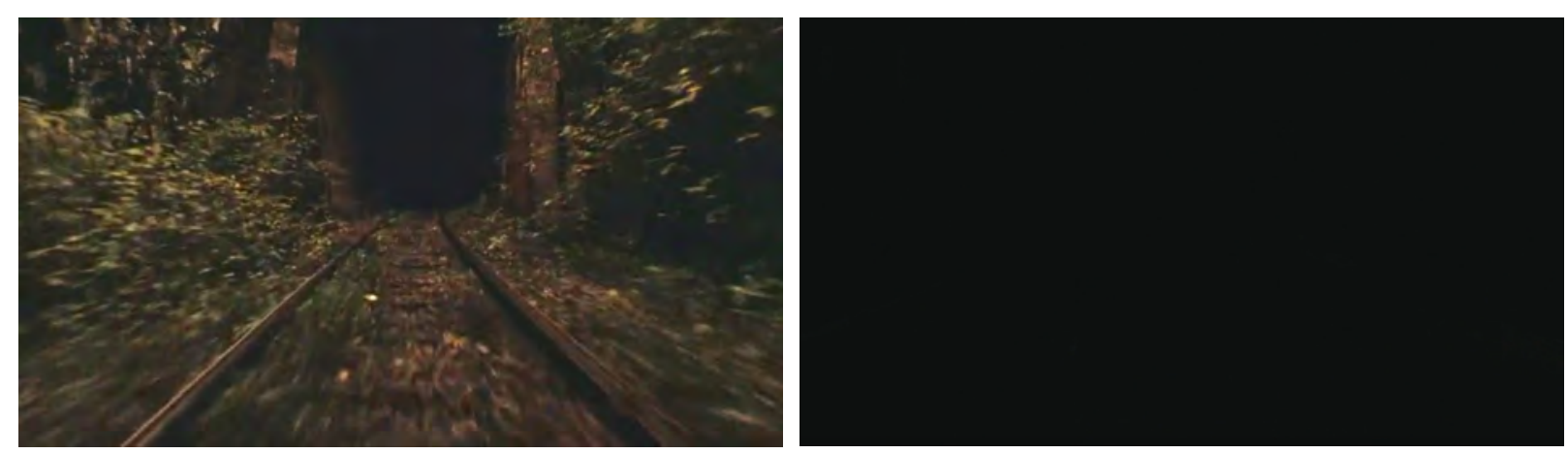

Fig. 329 - O Filme da Minha Vida (2017), Selton Mello

Em outros três planos a linha do trem assinala dúvidas e possibilidades sobre o caminho a seguir (figura 330). No primeiro deles, em um momento de delírio do personagem. Ao descobrir o segredo do pai, Tony retorna a Remanso em meio a uma tempestade. Vai até a casa de Paco, que não o atende. Acaba doente e tem um pesadelo que mistura imagens do filme Rio Vermelho (Red River, 1948), do pai, da mãe e do trilho do trem, desfocado e em alta velocidade.

No segundo plano, Tony encontra-se sobre o trilho, olhando para a curva. Ele sabe do segredo do pai mas não contou à sua mãe, tampouco sabe como agir em relação à situação. A imagem traduz a dúvida do personagem sobre o que deve fazer. 
O terceiro plano do trilho é uma foto. A imagem está desgastada e o trilho funde-se à bruma, neste momento Tony decide voltar a Remanso e encarar o pai. Desse modo, a linha do trem não aponta mais a dúvida, mas a certeza do caminho a trilhar.
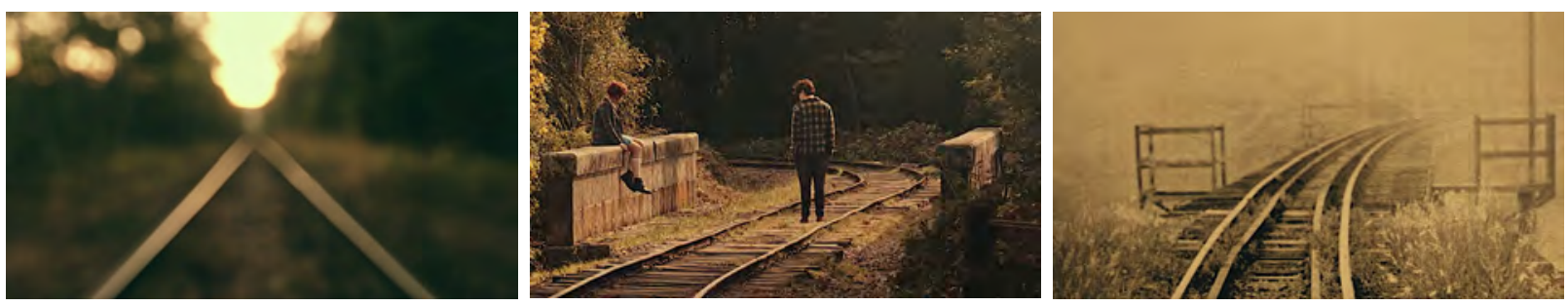

Fig. 330 - O Filme da Minha Vida (2017), Selton Mello

Os trilhos e o trem remetem ao segundo elemento cinematográfico referenciado em $O$ Filme da Minha Vida: o movimento. Como diz o personagem do maquinista, o trem movimenta as pessoas para resolverem seus problemas. Segundo Walter Carvalho, o filme deveria ser contado do ponto de vista deste personagem, pois ao transportar os filmes e as pessoas, acaba promovendo a ligação entre as duas cidades e entre os personagens da trama.

Além do espaço, o movimento de câmera e o movimento interno têm no filme um importante papel. Os movimentos são suaves, o primeiro deles é o travelling da motocicleta do pai até o rosto do menino, emoldurado pela janela. Tony diz: "meu pai sempre dizia, pra você ter uma vida equilibrada, você deve andar sobre duas rodas", ou seja, seria necessário domar o desequilíbrio natural de um veículo de duas rodas para ter uma vida equilibrada. E então começa a falar sobre o pai no passado, como se ele já não existisse mais.
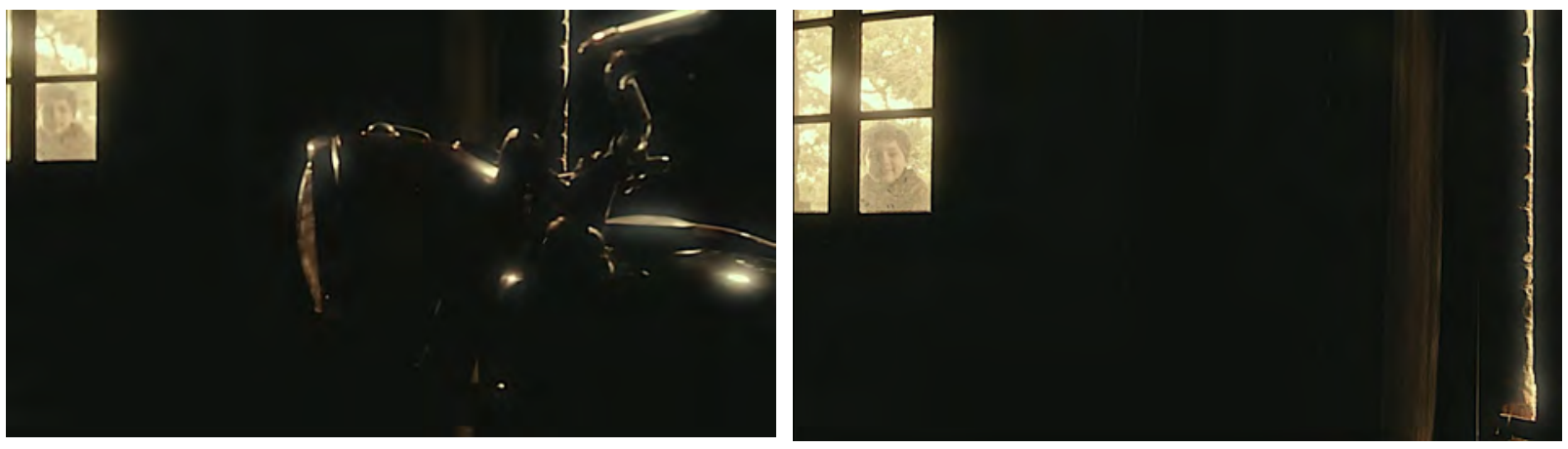

Fig. 331 - O Filme da Minha Vida (2017), Selton Mello

Há três elementos que produzem movimentos internos no filme: a bicicleta, a moto e o trem. A bicicleta pertence ao mundo de Tony, é com ela que o rapaz se locomove ao longo do filme. A moto representa o domínio do pai, o mundo adulto, aparece em movimento nas cenas de flash back, mas encontra-se estacionada na garagem durante sua ausência. Após a revelação do segredo, Tony apropria-se dela, e essa apropriação é fruto de seu 
amadurecimento, de sua entrada na vida adulta. No início do filme ele está de bicicleta, na última cena ele está de moto, com Luna na garupa, acompanhando o trem que leva sua mãe até a cidade vizinha.

As referências ao tempo constituem o terceiro elemento cinematográfico do filme. Após seu retorno a Remanso, a primeira imagem da nova vida de Tony é a de um relógio, seguida da abertura da janela do quarto, como se observasse o que está por vir.

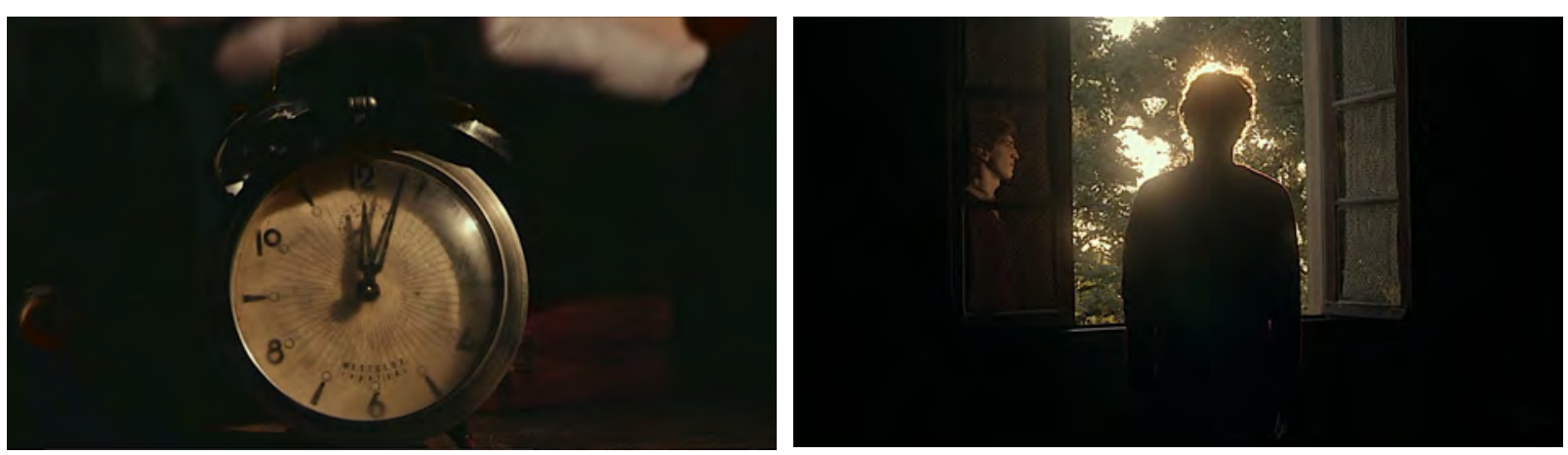

Fig. 332 - O Filme da Minha Vida (2017), Selton Mello

O tempo é trabalhado nas câmeras lentas, que ralentam o passar dos dias, aumentando a angústia de Tony com a falta de notícias do pai. A variação de velocidade (tempo) associase aos primeiríssimos planos (espaço) para ampliar os sentimentos dos personagens tanto em duração quanto em escala. É o que se pode ver na figura 333.
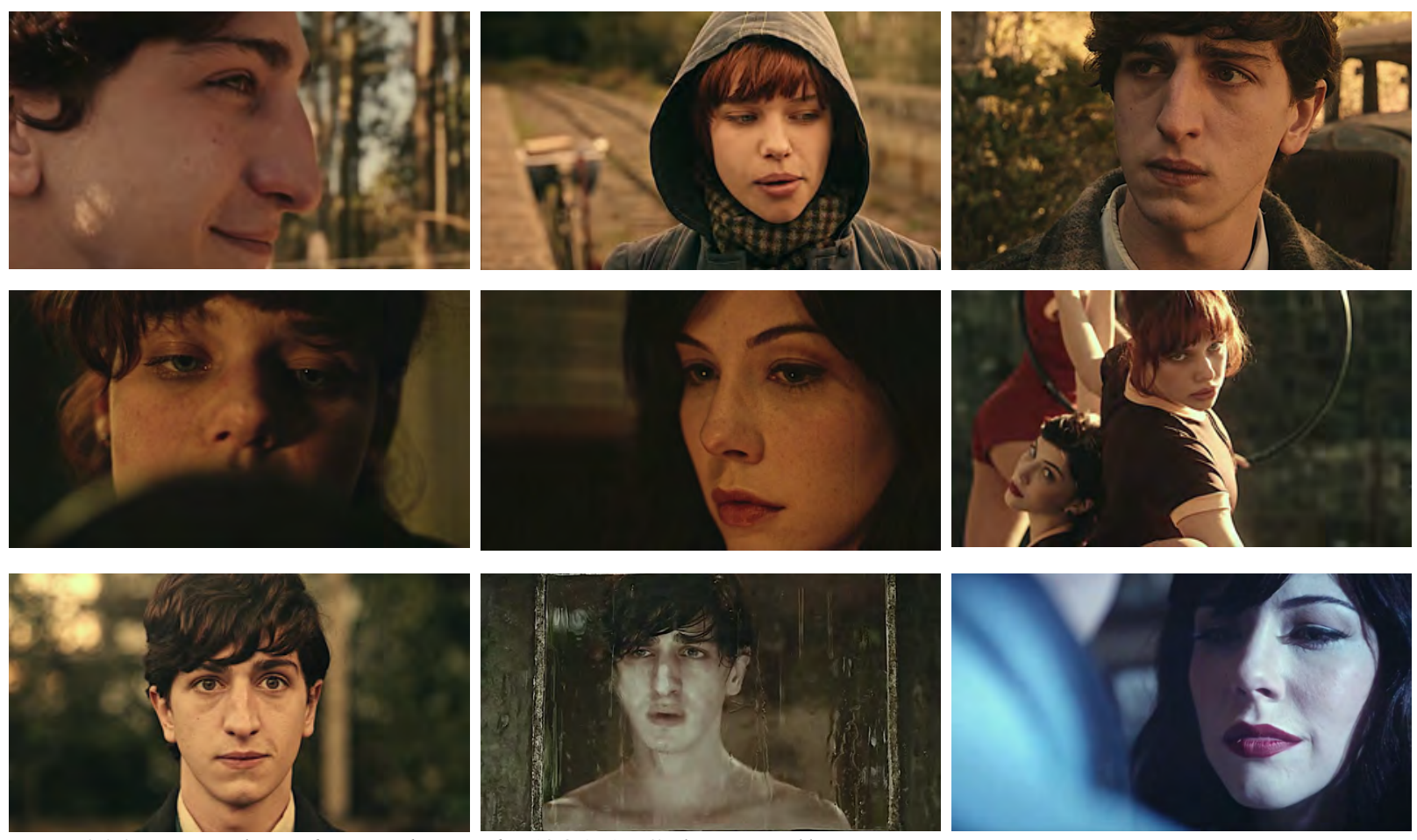

Fig. 333 - O Filme da Minha Vida (2017), Selton Mello 
O tempo também é trabalhado na montagem, que alterna momentos presentes com as lembranças felizes de Tony sobre seu pai. Nesse sentido, assemelha-se a Lavoura Arcaica, em que a memória traz a luz clara da infância, os tons quentes e até um momento de levitação dos personagens, motivado pelo amor a Deus (no primeiro caso) ou a uma mulher (no segundo caso).
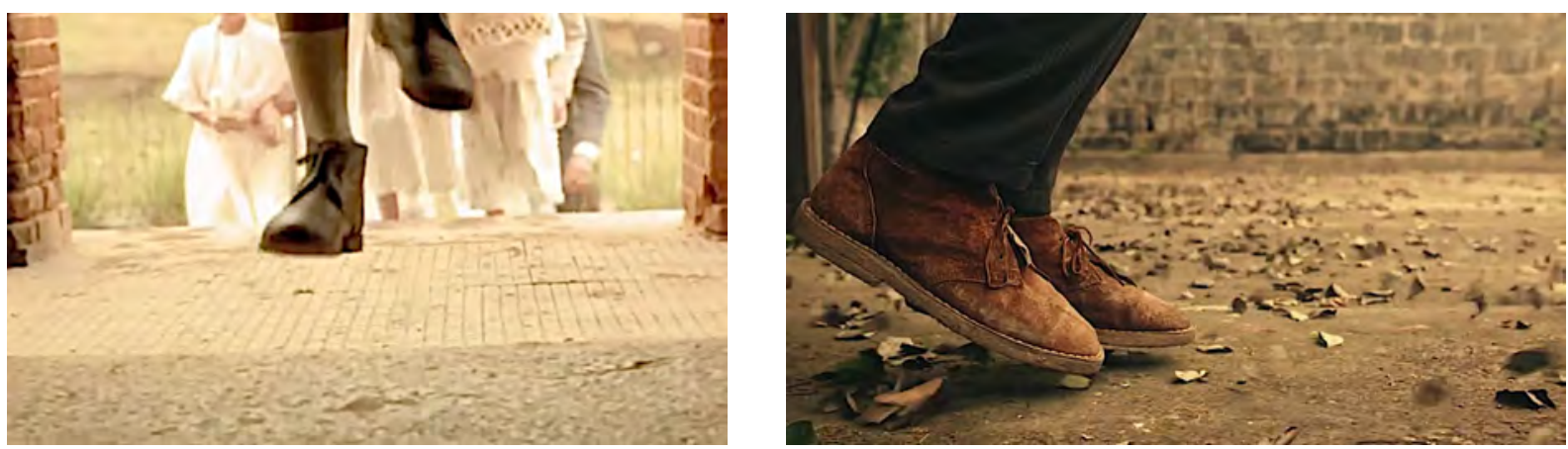

Fig. 334 - Lavoura Arcaica (esq) e O Filme da Minha Vida (dir)

Há semelhança entre os dois filmes no que tange a felicidade e a perturbação dos personagens, tratadas em termos luminosos. A começar com a cena da tempestade, em que os raios e trovões provocam estouros de luz, que refletem o estado emocional de Tony e Luna.
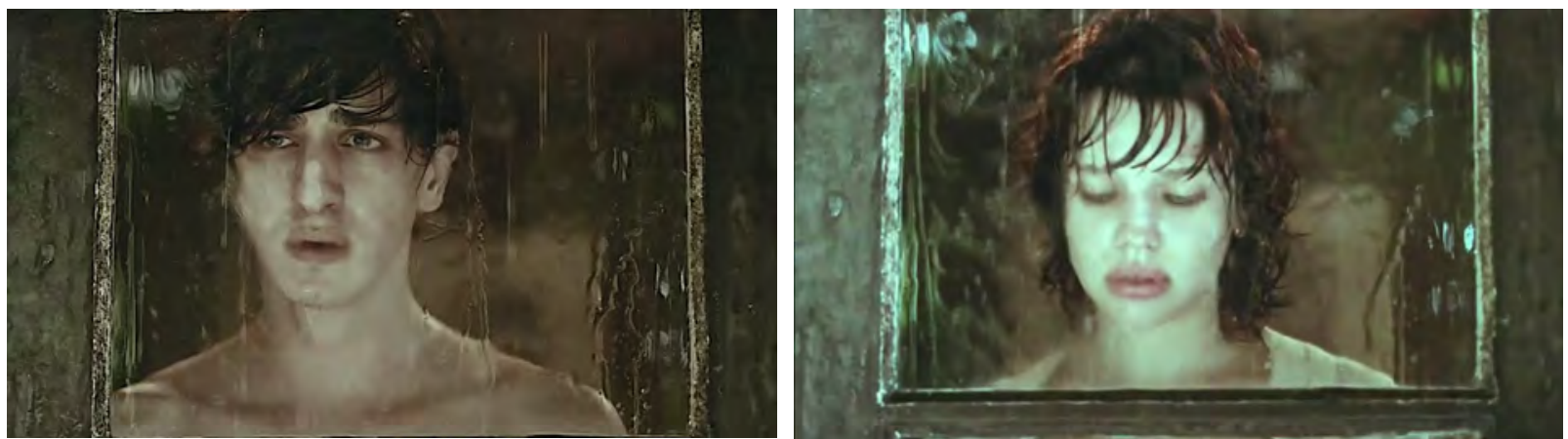

Fig. 335 - O Filme da Minha Vida (2017), Selton Mello

Ao final do sonho, Tony observa sua infância feliz com a família, a imagem é muito clara e os raios de sol inundam o quadro.
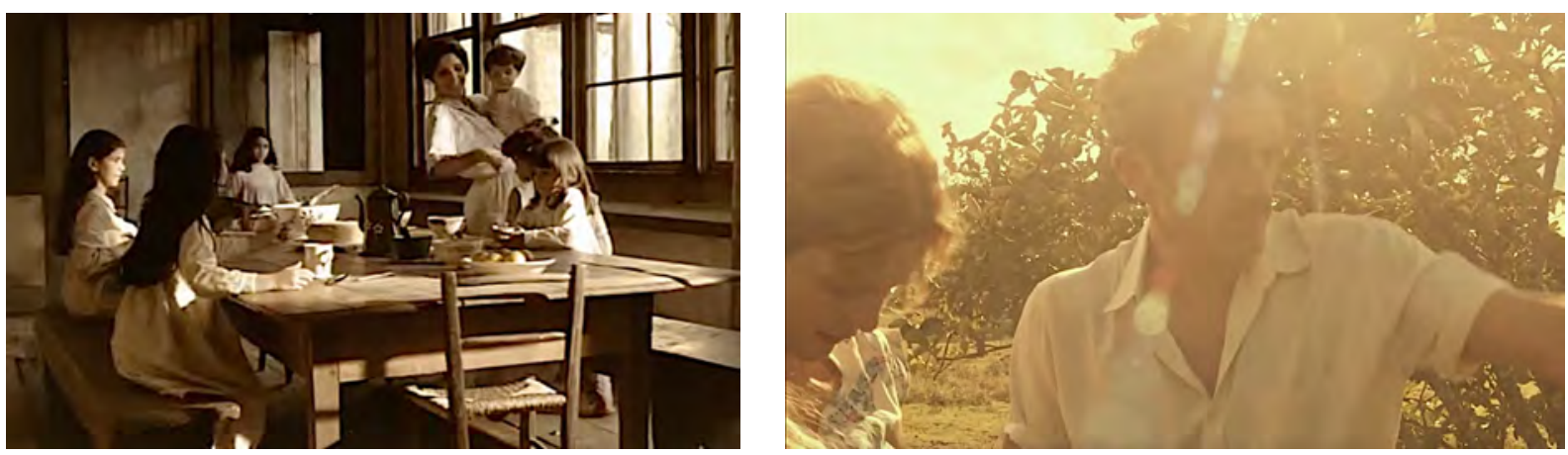

Fig. 336 - Lavoura Arcaica (esq) e O Filme da Minha Vida (dir) 
Em seguida a câmera faz um movimento para o alto e há uma mudança de intensidade na luz até que a imagem desmaterializa-se, tornando-se apenas um clarão.
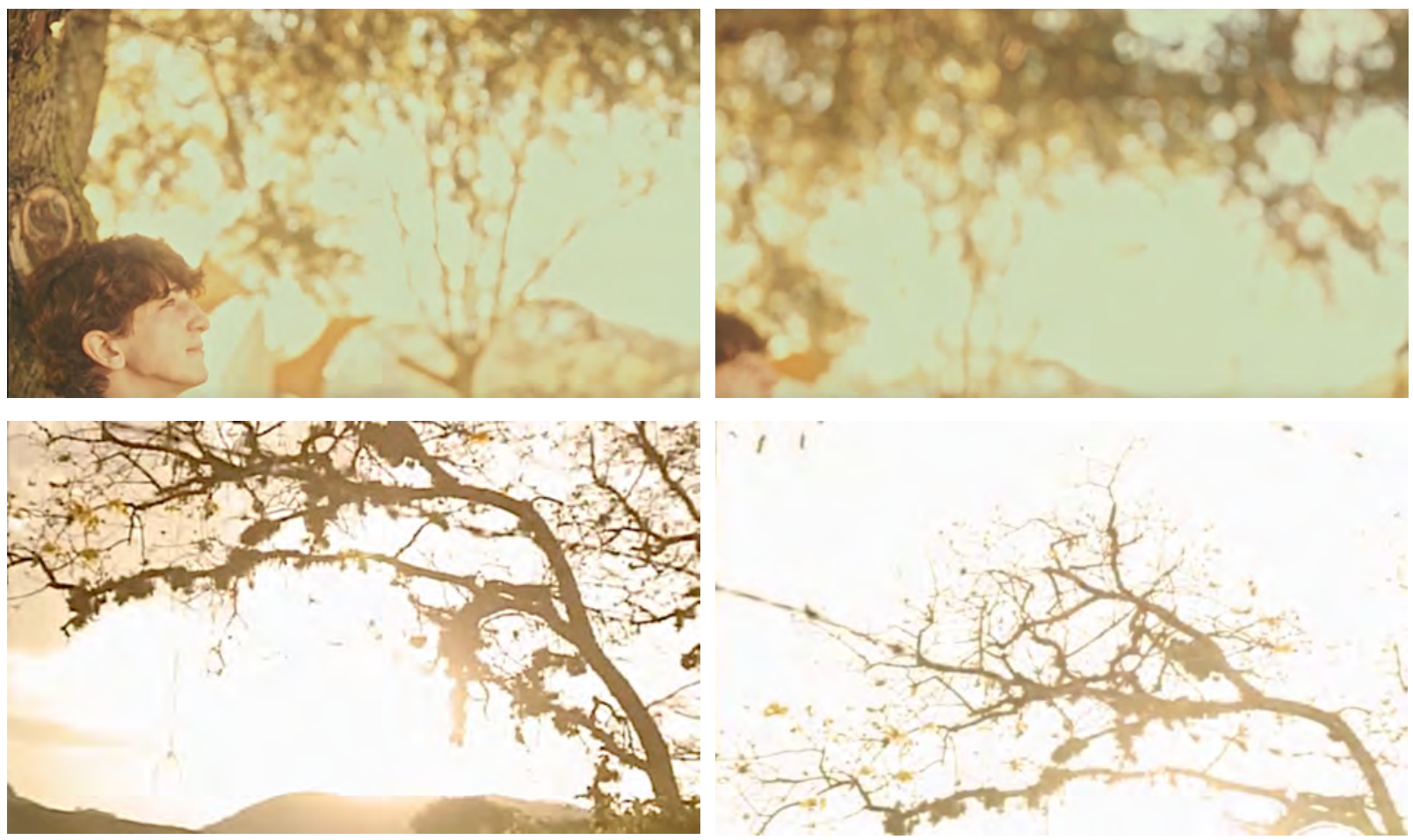

Fig. 337 - O Filme da Minha Vida (cima) e Lavoura Arcaica (baixo)

As perturbações de André (Lavoura Arcaica) e de Tony ( $O$ Filme da Minha Vida) se estabelecem em termos luminosos. Quando o segredo do pai vem à luz, o conflito de Tony se intensifica e é traduzido visualmente pelo estouro da luz clara da infância, que desmaterializa a imagem. Além da luz, os dois personagens são apresentados em termos de sombras, o que evidencia a dualidade de seus sentimentos, ou seja, seus estados emocionais conflitantes.
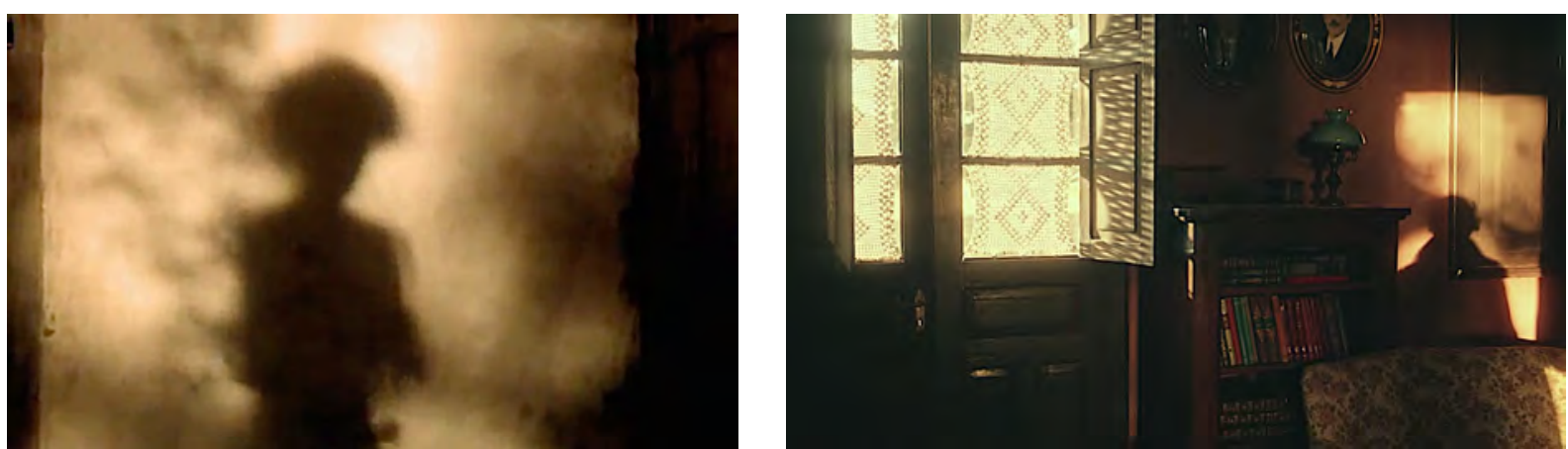

Fig. 338 - Lavoura Arcaica (esq) e O Filme da Minha Vida (dir)

Outro paralelo com Lavoura Arcaica é a sequência do sonho. Em Lavoura Arcaica a cena da parábola do homem faminto, contada pelo pai, é rodada em preto e branco. Em $O$ Filme da Minha Vida, Tony tem um sonho delirante sobre a partida do pai, que mescla 
imagens coloridas e sem cor.
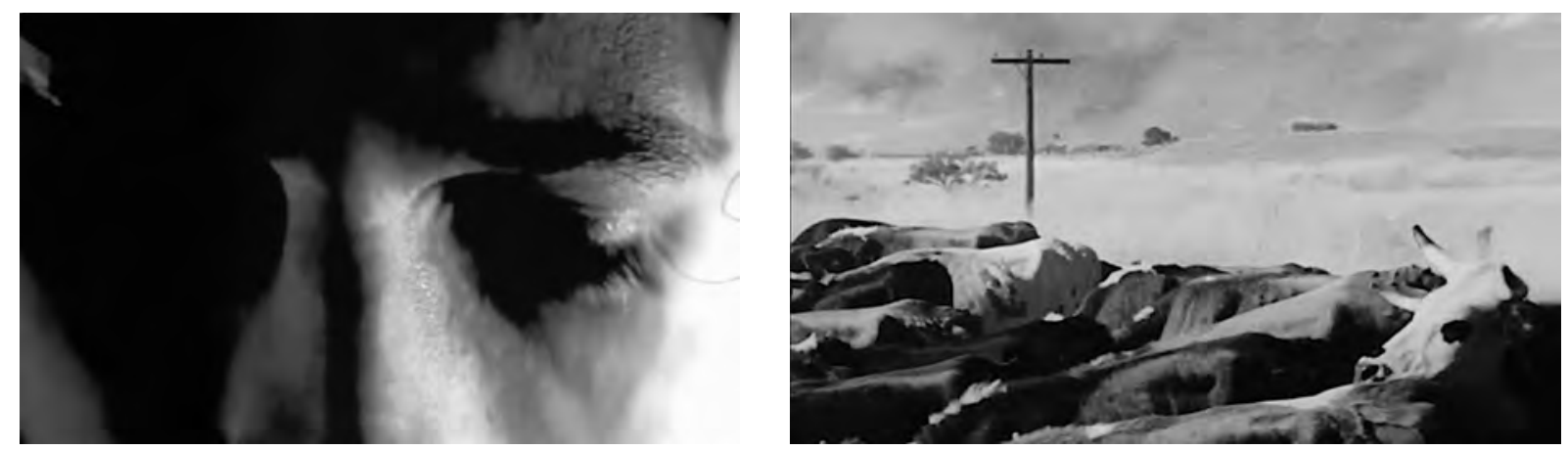

Fig. 339 - Lavoura Arcaica (esq) e O Filme da Minha Vida (dir)

O filme tem um trabalho apurado de cor, na paleta trazida pela direção de arte, na iluminação e na pós produção. A imagem tem uma tonalidade amarelada, o que the confere um aspecto envelhecido. Os matizes são dessaturados, como fotografias desgastadas pelo tempo. As paisagens lembram quadros do pintor inglês Thomas Gainsborough (1727-1788), como é possível ver na figura 340, comparando-se um fotograma do filme com Paisagem com gado e tropeiro (An extensive landscape with cattle and a drover, ca 1780). É possível notar a semelhança no tratamento do céu, da pastagem e das cores.
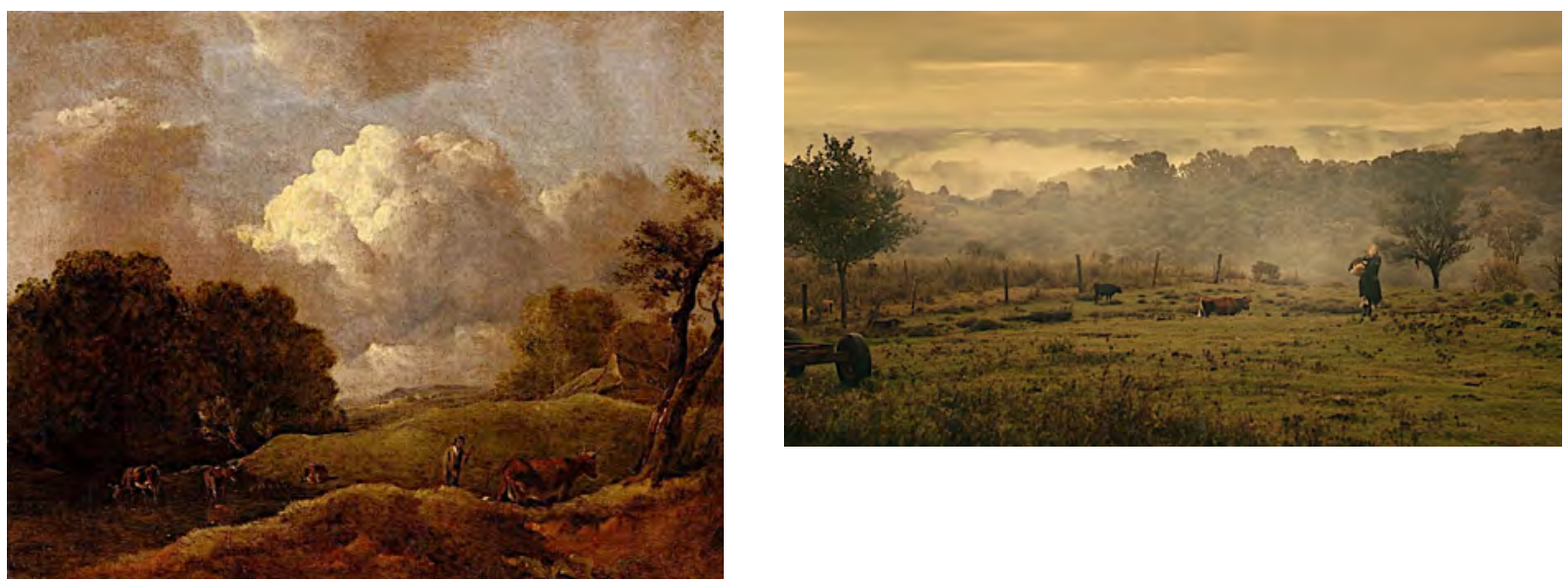

Fig. 340 - Paisagem com gado e tropeiro (esq) e O Filme da Minha Vida (dir)

Pouquíssimos quadros possuem a cor branca, as altas luzes são tonalizadas na pós produção. Na figura 341, o primeiro fotograma é um dos poucos exemplos em que há branco no filme. No modelo RGB, cada componente apresenta um valor de 0 (ausência de cor) a 255 (cor pura). No primeiro fotograma observa-se uma cor composta de R 255, G 255 e B 255, o que no sistema aditivo de cores equivale à luz branca. Já no segundo fotograma, a análise cromática da alta luz, com valor de luminosidade 100 no modelo HSL, traz os valores R 255, 
G 255 e B 198. Considerando que os valores de vermelho e verde são iguais e o valor de azul é menor, temos aqui um tom de amarelo.
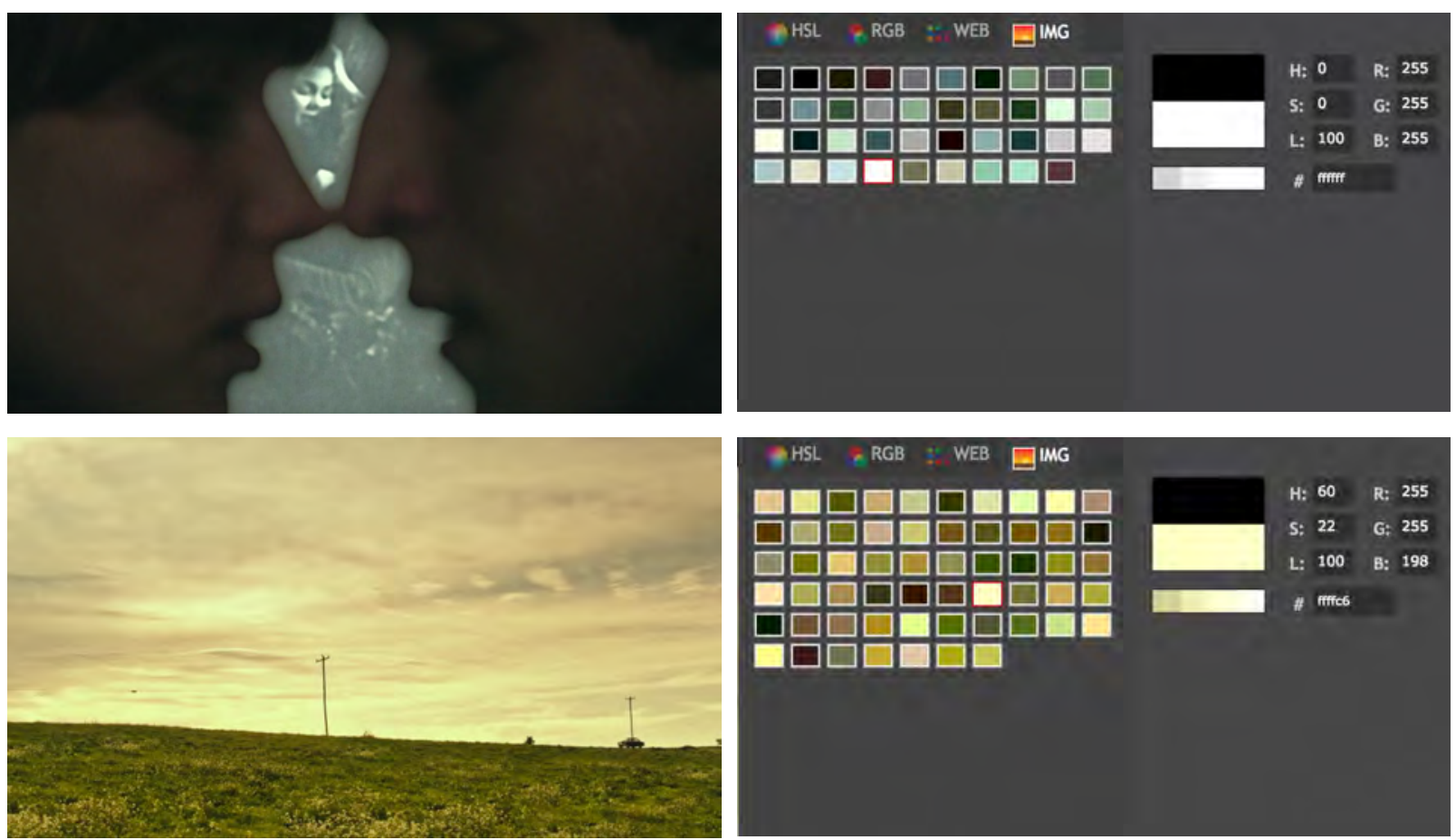

Fig. 341 - O Filme da Minha Vida (2017), Selton Mello

Um dos momentos mais importantes do filme é marcado por um procedimento que poderíamos chamar de movimento da cor-luz. Quando Tony diz a Petra que sabe de seu segredo, que sabe que ela é mãe do pequeno Jean, a cor da luz muda, alterna do azul para o vermelho. Esse movimento da luz marca o movimento interno do personagem, a mudança de seu estado emocional. É importante notar que esse procedimento não é comum nos filmes de Walter Carvalho, não tendo sido empregado nas obras analisadas nessa tese, o que apontaria para uma inovação em seu trabalho de iluminação.
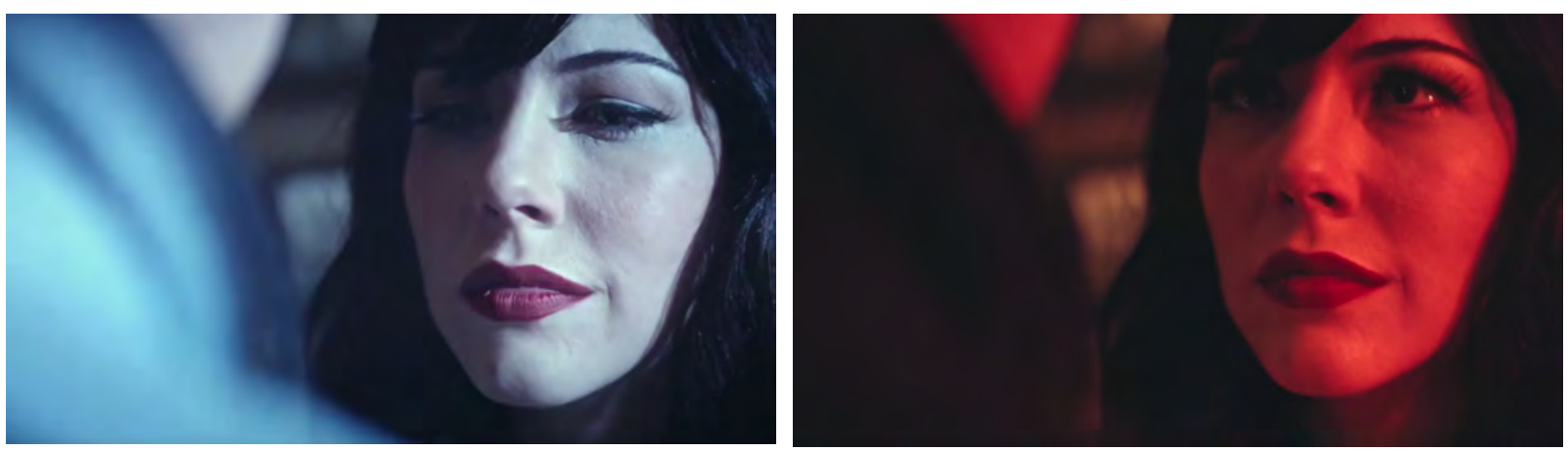

Fig. 342 - O Filme da Minha Vida (2017), Selton Mello

Ainda com relação ao tratamento de cor, verifica-se que não há diferença de registro entre passado e presente. É como se o passado e o presente se misturassem, fazendo parte de 
um momento único. Em sua carta de despedida, o pai de Tony diz: "O tempo passado embaralha meu tempo presente, preciso pensar no meu tempo futuro". Esse embaralhamento do tempo torna-se visível no tratamento uniforme da cor.

Na figura 343 temos à esquerda um plano de Tony criança com o pai, e à direita, um plano de Tony adulto. A paleta de cores das duas imagens é muito semelhante, como se pode ver na análise cromática das imagens feita no software Adobe Photoshop.
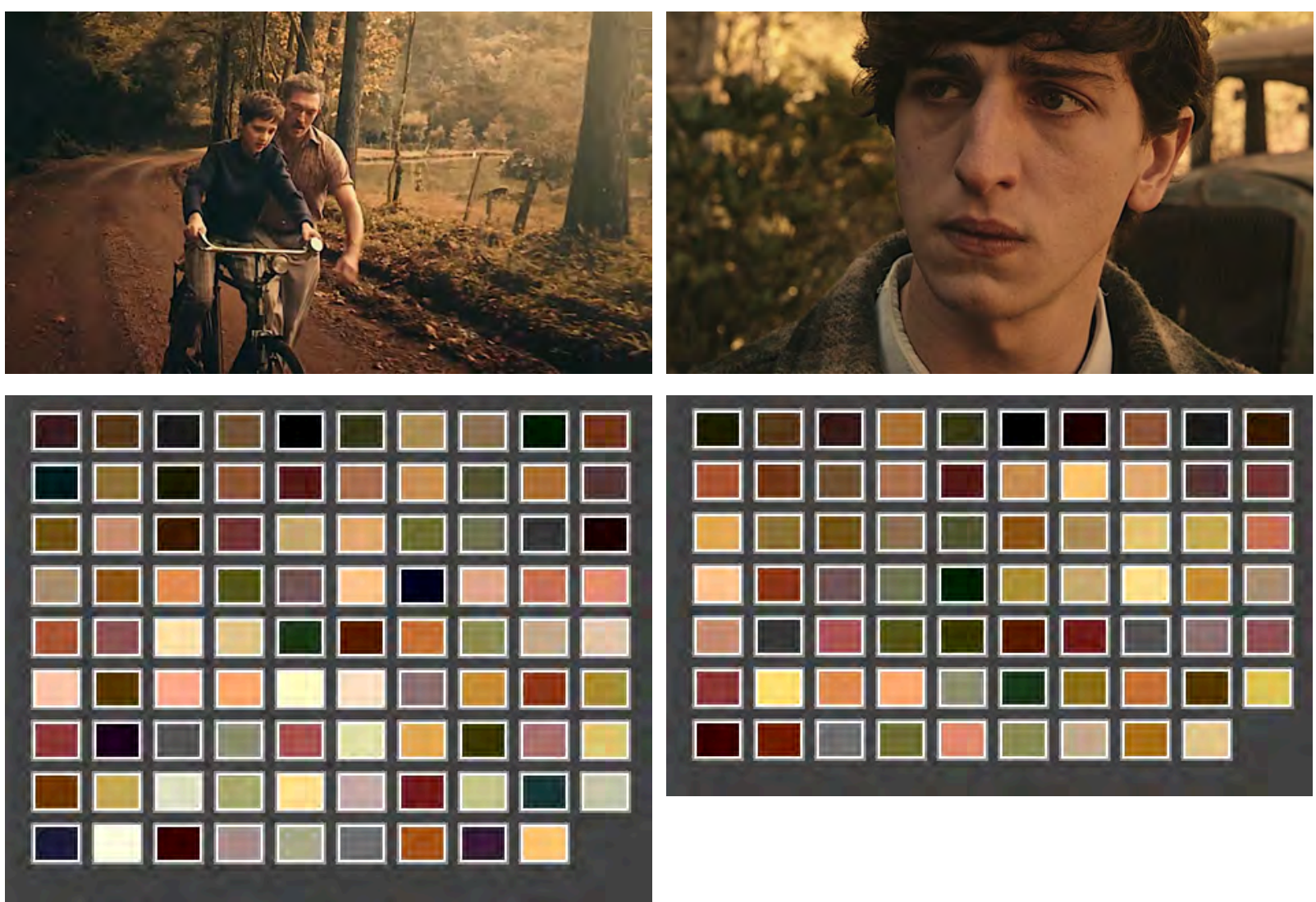

Fig. 343 - O Filme da Minha Vida (2017), Selton Mello

Por fim, vale lembrar que a personagem Luna traz um elemento metalinguístico ao filme e também uma referência ao trabalho de Walter Carvalho, uma vez que tem a fotografia como hobby e em muitos momentos observa o mundo a partir de uma câmera.
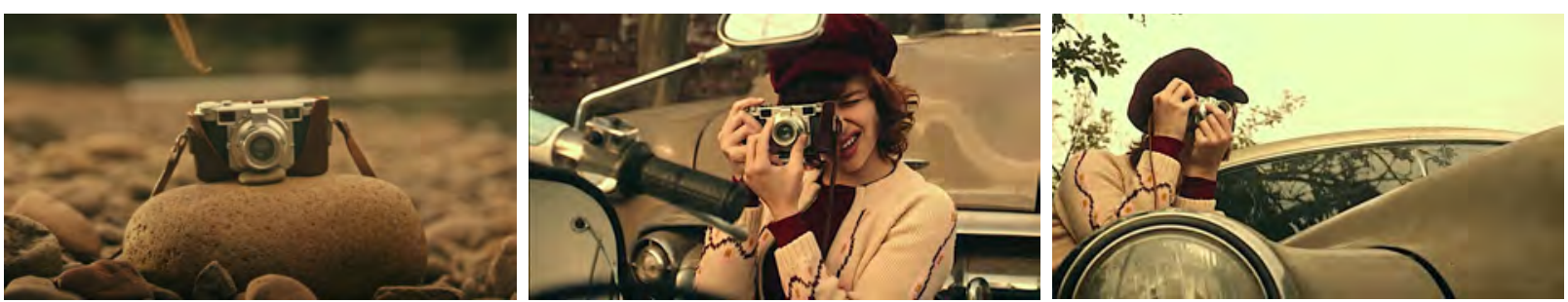

Fig. 344 - O Filme da Minha Vida (2017), Selton Mello

Além de fotografar, Luna revela e amplia suas imagens, assim como o segredo do pai de Tony é revelado durante o filme. 


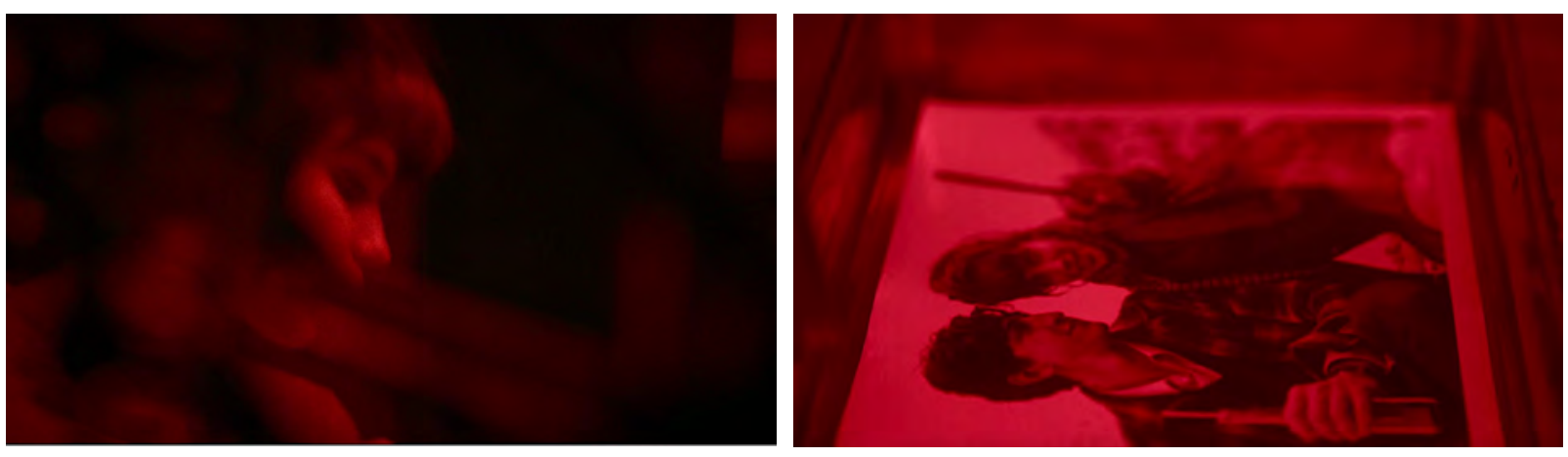

Fig. 345 - O Filme da Minha Vida (2017), Selton Mello

Em O Filme da Minha Vida, Walter Carvalho utiliza elementos técnicos e de composição que vêm sendo trabalhados por ele desde os primeiros filmes da Retomada. Certamente alguns elementos têm origem nas concepções do diretor, entretanto, a colaboração do diretor de fotografia acaba sendo determinante no resultado final da imagem. Não é possível delimitar a fronteira exata entre o trabalho de cada um deles, mas quando verificamos a semelhança de algumas imagens produzidas por Walter Carvalho em filmes de diretores diferentes, passamos a desconfiar de sua contribuição para os filmes. 


\section{CONCLUSÃO}

$\mathrm{Na}$ análise do corpus fílmico, buscamos a existência de traços que evidenciassem a contribuição autoral de Walter Carvalho, na tentativa de atribuir um estilo a este diretor de fotografia. Nessa investigação foi possível observar procedimentos recorrentes de iluminação, profundidade de campo e composição dos quadros, que se estendem a filmes não analisados no presente trabalho, como Amarelo Manga (2002) e Baixio das Bestas (2006), dirigidos por Cláudio Assis (1959- ), e Redemoinho (2016), dirigido por José Luiz Villamarim (1963- ).

O desenho de luz constitui um dos traços mais relevantes das obras de Walter Carvalho. A luz é criada a partir dos personagens e se relaciona com os corpos dos atores. Em Lavoura Arcaica, a iluminação dos corpos é fundamental para a construção da sexualidade dos irmãos, mas também da atmosfera sisuda que tem origem na educação patriarcal. Em Madame Satã, a busca do homem real e suas contradições aparece na forma como o corpo é iluminado, assim como a busca do mito em Heleno, ou ainda a família Breves, em Abril Despedaçado, cujas peles são iluminadas de modo a se confundirem com a terra seca do Vale das Almas.

A luz também é colocada na condição de personagem. É o caso da sequência inicial de Lavoura Arcaica, em que André observa a projeção de sombras no teto do quarto, ou ainda em Redemoinho, com planos-detalhe da luz que entra pelo telhado.
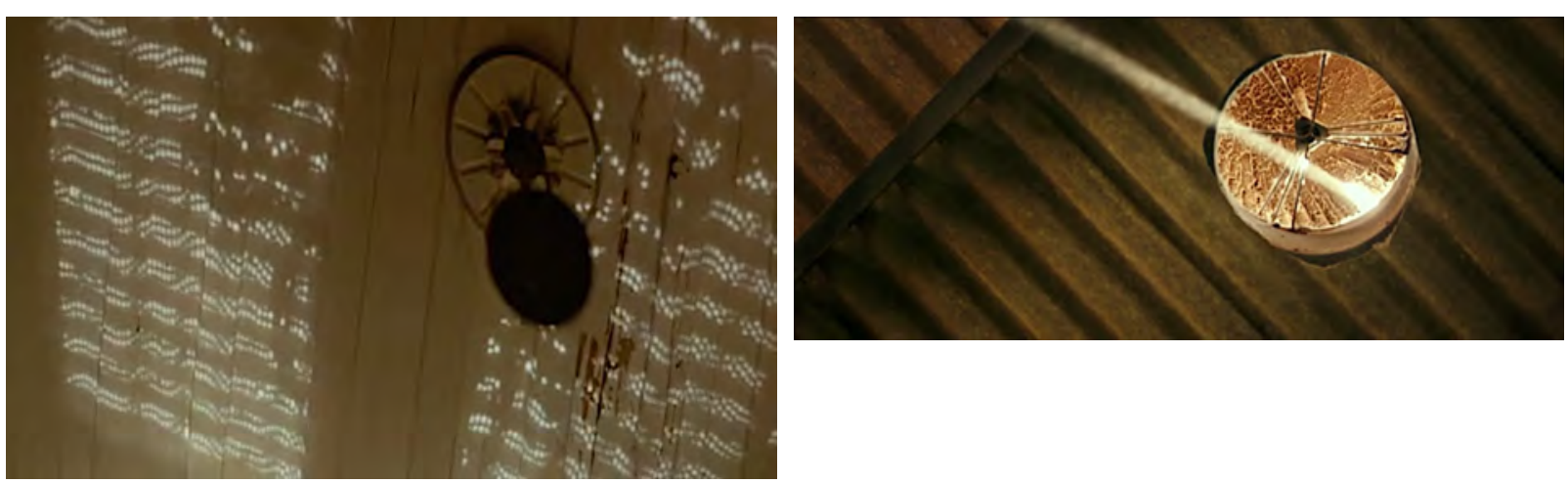

Fig. 346 - Lavoura Arcaica (esq) e Redemoinho (dir)

Mas a luz personagem torna-se ainda mais evidente em planos executados apenas por meio de luz e sombra, sem atores ou objetos de cena, como na cena de Lavoura Arcaica em que André se prepara para ir à igreja, ou na cena em que Tony anda de bicicleta em $O$ Filme da Minha Vida. 

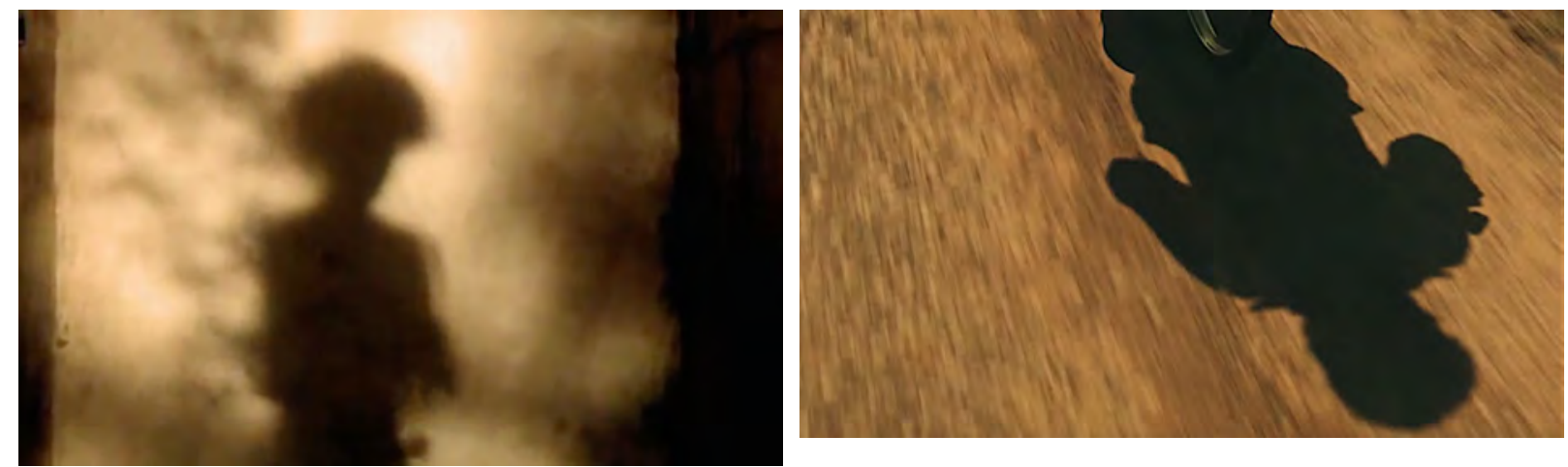

Fig. 347 - Lavoura Arcaica (esq) e O Filme da Minha Vida (dir)

Um terceiro aspecto recorrente no desenho de luz é o enquadramento das fontes pela câmera, como as velas em Lavoura Arcaica, Abril Despedaçado e Central do Brasil, e as lâmpadas e luminárias em Lavoura Arcaica e Madame Satã. Walter Carvalho evidencia a importância da luz, colocando-a em quadro em grande parte de suas obras.

Outro traço relevante no trabalho deste diretor de fotografia é a fluidez das imagens, que se configura em uma utilização original da profundidade de campo. O range de nitidez é estabelecido a partir da narrativa, mas a escolha dos elementos que estarão em foco não segue convenções. O foco nem sempre encontra-se no personagem que fala, algumas vezes está em parte do corpo do ator ou em um objeto de pequena relevância. É o que pode ser visto nos fotogramas de Lavoura Arcaica, Amarelo Manga e Redemoinho.
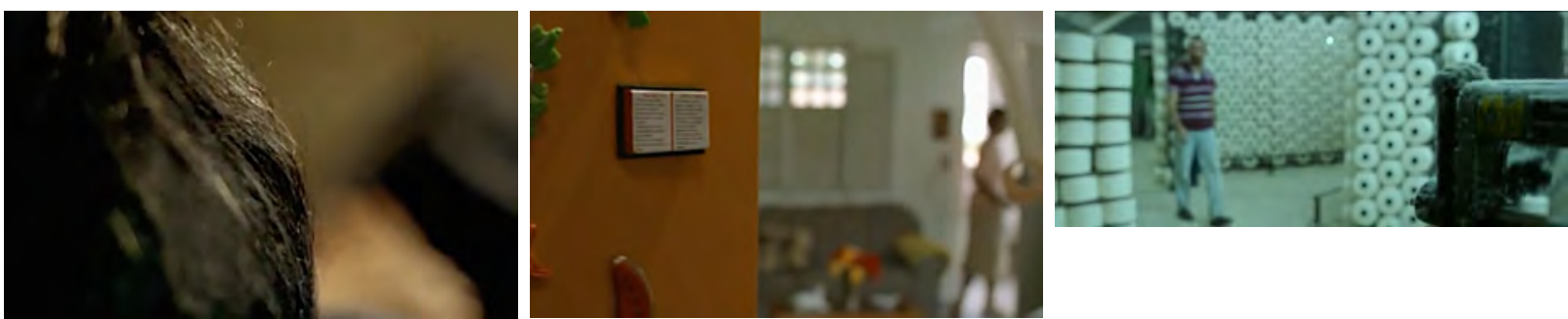

Fig. 348 - Lavoura Arcaica (2001), Amarelo Manga (2002) e Redemoinho (2016)

Há momentos em que o personagem se movimenta mas o foco não o acompanha, mantendo-se fixo em sua posição final. Desse modo, grande parte da cena fica desfocada, como pode-se observar na figura 349.
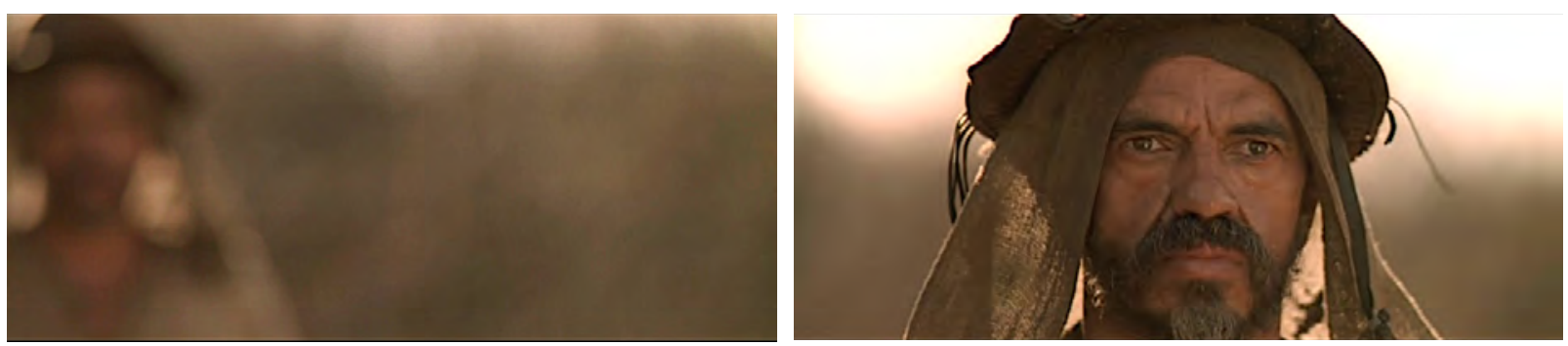

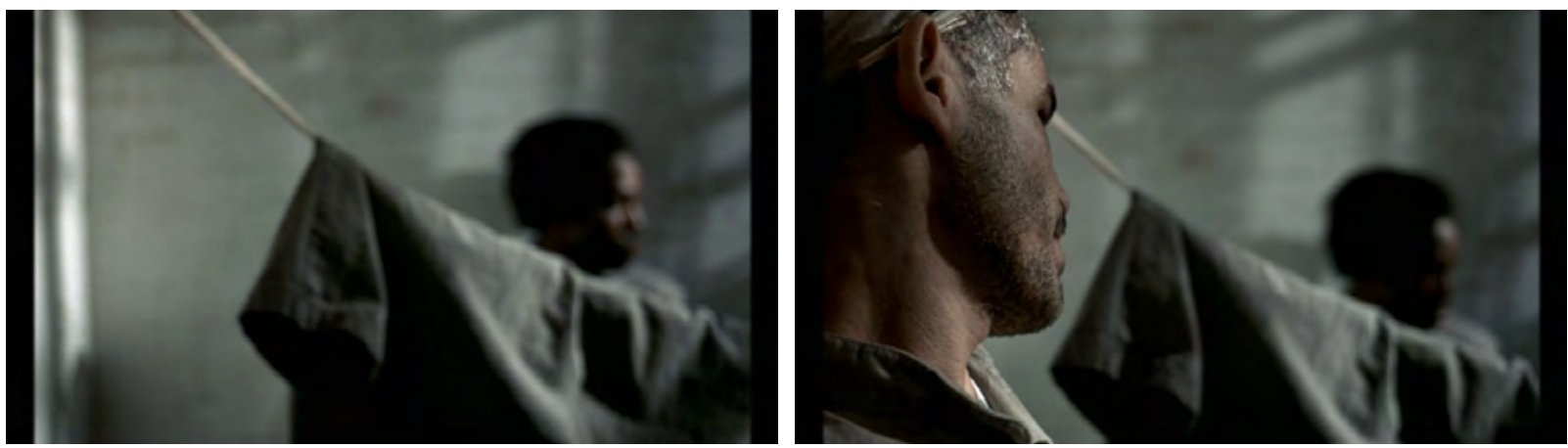

Fig. 349 - Abril Despedaçado (cima) e Madame Satã (baixo)

O foco na nuca dos atores aparece com frequência. Neste tipo de enquadramento, o mais comum seria estabelecer o foco no plano de fundo. Entretanto, Walter mantém a nitidez nas costas do personagem, contrapondo-o ao ambiente desfocado.
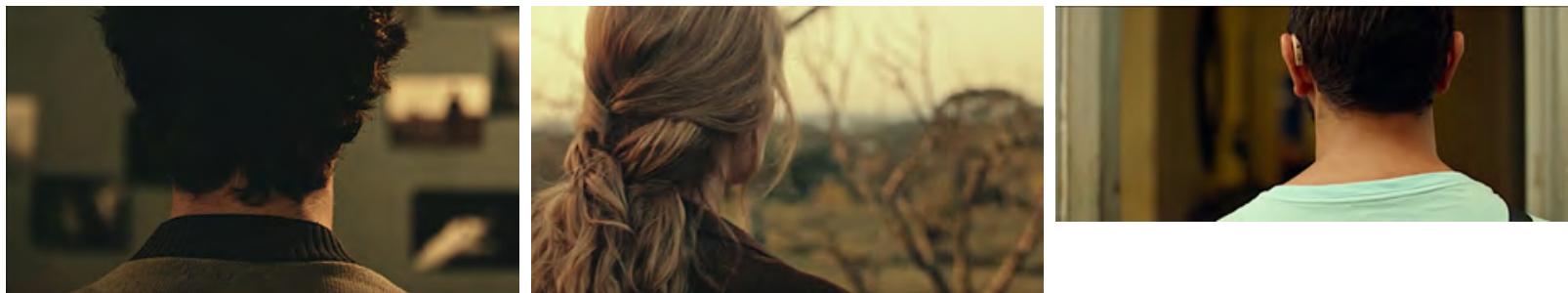

Fig. 350 - O Filme da Minha Vida (esq/centro) e Redemoinho (dir)

E em momentos de fluidez mais radical, Walter Carvalho utiliza o completo desfoque, criando imagens quase abstratas, como as dos fotogramas de Terra Estrangeira, Lavoura Arcaica e Madame Satã.
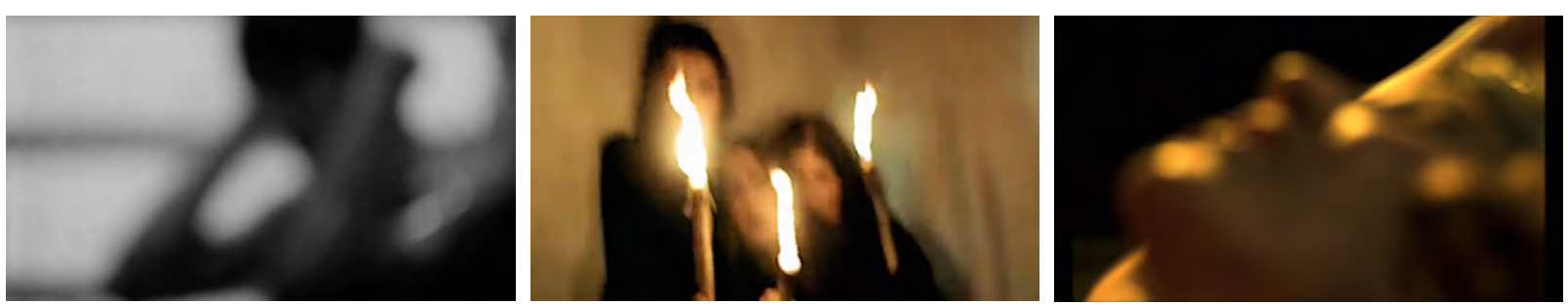

Fig. 351 - Terra Estrangeira (1995), Lavoura Arcaica (2001) e Madame Satã (2002)

Esta subversão ao uso corrrente da profundidade de campo configura um dos pilares de sua poética, que desconstrói, reinventa e transcende determinados padrões da linguagem cinematográfica. Esta subversão também se aplica a procedimentos técnicos inventivos, como o processamento da película de Madame Satã, em que o bleach bypass foi feito no negativo, não nas cópias. Para obter o resultado estético desejado, Walter realiza experimentos e transgride a técnica. Ao reinventar ou reorganizar a lógica de utilização do aparato cinematográfico, encontra a liberdade fotográfica proposta por Flusser. 
Em termos de composição, percebe-se a exploração de elementos gráficos. As linhas permeiam toda a sua obra, sejam linhas concretas ou criadas pela luz. Tais elementos, pertencentes ao campo do bidimensional, não comprometem a impressão de realidade das imagens, que é trabalhada pela justaposição de planos. Nos dois primeiros fotogramas da figura 352, de Terra Estrangeira, a tridimensionalidade é explorada a partir das várias alturas da locação e da cadeira disposta em primeiro plano. No terceiro, nono e décimo fotogramas, respectivamente de Terra Estrangeira, Amarelo Manga e Redemoinho, as grades separam o mundo interior do mundo exterior, relacionando-os por meio dos olhares. O mesmo acontece no sexto fotograma, de Central do Brasil. Também são de Central do Brasil o quarto e quinto fotogramas, cujas linhas promovem a ligação entre o primeiro plano e o plano do fundo. $\mathrm{O}$ sétimo e o oitavo fotogramas pertencem a Amarelo Manga, em que as linhas delimitam e emolduram os planos intermediários do quadro, assim como nos dois últimos fotogramas, respectivamente de Redemoinho e Baixio das Bestas.
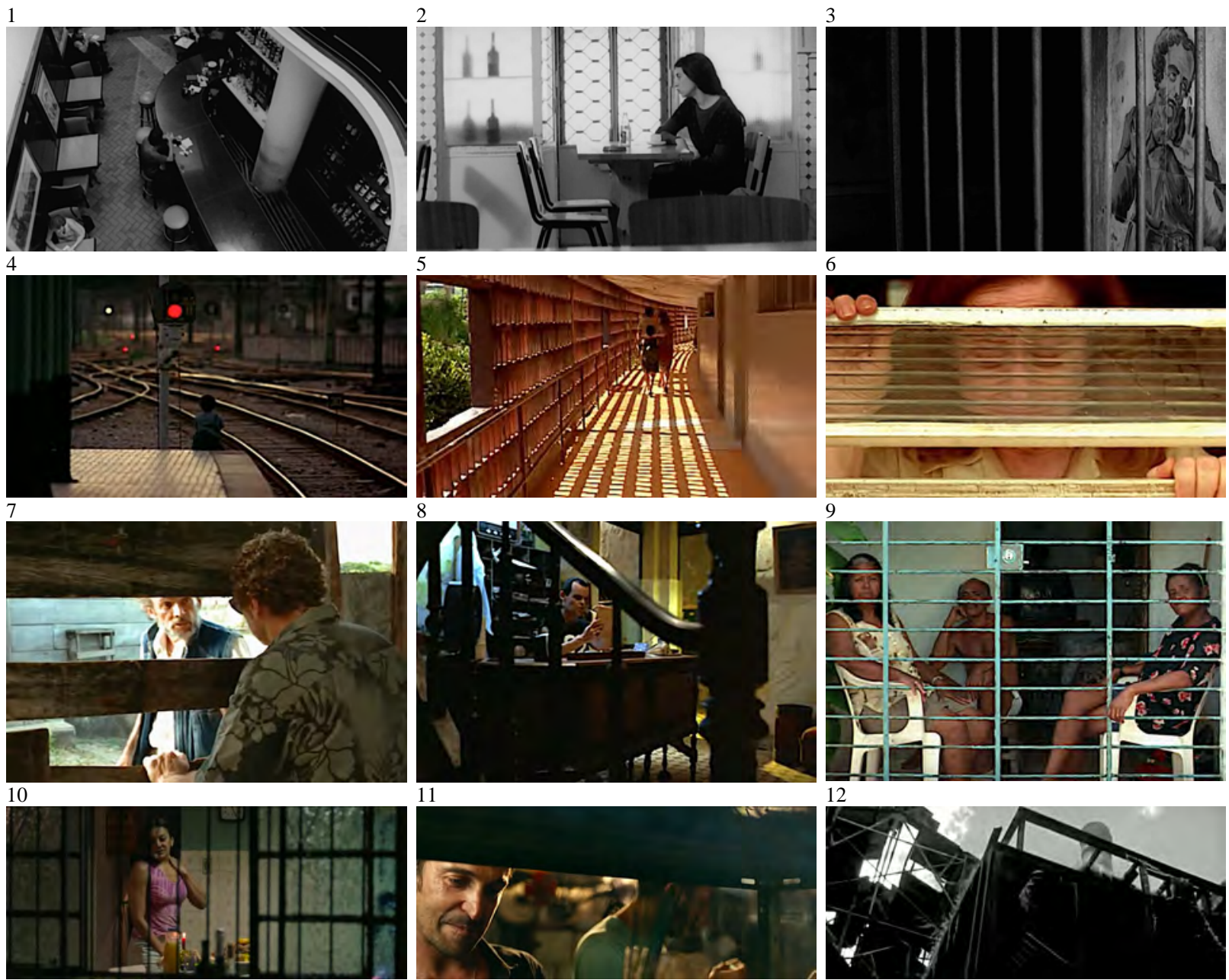

Fig. 352 - Utilização das linhas 
A impressão de realidade é reforçada pelos enquadramentos em profundidade, que muitas vezes apresentam uma porta ou uma janela ao fundo, prolongando o percurso do olhar. Na figura 353, há exemplos deste tipo de composição em Central do Brasil (1 e 2), Baixio das Bestas (3), Amarelo Manga (4, 5 e 6), Abril Despedaçado (7) e Redemoinho (8 e 9).
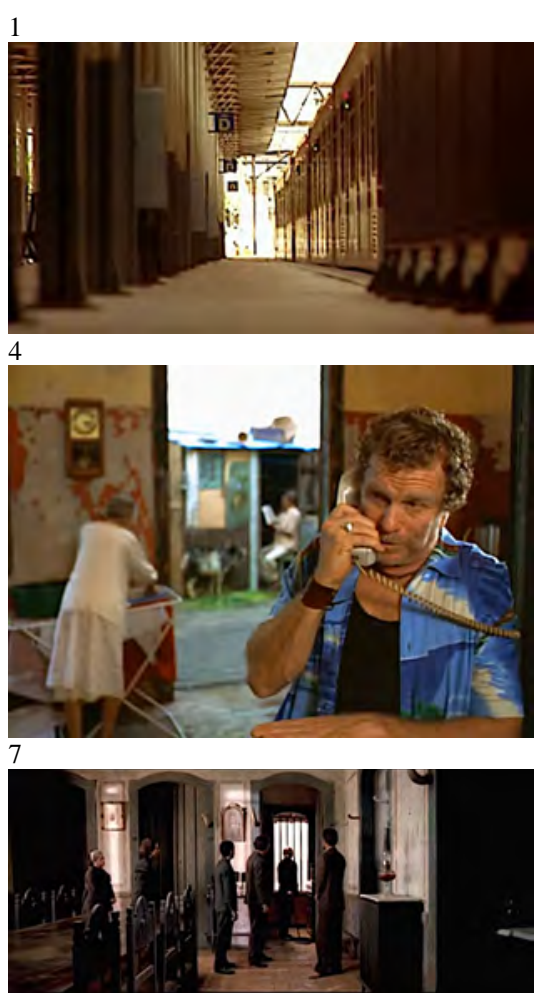
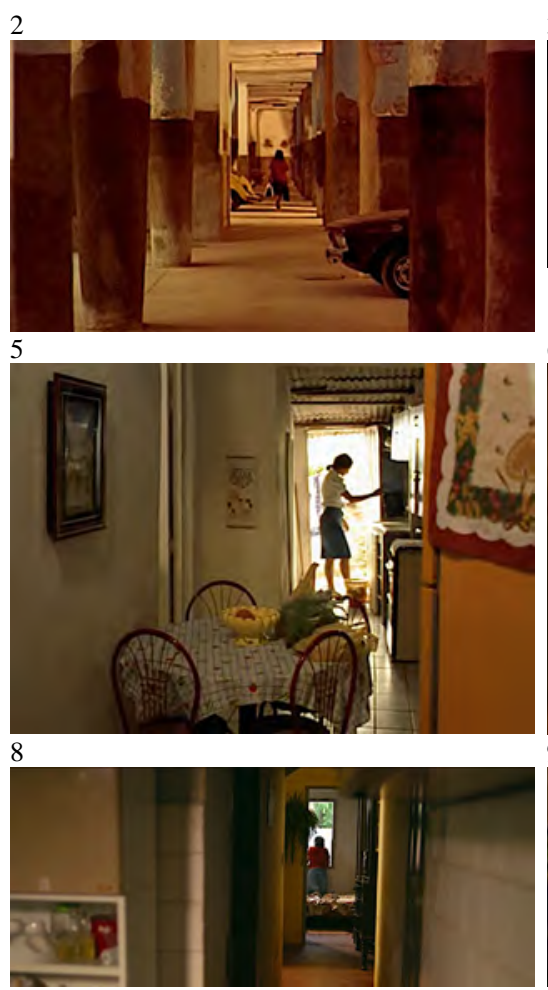
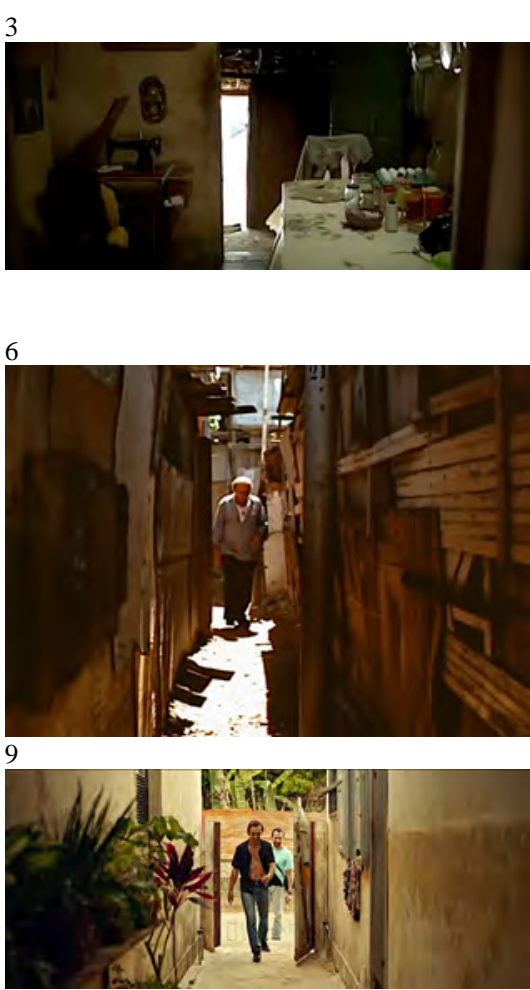

Fig. 353 - Composição em profundidade

Janelas, portas, espelhos e outros elementos do cenário emolduram os personagens, tornando mais elaboradas as composições. É o que vemos em Terra Estrangeira (1), Central do Brasil (2), O Filme da Minha Vida (3 e 9), Lavoura Arcaica (4), Amarelo Manga (5), Madame Satã (6), Heleno (7 e 8), Abril Despedaçado (10 e 11) e Baixio das Bestas (12).
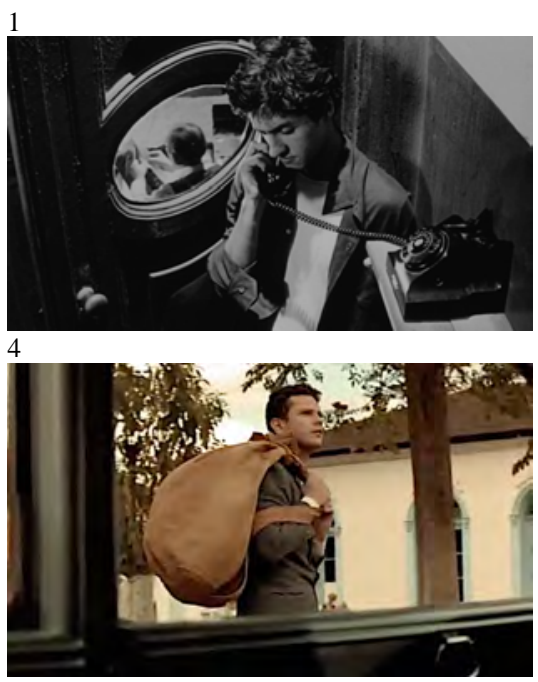
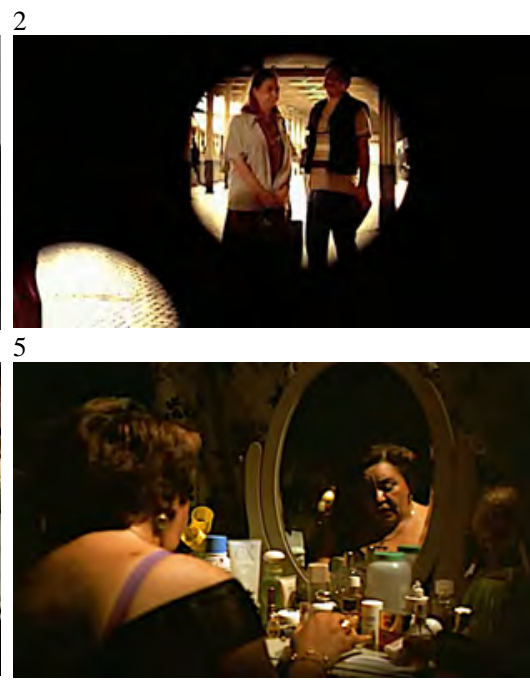
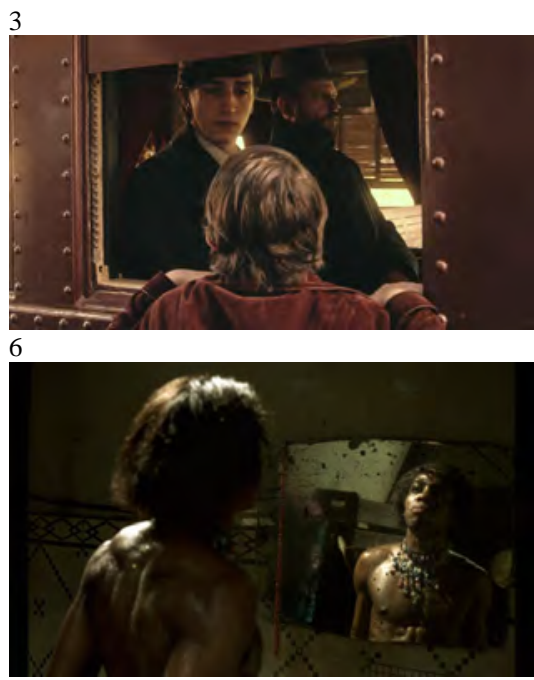

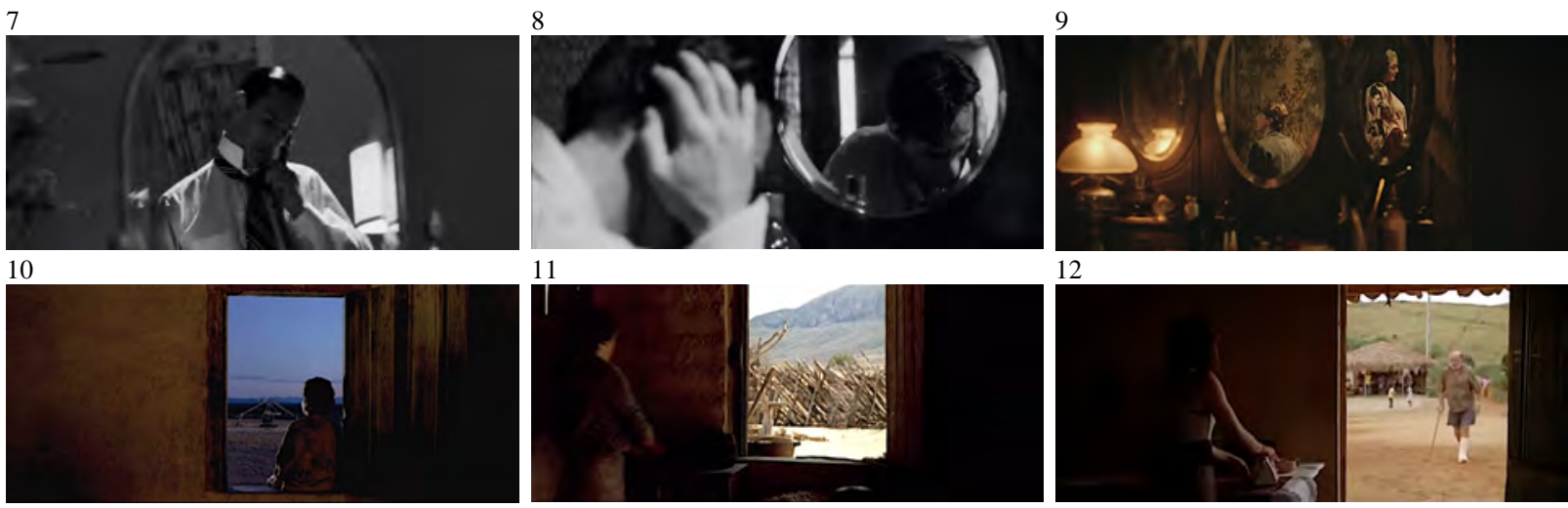

Fig. 354 - Molduras

Os planos zenitais são utilizados com frequência de maneira clássica, indicando situações de opressão do personagem, como nos fotogramas de Amarelo Manga (1, 2 e 3), Heleno (4 e 5), Abril Despedaçado (6) e Baixio das Bestas (9), mas também em momentos lúdicos dos personagens, como nos fotogramas 7 e 8, respectivamente de Abril Despedaçado e Baixio das Bestas. Nota-se, portanto, que um mesmo procedimento de composição é utilizado para a produção de efeitos visuais distintos.
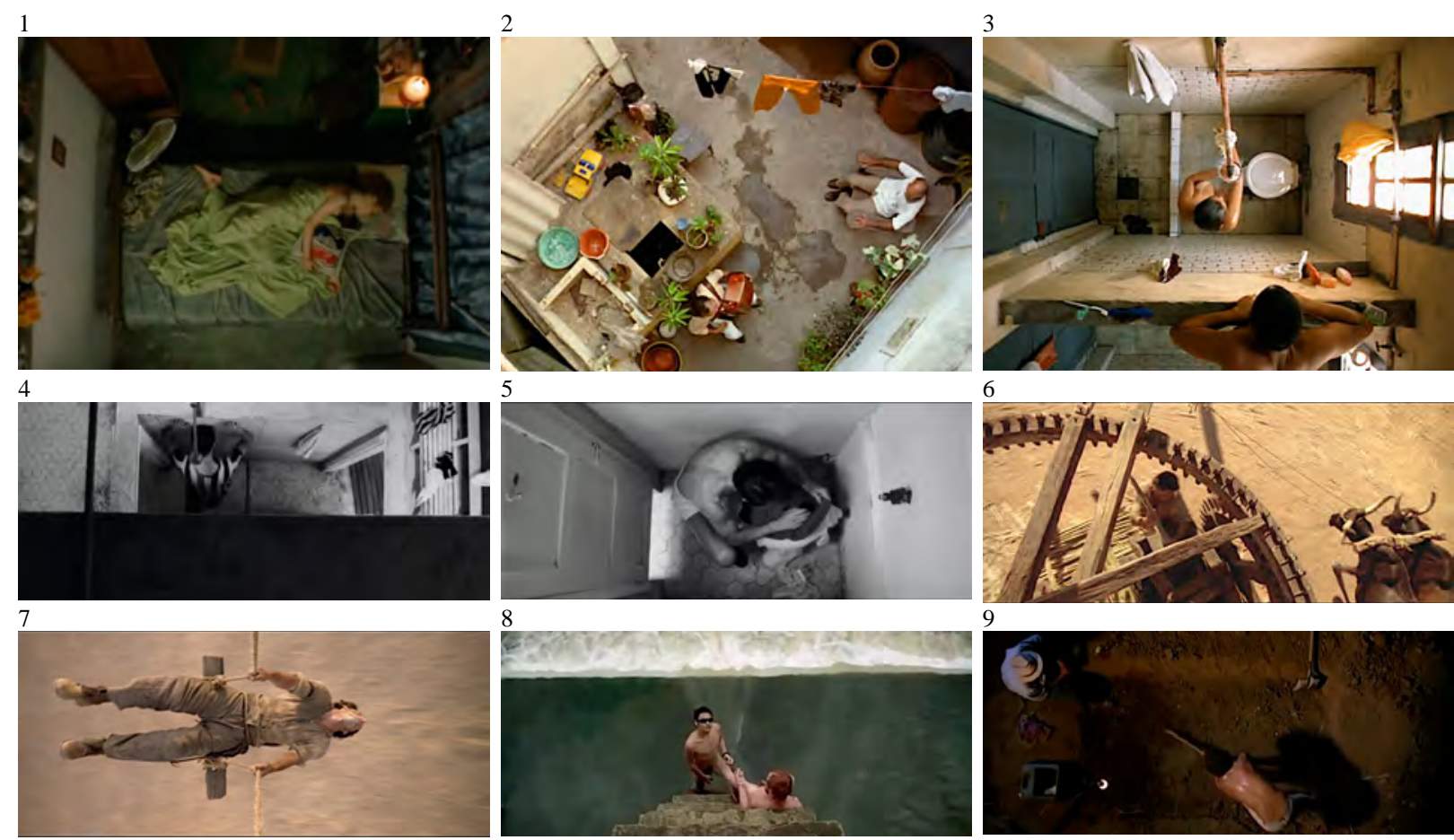

Fig. 355 - Planos zenitais

Primeiros planos dos atores, assim como os planos de observação dos personagens, são compostos de maneira semelhante em filmes de diferentes diretores. Na primeira linha da figura 356 temos Amarelo Manga, Terra Estrangeira e O Filme da Minha Vida, dirigidos respectivamente por Cláudio Assis, Walter Salles e Daniela Thomas, e Selton Mello. Na 
segunda linha temos Amarelo Manga, Terra Estrangeira e Heleno, este último dirigido por José Henrique Fonseca. As semelhanças evidenciam a contribuição de Walter Carvalho nas decisões estéticas dos filmes. Em 50 Anos Luz, Câmera e Ação, Edgar Moura (1948- ) resume a interação entre diretor de fotografia e diretor de cena da seguinte forma: "o diretor escolhe, o fotógrafo melhora o que foi escolhido pelo diretor" (MOURA, 2005, p. 250). O que podemos pensar ao compararmos as imagens da figura 356 é que a partir da decisão do diretor em realizar um primeiro plano ou plano de observação, Walter Carvalho atua de forma determinante para o resultado da composição.
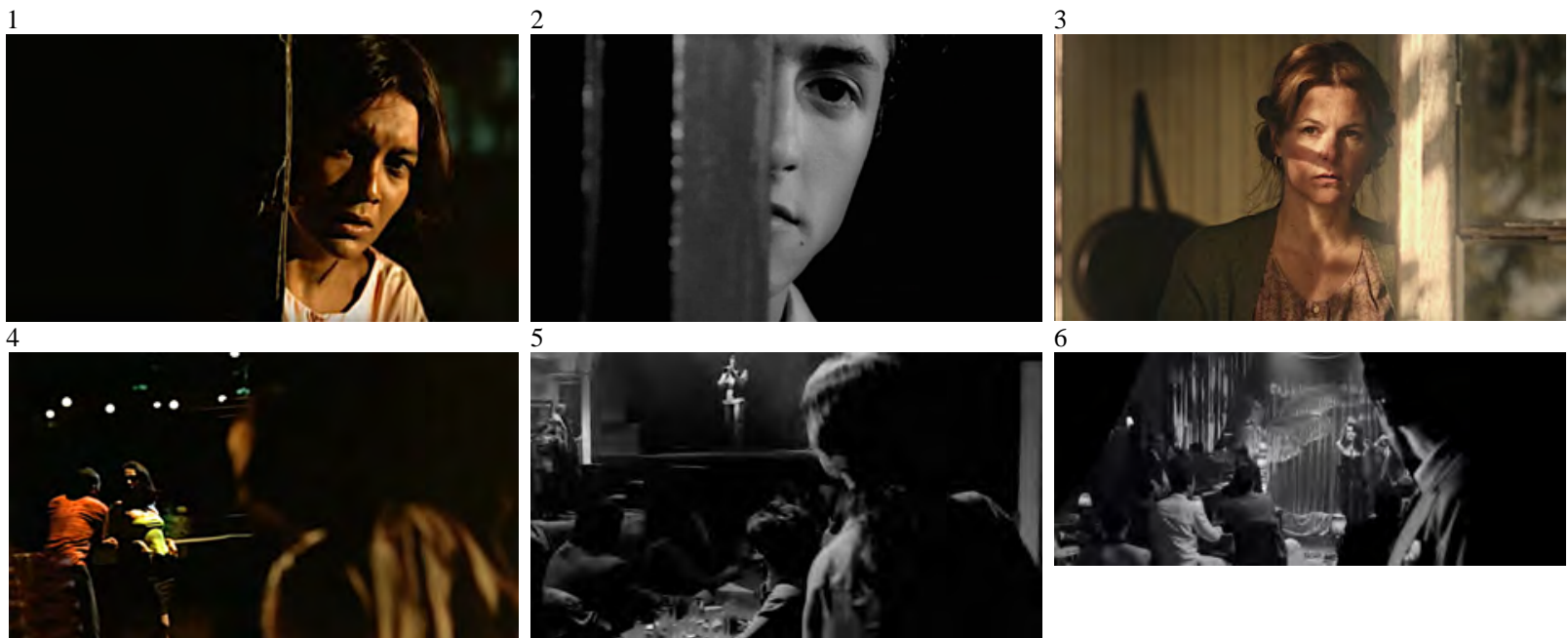

Fig. 356 - Primeiros planos e planos de observação

Mas o procedimento que mais se repete nos filmes fotografados por Walter é a tripartição do quadro, muitas vezes acentuada pelo contraste luminoso, fechando o enquadramento realizado com uma lente aberta. Na figura 357, verifica-se a tripartição em Terra Estrangeira (1), Central do Brasil (2 e 3), Amarelo Manga (4), Madame Satã (5), Lavoura Arcaica (6), Abril Despedaçado (7), Heleno (8) e Redemoinho (9).
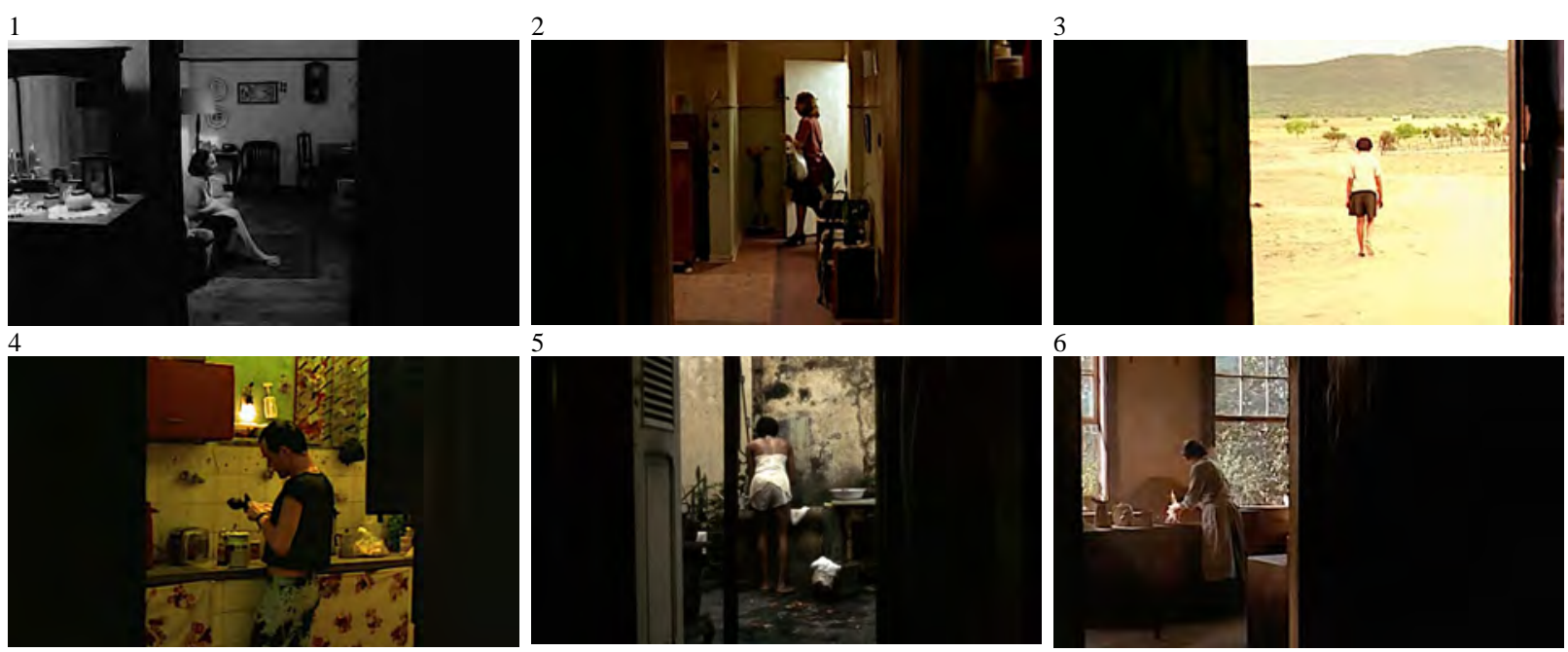

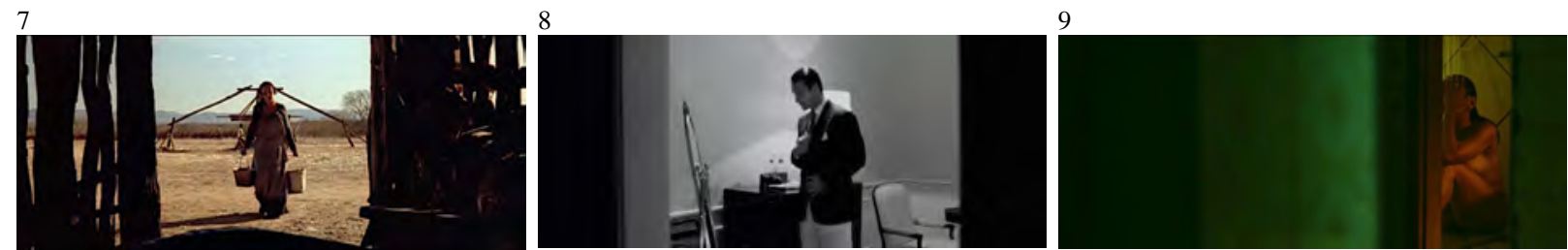

Fig. 357 - Tripartição do Quadro

Observa-se no processo criativo de Walter Carvalho a construção de visualidades intrinsecamente ligadas à narrativa e aos personagens. Mas além disso, verifica-se que suas memórias e referências estéticas estão presentes na realização dos filmes. Este fato aponta para a importância da história e do museu imaginário, bagagem imagética a partir da qual o artista faz associações que moldam sua forma de produzir imagens. No filme Iluminados, Walter Carvalho cita uma importante frase do diretor de fotografia Vittorio Storaro: "Ao produzir uma imagem, seja ela fotográfica, seja ela cinematográfica, tem por trás de você dois mil anos de história, esteja você consciente disso ou não".

Verifica-se no trabalho de Walter Carvalho uma consciência histórica que instrumentaliza seu espírito e sua forma de ver o mundo, e que acaba sendo impressa nas obras. A relação do artista com a história difere da forma como o historiador lida com a mesma matéria. O historiador institucionaliza o tempo, estabelecendo início, plenitude e queda dos processos. O artista recupera o tempo passado, que torna-se presente em suas referências e escolhas. Este fato corrobora a premissa de que a forma é a ideia visível, um veículo que se adequa a um conteúdo, validando a análise a partir de padrões internos das obras, que não despreza conceitos históricos e culturais do fenômeno fílmico. Além disso, reforça a convicção de que o papel do fotógrafo é crucial para o resultado estético dos filmes, uma vez que evidencia o trabalho de um agente criativo, muitas vezes oculto no trabalho coletivo. Walter Carvalho realiza uma fotografia que busca ao mesmo tempo a identidade da obra e uma expressão pessoal.

As referências à história da pintura e à história do cinema, como verificamos ao longo das análise, constituem um repertório que o diretor de fotografia carrega para cada novo trabalho, adequando-o ao contexto da narrativa e dos personagens.

A relação de Walter com a técnica apoia-se na consciência de que técnica é meio, mas poética é fim. Em outro momento do filme Iluminados, Walter Carvalho explicita suas motivações para a tomada de decisões técnicas. 
O processo de descobrir a fotografia de um filme se dá com a leitura do roteiro. Eu leio o roteiro como se estivesse lendo uma estória, aí eu me identifico ou não com algum personagem, me apaixono sem me preocupar com o que vou fazer com aquilo. Em uma segunda ou terceira leitura, eu vou lendo mais do ponto de vista técnico, que é uma compreensão do porquê uma determinada sequência ocorre no entardecer e não ao meio dia, porque ela acontece na varanda da casa e não em seu interior. Porque cinema é arte e técnica. A condição poética é exatamente a linguagem, e eu acho que a técnica deve estar a serviço dela. O que deve ser apurado não é a técnica, é a linguagem. Porque se você apurar, apurar, apurar a linguagem, ela se transforma em vida. E isso é o que a gente quer quando faz um filme (CARVALHO in LEAL, 2007).

Apurar a linguagem para que se transforme em vida é o que acontece quando os personagens e seus conflitos tornam-se reais para o espectador. Walter promove essa transformação manipulando variáveis técnicas e adotando procedimentos de composição que se repetem, mas adquirem diferentes significados nos filmes. Os elementos formais recorrentes, como iluminação, desfoque e composição, são trabalhados de forma a criar universos particulares, de acordo com cada narrativa. Memórias e referências se misturam a novos traços, criando uma cinematografia autêntica, criativa e integrada à construção fílmica.

Após a análise detalhada de seus filmes e compreendendo seu processo criativo, é possível concluir que seus traços constituem um estilo pessoal. Mas a utilização recorrente dos elementos aqui apontados está longe de constituir fórmulas ou de criar convenções que engessariam sua atuação criativa. Ao procedimento de utilizar elementos formais comuns, mas com diferentes significados, Walter Carvalho denomina "desconstruir o construído" (CARVALHO, 2011). Trata-se de reinventar e redescobrir a linguagem, tornando-a dinâmica. Isso significa que a cada novo trabalho apropria-se dos mesmos elementos cinematográficos para criar novos conceitos visuais, que fortalecem os conteúdos narrativos dos filmes. Seu estilo, portanto, é responsável por um cinema de expressão poética. 


\section{EPÍLOGO}

Clara: Tu já sabe ler?

Menino: Sei não... mas sei lê as figura.

(SALLES, MACHADO e AÏNOUZ, 2002,

roteiro do filme Abril Despedaçado)

Durante os quatros anos desta pesquisa não tive contato pessoal com Walter Carvalho. Tentei entrevistá-lo no ano anterior ao depósito da tese, mas ele estava iniciando um trabalho longo de ficção, com uma carga horária que impossibilitou nossa conversa. No início de 2020, quando já havia concluído a pesquisa, Walter me telefonou. Era um domingo de manhã e passamos um longo tempo falando sobre os filmes analisados, sobre seu processo de trabalho e a relação com os diretores.

Walter me contou que a fotografia de Abril Despedaçado começou com a construção da fazenda dos Breves. Antes da equipe de arte iniciar a produção do cenário, ele dormiu uma noite embaixo de uma árvore e esperou o sol nascer, tentando entender como a luz se movia naquele lugar. A partir daí, orientou a equipe de arte na construção do cenário, de uma forma que favorecesse a fotografia, permitindo filmar cenas que se passam em apenas alguns minutos, ao longo de todo o dia.

Mas Walter me contou mais uma coisa, que acalmou minhas angústias com relação à tese. Durante minha pesquisa, queria entender porque ao analisar seu trabalho dei ênfase aos enquadramentos em detrimento da iluminação. A luz é a matéria prima do fotógrafo, mas ainda assim, sentia-me mais atraída em falar do quadro. Ele me disse que durante muito tempo teve uma fidelidade à luz. Achava que a luz fazia tudo, e por isso, dava muita importância ao processo de colocar os refletores, um processo que segundo ele, era doloroso e demorado. Até que entendeu que o mais importante no seu trabalho era o ato de enquadrar, chamado por ele de "enquadradar", colocar em quadrados.

Contou-me que intuitivamente, desde Abril Despedaçado, ao pensar na triangulação entre a bolandeira, a casa dos Breves e a casa da rapadura, estava pensando no quadro e não na luz. Esse processo passou por todos os seus filmes e culminou em Redemoinho, quando entendeu que não deveria colocar os objetos em quadro, pois o quadro não manda no objeto, o objeto manda no quadro. "Enquadradar" significaria, então, ser olhado pelo objeto.

Achei que nossa conversa aconteceu no melhor momento possível, pois seu discurso não influenciou minhas análises. Entretanto, o que ouvi de Walter Carvalho me fez 
compreender como seu pensamento está presente nas imagens que estudei, corroborando a tese da imagem como ideia visível.

Detive-me cerca de dois meses na análise de cada filme, e quando terminava, sentia uma dificuldade imensa em me desapegar daquelas imagens. Até que conseguia seguir em frente e ser habitada pela visualidade do filme seguinte. Ao final, sentia-me muito próxima de Walter e seu universo, como se nos conhecêssemos há anos. Isso porque durante meu percurso de análise travei uma relação íntima com seu processo. E assim como ele, embora entendesse e vislumbrasse nos filmes a importância da luz, intuitivamente era o seu "enquadradar" que estava buscando.

Quando desliguei o telefone tive vontade de dar-lhe um grande abraço e de ser sua amiga para sempre. Tenho muita dificuldade com despedidas e, por isso, é com certa dor que me despeço desta pesquisa. Mas entendi que sigo habitada pela generosidade de Walter Carvalho. Generosidade que lhe é característica no trato com as pessoas, mas principalmente no que caracteriza sua criação, dando vida aos personagens que se constroem pela sua concepção visual, e presenteando o mundo com suas imagens. 


\section{REFERÊNCIAS ${ }^{1}$}

ABRANTES, Ana Cristina de Oliveira. Discurso e cinema: uma análise das metáforas visuais em Abril Despedaçado. 2017. 88f. Dissertação (Mestrado em Linguística) Universidade Federal do Rio de Janeiro, Rio de Janeiro, 2017.

AGEL, Henri. O cinema. Porto: Livraria Civilização Editora, 1972.

AÏNOUZ, Karim. Macabéa com raiva. Cinemais. Rio de Janeiro, n. 33, mar. 2003, p. 177187.

ALBERS, Josef. A interação da cor. São Paulo: Martins Fontes, 2009.

ALMENDROS, Nestor. Días de una cámera. Barcelona, Ed. Seix Barral, 1983.

ALMEIDA, Diana Silveira de. A interpretação da imagem na história da arte: questões de método. Disponível em:

<http://seer.ufrgs.br/index.php/icone/article/download/48596/33446>. Acesso em: 18 dez 2016.

ANDREW, J. Dudley. As principais teorias do cinema - uma introdução. Rio de Janeiro: Jorge Zahar, 2002.

ARGAN, Giulio Carlo. Arte moderna. São Paulo: Cia das Letras, 2008.

ARGAN, Giulio Carlo; FAGIOLO, Maurizio. Guia de história da arte. Lisboa: Editorial Estampa, 1992a.

ARGAN, Giulio Carlo. A História da Arte. In: História da arte como história da cidade. São Paulo: Martins Fontes, 1992b.

ARNHEIM, Rudolf. A arte do cinema. Lisboa: Edições 70, 1989.

Arte e percepção visual. São Paulo: Editora Pioneira, 2002.

Visual thinking. Los Angeles: University of California Press, 1969.

ASSOCIAÇÃO BRASILEIRA DE CINEMATOGRAFIA. Abril Despedaçado. Disponível em: 〈http://abcine.org.br/site/abril-despedacado/>. Acesso em: 19 nov 2018.

AUMONT, Jacques; MARIE, Michel. L'analyse des films. Paris: Armand Colin, 2015.

AUMONT, Jacques. A imagem. São Paulo, Ed. Papirus, 1993.

Moderno? Por que o cinema se tornou a mais singular das artes. São Paulo: Papirus, 2008.

As teorias dos cineastas. Campinas: Papirus. 2004.

A estética do filme. Campinas, Papirus, 1995.

ARANOVICH, Ricardo. Expor uma história. São Paulo: Editora Gryphus, 2004.

${ }^{1}$ De acordo com a Associação Brasileira de Normas Técnicas (ABNT NBR 6023) 
BARROS, José D'Assunção. Heinrich Wolfflin e sua contribuição para a Teoria da Visibilidade Pura. Disponível em: <http://www.ufsj.edu.br/portal2repositorio/File/existenciaearte/Edicoes/6_Edicao/Heinrich_Wolfflin_e_sua_contribuicao_par a_a_teoria_da_visibilidade_pura.pdf $>$. Acesso em: 05 mar 2017.

$\mathrm{BEACH}$, Christopher. A hidden history of film style: cinematographers, directors and the collaborative process. Oakland: University of California Press, 2015.

BENJAMIN, Walter. A obra de arte na era de sua reprodutibilidade técnica . Disponível em: $<$ http://www.mariosantiago.net/Textos\%20em\%20PDF/A\%20obra\%20de\%20arte\%20na $\% 20 \mathrm{era} \% 20 \mathrm{da} \% 20$ sua $\% 20$ reprodutibilidade $\% 20 \mathrm{t} \% \mathrm{C} 3 \% \mathrm{~A} 9$ cnica.pdf $>$. Acesso em: 01 out 2015.

BETTON, Gerard. Estética do cinema. São Paulo: Editora Martins Fontes,1987.

BONITZER, Pascal. Décadrages. Paris: Editions de l'Etoile, 1995.

BORDWELL, David; THOMPSON, Kristin. A arte do cinema: uma introdução. São Paulo, editora Unicamp e Edusp, 2013.

BORDWELL, David. Figuras traçadas na luz: a encenação no cinema. Campinas: Papirus, 2008.

O cinema clássico hollywoodiano: normas e princípios narrativos. In: RAMOS, Fernão Pessoa (org.). Teoria contemporânea do cinema, vol. 2: documentário e narratividade ficcional. São Paulo: Senac São Paulo, 2005.

Sobre a história do estilo cinematográfico. Campinas: Papirus, 2013.

BOSI, Alfredo. Arte e conhecimento em Leonardo da Vinci. São Paulo: Edusp, 2017.

BROWN, Karl. Adventures with D. W. Griffith. Nova York: Farrar, Straus \& Giroux, 1973.

BUSSINGER, Rebeca. Corpo, Gênero e Identidade em Madame Satã. In: Revista Psicología Política, Vol. 11, No. 21, 2011, pp. 91-107. Disponível

em: $<$ https://dialnet.unirioja.es/servlet/articulo?codigo=3895354> . Acesso em: 09 dez. 2018.

BUTCHER, Pedro; MÜLLER, Anna Luiza. Abril Despedaçado: história de um filme. São Paulo: Companhia das Letras, 2002.

CAETANO, Maria do Rosário. Cinema Brasileiro (1990-2002): da crise dos anos Collor à retomada. In: Revista Alceu, v. 8, $\mathrm{n}^{\circ}$ 15, dez. 2007, pp. 196-216. Disponível em: $<$ http://revistaalceu.com.puc-

rio.br/cgi/cgilua.exe/sys/start.htm?from_info_index=17\&infoid=279\&sid=27>. Acesso em: 30 set. 2018.

CANDA, Cilene Nascimento. A arte e a estética em Hegel: reflexões filosóficas sobre a autonomia e a liberdade humana. In: Theoria - Revista Eletrônica de Filosofia, v. 3, nº 06, 2011, pp. 66-79. Disponível em: 〈http://www.theoria.com.br/edicao0611/estetica_hegel.pdf〉. Acesso em: 30 jan. 2020.

CARRIÈRE, Jean-Claude. A linguagem secreta do cinema. Rio de Janeiro: Nova Fronteira, 1995. 
CARTIER-BRESSON, Henri. El instante decisivo. In: FONCUBERTA, Joan (org). Estética Fotográfica. Barcelona: Blume, 1984.

CARVALHO, Luiz Fernando. Sobre o filme Lavoura Arcaica. Cotia: Ateliê Editorial, 2002.

CARVALHO, Marcelo. O trem na paisagem: um olhar materialista sobre o cinema de Lumière. In: Galaxia (São Paulo, Online), n. 23, p. 86-97, jun. 2012. Disponível em: <https://revistas.pucsp.br/galaxia/article/download/7053/7590>. Acesso em 20 abr 2019.

CARVALHO, Walter. Fotografias de um filme: Lavoura Arcaica. São Paulo: Cosac \& Naify, 2003.

Walter Carvalho: fotógrafo. São Paulo: IMS, 2001.

CEPSRM. Página dinâmica para aprendizado do sensoriamento remoto. Disponível em: <http://www.ufrgs.br/engcart/PDASR/formcor.html>. Acesso em 17 fev 2018.

CHALMERS, Thomas; BEDDING, F. R (editores). The qualitative picture. In: Moving Picture World. Vol. 6, $\mathrm{n}^{\circ}$ 25, 25 de junho de 1910, pp. 1089-1090. Disponível em: <https://archive.org/details/movinwor06chal/page/1088/mode/2up>. Acesso em: 03 fev. 2020.

CHALUMEAU, Jean-Luc. As teorias da arte. Filosofia, crítica e história da arte de Platão aos nossos dias. Lisboa: Instituto Piaget, 2007.

CHION, Michel. El cine y sus ofícios (Le cinéma et sés metiérs). Barcelona, Ed. Cátedra Signo e Imagen, 1992.

COSTA, António. Direção de fotografia: uma forma de arte no cinema de ficção. Disponível em: <http://www.aim.org.pt/atas/pdfs/Atas-IVEncontroAnualAIM-23.pdf > Acesso em: 04 out 2015.

COUTO, Carlos Eduardo Mendes de A. Um breve panorama do cinema colorido no Brasil. Disponível em: <https://abcine.org.br/site/um-breve-panorama-do-cinema-coloridono-brasil/>. Acesso em: 21 jun 2019.

CRAWFORD, William. The keepers of light: a history and working guide to early photographic processes. Nova York: Morgan \& Morgan, 1979.

CRESPO, Nuno. A sobrevivência das imagens segundo Aby Warburg. Disponível em: $<$ https://www.publico.pt/temas/jornal/a-sobrevivencia-das-imagens-segundo-aby-warburg25855241>. Acesso em 26 mar 2017.

DENSER, Maria Teresa. O pensamento gráfico no cinema: a construção e a representação da imagem cinematográfica. 2008. 184f. Tese (Doutorado em Comunicação e Semiótica) - Pontifícia Universidade Católica de São Paulo, São Paulo, 2008.

DIDI-HUBERMAN, Georges. Devant l'image. Paris: Les Éditions de Minuit, 1990.

O que vemos, o que nos olha. São Paulo: Editora 34, 2010.

DUBOIS, Philippe. O ato fotográfico. Campinas: Papirus, 1994.

EISENSTEIN, Sergei. Cinematismo. Buenos Aires: Domingo Cortizo Editor, 1982. 
EISENSTEIN, Sergei. O sentido do filme. Rio de Janeiro: Jorge Zahar, 2002.

Reflexões de um cineasta. Rio de Janeiro: Jorge Zahar, 1969.

EISNER, Lotte H. A tela demoníaca: as influências de Max Reinhardt e do expressionismo. Rio de Janeiro: Paz e Terra, 1985.

FELLINI, Frederico. The book of dreams. Nova York: Rizzoli, 2007.

FLÜSSER, Vilém. Filosofia da caixa preta. São Paulo: Hucitec, 1985.

FOLEY, J. D.; VAN DAM, A.; FEINER, S.K.; HUGHES, J. F. Computer graphics: principles and practice. Reading, MA: Addison-Wesley, 1990. 1176p.

FRANCASTEL. Pierre. Imagem, visão e imaginação. São Paulo: Martins Fontes, 1983.

FRIEDBERG, A. The virtual window - from Alberti to Microsoft. Cambridge :MIT Press, 2006.

GAGE, John. Colour and culture: practice and meaning from antiquity to abstraction. London: Thames and Hudson, 1993.

1999.

Colour and meaning: art, science and symbolism. London:Thames and Hudson,

A cor na arte. São Paulo: Martins Fontes, 2012.

GOETHE, Johann Wolfgang von. Doutrina das cores. São Paulo: Editora Nova Alexandria, 2013.

GOMBRICH, Ernst. Arte e ilusão. São Paulo: Martins Fontes, 1986.

GREENBERG, Clement. Abstração pós-pictórica (1964). In: FERREIRA, Glória; MELLO, Cecília Cotrim de (orgs.). Clement Greenberg e o debate crítico. Rio de Janeiro: Zahar, 1997.

HEGEL, G. W. F. Cursos de estética. São Paulo: Editora da Universidade de São Paulo, 2000 .

HENDERSON, Robert. D.W. Griffith: his life and work. Nova York: Oxford University Press, 1972.

HIRSCH, Robert. Seizing the light: a social history of photography. Boston: McGraw-Hill, 2009.

HURKMAN, Alexis van. Color correction handbook: professional techniques for video and cinema. Berkeley,CA: Peachpit Press, 2010.

Apple pro training series: encyclopedia of color correction/field techniques using Final Cut Pro .Berkeley,CA: Peachpit Press, 2006.

JAMES, Jack. Digital intermediates for film and video. Waltham: Focal Press. 2006.

JOHNSON, Chris. The practical zone system for film and digital photography. Waltham: Focal Press. 2007 
JOLY, Martine. Introdução à análise da imagem. Lisboa: Edições 70, 1994.

JORDAN, Susana Madeira Dobal; SÁ, Ana Carolina Roure Malta de. Direção de Fotografia, Impressionismo e Barroco em Lavoura Arcaica. In: Revista Comunicação Midiática, vol. 12, no 3, jan. 2018. Disponível em: $<$ http://www2.faac.unesp.br/comunicacaomidiatica/index.php/comunicacaomidiatica/artic le/view/848/433>. Acesso em: 28 Out. 2018.

KALMUS, Natalie. Color Consciousness. Journal of the Society of Motion Picture Engineers 25 (2): 139-47, 1935.

KANDINSKY, Wassily. Composition 8. Disponível em:

<https://www.guggenheim.org/artwork/1924>. Acesso em 10 fev 2018.

KIERAN, Michael. Photoshop color correction. Berkeley,CA: Peachpit Press, 2002.

KRACAUER, Siegfried. Theory of film - the redemption of physical reality. New Jersey: Princeton University Press, 1997 [Original 1960].

KUDIELKA, Robert. Abstração como antítese: o sentido da contraposição na pintura de Piet Mondrian e Jackson Pollock. In: Novos Estudos CEBRAP, nº 51, julho 1998, pp. 15 a 35.

KUHN, Annette; WESTWELl, Guy. A Dictionary of Film Studies. Oxford: Oxford University Press, 2012.

KÜPPERS, Harald. Fundamentos de la teoría de los colores. Barcelona: Ediciones G. Gili, 1995.

La couleur: origine, méthodologie, application. Fribourg: Office du Livre, 1975.

LEAL, João Vitor.Walter Carvalho: a fotografia além da fotogenia. In: Cinémas d'Amérique Latine. Toulouse: Presses Universitaires Du Midi, nº 20 (2012), pp. 43-55.

LIGHTMAN, Heber A. (Ed.). American Cinematographer, v. 50, n.1, Jan. 1969.

LOPES, Denilson. Madame Satã. In: MURARI, Lucas; NAGIME, Mateus (orgs.). New queer cinema - cinema, sexualidade e política. $1^{\text {a }}$ Edição, Julho, 2015, p. 128.

LOWELL, Ross. Matters of light \& depth. New York: Lowel-Light Manufacturing, Inc., 1999.

MACHADO, Arlindo. Máquina e Imaginário. São Paulo: Edusp, 2001. Disponível em: <https://books.google.com.br/books?id=_M_TnM8UQNwC\&pg=PA15\&lpg=PA15\&dq=arli ndo+machado+homem+maquina\&source $=$ bl\&ots $=$ rxi9dvAo2a\&sig=3rBP_cWk9jCc5QXBN wLFn2bS1Og\&hl=en\&ei=Oze-TKDHPMP-

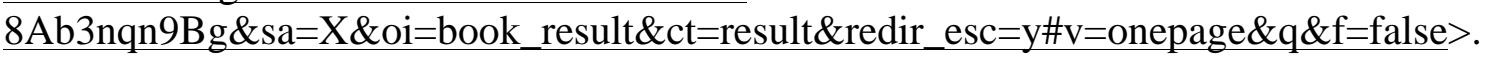
Acesso em: 14 jun. 2016.

Por um audiovisual gráfico. Disponível em:

<http://www.socine.org.br/rebeca/tematicas.asp?C\%F3digo=232>. Acesso em: 10 jun. 2016.

.Pré-Cinemas e Pós-Cinemas. Campinas: Papirus, 2011. 
MACHADO, Arlindo. Repensando Flusser e as imagens técnicas. Disponível em: $<$ http://www.iar.unicamp.br/disciplinas/ap858/AXILA/pagarlindomachado.html>. Acesso em: 27 ago. 2017.

MALKIEWICZ, Kris. Cinematography: a guide for film makers and film teachers. New York: Simon \& Schuster, 1992.

Film lighting: talks with Hollywood's cinematographers and gaffers. New York: A Touchstone, 2012.

MANNONI, Laurent. A grande arte da luz e da sombra: arqueologia do cinema. São Paulo: Ed. Senac; Ed. Unesp, 2003.

MARGULIS, Dan. Professional Photoshop: the classic guide to color correction, 5th Edition. Berkeley, CA: Peachpit Press, 2006.

MARTINS, André Reis. A luz no cinema. 2004. 209f. Dissertação (Mestrado em Artes Visuais) - Escola de Belas Artes, Universidade Federal de Minas Gerais, Belo Horizonte, 2004.

MATTOS, Antonio Carlos Gomes de. O outro lado da noite: filme noir. Rio de Janeiro: Editora Rocco, 2001.

MICHAUD, Philippe-Alain. Aby Warburg et l'image en mouvement. Paris: Macula, 1998.

MISEK, Richard. Chromatic Cinema. Oxford: Wiley-Blackwell, 2010.

MONDRIAN, Piet. Neoplasticismo na pintura e na arquitetura. São Paulo: Cosac \&Naify, 2008.

MORAES, Maria Fernanda Riscali de Lima. A fotografia do conflito: uma parceria entre Sergei Eisenstein e Eduard Tissé. 2015. 88f. Dissertação (Mestrado em Meios e Processos Audiovisuais) - Escola de Comunicações e Artes, Universidade de São Paulo, São Paulo, 2015.

MOURA, Edgar. 50 anos luz: câmera e ação. São Paulo: SENAC, 2005.

NASSAR, Raduan. Lavoura Arcaica. São Paulo: Companhia das Letras, 1989.

NEVES, Marcos Eduardo. Nunca houve um homem como Heleno. Rio de Janeiro: Editora Zahar, 2012.

NEWTON, Isaac. A letter of Mr. Isaac Newton, professor of the Mathematics in the University of Cambridge; containing his new theory about light and colours; sent by the author to the publisher from Cambridge, Febr. 6. 1671/72; in order to be communicated to the R. Society', Philosophical Transactions of the Royal Society, v.6, n.80, p. 3075-3087, 1672a. Traduzido em SILVA, C. C, \& MARTINS, R. A. A "Nova teoria sobre luz e cores" de Isaac Newton: uma tradução comentada. Revista Brasileira de Ensino de Física, v.18, p. 313- 27, 1996.

Optics. Nova York: Dover Publications, 1952. 
NOGUEIRA, Lisandro. Central do Brasil e o melodrama. In: Comunicação \& Informação, v. 3, n. 2, p. 155-159, 28 fev. 2013. Disponível em:

<https://www.revistas.ufg.br/ci/article/view/22870/13611 >. Acesso em: 01 jul 2019.

NORONHA, Danielle. Walter Carvalho, ABC, conta sobre o trabalho no filme

Redemoinho. Disponível em: <https://abcine.org.br/site/walter-carvalho-abc-fala-sobre-ofilme-redemoinho/>. Acesso em: 17 mar 2019.

OROPESA, Salvador. El cine según David Bordwell: neoformalismo y el concepto de totalidad. In: Hispania, vol. 98, no. 3, 2015, pp. 583-593. Disponível em: $<$ https://tigerprints.clemson.edu/cgi/viewcontent.cgi?article=1012\&context=languages_pu bs>. Acesso em: 30 jan. 2020.

OSTROWER, Fayga. Acasos e criação artística. Campinas: Unicamp, 2013.

Criatividade e processos de criação. Petrópolis: Vozes, 1987.

Universos da arte. Rio de Janeiro: Editora Campus, 1983.

PANOFSKY, Erwin. Significado nas artes visuais. São Paulo: Perspectiva, 1976.

PARAIRE, Philippe. O cinema de Hollywood. São Paulo: Martins Fontes, 1994.

PIFANO, Raquel Quinet. História da arte como história das imagens: a iconologia de

Erwin Panofsky. Disponível em:

<http://www.revistafenix.pro.br/PDF24/Artigo_05_Raquel_Quinet_Pifano.pdf >. Acesso em:

02 abr. 2017.

PINTO, Pedro Plaza. Central do Brasil: enquadramento, montagem e narrativa. In.: MONTEIRO R.H e ROCHA, C. (orgs.). Anais do VI Seminário Nacional de Pesquisa em Arte e Cultura Visual. Goiânia: UFG, FAV, 2013. p. 711-720. Disponível em: <https://seminarioculturavisual.fav.ufg.br/up/778/o/2013-087-eixo2_Pedro_Plaza_Pinto.pdf > Acesso em: 29 jun 2019.

PRAKEL, David. Iluminação. Porto Alegre: Bookman. 2010.

RABIGER, Michael. Direção de cinema: técnicas e estética. Rio de Janeiro: Elsevier, 2007.

RAMOS, Fernão Pessoa (org.). Teoria contemporânea do cinema. Volume 1. São Paulo: Ed. Senac/SP, 2005.

RENOIR, JEAN. Escritos sobre cinema, 1926-1971. Rio de Janeiro: Nova Fronteira, 1990.

RIEGL, Aloïs. Problemas de Estilo. Barcelona: Editorial Gustavo Gili, 1980.

RUSKIN, John. The elements of drawing and the elements of perspective. Londres: London Dent, 1912.

SALLES, Walter; MACHADO, Sérgio; AÏNOUZ, Karim. Abril Despedaçado (roteiro do filme). In: BUTCHER, Pedro; MULLER, Anna Luiza. Abril Despedaçado: História de um filme. São Paulo: Companhia das Letras, 2002.

SAMAIN, Etienne (org). O fotográfico. São Paulo: Hucitec/Senac, 2005. 
SANTOS, Gérson Tenório; LOPES, Paulo César Carneiro. Central do Brasil: alegoria e realidade. In: Revista Ângulo 138, Jul./Set., 2014. pp. 05 a 16. Disponível em: <http://publicacoes.fatea.br/index.php/angulo/article/viewFile/1396/1087>. Acesso em: 21 out 2018.

SCHAPIRO, Meyer. Style. In: Theory and philosophy of art: style, artist and society. NY: George Brazille, 1994.

SILVA, Geisa Rodrigues Leite da. Madame Satã desconstruindo a cena. In: Terceira Margem, [S.1.], v. 15, n. 24, p. 139-160, jun. 2017. ISSN 2358-727x. Disponível em: <https://revistas.ufrj.br/index.php/tm/article/view/10939/7998>. Acesso em: 09 dez. 2018.

Madame Satã: a potência de um corpo em cena (Madame Satã: the power of a body on the scene). In: Estudos da Língua(gem), [S.1.], v. 12, n. 1, p. 175, dez. 2014. ISSN 19820534. Disponível em:

<http://www.estudosdalinguagem.org/index.php/estudosdalinguagem/article/view/418/377>. Acesso em: 09 Dez. 2018.

Madame Satã: a voz do corpo negro. In: Revista Universitária do Audiovisual. São Carlos: UFSCAR, 2009. Disponível em: <http://www.rua.ufscar.br/madame-sata-a-voz-docorpo-negro/>. Acesso em: 17fev. 2019.

SONTAG, Susan. Sobre fotografia. São Paulo: Companhia das Letras, 2004.

SOUTO, Roberto Pinto. Segmentação de imagem multiespectral utilizando-se o atributo matiz .São José dos Campos: INPE, 2000. Disponível em: <www.obt.inpe.br/pgsere/SoutoR-P-2000/publicacao.pdf>. Acesso em: 17 fev 2018.

STAM, Robert. Introdução à teoria do cinema. 3. ed. Campinas, SP: Papirus, 2009.

STORARO, Vittorio. Writing with light: Volume 1: the light.. Milão: Electa, 2002.

Writing with light: the elements. Bilingual edition.Milão: Electa, 2003.

XAVIER, Ismail. O discurso cinematográfico: opacidade e transparência. Rio de Janeiro: Paz e Terra, 1984a.

Figuras do ressentimento no cinema brasileiro dos anos 90. In. : RAMOS, Fernão Pessoa e outros (orgs.). Estudos de Cinema 2000 - SOCINE. Porto Alegre : Sulina, 2001. p. 78-98.

D. W. Griffith: o nascimento de um cinema. São Paulo: Brasiliense, 1984 b.

Movimentos táticos para um tempo sem estratégia. In: Cinémas d'Amérique Latine. Toulouse: Presses Universitaires Du Midi, no 7 (1999), pp. 113-117. Disponível em <www.jstor.org/stable/42598730>. Acesso em: 27 set. 2018.

1983.

. Sertão Mar: Glauber Rocha e a estética da fome. Rio de Janeiro: Brasiliense, 


\section{FILMES ANALISADOS}

Terra Estrangeira. Direção: Walter Salles Júnior e Daniela Thomas. Video Filmes, 1995 [produção]. Distribuidora: Rio Filme, 1 DVD (100 min), son., preto e branco.

Central do Brasil. Direção: Walter Salles Júnior. Video Filmes, 1998 [produção]. Distribuidora: Europa Filmes, 1 DVD (106 min), son., colorido.

Lavoura Arcaica. Direção: Luiz Fernando Carvalho. Video Filmes, 2001 [produção]. Distribuidora: Rio Filme, 1 DVD (165 min), son., colorido.

Abril Despedaçado. Direção: Walter Salles Júnior. Video Filmes, 2001 [produção]. Distribuidora: Buena Vista International, 1 DVD (105 min), son., colorido.

Madame Satã. Direção: Karim Aïnouz. Video Filmes, 2002 [produção]. Distribuidora: Imagem Filmes, 1 DVD (100 min), son., colorido.

Heleno. Direção: José Henrique Fonseca. RT Features, 2011 [produção]. Distribuidora: Downtown Filmes, 1 DVD (116 min), son., preto e branco.

O Filme da Minha Vida. Direção: Selton Mello. Globo Filmes, 2017 [produção]. Distribuidora: Vitrine Filmes, 1 DVD (113 min), son., colorido. 